\title{
Caprock Canyonlands Archeology: A Synthesis of the Late Prehistory and History of Lake Alan Henry and the Texas Panhandle-Plains Volume II
}

Douglas K. Boyd

Prewitt and Associates, Inc.

Follow this and additional works at: https://scholarworks.sfasu.edu/ita

Part of the American Material Culture Commons, Archaeological Anthropology Commons, Environmental Studies Commons, Other American Studies Commons, Other Arts and Humanities Commons, Other History of Art, Architecture, and Archaeology Commons, and the United States History Commons

Tell us how this article helped you.

This Article is brought to you for free and open access by the Center for Regional Heritage Research at SFA ScholarWorks. It has been accepted for inclusion in Index of Texas Archaeology: Open Access Gray Literature from the Lone Star State by an authorized editor of SFA ScholarWorks. For more information, please contact cdsscholarworks@sfasu.edu. 
Caprock Canyonlands Archeology: A Synthesis of the Late Prehistory and History of Lake Alan Henry and the Texas Panhandle-Plains Volume II

\section{Creative Commons License}

\section{(c) (1) $\Theta$}

This work is licensed under a Creative Commons Attribution-NonCommercial-No Derivative Works 4.0 International License. 


\section{CAPROCK CANYONLANDS ARCHEOLOGY:}

A Synthesis of The Late Prehistory and History of Lake Alan Henry and The Texas Panhandle-Plains

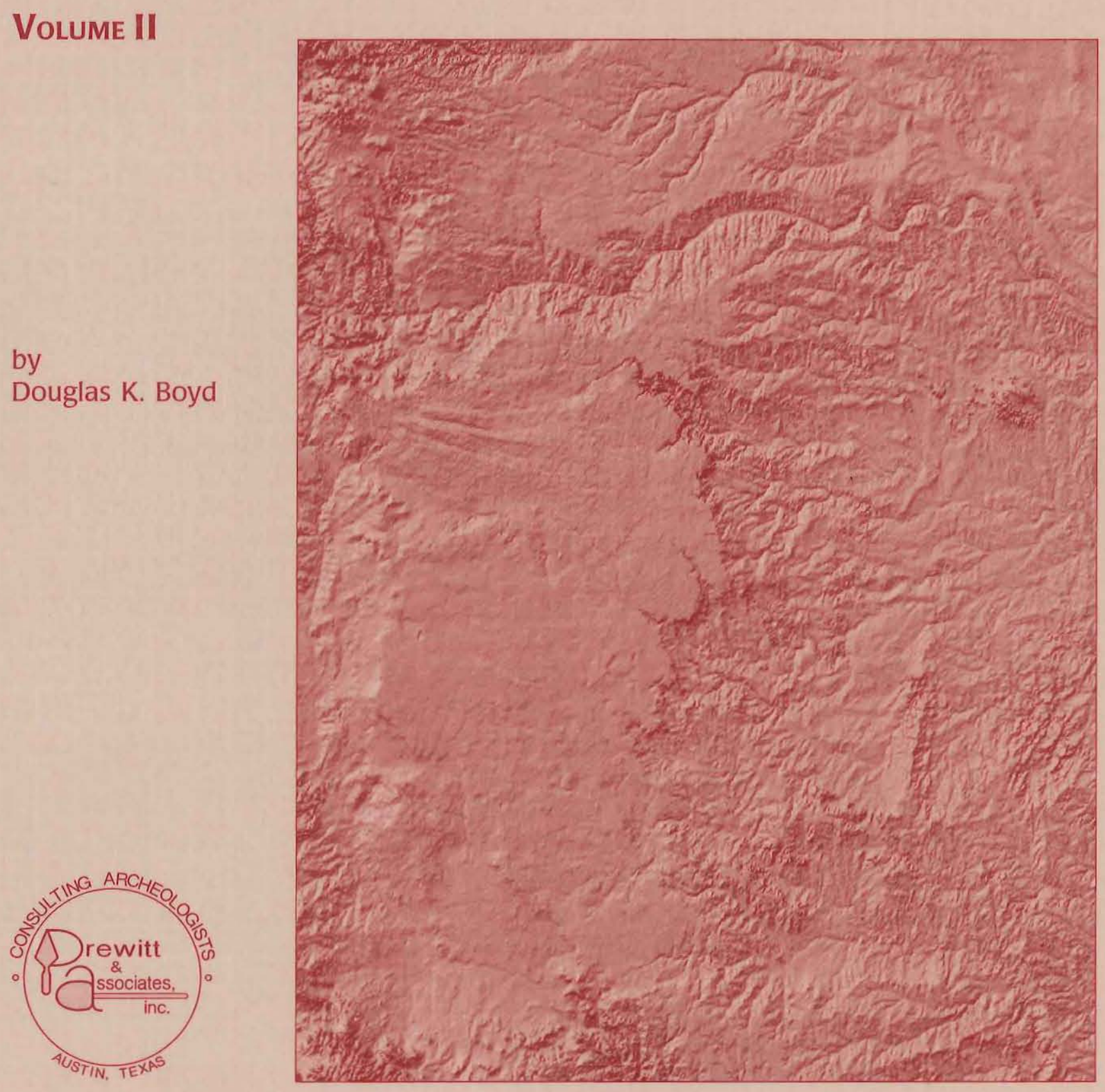

REPORTS OF INVESTIGATIONS, NUMBER 110

TEXAS ANTIQUITIES COMMITTEE ARCHEOLOGY PERMIT NO. 954 


\section{Prewitt and Associates, Inc. \\ Consulting Archeologists \\ 7701 N. Lamar, Suite 104 \\ Austin, Texas 78752-1012}

(512) 459-3349

\section{Lake Alan Henry Reports}

Phase I Cultural Resources Investigations at Justiceburg Reservoir on the Double Mountain Fork of the Brazos River, Garza and Kent Counties, Texas, by Douglas K. Boyd, Martha Doty Freeman, Michael D. Blum, Elton R. Prewitt, and J. Michael Quigg. 2 vols. Reports of Investigations No. 66. 1989 (xiv +643 pp., maps, illus., appendixes).

Phase II Investigations at Prehistoric and Rock Art Sites, Justiceburg Reservoir, Garza and Kent Counties, Texas, by Douglas K. Boyd, James T. Abbott, William A. Bryan, Colin M. Garvey, Steve A. Tomka, and Ross C. Fields. 2 vols. Reports of Investigations No. 71.1990 (xiv +571 pp., maps, illus., appendixes).

Phase II Historical Investigations at Justiceburg Reservoir, Garza and Kent Counties, Texas, by Martha Doty Freeman and Douglas K. Boyd. Reports of Investigations No. 72.1990 (ix + 156 pp., maps, illus., appendix).

Archeological Survey of Wildlife Mitigation Lands, Justiceburg Reservoir, Garza County, Texas, by Douglas K. Boyd, C. Britt Bousman, and Martha Doty Freeman. Reports of Investigations No. 79. 1991 (vii + 75 pp., maps, illus., appendix).

Data Recovery at Justiceburg Reservoir (Lake Alan Henry), Garza and Kent Counties, Texas: Phase III, Season 1, by Douglas K. Boyd, Steve A. Tomka, C. Britt Bousman, Karen M. Gardner, and Martha Doty Freeman. Reports of Investigations No. 84.1992 (xii + 256 pp., maps, illus., appendixes).

Data Recovery at Justiceburg Reservoir (Lake Alan Henry), Garza and Kent Counties, Texas: Phase III, Season 2, by Douglas K. Boyd, Jay Peck, Steve A. Tomka, and Karl W. Kibler. Reports of Investigations No. 88. 1993 (xxvi + 494 pp., maps, illus., appendixes).

Data Recovery at Lake Alan Henry (Justiceburg Reservoir), Garza and Kent Counties, Texas: Phase III, Season 3, by Douglas K. Boyd, Jay Peck, Steve A. Tomka, Karl W. Kibler, and Martha Doty Freeman. Reports of Investigations No. 93.1994 (xx +395 pp., maps, illus., appendixes).

Caprock Canyonlands Archeology: A Synthesis of the Late Prehistory and History of Lake Alan Henry and the Texas Panhandle-Plains, by Douglas K. Boyd, Steve A. Tomka, and Martha Doty Freeman. Reports of Investigations No. 110, 2 vols. 1997 (xiv +585 pp., maps, illus., appendixes). 


\title{
CAPROCK CANYONLANDS ARCHEOLOGY: A SYNTHESIS OF THE LATE PREHISTORY AND HISTORY OF LAKE ALAN HENRY AND THE TEXAS PANHANDLE-PLAINS
}

VOLUME II

by

\author{
Douglas K. Boyd \\ with Contributions by \\ Steve A. Tomka \\ and \\ Martha Doty Freeman \\ Co-Principal Investigators: Elton R. Prewitt and Ross C. Fields
}

REPORTS OF INVESTIGATIONS, NUMBER 110

Prewitt and Associates, Inc.

Consulting Archeologists

Austin, Texas

September 1997

TEXAS ANTIQUITIES COMMITTEE ARCHEOLOGY PERMIT NO. 954 


\section{VOLUME I}

CHAPTER 1: Lake Alan Henry Archeology and the Caprock Canyonlands

CHAPTER 2: Environmental Diversity in the Texas Panhandle-Plains

CHAPTER 3: Changing Perspectives in Texas Panhandle-Plains Archeology

CHAPTER 4: Archeological Research at Lake Alan Henry

CHAPTER 5: Historic Sites Investigations at Lake Alan Henry and in the Texas Panhandle-Plains

CHAPTER 6: Summary of Native American Archeology at Lake Alan Henry

CHAPTER 7: Analysis of Archeological Data from Lake Alan Henry

CHAPTER 8: Late Holocene Paleoenvironment of the Southern Texas Panhandle-Plains

\section{VOLUME II}

CHAPTER 9: The Late Archaic Period, ca. 2000 B.C. to A.D. 500

CHAPTER 10: Late Prehistoric I Period, A.D. 500 to 1100/1200

CHAPTER 11: Late Prehistoric II (A.D. 1100/1200-1541) and Protohistoric (A.D. 1541-1750) Periods

CHAPTER 12: Summary of Late Holocene Native American Adaptation in the Texas Panhandle-Plains REFERENCES CITED

APPENDIX A: Inventory and Summary of Lake Alan Henry Archeological Sites

APPENDIX B: Chronometric Dating at Lake Alan Henry

APPENDIX C: Concluding Studies

Series Technical Editor: Linda Nance Foster 


\section{TABLE OF CONTENTS}

CHAPTER 9: THE LATE ARCHAIC PERIOD, ca. 2000 B.C. to A.D. 500

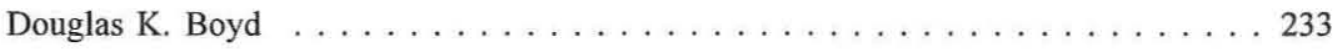

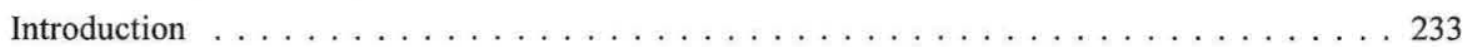

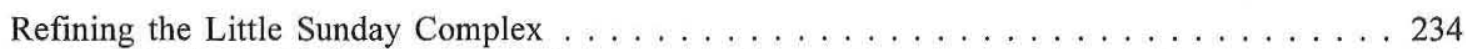

Archeological Sites of the Little Sunday Complex . . . . . . . . . . . . . . . 235

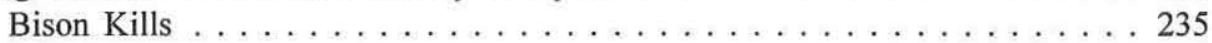

Campsites and Rockshelters . . . . . . . . . . . . . . . . . 243

Burials . . . . . . . . . . . . . . . . . . . . 253

Geographic Range . . . . . . . . . . . . . . . . . . . . . 256

Chronology, Material Culture, and Subsistence . . . . . . . . . . . . . 261

Settlement Pattern . . . . . . . . . . . . . . . . . . . . . . 264

Summary of the Little Sunday Complex . . . . . . . . . . . . . 266

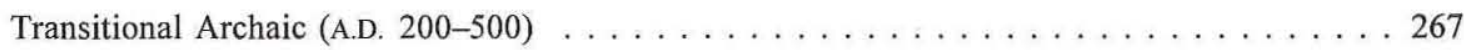

CHAPTER 10: LATE PREHISTORIC I PERIOD, A.D. 500 to $1100 / 1200$

Douglas K. Boyd . . . . . . . . . . . . . . . . . . . . . . . 271

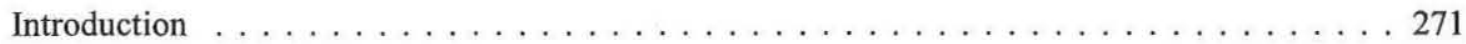

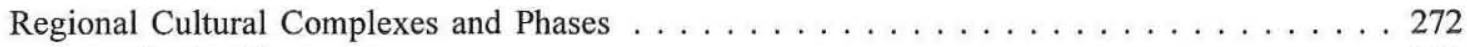

Custer Phase . . . . . . . . . . . . . . . . . . . . 272

Eastern Jornada Mogollon: Querecho and Maljamar Phases . . . . . . . . . . . 276

Middle Pecos: 18 Mile and Mesita Negra Phases . . . . . . . . . . . . . . . . 279

Blow Out Mountain Complex . . . . . . . . . . . . . . . . . . . . 280

The Lake Creek Complex: Plains Woodland Tradition in the

Northern Caprock Canyonlands . . . . . . . . . . . . . . . . . . . 281

Archeological Sites of the Lake Creek Complex/

Plains Woodland Tradition . . . . . . . . . . . . . . . . . . . 282

Possible Residential Bases . . . . . . . . . . . . . . . . . . . . . . 282

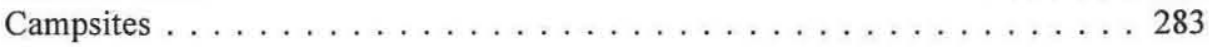

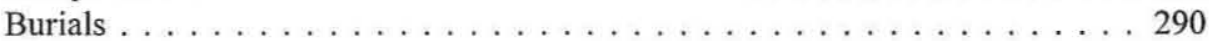

Chronology . . . . . . . . . . . . . . . . . . . . . . . . . 290

Material Culture and Features . . . . . . . . . . . . . . . . . 291

Subsistence and Site Function . . . . . . . . . . . . . . . . . 293

Seasonality and Settlement Patterns . . . . . . . . . . . . . . . . . 294

Geographic Range and Intercultural Relationships . . . . . . . . . . . . . . . . 294

The Palo Duro Complex: Southwestern Influence in the

Southern Caprock Canyonlands . . . . . . . . . . . . . . . . . . . . . . . . 295

Archeological Sites of the Palo Duro Complex . . . . . . . . . . . . . 295

Residential Bases . . . . . . . . . . . . . . . . . . . . . 295

Campsites . . . . . . . . . . . . . . . . . . . . . . . 301

Rockshelters . . . . . . . . . . . . . . . . . . . . . 304

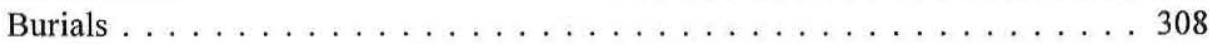

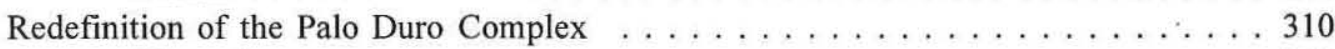

Chronology . . . . . . . . . . . . . . . . . . . . . 310

Subsistence and Site Function . . . . . . . . . . . . . . 310

Seasonality, Residential Mobility, and Settlement Pattern . . . . . . . . 326

Geographic Range and Intercultural Relationships . . . . . . . . . . . . 329 
CHAPTER 11: LATE PREHISTORIC II (A.D. 1100/1200-1541) AND

PROTOHISTORIC (A.D. 1541-1750) PERIODS

Douglas K. Boyd . . . . . . . . . . . . . . . . . . . . . . 337

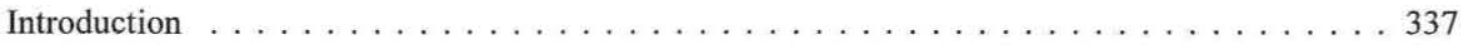

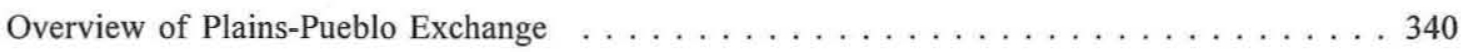

Late Prehistoric II Cultural Complexes and Phases . . . . . . . . . . . . . . 342

Antelope Creek Phase . . . . . . . . . . . . . . . . . . . . . . . . 343

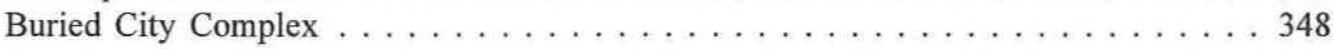

Washita River Phase . . . . . . . . . . . . . . . . . . . . . . . . . . . 349

Zimms Complex . . . . . . . . . . . . . . . . . . . . . . . . 350

Eastern Jornada Mogollon: Late Maljamar and Ochoa Phases . . . . . . . . . 351

Middle Pecos: McKenzie Phase . . . . . . . . . . . . . . . . . . . . 353

Post-Palo Duro Complex . . . . . . . . . . . . . . . . . . . . . . . . . 354

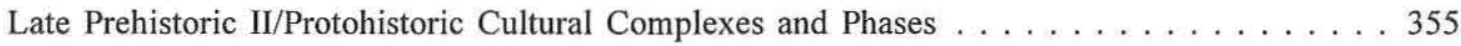

Edwards Complex . . . . . . . . . . . . . . . . . . . . 355

Wheeler Complex . . . . . . . . . . . . . . . . . . . . . . . . 359

Protohistoric Wichita . . . . . . . . . . . . . . . . . . . . . . . 359

Henrietta Complex . . . . . . . . . . . . . . . . . . . . . . 360

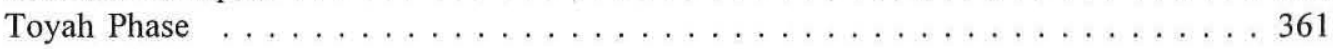

Undefined Cultural Complexes on the Southern Llano Estacado . . . . . . . . . 364

Tierra Blanca Complex . . . . . . . . . . . . . . . . . . . . . . . . . . . . . . 368

Archeological Sites . . . . . . . . . . . . . . . . . . . . . . . . . . . . 369

Residential Bases and Base Camps . . . . . . . . . . . . . . . 369

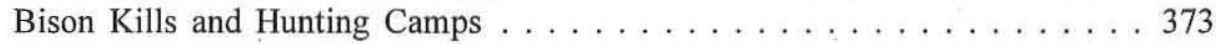

Rockshelter and Burial . . . . . . . . . . . . . . . . 376

Isolated Ceramic Vessels . . . . . . . . . . . . . . . . . . . 377

Undefined Tierra Blanca-like Sites . . . . . . . . . . . . . . 377

Garza Complex . . . . . . . . . . . . . . . . . . . . . . . . . . . . . . . 380

Archeological Sites . . . . . . . . . . . . . . . . . . . . 380

Residential Bases and Base Camps . . . . . . . . . . . . . . 380

Other Possible Residential Bases/Base Camps . . . . . . . . . . . . . . . 398

Bison Kills and Hunting Camps . . . . . . . . . . . . . . . . . . 399

Rockshelters . . . . . . . . . . . . . . . . . . . 414

Burials . . . . . . . . . . . . . . . . . . . . 418

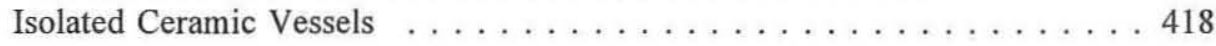

Discussion of the Tierra Blanca and Garza Complexes . . . . . . . . . . . . . . . 419

Chronology . . . . . . . . . . . . . . . . . . . . . . . . . . 419

Geographic Range . . . . . . . . . . . . . . . . . . . . . . 426

Arrow Points as Cultural and Chronological Indicators . . . . . . . . . . . . 427

Subsistence and Site Function . . . . . . . . . . . . . . . . . 430

Material Culture . . . . . . . . . . . . . . . . 430

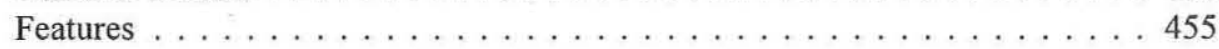

Faunal and Botanical Remains . . . . . . . . . . . . . . . . . 464

Seasonality, Residential Mobility, and Settlement Pattern . . . . . . . . . . . 471

Intercultural Relationships and Ethnicity . . . . . . . . . . . . . . . . 481 
CHAPTER 12: SUMMARY OF LATE HOLOCENE NATIVE AMERICAN ADAPTATION IN THE TEXAS PANHANDLE-PLAINS

Douglas K. Boyd . . . . . . . . . . . . . . . . . . . . 487

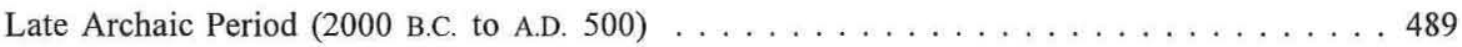

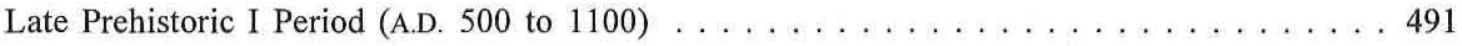

Late Prehistoric II (A.D. 1100 to 1541) and Protohistoric (A.D. 1541 to 1750) Periods . . . . 493

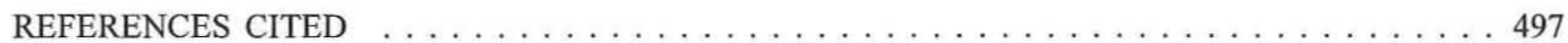

APPENDIX A: Inventory and Summary of Lake Alan Henry Archeological Sites $\ldots \ldots \ldots 47$

APPENDIX B: Chronometric Dating at Lake Alan Henry

Douglas K. Boyd . . . . . . . . . . . . . . . . . . . 563

APPENDIX C: Concluding Studies

Douglas K. Boyd . . . . . . . . . . . . . . . . . . . . . . . . 579 


\section{LIST OF FIGURES}

78. Locations of Late and transitional Archaic sites/components in the Southern Plains . . . . 237

79. Graph of calibrated radiocarbon dates for Late Archaic bison kills . . . . . . . . . . 239

80. Graph of calibrated radiocarbon dates for Late and transitional Archaic occupations . . . . 249

81. Locations of Late and transitional Archaic burials, lunate stone burials, and

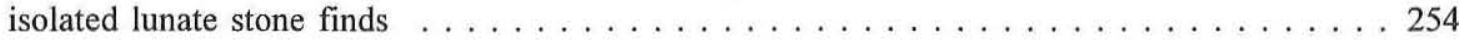

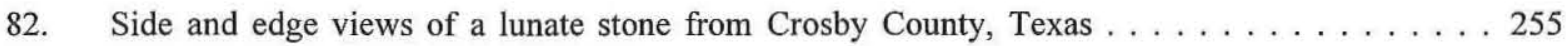

83. Large corner-notched projectile points from radiocarbon-dated contexts in the Southern Plains . . . . . . . . . . . . . . . . . . . . . . . . . . . . . . 269

84. Map of Late Prehistoric I cultural complexes in and around the Texas Panhandle-Plains . . . . . . . . . . . . . . . . . . . . . . 273

85. Map of Lake Prehistoric I sites in the Caprock Canyonlands and surrounding areas . . . . 274

86. Map of Late Prehistoric I burials in the Caprock Canylands and surrounding areas . . . . . 277

87. Graph of chronometric dates for Lake Creek/Plains Woodland components . . . . . . . . 291

88. Map of structures and features at the Kent Creek site . . . . . . . . . . . . . . . . 299

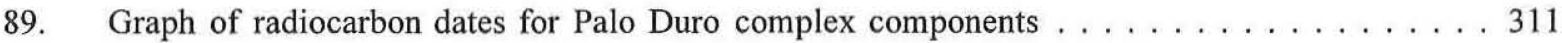

90. Comparison of artifact density and projectile point/grinding tool indexes

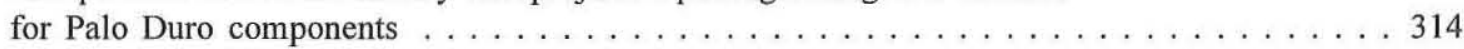

91. Early arrow points from the Sam Wahl site $\ldots \ldots \ldots \ldots \ldots \ldots \ldots \ldots \ldots \ldots \ldots \ldots \ldots$

92. Scallorn and Deadman's arrow points from the Kent Creek site $\ldots \ldots \ldots \ldots \ldots \ldots$

93. Scallorn and Deadman's arrow points from Deadman's Shelter $\ldots \ldots \ldots \ldots \ldots \ldots$

94. Map of Late Prehistoric II cultural complexes and phases in the Texas

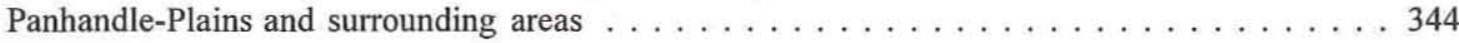

95. Map of Late Prehistoric II sites discussed in the text $\ldots \ldots \ldots \ldots \ldots \ldots \ldots \ldots \ldots$

96. Map of Late Prehistoric II/Protohistoric culture complexes and phases in the Texas Panhandle-Plains and surrounding areas $\ldots \ldots \ldots \ldots \ldots \ldots \ldots \ldots \ldots \ldots \ldots \ldots \ldots$

97. Map of Late Prehistoric II/Protohistoric sites discussed in the text $\ldots \ldots \ldots \ldots \ldots 7$

98. Map of Tierra Blanca complex sites discussed in the text $\ldots \ldots \ldots \ldots \ldots \ldots$

99. Map of Garza complex sites discussed in the text $\ldots \ldots \ldots \ldots \ldots \ldots \ldots \ldots \ldots \ldots$

100. Graph of calibrated radiocarbon and thermoluminescence dates for

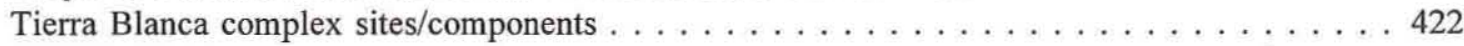

101. Graph of calibrated radiocarbon, thermoluminescence, and archeomagnetic

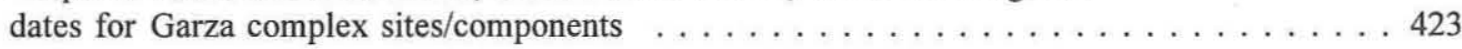

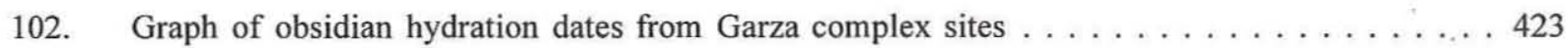

103. Comparison of adjusted artifact densities and projectile point/grinding tool

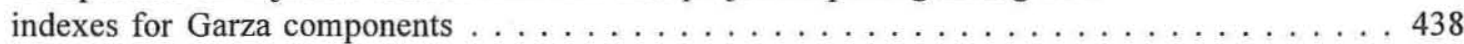


104. Generalized vessel forms represented in Tierra Blanca and Garza complex ceramic assemblages . . . . . . . . . . . . . . . . . . . . . 449

105. Comparison of interpretations of paleoenvironment, human exploitation of bison, and Native American culture history of the Caprock Canyonlands and the

Texas Panhandle-Plains during the middle to late Holocene . . . . . . . . . . . . . . . . . 490 


\section{LIST OF TABLES}

59. Selected Late and transitional Archaic bison kill/processing and habitation

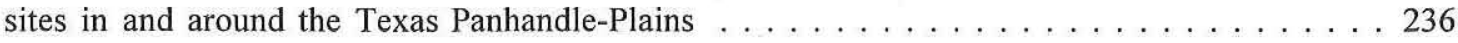

60. Late and transitional Archaic dart points found in selected survey areas

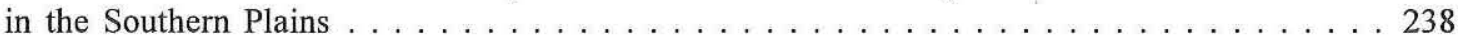

61. Summary of radiocarbon dates for Late Archaic bison kills in the Rolling Plains and Lower Pecos . . . . . . . . . . . . . . . . . . . . . . . . . . . . . 240

62. Summary of radiocarbon dates for Late and terminal Archaic occupations/

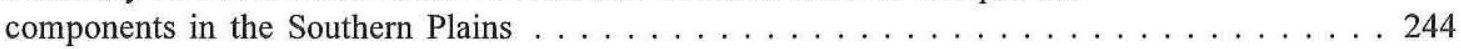

63. Summary of lunate stone finds in the Southern Plains $\ldots \ldots \ldots \ldots \ldots \ldots \ldots$

64. Summary of radiocarbon dates for Late and transitional Archaic burials . . . . . . . . 257

65. Comparison of material culture and other traits for Late Archaic components

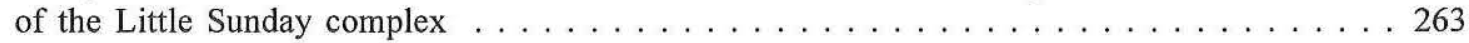

66. Selected Late Prehistoric I sites in and around the Texas Panhandle-Plains . . . . . . . 275

67. Summary of thermoluminescence and radiocarbon dates for Lake Creek complex

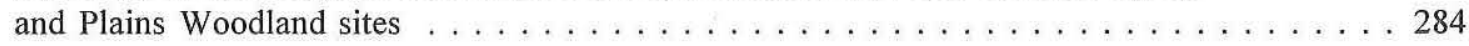

68. Artifact assemblages from selected Lake Creek/Plains Woodland components . . . . . . . . 292

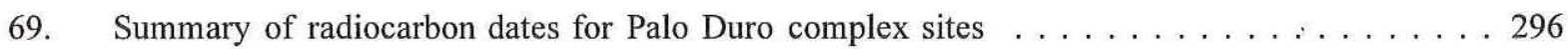

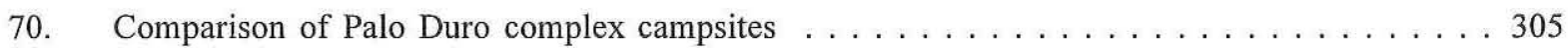

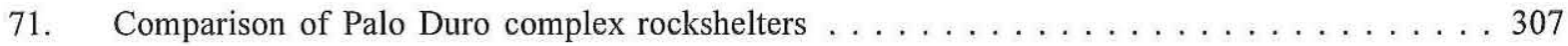

72. Summary of artifact assemblages attributed to Palo Duro complex components . . . . . 312

73. Comparison of artifact assemblages attributed to Palo Duro complex components . . . . 313

74. Comparison of grinding assemblages from the Sam Wahl and Kent Creek sites . . . . . 318

75. Comparison of size data for complete manos from Palo Duro complex residential bases . . . 319

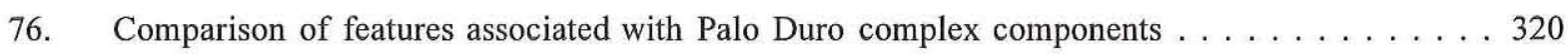

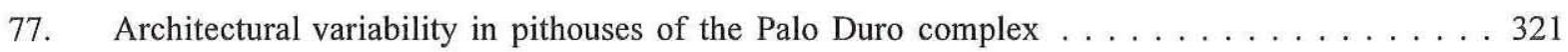

78. Comparison of faunal evidence for use of specific food resources at

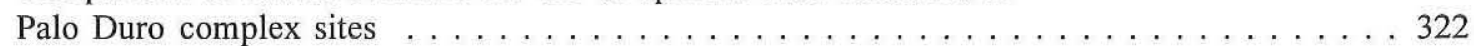

79. Comparison of macrobotanical evidence from Palo Duro complex components . . . . . . 324

80. Selected Late Prehistoric II sites in and around the Texas Panhandle-Plains . . . . . . . . . 346

81. Selected Late Prehistoric II/Protohistoric sites in and around the

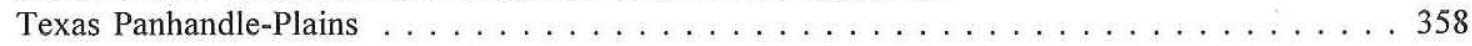

82. Texas Panhandle-Plains sites producing Perdiz arrow points $\ldots \ldots \ldots \ldots \ldots \ldots \ldots$

83. Age and relative frequency of Puebloan pottery types found on the southern

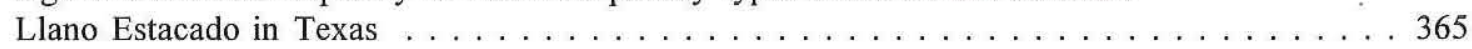

84. Summary of investigated sites on the southern Llano Estacado producing evidence of Late Prehistoric II and/or Protohistoric occupations by multiple and/or

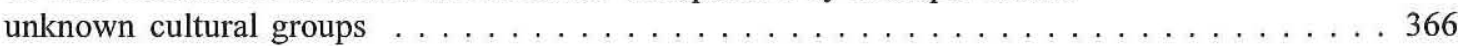


85. Tierra Blanca complex sites discussed in the text $\ldots \ldots \ldots \ldots \ldots \ldots \ldots \ldots$

86. Summary of radiocarbon dates for Tierra Blanca complex sites $\ldots \ldots \ldots \ldots \ldots \ldots$

87. Summary of artifacts recovered from excavations at the Fifth Green site . . . . . . . . 374

88. Summary of radiocarbon and thermoluminescence dates for undefined Tierra Blanca-like occupations at Palo Duro reservoir f . . . . . . . . . . . . . 378

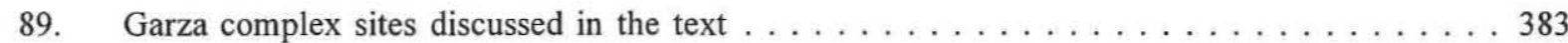

90. Summary of radiocarbon dates for Garza complex sites $\ldots \ldots \ldots \ldots \ldots \ldots$

91. Summary of artifacts recovered from the Montgomery site during the 1965 and 1978 investigations . . . . . . . . . . . . . . . . . . . . . . 394

92. Temporally diagnostic artifacts from the Floydada Country Club site . . . . . . . . . 396

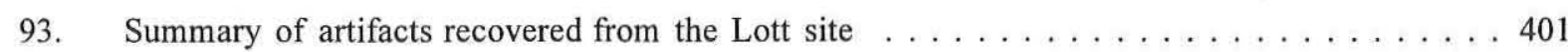

94. Intrasite spatial distributions of artifacts and features at the Lott site . . . . . . . . 402

95. Summary of chipped stone and ceramic artifacts recovered from Canyon Lakes

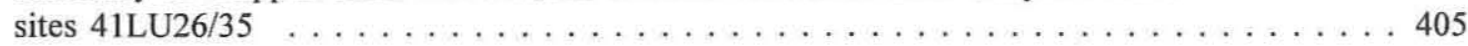

96. Comparison of artifacts recovered from the Garnsey Spring bison kill and campsite . . . . 411

97. Comparison of artifact collections from excavations at the Garnsey Spring

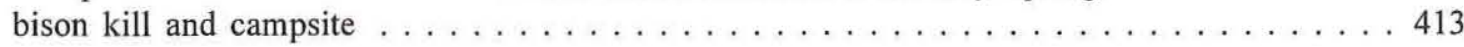

98. Cultural materials recovered from Blue Mountain Rockshelter . . . . . . . . . . . 415

99. Summary of absolute dates for tested/excavated Tierra Blanca and Garza complex

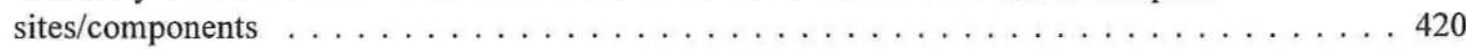

100. Chronology of Puebloan production of Rio Grande glazeware pottery . . . . . . . . 424

101. Lott and Garza points from well-dated contexts . . . . . . . . . . . . . . . 429

102. Review of material culture assemblages associated with Tierra Blanca

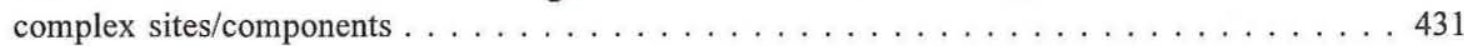

103. Review of material culture assemblages associated with Garza complex

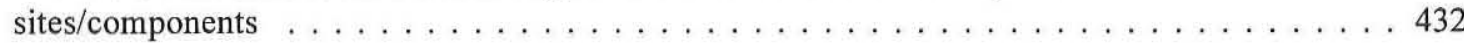

104. Summary of artifact assemblages attributed to Garza complex components . . . . . . 434

105. Comparison of artifact assemblages attributed to Garza complex components . . . . . . . 436

106. Comparison of adjusted artifact densities and estimated duration of occupations for Garza complex components . . . . . . . . . . . . . . . 437

107. Comparison of stone tool assemblages from Garza complex residential sites

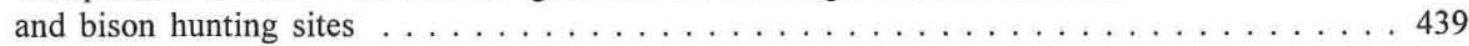

108. Summary of chipped stone assemblages for selected Garza complex sites . . . . . . . 440

109. Comparison of bifacial tool to unifacial tool ratios for residential sites,

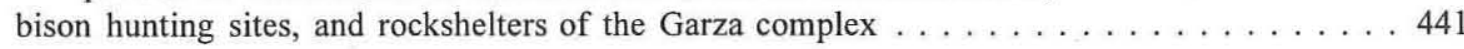

110. Frequency of unifacial scrapers in assemblages from Garza complex sites . . . . . . . 441

111. Summary of unifacial vs. bifacial lithic reduction represented in the lithic debitage assemblages from selected Garza complex sites . 
112. Summary of occurrence and completeness of manos and metates from

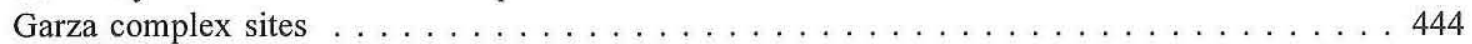

113. Summary of material types for manos and metates from Garza complex sites . . . . . . 445

114. Comparison of thickness measurements for metates from Garza complex

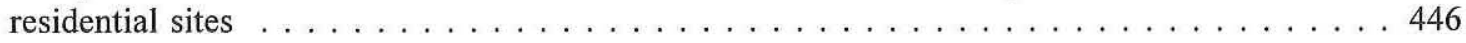

115. Comparison of size data for complete manos from Garza complex sites . . . . . . . . 446

116. Comparison of frequency of ceramic occurrence at Garza complex sites . . . . . . . . . 448

117. Summary of ceramic and stone pipes found at Garza complex sites $\ldots \ldots \ldots \ldots 50$

118. Summary of ornamental stone, bone, and shell artifacts at Garza complex sites . . . . . . 451

119. Summary of European-manufactured or -introduced artifacts recovered from Garza complex sites . . . . . . . . . . . . . . . . . . . . . . . 454

120. Comparison of features associated with Tierra Blanca complex components . . . . . . 455

121. Comparison of features and activity areas associated with Garza complex components . . . . 456

122. Summary of structures associated with Tierra Blanca and Garza complex occupations _. . . 458

123. Summary of unlined basin hearths associated with Tierra Blanca and Garza complex

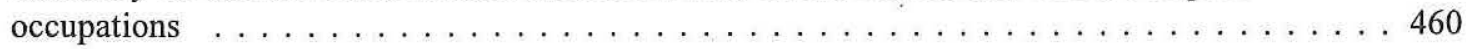

124. Summary of radiocarbon dates on unlined basin hearth and baking pits associated

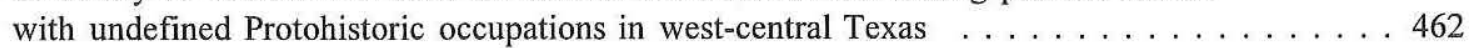

125. Summary of circular baking pits associated with Garza complex occupations . . . . . . . 463

126. Comparison of faunal evidence for use of specific food resources at

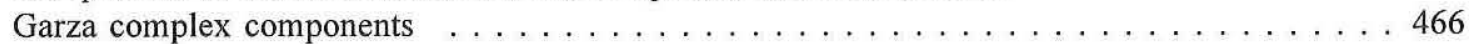

127. Identified charred seeds recovered from flotation samples from the Headstream and Longhorn sites . . . . . . . . . . . . . . . . . . . . . . . . . . . . . 469

128. Frequency of charred seeds in flotation samples from the Longhorn site

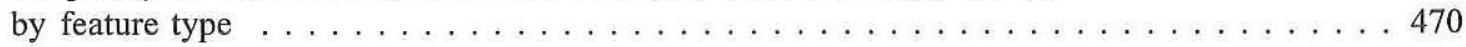

129. Summary of material types represented in chipped stone debitage from selected Garza complex sites . . . . . . . . . . . . . . . . . . . . . . . . 474

130. Summary of trace element obsidian source determinations on specimens from

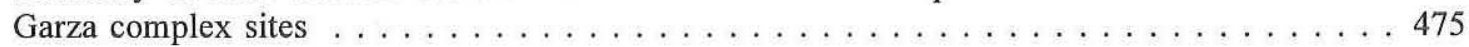

131. Summary of Puebloan and selected plainware ceramics from Tierra Blanca

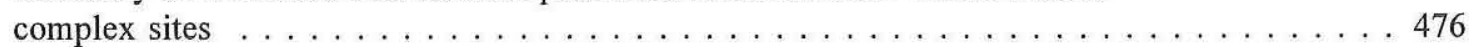

132. Summary of ceramic types recovered from Garza complex sites $\ldots \ldots \ldots \ldots \ldots \ldots$

133. Summary of archeological sites documented at Lake Alan Henry . . . . . . . . . . . . . 549

134. Summary of components defined at Lake Alan Henry archeological sites . . . . . . . . . 549

135. Inventory and summary of Lake Alan Henry archeological sites $\ldots \ldots \ldots \ldots \ldots \ldots 1$

136. Summary of radiocarbon dates by provenience and season of investigation $\ldots \ldots \ldots 66$

137. Summary of radiocarbon dates by provenience and material $\ldots \ldots \ldots \ldots \ldots 7$

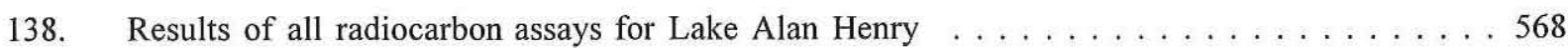

139. Results of Lake Alan Henry thermoluminescence dating . . . . . . . . . . . . . . 576 


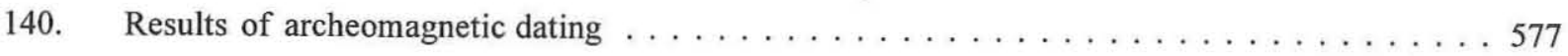





\section{THE LATE ARCHAIC PERIOD, ca. 2000 B.C. to A.D. 500}

by Douglas K. Boyd

\section{INTRODUCTION}

Paleoenvironmental data for the southern Panhandle-Plains indicate that the Late Archaic period climate was slightly drier than modern conditions but considerable more hospitable than the long droughts of the middle Holocene Altithermal period (see Chapter 8). Regional archeological data indicate that, relative to the preceding and subsequent periods, bison hunting was an extremely important subsistence activity, and a sizable proportion of the Late Archaic peoples in the Southern Plains appear to have been nomadic bison hunters who used a series of broad-bladed, corner- to sidenotched, straight- to expanding-stemmed dart points. David Hughes (1977:35-36, 1989:201) identified three varieties of these points as being similar to the following types:

Variety I cf. Ellis, Marcos, Castroville

Variety II cf. Palmillas, Williams, Ellis

Variety III cf. Trinity, Palmillas, Ensor

These three varieties can be collectively characterized, in a definition slightly modified from Lintz, Speth et al. (1991:290) to account for side-notched varieties, as being "large, thin, weakly barbed, [sideto-] corner-notched dart points with relatively short, straight-to-slightly-expanding stems, pointed-torounded barbs, and straight-to-markedly convex bases." Because of their large size, these points are often referred to as "broad-bladed" (e.g., Hughes
1976:30), and this term is used here to represent this dart point tradition (see Lintz, Speth et al. [1991:Figure 2] for an illustration of Variety I, II, and III points from the Twilla site).

Two assumptions are implicit throughout the discussions that follow. One is that these broadbladed points represent approximately contemporaneous styles. This assumption is supported by the fact that there is considerable stylistic variability among the dart points that occur in bison kills from the same general time span. In addition, such variability is evident in the seven dart points, illustrated by Gettys (1991), found in a Late Archaic triple burial in western Oklahoma. These dart points were interpreted as the cause of death for two of the three individuals in the grave, thus implying that they were in use at the same time.

The second assumption is that the specific type names for Late Archaic points are useful for characterizing the morphology of particular specimens. Most researchers in the Texas Panhandle-Plains have generally borrowed type names from Central Texas points defined in the Handbook of Texas Archeology (Suhm et al. 1954), but the Archaic archeological remains in the Panhandle-Plains region were largely unknown when this typology was devised. Many researchers (e.g., Hughes 1977:35) have lamented the fact that the Southern Plains dart points seldom fit neatly into the generic state typology. Some archeologists have assigned points to type classes in an uncritical manner, while others have avoided the 
problem altogether by not assigning type names. Still others have chosen to state that points are "type $\mathrm{x}$-like" rather than specifically identifying them. It is clear that a great deal of work remains to be done in regard to Archaic point styles and typology in the Southern Plains. For simplicity's sake, the dart point types assigned by original researchers are retained here, and no attempt to define a point typology specific to the Panhandle-Plains region is made. Be aware, however, that these type names should be viewed as gross morphological groupings and that there are many inconsistencies in point typologies of various researchers and projects.

Bison kill/butchering sites are not the only ones that have produced broad-bladed dart points; numerous campsites and rockshelters yielding these types of points have been recorded throughout the region, and several have been investigated. Collectively, these sites hint at a widespread, yet fairly coherent, Late Archaic cultural complex over a large portion of the Southern Plains (Table 59 and Figure 78).

Table 60 shows the distributions of various Late Archaic dart point types identified in selected survey areas in the Caprock Canyonlands and Rolling Plains; these data are from the following sources: Lake Alan Henry (all work by Prewitt and Associates [see Table 9]; Mackenzie Reservoir (Malone 1970:34-37; Hughes and Willey 1978:165); Mitchell Reservoir (Lintz et al. 1991:A-6-A-14; Quigg, Lintz, Oglesby, and Treece 1993:Table 8.4); Caprock Canyons State Park (Etchieson et al. 1977:47); Crowell Reservoir (Etchieson et al. 1978:86, 246-266); Truscott Reservoir (Etchieson et al. 1979:285-297); Clear Fork of the Brazos (Wulfkuhle 1986:434); Brazos Salt Pollution (Thurmond et al. 1981:77, Table 21); Dempsey Divide (Thurmond 1991a:Figure 15); and Melrose Air Force Range (Lintz et al. 1988:Table 7.1). These data provide evidence that this cultural tradition was very widespread. Comparable data do not exist for the southern High Plains because few large areas have been systematically surveyed or too few sites were found to represent a valid sample. The archeological survey at Melrose Air Force Range is included as a representative sample of Late Archaic dart points from the western edge of the Llano Estacado (i.e., the Mescalero Escarpment). Individual types are listed even if the report states that the specimen is "type X-like" or "cf. type X" rather than an absolute typological assignment.

The types that appear most consistently (i.e., in four or more survey areas) are Edgewood, Ellis, Ensor, Frio, Lange, Marcos, Marshall, Palmillas, and Williams. Six of these (all but Edgewood, Frio, and Marshall) are specifically mentioned by David Hughes $(1977,1989)$ as styles represented in Late Archaic bison kills. Jack Hughes (1991:22) also suggests that Edgewood, Ellis, Ensor, Lange, Marcos, Palmillas, Trinity, and Williams are the most common types in the Panhandle-Plains region. As Thurmond (1991a:118) observed, an intimate relatedness and precise contemporaneity of these Late Archaic points cannot be demonstrated, but all of these styles can be grouped under broad-bladed dart points. They commonly co-occur in surface contexts on sites throughout the region, and there are numerous examples of these styles co-occurring in tested or excavated sites as well. Along with their morphological similarities, the widespread distribution and general contemporaneity of these types suggest that a single cultural tradition produced them.

Many researchers have hinted at a connection between habitation sites that produce Late Archaic broad-bladed dart points and Late Archaic bison kills (e.g., Hofman 1989a:54; D. Hughes 1977:128, 1989:202; J. Hughes 1955:72, 1991:20-24; Leonhardy 1966:32; Thurmond 1991a:120), but no such concept has ever been formally defined. Only two archeological manifestations, the Little Sunday and Summers complexes, have been proposed, and neither of these adequately portrays what is now known for the Late Archaic period. The remainder of this chapter is an effort to redefine the Little Sunday complex to account for the Late Archaic broad-bladed bison hunting tradition in the Texas Panhandle-Plains and western Oklahoma.

\section{REFINING THE LITTLE SUNDAY COMPLEX}

Hughes (1955:72) proposed the name "Little Sunday" to represent the poorly understood Archaic remains in the Panhandle-Plains, but the archeological evidence from the Little Sunday site was limited to a small surface collection of artifacts presumably representing a single component. The Little Sunday site is now known to represent the Late Archaic period (J. Hughes 1991:21), but the complex was never adequately defined because there were no data on chronology, site function, or subsistence. In addition, some researchers outside the Southern 
Plains have misrepresented this complex and further confused the situation. For example, it has been stated that the Little Sunday complex was defined based on excavations at the site (Gunnerson 1987:39).

In contrast, the "Summers complex" was defined by Leonhardy (1966) based on a discrete assemblage of excavated and dated archeological materials in western Oklahoma, and researchers have noted that it appears to be a valid complex (e.g., Hughes 1984:112, 117). However, no additional sites have been attributed to the Summers complex.

Both the Little Sunday and Summers complexes have been discussed in the regional literature (e.g., Hofman 1989a:54, 59), but neither has been updated beyond its original definition. The two sites are located only $185 \mathrm{~km}$ (115 miles) apart, and both yielded artifacts suggesting cultural connections with Late Archaic bison kills. When viewed from a regional standpoint, they do not appear to be sufficiently different to warrant separate designations. A redefinition that combines these concepts should go by the name Little Sunday complex due to its historical precedent, although the Summers complex was much better defined (i.e., the data are more reliable in terms of archeological context and chronology).

In the discussions that follow, the Little Sunday complex is expanded from its original definition to encompass a great deal of old and new archeological information relating to the bison hunting Late Archaic peoples of the Southern Plains. This complex is not intended to represent a particular group of people and in no way approximates a cultural phase (as discussed by L. Johnson 1987). More appropriately, the Little Sunday complex is a concept that brings together a variety of archeological remains that represent a widespread and longlived cultural tradition or lifestyle that almost certainly crosscut cultural (e.g., linguistic and tribal) boundaries.

\section{Archeological Sites of the Little Sunday Complex}

\section{Bison Kills}

A large number of Late Archaic bison kills in the Rolling Plains indicate that the Little Sunday complex peoples relied heavily upon bison for subsistence during at least part of the year. Several kill/butchering sites have been reported, but only the Bell, Certain, Collier, Strong, and Twilla sites have been tested or excavated (Bement and Buehler 1994; Hughes 1977, 1989; Tunnell and Hughes 1955). A fifth site, the Kenton bison kill (34CI81) in Cimarron County, Oklahoma, also has been tested and could be Late Archaic in age, but it has not been dated and no diagnostics were recovered (Lintz 1976).

Most of the kills that have been tested, and several that have not, appear to represent natural impoundments at the heads of large arroyos (Hughes 1977:148; Bement and Buehler 1994:175). While it is possible that the kill at the Twilla site may have been a jump (Hughes 1977:60), arroyo traps seem to have been the preferred method of dispatching large numbers of animals, presumably in well-organized communal hunting ventures. As Hughes (1977:60) states, an arroyo would have "served admirably as both drive lane and impoundment for the kill."

Radiocarbon dates from bison kills, in direct association with the distinctive broad-bladed dart points, have been obtained for five sites in the Rolling Plains and one in the Lower Pecos (Table 61). The dating results from the Rolling Plains sites are not without problems. Hughes (1977) noted the disparity between the four radiocarbon dates that were first obtained from the Bell, Collier, Strong, and Twilla sites. Lintz, Speth et al. (1991) reported three additional dates for the Twilla site and discussed the problems with interpreting the bison kill dates. The four original dates reported by Hughes (1977) were done before fractionation corrections became standard, and no $\delta^{13} \mathrm{C}$ values were obtained. The $\delta^{13} \mathrm{C}$ values obtained on the three dates reported by Lintz, Speth et al. (1991) are inexplicably varied, ranging from -0.07 to -16.58 . Both Hughes and Lintz noted the possibility that the bone samples might have been contaminated because they had been improperly sampled and/or stored prior to being dated.

Radiocarbon dates for the Certain site in western Oklahoma have become available recently and provide the most reliable chronological evidence for a Late Archaic bison kill site. Five assays (four on bone collagen and one on charcoal) yielded calibrated radiocarbon ages that fall between A.D. 240 and 616, overlapping around A.D. 400 . These dates are from three separate areas of the site and could represent different kill events, but it appears that they all occurred within a relatively 
TABLE 59

SELECTED LATE AND TRANSITIONAL ARCHAIC BISON KILL/PROCESSING AND HABITATION SITES IN AND AROUND THE TEXAS PANHANDLE-PLAINS

\begin{tabular}{|c|c|c|}
\hline $\begin{array}{l}\text { Key to } \\
\text { Figure } 78\end{array}$ & Site Name (Number) & Reference \\
\hline \multicolumn{3}{|c|}{ BISON KILL/BUTCHERING SITES } \\
\hline $\begin{array}{r}1 \\
2 \\
3 \\
4 \\
5 \\
6 \\
7 \\
8 \\
9 \\
10 \\
11\end{array}$ & $\begin{array}{l}\text { Bell (PPHM-A696) } \\
\text { Certain (34BK46) } \\
\text { Collier (PPHM-A373) } \\
\text { Strong (PPHM-A694) } \\
\text { Twilla (PPHM-A73) } \\
\text { Buzzards Roost } \\
\text { Finch (PPHM-A128) } \\
\text { Hoover (PPHM-P96) } \\
\text { R.O. Ranch (PPHM-A695) } \\
\text { Sitter (PPHM-A127) } \\
\text { Sanders (41HF128)* }\end{array}$ & $\begin{array}{l}\text { Hughes } 1977,1989 \\
\text { Bement and Buehler } 1994 \\
\text { Hughes } 1977,1989 \\
\text { Hughes } 1977,1989 \\
\text { Hughes } 1977,1989 \\
\text { Hughes } 1977,1989 \\
\text { Hughes } 1977,1989 \\
\text { Hughes } 1977,1989 \\
\text { Hughes } 1977,1989 \\
\text { Hughes 1977, } 1989 \\
\text { Quigg, Lintz, Oglesby, Earls et al. } 1993\end{array}$ \\
\hline \multicolumn{3}{|c|}{ CAMPSITES } \\
\hline $\begin{array}{l}12 \\
13 \\
14 \\
15 \\
16 \\
17 \\
18 \\
19 \\
20 \\
21 \\
22 \\
23 \\
24 \\
25 \\
26 \\
27 \\
28 \\
29 \\
30 \\
31\end{array}$ & $\begin{array}{l}\text { Little Sunday (PPHM-A160) } \\
\text { Summers (34GR12) } \\
\text { Gobbler Creek Bridge (41GR383) } \\
41 \text { KT32 } \\
\text { Van York (41BD8) } \\
\text { 34RM334 } \\
\text { PPHM-A704 } \\
\text { Chalk Hollow (41RD51) } \\
\text { Beaver Dam (34RM208) } \\
\text { Swift Horse (34RM501) } \\
\text { County Line (41BI33) } \\
\text { 41BI90 } \\
\text { Bitter Creek (41HL62) and Polecat (41HL63) } \\
\text { Lake Creek (PPHM-A48) } \\
\text { Sandy Ridge (41HF5) } \\
\text { East Levee (41TG91) } \\
\text { Unnamed "Ellis" site } \\
\text { SPAS-LU10 } \\
\text { 41LU29/34 } \\
\text { 41LU75 }\end{array}$ & $\begin{array}{l}\text { Hughes } 1955 \\
\text { Leonhardy } 1966 \\
\text { Boyd et al. 1992; this volume } \\
\text { Denton } 1983 \\
\text { Mack } 1994 \\
\text { Thurmond } 1989 \\
\text { Pearson 1974 } \\
\text { Wedel 1975; Lintz 1995 } \\
\text { Thurmond 1988a, 1988b, 1988c, 1991a } \\
\text { Briscoe 1987, 1989a } \\
\text { Willey and Hughes 1978a } \\
\text { Katz and Katz 1976 } \\
\text { Hughes and Hood 1976 } \\
\text { Hughes 1962 } \\
\text { Quigg, Lintz, Oglesby, Earls et al. } 1993 \\
\text { Creel 1990 } \\
\text { Warnica 1965 } \\
\text { Brown 1990a, 1990b, 1991a, 1991b } \\
\text { Brown 1985 } \\
\text { Brown n.d. }\end{array}$ \\
\hline \multicolumn{3}{|c|}{ MESA-TOP CAMPSITES } \\
\hline $\begin{array}{l}32 \\
33 \\
34 \\
35\end{array}$ & $\begin{array}{l}\text { Cowhead Mesa (41GR120) } \\
\text { L-7 Mesa } \\
\text { Z-Bar-L Mesa (41CB32) } \\
\text { Red Butte (41BI238) }\end{array}$ & $\begin{array}{l}\text { Bilbo } 1986 \text {; Walter } 1992 \text {, n.d. } \\
\text { Walter 1992, n.d. } \\
\text { Walter 1992, n.d. } \\
\text { Etchieson et al. } 1977\end{array}$ \\
\hline \multicolumn{3}{|c|}{ ROCKSHELTERS } \\
\hline $\begin{array}{l}36 \\
37 \\
38 \\
39 \\
40\end{array}$ & $\begin{array}{l}\text { Blue Spring Shelter (PPHM-A485) } \\
\text { Canyon City Club Cave (PPHM-A251) } \\
\text { Deadman's Shelter (41SW23) } \\
\text { Boren Shelter No. } 2 \text { (41GR559) } \\
\text { Red Bluff Shelter (SMU-X41CX8) }\end{array}$ & $\begin{array}{l}\text { Hughes } 1978 \\
\text { Hughes } 1969 \\
\text { Willey and Hughes } 1978 \mathrm{~b} \\
\text { Peck et al. 1994b; this volume } \\
\text { Lorrain } 1968\end{array}$ \\
\hline
\end{tabular}

*Additional excavations reported by Quigg (1997b) indicate that the Sanders site is actually a campsite/bison processing site. 


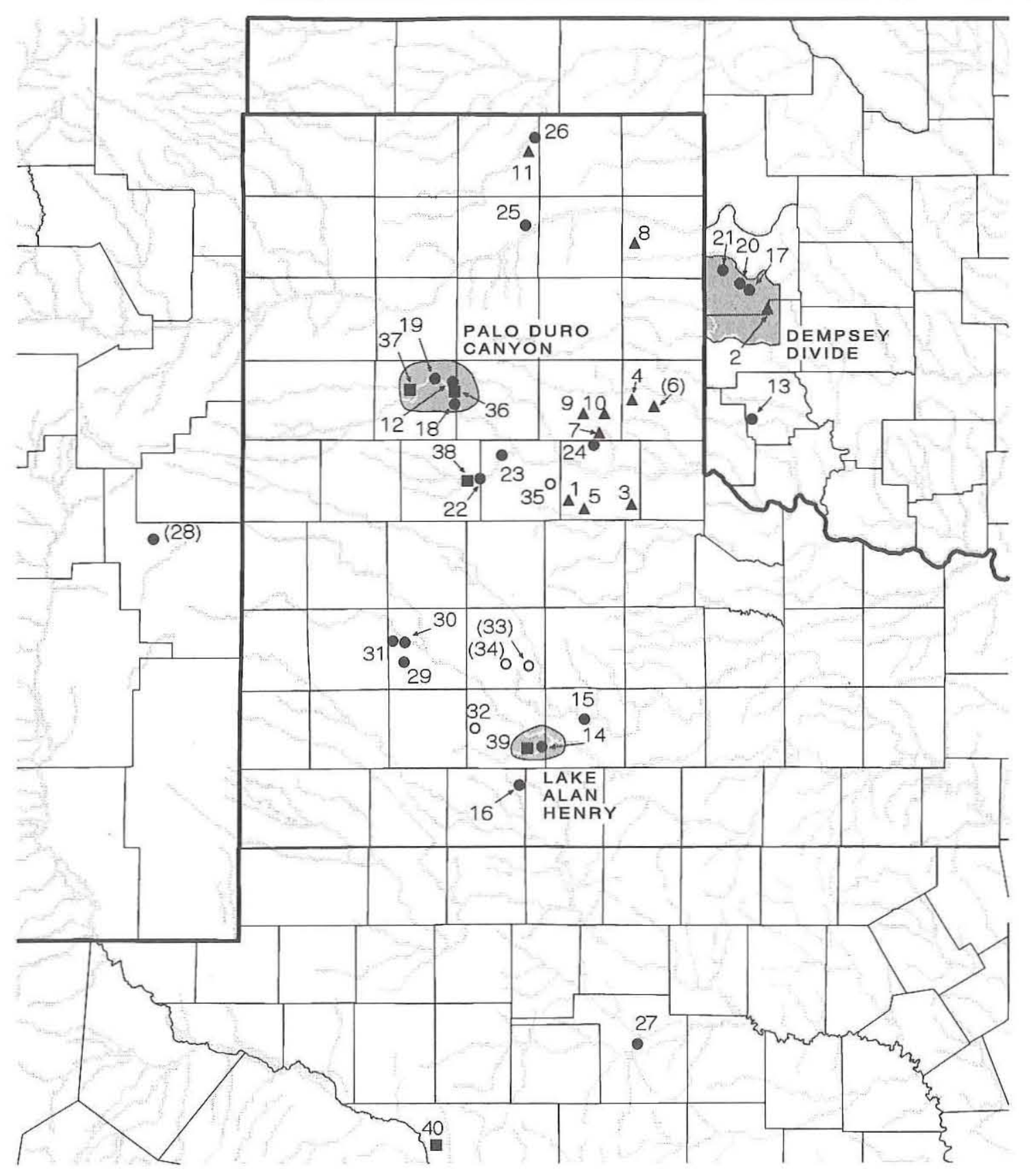

LATE ARCHAIC SITES

- Rockshelter

- Campsite

- Mesa-Top Campsite

A Bison Kill/Butchering Site

( ) Location not Precise

Archeological Area

PAIIITISLH

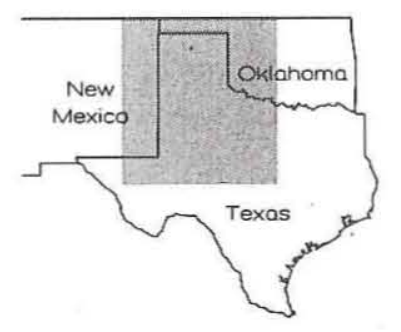

Figure 78. Locations of Late and transitional Archaic sites/components in the Southern Plains (excluding burials). 
TABLE 60

LATE AND TRANSITIONAL ARCHAIC DART POINTS FOUND IN SELECTED SURVEY AREAS IN THE SOUTHERN PLAINS

\begin{tabular}{|c|c|c|c|c|c|c|c|c|c|c|}
\hline \multirow[b]{2}{*}{ Type Name } & \multicolumn{5}{|c|}{ CAPROCK CANYONLANDS } & \multicolumn{4}{|c|}{ ROLLING PLAINS } & \multirow{2}{*}{$\begin{array}{c}\text { OTHER } \\
\text { Melrose Air } \\
\text { Force Range }\end{array}$} \\
\hline & $\begin{array}{l}\text { Lake Alan } \\
\text { Henry }\end{array}$ & $\begin{array}{l}\text { Mackenzie } \\
\text { Reservoir }\end{array}$ & $\begin{array}{l}\text { Mitchell } \\
\text { Reservoir }\end{array}$ & $\begin{array}{l}\text { Caprock Canyons } \\
\text { State Park }\end{array}$ & $\begin{array}{l}\text { Crowell } \\
\text { Reservoir }\end{array}$ & $\begin{array}{l}\text { Truscott } \\
\text { Reservoir }\end{array}$ & $\begin{array}{l}\text { Clear Fork of } \\
\text { the Brazos }\end{array}$ & $\begin{array}{l}\text { Brazos Salt } \\
\text { Pollution }\end{array}$ & $\begin{array}{l}\text { Dempsey } \\
\text { Divide }\end{array}$ & \\
\hline Carrizo & & & & & $\mathrm{x}$ & & & & & \\
\hline Castroville & $\mathrm{x}$ & & & & $\mathrm{x}$ & & & $\mathrm{x}$ & & \\
\hline Catán & & & & & $\mathrm{x}$ & & & & & \\
\hline Darl & & & & & $\mathrm{x}$ & $\mathrm{x}$ & $\mathrm{x}$ & & & \\
\hline Edgewood & & $\mathrm{x}$ & & & & $\mathrm{x}$ & $\mathrm{x}$ & $\mathrm{x}$ & & $\mathrm{x}$ \\
\hline Elam & & $\mathrm{x}$ & $\mathrm{x}$ & $\mathrm{x}$ & $\mathrm{x}$ & & & & & \\
\hline Ellis & & $\mathrm{x}$ & $\mathrm{x}$ & & $\mathrm{x}$ & $\mathrm{x}$ & & & $\mathrm{x}$ & $\mathrm{x}$ \\
\hline Ensor & $\mathrm{x}$ & & $\mathrm{x}$ & & & $\mathrm{x}$ & $\mathrm{x}$ & $\mathrm{x}$ & $\mathrm{x}$ & $\mathrm{x}$ \\
\hline Fairland & & $\mathrm{x}$ & & & & $\mathrm{x}$ & $\mathrm{x}$ & & & \\
\hline Frio & & & $\mathrm{x}$ & & $\mathrm{x}$ & $\mathrm{x}$ & & & $\mathrm{x}$ & \\
\hline $\begin{array}{l}\text { Godley/ } \\
\text { Yarbrough }\end{array}$ & & & & & & & & & & $\mathrm{x}$ \\
\hline Kent & & $\mathrm{x}$ & & & $\mathrm{x}$ & $\mathrm{x}$ & & & & \\
\hline Lange & & & & & $\mathrm{x}$ & $\mathrm{x}$ & & & & $\mathrm{x}$ \\
\hline Marcos & $\mathrm{x}$ & $\mathrm{x}$ & & & $\mathrm{x}$ & $\mathrm{x}$ & & & $\mathrm{x}$ & $\mathrm{x}$ \\
\hline Marshall & $\mathrm{x}$ & & & & & $\mathrm{x}$ & & $\mathrm{x}$ & $\mathrm{x}$ & \\
\hline Palmillas & & & & & $\mathrm{x}$ & $\mathrm{x}$ & & & $\mathrm{x}$ & \\
\hline Trinity & & & & & $\mathrm{x}$ & & & $\mathrm{x}$ & & \\
\hline Williams & & & $\mathrm{x}$ & & $\mathrm{x}$ & & & & $\mathrm{x}$ & $\mathrm{x}$ \\
\hline
\end{tabular}


short time. The three youngest bone dates produced $\delta^{13} \mathrm{C}$ values that range between -10.4 and -13.3 . These values are consistent with expectations for ${ }^{14} \mathrm{C}$ fractionation of Late Archaic bison bone and indicate that the dated samples are not contaminated.

To get reliable age estimates for the earlier assays, they need to be corrected and calibrated. In his summary of Late Archaic period sites, Thurmond (1991a:Tables 2-4) corrected these dates using a $\delta^{13} \mathrm{C}$ value of $-20 \pm 2$, which is recommended by Stuiver and Polach (1977) as a general estimate for all bone collagen. Based on bison isotope studies, however, the $\delta^{13} \mathrm{C}$ values for the Certain site bone samples appear to be better estimates. Consequently, each of the uncorrected dates was corrected in Table 61 using a $\delta^{13} \mathrm{C}$ value of -12.2 , which is the average of the three values obtained for the Certain site bison bone collagen dates, and calibrated according to Stuiver and Reimer (1993). Collectively, the dates suggest that Late Archaic bison kills occurred as early as 362 B.C. and as late as A.D. 988 (Figure 79). While the beginning date is acceptable, the terminal date is questionable.

The dates for the Twilla site suggest that there were two kill episodes widely separated in time, and field records indicate that there may have been two bone beds separated by a thin, sterile horizon of silt (Hughes 1989:187). The bison remains from the Collier site date to 357 B.C. to A.D. 1 and may be contemporaneous with the earlier kill at Twilla. None of the bison kill dates fall between A.D. 1 and 176 , but this gap is probably related to sample size rather than an absence of bison hunting during this time. The Bell and Certain site kills occurred between A.D. 176 and 616, most likely around A.D. 400. The later dates from Twilla are not troublesome because this kill could date toward the earlier part of its 1-sigma range. One reasonable interpretation is that the Bell, Certain, and late Twilla kills all occurred between A.D. 350 and 550 .

The single date from the Strong site (A.D. 691-988) is the only one that is problematical because it is significantly later than all of the others. Notably, no points have been recovered from the Strong site, however, and the interpretation that it is Late Archaic is based on its geologic setting (Hughes 1977:86-88). One can only speculate that (1) the date is incorrect or (2) the date is correct but the kill is not Late Archaic (i.e., it represents a Woodland period kill).

If the Strong site is excluded, all of the Rolling

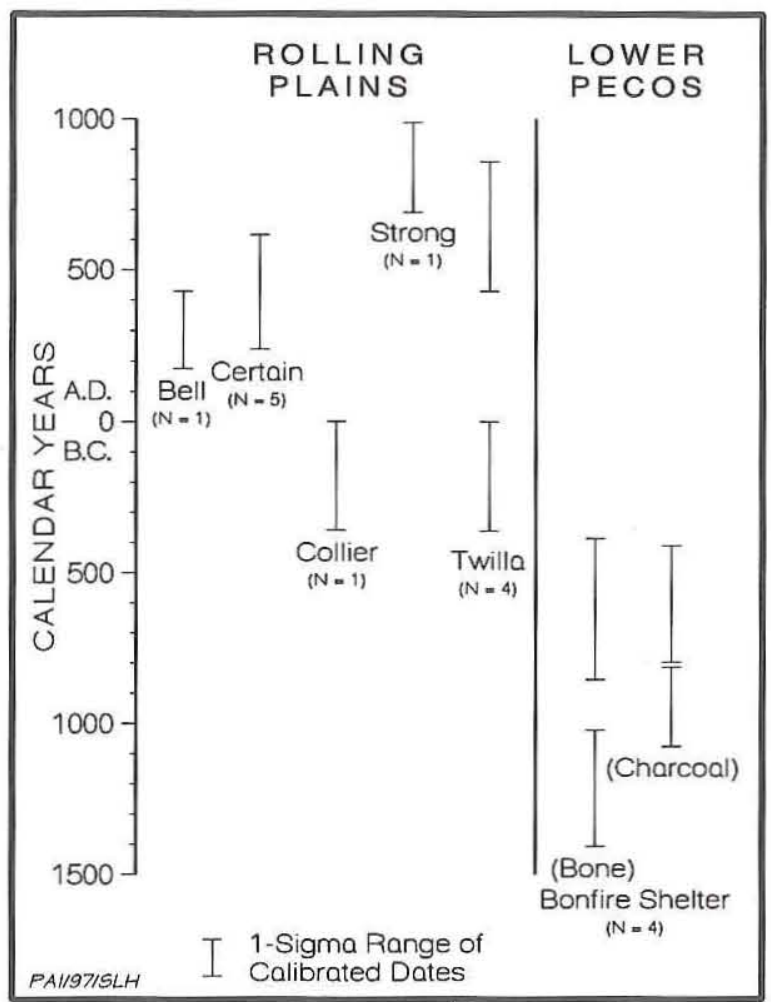

Figure 79. Graph of calibrated radiocarbon dates for Late Archaic bison kills (1-sigma ranges presented in Table 61; some are based on estimated $\delta^{13} \mathrm{C}$ values).

Plains bison kills may date between 400 B.C. and A.D. 600 . Notably, similar dart point styles (i.e., Castroville, Marcos, and Montell) have been radiocarbon dated in Central Texas at 300 B.C. to A.D. 550 in Prewitt's $(1981,1983)$ Uvalde and Twin Sisters phases (discussed below). Chronological placement of several other Rolling Plains bison kill localities (i.e., Buzzards Roost, Finch, Hoover, R.O. Ranch, and Sitter sites) discussed by Hughes (1977, 1989) is vague, but their geomorphic settings and/or associations with broad-bladed dart points indicate a Late Archaic affiliation.

The campsites and rockshelters discussed below suggest that the Late Archaic period began around 2000 B.C., and it is perplexing that all of the bison kills date after 400 B.C. Hughes (1977:26-28, 129-130, 1989:202) noted that all of the Texas kills apparently occurred near the end of a major period of arroyo cutting that ended 2,000 to 1,500 years ago when wetter conditions caused the subsequent gully filling. Thurmond (1991a:121) observed that the Certain site is in a similar geological setting and suggested that the sample of bison kills is skewed 
TABLE 61

SUMMARY OF RADIOCARBON DATES FOR LATE ARCHAIC BISON KILLS IN THE ROLLING PLAINS AND LOWER PECOS

\begin{tabular}{|c|c|c|c|c|c|c|c|}
\hline \multirow{2}{*}{$\begin{array}{l}\text { Site Name } \\
\text { and Number }\end{array}$} & \multirow[b]{2}{*}{ Reference } & \multirow{2}{*}{$\begin{array}{l}\text { Material and } \\
\text { Lab No. }{ }^{1}\end{array}$} & \multirow{2}{*}{$\begin{array}{l}\text { Uncorrected } \\
\text { Age, B.P. }\end{array}$} & \multirow{2}{*}{$\begin{array}{l}\delta^{13} \mathrm{C} \\
\% 0\end{array}$} & \multicolumn{2}{|c|}{ Corrected $^{2}$} & \multirow{2}{*}{$\begin{array}{l}\text { Calibrated Date Range and } \\
\text { Intercepts, B.C./A.D. }\end{array}$} \\
\hline & & & & & Age, B.P. & Date, B.C./A.D. & \\
\hline \multicolumn{8}{|c|}{ ROLLING PLAINS } \\
\hline $\begin{array}{l}\text { Bell } \\
41 \mathrm{HL} 65\end{array}$ & $\begin{array}{l}\text { Hughes 1977:131 } \\
\text { Lintz, Speth et al. 1991: } \\
\text { Table 1 }\end{array}$ & $\begin{array}{l}\text { Bone } \\
\text { RL-573 }\end{array}$ & $1520 \pm 110$ & $*$ & {$[1726 \pm 117]$} & [A.D. $224 \pm 117$ ] & [A.D. $176(264,275,340) 428]$ \\
\hline \multirow{5}{*}{$\begin{array}{l}\text { Certain } \\
\text { 34BK46 }\end{array}$} & \multirow{5}{*}{$\begin{array}{l}\text { Bement and Buehler } 1994 \\
\left({ }^{13} \mathrm{C} \text { values obtained courtesy }\right. \\
\text { of K. C. Kraft) }\end{array}$} & $\begin{array}{l}\text { Bone } \\
\text { Beta-28121 }\end{array}$ & $1400 \pm 70$ & * & {$[1606 \pm 81]$} & [A.D. $344 \pm 81$ ] & [A.D. $364(428,525) 543]$ \\
\hline & & $\begin{array}{l}\text { Bone } \\
\text { Beta-55386 }\end{array}$ & $1440 \pm 70$ & -10.4 & $1680 \pm 70$ & A.D. $270 \pm 70$ & A.D. $260(394) 428$ \\
\hline & & $\begin{array}{l}\text { Bone } \\
\text { Beta-55429 }\end{array}$ & $1370 \pm 90$ & -13.3 & $1560 \pm 90$ & A.D. $390 \pm 90$ & A.D. $416(537) 616$ \\
\hline & & $\begin{array}{l}\text { Bone } \\
\text { Beta-55837 }\end{array}$ & $1370 \pm 80$ & -12.8 & $1570 \pm 80$ & A.D. $380 \pm 80$ & A.D. $416(435,446,536) 600$ \\
\hline & & $\begin{array}{l}\text { Charcoal } \\
\text { Beta-66019 }\end{array}$ & $1730 \pm 60$ & -24.1 & $1740 \pm 60$ & A.D. $210 \pm 60$ & A.D. $240(262,278,295,324) 407$ \\
\hline $\begin{array}{l}\text { Collier } \\
\text { 41HL64 }\end{array}$ & $\begin{array}{l}\text { Hughes 1977:131 } \\
\text { Lintz, Speth et al. 1991: } \\
\text { Table 1 }\end{array}$ & $\begin{array}{l}\text { Bone } \\
\text { RL-571 }\end{array}$ & $1930 \pm 110$ & $*$ & {$[2136 \pm 117]$} & {$[186$ B.C. \pm 117$]$} & [357 B.C. (168 B.C.) A.D. 1] \\
\hline $\begin{array}{l}\text { Strong } \\
41 \text { CG31 }\end{array}$ & $\begin{array}{l}\text { Hughes 1977:131 } \\
\text { Lintz, Speth et al. 1991: } \\
\text { Table 1 }\end{array}$ & $\begin{array}{l}\text { Bone } \\
\text { RL-572 }\end{array}$ & $980 \pm 100$ & * & {$[1186 \pm 108]$} & [A.D. $764 \pm 108$ ] & [A.D. $691(784,786,877) 988$ ] \\
\hline \multirow{4}{*}{$\begin{array}{l}\text { Twilla } \\
41 \mathrm{HL} 1\end{array}$} & \multirow{4}{*}{$\begin{array}{l}\text { Hughes 1977:131 } \\
\text { Lintz, Speth et al. 1991: } \\
\text { Table 1 }\end{array}$} & $\begin{array}{l}\text { Bone } \\
\text { Beta-1927 }\end{array}$ & $1925 \pm 95$ & -0.07 & $\begin{array}{c}2335 \pm 100 \\
{[2131 \pm 103]}\end{array}$ & $\begin{array}{l}385 \text { B.C. } \pm 100 \\
{[181 \text { B.C. } \pm 103]}\end{array}$ & $\begin{array}{l}\text { 497-213 B.C. } \\
{[353 \text { B.C. }(167 \text { B.C. }) \text { A.D. 0] }}\end{array}$ \\
\hline & & $\begin{array}{l}\text { Bone } \\
\text { Beta-1928 }\end{array}$ & $1290 \pm 95$ & -8.98 & $\begin{array}{c}1550 \pm 100 \\
{[1496 \pm 103]}\end{array}$ & $\begin{array}{l}\text { A.D. } 400 \pm 100 \\
\text { [A.D. } 454 \pm 103\end{array}$ & $\begin{array}{l}\text { A.D. } 416-639 \\
\text { [A.D. } 429(582,589,598) 653]\end{array}$ \\
\hline & & $\begin{array}{l}\text { Bone } \\
\text { Beta-1929 }\end{array}$ & $1970 \pm 85$ & -16.58 & $\begin{array}{c}2110 \pm 85 \\
{[2176 \pm 94]}\end{array}$ & $\begin{array}{c}160 \text { в.C. } \pm 85 \\
{[226 \text { в.с. } \pm 94]}\end{array}$ & $\begin{array}{l}346 \text { B.C.-A.D. } 1 \\
{[362(201,185,174) 53 \text { B.C.] }}\end{array}$ \\
\hline & & $\begin{array}{l}\text { Bone } \\
\text { RL-570 }\end{array}$ & $1120 \pm 100$ & $*$ & {$[1326 \pm 108]$} & [A.D. $624 \pm 108$ ] & [A.D. $641(688)$ 859] \\
\hline
\end{tabular}




\begin{tabular}{|c|c|c|c|c|c|c|c|}
\hline \multicolumn{8}{|c|}{ Table 61 , continued } \\
\hline \multirow[b]{2}{*}{$\begin{array}{l}\text { Site Name } \\
\text { and Number }\end{array}$} & \multirow[b]{2}{*}{ Reference } & \multirow[b]{2}{*}{$\begin{array}{l}\text { Material and } \\
\text { Lab No. }\end{array}$} & \multirow[b]{2}{*}{$\begin{array}{l}\text { Uncorrected } \\
\text { Age, B.P. }\end{array}$} & \multirow[b]{2}{*}{$\begin{array}{l}\delta^{13} \mathrm{C} \\
\%\end{array}$} & \multicolumn{2}{|c|}{ Corrected } & \multirow[b]{2}{*}{$\begin{array}{l}\text { Calibrated Date Range and } \\
\text { Intercepts, B.C./A.D. }\end{array}$} \\
\hline & & & & & Age, B.P. & Date, B.C./A.D. & \\
\hline \multicolumn{8}{|c|}{ LOWER PECOS } \\
\hline \multirow{4}{*}{$\begin{array}{l}\text { Bonfire } \\
\text { Shelter, } \\
41 \mathrm{VV} 218 \\
\text { Bone Bed } 3\end{array}$} & \multirow{4}{*}{ Dibble and Lorrain 1968:51 } & $\begin{array}{l}\text { Bone } \\
\text { Tx-46 }\end{array}$ & $2310 \pm 210$ & $*$ & {$[2516 \pm 210]$} & {$[566$ B.C. \pm 210$]$} & $\begin{array}{l}{[855(762,625,623,610,593)} \\
387 \text { в.C. }]\end{array}$ \\
\hline & & $\begin{array}{l}\text { Bone } \\
\text { Tx-47 }\end{array}$ & $2810 \pm 110$ & $*$ & {$[3016 \pm 110]$} & {$[1066$ B.C. \pm 110$]$} & $\begin{array}{l}{[1407(1286,1284,1257,1226,} \\
1222,1195,1135) 1022 \text { в.с. }]\end{array}$ \\
\hline & & $\begin{array}{l}\text { Charcoal } \\
\text { Tx-106 }\end{array}$ & $2780 \pm 110$ & $*$ & {$[2796 \pm 110]$} & {$[846$ B.C. \pm 110$]$} & [1076 $(968,961,909) 813$ в.с.] \\
\hline & & $\begin{array}{l}\text { Charcoal } \\
\text { Tx-131 }\end{array}$ & $2510 \pm 100$ & $*$ & {$[2526 \pm 100]$} & [576 B.c. \pm 100$]$ & [797 (764, 602, 594411 в.с.] \\
\hline \multicolumn{8}{|c|}{$\begin{array}{l}{ }^{2} \text { Corrected ages/dates within brackets are estimates for bone collagen dates for which no } \delta^{13} \mathrm{C} \text { values were obtained. The corrected ages are based on } \\
\text { an estimated } \delta^{13} \mathrm{C} \text { value of }-12.2 \text { for bison bone, which is the average of the three values for the bone collagen dates from the Certain site. } \\
{ }^{3} \text { Calibrations are done by CALIB } 3.0 .3 \text { according to Stuiver and Reimer [1993], using calibration data set \#2. Calibrations in brackets are based on } \\
\text { estimated } \delta^{13} \mathrm{C} \text { values. }\end{array}$} \\
\hline
\end{tabular}


toward terminal Archaic sites because most older sites have been destroyed. All of the bison kills are located at the heads of draws just below interfluvial divides, and the nick points are thought to have been where the kills occurred. Thurmond reasons that headward erosion of these draws throughout the Late Archaic destroyed deposits from the early and middle parts of the period, with only those deposits from the terminal part of the Late Archaic (i.e., when the headward erosion slowed down or stopped) being preserved. This geomorphic explanation appears to fit well with the regional paleoenvironmental reconstruction (see Chapter 8).

Two interesting observations relate to the geographic distribution of the Late Archaic bison kills. First, none of these sites have been found in the Caprock Canyonlands. This does not mean that they do not exist there, but they appear to be much more common out into the Rolling Plains. Perhaps it was easier to hunt bison in the open Rolling Plains than in the confined canyonlands. Alternatively, bison kills may have occurred just as frequently in the canyonlands, but the kill sites there were more susceptible to destruction by erosion.

The second observation is that no Late Archaic bison kills have been reported on the southern Llano Estacado. Sufficient quantities of broad-bladed dart points have been found at some sites to suggest that the Late Archaic bison hunters did utilize the area to some extent, but no testing or excavations have been done at these sites and the majority may be ephemeral campsites (see below). Grant Hall (personal communication 1994) has visited a possible Late Archaic bison kill at Coyote Lake in Bailey County. Several dart points (including Marcos) have been collected from in and around a bone bed which becomes exposed during dry periods. This site has not been tested to confirm the age of these deposits, however, and Byrant (1953) reports that extensive cultural debris of all ages was found around the lake. Perhaps Late Archaic peoples did not hunt as often on the High Plains because bison were easier to trap in the eroded Lower Plains, or they may have utilized the lakes and draws as bison traps but the remains are not well preserved and are difficult to identify without subsurface testing.

Seasonality data for the bison kills are extremely poor. Hughes (1977:59, 80, 93, 96, 108, $178,190)$ notes that no evidence for seasonality was found at the Bell site, while the Collier, Strong, and Twilla site kills may have occurred during the summer-fall, winter-spring, and spring-summer, respectively. At the Certain site, no evidence of seasonality was found in two areas, but the bison in Trench A may have been killed during the late fallearly winter. Thus, the data are too gross to define a preferred season for hunting bison during the Late Archaic. A great deal of ethnographic evidence suggests that any form of communal bison hunting (with or without horses) would have been seasonally oriented and that there were preferred seasons for hunting, although the preferred season varied from group to group (e.g., Lehmer 1963; Quigg and Brumley 1984; Verbicky-Todd 1984; Wilson 1924). Generally, however, communal hunting was more common when bison were congregated into large herds during the late spring through fall and less common in winter when they dispersed into smaller groups (McHugh 1972:157; Roe 1972:94-118). In addition, bison are generally leaner and less nutritious during the harsh winter months and into early spring, and inclement winter weather would have made communal hunting more difficult.

Outside the Panhandle-Plains region, there is one bison kill that exhibits many similarities to those in the Rolling Plains. Bone Bed 3 at Bonfire Shelter (Dibble and Lorrain 1968:42-76), some $560 \mathrm{~km}$ (350 miles) south of the Rolling Plains, is dated 1407-387 B.C. and clearly represents a bison jump. Numerous broad-bladed dart points, including 19 Castroville, 3 Montell, and 2 untyped side notched, were found in direct association with the bone bed. Dibble and Lorrain (1968:72-74) discuss the similarities between these remains and those of the Rolling Plains bison kills but note that the Late Archaic bison kill is an unusual phenomenon in the Lower Pecos. It appears to be very Plains-like and is quite unlike the typical Late Archaic hunter/ gatherer materials in the region which show little or no emphasis on bison hunting. The Paleoindian bison kills in the lower strata of Bonfire also are anomalous in the region, and Dibble and Lorrain (1968:72) suggest four alternative hypotheses to account for the presence of the large Plains-style bison jumps in the Lower Pecos. They conclude that the most logical explanation is that "the influx of animals [bison] was unique or occurred over a very few years and the massive kill or kills at Bonfire Shelter was the work of knowledgeable bison hunters who had followed an unusual southward migration of large herds" (Dibble and Lorrain 1968:72). 


\section{Campsites and Rockshelters}

A relationship between the Late Archaic bison kills and numerous habitation sites has been suggested. Hughes (1989:203) is correct in stating that more campsites need to be investigated to fully understand the relationship, but there is a growing body of data (i.e., continuity of projectile point styles) that indicates a cultural link. Bison kills provide a considerable amount of detail on bison hunting and butchering techniques, but these sites have produced only minimal information on most other aspects of the hunters' lives. Habitation sites are the key to a better understanding of Late Archaic subsistence and settlement patterns.

A surface collection of 160 specimens from the Little Sunday site (Hughes 1955) in Randall County revealed a wide variety of Archaic artifacts eroding out of a buried cultural zone. Archaic dart points include nine Ellis, seven Refugio, two Palmillas, and one Lange, although the Refugio points are probably nothing more than preforms. One Folsom point also was found, but no arrow points or pottery were recovered. Hughes (1955:58) notes that these materials are probably associated with buried slablined hearths and bison bones, but few specific inferences may be made regarding subsistence activities. While this site obviously contains a concentration of materials that are dominantly Late Archaic in age, it is not clear whether it represents a single component. Although the dart points and other artifacts are presumed and appear to be contemporaneous, this interpretation cannot be confirmed without excavation data and radiocarbon dates. There is little evidence for an earlier Paleoindian occupation, so it is likely that the Folsom point was brought to the site by Late Archaic peoples.

Excavations $\left(116 \mathrm{~m}^{2}\right)$ at the Summers site in southwestern Oklahoma (Leonhardy 1966:17-32) produced dart points typed as Ensor, Gary, Lange, and Marshall. Faunal remains were abundant, but the only identifiable taxon was bison. A charcoal radiocarbon assay dated the cultural deposits to ca. 1206-797 B.C. Leonhardy (1966:30) felt that this date represents a maximum age for the site, and this single date does not necessarily represent the full temporal range of occupations. Also found were circular hearths and "stone-filled cooking pits" and a variety of tools thought to be related to processing animal remains (e.g., thin oval knives and unifacial scrapers) and plant foods (i.e., small manos and a thin slab metate fragment). Other lithic tools included Clear Fork gouges, scraper-planes, gravers, choppers, and a possible burin. Lithic materials were predominantly of local origin, but Alibates agate and Edwards chert also were present. Although multiple activities are represented at this site, the findings reinforce the idea that these Late Archaic peoples ranged widely and relied upon bison as their principal food resource (Leonhardy 1966 : 30-32).

When the Little Sunday and Summers sites are viewed in regional context, they clearly represent similar occupations. The broad-bladed dart points at both sites and bison remains at Summers are evidence of occupation by Late Archaic bison hunters. Consequently, these two locations serve as the type sites for the revised Little Sunday complex.

Many other sites in the Southern Plains have produced evidence of occupations that are related to the broad-bladed Late Archaic bison hunting complex. These sites are classified as campsites (i.e., habitation sites for which no structures are known) and rockshelters and are attributed to the Late or terminal Archaic on the basis of diagnostic dart points and/or radiocarbon dates (Table 62 and Figure 80). They constitute a large body of Late Archaic data, but, like the bison kills, they are not without interpretive problems. The vast majority are known only through surface data, and many of the tested or excavated sites have problems such as poorly established chronologies, lack of stratigraphic control, inadequate material culture samples, and mixed or otherwise inseparable components. In some cases, the published data are inadequate or the reports have yet to be published. In spite of these constraints, much can be cautiously inferred from these sites.

A comparison of all dated components producing Late Archaic materials in the Southern Plains reveals that the habitation sites span a much longer period of time and cover a larger geographic area than the bison kills (see Figure 78). Late Archaic occupations began at some sites prior to 1500 B.C., and the broad-bladed Late Archaic point tradition extends all across the Texas Plains, from north of the Canadian River to the southern end of the Rolling Plains.

While bison kill sites appear to be absent in the Caprock Canyonlands, as mentioned above, numerous Late Archaic occupation sites occur in this region. Late Archaic cultural materials are common at mesatop sites all along the Caprock Escarpment (Walter 


\begin{tabular}{|c|c|c|c|c|c|c|c|}
\hline \multicolumn{8}{|c|}{$\begin{array}{c}\text { TABLE } 62 \\
\text { UMMARY OF RADIOCARBON DATES FOR LATE AND TERMINAL ARCHAIC } \\
\text { OCCUPATIONS/COMPONENTS IN THE SOUTHERN PLAINS }\end{array}$} \\
\hline \multirow{2}{*}{$\begin{array}{l}\text { Site Name and } \\
\text { Number }\end{array}$} & \multirow[b]{2}{*}{ Reference } & \multirow{2}{*}{$\begin{array}{l}\text { Material and } \\
\text { Lab No. }\end{array}$} & \multirow{2}{*}{$\begin{array}{l}\text { Uncorrected } \\
\text { Date, B.P. }\end{array}$} & \multirow{2}{*}{$\begin{array}{l}\delta^{13} \mathrm{C} \\
\% 0\end{array}$} & \multicolumn{2}{|c|}{ Corrected $^{\prime}$} & \multirow{2}{*}{$\begin{array}{l}\text { Calibrated Date }{ }^{2} \text { Range and } \\
\text { Intercepts, B.C./A.D. }\end{array}$} \\
\hline & & & & & Age, B.P. & Date, B.C./A.D. & \\
\hline $\begin{array}{l}\text { Beaver Dam } \\
\text { 34RM208A }\end{array}$ & $\begin{array}{l}\text { Thurmond 1991a:120, } \\
\text { Tables 2-4 }\end{array}$ & $\begin{array}{l}\text { Charcoal } \\
\text { NZA-1388 }\end{array}$ & $1514 \pm 79$ & -24.53 & $1514 \pm 79$ & A.D. $436 \pm 79$ & A.D. $430(545,549,557) 642$ \\
\hline $\begin{array}{l}\text { Chalk Hollow } \\
\text { 41RD75 } \\
\text { Lower Midden }\end{array}$ & Wedel 1975; Lintz 1995 & $\begin{array}{l}19 \text { charcoal } \\
\text { dates }^{3}\end{array}$ & - & - & - & - & $1870-260$ в.С. \\
\hline \multirow{2}{*}{$\begin{array}{l}\text { Deadman's } \\
\text { Shelter } \\
41 \text { SW23 } \\
\text { Area 2, } \\
\text { Stratum D }\end{array}$} & \multirow{2}{*}{$\begin{array}{l}\text { Willey and Hughes } \\
1978 \mathrm{~b}: 189^{4}\end{array}$} & $\begin{array}{l}\text { Charcoal } \\
\text { SI-1899 }\end{array}$ & $1740 \pm 40$ & $*$ & {$[1756 \pm 57]$} & [A.D. $194 \pm 57$ ] & $\begin{array}{l}\text { [A.D. } 236(259,281,291,298 \text {, } \\
\text { 321) } 383 \text { ] }\end{array}$ \\
\hline & & $\begin{array}{l}\text { Charcoal } \\
\text { SI-1900 }\end{array}$ & $1830 \pm 60$ & $*$ & {$[1846 \pm 72]$} & [A.D. $104 \pm 72]$ & [A.D. $79(176,199,217) 319]$ \\
\hline $\begin{array}{l}\text { Summers } \\
\text { 41GR12, } \\
\text { Area 2 }\end{array}$ & Leonhardy 1966:29 & $\begin{array}{l}\text { Charcoal } \\
\text { GaK-694 }\end{array}$ & $2770 \pm 150$ & $*$ & {$[2786 \pm 155]$} & {$[836$ B.C. \pm 155$]$} & {$[1206(967,963,903) 797$ в.с. } \\
\hline \multirow{5}{*}{$\begin{array}{l}\text { Swift Horse } \\
\text { 34RM501 }\end{array}$} & \multirow{5}{*}{$\begin{array}{l}\text { Briscoe 1987:26-29, } \\
\text { 1989a:109, Table } 3\end{array}$} & $\begin{array}{l}\text { Charcoal } \\
\text { Beta-18429 }\end{array}$ & $1680 \pm 80$ & $*$ & {$[1696 \pm 90]$} & [A.D. $254 \pm 90]$ & [A.D. $245(362,367,384) 525]$ \\
\hline & & $\begin{array}{l}\text { Charcoal } \\
\text { Beta-18430 }\end{array}$ & $1610 \pm 90$ & $*$ & {$[1626 \pm 99]$} & [A.D. $324 \pm 99$ ] & [A.D. 264 (424) 543] \\
\hline & & $\begin{array}{l}\text { Charcoal } \\
\text { Beta-18431 }\end{array}$ & $1590 \pm 70$ & * & {$[1606 \pm 81]$} & [A.D. $344 \pm 81]$ & [A.D. $364(428) 543$ ] \\
\hline & & $\begin{array}{l}\text { Charcoal } \\
\text { Beta-18432 }\end{array}$ & $1650 \pm 70$ & * & {$[1666 \pm 81]$} & [A.D. $284 \pm 81$ ] & [A.D. $260(411) 533$ ] \\
\hline & & $\begin{array}{l}\text { Charcoal } \\
\text { Beta-18433 }\end{array}$ & $1820 \pm 100$ & * & {$[1836 \pm 108]$} & [A.D. $114 \pm 108$ ] & [A.D. $66(179,194,221) 340]$ \\
\hline
\end{tabular}




\begin{tabular}{|c|c|c|c|c|c|c|c|}
\hline \multicolumn{8}{|c|}{ Table 62 , continued } \\
\hline \multirow{2}{*}{$\begin{array}{l}\text { Site Name and } \\
\text { Number }\end{array}$} & \multirow[b]{2}{*}{ Reference } & \multirow{2}{*}{$\begin{array}{l}\text { Material and } \\
\text { Lab No. }\end{array}$} & \multirow{2}{*}{$\begin{array}{l}\text { Uncorrected } \\
\text { Date, B.P. }\end{array}$} & \multirow{2}{*}{$\begin{array}{l}\delta^{13} \mathrm{C} \\
\%\end{array}$} & \multicolumn{2}{|c|}{ Corrected } & \multirow{2}{*}{$\begin{array}{l}\text { Calibrated Date Range and } \\
\text { Intercepts, B.C./A.D. }\end{array}$} \\
\hline & & & & & Age, B.P. & Date, B.C./A.D. & \\
\hline \multirow{5}{*}{ 34RM334 } & \multirow{5}{*}{$\begin{array}{l}\text { Thurmond 1991a:121, } \\
\text { Tables 2-4 }\end{array}$} & $\begin{array}{l}\text { Charcoal } \\
\text { NZA-712 }\end{array}$ & $1789 \pm 81$ & -24.85 & $1789 \pm 81$ & A.D. $161 \pm 81$ & A.D. $131(244,305,316) 380$ \\
\hline & & $\begin{array}{l}\text { Charcoal } \\
\text { NZA-1246 }\end{array}$ & $1901 \pm 88$ & -24.31 & $1901 \pm 88$ & A.D. $49 \pm 88$ & A.D. $26(88,99,127) 238$ \\
\hline & & $\begin{array}{l}\text { Charcoal } \\
\text { NZA-1247 }\end{array}$ & $1425 \pm 70$ & -25.47 & $1425 \pm 70$ & A.D. $525 \pm 70$ & A.D. 565 (643) 665 \\
\hline & & $\begin{array}{l}\text { Charcoal } \\
\text { NZA-1248 }\end{array}$ & $990 \pm 190$ & -20.30 & $990 \pm 190$ & A.D. $960 \pm 190$ & A.D. $880(1024) 1260$ \\
\hline & & $\begin{array}{l}\text { Charcoal } \\
\text { Beta-37430 }\end{array}$ & $1500 \pm 80$ & $*$ & {$[1516 \pm 90]$} & [A.D. $434 \pm 90$ ] & [A.D. $428(544,553,556) 643]$ \\
\hline \multirow{4}{*}{$\begin{array}{l}\text { Sandy Ridge } \\
\text { 41HF5, } \\
\text { Block C }\end{array}$} & \multirow{4}{*}{$\begin{array}{l}\text { Quigg, Lintz, Oglesby, } \\
\text { Earls et al. 1993:178, } \\
\text { Table B-1 }{ }^{5}\end{array}$} & $\begin{array}{l}\text { Bison Bone } \\
\text { GX-16129-G }\end{array}$ & - & -12.8 & $2905 \pm 215$ & 954 в.с. \pm 215 & $\begin{array}{l}1406(1073,1063,1051,1029, \\
1023) 815 \text { в.C. }\end{array}$ \\
\hline & & $\begin{array}{l}\text { Bison Bone } \\
\text { GX-16130-G }\end{array}$ & - & -11.9 & $2970 \pm 240$ & 1020 B.C. \pm 240 & $\begin{array}{l}1487(1210,1201,1190,1175, \\
1140,1130,1116,1114) 831 \text { B.C. }\end{array}$ \\
\hline & & $\begin{array}{l}\text { Charcoal } \\
\text { Tx-7038 }\end{array}$ & $3450 \pm 50$ & -18.7 & $3560 \pm 50$ & 1610 B.C. \pm 50 & $\begin{array}{l}2006(1882,1837,1833) \\
1773 \text { в.C. }\end{array}$ \\
\hline & & $\begin{array}{l}\text { Charcoal } \\
\text { GT-7039 }\end{array}$ & $3460 \pm 80$ & -23.70 & $3470 \pm 80$ & 1520 B.C. \pm 80 & $\begin{array}{l}1881(1765,1764,1741) \\
1639 \text { в.C. }\end{array}$ \\
\hline
\end{tabular}




\begin{tabular}{|c|c|c|c|c|c|c|c|}
\hline \multirow{2}{*}{$\begin{array}{l}\text { Site Name and } \\
\text { Number }\end{array}$} & \multirow[b]{2}{*}{ Reference } & \multirow{2}{*}{$\begin{array}{l}\text { Material and Lab } \\
\text { No. }\end{array}$} & \multirow{2}{*}{$\begin{array}{l}\text { Uncorrected } \\
\text { Date, B.P. }\end{array}$} & \multirow{2}{*}{$\begin{array}{l}\delta^{13} \mathrm{C} \\
\%\end{array}$} & \multicolumn{2}{|c|}{ Corrected } & \multirow{2}{*}{$\begin{array}{l}\text { Calibrated Date Range and } \\
\text { Intercepts, B.C./A.D. }\end{array}$} \\
\hline & & & & & Age, B.P. & Date, B.C./A.D. & \\
\hline \multirow{7}{*}{$\begin{array}{l}\text { 41TG91 } \\
\text { Area A, Zones } \\
\text { A-4 to A-8 }\end{array}$} & \multirow{7}{*}{ Creel 1990:Table 2} & $\begin{array}{l}\text { Charcoal } \\
\text { Tx-4757 } \\
\text { Zone A-5/6 }\end{array}$ & $2070 \pm 110$ & $*$ & {$[2086 \pm 117]$} & {$[136$ в.C. \pm 117$]$} & $\begin{array}{l}{[340 \text { B.C. }(88,79,55)} \\
\text { A.D. } 54]\end{array}$ \\
\hline & & $\begin{array}{l}\text { Charcoal } \\
\text { Tx-4758 } \\
\text { Zone A-8 }\end{array}$ & $2370 \pm 70$ & $*$ & {$[2386 \pm 81]$} & {$[436$ B.C. \pm 81$)$} & [753 (404) 386 B.C.] \\
\hline & & $\begin{array}{l}\text { Charcoal } \\
\text { Tx-4760 } \\
\text { Zone A-7 }\end{array}$ & $2180 \pm 60$ & $*$ & {$[2196 \pm 72]$} & {$[246$ B.C. \pm 72$]$} & $\begin{array}{l}{[362(346,321,226,224,} \\
205) 121 \text { B.C. }]\end{array}$ \\
\hline & & $\begin{array}{l}\text { Charcoal } \\
\text { Tx-4761 } \\
\text { Zone A-8 }\end{array}$ & $2480 \pm 60$ & $*$ & {$[2496 \pm 72]$} & {$[546$ в.C. \pm 72$]$} & $\begin{array}{l}{[786(758,632,590,578} \\
561,457,452) 410 \text { в.С.] }\end{array}$ \\
\hline & & $\begin{array}{l}\text { Charcoal } \\
\text { Tx-4763 } \\
\text { Zone A-8 }\end{array}$ & $2800 \pm 60$ & $*$ & {$[2816 \pm 72]$} & {$[866$ B.C. \pm 72$]$} & $\begin{array}{l}{[1049(970,958,937)} \\
833 \text { B.C. }]\end{array}$ \\
\hline & & $\begin{array}{l}\text { Charcoal } \\
\text { Tx-4764A } \\
\text { Zone A-8 }\end{array}$ & $2540 \pm 80$ & $*$ & {$[2556 \pm 90]$} & {$[606$ B.C. \pm 90$]$} & [803 (770) 433 в.с.] \\
\hline & & $\begin{array}{l}\text { Charcoal } \\
\text { Tx-4764B } \\
\text { Zone A-8 }\end{array}$ & $2910 \pm 270$ & $*$ & {$[2926 \pm 273]$} & {$[976$ в.C. \pm 273$]$} & $\begin{array}{l}{[1449(1186,1184,1145,} \\
1096,1095,1081,1058, \\
1053) 804 \text { B.c. }]\end{array}$ \\
\hline \multirow{3}{*}{$\begin{array}{l}\text { Gobbler Creek } \\
\text { Bridge } \\
41 \text { GR383 }\end{array}$} & \multirow{3}{*}{$\begin{array}{l}\text { Boyd et al. 1994: } \\
56-57,76 \text {, Table } 48^{6}\end{array}$} & $\begin{array}{l}\text { Sediment } \\
\text { GX-16515 }\end{array}$ & - & -15.7 & $1865 \pm 140$ & A.D. $85 \pm 140$ & A.D. 3 (132) 341 \\
\hline & & $\begin{array}{l}\text { Sediment } \\
\text { GX-16626 }\end{array}$ & - & -15.0 & $1215 \pm 140$ & A.D. $735 \pm 140$ & $\begin{array}{l}\text { A.D. } 663(781,790,804,851 \text {, } \\
860) 989\end{array}$ \\
\hline & & $\begin{array}{l}\text { Charcoal } \\
\text { GX-166627-AMS }\end{array}$ & - & -25.5 & $1390 \pm 65$ & A.D. $560 \pm 65$ & A.D. $608(653) 688$ \\
\hline
\end{tabular}




\begin{tabular}{|c|c|c|c|c|c|c|c|}
\hline \multicolumn{8}{|c|}{ Table 62 , continued } \\
\hline \multirow{2}{*}{$\begin{array}{l}\text { Site Name and } \\
\text { Number }\end{array}$} & \multirow[b]{2}{*}{ Reference } & \multirow{2}{*}{$\begin{array}{l}\text { Material and } \\
\text { Lab No. }\end{array}$} & \multirow{2}{*}{$\begin{array}{l}\text { Uncorrected } \\
\text { Date, B.P. }\end{array}$} & \multirow{2}{*}{$\begin{array}{l}\delta^{13} \mathrm{C} \\
\% \mathrm{o}\end{array}$} & \multicolumn{2}{|c|}{ Corrected } & \multirow{2}{*}{$\begin{array}{l}\text { Calibrated Date Range and } \\
\text { Intercepts, B.C./A.D. }\end{array}$} \\
\hline & & & & & Age, B.P. & Date, B.C./A.D. & \\
\hline \multirow{5}{*}{$\begin{array}{l}\text { Boren Shelter } \\
\text { No. } 2 \\
\text { 41GR559 } \\
\text { Lower Shelter }\end{array}$} & \multirow{5}{*}{$\begin{array}{l}\text { Boyd et al. 1994: } \\
\text { 239-240, Table } 54\end{array}$} & $\begin{array}{l}\text { Charcoal } \\
\text { GX-14449 }\end{array}$ & $1155 \pm 210$ & -23.3 & $1180 \pm 210$ & A.D. $770 \pm 210$ & A.D. $652(881) 1146$ \\
\hline & & $\begin{array}{l}\text { Charcoal } \\
\text { Beta-60261 }\end{array}$ & $1920 \pm 70$ & -24.9 & $1930 \pm 70$ & A.D. $20 \pm 70$ & A.D. 4 (75) 209 \\
\hline & & $\begin{array}{l}\text { Charcoal } \\
\text { Beta-60262 }\end{array}$ & $1730 \pm 80$ & -25.4 & $1720 \pm 80$ & A.D. $230 \pm 70$ & $\begin{array}{l}\text { A.D. } 240(264,269,342,374 \text {, } \\
\text { 376) } 421\end{array}$ \\
\hline & & $\begin{array}{l}\text { Charcoal } \\
\text { Beta-60831 }\end{array}$ & $1320 \pm 110$ & -26.5 & $1300 \pm 110$ & A.D. $650 \pm 110$ & A.D. $645(691,752,760) 875$ \\
\hline & & $\begin{array}{l}\text { Charcoal } \\
\text { Beta-59832 }\end{array}$ & $1520 \pm 90$ & -24.5 & $1530 \pm 90$ & A.D. $420 \pm 90$ & A.D. $425(542) 641$ \\
\hline \multirow{4}{*}{$\begin{array}{l}\text { Canyon City } \\
\text { Club Cave } \\
\text { Levels } 4 \text { and } 5\end{array}$} & \multirow{4}{*}{$\begin{array}{l}\text { Hughes 1969:38-39, } \\
\text { Table } 1^{7}\end{array}$} & $\begin{array}{l}\text { Charcoal } \\
\text { WIS-404 } \\
\text { Level } 4\end{array}$ & $1650 \pm 55$ & $*$ & $1666 \pm 68$ & A.D. $284 \pm 68$ & [A.D. 262 (411) 529] \\
\hline & & $\begin{array}{l}\text { Charcoal } \\
\text { WIS-414 } \\
\text { Level } 4\end{array}$ & $1250 \pm 60$ & $*$ & $1266 \pm 72$ & A.D. $684 \pm 72$ & $\begin{array}{l}\text { [A.D. } 672(734,737,773) \\
874]\end{array}$ \\
\hline & & $\begin{array}{l}\text { Charcoal } \\
\text { WIS-420 } \\
\text { Level } 5\end{array}$ & $2100 \pm 60$ & $*$ & $2116 \pm 72$ & 166 B.C. \pm 72 & {$[345(164,132,118) 2$ B.c. $]$} \\
\hline & & $\begin{array}{l}\text { Charcoal } \\
\text { WIS-430 } \\
\text { Level } 5\end{array}$ & $2830 \pm 60$ & *. & $2846 \pm 72$ & 896 B.C. \pm 72 & $\begin{array}{l}{[1185(1004,987,874)} \\
899 \text { B.C.] }\end{array}$ \\
\hline \multirow{2}{*}{$\begin{array}{l}\text { Sanders } \\
41 \mathrm{HF} 128\end{array}$} & \multirow{2}{*}{$\begin{array}{l}\text { Quigg, Lintz, Oglesby, } \\
\text { Earls et al. 1993:333-346 }\end{array}$} & $\begin{array}{l}\text { Bison Bone } \\
\text { GX-16405-G }\end{array}$ & - & -10.2 & $2115 \pm 85$ & 165 в.С. \pm 85 & $\begin{array}{l}347 \text { B.C. }(164,133,117) \\
\text { A.D. } 0\end{array}$ \\
\hline & & $\begin{array}{l}\text { Bison Bone } \\
\text { GX-16406-G }\end{array}$ & - & -9.4 & $1770 \pm 90$ & A.D. $180 \pm 90$ & $\begin{array}{l}\text { A.D. } 133(257,283,287,301 \text {, } \\
\text { 319) } 406\end{array}$ \\
\hline
\end{tabular}


Table 62, continued

${ }^{1}$ Corrected ages in brackets are estimates for dates for which no $\delta^{13} \mathrm{C}$ values were obtained. The corrected ages are based on an estimated $\delta^{13} \mathrm{C}$ value of -24.00 for fossil wood charcoal (from Stuiver and Polach 1977).

${ }^{2}$ Unless otherwise stated, all calibrations are done by CALIB version 3.03 according to Stuiver and Reimer (1993), using a 1-sigma range for calibration data set \#2. Calibrations in brackets are based on the estimated $\delta^{13} \mathrm{C}$ values.

${ }^{3}$ Wedel (1975:273) obtained 19 dates for the Lower Midden at Chalk Hollow; these dates were not published, but he estimated that the Lower Midden dates to 1690-400 B.C. Lintz (1995) presents the original radiocarbon ages and tree ring calibrations using CALIB 2.0 (Stuiver and Reimer 1986).

${ }^{4}$ Excludes one charcoal date that is too young and out of stratigraphic sequence. Contamination and/or mixing of strata are suspected.

${ }^{5}$ Excludes two bone apatite dates (on the same bones as the collagen dates) that are considered invalid.

${ }^{6}$ Excludes one sediment date thought to be contaminated by younger carbon.

7Excludes one "anomalous" date from Level 5 that is significantly too young and out of stratigraphic sequence. Contamination is suspected.

${ }^{8}$ Additional investigations in 1995 included three corrected radiocarbon ages on charcoal as follows: Beta-91493, $1880 \pm 40$ B.P.; Beta-93287, $1690 \pm 70$ B.P.; and Beta-95636, $1860 \pm 80$ B.P. (Quigg 1997b:41).

*No $\delta^{13} \mathrm{C}$ correction done by radiocarbon lab. 


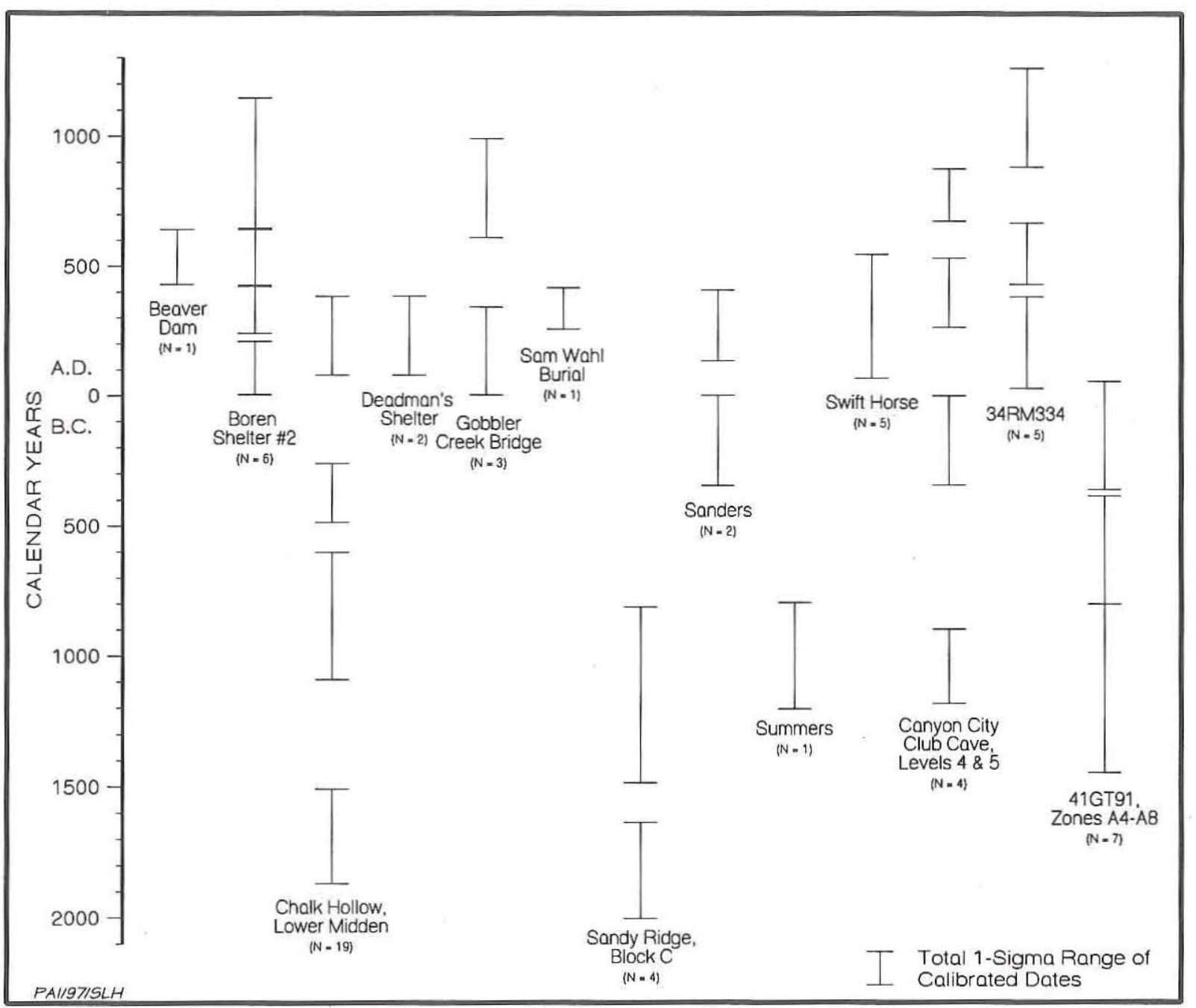

Figure 80. Graph of calibrated radiocarbon dates for Late and transitional Archaic occupations.

1992), generally within a few miles of the escarpment. In a report on several mesa-top sites with Late Archaic components, Walter (n.d.) speculates that they served as temporary campsites from which people could observe the edge of the High Plains and/or vast areas of the Rolling Plains for bison movement. The Cowhead Mesa site (41GR120), which was periodically collected and tested by the South Plains Archeological Society between 1957 and the 1970s, produced many expanding-stem dart points (Bilbo 1986:10) that are typed as Marcos and Castroville by Walters (n.d.). The L-7 and Z-Bar-L mesa sites, which recently were tested by Richard Walter (n.d.; personal communication 1994), also have produced numerous Marcos and Castroville points along with numerous scrapers. Etchieson et al. (1977:24-25) also note that a prominent mesa-top site, called Red Butte (41BI238), in Caprock Canyons State Park has yielded Ellis dart points.

Many Late Archaic campsites containing distinctive broad-bladed dart points have been recorded in other settings throughout the Caprock Canyonlands (see Table 60). Investigations of large areas, such as those mentioned in Table 60 , provide ample surface evidence indicating the presence of the Little Sunday complex, but very few habitation sites have been investigated to any extent. Although no well-defined Late Archaic components at Lake Alan Henry were investigated, several sites contained some evidence of human occupations in Late Archaic times. At the Gobbler Creek Bridge site, one early radiocarbon date (A.D. 3-341) and a single dart point tip provide evidence of a probable Late Archaic occupation, but the same stratum is domi- 
nated by Late Prehistoric I materials and also yielded two later radiocarbon dates (Boyd et al. 1992:80). If there are multiple components at this site, they are not separable and remain ill defined. Alternatively, the evidence may represent periodic reoccupation of the site during transitional Archaic and into Late Prehistoric I times. In either case, burned rock features and the high frequency of ground stones suggest that plant processing was the primary subsistence activity at this site (see Chapter 10).

Surface investigations at two other Lake Alan Henry sites (41GR583 and 41GR600) yielded Marcos dart points (Boyd et al. 1991:23-24, 35-36), and a third site (41KT159) produced a Castroville and a Marshall (Boyd et al. 1992:174). Although these sites were not tested, they appear to represent campsites that are part of the Little Sunday complex. The initial survey of the reservoir area (Boyd et al. 1989:Table 10) recorded 10 Late Archaic components, representing about 4 percent of all prehistoric components, but it is likely that many sites of undefined age may contain Late Archaic components.

Nearby in Kent County, a probable Late Archaic component at $41 \mathrm{KT} 32$ was tested (Denton 1983), but the resulting data are limited. Two untypeable dart point stems and other stone tools were recovered, along with scattered burned rocks, but the component remains poorly defined and no radiocarbon dates were obtained.

In Borden County south of Lake Alan Henry, Mack (1994) completed intensive systematic surface collection $\left(1,062 \mathrm{~m}^{2}\right)$ and minimal testing $\left(9 \mathrm{~m}^{2}\right)$ on a Late Archaic site. He recovered 2,843 artifacts from the Van York site (41BD8) and, based on its geomorphic setting and on the integrity of the artifact assemblage, suggested that a single Late Archaic occupation was represented. Although the artifact density was quite low, the variability in chipped and ground stone artifacts, along with the presence of at least four hearth features and scattered fire-cracked rocks, is indicative of a multifunctional campsite. No radiocarbon dates were obtained, but two Ellis and one Edgewood dart point were found. Although the bulk of the assemblage may indeed be Late Archaic, a Fresno arrow point casts a shadow of a doubt regarding a later occupation.

Based on his intensive survey of a large ranch and other work in Roger Mills County of western Oklahoma, Thurmond (1991a) concluded that the
Dempsey Divide was a "hotspot" of Late Archaic and Woodland activity. Located at the northern end of the Caprock Canyonlands, the intensive cultural activities in the Dempsey Divide are attributed to the presence of widespread Ogallala exposures and numerous freshwater springs. Many of these sites have yielded dart points similar to those found in the bison kills and typed as Ellis, Ensor, Frio, Marcos, Marshall, Motley, Palmillas, and Williams (Thurmond 1991a:Figures 15-18). The high frequency of campsites producing broad-bladed dart points, along with the proximity of the nearby Certain bison kill, indicate that the Dempsey Divide was utilized intensively by Late Archaic peoples.

Three deflated site remnants (34RM334, 34RM470, and 34RM507) in the Dempsey Divide have produced Late Archaic dart points (Ensor, Marcos, and Palmillas) in association with a range of chipped stone tools and debitage and broken bison and deer bones (Thurmond 1989). The investigations at these sites have not been reported, but four radiocarbon dates from 34RM334 indicate occupations between 2 B.C. and A.D. 665 , while a fifth date indicates later occupations at A.D. 880-1260 (Thurmond 1991a:121). Nearby at the Swift Horse site (34RM501), deposits dating to the first 500 years A.D. produced seven dart points (along with one arrow point and a few sherds of Woodland cordmarked pottery; see Transitional Archaic discussion) (Briscoe 1987, 1989a).

At least eight Late Archaic sites in the Palo Duro canyon area have been tested by various groups (i.e., West Texas State University, the Smithsonian Institution, and the Texas Historical Commission) but never adequately reported (Hughes 1978:40-41). A Late Archaic component buried at one Randall County site (PPHM-A704) has been minimally tested and reported by Pearson (1974). This report documents the detailed chemical and sedimentological investigations of the archeological strata and mentions some artifacts but never describes any of the cultural materials or interpretations. Blue Spring Shelter (PPHM-A485), along the north rim of Palo Duro Canyon, has also been tested, and a stratum containing Late Archaic materials is radiocarbon dated to A.D. 295 (uncorrected). This site is mentioned by Hughes (1978:41-44), but it has never been reported.

Late Archaic occupations have been identified in the lower levels of at least six stratified sites that have been tested or excavated in the Caprock 
Canyonlands. Three of these (i.e., Chalk Hollow, Beaver Dam, and County Line) are open campsites while three (i.e., Canyon City Club Cave, Deadman's Shelter, and Boren Shelter No. 2) are rockshelters. Most of these sites, with the possible exception of Chalk Hollow and Beaver Dam, suffer from the fact that the Late Archaic materials are mixed with, and inseparable from, later materials. It is not clear if these sites contain single transitional Archaic components or multiple components (i.e., mixed Late Archaic and Late Prehistoric).

The "lower midden" at Chalk Hollow contained large corner-notched dart points (typed as Marcos Castroville, Ensor, Williams, and Palmillas), an abundance of milling stone (i.e., metate) and mano fragments, an abundance of bison bone fragments, bone awls, bone gaming pieces, and slab-lined hearths (Wedel 1975:272). The upper midden consisted of a discrete Late Prehistoric I component with early arrow points and pottery, none of which were found in the lower midden. Wedel (1975:273) noted that the "earlier midden, with its relatively larger and heavier points, recalls to mind a number of recently discovered small bison kills situated along the eastern caprock of the Llano Estacado." The diversity of artifacts and features indicates that the Late Archaic component represents a residential base camp located near a freshwater spring. Within $8 \mathrm{~km}$ of Chalk Hollow, there are at least 40 upland playas, and Wedel suggests that the inhabitants hunted bison and pronghorn around these lakes.

Since the lower midden produced one of the most discrete Late Archaic assemblages in the region, it is unfortunate that the Smithsonian Institution's excavations at Chalk Hollow have never been analyzed and that the only published record is Wedel's (1975) five-page summary. However, an as yet unpublished paper by Lintz (1995) sheds some new light on the Late Archaic deposits. Although no reanalysis of artifacts was attempted, a review of artifact distributions confirmed that the excavations produced 22 dart points typed by Wedel as Marcos $(n=6)$, Castroville $(n=4)$, Williams $(n=3)$, Palmillas $(n=3)$, Ensor $(n=2)$, and unidentified $(n=4)$. Although it appears that half of these points came from some of the same $15-\mathrm{cm}$-thick excavation levels producing arrow points and pottery (i.e., the upper midden Palo Duro component; see Chapter 10), when Lintz replotted the point provenience by elevations, the majority $(n=18)$ were found to be associated with the lower midden deposits.
After studying the horizontal and vertical distribution of the radiocarbon dates, Lintz (1995) concluded that three distinct Late Archaic occupation zones can be identified within the lower midden. The earliest (represented by two radiocarbon assays) dates to $1870-1616$ B.C. The middle and most intensive occupation zone dates to $1092-602$ B.C. (as indicated by 11 to 13 assays), and the latest occupation zone dates to 471-260 B.C. (based on three assays). The stratigraphic evidence and artifact proveniences are not sufficient to relate specific dart point styles to specific occupation zones, and it appears that most styles were present in two or three of the occupation zones. Lintz also cautions that there are some stratigraphic inconsistences in the lower midden points and radiocarbon dates that may be due to extensive rodent disturbance. Lintz's study indicates that the site has considerable research potential and that more-precisely controlled stratigraphic excavations there could produce significant data for interpreting the Late Archaic period. To the author's knowledge, Chalk Hollow is the only site in the Texas Panhandle-Plains where multiple occupations are stratigraphically separable, within Late Archaicage deposits.

Oklahoma Archeological Society excavations at the Beaver Dam site (34RM208) in the Dempsey Divide provide evidence of Late Archaic and Woodland components (Thurmond 1991a:120). Comprehensive reports are not yet available, but preliminary summaries of various seasons of investigations have been made (Thurmond 1988a, 1988b, 1988c). Like Chalk Hollow, one area at the Beaver Dam site appears to have two discrete and separable components. The lower component produced five sidenotched points (cf. Ensor and Palmillas), while the upper component produced cordmarked pottery, Scallorn and Avonlea arrow points, and one Ensor dart point. A radiocarbon date from the culturally sterile zone between these components is calibrated to A.D. 430-642, indicating that the Late Archaic materials predate A.D. 430. A burial from the site (discussed below) also yielded a Late Archaic dart point and a lunate stone (Thurmond 1991b).

The County Line site (Willey and Hughes 1978a) at Mackenzie Reservoir yielded several untyped corner-notched dart point stems along with Scallorn-like arrow points but no pottery. Because of the wide range of chipped and ground stones (i.e., cores, knives, scrapers, choppers, gravers, hammerstones, drill, manos, and metates), abundant 
burned rocks, and five slab-lined hearths, the site was interpreted as a relatively permanent base camp. The bulk of the cultural debris was associated with a "well-defined living surface" which probably represents a single component. All of the cultural materials are diagnostic of the transitional Archaic and/or Late Prehistoric I, but no radiocarbon dates were obtained to determine the age or duration of occupation. Surface collecting and minimal testing of 41BI90, in lower Tule Canyon downstream from Mackenzie Reservoir, produced evidence of a Late Archaic component (Katz and Katz 1976:56-57, 107-108). Five dart points similar to Ellis and Ensor were recovered, but the sediments were deflated and mixed with Late Prehistoric II materials (i.e., Washita and Fresno points).

An unpublished report (Hughes 1969) on the Canyon City Club Cave reveals that the lower two levels were radiocarbon dated to terminal and Late Archaic times. Two dates obtained on Level 5, which was almost sterile, suggest human activities at 1185-899 B.C. and 345-2 B.C. Two dates obtained on Level 4 indicate occupations at A.D. 62-529 and A.D. 672-874. The cultural materials recovered from Level 4 included dart points (cf. Ellis and Lange), early (i.e., Scallorn and Deadman's) and late (i.e., Washita, Harrell, Fresno, and Perdiz) arrow points, cordmarked pottery (three types identified as grit tempered, sand tempered, and calcite tempered), and brownware (cf. Jornada Brown). The deposits appear to have been severely mixed, and dart points also were found in upper Levels 2 and 3. It appears that this shelter was occupied in Late or transitional Archaic times, but no definable component or artifact assemblage can be attributed to these occupations. The vast majority of the cultural materials appear to be related to later periods.

Willey and Hughes (1978b:185-190) report that the lowest cultural zone at Deadman's Shelter contained dart points (specimens similar to Edgewood, Elam, Ellis, Kent, and Lange) along with basal- and corner-notched arrow points (i.e., Deadman's and Scallorn) and brownware pottery from the Jornada Mogollon area. Excluding one aberrant date, two radiocarbon dates place the age of Stratum D at A.D. 79-383, suggesting that the dart and arrow points could have been used contemporaneously. Stratum D included a wide variety of chipped stones (cores, bifacial knives, unifacial scrapers, drills, gravers, denticulates, spokeshaves, and choppers) and ground stones (manos, metates, and pigment stones), rock-lined hearths, a shell pendant, and abundant burned and fragmented animal bones. Deer are well represented in the faunal assemblage, but bison remains are noticeably scarce (i.e., only one specimen). The excavations failed to reveal whether there were discrete Late Archaic occupations in Stratum D or whether this zone was transitional Archaic and/or early Neoindian.

The lower deposits in Boren Shelter No. 2 at Lake Alan Henry contained evidence of repeated occupations beginning by 2 B.C. and continuing until ca. A.D. 1030 (Peck et al. 1994b:239-246). Although seasonality evidence is lacking, the site may have served as a temporary winter shelter; occupations were short term and sporadic, encompassing a range of generalized hunting/gathering activities. One arrow point fragment and a single Ellis dart point were recovered from the lower deposits, but their precise ages could not be determined (see Chapter 6).

Testing of two sites in northern Hall County produced possible evidence of Late Archaic occupations (Hughes and Hood 1976). Surface collections and testing at the Bitter Creek site revealed a fairly discrete, shallowly buried occupational zone characterized by fire-cracked rocks scattered over a large area. The only diagnostic recovered was an Edgewood-like dart point (Hughes and Hood 1976: Figure 8a); no dates were obtained. Other lithic tools recovered include a few bifaces, scrapers, choppers, and gouges. The researchers concluded that the site had been occupied during the Late Archaic, but they also inferred an Early Archaic occupation based solely on the presence of gouges and choppers (Hughes and Hood 1976:54, 85). Since the idea that gouges are diagnostic of the Early Archaic is challenged (see Chapter 10), the archeological evidence suggests that the Bitter Creek site probably represents a Late Archaic camp. Based on surface collections and testing at the nearby Polecat site (41HL63), Hughes and Hood (1976:67, 83) suggest that it represents a Late Archaic occupation. No dates were obtained, but a metate fragment and single dart point stem fragment (untyped) were recovered. Given the proximity of these localities to several Late Archaic bison kills, it is possible that these sites are ephemeral Late Archaic camps. Because of the abundance of burned rocks, the types of tools recovered, and the paucity of dart points, both sites may represent specialized activity camps, perhaps where plant processing occurred. 


\section{Burials}

Several burials in the region are considered to be of Late Archaic age, and they can be generally divided into two types: burials with lunate stones and those without (Figure 81). Parsons et al. (1979), Redding and Parker (1991), and Thurmond (1991b) report that lunate stones (Figure 82) have been found at numerous locations in the Southern Plains. Parsons et al. (1979:80) state that seven burials with lunate stones are known and note they are typically cairn-covered, small oval pits that contain flexed skeletons, cremations, or secondary (i.e., bundle) burials. Of 11 documented lunate stone finds reported by Cockrum (1963), Holden (1929), Parsons et al. (1979), Redding and Parker (1991), and Thurmond (1991b), six were found in association with human burials while the others were surface finds (Table 63). Four of the six burials with lunate stones also had additional associated artifacts indicating a Late Archaic affiliation, but none have been independently dated. Thurmond (1991b:246) notes that lunate stones are commonly associated with "corner- and side-notched dart points of the Marcos, Marshall, and Ensor types - especially the last." These points suggest that lunate stone burials are associated with the Late Archaic bison hunters who roamed the Southern Plains. The burial in Roger Mills County, Oklahoma (Thurmond 1991b) is particularly revealing because the mortuary offerings included a lunate stone and an Ellis-like dart point in indisputable association. Notably, the dart point in the burial is quite similar to the dart points recovered from the nearby Certain site (cf. Thurmond 1991b:Figure 2 with Bement and Buehler 1994:Figure 7).

These artifacts have been called cariniform atlatl weights (e.g., Parsons et al. 1979), but the more generic term lunate stones does not carry any functional connotations, and other researchers (e.g., Thurmond 1991b) contend that their function is unknown. Minimal wear on the central notch (which is sometimes larger than the others) and on both faces of some specimens suggests that they were suspended on a strap or rope (Redding and Parker 1991). While they may have served as atlatl weights, they also might have been used solely as ornaments or status symbols. With one exception, the lunate stones are made of materials not found anywhere on the Llano Estacado or in the Lower Plains. Two specimens are made of unidentified materials, and one is made of diorite that may have come from New Mexico, but most are made of an igneous "greenstone." No positive source identifications have been made, but Parsons et al. (1979:77, 80) state that four of the greenstone lunate stones were tentatively identified by a geologist as rhyolite that was probably from the Davis Mountains of west Texas; one of these, the Old Tom specimen, was specifically (but tentatively) identified as Gomez rhyolite.

Since the majority of lunate stones are made of exotic materials and because they are only known to occur in funerary contexts, it may be inferred that these objects were of special significance within Late Archaic society. An accurate identification of the exotic lithic materials that were used to make lunate stones is crucial for understanding the interregional exchange and/or mobility of the Late Archaic bison hunters. More-precise excavation data on intraburial context and detailed artifact attribute and use-wear analyses are needed to address the function(s) of lunate stones.

Three conch shell pendants were recovered along with the lunate stone from the Old Tom burial in Dickens County. Parsons et al. (1979:77-78) note that similar shell pendants were recovered from the Ernest Witte site (G. Hall 1977:Figure 36, Form 7) and other sites along the Texas coast. Redding and Parker (1991:231, Figures 9 and 10) also note similarities between the Old Tom shell pendants and the Form 7 shell pendants recovered in association with Ensor points in the Late Archaic burials at Allens Creek in Austin County, Texas (Hall 1981). Like the lunate stones, these conch shell pendants denote extensive interregional exchange in Late Archaic times.

Late Archaic burials without lunate stones are fairly common, and it is likely that other burials of Late Archaic age are unrecognized. Isolated (often cairn-covered) burials of undefined age are ubiquitous in the Panhandle-Plains, but there is a notable absence of temporally diagnostic artifacts. Many of these burials are presumed to be Archaic in age, but most of the finds have not been properly excavated and reported (Hughes 1976:32).

Several burials without lunate stones are associated with the Late or transitional Archaic period, and five of these have been radiocarbon dated (Table 64). A burial at the Sam Wahl site (Boyd et al. 1994:60-64, 113-116), which included a hematite paint stone and a Scallorn arrow point as 


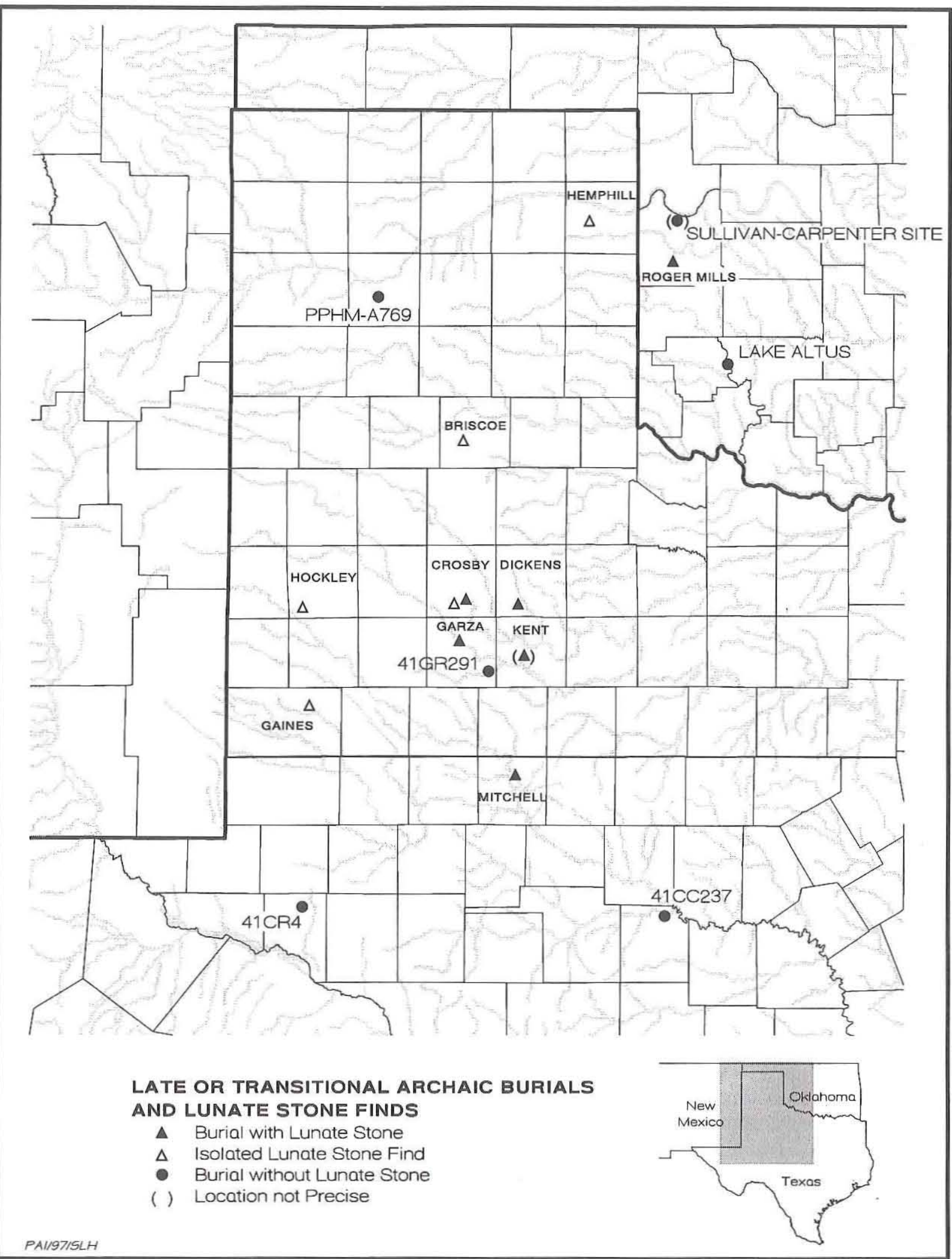

Figure 81. Locations of Late and transitional Archaic burials, lunate stone burials, and isolated lunate stone finds. 

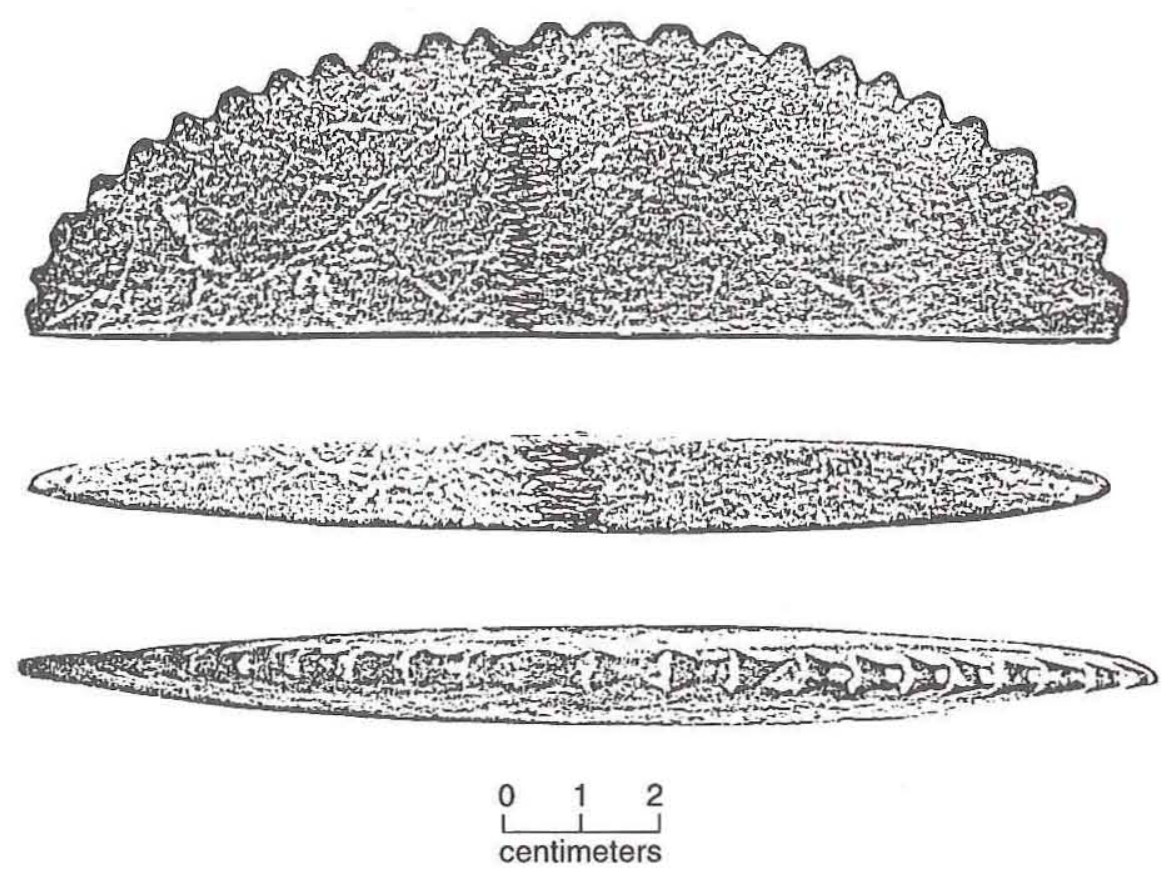

Figure 82. Side and edge views of a lunate stone from Crosby County, Texas (modified from Redding and Parker 1991:Figure 6E and F).

the only definite mortuary offerings, is radiocarbon dated to A.D. 256-415. There is some gap in time between this burial and the earliest occupations (i.e., Late Prehistoric I) at the site, and the two may or may not be related (see Chapter 10). The burial date indicates that it is contemporaneous with some of the Late Archaic bison kills, and the morphological similarities between this unusually large arrow point and broad-bladed dart points (discussed below) are consistent with this assessment.

Excavations at the Sullivan-Carpenter site in western Oklahoma (34RM668) identified two separate interments within a short distance of each other (Gettys 1991; Oklahoma Archeological Survey 1993). Burial 1 is a double burial dated to A.D. 896-1023; lacking any associated diagnostics, one must conclude that it is post-Archaic. Burial 2 is a triple burial with seven large corner-notched dart points associated, and two radiocarbon assays indicate that it dates to A.D. 261-578. The articulated remains of the three individuals interred in Burial 2 consist of one person that had been decapitated, with the skull placed inside the pit, and two who had apparently been killed by darts. One of the points was lodged in a vertebra, and the other six were found in the chest, upper arm, or pelvic areas of the latter two individuals. It is not known whether these people were dart point makers or whether they were newcomers who were killed by people who made dart points (see Chapter 10).

None of the numerous burials recovered from the shoreline of Lake Altus in western Oklahoma (Button and Agogino 1986, 1987) have produced Late Archaic artifacts, but at least two are radiocarbon dated to the terminal Archaic period. Both burials, one a single interment and one a multiple interment of five individuals, may be approximately contemporaneous at ca. A.D. 422-690. Both burials may be associated with a Late Archaic-into-Plains Woodland cemetery, and the multiple burial represents a family that was killed (see Chapter 10).

At Lake O. H. Ivie, a cairn burial (41CC237) containing the cremated remains of a child and the disarticulated remains (bundle burial) of an adult male is reported by Lintz, Treece et al. (1993a: 665-675). Although the artifacts found in the burial pit (i.e., thin bifacial preforms, unifacial tools, debitage, modified limonite fragments, and 19 Olivella shell beads) are not temporally sensitive, the burial is radiocarbon dated to A.D. 408-657. A possible cut mark observed on one rib may be evidence of dismemberment, and the individual's mandible was absent.

A flexed burial in Potter County (PPHM-A769) 
TABLE 63

SUMMARY OF LUNATE STONE FINDS IN THE SOUTHERN PLAINS ${ }^{1}$

\begin{tabular}{|c|c|c|c|c|}
\hline County/Reference & Material Description & Context & Associations & $\begin{array}{l}\text { Presumed } \\
\text { Age }\end{array}$ \\
\hline Briscoe, Texas & $\begin{array}{l}\text { Unidentified fine-grained } \\
\text { siltstone }\end{array}$ & Surface find & None & - \\
\hline $\begin{array}{l}\text { Crosby, Texas } \\
\text { Redding and Parker (1991) }\end{array}$ & $\begin{array}{l}\text { Igneous metamorphic rock, } \\
\text { slatelike, possibly greenstone }\end{array}$ & Slab-lined burial & $\begin{array}{l}\text { Ensor dart point; } \\
3 \text { Olivella shell beads }\end{array}$ & $\begin{array}{l}\text { Late } \\
\text { Archaic }\end{array}$ \\
\hline Crosby, Texas ${ }^{2}$ & Greenstone & Surface find & None & - \\
\hline $\begin{array}{l}\text { Dickens, Texas } \\
\text { Parsons et al. (1979) }\end{array}$ & $\begin{array}{l}\text { Greenstone, tentatively } \\
\text { identified as Gomez rhyolite } \\
\text { from Davis Mountains }\end{array}$ & $\begin{array}{l}\text { "Old Tom" } \\
\text { burial }\end{array}$ & $\begin{array}{l}3 \text { conch shell } \\
\text { pendants }\end{array}$ & $\begin{array}{l}\text { Late }^{3} \\
\text { Archaic }\end{array}$ \\
\hline Gaines, Texas & $\begin{array}{l}\text { Unidentified gray igneous } \\
\text { material speckled with black }\end{array}$ & Surface find & None & - \\
\hline $\begin{array}{l}\text { Garza, Texas } \\
\text { Cockrum (1963) }\end{array}$ & $\begin{array}{l}\text { Gray-green diorite, possibly } \\
\text { from New Mexico }\end{array}$ & $\begin{array}{l}\text { Multiple burial } \\
\text { of } 4 \text { individuals }\end{array}$ & None & - \\
\hline Hemphill, Texas & Unknown & Unknown & Unknown & - \\
\hline Hockley, Texas & Greenstone & Surface find & None & - \\
\hline $\begin{array}{l}\text { Kent, Texas } \\
\text { Holden (1929) }\end{array}$ & $\begin{array}{l}\text { Greenish stone "resembling } \\
\text { Mexican Jade" }\end{array}$ & $\begin{array}{l}\text { Cairn-covered } \\
\text { burial }\end{array}$ & None & - \\
\hline $\begin{array}{l}\text { Mitchell, Texas } \\
\text { Ray (1936) }\end{array}$ & 2 greenstone specimens & Cremated burial & $\begin{array}{l}\text { Shumla, Marcos, and } \\
\text { Fairland dart points; } \\
5 \text { stone pendants; } \\
\text { terrapin shell rattles }\end{array}$ & $\begin{array}{l}\text { Late } \\
\text { Archaic }\end{array}$ \\
\hline $\begin{array}{l}\text { Roger Mills, Oklahoma } \\
\text { Thurmond (1991b) }\end{array}$ & $\begin{array}{l}\text { Fossiliferous shale, locally } \\
\text { available in Ogallala } \\
\text { Formation gravels }\end{array}$ & Burial & $\begin{array}{l}\text { Marcos dart point; } \\
2 \text { bifaces }\end{array}$ & $\begin{array}{l}\text { Late } \\
\text { Archaic }\end{array}$ \\
\hline \multicolumn{5}{|c|}{$\begin{array}{l}{ }^{1} \text { General information for most of these lunate stone finds is reported by Redding and Parker (1991). Specific } \\
\text { references for individually reported specimens are listed in the table. } \\
{ }^{2} \text { This find was erroneously stated as being from Lubbock County by Redding and Parker (1991:232), but Rick } \\
\text { Walter (personal communication 1995) actually found this specimen in Crosby County. }\end{array}$} \\
\hline
\end{tabular}

produced a large "Scallorn-like" arrow point that may actually be a small dart point (Harrison and Griffin 1973:Figure 2A). The burial also yielded an obsidian pendant, 275 tubular bone beads, 38 hackberry seed beads, 2 mussel shell beads, and 11 modified prairie dog palates. The remains were not radiocarbon dated so their age is uncertain. Stickney and Stickney $(1984: 53-55,68)$ report an isolated burial in Crane County (41CR4) that contained three corner-notched points (one probable dart and two probable arrow points), but this burial also is undated.

\section{Geographic Range}

The geographic range of the Little Sunday 
TABLE 64

SUMMARY OF RADIOCARBON DATES FOR LATE AND TRANSITIONAL ARCHAIC BURIALS ${ }^{1}$

\begin{tabular}{|c|c|c|c|c|c|c|c|c|}
\hline \multirow{2}{*}{$\begin{array}{l}\text { Site Name } \\
\text { and Number }\end{array}$} & \multirow{2}{*}{$\begin{array}{l}\text { Description } \\
\text { of Burial/ } \\
\text { Diagnostics }\end{array}$} & \multirow[b]{2}{*}{ Reference } & \multirow[b]{2}{*}{ Lab No. } & \multirow{2}{*}{$\begin{array}{l}\text { Uncorrected } \\
\text { Age, B.P. }\end{array}$} & \multirow{2}{*}{$\begin{array}{l}\delta^{13} \mathrm{C} \\
\% 0\end{array}$} & \multicolumn{2}{|c|}{ Corrected $^{2}$} & \multirow{2}{*}{$\begin{array}{l}\text { Calibrated A.D. Date } \\
\text { Range and Intercepts }\end{array}$} \\
\hline & & & & & & Age, B.P. & Date, A.D. & \\
\hline $\begin{array}{l}\text { Sam Wahl } \\
41 G R 291\end{array}$ & $\begin{array}{l}\text { Feature } 23 \text {, cairn } \\
\text { burial with large } \\
\text { Scallorn point }\end{array}$ & Boyd et al. 1994 & Beta-61496 & $1530 \pm 60$ & -13.6 & $1720 \pm 60$ & $230 \pm 60$ & $\begin{array}{l}256(264,269,342, \\
374,376) 415\end{array}$ \\
\hline \multirow{2}{*}{$\begin{array}{l}\text { Sullivan- } \\
\text { Carpenter } \\
\text { 34RM668 }\end{array}$} & \multirow{2}{*}{$\begin{array}{l}\text { Burial 2, triple } \\
\text { burial with seven } \\
\text { corner-notched } \\
\text { dart points* }\end{array}$} & \multirow{2}{*}{$\begin{array}{l}\text { Gettys } 1991 \\
\text { Oklahoma Archeological } \\
\text { Survey } 1993\end{array}$} & Beta-56529 & $1510 \pm 100$ & -16.6 & $1640 \pm 100$ & $310 \pm 100$ & $261(420) 541$ \\
\hline & & & Beta- 57058 & $1430 \pm 90$ & -14.6 & $1600 \pm 90$ & $350 \pm 90$ & $\begin{array}{l}363(429,522,527) \\
578\end{array}$ \\
\hline \multirow{2}{*}{$\begin{array}{l}\text { Lake Altus } \\
\text { Burials } \\
34 \text { GR5 }\end{array}$} & $\begin{array}{l}\text { Multiple burial of } \\
\text { five individuals, } \\
\text { probably a family } \\
\text { that was killed* }\end{array}$ & $\begin{array}{l}\text { Button and Agogino } \\
1987: 31\end{array}$ & Beta- 17823 & $1270 \pm 90$ & - & {$[1411 \pm 99]$} & - & [557 (646) 690] \\
\hline & Single burial & $\begin{array}{l}\text { Button and Agogino } \\
\text { 1987:19 }\end{array}$ & Beta-17824 & $1390 \pm 90$ & - & {$[1531 \pm 99]$} & - & [422 (542) 642] \\
\hline $41 \mathrm{CC} 237$ & $\begin{array}{l}\text { Child cremation } \\
\text { and secondary } \\
\text { adult burial, no } \\
\text { diagnostics* }\end{array}$ & $\begin{array}{l}\text { Lintz, Treece et al. } \\
\text { 1993:665-675 }\end{array}$ & $G X-16403-G^{4}$ & - & -17.3 & $1525 \pm 145$ & $425 \pm 145$ & $408(543) 657$ \\
\hline
\end{tabular}

${ }^{1}$ All dates are on bone collagen.

${ }^{2}$ Corrected ages in brackets are estimates for dates for which no $\delta^{13} \mathrm{C}$ values were obtained. The corrected ages are based on an estimated $\delta^{13} \mathrm{C}$ value

of -16.2 for human bone, which is the average of five $\delta^{13} \mathrm{C}$ values obtained on Late Archaic-Woodland burials (one date from Sam Wahl burial, three dates from Burials 1 and 2 at Sullivan-Carpenter, and one date from 41CC237 burial).

${ }^{3}$ All calibrations are done by CALIB version 3.0.3 according to Stuiver and Reimer (1993), using calibration data set \#2 and 1-sigma ranges.

${ }^{4} \mathrm{~A}$ bone apatite date from the same bone sample is excluded.

*Probable evidence of violence. 
complex is much broader than previously thought. This is especially true given the widespread distribution of broad-bladed dart points (see Table 60 and Figure 78). Sites attributed to this complex seem to be most concentrated in the Caprock Canyonlands and the western portion of the Rolling Plains. This may represent the core area for the bison hunting peoples, but they ranged well beyond that on a regular basis. Once thought to be confined to the Red River drainage (Hughes 1989:203), recently reported investigations (e.g., Bement and Buehler 1994; Creel 1990; Quigg, Lintz, Oglesby, Earls et al. 1993; Thurmond 1991a, 1991b) extend the range farther to the north and south.

Sites producing broad-bladed dart points, Late Archaic radiocarbon dates, and/or other diagnostic Late Archaic artifacts occasionally are found in the Canadian River valley and its tributaries. Marmaduke and Whitsett (1975:87), for example, report a Late Archaic site (41OL39) on Alamosa Creek in Oldham County. Although predominantly a Woodland site, Hughes (1962) reported that three dart points (two are Ellis-like) were found at the Lake Creek site in Hutchinson County. No radiocarbon dates have been obtained, but it appears to be a transitional Archaic/Woodland site. In spite of the extensive work in the Lake Meredith area, only a few sites have yielded Late Archaic points (including Castroville and Ellis), and even fewer have been tested (Davis 1985:Table 1; Etchieson 1981:Table 2; Etchieson and Couzzourt 1987:Table 7-1; Green 1986:106-107; Phillips 1985). Late Archaic points occur in low frequencies and most often are found in sites dominated by Panhandle Aspect materials. The vast majority of sites and archeological work relate to the later Plains Village occupations (i.e., Panhandle Aspect); however, Green (1986:42-48, 60-67) reports testing two sites which yielded probable Late Archaic dart points, but neither site has a definable Late Archaic component.

Farther to the north, investigations at Palo Duro Reservoir (Hansford County) in the northern Texas Panhandle have produced evidence of occupations by Late Archaic bison hunters. Mitchell (1975:219221) notes that broad-bladed dart points are common in surface collections from Hansford County, and similar points were reported at numerous sites during the Palo Duro Reservoir survey (Peterson 1988: Figures 14-22). Subsequent data recovery produced four dart points (an unidentified corner-notched point, one resembling Bell or Calf Creek, and two
Marcos-like specimens) in association with bison remains at the Sandy Ridge site (Quigg, Lintz, Oglesby, Earls et al. 1993:209). Six radiocarbon dates were obtained from this stratigraphic zone; two were on bison bone collagen (or gelatin), two were on bison bone apatite from the same bones as the collagen dates, and two were on charcoal from sediment samples. The two dates on bison bone collagen (which were thought to be more accurate than the apatite dates) yielded calibrated ages with a range of 2006-1639 B.C., while the two charcoal dates were later, with a range of 1487-815 B.C. These dates are consistent with Late Archaic occupations, but the zone containing these materials also yielded 10 early-style basal- and corner-notched arrow points. The evidence may be interpreted in various ways, and Quigg, Lintz, Oglesby, Earls et al. (1993:210) suggested that the site might be multicomponent (i.e., separate Late Archaic and Woodland occupations) or that the arrow points are contemporaneous with the bison remains and dart points in a single occupation (see Chapter 10).

The Sanders site (41HF128), another Late Archaic site in Palo Duro Reservoir, was found in 1990 during the data recovery investigations. Limited testing (three backhoe trenches and three $1-\mathrm{x}-1-\mathrm{m}$ test units) revealed a buried cultural zone in the alluvial terrace adjacent to Palo Duro creek (Quigg, Lintz, Oglesby, Earls et al. 1993:333-346). The cultural zone, located at $90-150 \mathrm{~cm}$ below the surface within a thick cumulic A horizon, covers an estimated area of $588 \mathrm{~m}^{2}$. The investigations produced 741 bones, 43 burned rocks, 20 pieces of lithic debitage, 3 scrapers, 3 edge-modified flakes, and 2 bone tools. The faunal assemblage is dominated by small fragments, but 66 percent of the specimens are identifiable as bison, and no other species were identified (except for intrusive remains). Two bone collagen radiocarbon dates place the age of the cultural deposits at 347 B.C. to A.D. 406 (the span of the 1-sigma age ranges of the two calibrated dates).

Quigg, Lintz, Oglesby, Earls et al. (1993: 345-346) interpret the Sanders site as a Late Archaic secondary bison processing station representing a single event that occurred at about A.D. 100. The bison remains include at least one mature male and an immature male, indicating hunting of a mixed herd. Late-term fetal bison elements indicate that the event may have taken place in the late winter. No interpretations of cultural affiliation were offered 
due to the lack of diagnostic artifacts. The principal activities are thought to have been secondary butchering and processing of meat, hides, and bone grease, and it seems likely that at least short-term camping occurred at the Sanders site. In addition, the two bone radiocarbon dates and the geomorphic evidence for slow deposition of the 40-cm-thick cultural zone suggest that the Sanders site was a favorite camping/processing locality over an extended period of time. Additional investigations conducted in 1995 will help clarify the interpretations. ${ }^{5}$

Based on the presence of Late Archaic sites and broad-bladed dart points in Palo Duro Reservoir, it is likely that the Little Sunday complex extends as far north as the northern border of the Texas Panhandle. Since the archeology of the Oklahoma Panhandle is not well known, the northern extent of the complex may be arbitrarily set at the border between the Texas and Oklahoma Panhandles. This should be considered a temporary boundary, however, and it is noteworthy that White (1987) has surface collected numerous Marcos-like points from the Muncy site in the west-central part of Texas County, Oklahoma.

To the south, Stickney and Stickney (1984: 61-69) illustrate several broad-bladed dart points that were surface collected from Crane County, immediately below the southernmost tip of the Llano Estacado. In the San Angelo area, immediately due east of Crane County, broad-bladed, corner- and side-notched dart points, typed as Marcos, Castroville, and Ensor, were recovered in stratigraphic Zones A-4 to A-12 at 41TG91 (Creel 1990:36-50, 219-221, Tables 2 and 5), called the East Levee site by Lee Johnson (1994:242). Seven radiocarbon dates place the age of these points at 1449 B.C. to A.D. 54. Bison remains were found throughout these zones but were more common in the lower Zones A-9 to A-12, less common in the middle Zones A-8 to lower A-4, and absent in the subsequent Blow Out Mountain upper Zone A-4. Marcos

${ }^{5}$ Extensive excavations $\left(115 \mathrm{~m}^{2}\right)$ at the Sanders site in 1995 are reported by Quigg (1997b). The site is interpreted as a single-event bison-processing station and campsite that occurred during the month of March at approximately A.D. 150-250. This new work provides substantial evidence regarding Late Archaic bison hunters in the Southern Plains, including a unique assemblage of incised and painted bone ornaments not seen in any other contemporaneous sites. points were recovered in the lower zones (A-12 to $\mathrm{A}-8)$ and were in direct association with bison remains in Zone A-9. Marcos points were not found in the zones above and apparently were replaced by Ensor and Castroville points (discussed below). Green (1961) reported numerous Archaic points, including Frio, Lange, Castroville, Williams, and Marshall, mixed with Early-Middle Archaic materials in association with a burned rock midden at the Spring Creek site in Tom Green County. Based on these sites, the southern boundary of the Llano Estacado and the Rolling Plains seems to be a logical cutoff for the southern extent of the Little Sunday complex.

Late Archaic sites to the east and south of the San Angelo area have some similarities but are quite different from those of the Little Sunday complex. The Little Sunday complex includes some of the same point types as the San Marcos, Uvalde, and Twin Sisters phases of Central Texas (Prewitt 1985), but it is not clear how these manifestations are related. Bison may have been present in Central Texas during these phases, but bison hunting seems to have been relatively less. important to these peoples. Gathering and processing of plant foods were probably their primary subsistence activities.

Similarly, broad-bladed dart points are found with some regularity in the Stockton Plateau, a western extension of the Edwards Plateau. While Paisano points are by far the most abundant, Prewitt (1983:Figure 11) notes that Ensor, Frio, Montell, Marcos, and Shumla also are represented there. Bandy (1980) reports that these Late Archaic point types were found at numerous sites in the area, and some Late Archaic components were identified in excavations. Ensor, Frio, Marcos, and Marshall points are well represented among the dart points recovered from excavations at Red Bluff Shelter in Crockett County (Lorrain 1968). Broad-bladed dart points are generally associated with burned rock middens, rockshelters, or hearth fields which often have substantial and inseparable Late Prehistoric components. There is little evidence that bison hunting was of any importance to the people of the western Edwards Plateau, in contrast with the evidence for intensive plant processing. As in the Central Texas area, it is not clear how the western Edwards Plateau Late Archaic remains are related to those of the Southern Plains.

Late Archaic peoples occasionally followed bison herds even farther southward, well beyond 
their traditional Southern Plains range. The Late Archaic bison jump at Bonfire Shelter in Val Verde County, Texas, apparently represents a brief and isolated episode. There is no evidence to indicate that bison hunters journeyed into the Trans-Pecos area on a regular basis throughout the Late Archaic period.

To the east, the Late Archaic period is known mainly through surface investigations over most of the Rolling Plains, and broad-bladed dart points apparently are common. They extend all across the Rolling Plains and into the western Cross Timbers region. Documentation of local collections and extensive archeological survey at South Bend Reservoir in Young, Stephens, and Throckmorton Counties indicates that the following Middle to Late Archaic points are common (in descending order of frequency): Darl, Godley, Ensor, Castroville, Ellis, Marshall, Lange, Palmillas, Marcos, Gary, and Frio (Saunders et al. 1992:176-184). The research at South Bend Reservoir suggests that this area is more closely related to the Late Archaic of Central Texas, but these relationships are poorly understood.

As far as the western boundary of the Little Sunday complex is concerned, there are no excavated Late Archaic components on the southern Llano Estacado, and inferences must be based exclusively on surface investigations. Broad-bladed dart points appear to be found all across the southern Llano Estacado with some consistency, but never in any substantial quantities. Despite the extensive excavations at the Lubbock Lake site, no definite Late Archaic features and only two Late Archaic dart points have been recovered (E. Johnson 1987:111; Johnson and Holliday 1986:40). One is a reworked Ellis point from a stratigraphic trench, and the other is a reworked Marcos point from a Protohistoric feature. One of these is clearly an heirloom, and the other does not have sufficient contextual information to constitute a component. A few possible Late Archaic activity areas may represent camping events, but they are undated and produced no diagnostics (E. Johnson 1987:133). Based on these meager remains, there is only minimal evidence that Late Archaic peoples lived and hunted at the Lubbock Lake site (E. Johnson 1987: 161).

Other sites on the southern Llano Estacado have yielded Late Archaic artifacts. In his study of lake sites on the South Plains, Watts (1939:82-84) notes that large points (i.e., dart points) were as common as small points (i.e., arrow points) in surface collections from Rich Lake in Terry County. Looking at his illustrations (Watts 1939:Plate 19), Late Archaic broad-bladed points are well represented. Brown $(1985$, n.d.) notes that broad-bladed dart points (some typed as Ellis, Lange, and Williams) were recovered from surface collections at playa lake sites (41LU29/34 and 41LU75) in Lubbock County. Extensive surface collections from another playa lake campsite in Lubbock County (SPAS-LU 10) yielded numerous dart points similar to the Edgewood, Elam, Ellis, Marshall, Palmillas, and Williams types (Brown 1990a, 1990b, 1991a, 1991b). Unlike collections from many such sites, the Late Archaic materials seem to be more abundant at this site than Late Prehistoric artifacts. A recent survey of a 1,300-acre tract just southeast of Lubbock recorded only eight sites with prehistoric components but recovered a Castroville dart point from site 41LU104 (Schroeder and Rader 1995a). A few dart points (including Ensor and Marcos) were recovered from Andrews Lake (Collins 1968), and surface collection of a sand dune site near Tahoka Lake in Lynn County produced many dart points, including Edgewood, Ellis, Ensor, Marcos, Marshall, Palmillas, and Williams (Riggs 1965b). Randall (1970) reports that Castroville, Darl, Edgewood, and Godley points have been found in Lamb County.

Even farther west, Warnica (1965) reports that surface collections from a site 18 miles west of Portales in Roosevelt County, New Mexico, produced many Ellis and Edgewood dart points and numerous end scrapers. The majority of these artifacts are made of Quitaque flint (i.e., Tecovas jasper) from east of the Caprock Escarpment. This suggests that these Late Archaic peoples may have come from the Caprock Canyonlands area.

The examples mentioned above indicate that broad-bladed dart points are found all across the southern Llano Estacado, but all of these finds are from surface contexts and they are usually mixed with Late Prehistoric remains that are usually much more abundant. These Late Archaic materials are located primarily near pluvial and playa lakes and are suggestive of ephemeral campsites, but none have been adequately investigated. There does appear to be sufficient evidence, despite the scarcity of archeological investigations, to suggest that the Late Archaic bison hunting tradition did range onto the southern Llano Estacado. 
The western and southwestern boundaries of the Little Sunday complex are difficult to define due to the lack of data. The western boundary is tentatively placed along the edge of the Llano Estacado, and broad-bladed dart points are found in the Melrose Air Force Range (Lintz et al. 1988). Similar forms appear among the projectile points of extreme southeastern New Mexico (Leslie 1978:Type 8) and in the Pecos River valley (Jelinek 1967:103), but Hofman (1989a:53) notes that little is known about Archaic occupations of eastern New Mexico. No excavated Late Archaic components are known in the western and southern Llano Estacado, and contextual data are lacking. One suspects that the Plains bison hunting lifestyle disappeared to the west and southwest of the Llano Estacado, but it is impossible at this time to determine exactly where Plains adaptations ended and Southwestern desert adaptations, such as the Hueco Phase (Lehmer 1948; Sayles 1935; Suhm et al. 1954) began. Edgewood, Ellis, Ensor, Marshall, Palmillas, Williams, and Yarbrough points have been found in northeastern New Mexico along the Canadian River at Conchas (Baker et al. 1983:Table 2) and Ute (Hammack 1965) Lakes and along the upper Pecos River at Santa Rosa Lake (Los Esteros Reservoir; Ward et al. 1987:Table 22). Noting the presence of these point styles, along with Alibates agate from the Texas Panhandle, researchers have suggested that Plains peoples intruded into northeastern New Mexico during the Late Archaic (Campbell 1976a; Thoms 1976; Ward et al. 1987:32).

\section{Chronology, Material Culture, and Subsistence}

The radiocarbon dates for the bison kill sites and campsites (see Tables 61 and 62 and Figures 79 and 80 ) provide the main body of evidence for defining the chronology of the Little Sunday complex. Collectively, the data suggest that the complex dates from ca. 2000 B.C. to A.D. 500. However, the chronology can only be established in a very general sense, in part because of the bison bone dating problems discussed previously. More importantly, chronological interpretations are limited by the paucity of well-dated Late Archaic components. Many of the dated components can only be described in vague terms or appear to represent mixtures of Late Archaic materials with earlier and later cultural residues.
All of the bison kills and most of the habitation sites date to the latter half of the Late Archaic period. Of all the dated habitation sites, only six contain occupational evidence older than A.D. 1 (see Figure 80). The relative paucity of older Late Archaic sites could be due to geomorphic processes (i.e., destruction of earlier sites by erosion), such as suggested by Hughes (1977) and Thurmond (1991a) for the temporal bias observed in bison kills. Alternatively, the apparent scarcity of bison kills and campsites dating to the first half of the Late Archaic could be due to fewer people generating fewer sites or fewer bison and less bison hunting, resulting in fewer diagnostic dart points being deposited in sites and fewer sites recognized as Late Archaic. Perhaps a combination of these factors, i.e., geomorphic processes, fewer people, and fewer bison, is responsible.

The regional data indicate that the Little Sunday complex is characterized by large, broadbladed, corner- to side-notched dart points which are similar in gross morphology but exhibit wide variability in minor attributes. The broad-bladed points appear to have been in use for a long period of time, but it is unlikely that all of them were used throughout the entire Late Archaic period. More likely, various point styles were introduced, became popular and widespread, and were ultimately phased out at different times. The use of different point styles may have overlapped in time and space, and changes in one style may have occurred independent of changes in another. The archeological data are not sufficient to establish a detailed point sequence within the Little Sunday complex, but some tantalizing hints may be found.

Jack Hughes (1991:23) has suggested that Late Archaic dart points evolved from larger forms to smaller forms, stating that in the Panhandle-Plains, Castroville, Marcos, Marshall, Palmillas, and Williams are earlier than Edgewood, Elam, Ellis, Ensor, Kent, Lange, and Trinity. This impression may well prove to be true, but the archeological data currently available are not conclusive. Although the archeological contexts of the projectile points from 41TG91 are not precise, their stratigraphic positions in Area A (Creel 1990:Table 5, 36-49, 220-221) are interesting. Marcos points were found in the lower Late Archaic strata (one in Zone A-12, one in Zone A-9, and five in Zone A-8). Zone A-8 has five radiocarbon dates which range from 1449 to 386 B.C., and the Marcos points appear to date to 
this time period and probably somewhat earlier. The Castroville and Ensor points (one each) were found in Zone A-4 which marks the terminal Archaic/Blow Out Mountain transition. Two radiocarbon dates on the underlying strata (Zones A-5/6 and A-7) range from 362 B.C. to A.D. 54, and the Castroville and Ellis points presumably postdate this by an unknown amount of time. Thus, assuming that they were not picked up and redeposited by later people, the Castroville and Ellis were used later than the Marcos points at 41TG91.

One perplexing problem, assuming the dates are approximately correct, is that Castroville and Montell points appear at Bonfire Shelter considerably earlier, 1407-387 B.C., than they do in Prewitt's (1985) Central Texas Uvalde phase at 300 B.C.-A.D. 150. This suggests that either the data on their temporal occurrence are not precise in one or both regions, or that the Castroville and Montell points were used for a long period of time, and perhaps at different times, in these regions. It also is worth noting that the Bonfire points typed as Castroville include a great deal of variability, and many individual specimens would be classified differently by other researchers (see Dibble and Lorrain 1968:Figures 23 and 24).

The cultural activities associated with the Little Sunday complex are not particularly well known. Since many of the components contain a mix of Late Archaic and Late Prehistoric materials, only the artifact assemblages and trait lists from three sites-Little Sunday, Summers, and Chalk Hollow-appear to be truly representative of the complex, and even these have their problems (Table 65). For the Little Sunday and Summers sites, the assemblages are very small and they are not directly compatible because the former is a selective surface collection while the latter consists of half surface/ half excavated artifacts. For Chalk Hollow, the assemblage has not been described, but the presence of some artifact classes was noted. In terms of features, only a few at the Summers site have been described while those at Chalk Hollow have not. Burned rock and other features are probably present at Little Sunday, but little can be inferred from surface data alone.

Assuming that these components are exclusively Late Archaic, they demonstrate a range of activities well beyond that indicated by evidence from the bison kills. The variability in artifacts and features indicates that these components represent multifunc- tional campsites, but bison remains are well represented in all cases.

Clear Fork gouges were recovered at the Little Sunday and Summers sites, and Leonhardy (1966:30) suggested that they were a distinctive tool of the Summers complex. Other researchers have suggested that Clear Fork gouges (includes unifacial and bifacial varieties as defined by Turner and Hester [1993:246-249]) are temporally diagnostic tools of the Archaic period in the Southern Plains (e.g., Bagot and Hughes 1979:50; Etchieson et al. 1977:33, 35, 1978:83, 1979:353; Hughes 1984:116). This perception is based largely on their co-occurrence with dart points at many surface-collected sites, but there are very few examples of gouges from excavated and/or dated contexts. Besides the Late Archaic, Clear Fork gouges have been found in association with Early to Middle Archaic remains at the Gore Pit site (Bastian 1964; Hammatt 1976). They also have been found at many sites that have transitional Archaic materials but are dominated by Late Prehistoric remains, such as the Sam Wahl and Cat Hollow sites at Lake Alan Henry (see Chapter 6), the Blue Clay site at Mackenzie Reservoir (Willey et al. 1978b), and the Kent Creek site (Cruse 1992). In the Crowell Reservoir area where gouges were considered to be diagnostic Archaic tools, these tools have been found at a tested site (41FD47) that produced several arrow points but no dart points (Etchieson et al. 1979:215, Table 22). Researchers in Oklahoma also have noted that Clear Fork gouges have been found in apparent postArchaic contexts (e.g., Saunders 1978:80).

While Clear Fork gouges occur much more commonly in association with dart points and they appear to have been widely used in Archaic times (J. Hughes 1976, 1980, 1991), there is not sufficient evidence to indicate that the use of Clear Fork gouges was confined to the Archaic period. They probably were used by Paleoindians in Texas (Hall et al. 1982:342; Hughes 1980:145), and there is evidence to indicate that they were used well into Late Prehistoric times. Summarizing gouges in the Panhandle-Plains, Jack Hughes (1991:19) suggested that they are "indicative mainly of the Early Archaic, from about 5000 to 2000 B.C., but appeared somewhat earlier, in Late Paleoindian time, and in some regions, may have lingered into Late Archaic and even into Neoindian times."

Gouges are thought to denote some particular activity, or a range of activities, but there is 
TABLE 65

COMPARISON OF MATERIAL CULTURE AND OTHER TRAITS FOR LATE ARCHAIC COMPONENTS OF THE LITTLE SUNDAY COMPLEX

\begin{tabular}{|c|c|c|c|}
\hline Artifact Class & $\begin{array}{l}\text { Little Sunday } \\
\text { (Hughes 1955) }\end{array}$ & $\begin{array}{c}\text { Summers } \\
\text { (Leonhardy 1966) }\end{array}$ & $\begin{array}{c}\text { Lower Midden at Chalk } \\
\text { Hollow (Wedel 1975) }\end{array}$ \\
\hline Dart Points & 23 & 9 & $\mathrm{x}$ \\
\hline Bifaces & & & $\mathrm{x}$ \\
\hline Knives & 21 & 2 & \\
\hline Thin Bifaces & & 5 & \\
\hline Fragments/Unidentified & & 14 & \\
\hline Blades & 10 & & \\
\hline Drills & 5 & & \\
\hline Gravers & 5 & 12 & \\
\hline Scrapers & 72 & 25 & * \\
\hline Gouges (Clear Fork type) & 2 & 2 & \\
\hline Scraper-Planes & & 9 & \\
\hline Utilized Flakes & & 14 & \\
\hline Choppers & 8 & 26 & $\mathrm{x}$ \\
\hline Cores & & $\mathrm{x}$ & \\
\hline Debitage & & $\mathrm{x}$ & $\mathrm{x}$ \\
\hline Hammerstones & & 2 & $\mathrm{x}$ \\
\hline Manos & 7 & 3 & $\mathrm{x}$ (abundant) \\
\hline Metates & 5 & 1 & $\mathrm{x}$ (abundant) \\
\hline Conch Shell Pendant Fragment & 2 & & : \\
\hline Total No. of Artifacts & 160 & 124 & $?$ \\
\hline Faunal Remains & bison & & bison and other large mammals \\
\hline Burned/Fire-Cracked Rocks & $\mathrm{x}$ & & \\
\hline Burned Rock Features/Hearth & & $\mathrm{x}$ & $\mathrm{x}$ \\
\hline Other Features & & $\begin{array}{l}\text { Rock-filled pit with } \\
\text { bison bones, ash lens, } \\
\text { bison bone concentrations }\end{array}$ & \\
\hline
\end{tabular}

considerable debate about their precise function. Most researchers seem to agree that these tools were usually hafted and used like a modern carpenter's plane (e.g., Wulfkuhle 1986:275-277), but there are various ideas about the materials on which they were used. For example, Shiner (1975) suggested that they were used for hide scraping (i.e., basically a variation of end scrapers), while Hester et al. (1973) concluded from use-wear studies that gouges in South Texas were used primarily as woodworking tools. Hall et al. (1982:340-348) present a thorough discussion of the dating and function of these tools but come to no definitive conclusions. Ray (1941: 161-162) thought that hafted gouges in the Rolling Plains were used as multifunctional tools and served as digging sticks, woodworking tools, and hide scrapers. In support of Ray's multifunctional tool hypothesis, Boyd et al. (1989:175, 241) notes that microwear analysis of the bit edge of one Clear Fork gouge from Lake Alan Henry yielded evidence of hide working, while organic residues were tentatively identified as plant remains on one gouge and 
animal remains on another (although the residue samples were extracted from the entire gouge and the latter could reflect haft residue). Given the paucity of conclusive evidence, one cannot assume that Clear Fork gouges are diagnostic Archaic tools or that they had a single specific function. It is interesting that gouges are rare on the southern High Plains but common in the Lower Plains to the east (Bell 1957; Hughes 1980). This may be related to their functional role and the distribution of some specific resource (or resources) that required their use. The differential distribution of wood, nearly absent on the High Plains and abundant in the Lower Plains, mirrors the distribution of gouges and seems to provide additional circumstantial evidence for their use as woodworking tools (J. Hughes 1991:18).

Ground stone tools, usually thin slab metates and small manos, appear to be consistently present at Late Archaic occupation sites, and Wedel (1975) noted that they were abundant in the Lower Midden at Chalk Hollow. The presence of manos and metates is generally considered to be evidence of plant processing. As mentioned above, lunate stones are distinctive artifacts that are Late Archaic in age and occur primarily as mortuary offerings. Similarly, since conch shell pendants have only been found in Late Archaic burial contexts in the Panhandle-Plains, these mortuary offerings may be diagnostic of the complex.

In terms of subsistence, some habitation sites are rich in bison remains while others are not. Bison remains and dart points are well represented at the Little Sunday site and in the lower midden at Chalk Hollow, but other sites in the Caprock Canyonlands show little emphasis on bison hunting. Subsistence activities during Late Archaic times are predominantly associated with plant processing at several Lake Alan Henry sites. This appears to be generally true for the earliest deposits at the Gobbler Creek Bridge site, at the Cat Hollow site, and at Boren Shelter No. 2 (see Chapter 6). While these occupations may be dominated by Late Prehistoric I materials, it does appear that substantial plant processing occurred during transitional Archaic times (A.D. 1-500). This may be contrasted with Stratum D at Deadman's Shelter, which also represents transitional Archaic occupations. There is a clear emphasis on hunting (i.e., abundance of dart points, arrow points, and scrapers) at this site, but deer and smaller animals seem to have been the primary game animals (only one bison element was present).

Two other campsites beyond the Caprock Canyonlands exhibit similar variability in subsistence emphasis. At the Sandy Ridge site in the northern Texas Panhandle, bison bones comprise 87 percent of the transitional Archaic campsite's faunal assemblage (Quigg, Lintz, Oglesby, Earls et al. 1993:210). Conversely, at 41TG91 in northwest Central Texas, Creel (1990:219-221) notes that bison remains are present in the Late Archaic strata, but they are only well represented in one stratum, and even there they apparently do not represent an important food resource. Numerous mussel shell concentrations and slab-lined hearths, and an extremely diverse faunal assemblage, indicate that activities other than bison hunting were more important there.

The variability in subsistence activities represented at canyonland campsites and rockshelters suggests that some localities served as base camps for a variety of hunting/foraging activities while bison hunting continued from other base camps. It also appears that bison hunting may be better represented in some of the earliest Late Archaic campsites (such as the lower midden at Chalk Hollow and Block $\mathrm{C}$ at Sandy Ridge) than in some terminal Archaic campsites. Perhaps this is related to the decline of bison populations during the transitional Archaic (discussed below).

\section{Settlement Pattern}

One characteristic that was proposed for the Summers complex (Leonhardy 1966:30-32) is the predominant use of local cherts and quartzites, mainly the variety that Leonhardy called "Ogallala chert". ${ }^{6}$ At the Summers site, there appears to have been a heavy dependence upon local quartzites and cherts for most types of tools. In addition, the data suggest limited but consistent use of good-quality nonlocal cherts (such as Alibates, Edwards, and Florence A chert) for making some tools, primarily projectile points.

This same pattern is evident at many other Late Archaic sites. Most of the dart points and the few

\footnotetext{
${ }^{6}$ This material, found in the Ogallala Formation and in secondary gravel deposits (e.g., Lingos gravels) in the Rolling Plains, is called Potter chert in the Lake Alan Henry investigations. It is classified as silicified siltstone by Holliday and Welty (1981).
} 
lithic tools found in the bison kill sites are made of local materials. No nonlocal materials are represented at the Certain (Bement and Buehler 1994), Strong, and Collier sites, but the same nonlocal materials as in the Summers site are represented at the Bell (i.e., Alibates) and Twilla (i.e., Alibates, Tecovas, and Florence) sites (Hughes 1977). Local materials are dominant in the Little Sunday assemblage, but Alibates agate, Edwards chert, and Dakota quartzite (from Cretaceous deposits in northeastern New Mexico) are present (Hughes 1955). Nonlocal materials in the lower midden at Chalk Hollow include Alibates, Edwards, and Tecovas (Wedel 1975). Dart points in the Dempsey Divide are made primarily of local materials, but Alibates and Edwards also are represented (Thurmond 1991a: Figures 15-18). The closest source of Edwards chert is over $300 \mathrm{~km}$ south of the Dempsey Divide.

The overwhelming dominance of local Ogallala and Lingos materials in the Late Archaic assemblages can be interpreted as evidence that the bison hunters were at home in the Caprock Canyonlands and Rolling Plains. The low percentages of nonlocal materials indicate that they occasionally ventured west and northwest into the Canadian River valley, northeast into south-central Kansas, and as far south as the Edwards Plateau or Callahan Divide. Moreextensive mobility or trade is indicated by the exotic materials represented in the burial offerings. The lunate stones may indicate movement or trade to the southwest if the source(s) of the greenstones is the Davis Mountains, and the conch shell pendants provide evidence of trade with the coastal region, perhaps via Central Texas. The locations of all of the known lunate stone burials (see Figure 81) also suggest that the home territory for these Late Archaic peoples was the Caprock Canyonlands.

Based on his findings from the lower midden at Chalk Hollow, Wedel (1975:273) was the first to propose a dual settlement strategy for the Late Archaic period:

That the Archaic peoples whose remains we recovered at Chalk Hollow were permanent year-around residents of the canyon-bottom site appears unlikely. I would suggest, rather, a sort of transhumance that involved spring, summer, and fall residence on the upland around the nearby lakes and ponds, with bison, pronghorn, and perhaps waterfowl as principal food resources, and winter residence in the canyon.

While this scenario is plausible, there is not much direct evidence for pronghorn and waterfowl as major food resources. The margins of the canyonlands and the Rolling Plains may have been the primary area frequented by these people during the spring through fall, or it may have been of at least equal importance to the High Plains.

Based on his studies in the Dempsey Divide, Thurmond (1991a) proposed a similar scenario in which microenvironmental diversity controlled the local subsistence and settlement patterns. He argued that because the Dempsey Divide is located along the edge of the High Plains, it is a unique canyonland ecotone that offered prehistoric peoples protection from the elements, abundant fresh water from Ogallala springs, ample wood, and a diversity of plant and animal resources not found in adjacent areas. Comparing survey data for the Dempsey Divide with survey data from the mixed grass prairie of Quartermaster Creek (Moore 1984, 1988) located about 10 miles to the northwest, Thurmond (1991a:138-140) showed how the two environmentally distinct areas were used quite differently by prehistoric peoples. While the site densities in these two areas are roughly equivalent, it appears that the canyonlands of the Dempsey Divide were intensively occupied during Late Archaic and Woodland times with campsites being the dominant site type, but that later Plains village occupations are rare. Exactly the opposite is true for the Quartermaster Creek area, where Late Archaic and Woodland occupations are rare but Plains Village sites are abundant. Thurmond (1991a:140) suggests that the mobile Late Archaic/Woodland peoples made their home base in the Dempsey Divide to exploit its diversity of resources yet still have access to the adjacent Plains area for hunting bison. The Plains Villagers, however, may have moved out of the Dempsey Divide canyonlands, because much of that area was less suitable for agriculture, and into the better farmland along Quartermaster Creek.

The Dempsey Divide canyonland is a small area in terms of its east-west extent, but it is a northern extension of the Caprock Canyonlands zone defined in Chapter 2. In many ways, the Dempsey Divide is typical of all of the canyonlands along the Caprock Escarpment, including those in the vicinity of Lake Alan Henry. Thus, Thurmond's model of 
Late Archaic settlement in the Dempsey Divide is applicable over all of the Caprock Canyonlands. The regional archeological data summarized above indicate that the vast majority of the Late Archaic habitation sites are located in the canyonlands along the eastern Caprock Escarpment while the bison kills are located mainly in the Rolling Plains (and perhaps on the Llano Estacado?). The obvious scenario suggested by these data is that the Little Sunday complex peoples lived mainly in the Caprock Canyonlands to take advantage of its rich concentration of resources and traveled seasonally out into the Rolling Plains and Llano Estacado to hunt bison.

This settlement model is consistent with a study of bison behavior which concluded that:

Clearly, then, the hypothesis that prehistoric bison on the northern Great Plains employed a dual migration/nonmigration, in which some herds migrated annually and others remained sedentary in suitable woodlands, is supported by ecological and historical observations. ... Knowledge of this dispersion behavior leads directly to a human settlement hypothesis which stresses the advantages of locating habitations in topographically anomalous, wooded environments on the Plains grasslands in order to take advantage of a reliable bison supply and a high variety of vegetal and other animal resources which tended to concentrate in such places [Epp 1988:317].

Although this study concentrated on the northern Great Plains, these conclusions are applicable to the Southern Plains as well. There is ample evidence favoring an interpretation that Late Archaic peoples in the Southern Plains utilized a dual settlement strategy, with the Caprock Canyonlands serving as their primary habitation area and base for limited hunting and foraging operations while the surrounding Llano Estacado and Rolling Plains served primarily as their bison hunting range.

This scenario may be considered a variation of "central-based wandering," proposed as one of two settlement models for the Late Archaic by Hughes (1977:154-162). The alternative "restricted wandering" model does not seem to fit the data well. Central-based wandering represents "a community that spends part of each year wandering and the rest at a settlement or 'central base,' to which it may or may not consistently return in subsequent years" (Beardsley 1955:138). Hughes (1977:158) indicated that this model assumes that a significant subsistence base existed in the settlement area or central base, such as (1) "a storable or preservable wild food harvest," (2) "a locally abundant food," or (3) "incipient agriculture producing a small harvest" (Beardsley 1955:138). Hughes (1977:158) suggested that incipient agriculture may have been the important resource base, but based on the archeological data described above, there is no evidence for this. Perhaps incipient agriculture played a role during the terminal Archaic/Woodland transition, but it is doubtful that it was a factor for most of the Late Archaic period. Alternatively, the diversity and density of various plants and animals in the Caprock Canyonlands may have been sufficient to constitute "a locally abundant" food source and allow for "a storable or preservable wild food harvest."

One unresolved problem is the degree to which Late and terminal Archaic peoples were affected by intersocietal warfare. The evidence for violence is strong since 8 (possibly 9) of the 11 individuals from four radiocarbon-dated terminal Archaic burials (see Table 64) probably were killed. Such a high frequency of violence would have played a major role in the societies that participated, but how such hostilities affected regional settlement patterns is not known.

\section{Summary of the Little Sunday Complex}

The Little Sunday and Summers complexes, as originally proposed by Hughes (1955) and Leonhardy (1966), have been redefined in light of the significant increase in archeological data over the past three decades. The redefined Little Sunday complex now includes a much broader geographic area and a wider range of site types and cultural activities. The complex is intended to represent a cultural tradition or lifestyle that covers a long span of time and a broad geographical area but is characterized by a variety of attributes recognizable in the archeological record. It is not intended to represent a specific group of people and is not analogous to a phase. Rather, it is hoped that future research will result in better archeological data that may be useful for refining the Late Archaic cultural sequence and ultimately defining one or more cultural phases to replace the concept of the Little Sunday complex. 
While many details remain unclear, it appears that the Caprock Canyonlands served as the pivotal central base region for Little Sunday complex peoples, and bison was the key resource around which their lives revolved. These people lived in the canyonlands for a significant part of the year, exploiting a wide range of plant and animal resources. During other seasons, small bands ranged widely onto the High Plains and Rolling Plains, following and searching for bison herds and conducting logistically organized communal hunts. This settlement model is simplistic, but it should serve as a testable hypothesis for future research on the Late Archaic in the Southern Plains. The acquisition of reliable seasonality and nonhunting subsistence data is of critical importance for further defining the Late Archaic period.

Some of the archeological assumptions and implications for testing this model of seasonal canyonland foraging/Plains bison hunting are summarized as follows:

1. During Late Archaic times, the distribution of subsistence resources varied considerably, both across the landscape and seasonally. Efficient exploitation of these resources required considerable mobility geared toward the seasonal movements and/or availability of specific resources, particularly bison. Hence, subsistence activities and land-use patterns of human populations varied seasonally, resulting in the formation of different types of sites in different settings.

2. Large bison kill/processing sites and temporary hunting camps will be located primarily on the Llano Estacado or in the Rolling Plains, in areas where mobility of large herds was generally unconstrained. These sites will probably cluster in one or two specific seasons. Most bison kills will yield evidence of communal hunting methods such as jumps and traps, although opportunistic hunting of individual animals or small herds also may have occurred. Limited butchering of some animals may be evident in some sites, indicating that more animals were killed than could be immediately used by small nomadic bands. Some temporary camps that were occupied during hunts will be located near or adjacent to kill sites and include evidence of butchering. Other temporary camps, such as the mesa-top sites, may have been occupied when people were searching for bison and/or preparing for the hunt (e.g., tool maintenance).

3. Multifunctional base campsites and rock- shelters in the canyonlands were repeatedly occupied over many years and denote a wide range of subsistence activities. Some opportunistic hunting of bison may be evident, but the kills probably occurred offsite and faunal remains should generally reflect secondary processing. Plant procurement and processing, as evidenced by grinding tools, were likely to be prominent activities at some campsites.

4. All sites will provide evidence of extensive use of local resources, but some nonlocal materials will be present due to the extensive area over which these people ranged. Ceremonial artifacts of exotic origin, such as conch shell ornaments and lunate stones, denote participation in a widespread exchange system and will be found mainly in base camps and in human burials.

\section{TRANSITIONAL ARCHAIC (A.D. 200-500)}

A critical research question is the timing of the transition between the Late Archaic and Late Prehistoric periods in the Southern Plains. The Late Prehistoric period is presumed to begin with the appearance of the bow and arrow and pottery, although these two cultural innovations did not necessarily occur at precisely the same time. While many sites contain materials attributed to both time periods, the main problem with dating the transition is that there are very few cases where diagnostic points or ceramics have been found in well-dated contexts (see Chapter 10). Unfortunately, much of the "dating" that has been done in the region is based solely on typological comparisons and extrapolating absolute dates for points and pottery from other regions. The result is that there is a great deal of confusion regarding the timing of the transitional Archaic. This period is a critical one in terms of cultural dynamics and warrants special attention.

The earliest occurrence of ceramics in the Caprock Canyonlands area is at Deadman's Shelter (Willey and Hughes 1978b), where 29 Mogollon brownware sherds (cf. Jornada Brown) were recovered in a stratum dated to A.D. 79-383. The association between these two dates and the ceramics is not absolutely clear, however, and a third radiocarbon age of A.D. 1260-1429 from the same stratum is discounted because it is much younger and out of stratigraphic sequence. Although the deposits were bioturbated and there is potential for later potsherds to be mixed in the earlier stratum, the appearance of 
brownware pottery in the first few centuries A.D. is not unreasonable since these wares were being manufactured in the Southwest by ca. A.D. 100 (Whalen 1981a:Table 1), if not earlier.

Briscoe (1987, 1989a) reported early dates associated with three Woodland cordmarked sherds, of an undefined type for which he suggested the name Lake Creek Cordmarked, from the Swift Horse site in western Oklahoma. Five radiocarbon assays indicate that the deposits containing the sherds date from A.D. 66 to 543. The specific contexts of these sherds are not discussed, but they presumably date within this time frame. It is unclear how they relate to the site's stratigraphy and other cultural materials, and the same deposits yielded seven dart points but only one arrow point. Perhaps the dart points predate the pottery, and a Late Archaic component is overlain and mixed with an ephemeral Woodland component. Alternatively, the dart points and pottery may have been in use at the same time. This interpretation is reasonable since Woodland manifestations are thought to begin between A.D. 100 and 500 in southern Colorado, Kansas, and central Oklahoma (Hofman and Brooks 1989; Vehik 1984).

Two other examples of potentially early ceramics are reported, but the temporal associations are even less certain. Wedel (1975) found brownware pottery in the upper midden at Chalk Hollow, a stratum dated to A.D. 400-850 (uncorrected/uncalibrated), but the frequency of these sherds and the associations between the radiocarbon dates and the sherds are not discussed. A few sherds of cordmarked pottery were found in Levels 4 and 5 at the Canyon City Club Cave, which are dated to 2 B.C.-A.D. 874 and 1185-899 B.C., respectively. Because the deposits were seriously bioturbated, Hughes (1969) speculated that these sherds were intrusive from the overlying, undated Level 3 (where pottery was most frequent).

Archeological work in the Southern Plains also reveals a consistent overlap in the occurrence of dart and early arrow points. Several sites have yielded arrow and dart points in radiocarbon-dated archeological contexts suggesting approximate contemporaneity. As the following examples indicate, numerous researchers have suggested that the evidence is strong in favor of contemporaneous use of darts and arrows for some period of time. Willey and Hughes (1978b) report arrow points and dart points in the lower stratum of Deadman's Shelter, dated to A.D. 79-383. Hughes (1969) found dart and arrow points together in Level 4 of the Canyon City Club Cave, dated to 2 B.C.-A.D. 1260. Thurmond (1989) reported an AMS radiocarbon date, calibrated to A.D. 131-380 (see Table 62), on charcoal from a hearth at 34RM334. Because of its tentative association with Ensor, Marcos, and Palmillas points, he suggested that this Late Archaic component dates well into what is traditionally thought of as the Woodland time period. Taylor (1987) and Quigg, Lintz, Oglesby, Earls et al. (1993:209-210) report finding early-style arrow points in tentative association with radiocarbon dates between 1700 and 500 B.C.

The earliest well-documented arrow point in the Panhandle-Plains is a large corner-notched specimen from a radiocarbon-dated burial (Feature 23) at the Sam Wahl site at Lake Alan Henry (Boyd et al. 1994:Figure 21d). The arrow point was a grave offering and is directly associated with a calibrated bone collagen date of A.D. 256-415. Because of its excellent context, this specimen may shed some light on the transitional Archaic and the shift from dart to arrow points. Several dart points from dated archeological contexts exhibit striking morphological similarities with this arrow point. Two dart points are from the Twilla site (Figure $83 a, b$ ). It is uncertain which of the two kill events they are associated with, but they may date to A.D. $0-362$ or 429-859. One dart point from the Certain site (Figure 83c) came from Trench $\mathrm{A}$ and is associated with two calibrated dates of A.D. $260-428$ and 364-543. The other specimens (Figure $83 d, e$ ) are two of the seven dart points from a triple burial at the Sullivan-Carpenter site, which yielded calibrated bone collagen dates of A.D. 261-541 and 363-578. These points appear to have been used to kill some or all of the individuals in the grave; hence, the association between the burial date and the use of the points is good. If all of these dates and contextual interpretations are correct, one must conclude that the Sam Wahl arrow point (Figure 83f) was used at approximately the same time, if not earlier, than the morphologically similar corner-notched dart points.

The differences in the sizes support the interpretation that the Sam Wahl specimen is an arrow point while the others are dart points. Based on its measurements (i.e., length $=60 \mathrm{~mm}$, maximum width $=12 \mathrm{~mm}$, thickness $=5 \mathrm{~mm}$, and neck width $=8 \mathrm{~mm}$ ), the Sam Wahl specimen would be classified as an arrow point according to Knight and 


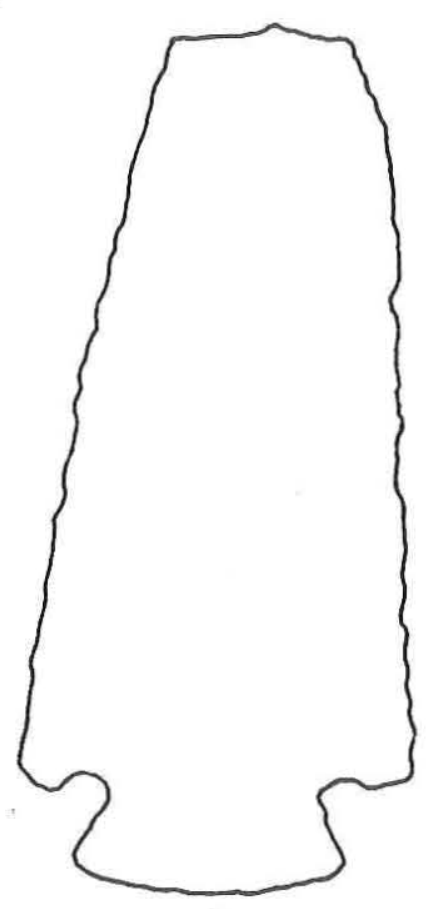

a

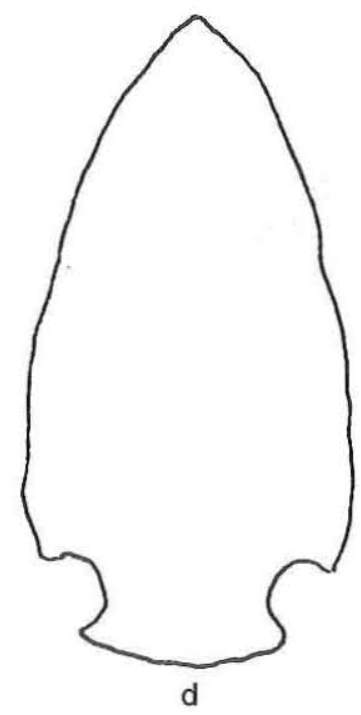

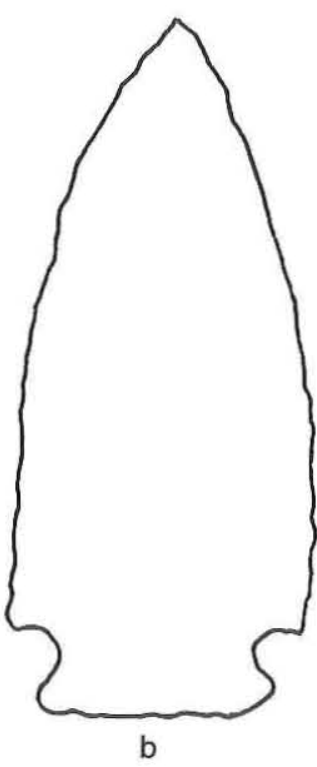
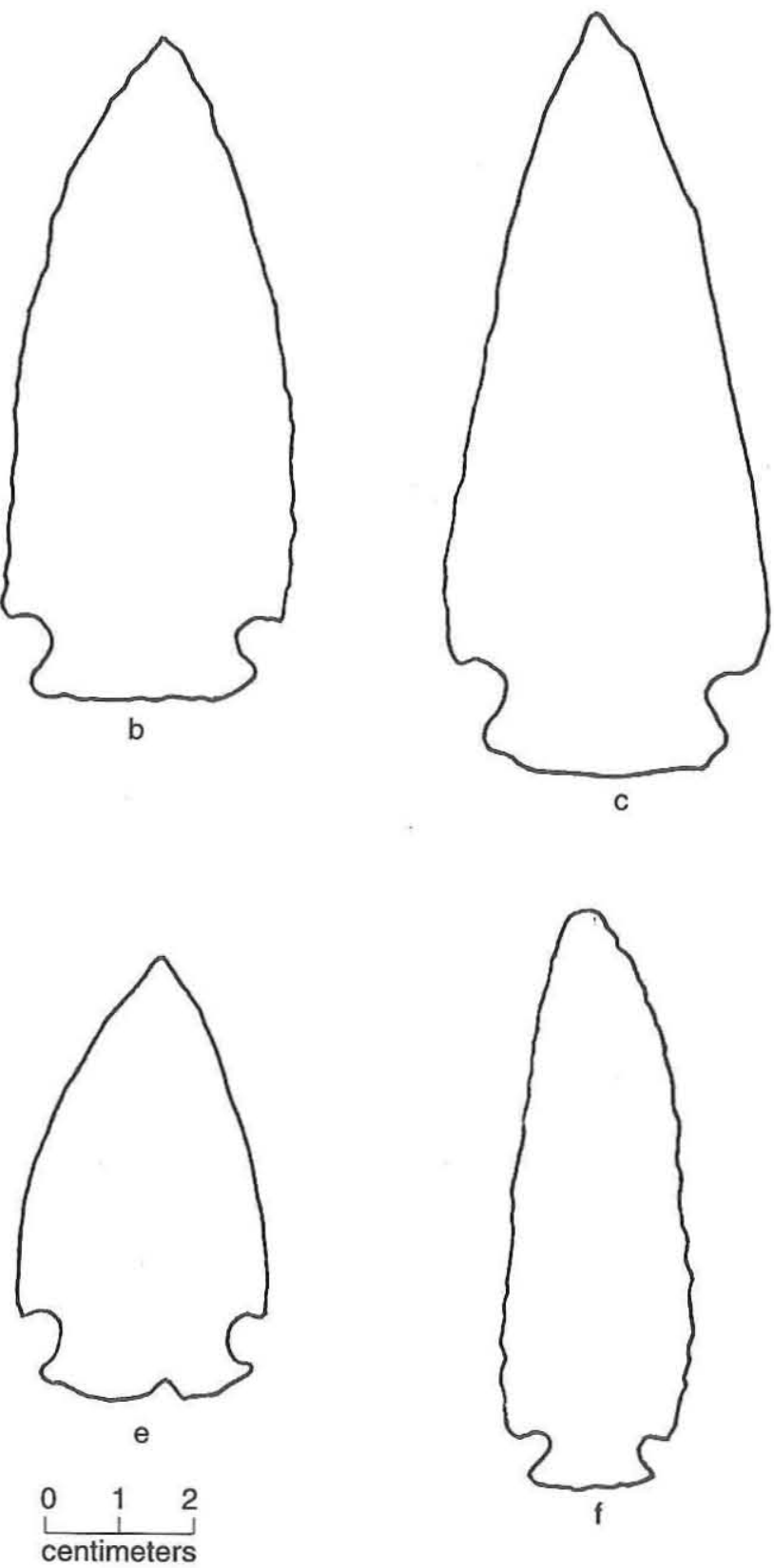

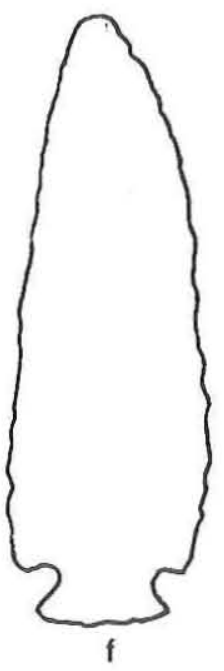

Figure 83. Large corner-notched projectile points from radiocarbon-dated contexts in the Southern Plains. (a-b) Dart points from the Twilla bison kill (from Hughes 1977:Figure 7); (c) dart point from the Certain bison kill (from Bement and Buehler 1994:Figure 7); $(d-e)$ dart points from Burial 2 at the Sullivan-Carpenter site (from Gettys 1991:1); $(f)$ arrow point from burial (Feature 23) at the Sam Wahl site (from Boyd et al. 1994:Figure 21).

Keyser's (1983) statistical method for the Northwestern Plains. Other studies have shown that the neck width is the most critical measurement distinguishing dart points from arrow points. For a large sample of projectile points from several sites in the Great
Basin, Corliss (1972:Figure 3) demonstrated that there is a statistical break in the bimodal distribution of projectile point neck widths between 8 and $9 \mathrm{~mm}$, which he interprets to be the break between arrow points and dart points. In a similar study, Roney 
(1985:6-9) demonstrated that the same bimodal pattern occurred in projectile points from the Guadalupe Mountains in southeastern New Mexico. $\mathrm{He}$ also suggests that specimens with neck widths of $8 \mathrm{~mm}$ or less were arrow points. Using this criterion, the 8-mm-neck width of the point from the Sam Wahl site burial would indicate that it is an arrow point.

In contrast, measurements for 10 Twilla site dart points indicate that the neck widths generally range from 17 to $21 \mathrm{~mm}$, with one aberrant specimen measuring $12 \mathrm{~mm}$; the average for all specimens is $18.4 \mathrm{~mm}$ (Hughes 1977:Table 2). Similarly, the six points from the Certain site (Bement and Buehler 1994:Figure 7) all have neck widths of ca. $20 \mathrm{~mm}$, and the six points associated with Burial 2 at the Sullivan-Carpenter site illustrated by Gettys (1991:1) have neck widths ranging from 12 to $18 \mathrm{~mm}$. The similarities in morphology between the Sam Wahl arrow point and the approximately contemporaneous dart points at the other sites certainly suggest a genetic connection and considerable continuity of style from late dart points to early arrow points. If the early corner-notched arrow point (i.e., Scallornlike) tradition did indeed appear on the Southern Plains sometime before A.D. 500, this has important implications for understanding the archeology of Central Texas. These arrow points first appear in the Austin Phase at around A.D. 700, and the fact that they are earlier in the Southern Plains supports Prewitt's (1985) idea that they came into Central Texas from the north.

An increasing amount of archeological evidence in the Southern Plains indicates that dart points, arrow points, and ceramics may have been used together during the early part of the first millennium A.D. While the exact timing of this overlap is far from certain, the transitional Archaic period is particularly critical because many complex cultural changes occurred at this time. The appearance of the bow and arrow and the distinctive Woodland and Southwestern ceramic traditions signal the arrival of new peoples and/or ideas and influences in the region. Perhaps not coincidentally, it is also at this time that the first good evidence of violence appears in the Southern Plains. This suggests that new groups of people had arrived and/or that human populations had increased to the point that intercultural conflicts developed. This violence appears to have intensified during the centuries that followed (Brooks 1994).

At the same time that human populations may have been increasing, bison decreased throughout the region (e.g., Dillehay 1974; Hofman and Brooks 1989:61). There is not sufficient evidence to indicate that bison populations migrated out of the Southern Plains to other areas. If large numbers of bison did move into adjacent areas, such as Central or South Texas or the Pecos River valley, this has not yet been recognized in the archeological record. A more likely scenario is that bison populations decreased over a very large area around A.D. 400-500 and remained relatively low for the next five or six centuries.

A variety of related factors probably were responsible for this decrease. Climatic changes, such as the brief mesic period proposed for this time (e.g., Hofman and Brooks 1989:61), may have caused a decline in the grassland habitat favored by bison (perhaps by decreasing the overall amount of short grass as mixed-grass prairies migrated westward?). One possibility (Elton Prewitt, personal communication 1994) is that bison populations were already under climatic stress during the terminal Archaic and that increasing numbers of people competing for the resource led to serious overexploitation. Late Archaic bison hunters were not conservationists, and the presence of minimally butchered animals in kill sites attests to the fact that their arroyo traps usually killed many more animals than could be used. Hughes (1989:203) noted that there was minimal butchering of animals at several bison kills, and Bement and Buehler (1994:177,181) observed that the six arroyos at the Certain site contain at least seven discrete kill episodes involving some 150-200 animals, many of which were only minimally butchered. Most of the documented bison kills seem to have occurred within the span of a few centuries at the end of the Late Archaic period, and even if there is a geomorphic bias in the sample, this does not preclude the possibility that bison kills were actually more common at this time. Bement and Buehler (1994:181) stated that "the Certain site bears testimony of intensive bison exploitation during the final centuries of the Late Archaic on the Southern Plains." Bison hunting may have been most intense during the waning years of the Late Archaic because increasing numbers of people were hunting bison. Thus, the disappearance of the Late Archaic lifestyle from the Southern Plains may have resulted from a combination of climatically induced stress and dwindling bison herds, coupled with increasing human populations, an intensification of hunting, and intersocietal conflicts stemming from competition for control of increasingly limited resources and territory. 


\section{LATE PREHISTORIC I PERIOD, A.D. 500 to $\mathbf{1 1 0 0 / 1 2 0 0}$}

by Douglas K. Boyd

\section{INTRODUCTION}

Paleoclimatic interpretations for the Southern Plains suggest that the Late Prehistoric I period was probably wetter than the preceding Late Archaic period. It appears that conditions were generally less favorable for bison. While the precise relationships between climate, vegetation, and bison may never be fully understood, a decline in the number of bison in the Southern Plains occurred around A.D. 500 , and bison populations probably remained low until around A.D. 1200 (Dillehay 1974:187). Two major events, the westward spread of Eastern Woodland culture and the eastward spread of Southwestern Puebloan culture, had a significant and widespread impact on the peoples of the Southern Plains during this interval. The two traditions met, or perhaps collided, along the eastern margins of the Llano Estacado. The Caprock Canyonlands apparently played a prominent role in the cultural developments and interactions during the first millennium A.D.

The Woodland tradition spread westward from the upper Midwest into the Great Plains, arriving in north-central Oklahoma by A.D. $100-300$ and in south-central Oklahoma before A.D. 450. There are many diagnostic traits such as "corner-notched dart and arrow points, shell disc beads, burial in mounds or ossuaries, an increase in the frequency of ground stones, and the appearance of tools associated with horticulture" (Vehik 1984:175); however, it is the distinctive cordmarked pottery (elongated forms with conoidal bottoms) that is the hallmark of the Woodland tradition. Not all diagnostic traits are manifest in the Oklahoma Plains Woodland sites. It is not until ca. A.D. 800 that good evidence for agriculture and semipermanent villages appears (Vehik 1984: 195-197). Despite the absence of definite evidence for pre-A.D. 800 agriculture, most of the Woodland complexes in the Southern Plains are thought to begin between A.D. 100 and 500 (Hofman and Brooks 1989). Other researchers have noted that agriculture probably appeared earlier in the Plains. In the Chaquaqua Plateau of southeastern Colorado, for example, Campbell (1976a:53-54) suggests a date of A.D. 500 for the appearance of maize.

By A.D. $50-250$, the Woodland tradition had spread into the Delaware Canyon area of westcentral Oklahoma (Ferring 1982, 1986). Archeological evidence from sites on the Thurmond Ranch (Thurmond 1991a) and the Swift Horse site (Briscoe 1987) suggests that it had spread into western Oklahoma as early as A.D. 200-400. A thermoluminescence date of A.D. 520 on a cordmarked sherd from the Tascosa Creek site is the earliest occurrence of Woodland pottery in the Texas Panhandle. Absolute chronological evidence is limited, however, and the appearance of the Woodland tradition in the Panhandle-Plains occurred at approximately the same time as the disappearance of the Late Archaic bison hunting lifestyle, between ca. A.D. 1 and 500. Plains Woodland remains in the Texas Panhandle are recognized archeologically as the Lake Creek complex (J. Hughes 1962, 1991). 
Jornada Mogollon culture of south-central New Mexico, Trans-Pecos Texas, and northern Chihuahua (Lehmer 1948) expanded across all of southeastern New Mexico and onto the western edge of the Llano Estacado during this time. This eastern extension of the Jornada Mogollon (Corley 1965a, 1965b; Leslie 1979) may represent the spread of Jornada Mogollon peoples, or at least considerable expansion of their cultural influence among neighboring peoples. Additional Southwestern influence, archeologically recognizable by the sporadic occurrence of Mogollon brownware pottery, can be traced all across the southern Llano Estacado, particularly around large playas or pluvial lakes, and into the southern Caprock Canyonlands. First recognized at a small rockshelter in Swisher County, Texas, the Palo Duro complex (Willey and Hughes 1978b) appeared to represent a group of hunter-gatherers who simply obtained brownware pottery in trade, directly or indirectly, with Jornada peoples. More-recent archeological findings of residential base camps with pithouses and storage facilities at the Kent Creek (Cruse 1992) and Sam Wahl (Boyd et al. 1994; see Chapter 6) sites are changing our perceptions about who the Palo Duro peoples were. It now appears that the Jornada Mogollon influence involved much more than just pottery (see J. Hughes 1991).

Although there are many similarities between the Lake Creek and Palo Duro complexes, the differences in these manifestations have been interpreted as evidence that two groups of people occupied the Texas Panhandle-Plains during the first millennium A.D. Assuming the distribution of pottery traditions represents the maximum extent of cultural influence (e.g., the extent of exchange networks, diffusion of technology, or even the spread of related peoples), Couzzourt (1982, 1985) and Jack Hughes (1991) interpret the archeological data as indicating that a cultural boundary between Woodland- and Southwestern-influenced peoples existed along the drainage divide between the Canadian and Red Rivers. In the 1940s, Krieger $(1946,1978)$ noted this boundary and suggested that it represented the southerly limit of Central Plains tradition complexes or influence. Brownware pottery occurs in very few sites in the Canadian River drainage, while it is much more common to the south in the Red River and Brazos River drainages. Conversely, sites yielding Woodland pottery are common in the Canadian River valley. Only a few are found in the northerly tributaries of the upper
Red River, and none are known south of the Prairie Dog Town Fork.

This chapter has four main goals: (1) to briefly summarize other cultural complexes and phases that surround the Palo Duro and Lake Creek complexes; (2) to better define the Lake Creek complex and summarize the important sites attributed to it; (3) to reevaluate and redefine the Palo Duro complex in light of recent archeological finds and summarize important sites attributed to it; and (4) to discuss the broader intercultural relationships between the Palo Duro and Lake Creek cultures and the peoples around them. Figures 84 and 85 show the locations of the culture complexes/phases and sites discussed in this chapter. Table 66 lists the sites discussed in this chapter and serves as the key for Figure 85. Figure 86 shows the locations of selected burial sites discussed in this chapter.

\section{REGIONAL CULTURAL COMPLEXES AND PHASES}

The cultural changes that characterize the Late Prehistoric I period in the Caprock Canyonlands are complex and cannot be fully understood without some background on archeological manifestations defined for surrounding areas. This period spans the entire Plains Woodland stage of cultural development in the Texas Panhandle. The later part of the period is contemporaneous with late Plains Woodland/ formative Plains Village occupations in western Oklahoma. The Late Prehistoric I period also covers most of the pithouse cultural periods in eastern New Mexico and ends at the time of the pithouse to surface pueblo transition. The discussions that follow review several archeological complexes and phases that are important with respect to the Lake Creek and Palo Duro complexes. For general information on these and other Plains Woodland and Plains Village manifestations in the southern Great Plains, the reader is referred to Bell (1984), Brooks (1989), Creel (1990), Hofman (1975, 1978a, 1984a, 1984b), Hofman and Brooks (1989), J. Hughes (1991), Jelinek (1967), and Lintz (1982, 1984, 1986).

\section{Custer Phase}

As summarized by Brooks (1989:75-77), the Custer phase is defined as an early Plains Village complex covering most of west-central Oklahoma. 


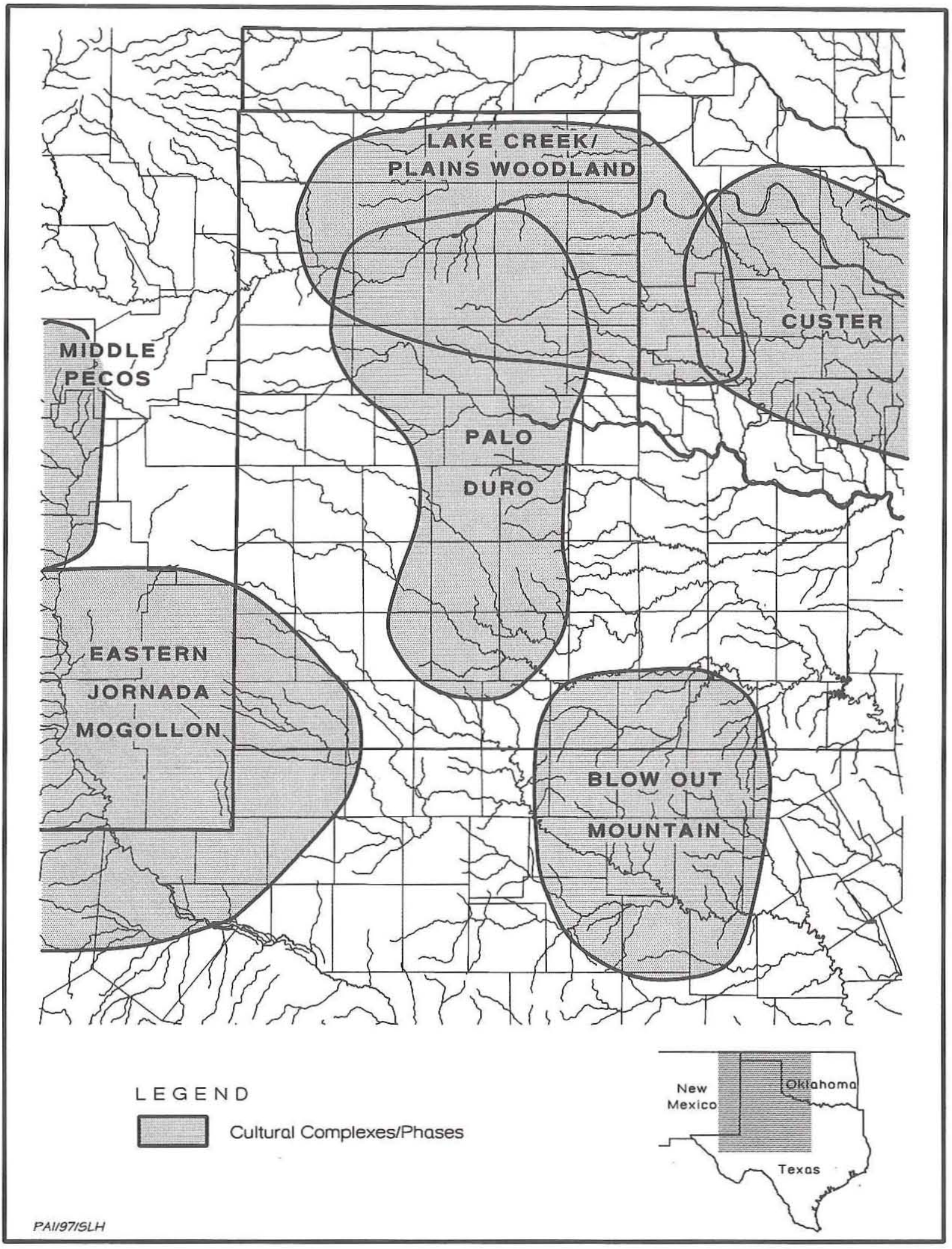

Figure 84. Map of Late Prehistoric I cultural complexes in and around the Texas Panhandle-Plains. 


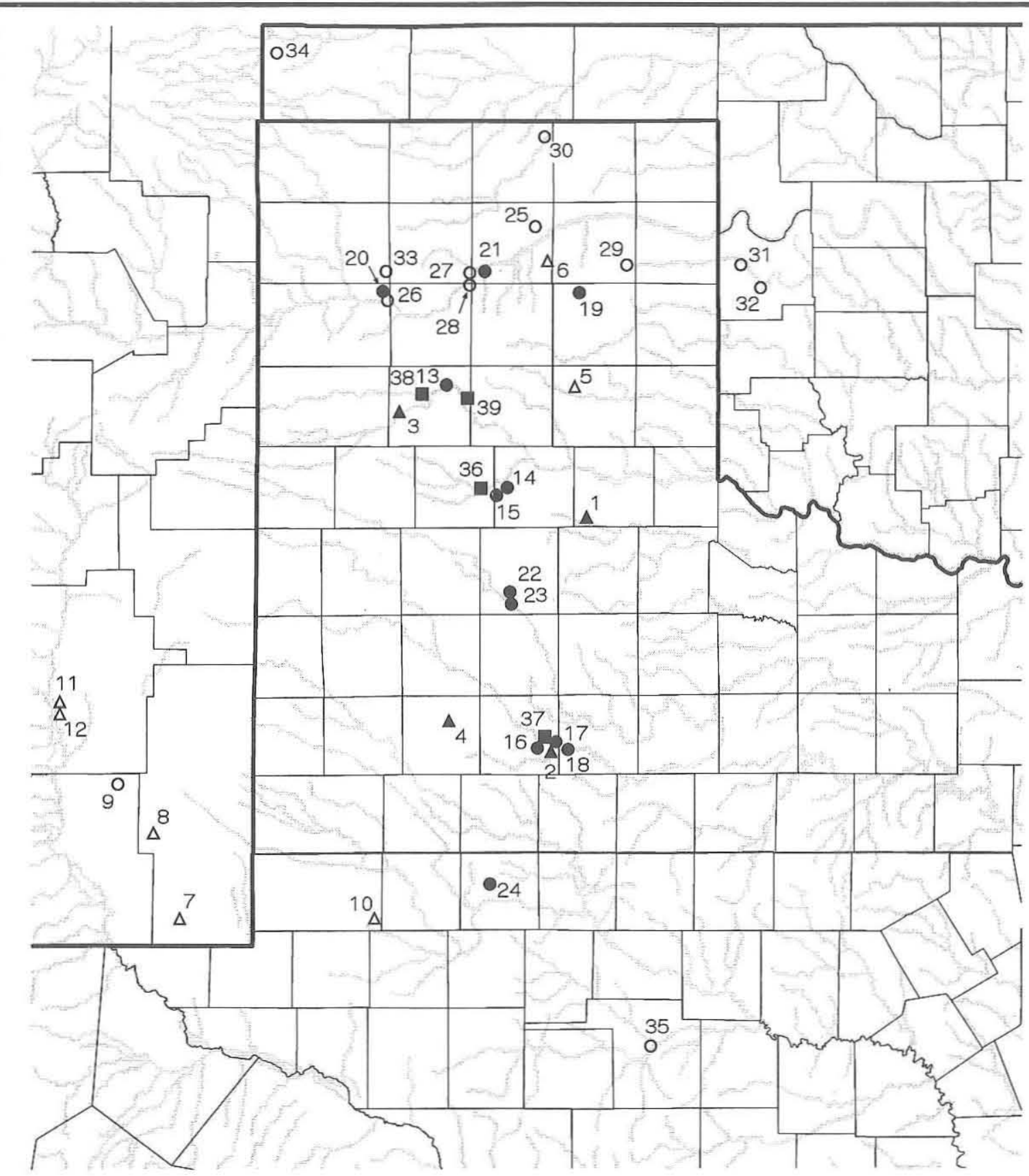

PALO DURO COMPLEX SITES

Rockshelter

- Campsite

$\Delta$ Residential Base

OTHER SITES

O Campsite

$\Delta$ Residential Base

PAIISTISLH

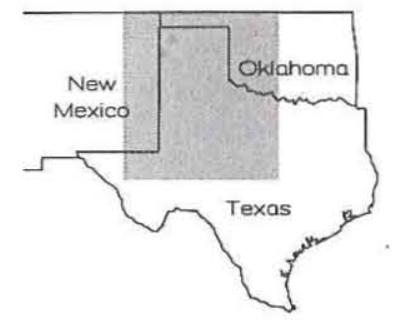

Figure 85. Map of Late Prehistoric I sites in the Caprock Canyonlands and surrounding areas. 
TABLE 66

SELECTED LATE PREHISTORIC I SITES IN AND AROUND THE TEXAS PANHANDLE-PLAINS

\begin{tabular}{|c|c|c|c|}
\hline $\begin{array}{l}\text { Key to } \\
\text { Figure } 85\end{array}$ & Site Name (Number) & Cultural Affiliation & Reference \\
\hline \multicolumn{4}{|c|}{ RESIDENTIAL BASES } \\
\hline 1 & Kent Creek (41HL66) & Palo Duro complex & Cruse 1992 \\
\hline 2 & Sam Wahl (41GR291) & Palo Duro complex & $\begin{array}{l}\text { Boyd et al. 1994; } \\
\text { this volume }\end{array}$ \\
\hline 3 & Buffalo Lake (PPHM-A2042) & Palo Duro complex (?) & Hays 1986 \\
\hline 4 & Tahoka Lake & Palo Duro complex (?) & $\begin{array}{r}\text { Lee Johnson, personal } \\
\text { communication } 1993\end{array}$ \\
\hline 5 & Greenbelt (41DY17) & Lake Creek complex & Campbell 1983 \\
\hline 6 & Duncan Ranch Site 1 (41HC124) & Lake Creek complex & Gustafson 1994a, 1994b \\
\hline 7 & Merchant (LCAS-E4) & Eastern Jornada Mogollon & Leslie 1965 \\
\hline 8 & Laguna Plata (LA-5148) & Eastern Jornada Mogollon & $\begin{array}{l}\text { Lea County Archeological } \\
\text { Society 1971; Runyan } \\
1972\end{array}$ \\
\hline 9 & Boot Hill (LCAS-B5) & Eastern Jornada Mogollon & Corley and Leslie 1960 \\
\hline 10 & Salt Cedar (41AD2) & Eastern Jornada Mogollon & Collins 1968 \\
\hline 11 & King Ranch (LA 26764) & $\begin{array}{l}\text { Middle Pecos or Eastern } \\
\text { Jornada Mogollon }\end{array}$ & Wiseman 1981, 1988 \\
\hline 12 & Fox Place (LA 68188) & $\begin{array}{l}\text { Middle Pecos or Eastern } \\
\text { Jornada Mogollon }\end{array}$ & $\begin{array}{l}\text { Wiseman, personal } \\
\text { communication } 1993\end{array}$ \\
\hline \multicolumn{4}{|c|}{ CAMPSITES } \\
\hline 13 & Chalk Hollow (PPHM-A883) & Palo Duro complex & Wedel 1975; Lintz 1995 \\
\hline 14 & Blue Clay (41BI42) & Palo Duro complex & Willey et al. $1978 \mathrm{~b}$ \\
\hline 15 & County Line (41BI33) & Palo Duro complex (?) & Willey and Hughes 1978a \\
\hline 16 & Cat Hollow (41GR303B) & Palo Duro complex & $\begin{array}{l}\text { Peck et al. 1994a; } \\
\text { this volume }\end{array}$ \\
\hline 17 & Gobbler Creek Bridge (41GR383) & Palo Duro complex (?) & $\begin{array}{l}\text { Boyd et al. 1994; } \\
\text { this volume }\end{array}$ \\
\hline 18 & South Sage Creek (41KT33) & Palo Duro complex & $\begin{array}{l}\text { Boyd et al. 1992; } \\
\text { this volume }\end{array}$ \\
\hline 19 & Fatheree (41GY32) & Palo Duro/Lake Creek complexes & Hughes et al. 1978 \\
\hline 20 & Maintenance Barn (PPHM-A1543) & Palo Duro complex (?) & Couzzourt 1982 \\
\hline 21 & South Ridge (PPHM-A1568) & Palo Duro complex & Etchieson 1979 \\
\hline 22 & Floydada Country Club (41FL1) & Palo Duro complex (?) & Word $1963,1991 \mathrm{a}$ \\
\hline 23 & Montgomery (41FL17) & Palo Duro complex (?) & Word 1965; Northern 1979 \\
\hline 24 & Big Spring (41HW2) & Palo Duro complex (?) & Sommer 1971 \\
\hline 25 & Lake Creek (PPHM-A48) & Lake Creek complex & Hughes 1962 \\
\hline 26 & Tascosa Creek (PPHM-A2060) & Lake Creek complex & Couzzourt 1985, 1988 \\
\hline 27 & Sanford Reservoir unnamed (41MO5) & Lake Creek complex & Green 1986 \\
\hline 28 & Sanford Reservoir unnamed (41PT29) & Lake Creek complex & Green 1986 \\
\hline 29 & Night Storm (41RB21) & Lake Creek complex & Hughes et al. 1978 \\
\hline 30 & Sandy Ridge (41HP5) & Lake Creek complex & $\begin{array}{l}\text { Quigg, Lintz, Ogelsby, } \\
\text { Earls et al. } 1993\end{array}$ \\
\hline 31 & Swift Horse (34RM501) & Lake Creek complex (?) & Briscoe 1987,1989 a \\
\hline 32 & Beaver Dam (34RM208) & Plains Woodland & $\begin{array}{l}\text { Thurmond 1988a, 1988b, } \\
\text { 1988c, 1991a }\end{array}$ \\
\hline 33 & Middle Cheyenne (PPHM-A2082) & Lake Creek complex & Couzzourt 1982, 1985 \\
\hline 34 & Carrizozo Bridge (34CI199) & Plains Woodland & Saunders 1983 \\
\hline 35 & East Levee (41TG91) & Blow Out Mountain complex & Creel 1990 \\
\hline
\end{tabular}




\begin{tabular}{|c|c|c|c|}
\hline \multicolumn{4}{|c|}{ Table 66 , continued } \\
\hline $\begin{array}{l}\text { Key to } \\
\text { Figure } 85\end{array}$ & Site Name (Number) & Cultural Affiliation & Reference \\
\hline \multicolumn{4}{|c|}{ ROCKSHELTERS } \\
\hline 36 & Deadman's Shelter (41SW23) & Palo Duro complex & Willey and Hughes $1978 \mathrm{~b}$ \\
\hline 37 & Boren Shelter No. 2 (41GR559) & Palo Duro complex & $\begin{array}{l}\text { Peck et al. } 1994 \mathrm{~b} \\
\text { this volume }\end{array}$ \\
\hline 38 & $\begin{array}{l}\text { Canyon City Club Cave } \\
\text { (PPHM-A251) }\end{array}$ & Palo Duro complex & Hughes 1969 \\
\hline 39 & Blue Spring Shelter (PPHM-A485) & Palo Duro complex & Hughes 1978 \\
\hline
\end{tabular}

The Custer phase is the predecessor of the Plains Village Washita River phase and "has its roots in a Plains Woodland source" (Brooks 1989:77). It may have evolved out of the Keith focus or phase of north-central Kansas, or another similar but undefined Plains Woodland manifestation in western Kansas (Hofman 1978a:23-24; Hofman and Brooks 1989:66). While Woodland complexes have been defined for central Oklahoma (e.g., the Pruitt complex), pre-A.D. 800 Plains Woodland culture in western Oklahoma is poorly defined, although it appears very similar to the Lake Creek complex (see below). The transition from Plains Woodland to early Plains Village occurred by A.D. 650 in central Oklahoma, but there is no firm evidence to indicate that this change occurred earlier than A.D. 800 in western Oklahoma. Based on radiocarbon dates, the Custer phase is thought to date between A.D. 800 and 1250 (Brooks 1989:76).

Based on detailed comparisons of sites of the Zimms complex and the Custer and Washita River phases, Drass and Moore (1987:413-414) identified the following characteristics as diagnostic of the Custer phase:

1) small to medium sized camps or villages occurring on ridge toes above streams; 2) occupations dating sometime between A.D. 800 and 1250 ; 3) numerous storage/trash pits present on sites; 4) permanent structures possibly present (one rectangular house with a central hearth has been found at a site dated to this period); 5) ceramic assemblages containing at least $50 \%$ and probably over $60 \%$ cordmarked pottery that is generally tempered with fossiliferous shale; 6 ) projectile point styles including a combination of corner-notched/stemmed, side-notched, and unnotched arrows with at least $40 \%$ of these being corner-notched/stemmed; 7) lithic assemblages made from predominantly local materials and Alibates, the latter probably obtained from local gravels and/or possibly from the Texas panhandle quarries; 8) small bone tool inventories composed mostly of nonagricultural tools; and 9) an economy based on hunting, gathering, and the cultivation of corn.

The earliest occurrence of corn in western Oklahoma is from the Linville II site (34RM492), associated with radiocarbon dates that range from A.D. 903 to 1330 (corrected). The absence of corn in other Custer phase sites and in earlier contexts, however, may be due to inadequate sampling and/or poor recovery techniques (Drass and Moore 1987: 409, 415). The identification and dating of the earliest use of domesticated plants in the Custer phase is a critical research problem that reoccurs in many other Late Prehistoric I complexes and phases.

Brooks (1989:76) notes that information about Custer phase burials is limited but that they generally occur in flexed positions in circular or oval pits with few or no artifacts associated and no indication of status differentiation. Some of the burials at Lake Altus, Oklahoma, may be associated with the Custer phase, but others are apparently Plains Woodland.

\section{Eastern Jornada Mogollon: Querecho and Maljamar Phases}

As originally defined by Lehmer (1948:Figure 22), the culture area for the Jornada Branch of the Mogollon was confined to northern Chihuahua, far 


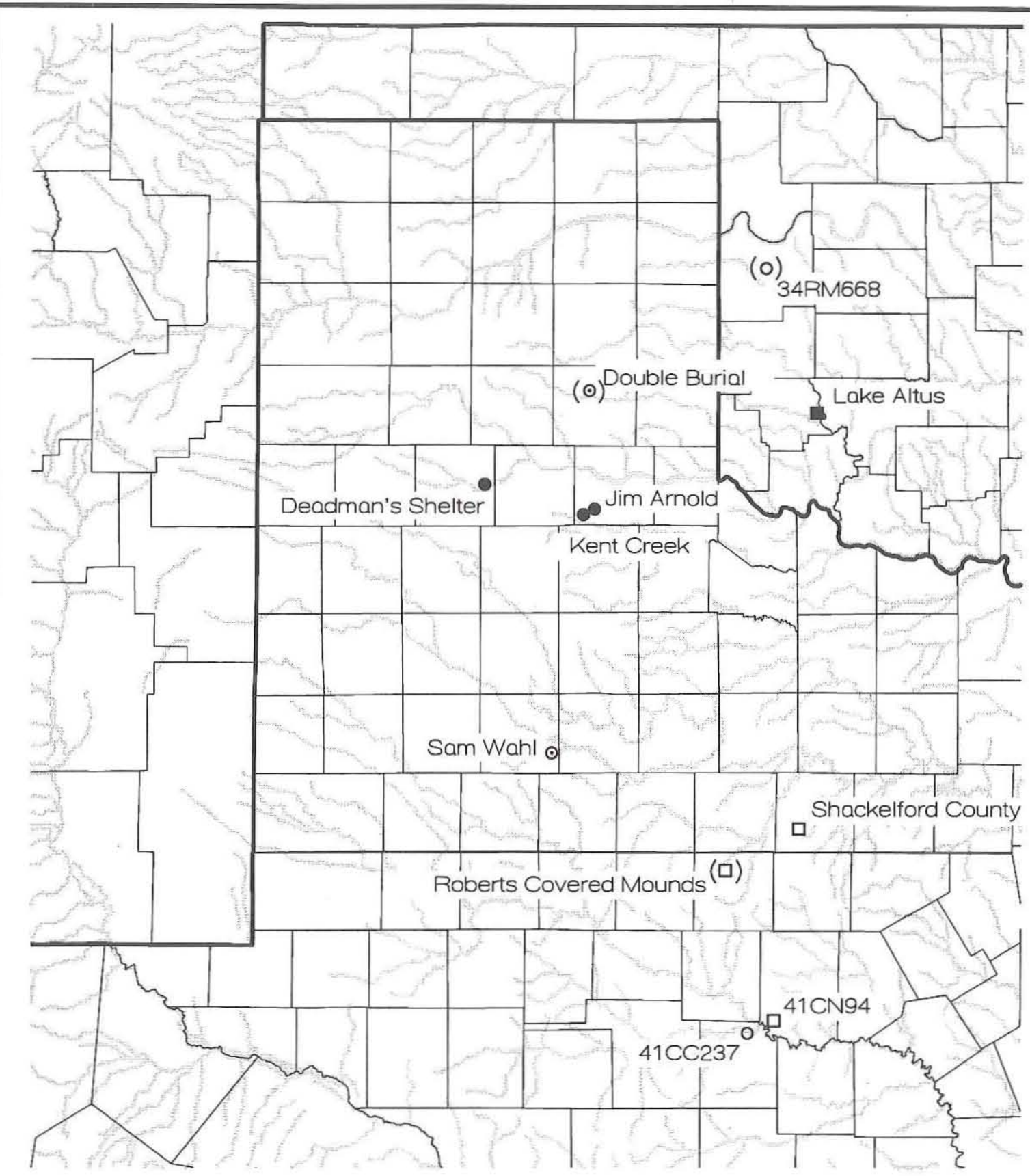

CULTURAL AFFILIATION

- Palo Duro Complex

- Unknown, possibly Palo Duro Complex

- Plains Woodland/Custer Phase

ㅁ Blow Out Mountain Complex

○ Unknown

( ) Location not Precise

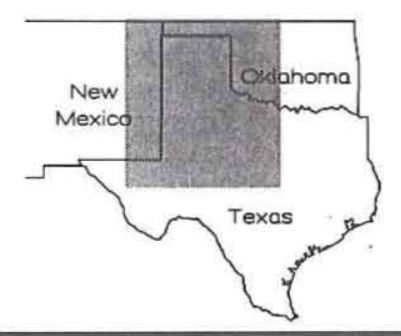

Figure 86. Map of Late Prehistoric I burials in the Caprock Canyonlands and surrounding areas. 
western Texas, and south-central New Mexico. The eastern extension of the Jornada Mogollon was proposed by Corley $(1965 \mathrm{a}, 1965 \mathrm{~b})$ to account for Jornada Mogollon-like archeological remains encountered in southeastern New Mexico, east of the Pecos River. Investigations at Andrews Lake by Collins $(1966,1968)$ extended the range onto the southwestern Llano Estacado as far east as Midland. Other investigations are reported for the Boot Hill site by Corley and Leslie (1960), the Merchant site by Leslie (1965), the Monument Spring site by Leslie (1968), the Laguna Plata site by the Lea County Archeological Society (1971), and the Bull Hill site by Shawn (1975). Based on these limited investigations and extensive survey data, Leslie (1979) further defined the Eastern Jornada culture area, and Jack Hughes (1991) provides the most recent summary.

The eastern Jornada extension is divided into three cultural phases-Querecho, A.D. 950-1100; Maljamar, A.D. 1100-1300; and Ochoa, A.D. 13001450 - that are characterized by cultural changes analogous to those represented by Lehmer's (1948) southern Jornada Mogollon phases (i.e., Mesilla, Dona Ana, and El Paso). The Querecho and Maljamar phases are contemporaneous with the end of the Late Prehistoric I period and the transition between Late Prehistoric I and II, respectively.

Eastern Jornada sites are generally classified as either seasonal camps or house sites (i.e., residential bases), and it appears that the latter are well represented in the eastern Pecos valley and along the Mescalero Escarpment (see Leslie 1979:Figure 3). Leslie (1979:179) proposed that the Eastern Jornada manifestation represents "groups of/or related to the Jornada Branch of the Mogollon" but thought that they retained a more nomadic hunter-gatherer lifestyle, did not practice agriculture, and utilized shin oak acorns and mesquite beans as primary subsistence resources.

The Querecho phase (Leslie 1979:188-190) represents the first use of ceramics in the area and is characterized by a variety of brownwares, occasional intrusive painted wares (e.g., Mimbres Blackon-white), and corner-notched dart and arrow points. There seems to have been a shift from slab metates to oval-basin metates during this phase. No structures have been attributed to this period, but pithouses are likely if it is truly analogous to the Mesilla phase.

The Maljamar phase (Leslie 1979:190-191) may represent a more sedentary lifestyle and spans the transitions from pithouses to surface houses and from corner- to side-notched arrow points. These changes appear to have begun around A.D. 1200. The first half of the Maljamar phase is characterized by villages with as many as $20-30$ pithouses. Limited architectural data are available, but these pithouses are generally rectangular and were often dug into bedrock caliche. Exterior posts have been found, but no interior roof support posts are known. Firepits are found in the center of the floor along the back wall, and the only documented entryway is in the form of a ramp opposite the firepit. The most common metates are oval-basin types, and bedrock mortars also were used (it is likely that wooden mortars were used also). Burials are associated with this phase and occur in pithouses, trash mounds, and nearby sandy areas, but no other details are presented. A variety of brownwares were used throughout the Maljamar phase, although a few new types also appeared after A.D. 1200. Several types of imported decorated wares are presumed to date to A.D. 1250 or later. Three varieties of brownware pottery - Northern, Central, and Southern Area Brown (and some Red-on-brown) - are distinctive from other variants of Jornada and El Paso brownwares and are thought to represent locally made pottery types that were produced throughout the Querecho and Maljamar phases. These types are not easily distinguishable by visual examination and have not found widespread acceptance among researchers. Although the problems are far from resolved, attempts to sort out the compositional variability within Jornada tradition brownwares through petrographic analyses have been made recently (e.g., Garrett 1988a, 1988b, 1988c, 1991; Hill 1988, 1990; Robinson 1992, 1994).

There are a few notable interpretive problems with the Eastern Jornada chronology. First, the entire Eastern Jornada chronology is based largely on projectile point and ceramic typologies (i.e., dates associated with points and pottery) established outside the region and the tenuous associations between surface-collectedartifacts and uninvestigated features. The chronology should be viewed critically because so few sites have been investigated, and there are no radiocarbon dates available for any of them. Second, by stating that most of the Maljamar phase "pithouse villages are larger and usually occur at the same locations as the earlier sites," Leslie (1979:190) implies that Querecho phase occupations are present at pithouse villages. Consequently, in 
the absence of radiocarbon dates and based solely on artifact typology, it is virtually impossible to differentiate pithouses that might belong to the Querecho phase from those of the Maljamar phase. Third, while the idea that the influx of side-notched arrow points and new types of imported pottery occurred simultaneously with the shift from pithouses to surface houses at around A.D. 1200-1250 appears reasonable, it is little more than an educated guess. And finally, while the importance of plant foods is demonstrated by the ground stone tools (manos, metates, and pestles) and mortars, the idea that mesquite beans and shin oak acorns were staple resources is based on their modern distribution and abundance and has yet to be documented archeologically.

One additional observation is important. Leslie $(1979: 192)$ notes that while sites with pithouses are relatively common in southeastern New Mexico, no pithouses have been found at any of the Texas sites on the southern Llano Estacado. It is possible that pithouses are not present, or are very rare, on the southern Llano, but it is also possible that they have yet to be identified because of the paucity of subsurface investigations and the difficulty in recognizing them through surface evidence alone.

\section{Middle Pecos: 18 Mile and Mesita Negra Phases}

Based on extensive survey and testing along the middle Pecos in southeastern New Mexico, Jelinek (1967) proposed a cultural sequence of three phases from A.D. 800 to 1350 . The three phase names, each having an early and a late subphase, are 18 Mile (A.D. 800-1000), Mesita Negra (A.D. 10001150), and McKenzie (A.D. 1200-1350). The first two date to the end of the Late Prehistoric I period.

The Early 18 Mile phase represents the eastward spread of a semisedentary Puebloan lifestyle into the Pecos River valley late in the eighth century, but it appears to represent local groups adopting new lifestyles rather than a migration of Puebloan peoples. Pithouses and maize agriculture may have spread into the region at this time as well, but there is little evidence to support this. Plain brownware pottery appeared at this time along with some Anasazi wares. Gathering and processing of wild plant foods seem to have been the primary subsistence activities.

By the Late 18 Mile phase, well-established small sedentary communities appeared in the valley with a variety of pithouse forms (including some contiguous rectangular pitrooms), slab-lined storage cists, corner-notched arrow points, and abundant brownwares (dominantly Jornada Brown and Middle Pecos Micaceous Brown, less common is South Pecos Brown). Imported ceramics denote continued influence from the Rio Grande Anasazi. Maize agriculture appears to have become the primary subsistence base.

In the Early Mesita Negra phase, locally manufactured reduced-fired pottery appeared (i.e., grayware types - Crosby Black-on-gray and Middle Pecos Black-on-white), along with some imported Chupadero Black-on-white. Middle Pecos Micaceous Brown was still the dominant ware, and other varieties of brownware were present also (e.g., Jornada Brown, South Pecos Brown, and Roswell Brown). Architectural data are lacking, but the subsistence base remained unchanged.

There appears to have been a decrease in influence from the Rio Grande, contrasted by an increase in Chupadero/Jornada influence during the Late Mesita Negra phase. This is indicated by large quantities of imported Chupadero Black-on-white, an increase in the amount of graywares and Roswell Brown, and a decrease in the amount of Anasazi pottery and Micaceous Brown. Pithouses may have continued to be used in this period, and the subsistence base remained the same. Bison remains appeared in sites for the first time.

At the southern end of Jelinek's (1967) study area in the vicinity of Roswell, circular pithouses have been found at the Fox Place and the King Ranch site, and those at the latter may have been occupied around A.D. 1150-1250 (Wiseman 1981, 1988, personal communication 1993). Farther to the south along the Pecos River in the Carlsbad area, brownware pottery is common, but there is no evidence for the development of a sedentary lifestyle or the practice of agriculture (e.g., Henderson 1976; Katz and Katz 1985).

In the Sierra Blanca area west of Roswell, Kelley (1984) proposed a similar sequence of cultural developments (i.e., the Corona and Lincoln phases in the north and the Early and Late Glencoe phases in the south) which show evidence of increasing sedentism, emphasis on maize agriculture, and a shift from pithouses to surface pueblos.

The ceramic period archeology north of the middle Pecos area is poorly known; however, Jack 
Hughes (1991:29) has observed that corner-notched arrow points and Jornada-like brownware pottery are found together all across east-central New Mexico as far north as the Canadian River (see Dick 1953; Hammack 1965; Mobley 1978; Roberts 1942). These artifacts have been found in components dating to A.D. 1050-1150 at Santa Rosa Lake (Los Esteros Reservoir) in Guadalupe County, New Mexico (Mobley 1978). Since evidence for semipermanent occupations is lacking, these areas may have been inhabited primarily by hunting-gathering peoples during the ceramic period.

\section{Blow Out Mountain Complex}

Based on work at 41TG91 and a review of early work in the Abilene area by Cyrus Ray (1929) and others (e.g., Sayles 1935), Creel (1990:15-18) proposed the Blow Out Mountain phase to represent a transitional Late Prehistoric I to Late Prehistoric II cultural manifestation in west-central Texas. The geographic range for Blow Out Mountain includes most or all of 12 counties around Abilene (Fisher, Jones, Shackelford, Nolan, Taylor, Callahan, Coke, Runnels, Coleman, Tom Green, Concho, and McCulloch). As discussed below, Blow Out Mountain should be considered as a complex rather than a phase.

The Blow Out Mountain complex is tentatively dated to A.D. $800 / 900$ to 1300 , but radiocarbon dates are available only from 41TG91. No ceramics (local or imported) are attributed to this complex, and it is recognized primarily by three groups of arrow points. The most common have a "straight or slightly contracting stem, straight or somewhat rounded base, generally prominent barbs, and often serrated blade edges" and are similar to the Alba and Bonham types (Creel 1990:16); they have recently been called Moran points (Forrester 1987; Turner and Hester 1993:225). The second group, also common, are diminutive forms of Zepher or Darl that are now call Chadbourne arrow points (Turner and Hester 1993:207). The third group is less common and includes points with strongly contracting stems, rounded bases, and well-defined shoulders that are Cliffton-like. A fourth group of side-notched, concave-based points are typed as Washita, but these obviously represent a style found late in the Blow Out Mountain complex and into the Toyah phase. Large, well-made, triangular bifaces may also be characteristic.
Not much is known about subsistence and settlement patterns during the Blow Out Mountain complex, and stone-lined hearths are the only associated features, besides burials. Based on his work at 41TG91, Creel (1990) reports that many animals were eaten (i.e., deer, prairie dog, jackrabbit, cottontail, turtle, fish, and river mussel). Bison remains, which were common in Late Archaic and Toyah phase strata, were not found in the Blow Out Mountain strata. This, along with the absence of typical bison hunting tools (e.g., knives and scrapers), led Creel (1990:227-228) to speculate that bison were rarely hunted and that Blow Out Mountain peoples were generalized hunter-gatherers.

A large number of burials (many excavated in the 1930 s by Ray, Sayles, and others) are attributed to the Blow Out Mountain complex. Unfortunately, published data are nonexistent or inadequate for most, and none have been radiocarbon dated. In the 1930s, Ray (1932, 1933, 1936, 1946) investigated numerous burials found on prominent hills and ridges, both as isolated cairn-covered burials and as large rock cairns containing individual and multiple graves. These "covered mounds" or "stone cist mounds," as Ray $(1932,1933)$ called them, represent cemeteries that usually contain primary burials in flexed positions. Cremated remains and secondary interments are sometimes present as well. Many burials in the region, both isolated and in covered mounds, are found inside rock-lined cists, but most contain few grave goods and no diagnostics. Hence, their association with the Blow Out Mountain complex is tentative and is based on similarities with other burials that have stemmed (Group 1) points associated. The context of some of these points, however, suggests that they represent the cause of death rather than grave offerings.

The Roberts Covered Mound No. 3 (probably in Taylor County) is a good example of a Blow Out Mountain complex cemetery, and Ray (1933) reports that this mound contained 10 individual interments. Two were bundle burials found in the upper part of the mound, and one of these had a stemmed (Group 1) arrow point associated with it (Ray 1933:Plate 8). The other eight were primary flexed burials in individual cists. Few artifacts were found in association; a bison toe bone and a bone awl are the only items mentioned. Five of the primary burials had no mandibles. Their absence could not be attributed to any form of disturbance, and Ray (1933:19-20) suggested that the jaws were taken as war trophies. 
A mandible also was inexplicably missing from another cist grave in the nearby Alexander Mound (Ray 1933:22).

Forrester (1951) reports similar findings in a series of burials in Shackelford County. A total of 18 individuals were found in four separate burial areas, or "burial plots," within 300 yards along a creek terrace. Of particular interest, the two young males in Burial Plot II had been killed. Both had stemmed (Group I) arrow points in contexts indicating that they were the cause of death, and one individual was missing his hands and feet. Cut marks on the distal ends of the ulnas suggest that they were removed as war trophies. In addition, the charred mandible of a child was found in the chest area of one skeleton, indicating that this war trophy had been worn as a pendant.

There are also some interesting features within Burial Plot III, which is similar to Ray's (1933) covered mound cemeteries. Of nine individuals in Burial Plot III, two are adult males buried with grave offerings (i.e., mussel shells and deer bone tools) reminiscent of those in the burials associated with the Palo Duro complex (described below). One of these men had been buried in a single grave with an elderly woman and two infants. A stemmed (Group I) arrow point was found in association with the male skeleton. Its context was not such that Forrester (1951) recognized it as a possible arrow wound, but its proximal and distal breaks most likely were caused by impact. The point's proximal break is almost identical to that on the arrow point embedded in the humerus of Skeleton 2 in Burial Plot II. Thus, it is likely that the adult male in this mass grave had been killed, and it is possible that the other three individuals buried with him were killed also.

Although none of the Shackelford County burials have been radiocarbon dated, the association with early style arrow points indicates that they date to Late Prehistoric I times and suggests a likely affiliation with the Blow Out Mountain complex (Creel 1990:17). Based on the Alba- and Sabinallike arrow points associated with these burials, Forrester (1987) proposed that they be called Moran points. However, the Moran arrow points illustrated by Turner and Hester (1993:225) encompass a great deal of morphological variability.

A cairn burial, one of several cairns at 41CN94 near Lake O. H. Ivie (see Lintz, Treece et al. 1993:647-649), was excavated by the Concho Valley
Archeological Society. The finds are not yet reported, but the individual was a young male and a Sabinal arrow point with serrated blade was associated (J. A. Jaquier, personal communication 1993). This point is similar to the Moran points found in the Shackelford County burials. This burial is remarkably similar to other Blow Out Mountain burials.

Many interpretive problems are evident for the Blow Out Mountain complex. Most problems stem from the limited sample of investigated sites and the lack of chronological control. The proposed beginning date of A.D. 800 is not well supported, and the complex may well have begun several centuries earlier. There also is no compelling evidence to support the direct association of early corner-notched and late side-notched arrow points as being characteristic of Blow Out Mountain culture. As noted throughout the Southern Plains, this transition probably occurred after A.D. 1100-1200, and it marked a significant cultural change. There may be a transitional aspect to the culture, but it is not appropriate to include the post-A.D. 1200 manifestations as part of the complex. There is no logical reason why the complex should not end with the appearance of side-notched arrow points at around A.D. 1150. The absence of ceramics is another perplexing problem that is probably related to inadequate sampling. While it is possible that Blow Out Mountain peoples did not make ceramics or use pottery obtained in trade, this seems unlikely. Equally perplexing is the unique nature of the cist burials and cemeteries and the evidence for violence. Lacking precise dating, however, it is impossible at present to understand the relationships between the burials and the campsite remains. It is possible that many of the burials predate A.D. 800. The morphological consistency of the projectile points associated with the burials, as well as the evidence for violence, are intriguing aspects that have yet to be explored in detail.

\section{THE LAKE CREEK COMPLEX: PLAINS WOODLAND TRADITION IN THE NORTHERN CAPROCK CANYONLANDS}

The similarities between corner-notched dart points (i.e., Ellis and Marcos) and early Scallorn-like arrow points (see Figure 83) has led researchers to suggest that the Late Archaic bison hunters had a 
close affinity with local Plains Woodland peoples, or the Lake Creek complex as it is called in the Texas Panhandle (J. Hughes 1962, 1991). Jack Hughes (1991:26) notes that the artifact inventory of the Lake Creek complex is "basically similar to the late Archaic inventory." Thurmond (1991a:120) notes that "it is generally not possible to differentiate Late Archaic and Woodland components in western Oklahoma on the basis of small artifact collections." These similarities may indicate that, rather than replacement of one group by another, some of the indigenous Late Archaic peoples in the Texas Panhandle and western Oklahoma gradually came under the Woodland influence that was spreading into the Great Plains.

Corner-notched arrow points replaced dart points, but they often co-occur in transitional sites. The diagnostic cordmarked pottery of the Lake Creek complex is "seldom abundant, usually consisting of a few big thick fragments of large conoidal vessels, tempered with liberal quantities of coarse particles of crushed rock and/or bone, and boldly impressed with long parallel cordmarks" (J. Hughes 1991:25). While later Plains Village pottery includes similar cordmarked wares (such as Borger Cordmarked for the Panhandle Aspect), the earlier Woodland pottery is generally distinctive and identifiable.

Numerous Woodland components have been identified at sites in the Dempsey Divide area of Roger Mills County, Oklahoma (Thurmond 1991a), and archeological testing of the Beaver Dam (Thurmond 1988a, 1988b, 1988c) and Swift Horse sites (Briscoe 1987) indicates that they are generally similar to, if not virtually indistinguishable from, Lake Creek sites of the Texas Panhandle. Hofman and Brooks (1989:57-69) have observed that Plains Woodland culture in western Oklahoma appears to be very similar to the Lake Creek complex. The following discussion concentrates on sites/components that are either specifically attributed to the Lake Creek complex in the Texas Panhandle or sites that are assigned to the Plains Woodland period in other regions. This discussion attempts not to redefine the Lake Creek complex but rather to clarify the Plains Woodland phenomenon in the Texas Panhandle and western Oklahoma.

\section{Archeological Sites of the Lake Creek Complex/Plains Woodland Tradition}

Sites that are attributed to the Lake Creek complex or the Woodland period are generally campsites, but two sites in the Texas Panhandle may contain evidence of Plains Woodland village occupations. No rockshelters with well-defined Lake Creek components have been found. While bison kills are well represented in the Late and transitional Archaic, they are notably absent in the Woodland period. The chronology of the complex has been established by thermoluminescence and radiocarbon dates from burial and habitation sites (Table 67), but many of the dates (particularly those from the Sandy Ridge site) are not consistent with archeological expectations for Plains Woodland components.

\section{Possible Residential Bases}

\section{GREENBELT SITE (41DY17)}

First investigated in 1966 by the PanhandlePlains Historical Museum (Jack T. Hughes, personal communication 1994), additional investigations were conducted by Texas Tech University in 1979 and 1980. Campbell (1983) reports the findings of both seasons of excavations (ca. $37 \mathrm{~m}^{2}$ ), which uncovered one complete rectangular pithouse and portions of two others, along with numerous storage pits (some backfilled with trash) and a wide range of cultural materials. No radiocarbon dates were obtained, and Campbell (1983:70) notes that the diagnostic ceramics indicate that the occupations occurred around A.D. 1200 to 1450 . He also acknowledges that the presence of a few corner-notched arrow points and two Mogollon brownware sherds may be evidence of earlier occupations.

Cordmarked pottery $(n=579)$ dominates the ceramic assemblage (89 percent). Although no serious attempt to identify different varieties was made, at least two temper groups were observedone with crushed quartzite and the other with crushed bone. While the quartzite-tempered sherds may represent Borger Cordmarked pottery (there is a significant Antelope Creek phase component at the site), the bone-tempered sherds probably represent a Woodland period ware. Hughes et al. (1978:102) note that cordmarked pottery tempered with bone occurs in Plains Woodland sites around the Red Deer Creek valley in the northeastern Texas Panhandle and in the Custer focus to the east. Field notes from the 1966 excavations indicate that "fragments of a thick corded vessel, looking Woodlandish" were found on the oldest of several floor zones inside a 
pithouse (Jack Hughes field notes, June 23, 1966). Jack Hughes (personal communication 1994) suggests that the Greenbelt site represents a large pithouse village that was continuously occupied from the Woodland period through Panhandle aspect times, with the later occupations having been more intensive and obscuring the earlier remains. ${ }^{7}$

\section{DUNCAN RANCH SITE 1 (41HC124)}

Surface collections and limited testing produced evidence of Plains Woodland and Panhandle Aspect occupations at Duncan Ranch Site 1 in Hutchinson County (Gustafson 1994a, 1994b). Cordmarked sherds from the site are apparently tempered with caliche, crushed rock (possibly scoria), and/or sand and are thought to be similar to ceramics of the Custer phase. Projectile points include a few late dart points and early and late arrow points. The minimal testing (three $1-\mathrm{x}-1-\mathrm{m}$ units) confirmed that there is a buried component with cultural deposits up to $90 \mathrm{~cm}$ deep. There appears to be a significant Woodland component, and a Deadman's point and a Mogollon brownware sherd hint at possible Palo Duro complex occupations. A plastered layer, presumably a pithouse floor, was encountered at $53 \mathrm{~cm}$ below the ground surface in another test unit, and fire-cracked quartzite, charcoal, utilized flakes, debitage, a hammerstone, an Ellis dart point, and a Scallorn arrow point are reported to have been found on or near the floor. A charcoal sample obtained on or near the presumed structure floor produced a calibrated radiocarbon date of A.D. 993-1151 (see Table 67).

Gustafson (1994b:201-204) argues that the data suggest that a cultural transition from Plains Woodland into Panhandle Aspect is represented at this site. It is possible that the Duncan Ranch Site 1 does represent a Plains Woodland village that was occupied into Panhandle aspect times, but the idea of in situ cultural transformation is not well supported. Other researchers have suggested a genetic connection between the local Plains Woodland and Panhandle aspect (Couzzourt 1982:72; J. Hughes 1991:33;

\footnotetext{
${ }^{7}$ Additional investigations conducted at the Greenbelt site during the 1996 Texas Archeological Society field school found more structures and features. At this time, the site was renamed the Harrison-Greenbelt site in honor of the late Billy Harrison.
}

Lintz 1986:226-236), but this hypothesis has yet to be adequately tested.

\section{Campsites}

\section{LAKE CREEK SITE (PPHM-A48)}

The Lake Creek site, located along a tributary just north of the Canadian River in Hutchinson County, Texas, was tested in 1952 and is reported by Hughes (1962). A $5-\mathrm{x}-15-\mathrm{ft}$ test trench (ca. $7 \mathrm{~m}^{2}$ ) yielded evidence of one primary Woodland occupation and sparse evidence of a later ephemeral occupation. Collections (excluding debitage) were limited to 103 specimens from surface contexts and 51 from the test trench. Of these, 17 are unmodified bones (11 bison, 1 deer, 2 jackrabbit, 1 rodent, and 2 turtle), and 4 are unmodified mussel shells. The 133 artifacts include a bird-bone bead, cornernotched dart points, corner- and side-notched arrow points, and a variety of chipped (knives, scrapers, and gravers), battered (hammerstones and choppers), and ground stone tools. The latter are unusually abundant and consist of 21 manos ( 5 complete) and 10 metates (1 complete). Hughes (1962:80, 81) notes that the manos and metates were different (i.e., generally thinner and smaller) than the ground stones of the Panhandle aspect. The ceramic assemblage consists of 48 sherds, of which 90 percent are an unidentified cordmarked type (definitely not Borger Cordmarked) tempered with crushed dolomite or caliche; a single rim sherd is incised, while a base sherd is suggestive of a conical-bottomed vessel. The other five sherds are of an untyped brownware that resembles the wares of the middle Pecos River valley.

The artifact assemblage may be somewhat representative of Plains Woodland occupations, probably during the transitional Archaic period. A few artifacts appear to be associated with an ephemeral later, probably Panhandle aspect, occupation. Hughes (1962) notes that an end scraper and a bison bone were found in the uppermost level and probably relate to a later component, and a surfacecollected beveled knife is almost certainly a later addition as well.

Although the investigations were limited, Hughes (1962:83) suggested the name Lake Creek focus to represent Woodland period occupations in the Texas Panhandle. Lake Creek focus is still used occasionally (e.g., Hofman and Brooks 1989:69), but 


\begin{tabular}{|c|c|c|c|c|c|c|c|}
\hline \multicolumn{8}{|c|}{$\begin{array}{l}\text { SUMMARY OF THERMOLUMINESCENCE AND RADIOCARBON DATES } \\
\text { FOR LAKE CREEK COMPLEX AND PLAINS WOODLAND SITES }\end{array}$} \\
\hline \multirow{2}{*}{$\begin{array}{l}\text { Site Name } \\
\text { and Number }\end{array}$} & \multirow[b]{2}{*}{ Reference } & \multirow{2}{*}{$\begin{array}{l}\text { Material and } \\
\text { Lab No. }\end{array}$} & \multirow{2}{*}{$\begin{array}{l}\text { Uncorrected } \\
\text { Age, B.P. }\end{array}$} & \multirow{2}{*}{$\begin{array}{l}\delta^{13} \mathrm{C} \\
\%\end{array}$} & \multicolumn{2}{|c|}{ Corrected $^{1}$} & \multirow{2}{*}{$\begin{array}{l}\text { Calibrated Date Range } \\
\text { and Intercepts, A.D. }{ }^{2}\end{array}$} \\
\hline & & & & & Age, B.P. & Date, A.D. & \\
\hline \multicolumn{8}{|c|}{ THERMOLUMINESCENCE DATE } \\
\hline $\begin{array}{l}\text { Tascosa Creek } \\
\text { PPHM-A2060 }\end{array}$ & Couzzourt 1988:49 & $\begin{array}{l}\text { Cordmarked Sherd } \\
\text { Alpha-3084 }\end{array}$ & - & - & - & - & $400-640$ \\
\hline \multicolumn{8}{|c|}{ RADIOCARBON DATES } \\
\hline \multirow{2}{*}{$\begin{array}{l}\text { Sandy Ridge } \\
41 \mathrm{HF} 5 \text {, Block A }\end{array}$} & \multirow{2}{*}{$\begin{array}{l}\text { Quigg, Lintz, Oglesby, } \\
\text { Earls et al. 1993: } \\
\text { Table B3 }\end{array}$} & $\begin{array}{l}\text { Sediment } \\
\text { Tx-7036 }\end{array}$ & $1100 \pm 70$ & -13.8 & $1280 \pm 70$ & $670 \pm 70$ & $661(694,698,715,746,769) 870$ \\
\hline & & $\begin{array}{l}\text { Sediment } \\
\mathrm{Tx}-7037\end{array}$ & $910 \pm 60$ & -14.6 & $1090 \pm 60$ & $860 \pm 60$ & $889(984) 1020$ \\
\hline \multirow{2}{*}{$\begin{array}{l}\text { Sandy Ridge } \\
41 \mathrm{HF} 5 \text {, Block B }\end{array}$} & \multirow{2}{*}{$\begin{array}{l}\text { Quigg, Lintz, Oglesby, } \\
\text { Earls et al. 1993: } \\
\text { Table B3 }\end{array}$} & $\begin{array}{l}\text { Sediment } \\
\text { Tx-7033 }\end{array}$ & $410 \pm 60$ & -13.8 & $560 \pm 60$ & $1390 \pm 60$ & $1319(1408) 1435$ \\
\hline & & $\begin{array}{l}\text { Sediment } \\
\text { Tx-7034 }\end{array}$ & $700 \pm 60$ & -13.4 & $880 \pm 60$ & $1070 \pm 60$ & $\begin{array}{l}1037(1163,1169,1192,1203 \\
1205) 1258\end{array}$ \\
\hline \multirow{5}{*}{$\begin{array}{l}\text { Swift Horse } \\
\text { 34RM501 }\end{array}$} & \multirow{5}{*}{ Briscoe 1987:26-29 } & $\begin{array}{l}\text { Charcoal } \\
\text { Beta-18429 }\end{array}$ & $1680 \pm 80$ & - & {$[1696 \pm 90]$} & - & {$[245(362,367,384) 525]$} \\
\hline & & $\begin{array}{l}\text { Charcoal } \\
\text { Beta-18430 }\end{array}$ & $1610 \pm 90$ & - & {$[1626 \pm 99]$} & - & [264 (424) 543] \\
\hline & & $\begin{array}{l}\text { Charcoal } \\
\text { Beta-18431 }\end{array}$ & $1590 \pm 70$ & - & {$[1606 \pm 81]$} & - & {$[364(428) 543]$} \\
\hline & & $\begin{array}{l}\text { Charcoal } \\
\text { Beta-18432 }\end{array}$ & $1650 \pm 70$ & - & {$[1666 \pm 81]$} & - & [260 (411) 533] \\
\hline & & $\begin{array}{l}\text { Charcoal } \\
\text { Beta-18433 }\end{array}$ & $1820 \pm 100$ & - & {$[1836 \pm 108]$} & - & {$[66(179,194,221) 340]$} \\
\hline
\end{tabular}




\begin{tabular}{|c|c|c|c|c|c|c|c|}
\hline \multicolumn{8}{|c|}{ Table 67, continued } \\
\hline \multirow[b]{2}{*}{$\begin{array}{l}\text { Site Name } \\
\text { and Number }\end{array}$} & \multirow[b]{2}{*}{ Reference } & \multirow[b]{2}{*}{$\begin{array}{l}\text { Material and } \\
\text { Lab No. }\end{array}$} & \multirow[b]{2}{*}{$\begin{array}{l}\text { Uncorrected } \\
\text { Age, B.P. }\end{array}$} & \multirow[b]{2}{*}{$\begin{array}{l}\delta^{13} \mathrm{C} \\
\% 0\end{array}$} & \multicolumn{2}{|c|}{ Corrected } & \multirow[b]{2}{*}{$\begin{array}{l}\text { Calibrated Date Range } \\
\text { and Intercepts, A.D. }\end{array}$} \\
\hline & & & & & Age, B.P. & Date, A.D. & \\
\hline $\begin{array}{l}\text { Duncan Ranch } \\
\text { Site } 1 \\
41 \mathrm{HC} 124\end{array}$ & $\begin{array}{l}\text { Gustafson 1994b:153, } \\
225\end{array}$ & $\begin{array}{l}\text { Charcoal } \\
\text { Beta-71961 }\end{array}$ & - & * & $1000 \pm 60$ & - & $993(1023) 1151$ \\
\hline $\begin{array}{l}\text { Beaver Dam } \\
\text { 34RM208A }\end{array}$ & $\begin{array}{l}\text { Thurmond 1991a: } \\
\text { Tables 2-4 }\end{array}$ & $\begin{array}{l}\text { Charcoal } \\
\text { NZA-1388 }\end{array}$ & $1514 \pm 79$ & -24.5 & $1514 \pm 79$ & $436 \pm 79$ & $428(545,549,557) 644$ \\
\hline \multirow{2}{*}{$\begin{array}{l}\text { Lake Altus } \\
\text { Burials } \\
\text { 34GR5 }\end{array}$} & \multirow{2}{*}{$\begin{array}{l}\text { Button and Agogino } \\
\text { 1987:19, } 31\end{array}$} & $\begin{array}{l}\text { Bone } \\
\text { Beta-7823 }\end{array}$ & $1270 \pm 90$ & - & {$[1411 \pm 99]$} & - & [557 (646) 690] \\
\hline & & $\begin{array}{l}\text { Bone } \\
\text { Beta-7824 }\end{array}$ & $1390 \pm 90$ & - & {$[1531 \pm 99]$} & - & [422 (542) 642] \\
\hline \multirow{3}{*}{$\begin{array}{l}\text { Sullivan- } \\
\text { Carpenter } \\
\text { 34RM668 }\end{array}$} & \multirow{3}{*}{$\begin{array}{l}\text { Gettys } 1991 \\
\text { Oklahoma Archeological } \\
\text { Survey } 1993\end{array}$} & $\begin{array}{l}\text { Bone } \\
\text { Beta-56528 }\end{array}$ & $980 \pm 70$ & -18.9 & $1070 \pm 70$ & $880 \pm 70$ & $896(990) 1023$ \\
\hline & & $\begin{array}{l}\text { Bone } \\
\text { Beta-56529 }\end{array}$ & $1510 \pm 100$ & -16.6 & $1640 \pm 100$ & $310 \pm 100$ & $261(420) 541$ \\
\hline & & $\begin{array}{l}\text { Bone } \\
\text { Beta-57058 }\end{array}$ & $1430 \pm 90$ & -14.6 & $1600 \pm 90$ & $350 \pm 90$ & $363(429,522,527) 578$ \\
\hline \multicolumn{8}{|c|}{$\begin{array}{l}\text { 'Corrected ages in brackets are estimates for dates for which no } \delta^{13} \mathrm{C} \text { values were obtained. The corrected ages are based on an estimated } \delta^{13} \mathrm{C} \text { value } \\
\text { of }-24.00 \text { for fossil wood charcoal (from Stuiver and Polach 1977) or }-16.2 \text { for human bone (the average of five } \delta^{13} \mathrm{C} \text { values obtained for Late/transitional } \\
\text { Archaic burials - see Chapter 9). } \\
{ }^{2} \text { All calibrations are done by CALIB version } 3.03 \text { according to Stuiver and Reimer (1993), using a 1-sigma range for calibration data set \#2. Calibrations in } \\
\text { brackets are based on the estimated } \delta^{13} \mathrm{C} \text { values. The thermoluminescence date is not calibrated. } \\
{ }^{*} \text { Not presented in report. }\end{array}$} \\
\hline
\end{tabular}


Jack Hughes (1991:25) most recently used Lake Creek complex. The latter name seems preferable since the manifestation is still poorly defined.

\section{TASCOSA CREEK SITE (PPHM-A2060), EARLY COMPONENT}

Limited testing (seven 2-x-2-m units, or $28 \mathrm{~m}^{2}$ ) of the Tascosa Creek site (Couzzourt 1985, 1988) indicates long-term occupations consisting of at least two probable components that are vaguely separated both horizontally and vertically. The separation is not clean, however, and there appears to be some mixing of materials in some parts of the site. The cultural materials are not described or analyzed separately (i.e., by components), but inferences are made regarding the nature of the two components. A burial also was found, but it is undated and contained no temporally diagnostic artifacts.

Diagnostic points include a few Ellis-like dart points, a few basal-notched (Deadman's-like) arrow points, and numerous corner-notched (Scallorn-like) and side-notched (cf. Washita-like) arrow points. Pottery includes calcite-tempered cordmarked ware (a Woodland variety) and at least four varieties of brownware pottery, identified by Jack Hedrick as Jornada Brown, Middle Pecos Micaceous Brown, McKenzie Brown, and an unidentified type that may be of local manufacture. Two thermoluminescence dates on ceramics seem to verify this interpretation. A date of A.D. 400-640 was obtained on a cordmarked sherd (see Table 67) and a date of A.D. 1350-1450 was obtained on a Middle Pecos Micaceous sherd (Couzzourt 1988:49).

Couzzourt (1985:94-95) interprets the data as evidence for a Woodland component and an unidentified "brownware" component. The Woodland component is characterized by the calcite-tempered cordmarked pottery (representing large shoulderless vessels with conoidal bottoms), Scallorn-like and Deadman's-like arrow points, an absence of bison remains and predominance of small mammal bones, and large numbers of grinding implements and burned rocks. The later brownware component was characterized by the brownwares, side-notched points, and bison bones (discussed later in this chapter).

Couzzourt (1985) originally thought that the two components were close in time and that the Woodland and brownware groups may have even interacted to some extent. Based on the thermolumi- nescence dates, however, Couzzourt (1988) revised his interpretations to suggest that there probably was some time separation between them, with the brownware component being contemporaneous with Panhandle aspect occupations in the area.

Some of the cultural materials attributed to the early component seem to be related more to the Palo Duro complex than to Lake Creek. The Deadman's arrow points are definitely associated with the early component, and it appears that at least one of the brownware sherds is as well (Couzzourt 1985:94). Although mixing of materials may account for this, the possibility that an ephemeral Palo Duro occupation is mixed with the early Woodland component cannot be discounted, especially since possible Palo Duro complex components have been identified in nearby sites (see South Ridge site).

\section{SANFORD RESERVOIR SITES (41MO5 AND 41PT29)}

Green (1986) conducted survey and testing in the Sanford Reservoir (now Lake Meredith) area and recovered late dart and early arrow points in a number of Panhandle aspect sites. Lake Creek components were identified only at two sites, however, and they are interpreted as representing temporary or seasonal camps. No radiocarbon dates were obtained for these occupations.

A series of test trenches and $10-\mathrm{x}-10-\mathrm{ft}$ units (approximately 60 to $68 \mathrm{~m}^{2}$ ) at $41 \mathrm{MO} 5$ produced evidence of an upper Panhandle aspect component and a lower Lake Creek component that yielded some Late Archaic dart points and numerous cornerto basal-notched arrow points. Borger Cordmarked sherds were associated with the upper component, but no sherds were recovered from the lower component (although one "unidentified sherd" could be a Woodland sherd). Green (1986:Table 3) summarizes the artifacts from $41 \mathrm{MO}$, but they are not separated by components and are of minimal value for evaluating the Lake Creek component.

Testing at 41PT29 produced evidence of a Woodland component that appears to be fairly discrete. Twenty 5-x-5-ft units were excavated (ca. $47 \mathrm{~m}^{2}$ ), and features consisted of four clusters of fire-cracked rocks interpreted as probable boiling stone dumps, one unlined basin-shaped hearth, and a cache of ca. 1,000 Alibates flakes. The artifacts, summarized by Green (1986:Table 5), may be representative of a Lake Creek component, although 
the presence of Late Archaic materials suggests that it may date to the transitional Archaic period. Green (1986:67) suggested that no Panhandle aspect artifacts were found, but at least one artifact, a beveled knife, is almost certainly associated with a later occupation.

While individual artifacts and classes are not described, the Woodland component at 41PT29 is characterized by unclassified and corner-notched dart and arrow points (it is unclear how many of each), side and end scrapers, oval and triangular bifaces, and unusually high numbers of manos and crude bifaces/choppers. One unifacial Clear Fork gouge also was recovered.

\section{NIGHT STORM SITE (41RB21)}

The Night Storm site was recorded during a reconnaissance survey of the Red Deer Creek drainage, a southern tributary to the Canadian River, by Hughes et al. (1977). Subsequent surface collection and minimal testing (six 5 -x-5-ft units, or $14 \mathrm{~m}^{2}$ ) revealed evidence of a single component that is transitional between Plains Woodland and Plains Village. The site contains some typical Panhandle aspect materials (i.e., Washita/Harrell points, end scrapers, and beveled knives), and the dominant lithic material is Alibates agate (Hughes et al. 1978:75-110). No slab-lined structures were encountered, and no typical Borger Cordmarked pottery was recovered. The pottery that was found is mostly cordmarked, but includes some plain or smoothed cordmarked, with many variations in temper: sand, scoria, calcite, sand and bone, sand and scoria, and scoria and bone. All of these variations are diagnostic of Woodland period pottery of the Texas Panhandle or Custer phase in western Oklahoma, and cordmarked pottery with scoria and/or bone temper is thought to be the earliest variety (Hughes et al. 1978:106-107). Because the materials are not stratigraphically separable in the thin (ca. 12 inch) cultural deposits and without radiocarbon dates to confirm the chronology, the interpretation that the site represents a single transitional Plains Woodland/Village component is tentative.

\section{FATHEREE (41GY32) SITES}

The Fatheree site also was recorded during a reconnaissance survey of the Red Deer Creek drain- age (Hughes et al. 1977). Subsequent surface collections from one part of the site, Area 5, recovered Woodland cordmarked pottery tempered with crushed quartzose rocks, along with a Deadman's arrow point (Hughes et al. 1978:165, 168). The sherds were found in situ in a buried occupational zone, while the point was found out of context in a gully along with burned rocks, flint flakes, and bone fragments. Hughes et al. (1978:166) interpret Area 5 as a "Woodland component with Deadman points in association with Woodland pottery." Testing of nearby Area 1, however, revealed a probable Palo Duro component (discussed below), and it is possible that the point from Area 5 is from this occupation and was not associated with the cordmarked pottery. No Mogollon brownware sherds were found in Area 5, but they were recovered from Area 1 and from other Woodland or Palo Duro complex sites along Red Deer Creek (Hughes et al. 1978:9). Area 5 was not tested, and the total collection consists of the pottery and point.

\section{SANDY RIDGE SITE (41HF5)}

Buried cultural zones in an alluvial terrace at the Sandy Ridge site produced evidence of probable Woodland occupations in three separate areas (Blocks A-C). Fourteen radiocarbon dates were obtained, and the majority of the artifacts are of Late Archaic and/or Plains Woodland age (Quigg, Lintz, Oglesby, Earls et al. 1993:117-214). Not all of the dates are from archeological contexts, but a high degree of stratigraphic consistency was noted. Many of the dates are useful for interpreting the archeological remains, but there are some inconsistencies between the artifactual evidence and radiocarbon ages.

Block A $\left(107 \mathrm{~m}^{2}\right)$ produced 3,474 pieces of lithic debris and 85 stone tools, including cornernotched and stemmed dart and arrow points and two bone-tempered cordmarked sherds (petrographic analysis indicates that 57 percent of the nonplastic inclusions are burned bone). No features or ground stones were found, and the primary activities represented are hunting and processing of animals. This area is interpreted as a "general hunting camp occupied by a very mobile hunter and gather population" (Quigg, Lintz, Oglesby, Earls et al. 1993:154). No archeological materials were radiocarbon dated, but two soil humate dates from the same stratum yielded calibrated dates of A.D. $889-1020$ and 
A.D. 661-870 (see Table 67). These represent a minimum age for the Block A cultural deposit, and, along with other soil humate dates that bracket the cultural zone, suggest that the occupations date to between 50 B.C. and A.D. 750 .

Block B $\left(87 \mathrm{~m}^{2}\right)$ produced 7,484 pieces of lithic debris and 27 stone tools, including cornernotched dart and arrow points, associated with burned rock clusters but no ceramics or ground stones. Two soil humate radiocarbon dates provide gross chronological control and are calibrated to A.D. 1037-1258 and A.D. 1319-1435 (see Table 67). The Block B cultural zone is estimated to date between 50 B.C. and A.D. 1350 . While the age estimate indicates that the occupations extend well into Plains Village times, no artifacts generally associated with the Panhandle aspect were found. Three obsidian hydration dates, obtained on the only three obsidian flakes recovered, range from A.D. 1548 to 1653 and further confuse the issue in that they fall into the early Protohistoric period. The dates are thought to be good, but the dated specimens are considered to be intrusive into the earlier assemblage "due to rodent activities in the poorly consolidated sandy matrix" (Quigg, Lintz, Oglesby, Earls et al. 1993:175). Thus, there is considerable uncertainty as to the integrity of the Block B assemblage.

Block C $\left(49 \mathrm{~m}^{2}\right)$ consists of a $45-\mathrm{cm}$-thick cultural deposit that produced 2,463 pieces of lithic debris and 112 stone tools associated with six features. The assemblage included corner- and basal-notched dart and arrow points, but no pottery was found. Two manos and five metates provide indirect evidence of plant processing, but most of the other lithic tools (i.e., points, scrapers, and edgemodified flakes) are probably related to hunting and butchering. A substantial faunal assemblage $(n=$ 3,560) included many intrusive remains (i.e., burrowing animals), but three species were exploited for food. Deer, jackrabbit, and bison apparently were hunted, and the bison remains are clearly dominant (accounting for 6 percent of the entire bone assemblage and 87 percent of the identifiable remains). A 6-x-5-m oval charcoal stain was considered too irregular to represent a structure and was interpreted as a possible bone grease processing area. Other features encountered were smaller charcoal/ash stains and burned caliche concentrations. The Block $\mathrm{C}$ data are interpreted as evidence of repeated short-term occupations by mobile hunter- gatherers.

Four radiocarbon assays for Block $\mathrm{C}$ produced dates that are much earlier than expected, with the calibrated ages for two bone collagen samples overlapping at 1749-546 B.C. and the calibrated ages for two humate/charcoal samples overlapping at 2097-1609 B.C. (see Table 62). Stratigraphic consistency for radiocarbon dates above and below the Block $\mathrm{C}$ cultural zone suggests that these ages are correct, thus placing the occupations in the Late Archaic period. While the dart points are not inconsistent with these dates, the arrow points seem out of place. The arrow points could date to the time period indicated by the dates, as Quigg, Lintz, Oglesby, Earls et al. (1993:209) note that a central Oklahoma find (see Taylor 1987) produced an arrow point at the same level as a hearth radiocarbon dated to ca. 940-480 B.C. (uncalibrated 1-sigma range of two charcoal dates). But, an alternative and morecautious interpretation is that the cultural zone(s) represents mixed Late Archaic and Late Prehistoric I deposits. The matrix throughout the cultural zone is primarily sand, and extensive bioturbation is evident. Both conditions indicate that vertical movement of charred remains and artifacts, both upand down-profile, is likely, and it is possible that the samples selected for dating represent only the earliest occupations. Thus, as Quigg, Lintz, Oglesby, Earls et al. (1993:214) suggest, the arrow points and radiocarbon dates may not be associated at all.

In conclusion, the inconsistencies between the radiocarbon dates and artifacts at the Sandy Ridge site indicate that Blocks $\mathrm{B}$ and $\mathrm{C}$ probably represent Plains Woodland deposits that are mixed with later and earlier occupations, respectively. Only Block A has artifacts and radiocarbon dates that are consistent with a single component that may be associated with the Lake Creek complex.

\section{SWIFT HORSE SITE (34RM501)}

Test excavations (approximately 6-12 $\mathrm{m}^{2}$ excavated) at the Swift Horse site (Briscoe 1987, 1989a) revealed a 70-cm-thick midden deposit that represents Late Archaic and early Plains Woodland occupations. This inference is supported by artifactual evidence and five charcoal radiocarbon dates. Briscoe (1987) felt that the most likely period of occupation was between A.D. 130 and 400 . When the dates are corrected and calibrated (see Table 67), 
they indicate that the accumulation of the midden occurred between 66 and 543 A.D. (total 1-sigma range). Seven dart points were recovered along with one arrow point fragment and three Woodland sherds. The three sherds, which are thought to represent three different vessels, are described as "cordmarked wares with varying amounts of granite, scoria, grit and unidentified tempering materials," and Briscoe (1987:41-42) suggested that they are "Lake Creek Cordmarked," although no such type has ever been formally described. In addition, three manos, two metate fragments, and a nutting stone are reported. Another artifact of interest is a gougelike core tool that may have been hafted.

The Swift Horse midden produced a considerable amount of well-preserved faunal remains $(2,361$ bones) that were subjected to a cursory examination to identify taxa (Briscoe 1987:50-60, Table 3). Deer and antelope are not well represented (i.e., only 20 elements); the best-represented species is bison $(n=232)$, accounting for 10 percent of the total assemblage and over 25 percent of all identifiable remains. The only other animal that appears in any significant frequency and is thought to have been hunted is rabbit ( $\mathrm{n}=172 ; 7$ percent of the assemblage; 20 percent of identifiable remains). The remains of birds, turtle, snake, and catfish also were recovered, but without detailed faunal analysis it is not known whether any of these represent intrusive remains rather than food resources.

Briscoe (1987:75-76) thought that the primary subsistence activities were related to hunting, and juvenile bison bones indicate that some of the occupations occurred during late winter to early spring. Large quantities of fire-cracked rocks may be evidence of stone boiling. No evidence for horticulture was found.

The stratigraphic, chronological, and artifactual evidence may be interpreted in two ways. The midden deposit could represent a slow accumulation of cultural materials derived from separate occupations during the Late Archaic and Late Prehistoric I periods, or it may represent a rapid accumulation of cultural materials derived from a series of occupations spanning the transition from the Late Archaic to Plains Woodland period. The consistency of the radiocarbon dates from various depths suggests that the latter is most likely, but the vertical distribution of artifacts is not discussed, and it is difficult to evaluate the possibility that two or more components may be present. In any case, the Swift Horse site artifacts appear little different from those of the Late Archaic period except for the addition of arrow points and pottery. This interpretation is consistent with Thurmond's (1991a) observation that Late Archaic and Woodland occupations in western Oklahoma are quite similar and often indistinguishable.

\section{BEAVER DAM SITE (34RM208), AREA A}

Thurmond (1988a, 1988b, 1988c, 1991a:120) presents preliminary interpretations of Oklahoma Anthropological Society testing of Area A at the Beaver Dam site, indicating the presence of two separate components with Late Archaic occupations overlain by Woodland occupations. A buried cultural zone at $40-60 \mathrm{~cm}$ below the surface produced six corner-notched Scallorn and Avonlea arrow points, two Woodland cordmarked sherds, and one Ensor dart point. An underlying cultural zone, at $150-160 \mathrm{~cm}$, produced only dart points. A calibrated radiocarbon date of A.D. 428-644 (see Table 67) was obtained on charcoal from between these two zones (at $135 \mathrm{~cm}$ ), indicating that the upper Woodland zone is later. No details are available yet, but the Woodland component produced a surprising amount of bison remains (Thurmond 1988b) and it may well date to transitional Archaic times.

\section{OTHER CAMPSITES}

A few other Woodland sites warrant mention. Couzzourt (1982:67, 70, 74, 77, 134, 1985:74) indicates that the Middle Cheyenne site (PPHM-A2082) has been tested and produced Plains Woodland materials. This site probably contains a Lake Creek component, but the investigations have never been reported.

Salvage excavations at the Carrizozo Bridge site (mainly excavation of feature areas after the site had been bladed) produced evidence of Plains Woodland occupations between A.D. 850 and 1050, based on three uncalibrated radiocarbon dates (Saunders 1983). Seventeen features were recorded, including rocklined hearths, trash pits (original function may have been as baking pits), a mussel shell concentration, and a midden area. One potsherd, tentatively identified as Taos Plain, was found along with two Scallorn arrow points and a few corner-notched dart 
points. It is interpreted as a foraging campsite where repeated occupations occurred. The ground stone assemblage indicates that plant processing was an important activity, and abundant mussel shells suggest that mussels were used as food. Saunders (1983) identifies the site as a Woodland component, but its location along the Oklahoma-New Mexico border in western Cimarron County, Oklahoma, is problematic. It is not known whether it represents a western occurrence of the Lake Creek complex, something similar to the Plains Woodland of southeastern Colorado, or something else entirely (see Geographic Range and Intercultural Relationships).

Archeological work in the Buried City area of Wolf Creek in the northeastern corner of the Texas Panhandle also provides evidence of occupations during the Woodland period. Although no components have been intensively investigated, Hughes and Hughes-Jones (1987:105) note that "there is an abundance of early sites in the Wolf Creek valley representing the Woodland time period so it is conceivable that the Buried City Complex evolved locally from the Plains Woodland Tradition of the Texas Panhandle."

\section{Burials}

Although no burials have been specifically attributed to the Lake Creek complex, probable Plains Woodland burials have been found in western Oklahoma. Numerous human burials exposed by shoreline erosion at Lake Altus, in Greer County, Oklahoma, indicate that two adjacent sites (34GR5 and 34GR6) may contain cemeteries associated with the Woodland period and perhaps the Custer phase also (Agogino and Button 1985; Boyd 1982; Button and Agogino 1986, 1987). These burials occur mainly as individual primary (usually flexed) skeletons in isolated graves but also include a few secondary burials and one primary interment of five individuals. Although many of the burials contained no artifacts and have not been dated, they are at sites dominated by Late Prehistoric I materials, including abundant cordmarked pottery. Cordmarked sherds have been found in the fill of two of the burials, and sherds from one were identified as Stafford Cordmarked, a diagnostic type of the Custer phase (Boyd 1982:10-16). In addition, one burial is dated to A.D. 422-642 (calibrated), and the multiple interment of five individuals is dated to A.D. 557690 (calibrated) (see Table 67). The artifactual evidence (i.e., pottery) suggests that these cemeteries might be affiliated with the Custer phase, but the dates indicate that some of the burials are earlier. Which cultural complex or period the burials are assigned to is a matter of semantics and the lack of chronological control. It is possible that these were Woodland people who lived in a village near the cemetery. Perhaps more relevant is the fact that there are two clear cases of violence within the cemetery. One individual, possibly a bundle burial, had an untyped fragmentary arrow point embedded in its ulna (Boyd 1982:15-16; LeVick and LeVick 1966), and one of the individuals in the multiple burial had a fatal blow to the head. The composition of the multiple burial group - an elderly male with the head injury, a middle-aged female, two juvenile males, and a female child-led Button and Agogino (1987:30-31) to speculate that the entire group had been killed.

Two burials at the Sullivan-Carpenter site, also in western Oklahoma, are of considerable interest with respect to Plains Woodland occupations. A double burial (Burial 1) with no associated artifacts dates well within the Plains Woodland period at A.D. 896-1023, while a triple burial (Burial 2) falls into the transitional Archaic at A.D. 261-578 (both dates calibrated, see Table 67). The individuals in the latter had been killed, as indicated by the unambiguous associations of seven dart heads in two of the bodies and decapitated third body. While these people were killed by persons using dart points, they did not necessarily use darts themselves. Given the timing of the event, it is possible that these were Plains Woodland people killed because they were encroaching on the territory of bison hunting Late Archaic peoples (see Chapter 9).

The cultural affiliation of a double burial in Donley County (Witte 1955) also is uncertain, but violence is clearly represented. The two men in this burial (discussed below under the Palo Duro complex) had been killed by arrows tipped with Deadman's-like points. It has been suggested that they may have been members of the Palo Duro culture (Cruse 1992; J. Hughes 1991), but it also is possible that they were from another, perhaps Plains Woodland, culture and were killed by Palo Duro peoples.

\section{Chronology}

Plains Woodland materials (i.e., early arrow 
points and cordmarked pottery) generally appeared during the transitional Archaic period and continued until the appearance of Plains Village cultures at around A.D. 800 in western Oklahoma and around A.D. 1100 in the Texas Panhandle. Sites and components that have been attributed to the Lake Creek complex (with the exception of the Block C component at the Sandy Ridge site) are generally dated between A.D. 0 and 800 (Figure 87). While these dated components conform to archeological expectations, the small sample is inadequate for understanding the chronology of the complex. The two betterdated campsite components (i.e., Beaver Dam and Swift Horse) cluster between A.D. 0 to 650 and represent transitional Archaic/Woodland occupations. No discrete components date between A.D. 650 and 1100 , and, even when all of the undated components are considered, there does not appear to be a single example of a pure Lake Creek/Plains Woodland component.

\section{Material Culture and Features}

Only four components have sufficient contextual integrity and quality of published data to define artifact assemblages that may be representative of the Lake Creek complex, and even these have some potential for mixing with earlier and later materials.

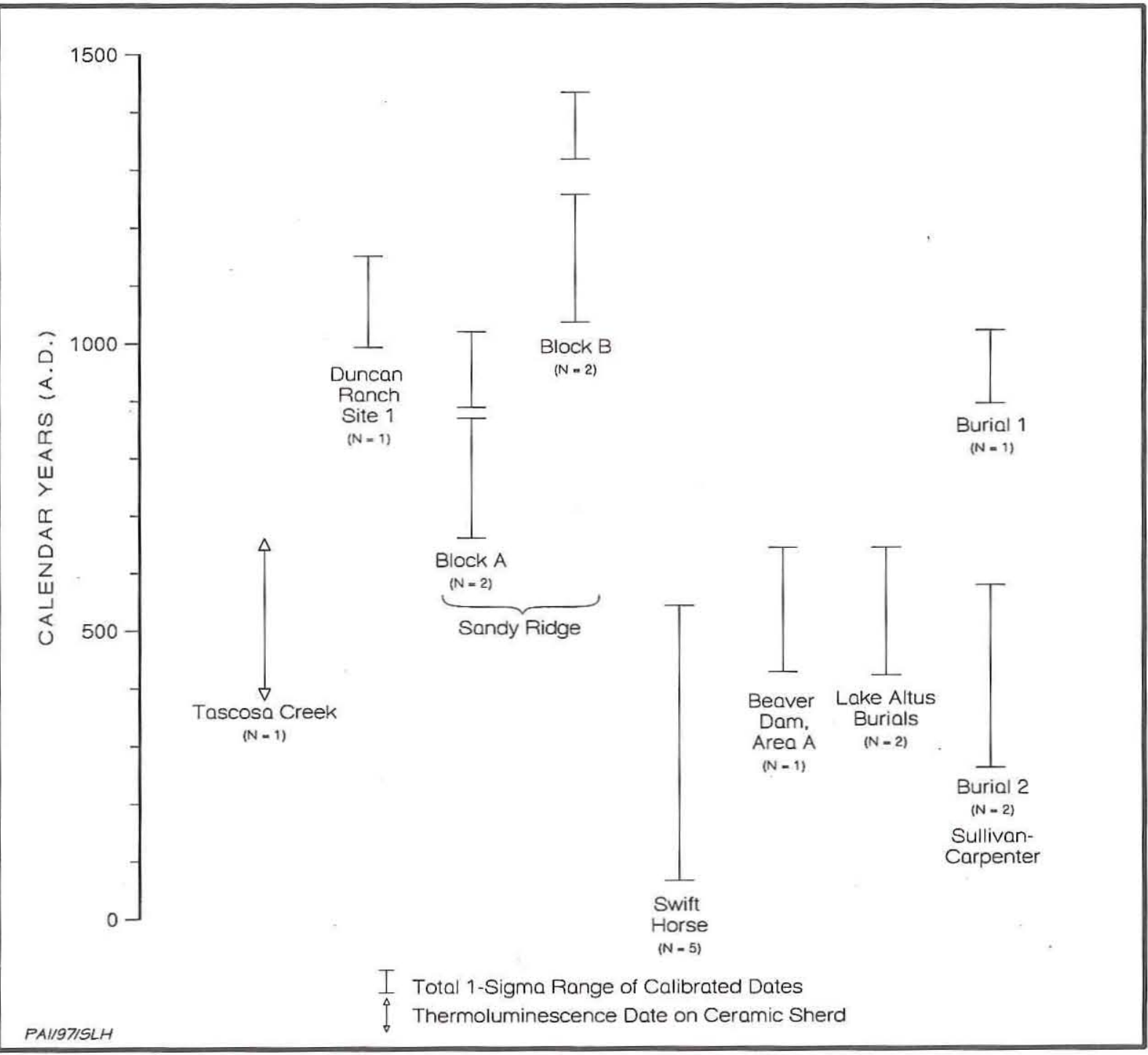

Figure 87. Graph of chronometric dates for Lake Creek/Plains Woodland components (using data from Table 67). 
erable amount of variability is represented in the manos ( 5 are complete) from the Lake Creek site, which (1) are made of tabular sandstones or quartzitic cobbles, (2) are round, oval, or rectangular in form, (3) are bifacially or unifacially ground, and (4) have flat, convex, or beveled faces. Metates (only one is complete) are all made of tabular pieces of fine-grained sandstone and most are of the slab type (i.e., flat grinding faces), but oval-basin metate fragments are present at the Lake Creek and Swift Horse sites (one specimen from the latter site exhibits extensive bifacial wear). The ground faces of many manos and metates have been pecked, and it is possible that choppers and cobble tools were used to resharpen grinding surfaces. A small nutting stone, presumably used as an anvil, is the only other form of ground stone tool represented.

The occurrence of a few sherds of Mogollon brownwares and occasional Deadman's-like points in these and other Lake Creek components may indicate some interaction between the Lake Creek and Palo Duro cultures (discussed below). Woodland cordmarked pottery from Lake Creek components has never been analyzed in any detail, with the exception of six sherds from the Sandy Ridge site (ReeseTaylor 1993). Petrographic analysis of these specimens demonstrates a considerable amount of variation in composition (e.g., temper variations include crushed bone and crushed rocks such as quartzite, granite, scoria, caliche, or dolomite), the significance of which is not yet understood.

Features found at sites with Lake Creek complex or Plains Woodland components are not well defined, primarily because very few have been dated or can be associated with these components with any confidence. There is considerable variability in the types of features that may be associated with Lake Creek components (i.e., pit structures, fire-cracked and burned rock clusters, charcoal and/or ash stains, and rock-lined and unlined hearths), but few functional interpretations may be offered because their ages are in question. Only the "midden" feature at the Swift Horse site has been adequately dated; however, it is unclear whether it represents a true midden (i.e., a refuse disposal area) or simply a thick cultural zone.

\section{Subsistence and Site Function}

Three important observations have been made in regard to the sites of the Lake Creek complex:
(1) bison remains are scarce; (2) ground stones are generally well represented; and (3) there is no definitive evidence for the practice of agriculture (J. Hughes 1991:25-26). Each of these is discussed below, along with other interpretations of material culture and subsistence.

The scarcity of bison remains has long been posited as evidence that bison hunting was of little importance to Southern Plains Woodland peoples. The archeological data discussed above, however, appear to contradict this interpretation to some extent. Bison remains are not well represented at the Tascosa Creek site but were abundant at the Sandy Ridge site and present in significant quantities at the Swift Horse and Beaver Dam sites. The fact that all of the components with bison remains date from Late or transitional Archaic into Woodland times suggests that they are not truly representative of the Woodland period after A.D. 500. Lacking any Lake Creek/Plains Woodland components that definitely date after A.D. 500, the relative importance of bison hunting during much of the Plains Woodland period is not known. Wedel (1986:91-92) has stated that bison hunting may have been of more importance to Central Plains Woodland peoples than previously thought, but there are little reliable data pertaining to Southern Plains Woodland cultures.

Differences in the frequencies of specific artifacts (see Table 68) may be interpreted in many ways but generally are related to site function (i.e., the kinds of activities that occurred at each locality). The greater frequency of cores and flakes at 41PT29 probably relates to the fact that the site occurs very near the Alibates flint quarries while the other sites are much farther from sources of quality lithic materials. The ratio of projectile points to ground stones, expressed in the form of an index (number of projectile points/number of ground stones), is considered to be a crude measure of the relative importance of hunting vs. plant processing. Plant processing is well represented at three components (with indexes of 0.13 for Lake Creek, 0.84 for 41PT29, and 1.16 for Swift Horse), but no ground stone tools were found in Block A at the Sandy Ridge site. These data suggest that there may be functional differences between campsites but that plant processing was a rather important activity for Lake Creek peoples.

The presence or absence of horticulture is problematic. There is evidence that Plains Woodland peoples in southern Colorado (i.e., the Graneros 
focus) and in the Cimarron area of north-central New Mexico (i.e., the Vermejo phase) were semisedentary and practiced horticulture as early as A.D. 500-750 (Gunnerson 1987:62-63; Stuart and Gauthier 1988:306). Similarly, evidence for horticulture appears in western Oklahoma (i.e., the Custer phase) at around A.D. 800 if not before (Brooks 1989; Hofman 1984a). In contrast, no direct evidence for domesticated plants or incipient horticulture (e.g., farming tools) has been found within the Lake Creek complex. This is not surprising, however, given the limited number of archeological investigations of Lake Creek components in general and, more specifically, the near absence of systematic recovery and analysis of macrobotanical remains. It is likely that evidence for agriculture would only be found in residential bases rather than in temporary camps. Neither of the two sites suggested as candidates for Plains Woodland residential bases has been adequately investigated, however, and the question of horticultural subsistence within the Lake Creek complex remains unanswered.

\section{Seasonality and Settlement Pattern}

Thurmond's (1991a) settlement pattern model for Late Archaic/Woodland peoples in the Dempsey Divide area of western Oklahoma (see Chapter 8) is, in a general sense, a reasonable view of how Lake Creek peoples lived, although few of the important details (e.g., relative importance of specific food resources and seasonal scheduling of subsistence activities and movements) are known. It seems that the Lake Creek peoples lived primarily in the Canadian Breaks and northern Caprock Canyonlands because that is where the important resources (water, plants, and animals) were most abundant, diverse, and predictable. It is equally likely that they exploited a wide variety of resources on a seasonal basis and ranged, at least occasionally, onto the nearby High Plains and Rolling Plains. Beyond this simplistic view, the settlement pattern of the Lake Creek complex is not well understood. Besides the limited sample of investigated sites and the near lack of seasonality data, the uncertainties of whether Lake Creek peoples practiced agriculture and/or lived in residential bases for part of the year are particularly nagging problems. What does seem to set the Lake Creek culture apart from the Late Archaic period, then, is a significant increase in the emphasis on plant resources, regardless of whether horticulture was practiced. In addition, bison hunting may have played a much less important role, at least relative to the preceding late and transitional Archaic peoples.

If Lake Creek peoples did live in residential bases during part of the year while they intensively exploited plant foods, then their settlement pattern might look much like that proposed for the Palo Duro complex below. Alternatively, Lake Creek peoples may have maintained a high degree of mobility and continued in a Late Archaic huntergatherer mode, while their subsistence activities shifted slightly toward more-intensive use of plants and less bison hunting.

\section{Geographic Range and Intercultural Relationships}

As defined by Jack Hughes (1991), the Lake Creek complex is confined mainly to the Canadian River valley but extends southward into the canyonlands of the upper Red River drainage. Recent work at the Sandy Ridge site (Quigg, Lintz, Oglesby, Earls et al. 1993), the Swift Horse site (Briscoe 1987, 1989), and the Beaver Dam site and elsewhere in the Dempsey Divide (Thurmond 1988a, 1988b, 1988c, 1991a) indicates that the complex, or something closely akin to it, extends north of the Canadian River into the Oklahoma Panhandle and east into western Oklahoma. Current information suggests that the Lake Creek culture covers all of the Texas Panhandle, i.e., the 20 northernmost counties in the state, and several Oklahoma counties along the eastern border of the Texas Panhandle.

A similar, but still poorly defined, manifestation exists in the Oklahoma Panhandle, as evidenced by Plains Woodland remains in the Kenton Caves (Lintz and Zabawa 1984), in Black Mesa State Park (Haury 1982; Saunders 1978), and at the Nall (Baker et al. 1957), Johnson-Cline (Lintz 1978), and Carrizozo Bridge (Saunders 1983) sites. Due to the paucity of archeological work in these areas, it is unclear how these sites fit into the larger picture (Hofman and Brooks 1989:68; Lintz and Zabawa 1984:172-173). The northeastern corner of New Mexico also is largely unknown, but it appears that Plains Woodland manifestations, or at least Woodland cordmarked pottery, do extend as far west as Clayton, New Mexico (Stuart and Gauthier 1988: 303). Other Plains Woodland manifestations are documented to the north, such as the Keith focus in 
central Kansas and the Graneros focus of southeastern Colorado (Campbell 1976a; Gunnerson 1987; Hofman and Brooks 1989), but the relationships between these and the Lake Creek complex are unknown.

The eastern boundary of Lake Creek, if one includes the western Oklahoma Woodland sites as part of the complex, is not certain, but a comparative study of archeological survey data in western Oklahoma by Thurmond (1991a:138-140) sheds some light on the problem. It was observed that Late Archaic/Woodland components are very common in the Dempsey Divide area of southwestern Roger Mills and northwestern Beckham Counties. Late Archaic/Woodland components are present but are much less frequent farther to the east in the Quartermaster Creek watershed of northeastern Roger Mills, southwestern Dewey, and northwestern Custer Counties (Moore 1984). The contrast is striking, and Thurmond (1991a:Table 10) notes that Late Archaic/Woodland components account for 55 percent of all components in the Dempsey Divide but only 10 percent of all components in the Quartermaster Creek area (while the opposite is true for later Plains Village period sites in these areas). Thurmond (1991a) attributes the high density of Late Archaic/Woodland occupations to the fact that these people chose to live in the well-watered, wooded canyonlands. There may have been a sharp decline in the intensity of occupation in the Rolling Plains, and the eastern edge of the Caprock Canyonlands seems to be a convenient boundary for the Lake Creek complex. The relationships between Lake Creek complex and Plains Woodland manifestations farther to the east, such as the Pruitt complex (Hofman and Brooks 1989) and Woodland sites at Delaware Canyon in Caddo County, Oklahoma (Ferring 1982, 1986), remain a mystery.

The southernmost boundary of the Lake Creek complex is located somewhere along the Prairie Dog Town Fork of the Red River and is marked by the southern extent of Woodland cordmarked pottery. In the 1940s, Krieger $(1946,1978)$ observed the existence of this cultural boundary and suggested that it represented the southerly limit of Central Plains tradition complexes or influence. This southern boundary of Plains Woodland culture coincides with the northern boundary of the Palo Duro complex (discussed below) and has considerable implications for understanding Late Prehistoric I cultural interactions.

\section{THE PALO DURO COMPLEX: SOUTHWESTERN INFLUENCE IN THE SOUTHERN CAPROCK CANYONLANDS}

Based on the 1973-1974 excavations at Deadman's Shelter in Mackenzie Reservoir, Willey and Hughes (1978b) proposed that the site was representative of a widespread cultural manifestation characterized mainly by Mogollon brownwares and early corner- and basal-notched stemmed arrow points. Many other sites in the Red River drainage had produced similar materials and were thought to be related to this new "Palo Duro complex" (Willey and Hughes 1978b:190). Several more Palo Duro sites have been investigated since that time, including some in the Brazos River drainage, and the complex now covers a larger area than was originally proposed (see Figures 84 and 85 ). The chronology of the Palo Duro complex is known primarily from radiocarbon dates from eight sites (Table 69). Based on the findings of the original and more-recent investigations, it is now possible to provide a more concise summary and reinterpretation of the Palo Duro complex and the sites attributed to it.

\section{Archeological Sites of the Palo Duro Complex}

Most of the Palo Duro sites that have been tested or excavated may be grouped into one of two site type categories-campsites or rockshelters. Recent investigations have added a third category, that of residential bases, to the site type inventory and added a new dimension to the settlement pattern. In addition, there now seems to be considerable variability in site function within the campsites and rockshelters. A fourth class of archeological remains, that of human burials, also has important implications for defining the complex. Each of these site types is discussed below.

\section{Residential Bases}

Only two sites - Kent Creek and Sam Wahlcan be confidently identified as residential bases. The Kent Creek site, located along a spring-fed tributary of the North Pease River, was excavated in 1985 and 1986 by Cruse (1992) and was the first site where habitation structures were identified. The 
TABLE 69

SUMMARY OF RADIOCARBON DATES FOR PALO DURO COMPLEX SITES

\begin{tabular}{|c|c|c|c|c|c|}
\hline $\begin{array}{l}\text { Site Name, Number, } \\
\text { Component, Reference }\end{array}$ & $\begin{array}{l}\text { Lab No., Material, } \\
\text { and Provenience }\end{array}$ & $\begin{array}{l}\text { Uncorrected } \\
\text { Age B.P. }\end{array}$ & $\begin{array}{l}\delta^{13} \mathrm{C} \\
\% 0\end{array}$ & $\begin{array}{l}\text { Corrected } \\
\text { Age B.P. }\end{array}$ & $\begin{array}{l}\text { Calibrated Date and } \\
\text { Intercepts, A.D. }{ }^{1}\end{array}$ \\
\hline \multicolumn{6}{|c|}{ RESIDENTIAL BASES } \\
\hline \multirow{3}{*}{$\begin{array}{l}\text { Kent Creek, } 41 \text { HL66 } \\
\text { Cruse 1992:57, } 64\end{array}$} & $\begin{array}{l}\text { Tx-5323, Charcoal, } \\
\text { Structure } 1 \text { floor }\end{array}$ & $1240 \pm 120$ & - & {$[1256 \pm 127]$} & $665(776) 977$ \\
\hline & $\begin{array}{l}\text { Tx-5665, Charcoal, } \\
\text { Feature 5, upper }\end{array}$ & $840 \pm 250$ & - & {$[856 \pm 253]$} & 902 (1211) 1393 \\
\hline & $\begin{array}{l}\text { Tx-5709, Charcoal, } \\
\text { Feature 5, lower }\end{array}$ & $1160 \pm 80$ & - & {$[1176 \pm 90]$} & $733(884) 985$ \\
\hline \multirow{6}{*}{$\begin{array}{l}\text { Sam Wahl, 41GR291, } \\
\text { Early Occupation period } \\
\text { Boyd et al. 1994:Table } 6\end{array}$} & $\begin{array}{l}\text { Beta-61498, } \\
\text { Charcoal, Feature } 17\end{array}$ & $1210 \pm 80$ & -22.6 & $1250 \pm 80$ & $686(776) 936$ \\
\hline & $\begin{array}{l}\text { Beta-61499/ } \\
\text { CAMS-5824, } \\
\text { Charcoal, Feature } 19\end{array}$ & - & - & {$[1390 \pm 60]$} & $610(653) 688$ \\
\hline & $\begin{array}{l}\text { Beta-59822, } \\
\text { Charcoal, Feature } 29\end{array}$ & $1370 \pm 90$ & -24.7 & $1380 \pm 90$ & $603(656) 766$ \\
\hline & $\begin{array}{l}\text { Beta-61501, } \\
\text { Charcoal, Feature } 37\end{array}$ & $980 \pm 80$ & -25.1 & $970 \pm 80$ & $\begin{array}{l}997(1031,1144, \\
1146) 1189\end{array}$ \\
\hline & $\begin{array}{l}\text { Beta-59823, } \\
\text { Charcoal, Feature } 37\end{array}$ & $1020 \pm 90$ & -24.5 & $1030 \pm 90$ & $\begin{array}{l}900(1002,1010, \\
1017) 1151\end{array}$ \\
\hline & $\begin{array}{l}\text { Beta-61500, } \\
\text { Charcoal, Feature } 41\end{array}$ & $1180 \pm 80$ & -23.5 & $1200 \pm 80$ & $\begin{array}{l}693(783,788,814, \\
818,831,839,869) \\
979\end{array}$ \\
\hline \multicolumn{6}{|c|}{ CAMPSITES } \\
\hline \multirow{2}{*}{$\begin{array}{l}\text { Cat Hollow, } \\
\text { 41GR303B, Lower Zone } \\
\text { Boyd et al. 1994: } \\
\text { Table } 28\end{array}$} & $\begin{array}{l}\text { Tx-6295, } \\
\text { Sediment, Feature } 8\end{array}$ & $1150 \pm 50$ & -18.6 & $1250 \pm 50$ & $690(776) 871$ \\
\hline & $\begin{array}{l}\text { Beta-59827/ } \\
\text { CAMS-5168, } \\
\text { Charcoal, nonfeature }\end{array}$ & - & - & {$[1880 \pm 50]$} & 73 (130) 229 \\
\hline $\begin{array}{l}\text { Chalk Hollow, } \\
\text { PPHM-A883, } \\
\text { "Upper Midden" } \\
\text { Wedel 1975:273 }\end{array}$ & - & - & - & - & $\begin{array}{l}400-850^{2} \\
\text { (uncorrected/ } \\
\text { uncalibrated) }\end{array}$ \\
\hline \multirow{3}{*}{$\begin{array}{l}\text { Gobbler Creek Bridge, } \\
41 \text { GR383 } \\
\text { Boyd et al. 1992:56-57 }\end{array}$} & $\begin{array}{l}\text { GX-16626, } \\
\text { Sediment, Feature } 13\end{array}$ & - & -15.0 & $1215 \pm 140$ & $\begin{array}{l}662(780,790,800, \\
850,860) 989\end{array}$ \\
\hline & $\begin{array}{l}\text { GX-16627-AMS, } \\
\text { Charcoal, Feature } 13\end{array}$ & - & -25.5 & $1390 \pm 65$ & $607(650) 688$ \\
\hline & $\begin{array}{l}\text { GX-16515, } \\
\text { Sediment, Nonfeature }\end{array}$ & - & -15.7 & $1865 \pm 140$ & $3(130) 341$ \\
\hline
\end{tabular}




\begin{tabular}{|c|c|c|c|c|c|}
\hline \multicolumn{6}{|l|}{ Table 69, continued } \\
\hline $\begin{array}{l}\text { Site Name, Number, } \\
\text { Component, Reference }\end{array}$ & $\begin{array}{l}\text { Lab No., Material, } \\
\text { and Provenience }\end{array}$ & $\begin{array}{l}\text { Uncorrected } \\
\text { Age B.P. }\end{array}$ & $\begin{array}{c}\delta^{13} \mathrm{C} \\
\% o\end{array}$ & $\begin{array}{l}\text { Corrected } \\
\text { Age B.P. }\end{array}$ & $\begin{array}{l}\text { Calibrated Date and } \\
\text { Intercepts, A.D. }\end{array}$ \\
\hline $\begin{array}{l}\text { Gobbler Creek Bridge, } \\
\text { continued }\end{array}$ & $\begin{array}{l}\text { GX-16512 } \\
\text { Sediment, Nonfeature }\end{array}$ & - & -17.1 & $450 \pm 124$ & $*^{3}$ \\
\hline $\begin{array}{l}\text { South Sage Creek, } \\
41 \mathrm{KT} 33 \\
\text { Boyd et al. 1992:102 }\end{array}$ & $\begin{array}{l}\text { GX-16513/16514, } \\
\text { Charcoal, Feature } 12\end{array}$ & - & -26.0 & $1005 \pm 110$ & $901(1020) 1187$ \\
\hline \multicolumn{6}{|c|}{ ROCKSHELTERS } \\
\hline \multirow{5}{*}{$\begin{array}{l}\text { Deadman's Shelter, } \\
41 \text { SW23, Area II, } \\
\text { Strata B and D } \\
\text { Willey and Hughes } \\
\text { 1978b:187, } 189\end{array}$} & $\begin{array}{l}\text { SI-1897, Charcoal, } \\
\text { Stratum B }\end{array}$ & $1485 \pm 70$ & - & {$[1501 \pm 81]$} & $\begin{array}{l}{[432(564,566,} \\
580,592,596) 645]\end{array}$ \\
\hline & $\begin{array}{l}\text { SI-1898, Charcoal, } \\
\text { Stratum B }\end{array}$ & $1240 \pm 65$ & - & {$[1256 \pm 76]$} & [686 (776) 883] \\
\hline & $\begin{array}{l}\text { SI-1899, Charcoal, } \\
\text { Stratum D }\end{array}$ & $1740 \pm 40$ & - & {$[1756 \pm 57]$} & $\begin{array}{l}{[236(259,281,} \\
291,298,321) 383]\end{array}$ \\
\hline & $\begin{array}{l}\text { SI-1900, Charcoal, } \\
\text { Stratum D }\end{array}$ & $1830 \pm 60$ & - & {$[1846 \pm 72]$} & $\begin{array}{l}{[79(176,199,217)} \\
319]\end{array}$ \\
\hline & $\begin{array}{l}\text { SI-1901, Charcoal, } \\
\text { Stratum D }\end{array}$ & $630 \pm 140$ & - & - & $*^{4}$ \\
\hline \multirow{5}{*}{$\begin{array}{l}\text { Boren Shelter No. } 2 \\
\text { 41GR559, Lower Shelter } \\
\text { Boyd et al. 1994: } \\
\text { Table } 54\end{array}$} & $\begin{array}{l}\text { GX-14449, Charcoal, } \\
\text { Feature } 5\end{array}$ & $1155 \pm 210$ & -23.3 & $1180 \pm 210$ & $652(881) 1146$ \\
\hline & $\begin{array}{l}\text { Beta-60261, Charcoal, } \\
\text { Feature } 16\end{array}$ & $1920 \pm 70$ & -24.9 & $1930 \pm 70$ & $4(75) 209$ \\
\hline & $\begin{array}{l}\text { Beta- } 60262 \text {, Charcoal, } \\
\text { Feature } 13 / 26\end{array}$ & $1730 \pm 80$ & -25.4 & $1730 \pm 80$ & $\begin{array}{l}238(263,276,338) \\
418\end{array}$ \\
\hline & $\begin{array}{l}\text { Beta-59831, Charcoal, } \\
\text { Feature } 22\end{array}$ & $1320 \pm 110$ & -26.5 & $1300 \pm 110$ & $\begin{array}{l}645(691,752,760) \\
875\end{array}$ \\
\hline & $\begin{array}{l}\text { Beta-59832, Charcoal, } \\
\text { Feature } 24\end{array}$ & $1520 \pm 90$ & -24.5 & $1530 \pm 90$ & $425(542) 641$ \\
\hline \multirow{4}{*}{$\begin{array}{l}\text { Canyon City Club Cave, } \\
\text { PPHM-A251, } \\
\text { Levels } 3 \text { and } 4 \\
\text { Hughes 1969:Table } 1\end{array}$} & $\begin{array}{l}\text { WIS-408, Charcoal, } \\
\text { Level } 3\end{array}$ & $620 \pm 45$ & - & - & $* 4$ \\
\hline & $\begin{array}{l}\text { WIS-402, Charcoal, } \\
\text { Level } 3\end{array}$ & $1260 \pm 55$ & - & {$[1276 \pm 68]$} & $\begin{array}{l}{[666(694,697,} \\
726,745,770) 866]\end{array}$ \\
\hline & $\begin{array}{l}\text { WIS-404, Charcoal, } \\
\text { Level } 4\end{array}$ & $1650 \pm 55$ & - & {$[1666 \pm 68]$} & [262 (411) 529] \\
\hline & $\begin{array}{l}\text { WIS-414. Charcoal, } \\
\text { Level } 4\end{array}$ & $1250 \pm 60$ & - & {$[1266 \pm 72]$} & $\begin{array}{l}{[672(734,737,} \\
773) 874]\end{array}$ \\
\hline $\begin{array}{l}\text { Blue Spring Shelter, } \\
\text { PPHM-A485, } \\
\text { Palo Duro levels } \\
\text { Hughes 1978:43 }\end{array}$ & - & - & - & - & $\begin{array}{l}815-1100^{5} \\
\text { (uncorrected/ } \\
\text { uncalibrated) }\end{array}$ \\
\hline
\end{tabular}




\begin{tabular}{|c|c|c|c|c|c|}
\hline \multicolumn{6}{|l|}{ Table 69 , continued } \\
\hline $\begin{array}{l}\text { Site Name, Number, } \\
\text { Component, Reference }\end{array}$ & $\begin{array}{l}\text { Lab No., Material, } \\
\text { and Provenience }\end{array}$ & $\begin{array}{l}\text { Uncorrected } \\
\text { Age B.P. }\end{array}$ & $\begin{array}{l}\delta^{13} \mathrm{C} \\
\% 0\end{array}$ & $\begin{array}{l}\text { Corrected } \\
\text { Age B.P. }\end{array}$ & $\begin{array}{l}\text { Calibrated Date and } \\
\text { Intercepts, A.D. }\end{array}$ \\
\hline \multicolumn{6}{|c|}{ BURIAL } \\
\hline $\begin{array}{l}\text { Sam Wahl, } \\
\text { 41GR291, Burial } \\
\text { Boyd et al. 1994:Table } 6\end{array}$ & $\begin{array}{l}\text { Beta-61496, Bone, } \\
\text { Feature } 23\end{array}$ & $1530 \pm 60$ & -13.6 & $1720 \pm 60$ & $\begin{array}{l}256(264,269,342 \\
374,376) 415\end{array}$ \\
\hline \multicolumn{6}{|c|}{$\begin{array}{l}{ }^{1} \text { Unless otherwise stated, all ages represent the calibrated 1-sigma age range using data set \#2 in CALIB version } \\
3.03 \text { (Stuiver and Reimer 1993). Corrections and calibrations in brackets are based on estimated } \delta^{13} \mathrm{C} \text { values } \\
\text { of }-24.00 \text { for fossil charcoal (Stuiver and Polach 1977). }\end{array}$} \\
\hline \multicolumn{6}{|c|}{$\begin{array}{l}{ }^{2} \text { Wedel's (1975) estimate of the age of the upper midden based on six uncorrected radiocarbon dates. See Lintz } \\
\text { (1995) for a recent reanalysis of the radiocarbon dates. }\end{array}$} \\
\hline \multicolumn{6}{|c|}{${ }^{3}$ Date considered by original researchers to be too recent and probably contaminated. } \\
\hline \multicolumn{6}{|c|}{${ }^{4}$ Date is out of stratigraphic sequence and is considered erroneous by the original investigator. } \\
\hline \multicolumn{6}{|c|}{${ }^{5}$ Hughes's (1978) estimate of the age of the Palo Duro levels based on an unspecified number of dates. } \\
\hline
\end{tabular}

early occupation period at the Sam Wahl site, located in the canyonlands along the Double Mountain Fork of the Brazos River in Garza County, was identified as a residential base based on excavations by Boyd et al. (1994).

\section{KENT CREEK SITE (41HL66)}

The Kent Creek site, located in southeastern Hall County along the margin between the Caprock Canyonlands and the Rolling Plains, is the residential base "type site" for the Palo Duro complex. The site occupies a prominent ridge toe $10 \mathrm{~m}$ above the wide floodplain of Kent Creek. The 1985-1986 excavations (a total of $62 \mathrm{~m}^{2}$ ) uncovered two complete rectangular pithouses (Figure 88). Structure 1 is a rectangular $(4.3 \times 3.3 \mathrm{~m})$ house with an eastfacing entryway centered along one long wall. Interior features include a trough or step-down just inside the house (probable water-trap), a large posthole just off-center, three other postholes along the front and side walls, and two clusters of burned caliche rocks lying on the floor. The function of the latter is unknown, although the possibility of heating ovens is suggested. A subfloor human burial also was found in the center of Structure 1, but the house was abandoned at the time the individual was interred (see Burials below). The absence of an interior hearth is perplexing, but the subfloor burial could have destroyed one. Charcoal from the floor was radiocarbon dated to A.D. 665-977 (calibrated, see Table 69), providing an approximate age for the occupation of the pithouse and the subfloor burial.

Structure 2 is a rectangular $(2.3 \times 3.3 \mathrm{~m})$ house with a west-facing entryway, extending from a corner of one short wall. No interior features were found except for shallow "troughs" or depressions along the front and back walls (possible water traps). The floor of this structure was virtually devoid of artifacts.

Because of their differences, Structure 1 is interpreted as a habitation while Structure 2 is thought to represent a storage facility; they exhibit some similar characteristics, however. Both structures have clay-plastered entryways, approximately $1 \mathrm{~m}$ wide and over $2 \mathrm{~m}$ long, in the form of ramps that gradually slope upward from the floor level. These pithouses are shallow, with floor levels at ca. $35 \mathrm{~cm}$ below the ground surface. Some erosional beveling of the landforms has probably occurred, but it is unlikely that the houses were dug down much more than $50 \mathrm{~cm}$, and some form of superstructure must have extended above ground. Pieces of daub recovered from the fill of Structure 1 suggest that it may have had a wattle-and-daub superstructure. Patches of clay/gravel and large rocks with plaster remnants found in the fill may indicate that Structure 1 had a partial masonry superstructure.

A possible third structure is a small subrectangular $(190 \times 85 \mathrm{~cm})$ depression, partially underlain by a thin gravel lens. Some daub was observed in the fill, and the bottom of the depression is thought 


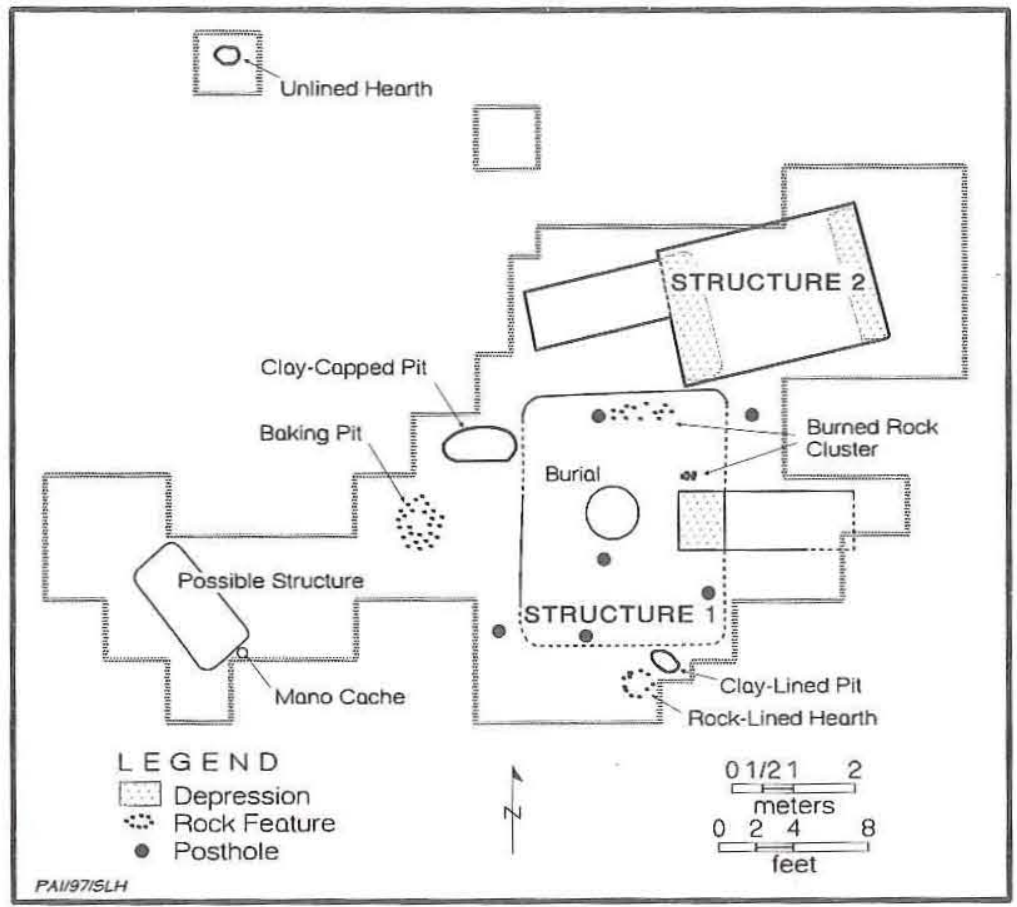

Figure 88. Map of structures and features at the Kent Creek site (modified from Cruse 1992:Figure 6).

to represent a prepared surface at approximately the same level as the other house floors. The precise function of this feature is unknown, although it may well have been a small pitroom. A mano cache (two quartzite and one sandstone mano) was found adjacent to this feature.

Extramural features consist of two oval pits (one clay lined and one clay capped) that may have functioned as storage facilities, a small rock-lined hearth, an unlined hearth, and a large rock-lined hearth or baking pit. The latter is a circular pit ( $80 \mathrm{~cm}$ diameter, $30 \mathrm{~cm}$ deep), filled with ash, charcoal, and burned rocks. Additional burned rocks, some bones, and three manos were scattered at the top and around the edges of the pit. Charcoal from the lower and upper portions of the feature provide radiocarbon dates of A.D. 733-985 and A.D. $902-1393$, respectively (calibrated dates, see Table 69).

The precise duration of the occupations at the Kent Creek site is not well established since there are only three radiocarbon dates. The two dates from the baking pit are problematic. They may indicate reuse of the feature at different times, but two use episodes some 300 years apart does not seem likely. The 1-sigma ranges for these two dates do overlap somewhat, at A.D. $902-$ 985 , and the feature might date to this time. That the older date is accurate while the upper sample may have been contaminated seems most likely, however, since the standard deviation for the upper date is inexplicably large (i.e., \pm 250 years). Since the earlier date overlaps neatly with the date for Structure 1 , it is suggested that the occupations occurred primarily around A.D. 700-1000. Cruse (1992:124) calibrated an average of the three dates and concluded that the site was occupied between A.D. 690 and 1010 and that the total duration of the occupations may have been between 100 and 300 years.

The artifacts collected include 57 arrow points (Deadman's and Scallorn are the only identifiable types), 12 dart points (some identified as Ellis), a variety of other chipped lithic tools (bifaces, unifaces, drills, gouges, and spokeshaves), cores and debitage, 20 manos and 8 metate fragments, and 34 brownware sherds. Of the latter, most were identified as Jornada Brown, Roswell Brown, or Middle Pecos Micaceous Brown, while one sherd was unlike any Jornada Mogollon pottery and could represent a locally made brownware. The faunal assemblage indicates that the inhabitants killed and ate more deer and/or antelope than any other animals, and only one bison element was recovered. Other animals that may have been utilized for food include skunks, rabbits, and turtles, while snake, prairie dog, and other rodent remains are probably intrusive. Pollen analyses provided somewhat equivocal results (and a preservation bias is likely), but slightly higher concentrations of Cheno-ams were observed in some features. Charred plant remains recovered from extramural features indicate that goosefoot and purslane may have been food resources and that juniper and cottonwood/ willow were used as firewood. In addition, charred acorns were recovered from the fill of the burial and from a trough depression inside Structure 2. Although the species was not identified, it is likely that these represent the use of shin oak (Quercus havardii) as a food resource. The number of 
analyzed pollen and flotation samples is minimal, and Cruse (1992:141) notes that "the possibility that horticulture was practiced cannot be ruled out."

The Kent Creek site is interpreted as a multifunctional residential village, but its size (i.e., the number of pithouses present) is unknown because the excavated area represents only a small portion of a much larger site. Procurement and processing of a wide range of plants and animals are represented, along with the full range of lithic tool manufacture and maintenance.

\section{SAM WAHL SITE (41GR291), EARLY OCCUPATION}

The findings from the Sam Wahl site (see Chapter 6) indicate that there are three components or periods of occupation-a burial component, an early occupation period, and a late occupation period. Significant archeological remains date to Late Prehistoric I times, and they are classified as the early occupation period. The early occupation is characterized by a feature complex consisting of an oval pithouse, circular storage pits, baking pits, and bedrock mortars that are radiocarbon dated to A.D. 600-1050. The associated artifacts (see Table 34) include an unusually high frequency and variety of grinding tools (i.e., large oval-basin metates and convex-face manos, slab metates and flat-faced manos, and ovate pestles used in conjunction with bedrock mortars). The features and artifacts indicate that the inhabitants were preoccupied with the collecting, processing, and storage of plant foods and that hunting was of minimal importance. It is not known what plant foods were stored, but good evidence for the use of mesquite beans as a food resource was found. Other charred remains, such as Chenopodium and cucurbit seeds, also may represent wild plant foods. The possibility that the early occupants practiced limited maize agriculture should not be ruled out based solely on negative evidence.

The early occupation is characterized as a small pithouse village that was probably occupied on a seasonal basis. Definitive seasonality data are minimal, but the occupations were probably seasonal, with most wild plant foods (e.g., mesquite beans) being ready for harvest in late summer/fall and storage perhaps indicating use through the winter. If limited agriculture was practiced, the occupations may have been biseasonal, probably during spring planting and late summer/fall harvest.
The burial component (discussed below) cannot be assigned to a cultural complex with any confidence, but the early occupations are attributed to the Palo Duro complex. There is not enough evidence to determine whether the late occupations represent a late variant of the Palo Duro complex or something else entirely (see Chapter 11). The evidence from 41GR291 seems to indicate that a dramatic change in site function and subsistence occurred around A.D. 1050/1100. Hunting seems to have been increasingly important, and the inhabitants may have shifted from living in pithouses to living in surface houses (i.e., pithouses evolved into or were replaced by surface houses) at this time.

\section{DISCUSSION}

Besides the Kent Creek and Sam Wahl sites, two other sites have been tentatively proposed as possible residential bases. Hays (1986:10-11, 20) identifies a probable Palo Duro complex site (PPHM-A2042) in the Buffalo Lake National Wildlife Refuge in Randall County, Texas. This site was initially visited in 1980 by Hughes, who observed a greater density of cultural materials (e.g., bone fragments, fire-cracked quartzite, burned caliche, and lithic debris) than seen at any other site in the refuge (Jack T. Hughes field notes, February 6, 1980). Artifacts observed or collected consist of dart points, arrow points (including some Deadman's), bifaces, unifaces, ground stones, and sherds of Mogollon brownware. A test pit indicated that substantial buried deposits exist. Hughes noted that several depressions might be pithouses. Without further testing, however, this interpretation is tentative.

Tahoka Lake, a large pluvial lake in Lynn County, Texas, also has been suggested as a possible location of a pithouse site that might be related to the Palo Duro complex (see Boyd 1995). Lee Johnson (personal communication 1992) remembered seeing possible pithouse depressions and Mogollon ceramics in the vicinity of Tahoka Lake many years ago, prior to complete cultivation of the area. Lacking an adequate investigation, however, it is impossible to evaluate the suggestion further. Surface collections from a site 3 miles south of Tahoka Lake have yielded corner-notched and stemmed arrow points indicating the presence of Late Prehistoric I occupations, but no pottery was found (Riggs 1965b). Watts (1963:1-4) notes that 
undifferentiated brownwares have been found near Tahoka Lake and at many other lake sites on the southern Llano Estacado. Watts's (1963) study is outdated, but another ceramic distribution study in progress (Wiseman et al. 1994) may eventually provide much more detailed information on Southwestern wares on the Llano Estacado. Given the limited data available at this time, the presence of Palo Duro complex occupations on the southern Llano Estacado cannot be discounted. In addition, circumstantial evidence suggests that the South Sage Creek site might contain pithouses. Lacking definitive archeological evidence, however, this site must be classified as a campsite (see below).

\section{Campsites}

Archeological investigations at many campsites in the Caprock Canyonlands have produced evidence of Palo Duro occupations, and 10 of these are discussed individually below. A few minimally tested sites have yielded possible Palo Duro complex materials, but the components cannot be adequately defined. Scallorn-like arrow points and brownwares typed as Jornada Brown, El Paso Brown, Roswell Brown, and Middle Pecos Micaceous Brown have been recovered in different areas of the Floydada County Club site (Word 1963, 1991a). Similarly, testing at the Montgomery site, also in Floyd County, produced Scallorn points and El Paso Brown, Jornada Brown, and untyped brownwares (Northern 1979; Word 1965). It is likely that Palo Duro components are present at both of these sites, but they are effectively masked by, and probably mixed with, Late Prehistoric II and Protohistoric remains.

Sommer (1971) reports that minimal testing $\left(15 \mathrm{~m}^{2}\right)$ at the Big Spring site (41HW2) exposed several hearths and recovered stemmed dart and arrow points (typed as Paisano, Cliffton, and Bonham), along with sherds of Roswell Brown and Ochoa Indented. The site is undated and its chronological placement is uncertain. It could date to either the Late Prehistoric I or II periods, or both. The points and Roswell Brown pottery could indicate affiliation with the Palo Duro complex, but Ochoa Indented is thought to be a later type that was made around A.D. 1300-1500 (Collins 1968:101; Runyan and Hedrick 1987:42-43), although its chronology is not well established.
CHALK HOLLOW (PPHM-A883), UPPER MIDDEN

Smithsonian Institution excavations (five 1.5-x-1.5-m units, or $11.25 \mathrm{~m}^{2}$ ) at Chalk Hollow, a tributary of the Prairie Dog Town Fork of the Red River in Randall County, are briefly reported by Wedel (1975). The upper midden (actually a buried cultural zone rather than a true midden) dates to A.D. $400-850$ (Wedel's interpretation of the total range of six uncorrected and uncalibrated radiocarbon dates) and is characterized by:

(1) small stemmed or corner-notched projectile points, mostly under $45 \mathrm{~mm}$ long and generally in the Scallorn, or Scallorn-like category; (2) unifacially chipped (planoconvex) end scrapers; (3) bifacial chipped knives; (4) milling slabs and manos of varying sizes; (5) occasional potsherds of plain brown ware, probably not of local manufacture; (6) split mamal [sic] bone awls; (7) bone gaming pieces; (8) flint debitage, including Alibates agatized dolomite, Tecovas (Quitaque) flint, Edwards Plateau chert, and other materials; (9) obsidian; (10) unformalized hearths, with burned stones abundant and widely scattered; (11) animal bone in highly variable amounts, including bison, occasional cervid or pronghorn, coyote or wolf, and unidentified small rodents [the latter being intrusive] [Wedel 1975:272].

Wedel (1975:273) observed that the upper midden correlated in time with Central Plains Woodland complexes and is in many ways similar to the Lake Creek site, located $175 \mathrm{~km}$ north of Chalk Hollow. Since then, the upper midden has been attributed to the Palo Duro complex by Willey and Hughes (1978b:190) and Jack Hughes (1991:26). Because the investigations have never been adequately reported, it is impossible to fully evaluate the upper midden cultural deposit, but it appears to represent one of the most discrete Palo Duro components yet found. It also is notable because it is the most northerly component that contains no hint of mixing with Woodland occupation materials (i.e., the absence of Woodland cordmarked pottery).

Lintz (1995) conducted a review of all of the field records and radiocarbon data pertaining to the 
Chalk Hollow site in the collections of the Smithsonian Institution. Using tree ring corrections by Stuiver and Reimer (1986), Lintz concluded that the upper midden does represent a fairly discrete component most likely associated with the Palo Duro complex. Five radiocarbon dates from the upper midden (samples SI-1296, 1297, 1289, 1298, and 1704) give a total corrected range of A.D. 404-975, with three dates being tightly clustered with a total range of A.D. 550-680. Lintz determined that 14 arrow points and 13 potsherds are from the upper levels and suggests that there is a strong horizontal and vertical association of arrow points and pottery with the upper midden. Wedel typed the arrow points as 11 Scallorn and 1 each unidentified stemmed, unidentified serrated, and Fresno?, while the pottery was simply called "plain brown wares." No reexamination of artifacts was attempted, but Lintz (1995) notes the possibility that some of the Scallorn points might actually be Deadman's. A complete and thorough reanalysis of the upper midden archeological evidence could provide significant data relating to the Palo Duro complex.

\section{BLUE CLAY SITE (41BI42, AREA I)}

The Blue Clay site, located on a terrace above Tule Creek in Mackenzie Reservoir, was tested (twenty-eight 5-x-5-ft units, or $65 \mathrm{~m}^{2}$ ) in 1973-1974 by Willey et al. (1978b). Artifacts from the site included diagnostic Deadman's and Scallorn points and brownware sherds that were typed by A. H. Warren as Jornada Brown. While one sherd was tempered with sand, the others contained crushed rock (perhaps aplite) from the Sierra BlancaSacramento Mountain area. These same variations were observed in the brownwares from Deadman's Shelter, located less than $1 \mathrm{~km}$ from the Blue Clay site. One unlined and two rock-lined hearths were discovered, but no radiocarbon dates were obtained.

\section{COUNTY LINE SITE (41BI33)}

The 1973-1974 investigations at the County Line site (Willey and Hughes 1978a) revealed a shallowly buried, single-component living surface. The excavations (ca. $70 \mathrm{~m}^{2}$ ) exposed scattered burned rocks and five bowl-shaped, rock-lined hearths. No radiocarbon dates were obtained, but diagnostic projectile points indicate that the occupations were primarily during the Late Prehistoric I period. Twenty-three arrow points included 1 Deadman's-like and 10 Scallorn-like specimens. Three corner-notched dart points could indicate that transitional Archaic occupations are represented, but they were found in the same levels as arrow points. Perhaps dart points were still being used during Late Prehistoric I times, or they may have been scavenged from earlier sites. Willey and Hughes (1978a:136) interpreted the County Line site as a multifunctional "relatively permanent base camp," but pottery was noticeably absent. Cores, knives, scrapers, arrow points, and choppers were found in higher frequencies than at other sites in Mackenzie Reservoir. The artifacts suggest that hunting and processing of animals were important activities, but the faunal assemblage is not particularly informative. The remains of bison, birds, and rodents were among the 18 identifiable elements.

\section{CAT HOLLOW SITE (41GR303B), LOWER ZONE}

Investigations at the Cat Hollow site (see Chapter 6) indicate that the lower zone deposits contain an extensive layer of burned rocks and at least two intrusive baking pit features. The site represents a specialized plant processing locality, with burned rock debris discarded from repeated pit baking episodes between A.D. 73 and 871 (see Table 69). No points or pottery are associated with the lower zone, but two dart points and two Scallorn arrow points were recovered from the surface and upper zone. The Cat Hollow site is assigned to the Palo Duro complex because it is contemporaneous with the early occupations at the Sam Wahl site, located only $700 \mathrm{~m}$ to the east.

\section{GOBBLER CREEK BRIDGE SITE (41GR383)}

Archeological excavations at the Gobbler Creek Bridge site (see Chapter 6) revealed a buried cultural zone dominated by an extensive scatter of burned sandstone and three discrete features. One feature was interpreted as the rock-lined bottom of a baking pit, while the other two were interpreted as large piles of burned rocks that were discarded, presumably from cleaning out baking pits. Three radiocarbon dates on these features indicate that the occupations occurred between A.D. 3 and 989 (see Table 69). No pottery was found, but a Scallorn-like 
arrow point and a dart point fragment were recovered. The variability in the stone tool assemblage was suggestive of a multifunctional campsite, but a high frequency of ground stones (many of which had been recycled as hearthstones) and the massive amount of burned rocks indicated that plant processing was the primary activity. A probable pestle recovered from the excavation may have been used in one of the three bedrock mortars located on the site.

\section{SOUTH SAGE CREEK SITE (41KT33)}

The South Sage Creek site (see Chapter 6) is interpreted as a multifunctional campsite occupied near the end of the Late Prehistoric I period, at around A.D. 901-1187 (see Table 69). While other areas of this large site yielded artifacts that may indicate earlier occupations (i.e., two dart points), the excavation block produced early (i.e., Scallorn) and late (i.e., Harrell) arrow points and Jornada Mogollon pottery. The age of the excavated remains is based on a single radiocarbon date and is somewhat tentative, but the diversity of artifacts is indicative of a multifunctional campsite where plant processing is thought to have been the major subsistence activity. Many of the characteristics observed for the South Sage Creek site (e.g., the nature of the ground stone assemblage and the frequent reuse of ground stone fragments in hearth construction) are quite similar to those observed at the Sam Wahl site. The possibility that the South Sage Creek site represents a residential base is discussed below.

\section{FATHEREE SITE (41GY32), AREA 1}

Minimal testing (three 5-x-5-ft units, or $7 \mathrm{~m}^{2}$ ) and surface collection of Area 1 at the Fatheree site revealed evidence of a probable Palo Duro component (Hughes et al. 1978:125-169). A dark midden zone contained large quantities of burned rocks, bone scraps, and lithic debris indicative of repeated occupations over an extended period of time, along with corner-notched dart points; Scallorn, Deadman's, and Young (probably preforms) arrow points; and Mogollon pottery. "In its range of artifact types, and its variety of animal remains, with little emphasis on bison, Area 1 is remarkably similar to the Deadman's Shelter in Mackenzie Reservoir" (Hughes et al. 1978:167). Further interpretation of Area 1 is limited due to the minimal nature of the investigations.

\section{MAINTENANCE BARN SITE (PPHM-A1543), LOWER COMPONENT}

The Maintenance Barn site, north of the Canadian River in Oldham County, is one of the most northerly sites where a Palo Duro component has been recognized. Minimal testing $\left(28 \mathrm{~m}^{2}\right)$ indicates that it consists of two stratigraphic components that are difficult (if not impossible) to separate. An upper Panhandle aspect (i.e., Antelope Creek phase) component dominates the site, while the lower, earlier, more-ephemeral component is not well defined (Couzzourt 1982). Interpretations are limited because the artifacts cannot be neatly divided into discrete assemblages and no radiocarbon dates have been obtained.

The lower component did contain a few sherds of brownware that are, according to Jack Hedrick (in Couzzourt 1982:112, 132-133), similar to brownware sherds found at the Floydada Country Club site; they are unlike any variations found in the Jornada Mogollon area and may represent locally made Panhandle brownwares. Because the lower component also includes a few diagnostic corner-notched arrow points and preforms, Couzzourt (1982:95) speculated that "the Early NeoIndian occupants were probably representatives of or related to the Palo Duro Culture, although artifactual evidence is lacking for a positive identification." It also was suggested that the lower-zone occupants engaged in the following activities: "hunting, gathering, tool making and repair, hearth construction (unlined basin-shaped pit), food preparation, leatherworking or hide preparation (scrapers only), and limited on-site butchering" (Couzzourt 1982:95). While bison remains are well represented in the upper zone, most of the faunal remains attributed to the lower zone are unidentified bone scraps and bison is not mentioned.

\section{SOUTH RIDGE SITE (PPHM-A1568), EAST END}

The South Ridge site, reported by Etchieson (1979), is located just south of the Canadian River within the Lake Meredith Recreation Area, and it is the northernmost locality that includes a component attributed to the Palo Duro complex. Minimal testing (ca. $80 \mathrm{~m}^{2}$ ) revealed two horizontally separate areas containing two different components. An 
Antelope Creek phase occupation is present in the western end, while the eastern end yielded dart points, Deadman's (but no Scallorn) arrow points, and untyped brownware sherds that compare favorably with Jornada Brown. No features were encountered and no dates were obtained. Etchieson (1979:100) interprets the east end of the site (where $32 \mathrm{~m}^{2}$ of excavations were conducted) as a base camp at which plant processing, hunting, and hideworking were the primary activities.

\section{DUNCAN RANCH SITE 1 (41HC124)}

Surface collections and limited testing at the Duncan Ranch Site 1 in Hutchinson County produced abundant evidence of Plains Woodland and Panhandle aspect occupations (discussed previously under Lake Creek complex). In addition, Gustafson (1994b:130, 184) reports that a Deadman's arrow point was recovered from a test unit and a Mogollon brownware sherd was found on the surface. This evidence suggests the possibility of Palo Duro complex occupations such as encountered at the nearby Fatheree Site (Area 1).

\section{DISCUSSION}

Subsurface investigations at many open campsites have produced definable Palo Duro components with artifact assemblages that are useful for comparative purposes, while investigations at other campsites have yielded only minimal evidence of Palo Duro occupations (Table 70). The level of work at these sites varies from minimal testing with scattered units to comprehensive excavations involving large blocks of contiguous units. The discreteness of the Palo Duro components or occupations and the quality of the data reporting also range from very good to very poor. To illustrate the differences, only five of the campsites meet the following criteria: (1) have discrete Palo Duro components with definable artifact assemblages of over 1,000 specimens; (2) have had more than $30 \mathrm{~m}^{2}$ of hand excavation; and (3) have adequately reported excavation data that are useful for comparative purposes. As discussed later, however, it is clear that the campsites vary considerably in terms of site function and intensity of use/occupation.

One point in regard to open campsite investigations is worth stressing. Most campsites attributed to the Palo Duro complex were investigated before pithouse structures were recognized as an important component of the complex. The existence of residential base villages has only been realized within the last decade, and archeologists were not consciously searching for such evidence prior to this time. Cruse (1992) excavated at the Kent Creek site for quite some time before accidentally discovering the pithouses there, and a substantial mechanical testing effort at the Sam Wahl site was specifically designed to search for buried houses. Since the pithouses at these sites were not detectable on the surface, it is possible that many of the campsites listed in Table 70 are actually residential bases. Sites that have a wide diversity of features and artifact types, brownware ceramics, and large ground stone tool assemblages are particularly suspect.

The South Sage Creek site is an example of a site that is a good candidate for a possible residential base. It is the only other site in the region that has yielded a complete large basin metate, like those found in association with the pithouse and storage pits at the Sam Wahl site. The South Sage Creek site was not recognized as a Palo Duro complex site at the time that the data recovery was planned, however, and without realizing the potential for structural remains, the investigation strategy was quite different from that employed at the Sam Wahl site.

\section{Rockshelters}

Intensive investigations at four rockshelters in the Caprock Canyonlands have produced evidence of occupations by Palo Duro peoples or dating to Palo Duro complex times. One of these, Deadman's Shelter, is the type site for the complex.

\section{DEADMAN'S SHELTER (41SW23, AREA II)}

Deadman's Shelter, located in the canyonlands within $1 \mathrm{~km}$ of the Caprock Escarpment, was excavated during the 1973-1974 investigations at Mackenzie Reservoir (Willey and Hughes 1978b). This small rockshelter, which is the type site for the Deadman's arrow point, contained large quantities of cultural debris throughout the 2-m-thick stratified deposits. Within the $30-\mathrm{m}^{2}$ excavation area, strata were designated as $\mathrm{A}$ through $\mathrm{E}$ from top to bottom, and the majority of the artifacts were confined to two distinct cultural zones-Strata B and D. Cultural features were scattered randomly throughout 
TABLE 70

COMPARISON OF PALO DURO COMPLEX CAMPSITES

\begin{tabular}{|c|c|c|c|c|c|c|c|}
\hline \multirow[b]{2}{*}{ Site/Component } & \multirow{2}{*}{$\begin{array}{l}\text { Area } \\
\text { Excavated } \\
\left(\mathrm{m}^{2}\right)\end{array}$} & \multirow[b]{2}{*}{$\begin{array}{l}\text { No. of } \\
\text { Dates }\end{array}$} & \multirow{2}{*}{$\begin{array}{l}\text { No. of Artifacts } \\
\text { in Palo Duro } \\
\text { Assemblage }\end{array}$} & \multicolumn{2}{|c|}{ Diagnostic Artifacts } & \multicolumn{2}{|c|}{ Assessment of } \\
\hline & & & & Points & $\begin{array}{l}\text { Brownware } \\
\text { Sherds }\end{array}$ & $\begin{array}{l}\text { Palo Duro } \\
\text { Component }\end{array}$ & $\begin{array}{l}\text { Data } \\
\text { Quality }\end{array}$ \\
\hline $\begin{array}{l}\text { Chalk Hollow, } \\
\text { upper midden } \\
\text { Blue Clay } \\
\text { County Line } \\
\text { Cat Hollow } \\
\text { Gobbler Creek Bridge } \\
\text { South Sage Creek } \\
\text { Fatheree, Area 1 } \\
\text { Maintenance Barn } \\
\text { South Ridge, East } \\
\text { Floydada Country Club } \\
\text { Montgomery } \\
\text { Big Spring }\end{array}$ & $\begin{array}{r}11 \\
65 \\
70 \\
27 \\
53 \\
62 \\
7 \\
28 \\
32 \\
108 \\
>20 \\
15\end{array}$ & $\begin{array}{l}6 \\
- \\
- \\
2 \\
3 \\
1 \\
- \\
- \\
- \\
- \\
- \\
-\end{array}$ & $\begin{array}{r}? \\
1,701 \\
1,492 \\
623 \\
2,160 \\
2,052 \\
213 \\
? \\
1,077 \\
? \\
? \\
?\end{array}$ & $\begin{array}{l}\mathrm{x} \\
\mathrm{x} \\
\mathrm{x} \\
\mathrm{x} \\
\mathrm{x} \\
\mathrm{x} \\
\mathrm{x} \\
\mathrm{x} \\
\mathrm{x} \\
\mathrm{x} \\
\mathrm{x} \\
\mathrm{x}\end{array}$ & $\begin{array}{l}x \\
x \\
x \\
x \\
x \\
x \\
x\end{array}$ & $\begin{array}{l}\text { good } \\
\text { good } \\
\text { good } \\
\text { good } \\
\text { good } \\
\text { good } \\
\text { fair } \\
\text { poor } \\
\text { good } \\
\text { poor } \\
\text { poor } \\
\text { unknown }\end{array}$ & $\begin{array}{l}\text { none } \\
\text { good } \\
\text { good } \\
\text { fair } \\
\text { good } \\
\text { good } \\
\text { fair } \\
\text { fair } \\
\text { good } \\
\text { poor } \\
\text { poor } \\
\text { fair }\end{array}$ \\
\hline \multicolumn{4}{|c|}{$\begin{array}{l}\text { Component } \\
\text { good = discrete component } \\
\text { fair = may be discrete component, but investigations are limited } \\
\text { poor = component is mixed or otherwise poorly defined } \\
\text { unknown = possible Palo Duro component cannot be adequately } \\
\text { defined }\end{array}$} & \multicolumn{4}{|c|}{$\begin{array}{l}\text { Data Quality } \\
\text { good = data adequately reported, and sample } \\
\text { size is adequate } \\
\text { fair = data adequately reported, but sample } \\
\text { size is small } \\
\text { poor }=\text { assemblages are not defined/definable } \\
\text { none = no data are reported }\end{array}$} \\
\hline
\end{tabular}

the shelter and include three unlined hearths, five rock-lined hearths, and one human burial (discussed below). Four calibrated radiocarbon dates (excluding one that is considered erroneous) indicate that Stratum B dates to ca. A.D. $432-883$ and Stratum D dates to ca. A.D. 79-383 (see Table 69).

Stratum D apparently represents the transitional Archaic period (discussed earlier in this chapter) and yielded 22 arrow points and 8 dart points, while Stratum B represents a Late Prehistoric zone and produced 14 arrow points and only 1 dart point (which may have been picked up by later people). Twenty-nine ceramic sherds were identified as Jornada Brown by A. H. Warren. A few sherds were sand tempered, while most were tempered with crushed rock (andesite and aplite) from the Sierra Blanca area. The sherds were found in Strata B through $\mathrm{E}$ and apparently date to both occupation periods. Unfortunately, because of severe bioturbation and the inability to define the undated transitional zones (i.e., $\mathrm{B} / \mathrm{C}, \mathrm{C}$, and $\mathrm{C} / \mathrm{D}$ ), no discrete assemblages were separated and the entire assemblage was analyzed as a single unit, representing the period A.D. 79-883 (based on four radiocarbon dates, see Table 69).

A wide range of other artifacts was recovered from Deadman's Shelter, including bifaces, unifaces, choppers, edge-modified flakes, hammerstones, cores and debitage. Ground stones are well represented and include both concave- and flat-faced manos, circular- and oval-basin metate fragments, small ground tablets, pigment stones, and two shaft abraders (or awl sharpeners). Among the faunal remains are modified bones (including awls) and mussel shells that were made into pendants or used as scrapers.

Identification of the unmodified faunal remains (over 3,000 bones) by Schultz and Rawn (1978) provides an impressive list of species. The large number of remains attributed to burrowing rodents and denning carnivores, however, suggests that a significant portion of the assemblage could be 
intrusive. Butchered deer bones $(\mathrm{MNI}=21)$ are common, and deer undoubtedly were utilized as food by humans; most of the bone tools were deer. The only other medium-large mammals in the assemblage are pronghorn $(\mathrm{MNI}=1)$ and bison $(\mathrm{MNI}=1)$.

\section{BOREN SHELTER NO. 2 (41GR559), LOWER SHELTER}

The findings from Boren Shelter No. 2 (see Chapter 6) indicate that the lower shelter deposits represent periodic occupations by small groups for short periods between A.D. 4 and 1146 (based on five radiocarbon dates, see Table 69). The ephemeral features and sparse artifacts (only 28 tools and 88 pieces of debitage) encountered in the ca. $15-\mathrm{m}^{2}$ excavation indicate that this shelter served only as a temporary haven. An Ellis dart point is the only diagnostic artifact from the lower deposits. Activities probably involved the hunting and butchering of animals, but few identifiable faunal remains were recovered. Based on its location, it is speculated that occupations were primarily during the winter and/or periods of inclement weather. The lower shelter occupations are tentatively assigned to the Palo Duro complex based on their age and the corner-notched point.

\section{CANYON CITY CLUB CAVE (PPHM-A251)}

Excavation (estimated at $41 \mathrm{~m}^{2}$ ) of the Canyon City Club Cave, a small rockshelter in Randall County, produced evidence of a possible Palo Duro and/or Woodland component. This work, summarized in a draft manuscript that has never been published (Hughes 1969), included 11 charcoal radiocarbon dates that established the chronology for five excavation levels. Interpretation of the evidence from this site is not without problems. Three of the dates are out of sequence and were thought to be anomalous, and severe bioturbation and mixing of materials is clearly evident in the vertical distributions of artifacts (Hughes 1969:Tables 2 and 4). Level 5 dates to the Late Archaic period but produced very little cultural material. Level 4, with two calibrated dates of A.D. 262-529 and A.D. $672-874$ (see Table 69), has been specifically attributed to the Palo Duro complex (J. Hughes 1991:26). Although five Borger Cordmarked sherds were found in Level 4, Hughes (1969) considers these to be intrusive from the overlying levels (3 and 2) which contained numerous sherds of Borger Cordmarked $(n=139)$ thought to represent occupations of Panhandle aspect peoples. Only two features, a rock-lined hearth and a charcoal lens, were encountered in Level 4. Excluding one erroneous date, a single calibrated charcoal radiocarbon date of A.D. 666-866 (see Table 69) indicates that some of the cultural materials in Level 3 also may be contemporaneous with the Palo Duro occupations.

The evidence for a Palo Duro occupation consists of one corner-notched Scallorn and two "long-barbed" (later typed as Deadman's) arrow points found in Level 4 and a single sherd of Mogollon brownware found in an undated dump area outside the shelter (Hughes 1969:Tables 2 and 4). The four corner-notched dart points found in Level 4 are not necessarily out of place, as discussed earlier in this chapter. Level 4 does not constitute a definable component, however, and the 44 artifacts from this level include later materials that clearly represent mixing. Besides the five Borger Cordmarked sherds, four arrow points (one Fresno, one Perdiz-like, and two Washita) and a beveled knife probably go with the Panhandle aspect occupation. If the ratio of eight early points (dart points and early arrow points) to four late points is used as an indicator of the amount of mixing, then as much as one-third of the Level 4 artifacts may be intrusive. If roughly 33 percent of the materials is factored out, then the artifact density in Level 4 is very low (only 29 artifacts excluding debitage).

In contrast to the sparse artifacts, Level 4 had the highest density of faunal remains (1,884 elements representing 65 species), which are analyzed and reported by Duffield (1970) and summarized by Hughes (1969:120-139). The faunal assemblage (Hughes 1969:Tables 7 and 8) indicates that hunting was an important activity, but no single species seems to have been favored. The largest percentage (60.8 percent) of remains are of small animals that are found in close proximity to the site and in riverine environments (cottontails, jackrabbits, muskrats, prairie dogs, various rodents, skunks, dogs, coyotes, foxes, raccoons, badgers, frogs, catfish, and drum). Larger animals included deer, antelope, and bison. Some faunal remains (i.e., juvenile deer and bison, migratory ducks) are interpreted as evidence that some Level 4 occupations occurred between spring and fall. Because of the mixing of strata, though, there will always be considerable doubt 
about the associations between artifacts and faunal remains in Level 4.

\section{BLUE SPRING SHELTER (PPHM-A485)}

Hughes (1978:41-44, 1991:26) mentions that the Blue Spring Shelter, in Randall County along the north canyon rim just above Palo Duro Canyon State Park, contains stratified deposits that include a Palo Duro component with occupations dating to A.D. 815-1110 (uncorrected and uncalibrated, see Table 63). The investigations are not reported, however, and the component cannot be evaluated. Faunal remains from the shelter were analyzed and are reported by Duffield (1970).

\section{DISCUSSION}

The archeological evidence indicates that these canyonland rockshelters were used in different ways by Palo Duro peoples (Table 71). Occupations at Boren Shelter No. 2 (lower shelter) were brief and periodic, generating little cultural debris (only 28 artifacts excluding debitage). Occupations at the Canyon City Club Cave also appear to have been brief and generated few artifacts (44 excluding debitage), but the greater number of points and bones indicates that hunting was a primary activity.
In contrast, a higher frequency of artifacts (643 excluding debitage) indicates that occupations at Deadman's Shelter were much more intensive (i.e., of longer duration and more frequent). While hunting is well represented (i.e., points account for 15 percent of all artifacts), the number of manos and metates is high (17 percent of all artifacts). In addition, the total artifact assemblage from Deadman's is quite variable and denotes a wide range of activities. Consequently, the occupations at Deadman's Shelter were more like those at multifunctional campsites or residential bases than those at the other rockshelters.

Hughes and Willey (1978:272) state that four occupied rockshelters at Mackenzie Reservoir and others elsewhere along the Caprock Escarpment may have been utilized at different times of the year, but they suggest that some seasonal inferences may be made (based mainly on observations by Jack Hughes and Bill Harrison). South-facing shelters along north canyon rims would have been comfortably warm in the winter, being sheltered from the north wind and exposed to sunshine all day, but they would have been unbearably hot during the summer. In contrast, north-facing shelters along south canyon rims would have been too cold in the winter, but the southerly breeze and shade would have been quite comfortable in the summertime. These same observations were

\begin{tabular}{|l|c|c|c|}
\hline \multicolumn{4}{|c|}{ COMPARISON OF PALO DURO COMPLEX ROCKSHELTERS } \\
\hline Attributes & $\begin{array}{c}\text { Deadman's Shelter } \\
\text { (all strata) }\end{array}$ & $\begin{array}{c}\text { Canyon City Club Cave } \\
\text { (Level 4) }\end{array}$ & $\begin{array}{c}\text { Boren Shelter No. 2 } \\
\text { (Lower Shelter) }\end{array}$ \\
\hline Shelter size $\left(\mathrm{m}^{2}\right)$ & $35-50^{*}$ & 16.7 & $<30$ \\
\hline $\begin{array}{l}\text { Area excavated }\left(\mathrm{m}^{2}\right) \text {, including areas } \\
\text { outside shelter }\end{array}$ & 30 & 41.8 & 15 \\
\hline No. of artifacts (excluding debitage) & 630 & 44 & 28 \\
\hline $\begin{array}{l}\text { No. of pieces of debitage } \\
\text { No. of faunal elements }\end{array}$ & 3,720 & 1,844 & 482 \\
\hline $\begin{array}{l}\text { No. of points/manos and metates } \\
\text { The size of the shelter is estimated because dimensions are not given and the shelter was not completely } \\
\text { excavated. }\end{array}$ & $96 / 108$ & $13 / 4$ & $1 / 0$ \\
\hline \begin{tabular}{l} 
Note: See Table 66 for references to site investigations. Blue Spring Shelter is excluded from this table \\
\hline
\end{tabular}
\end{tabular}


made by archeologists working at the south-facing Boren Shelter No. 2 during the fall of 1992.

\section{Burials}

\section{DEADMAN'S SHELTER}

The burial of an adult male, lying on his stomach in an almost extended position with legs semiflexed in an oval pit inside Deadman's Shelter, is described by Willey and Hughes (1978b:154, 190). The skeleton was accompanied by a complete terrapin (mud turtle) shell on one side of the pelvis, nine modified deer bones (an awl, an ulna, an antler tool, and six neatly-stacked metapodial halves representing three complete metapodials) on the other side of the pelvis, and two unmodified mussel shells beneath the lower right leg (a modified antler fragment also is mentioned as having come from the burial, but its context is not stated). Based on the placement of these specimens, they appear to represent items placed into the grave as offerings (rather than having been worn as clothing, for example).

The burial may have occurred during or near the end of Stratum D times, radiocarbon dated to A.D. 79-383 (see Table 69). Based on similarities in cranial measurements, Willey (1978) indicated that the Deadman's cranium was most similar to skeletal populations at Pecos Pueblo and to the Middle Woodland and Kansas Hopewell populations. He tentatively suggested a possible genetic affiliation representing a mixture of Southwestern and Woodland traits.

\section{KENT CREEK SITE}

The burial of an adult female, tightly flexed in a circular pit in the floor of Structure 1, contained four modified deer bones (one awl and three split metapodial halves, possibly awl blanks) and three mussel shells. One of the mussel valves has a serrated edge and may have been a scraper, while the other two had holes drilled in them and were found in the neck/chest area, indicating that they probably were worn as pendants. No definitive functions for the modified deer bones may be inferred from their placement; one split metapodial was found over the skull, the awl and one split metapodial were found in the chest area, and the third split metapodial was found in the abdominal area. Perhaps these bones were used as fasteners to pin together the edges of a perishable wrapping (e.g., a blanket or hide robe) around the body. It also is possible that some of the bones in the upper torso may have been part of a necklace (along with the mussel shell pendants). Alternatively, the bones and at least one of the mussel valves may have been placed into the grave as separate offerings.

The tip of an arrow point was found beneath the left clavicle, and since the body was lying on the bottom of the pit, Cruse (1992:55) speculated that an arrow wound may have been the cause of death. Osteological analysis of the skeletal remains is reported by Miller (1992), but no unusual anomalies were noted. Since the pit was dug into the floor and the gravelly fill was piled up above the level of the floor, the pithouse probably was abandoned immediately after the interment. Thus, a radiocarbon date on charcoal from the floor of Structure 1 places the approximate age of the interment at A.D. 665-977 (see Table 69).

\section{JIM ARNOLD SITE}

The Jim Arnold site in Hall County consists of a ca. 2-ft-thick cultural zone exposed as the capping layer in a gravel pit excavation. Two separate but closely spaced burial pits were observed in the profile and subsequently investigated by Tunnell (1964). Both burials had been disturbed by gravel pit operations and subsequent slumping of the edges of the gravel pit walls. Hence, the skeletal materials and artifacts recovered are incomplete, but sufficient information was salvaged to indicate the nature of the graves. Burial 1, a young adult female, had been dislodged from the burial pit, but four modified deer bones (two awls and two awl fragments) were found with the redeposited skeletal remains immediately below the burial pit.

Burial 2, an adult male, was partially intact and had been in a semiflexed position inside an oval pit. Associated artifacts consisted of six modified deer bones (three awls and three split metapodial halves), three mussel shell valves (two unmodified and one with $\mathrm{V}$-notches along one edge), and a bifacial chert knife. All of these specimens were found in situ, clustered along one edge of the pit near the skull. Their context indicates that they were placed in the grave as offerings.

The graves, located within $1 \mathrm{~m}$ of each other, were similar. Both were primary interments in shallow oval pits, in identical stratigraphic contexts 
with identical pit fill, and contained modified deer bones. Tunnell (1964) noted that the burial pits were intrusive into the sterile gravel layer from somewhere in or near the bottom of the overlying cultural zone. No investigation of the cultural zone was made, but flint artifacts and bison bones were noted, and dart points were found on the surface. Tunnell (1964) could not determine their age and cultural affiliation, but subsequent researchers (J. Hughes 1991; Miller 1992; Willey and Hughes 1978b:190) have indicated that the Jim Arnold burials are probably associated with the Palo Duro complex. The burial site is located less than $2 \mathrm{~km}$ from the Kent Creek site. Lacking a radiocarbon date or any temporally diagnostic artifacts, assignment to the Palo Duro complex is based only on similarities in mortuary offerings.

\section{DISCUSSION}

The four burials described above exhibit many similar mortuary characteristics. All are primary burials containing modified deer bones as grave offerings. Three contained a combination of deer bone awls, split deer metapodials (awl preforms), and unmodified mussel shells. The burials differ in pit shape (round to oval) and in skeletal placement within the pits (nearly extended to tightly flexed). Differences in their intrasite contexts-one in a house, two in an open campsite, and one in a rockshelter-may account for some of this variability.

These four burials demonstrate that there is some degree of consistency in Palo Duro mortuary traits, and both males and females (two of each sex) seem to have been buried with similar grave offerings. The two closely spaced burials at the Jim Arnold site suggest that Palo Duro peoples may have buried their dead in cemeteries, as well as in rockshelters and in pithouses. However, this conclusion must be considered tentative because of the small size of the burial sample and the lack of radiocarbon dates associated with the Jim Arnold burials. It is possible that there may be more variability in Palo Duro mortuary practices than the current evidence indicates.

Two other burial sites in the region contain remains that may represent Palo Duro peoples. Two individuals buried in a single cairn-covered pit in Donley County were excavated in 1938 (Witte 1955). Both were buried in flexed positions, but one was reported to have been placed "head downward" on top of a "carefully prepared sitting burial" (Witte 1955:85). The skeletons represent adults (sex not determined) that had apparently been killed. Two arrow points were found among the ribs and left scapula of the first individual, and five arrow points were found in the torso and pelvic areas of the second person. The points, several of which have impact breaks, are quite similar to Deadman's points in that they have corner to basal notches and long prominent barbs (see Witte 1955:Plate 13), but the burial specimens are generally larger (i.e., longer and wider with slightly broader expanding stems) and have serrated blades. No grave offerings were present, but the points indicate that the burial dates to the Late Prehistoric I period. Although its precise location is not stated, the Double Burial site is located between 50 and $100 \mathrm{~km}$ north of the Kent Creek site.

The Double Burial is undated, but the associated points indicate that it is probably contemporaneous with, and perhaps related to, the Palo Duro complex. This was suggested by Willey and Hughes (1978b:190) based primarily on the similarities of the burial points to the Deadman's arrow point style. This interpretation is plausible, but the fact that these two individuals were probably killed by arrows tipped with Deadman's-like points suggests that these individuals may have been killed by people of the Palo Duro complex rather than belonging to the Palo Duro complex; this possibility also has been noted by Lintz (1986:225). Another "sitting" burial, this one excavated at one of the Alexander Mounds in Jones County and attributed to the Blow Out Mountain complex, also has probable evidence of violence in that the person's mandible was missing (Ray 1933:22).

The only other burial that might be associated with the Palo Duro complex is one found at the Sam Wahl site (see Chapter 6). It is a single, cairncovered human interment radiocarbon dated to A.D. 256-415. The human skeletal materials were found in an oval pit and are interpreted as a secondary (i.e., bundle) burial of a middle-aged male. The bones were extremely fragmented and jumbled, and their context in a tight cluster in one portion of the pit suggested that they might have been confined inside an organic container such as a basket or a hide bag. The only grave inclusions were a ground and faceted piece of hematite (i.e., paint stone) and a 6-cm-long Scallorn arrow point. The latter was 
found in a context suggesting that an arrow had been laid over the bone cluster.

Since the Sam Wahl site burial dates to the transitional Archaic period and predates the earliest known occupations at the site, it is possible that the burial is not associated with the Palo Duro complex at all. This interpretation is supported by the fact that the Sam Wahl burial is quite different from the three Palo Duro burials described above, none of which are secondary cairn burials. An alternative interpretation is that the burial is affiliated with the early Palo Duro complex. This is supported by three lines of circumstantial evidence: (1) the burial may be contemporaneous with the Palo Duro complex burial at Deadman's Shelter; (2) the associated Scallorn arrow point, although unusually large, would not be stylistically out of place in the Palo Duro complex; and (3) the burial was found at a pithouse village of the Palo Duro complex, although it apparently predates the village. Based on the current evidence, however, the cultural affiliation of the burial from the Sam Wahl site is debatable, and the possibility that it represents a burial of a transitional Archaic or even a Plains Woodland (i.e., Lake Creek) individual cannot be discounted.

\section{Redefinition of the Palo Duro Complex ${ }^{8}$}

\section{Chronology}

Many Palo Duro complex components have been radiocarbon dated (Figure 89). Occupations that are attributed to the complex may have begun during transitional Archaic times (ca. A.D. 0-500), and they are definitely recognizable by at least A.D. 500. Palo Duro occupations apparently continued until around A.D. 1100, but they seem to have disappeared suddenly. Thus, the Palo Duro complex is contemporaneous with the Plains Woodland occupations in the northern Texas Panhandle (i.e., the Lake Creek complex) and western Oklahoma, the Blow Out Mountain complex of west-central Texas, and the pithouse phases of the Jornada Mogollon and Middle Pecos areas.

${ }^{8}$ An earlier version of this section was published in the Bulletin of the Texas Archeological Society (Boyd 1995).

\section{Subsistence and Site Function}

\section{MATERIAL CULTURE}

A comparison of artifacts recovered from residential base camps, rockshelters, and campsites indicates that there are some significant similarities and differences between and among these site types. The data presented in Tables 72 and 73 show that Palo Duro material culture is extremely diverse overall but that there are some sites, presumably where limited or special activities occurred, where diversity is low. The data may be compared using an artifact diversity index (the number of artifact categories represented out of 18 possible categories, excluding the dart point and other categories) as a rough representation of variability in activities. Not surprisingly, the residential bases have the greatest diversity with $14-17$ of the 18 categories represented. Deadman's Shelter also has a high diversity with 16 categories represented, while all of the campsites exhibit moderate artifact diversities with between 11 and 14 categories represented. Boren Shelter No. 2 has the lowest diversity with only 9 of the 18 categories represented.

Two other calculations presented in Table 73 are useful for comparing and contrasting these components. One is the total artifact density, calculated as the number of artifacts per $\mathrm{m}^{2}$ of excavation, and the other is the adjusted artifact density, calculated as the number of artifacts (excluding unmodified debitage) per $\mathrm{m}^{2}$ of excavation. These artifact densities are considered to be crude measures of the relative intensity and/or duration of occupation.

The Kent Creek site and Deadman's Shelter have much higher total artifact densities than any of the other sites. As discussed below, this may be due to differences in site function or the total duration and intensity of the occupations, but one other factor also plays a role in the unusually high artifact density at Kent Creek. The Kent Creek site has a significantly higher percentage of unmodified debitage (accounting for 97 percent of all artifacts recovered) than Deadman's Shelter (where debitage represents 86 percent of all artifacts) or any of the other sites (debitage represents 76-91 percent of all artifacts). Tecovas jasper, which is found in the stream terrace gravels exposed on-site, makes up 


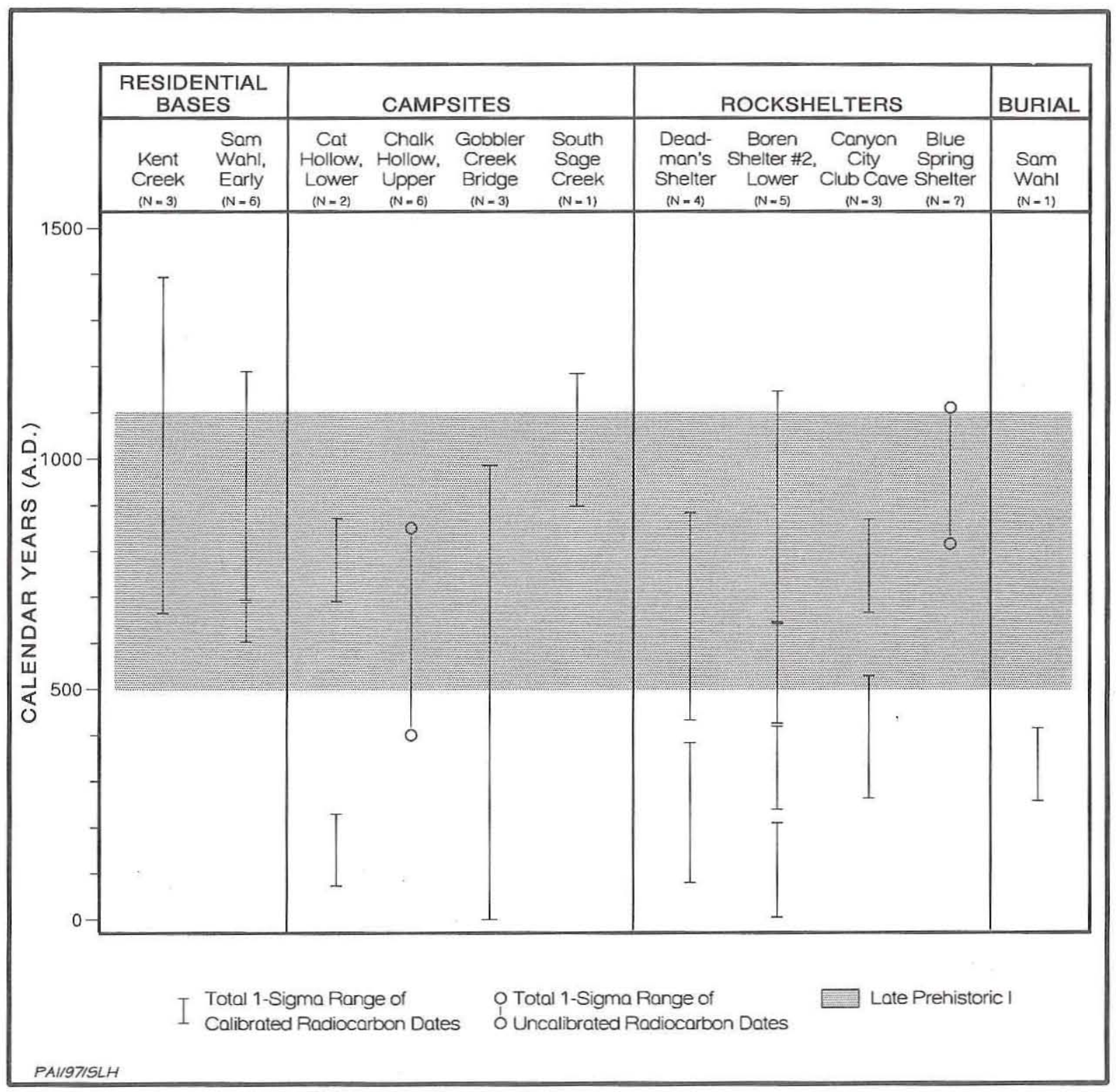

Figure 89. Graph of radiocarbon dates for Palo Duro complex components (using data from Table 69).

over 90 percent of all the stone artifacts at Kent Creek, and most of the corticate debitage represents stream-worn gravels (Cruse 1992:Table 2, 72). Because the Kent Creek occupants were sitting on a substantial chert source area, it is not surprising that they generated a higher percentage of waste lithic debris than people in areas located much farther from good-quality lithic sources.

The immediate availability of lithic material is only a partial explanation, however. When the adjusted artifact densities (which factor out debitage) are compared, Kent Creek falls to second place but still appears to have been used more intensively than most of the other sites. The adjusted artifact density indicates that the most intensively occupied site is Deadman's Shelter. The radiocarbon dates suggest that this may be due in part to the long duration of repeated occupations there (perhaps as much as 500-800 years, see Figure 89 ). The spatial confinement of activities within the rockshelter probably also played a role in that refuse discarded or lost inside would be much more concentrated.

Radiocarbon dates indicate that the residential base at Kent Creek was occupied for at least 


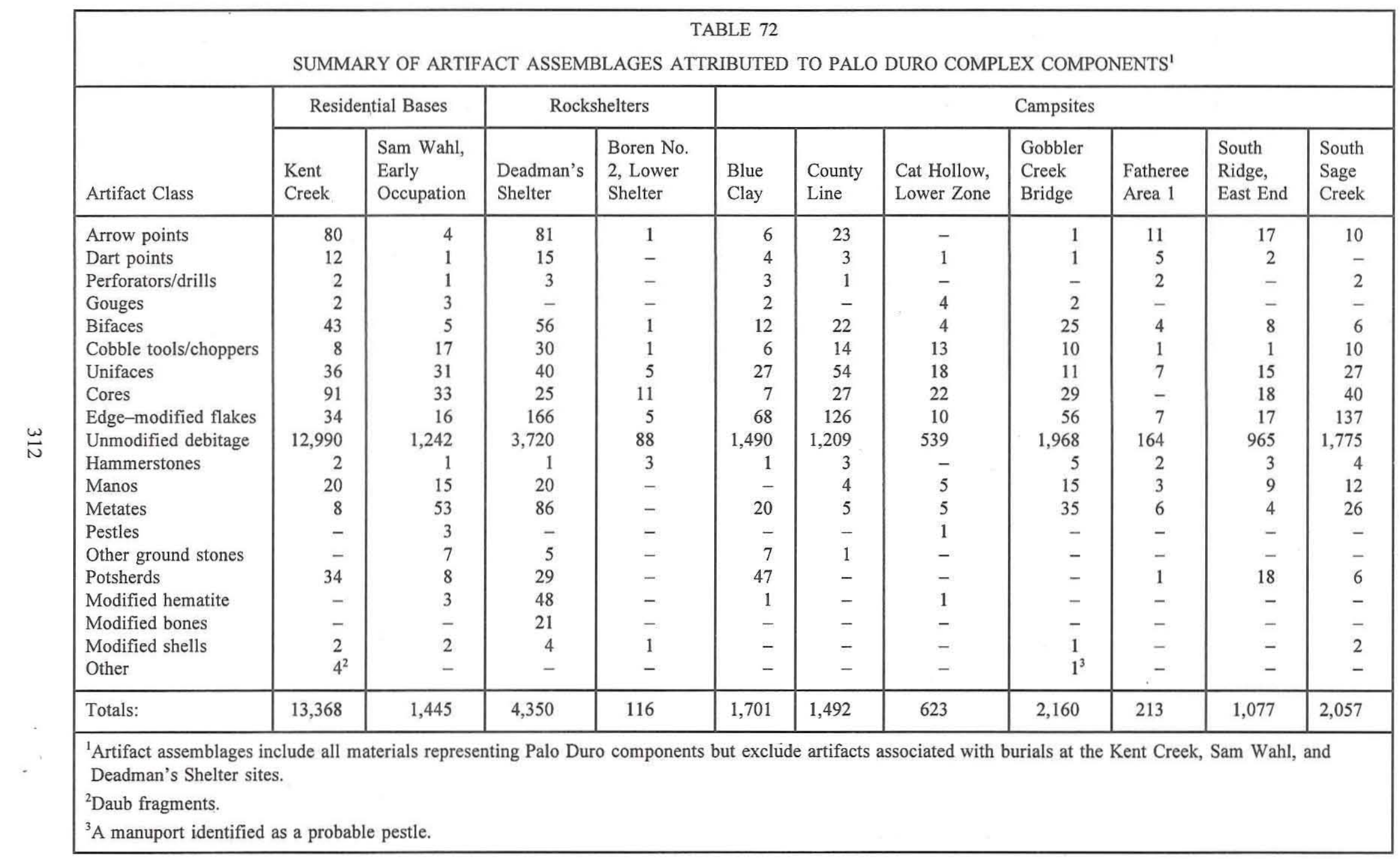




\begin{tabular}{|c|c|c|c|c|c|c|c|c|c|c|c|}
\hline \multicolumn{12}{|c|}{$\begin{array}{c}\text { TABLE } 73 \\
\text { COMPARISON OF ARTIFACT ASSEMBLAGES ATTRIBUTED TO PALO DURO COMPLEX COMPONENTS }\end{array}$} \\
\hline & \multicolumn{2}{|c|}{ Residential Bases } & \multicolumn{2}{|c|}{ Rockshelters } & \multicolumn{7}{|c|}{ Campsites } \\
\hline : & $\begin{array}{l}\text { Kent } \\
\text { Creek }\end{array}$ & $\begin{array}{l}\text { Sam Wahl, } \\
\text { Early } \\
\text { Occupation }\end{array}$ & $\begin{array}{l}\text { Deadman's } \\
\text { Shelter }\end{array}$ & $\begin{array}{l}\text { Boren \#2, } \\
\text { Lower } \\
\text { Shelter }\end{array}$ & $\begin{array}{l}\text { Blue } \\
\text { Clay }\end{array}$ & $\begin{array}{l}\text { County } \\
\text { Line }\end{array}$ & $\begin{array}{l}\text { Cat Hollow, } \\
\text { Lower Zone }\end{array}$ & $\begin{array}{l}\text { Gobbler } \\
\text { Creek } \\
\text { Bridge }\end{array}$ & $\begin{array}{l}\text { Fatheree } \\
\text { Area } 1\end{array}$ & $\begin{array}{l}\text { South } \\
\text { Ridge, } \\
\text { East End }\end{array}$ & $\begin{array}{l}\text { South } \\
\text { Sage } \\
\text { Creek }\end{array}$ \\
\hline Total Artifacts & 13,368 & 1,445 & 4,350 & 116 & 1,701 & 1,492 & 623 & 2,160 & $194^{1}$ & 1,077 & 2,057 \\
\hline $\begin{array}{l}\text { Total Artifacts } \\
\text { (excluding debitage) }\end{array}$ & 378 & 203 & 630 & 28 & 211 & 283 & 84 & 192 & $30^{1}$ & 112 & 282 \\
\hline Area Excavated $\left(\mathrm{m}^{2}\right)$ & 62 & 94 & 30 & 15 & 65 & 70 & 27 & 53 & 7 & 32 & 62 \\
\hline Activity Diversity Index ${ }^{2}$ & 14 & 17 & 16 & 9 & 14 & 12 & 11 & 12 & 11 & 11 & 13 \\
\hline Total Artifact Density ${ }^{3}$ & 215.6 & 15.4 & 145.0 & 7.7 & 26.2 & 21.3 & 23.1 & 40.8 & 27.7 & 33.7 & 33.1 \\
\hline Adjusted Artifact Density ${ }^{4}$ & 6.1 & 2.2 & 21.0 & 1.9 & 3.3 & 4.0 & 3.1 & 3.6 & 4.3 & 3.5 & 4.5 \\
\hline $\begin{array}{l}\text { Projectile Point/Grinding } \\
\text { Tool Index }\end{array}$ & 3.3 & $<0.1$ & 0.9 & $<0.1^{6}$ & 0.5 & 2.9 & $<0.1$ & $<0.1$ & $1.8^{6}$ & 1.5 & 0.3 \\
\hline $\begin{array}{l}\text { 'Excludes } 19 \text { surface specin } \\
{ }^{2} \mathrm{Number} \text { of artifact categori } \\
{ }^{3} \mathrm{Number} \text { of artifacts } / \mathrm{m}^{2} \text {. } \\
{ }^{4} \mathrm{Number} \text { of nondebitage art } \\
{ }^{5} \mathrm{Number} \text { of arrow points } / \mathrm{nu} \\
{ }^{6} \text { Validity of index is questic }\end{array}$ & $\begin{array}{l}\text { ens. } \\
\text { es. } \\
\text { facts } / \mathrm{m}^{2} \text {. } \\
\text { mber of } \mathrm{m} \\
\text { nable due }\end{array}$ & $\begin{array}{l}\text { nos, metates, } \\
\text { o small samp }\end{array}$ & $\begin{array}{l}\text { nd pestles. } \\
\text { size. }\end{array}$ & & . & & & & & & \\
\hline
\end{tabular}


$200-400$ years and perhaps as long as $400-700$ years. The least intensively used site (except for Boren Shelter No. 2) is Sam Wahl. Its radiocarbon dates indicate that it was occupied repeatedly for a long time, perhaps as much as 450 years (see Figure 89). Thus, one must suspect that the differences in the artifact densities at these two sites are related primarily to site function rather than the duration of the occupations.

Another calculation useful for identifying site function is the projectile point-grinding tool index (see Table 73), calculated as the number of projectile points divided by the number of grinding tools (manos, metates, and pestles only). This is a crude measure of the relative importance of hunting vs. plant processing. When the adjusted artifact densities are compared with the point/grinding tool indexes, the components display considerable variability that may be attributed to differential site function and use intensity (Figure 90).

Somewhat surprisingly, the Kent Creek site has the highest representation of hunting activities, while the Sam Wahl site is at the opposite end of the spectrum. This difference is interpreted as evidence that these two residential bases functioned differently. While the diversity of artifacts indicates that both sites were multifunctional, the data presented in Figure 90, along with other evidence discussed

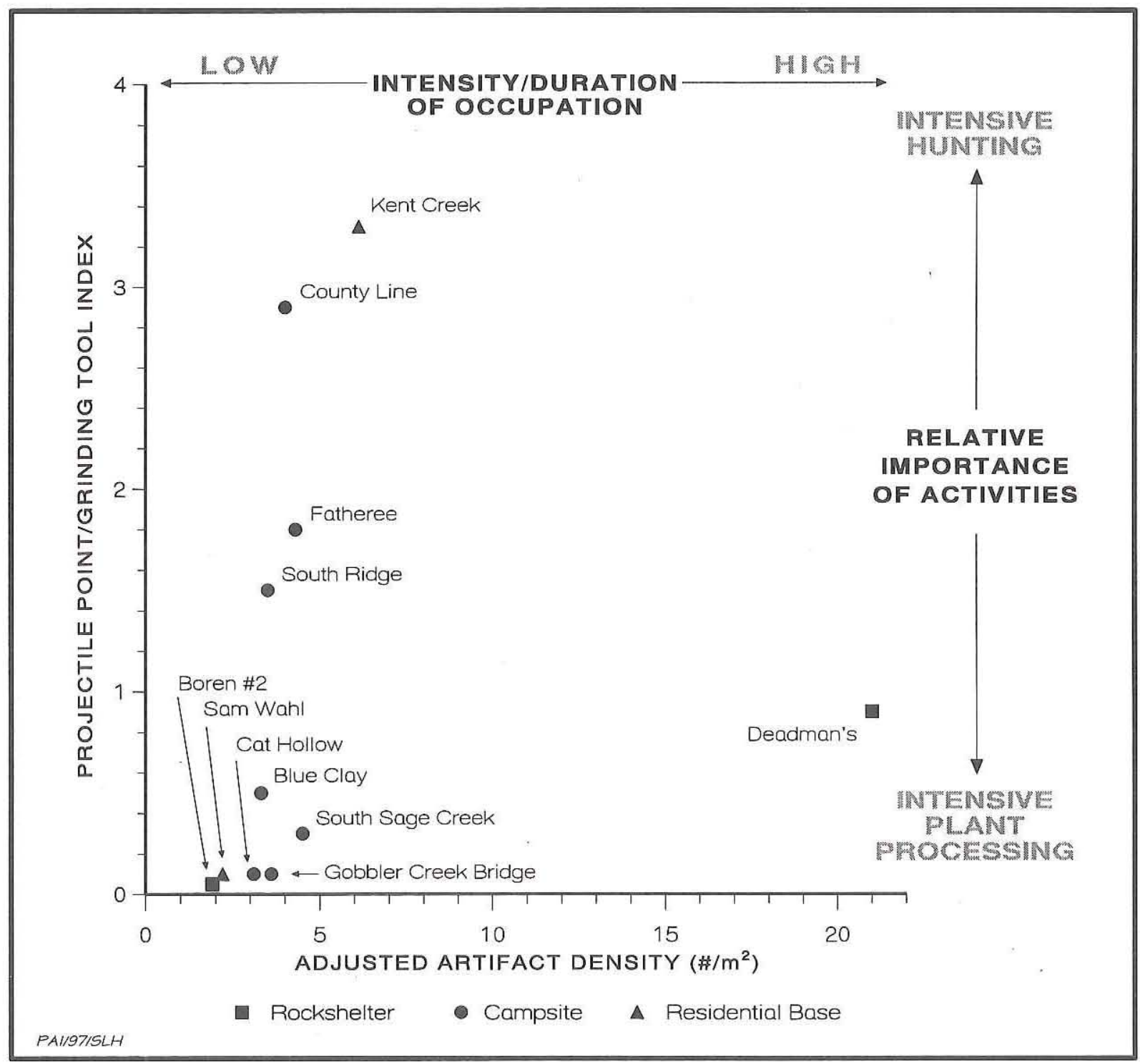

Figure 90. Comparison of artifact density and projectile point/grinding tool indexes for Palo Duro components. 
below, support the interpretation that the Sam Wahl site was a specialized residential base. The primary activities there were related to the processing, storage, and utilization of plant foods. The low artifact density at Sam Wahl is explained by the fact that these activities would have generated much less residue, particularly chipped stone, than would hunting activities.

All of the campsites exhibit similar artifact densities, but they vary considerably in terms of site function. While hunting activities are fairly well represented at the County Line, Fatheree, and South Ridge sites, plant processing was very much the dominant activity at the Blue Clay, South Sage Creek, Gobbler Creek Bridge, and Cat Hollow sites. In this regard, the latter sites are more like the Sam Wahl site than they are the other campsites.

The chipped stone tool assemblages (see Table 73) can be characterized as being rather homogeneous, but the relative frequencies of various artifact groups vary considerably from site to site. When only the chipped stone tools (i.e., projectile points, drills, gouges, bifaces, cobble tools, unifaces, and edge-modified flakes) are considered and sites with samples of less than 50 specimens are excluded, some interesting patterns emerge. Unifaces and edge-modified flakes are the most common tools, and they respectively constitute $10-40$ percent and $20-53$ percent of all chipped stone tools. These categories cannot be attributed to specific functions, and they occur in high frequencies both in sites where activities were mainly hunting oriented and in sites were plant processing was the dominant activity. Projectile points, bifaces, and cobble tools are generally less common but are quite variable from site to site, making up 2-43 percent, 3--24 percent, and 2-26 percent of the collections. Cobble tools tend to be much better represented at plant processing sites. It has been suggested that these tools may have been used to refurbish grinding stones (Boyd et al. 1994:78-79, 145). Two classes-drills and gouges - are generally rare, constituting $0-5$ percent and $0-8$ percent of chipped stone tools.

Most of the gouges are Clear Fork type unifaces (Turner and Hester 1993:246-249), and they usually have some evidence of haft wear. There is a tendency, albeit weak, for these tools to be better represented at sites where intensive plant processing occurred. If gouges were used for woodworking, as has been suggested for South Texas (Hester et al. 1973), then it is possible that they were used as adzes for making and maintaining digging sticks or other wooden tools. Alternatively, gouges could have been used to tip the ends of multipurpose scraping/planing tools or digging sticks (Ray 1941: 161-162). Clear Fork gouges have been found in sufficient frequencies and at enough Palo Duro complex sites to dispel the popular notion that they are diagnostic Archaic tools in the Panhandle Plains (e.g., Bagot and Hughes 1979:50; Etchieson et al. 1977:33, 35, 1978:83, 1979:353; D. Hughes 1984: 116; J. Hughes 1991:19).

Dart points are present at some sites, and despite the possibility that there could be earlier components in some cases, there is growing evidence for contemporaneous use of dart and arrow points between ca. A.D. 200 and 500 (see Chapter 9). The arrow points are early corner-notched and stemmed forms that are usually typed as Scallorn and Deadman's, respectively. However, the arrow point assemblages also are characterized by a great deal of variability, and specimens that can be considered classic Scallorn or Deadman's forms are rare. One need only look at arrow point forms from the Sam Wahl, Kent Creek, and Deadman's Shelter sites to see the diversity in gross morphology (Figures 91-93). Points typed as Deadman's generally have the diagnostic long slender barbs and long straight or bulbous stems, but other variations include specimens with shorter, often reworked, barbs and wider, Scallorn-like expanding stems. Most of the points typed as Scallorn do not fit the classic wide-stemmed form illustrated by Turner and Hester (1993: 230) but conform more closely to the coryell and eddy varieties illustrated by Jelks (1962:Figure 13). The Scallorn and Scallorn-like specimens from Palo Duro sites often appear to be nothing more than reworked Deadman's points with the barbs shortened or removed altogether.

Ground stone tools are well represented at some Palo Duro sites, but the assemblage from Sam Wahl is unusual in comparison with those from the other sites. Three sets of grinding tools are represented at the Sam Wahl site. One set consists of the thin oval slab pestles used with pointed-oval bedrock mortars. These may be tools for grinding mesquite beans, as has been suggested for mortars (bedrock and portable) and pestles throughout the southwestern United States (Bell and Castetter 1937). The abundance of pestles at Mesilla phase sites in the Tularosa Basin is considered to be evidence of extensive mesquite processing (Carmichael 1986: 


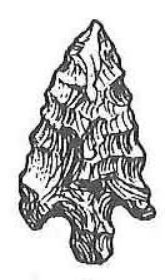

a
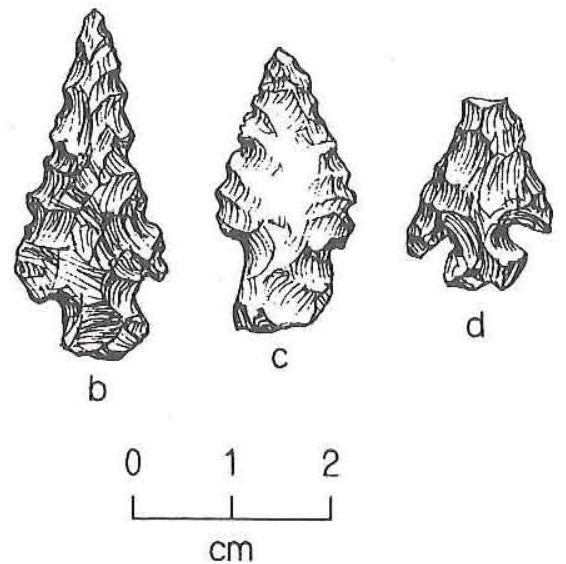

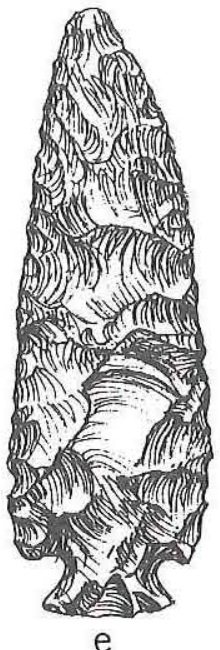

e
Figure 91. Early arrow points from the Sam Wahl site. (a) Bonham; $(b-e)$ Scallorn. A barb fragment typed as Deadman's is not illustrated. Specimen $e$ is associated with the cairn burial.

220). It is possible that bedrock mortars, which are common in the Caprock Canyonlands, may have been used in a similar fashion.

The second set of grinding tools consists of flat-faced manos, usually sandstone, used with flatslab metates. The third set consists of convex-faced manos, usually quartzite, used with oval-basin metates. The latter set is the best represented of the three grinding tool kits at the Sam Wahl site. Caching (or storing) of complete large oval-basin metates may indicate that this grinding tool kit was the most important in terms of the materials processed at Sam Wahl.

Although less abundant, grinding tools from the Kent Creek site exhibit roughly the same morphological variability as those from Sam Wahl. At Kent Creek, no complete metates were found, but the fragments represent both slab and basin types (including one fragment of a thick slab with a deeply worn concavity). The manos are either oval in shape with flat or convex faces or they are rectangular in shape with flat faces. Two of the rectangular manos have beveled faces.

When the ground stone assemblages from the residential bases are compared by material type and completeness, an interesting pattern emerges (Table 74). Metate fragments heavily dominate the assemblage at Sam Wahl, but they are only moderately abundant at Kent Creek. In addition, most of the

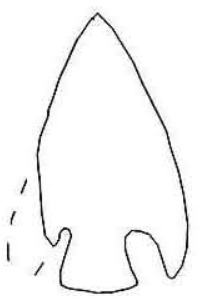

a

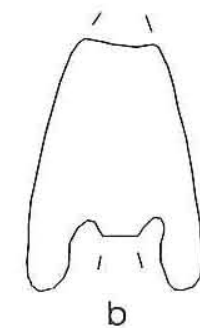

b

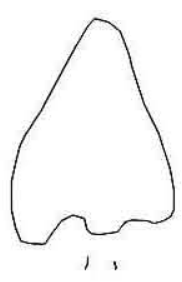

C

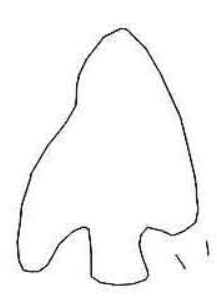

d

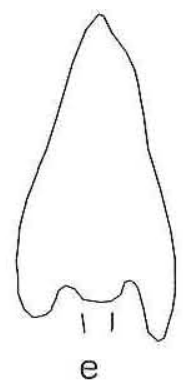

e

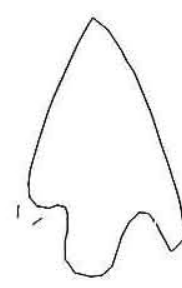

$f$

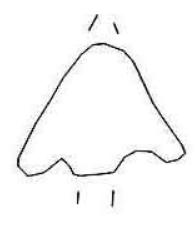

g

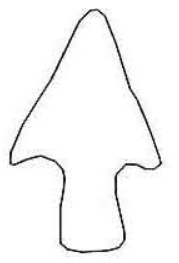

h

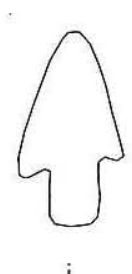

i
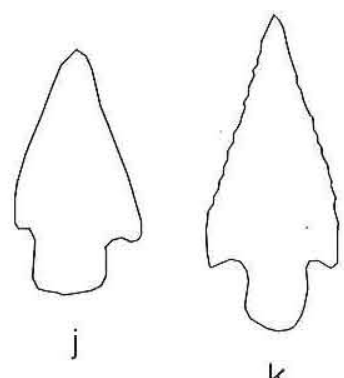

k

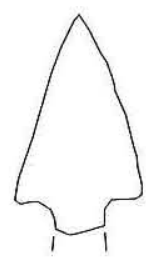

।

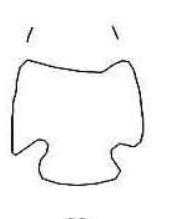

m

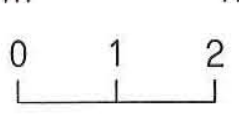

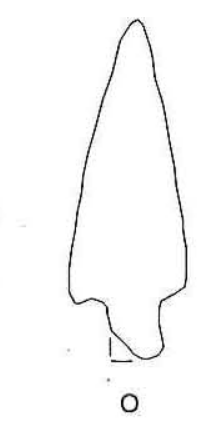

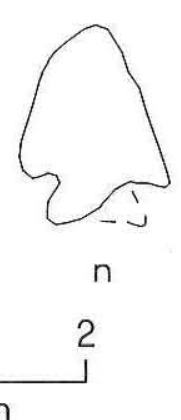

$\mathrm{cm}$

Figure 92. Scallorn and Deadman's arrow points from the Kent Creek site. $(a-g)$ Deadman's; $(h-o)$ Scallorn. Drawn from selected specimens illustrated in Cruse (1992:Figure 18). 


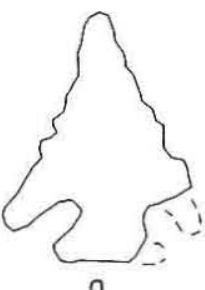

a
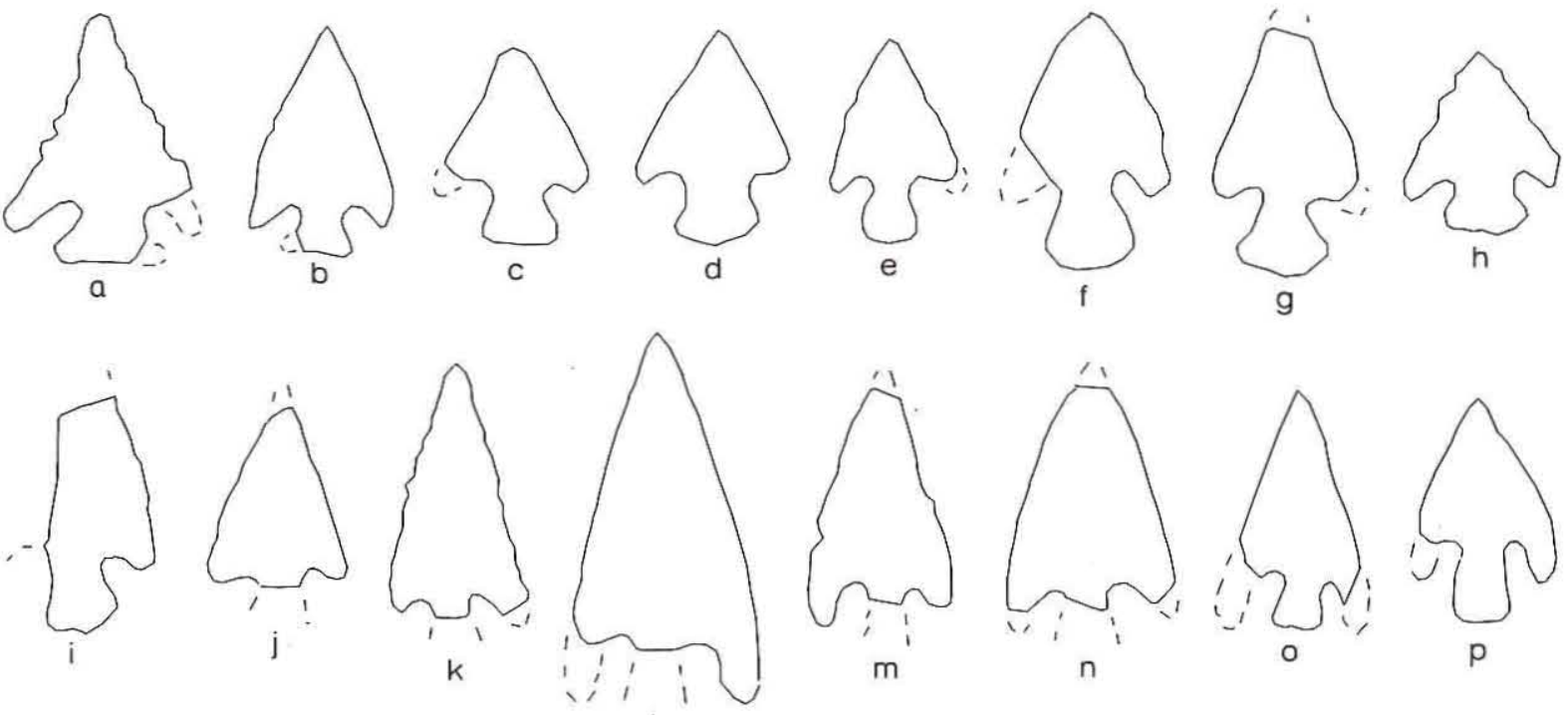

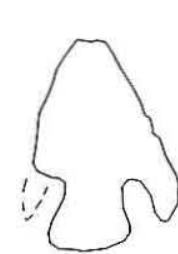

q
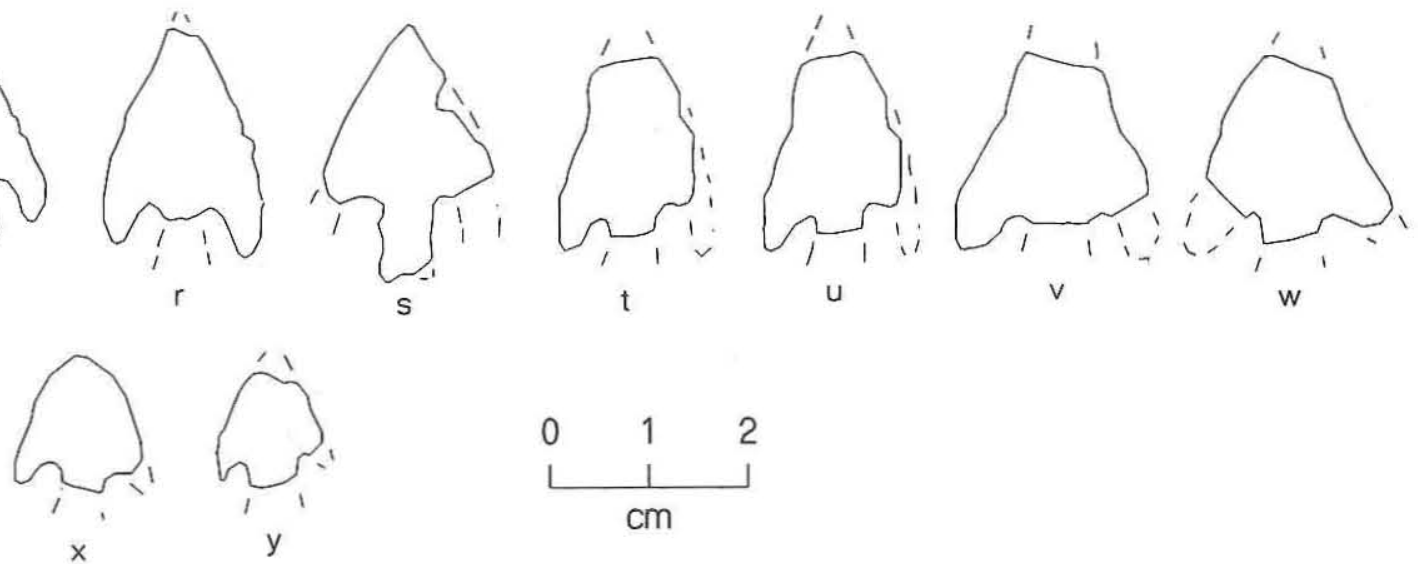

Figure 93. Scallorn and Deadman's arrow points from Deadman's Shelter. $(a-j)$ Scallorn; $(k-y)$ Deadman's. Drawn from selected specimens illustrated in Willey and Hughes (1978b:Figures 54 and 55).

metate fragments at Sam Wahl were recycled (i.e., reused as hearthstones) while none of those at Kent Creek were found in recycled contexts. Since Triassic sandstones and Quaternary gravel outcrops are immediately available at both sites, the distance to material sources is not a factor affecting the frequency of grinding tools. While it is possible that grinding activities were simply more important at Sam Wahl, this explanation is not totally satisfactory. Schlanger (1990) has observed that complete and fragmentary ground stones are considerably more abundant in village sites that were occupied for longer periods of time. The early occupations at the Sam Wahl site lasted for some 400 years or more (based on six radiocarbon dates), certainly long enough for many grinding implements to have been broken and recycled. The chronology of the Kent
Creek site is less precise, but if it was reoccupied for only one or two centuries then the lower incidence of grinding tool recycling could be a function of time rather than evidence that grinding activities were less important.

The results of a study of ground stone tools in the Jornada Mogollon area by Calamia (1991) support the interpretation that the Sam Wahl and Kent Creek sites are both residential bases but that their functions were somewhat different. Calamia (1991:Figure 8) shows that only ca. 38 percent of the manos found at Jornada Mogollon residential bases are complete, compared to ca. 77 percent complete manos at special activity sites. The higher frequency of broken manos at residential bases is thought to be related to the greater intensity and/or duration of occupations there. The percentages of 


\begin{tabular}{|c|c|c|c|c|c|c|c|c|}
\hline \multirow[b]{4}{*}{ Tool Class } & \multicolumn{7}{|c|}{$\begin{array}{l}\text { TABLE } 74 \\
\text { OF GRINDING ASSEMBLAGES FROM } \\
\text { WAHL AND KENT CREEK SITES }\end{array}$} & \\
\hline & \multicolumn{4}{|c|}{ Sam Wahl, Early Occupation } & \multicolumn{4}{|c|}{ Kent Creek } \\
\hline & \multicolumn{2}{|c|}{ Sandstone } & \multicolumn{2}{|c|}{ Quartzite } & \multicolumn{2}{|c|}{ Sandstone } & \multicolumn{2}{|c|}{ Quartzite } \\
\hline & \# & $\%$ & \# & $\%$ & \# & $\%$ & $\#$ & $\%$ \\
\hline $\begin{array}{l}\text { Manos } \\
\text { Complete } \\
\text { Fragments }\end{array}$ & $\begin{array}{l}1 \\
4\end{array}$ & $\begin{array}{l}1.3 \\
5.1\end{array}$ & $\begin{array}{l}5 \\
5\end{array}$ & $\begin{array}{l}6.4 \\
6.4\end{array}$ & $\begin{array}{l}6 \\
6\end{array}$ & $\begin{array}{l}21.4 \\
21.4\end{array}$ & $\begin{array}{l}2 \\
6\end{array}$ & $\begin{array}{r}7.1 \\
21.4\end{array}$ \\
\hline $\begin{array}{l}\text { Metates } \\
\text { Complete } \\
\text { Fragments }\end{array}$ & $\begin{array}{r}5 \\
48\end{array}$ & $\begin{array}{r}6.4 \\
61.5\end{array}$ & - & - & $\frac{-}{8}$ & $\begin{array}{c}- \\
28.6\end{array}$ & $\begin{array}{l}- \\
-\end{array}$ & $\begin{array}{l}- \\
-\end{array}$ \\
\hline $\begin{array}{l}\text { Pestles } \\
\text { Complete } \\
\text { Fragments }\end{array}$ & - & $\overline{3.8}$ & - & - & $\begin{array}{l}- \\
-\end{array}$ & - & $\begin{array}{l}- \\
-\end{array}$ & - \\
\hline $\begin{array}{l}\text { Other } \\
\text { Complete } \\
\text { Fragments }\end{array}$ & $\frac{-}{7}$ & - & - & $\begin{array}{l}- \\
-\end{array}$ & $\begin{array}{l}- \\
-\end{array}$ & - & - & - \\
\hline Subtotals: & 68 & 87.1 & 10 & 12.8 & 20 & 71.4 & 8 & 28.5 \\
\hline Grand Totals: & & $78(1$ & $0.0)$ & & & 28 & $0.0)$ & \\
\hline
\end{tabular}

that the Palo Duro components at Kent Creek and Sam Wahl were more or less contemporaneous and that the Sam Wahl site was occupied later (i.e., the post-A.D. 1100 late occupation period) than the Kent Creek site. Hence, the data indicate differences in site function, and it is possible that different plants were processed at the two sites and may have required different grinding tools.

No conclusions regarding horticulture may be drawn solely from the nature of the grinding tools at residential bases. While the Palo Duro complex does not include the trough metates and large, two-handed manos characteristic of many Southwestern agriculturalists, the grinding tools are robust compared to those of simpler hunter-gatherer groups. The Palo Duro assemblages seem to indicate an intensity of plant

whole manos at the Sam Wahl and Kent Creek sites (ca. 40 percent at each) are very close to the figure given for Jornada Mogollon residential bases.

Calamia (1991:Figures 2-7) also uses mano size as an indirect measure of residential mobility and intensity of plant processing in the Jornada region. He demonstrates that manos are generally smaller at special activity sites than at residential bases, and that there was a general increase in the size of manos through time (from the Archaic period to the El Paso phase). Other researchers have suggested that increasing mano size is a reflection of increasing dependence upon plant foods in general and horticulture in particular (e.g., Mauldin 1991, 1993).

Table 75 shows that the manos at the Sam Wahl site are considerably smaller than those at the Kent Creek site. This may indicate that grinding activities were more intensive at the Kent Creek site but that the overall duration of occupations was longer at the Sam Wahl site. If the site occupations were sequential, these data could reflect increasing dependence upon plant resources through time, as is suggested for the Jornada area. However, it appears processing somewhere between these two extremes. The Palo Duro grinding tools are basically similar to those of the Antelope Creek phase peoples who grew corn, squash/pumpkins, and beans in the northern Texas Panhandle, and Lintz (1982:43, 1986:33-35) notes that these bison-hunting horticulturalists used only one-handed manos, grinding basins, and mortars and pestles to process their plant foods. Based on the similarities, the intensity of plant processing by Palo Duro peoples may have been comparable to that of some Plains Village groups. It cannot be assumed, on the other hand, that the same intensity of plant processing must be evidence of farming (Morris 1990:186-187, 191).

Ceramics are usually absent or rare in most Palo Duro sites, accounting for less than 9 percent of all artifacts (excluding debitage); sherds are relatively common at the Blue Clay and South Ridge sites, however, where they make up 22 percent and 16 percent of all artifacts (excluding debitage). The absence of potsherds in some sites could be due to limited sampling, but their absence at other sites that have produced large samples is intriguing. The fact 


\begin{tabular}{|l|c|c|}
\hline \multicolumn{3}{|c|}{ TABLE 75 } \\
COMPARISON OF SIZE DATA FOR \\
COMPLETE MANOS FROM PALO DURO \\
COMPLEX RESIDENTIAL BASES
\end{tabular}

that no sherds were found at the County Line and Gobbler Creek Bridge sites, despite fairly extensive investigations, may indicate that pottery was not used at these sites, perhaps identifying these as special-activity sites.

The brownware pottery found at Palo Duro sites is generally classifiable as belonging to the Jornada Mogollon tradition. Detailed visual analyses and identifications by Southwestern ceramicists (i.e., Jack Hedrick, Regge Wiseman, and A. H. Warren) indicate that several varieties are present, and they probably represent different source areas within southeastern New Mexico and/or western Texas. The types that have been specifically mentioned are Jornada Brown (and Alma Plain), Roswell Brown, Middle Pecos Micaceous Brown, South Pecos Brown, and McKenzie Brown. Some researchers recognize many regional variations within the Jornada Mogollon brownwares and are willing to make visual type identifications in some cases. Others think that few or no types may be identified accurately by visual examinations alone. Petro- graphic studies of brownwares from several Palo Duro sites, however, generally support the visual type identifications.

Petrographic studies of Palo Duro complex brownwares include the following: two sherds from 41BI265 (Etchieson et al. 1977:64); three sherds from Deadman's Shelter, six from the Kent Creek site, and three from the South Sage Creek site (Robinson 1992); and five sherds from the Sam Wahl site (Robinson 1994). These data indicate considerable compositional variability in the brownwares representing different source areas. These studies also have confirmed that almost all of this pottery is of nonlocal origin and was made in the Jornada Mogollon or Middle Pecos areas. As yet, there have been no convincing studies to indicate that brownware pottery was made in the Caprock Canyonlands, although occasional sherds that do not match any varieties of Jornada brownware are considered possible candidates for locally made wares (e.g., one sherd at Kent Creek was identified as possibly being of local manufacture).

There may be some evidence, albeit weak, for temporal differentiation of brownware types. Thicker brownwares tempered with crushed igneous rocks primarily containing quartz and feldspar, such as the Jornada Brown/Alma Plain found at Deadman's Shelter, appear to be the earliest brownwares in the Texas Panhandle-Plains, perhaps appearing prior to A.D. 500, while thinner sherds with more-variable crushed rock tempers may be later. In particular, some sherds found at the Kent Creek and South Sage Creek sites contain significant quantities of biotite (see Robinson 1992, 1994). These have been tentatively identified as Middle Pecos Micaceous Brown, and some distinctive sherds from the Sam Wahl site have been tentatively identified as South Pecos Brown. According to Jelinek (1967), these wares were manufactured in the Middle Pecos area between A.D. 800 and 1300 .

There are some interesting patterns in the occurrence of bone and mussel shell artifacts. Most notable is the presence of modified deer bones (primarily metapodial awls and awl blanks) and modified and unmodified mussel shells (scrapers, pendants, and shell blanks) in human burials. The distribution of modified bones in nonburial contexts is almost certainly related to differential preservation rather than differing site function, and this explains the absence of modified bones in residential bases and campsites. Modified bones were found in only 
one site, the intensively occupied Deadman's Shelter, where bone preservation was very good. Since differential preservation does not seem to be a factor in the rockshelters, one may assume that bone tools were not commonly used and/or discarded in the ephemerally occupied rockshelters. The 21 bone artifacts that were found at Deadman's Shelter include awls and awl blanks made of split deer metapodials, polished deer antler tips (flaking tools?), and unidentifiable fragments that were cut, polished, and/or incised. One fragment with two drilled holes in it may have been a pendant.

Mussel shell fragments are common in many sites, and differential preservation is less likely to have been a factor affecting the distribution of shell artifacts. While there is minimal evidence for the use of mussels as food (see Subsistence and Site Function), the ubiquity of modified shells suggests other uses. Mussel shells may have been used occasionally as scrapers, but the most common forms of modification (such as cut edges, drilled holes, notches, and surface etching) are thought to represent shell jewelry (i.e., pendants) or waste debris as a byproduct of the manufacture of ornaments. Evidence for the use and/or manufacture of shell ornaments was found at the South Sage Creek, Sam Wahl, and Kent Creek sites. Further evidence is found at Kent Creek, where a woman was buried wearing mussel shell pendants.

\section{FEATURES}

A comparison of feature types (Table 76) shows a wide range of generalized and specific activities and supports the evidence for differential site functions seen in Figure 90. As expected, the diversity of features is greatest for the residential bases, while diversity is somewhat less variable for the campsites and rockshelters. There are some obvious correlations, such as the presence of pithouses and storage pits only at residential bases, but the most ubiquitous features at all sites are rocklined and unlined hearths, burned rock clusters, and baking pits. While the former types are considered general heating/cooking features, the baking pits are more-substantial rock-lined pits that are interpreted as plant cooking ovens (see Boyd et al. [1994:38-43, 135-138] for descriptions of baking pits found at Lake Alan Henry). Baking pits were found at the Gobbler Creek Bridge and Cat Hollow sites, along

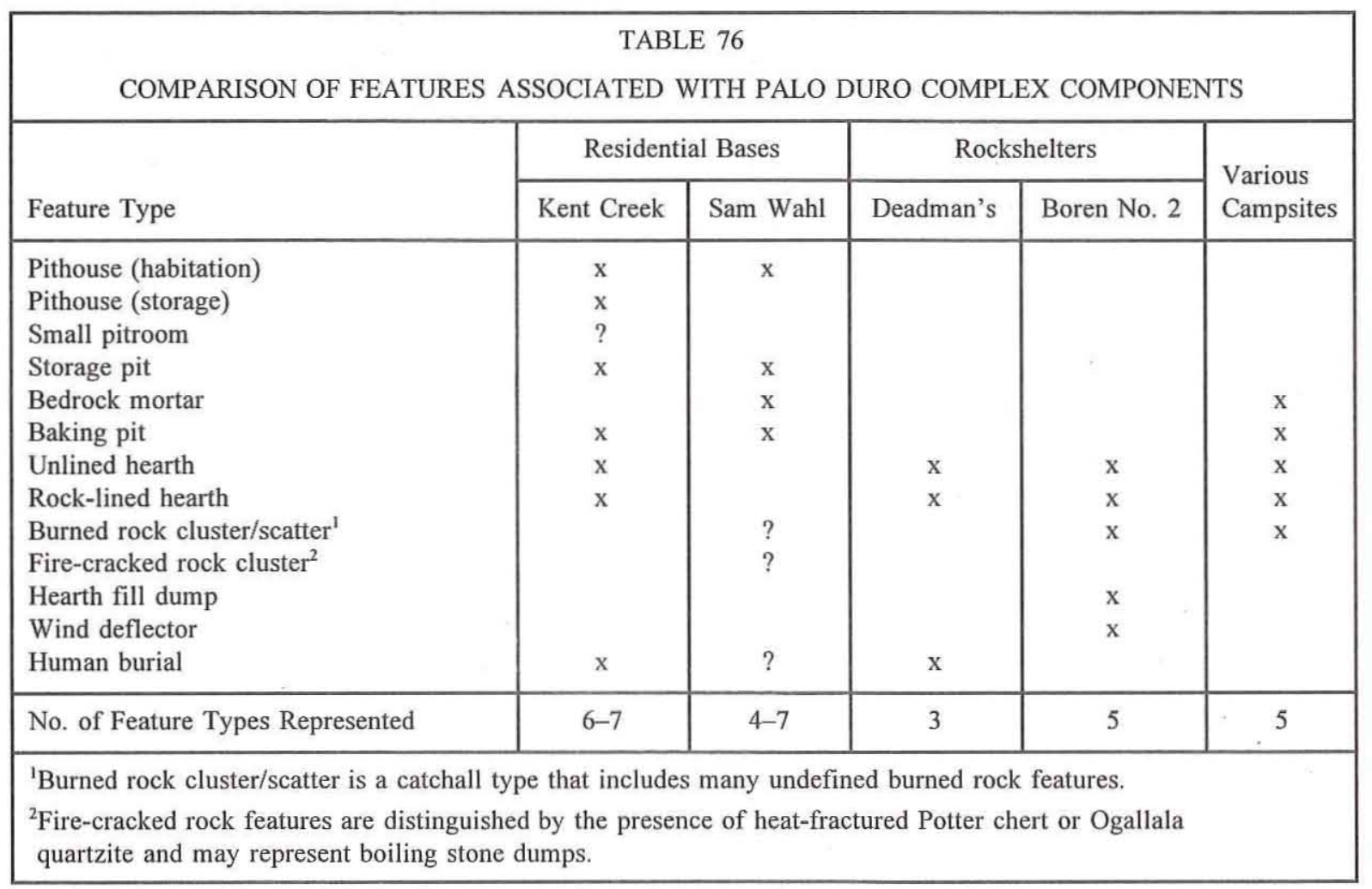


with large quantities of burned rocks thought to be residue discarded during pit baking. Because of the tremendous quantities of burned rocks at these sites, they are interpreted as specialized plant processing campsites. Baking pits also are represented at both residential bases, and cooking in earth ovens seems to have been an important food processing technology for Palo Duro peoples.

There is considerable variability in the architecture of the roughly contemporaneous pithouses at the Kent Creek and Sam Wahl sites (Table 77). These three pithouses include both ovate and rectangular forms, their sizes vary somewhat (with floor areas ranging from 7.6 to $14.2 \mathrm{~m}^{2}$ ), and the entry directions all differ. There also are many differences in the interior features and in the hypothesized construction of the superstructures.

\section{FAUNAL AND BOTANICAL REMAINS}

The animal bones recovered from sites, summarized in Table 78, have generally been treated in one of three ways: they have been ignored during analysis; they have been identified and listed by taxa but not analyzed; or they have been identified by taxa and analyzed for evidence of modification (e.g., burning and butchering) and their intrasite distributions have been carefully studied. This differential treatment helps explain many of the question marks in Table 78. It also is important to realize that in many cases, particularly when dealing with rodents and other burrowing animals and with rockshelter assemblages, it is unclear whether animal bones were introduced by natural processes rather than human activity.

The largest faunal assemblages are from the Kent Creek site and Deadman's Shelter. At both, deer is the only medium to large animal recognized as having been a significant food resource, while bison is poorly represented. A wide variety of other small animals are present, but their relative importance as food resources is comparatively low or unclear. In contrast to these sites, the faunal evidence indicates that rabbits and rodents were the animals most frequently eaten by Palo Duro peoples at Boren Shelter

TABLE 77

ARCHITECTURAL VARIABILITY IN PITHOUSES OF THE PALO DURO COMPLEX

\begin{tabular}{|c|c|c|c|}
\hline \multirow[b]{2}{*}{ Attributes } & \multicolumn{2}{|c|}{ Kent Creek Site } & \multirow{2}{*}{$\begin{array}{c}\text { Sam Wahl Site } \\
\text { Pithouse }\end{array}$} \\
\hline & Pithouse 1 & Pithouse 2 & \\
\hline $\begin{array}{l}\text { Shape } \\
\text { Size }(\mathrm{m}) \\
\text { Floor area }\left(\mathrm{m}^{2}\right) \\
\text { Entry direction } \\
\text { Entry type } \\
\text { Depth }(\mathrm{cm})^{1}\end{array}$ & $\begin{array}{c}\text { rectangular } \\
4.3 \times 3.3 \\
14.2 \\
\text { east } \\
\text { plastered ramp } \\
35+\end{array}$ & $\begin{array}{c}\text { rectangular } \\
3.3 \times 2.3 \\
7.6 \\
\text { west } \\
\text { plastered ramp } \\
33+\end{array}$ & $\begin{array}{c}\text { ovate } \\
3.5 \times 3 \\
10.5 \\
\text { southeast (?) } \\
\text { unknown } \\
45+\end{array}$ \\
\hline $\begin{array}{l}\text { Interior Features } \\
\text { Troughs (or water traps?) } \\
\text { Large postholes } \\
\text { Small postholes } \\
\text { Hearth } \\
\text { Rock clusters/ovens }\end{array}$ & $\begin{array}{l}\text { yes } \\
\text { yes } \\
\text { yes } \\
\text { no } \\
\text { yes }\end{array}$ & $\begin{array}{l}\text { yes } \\
\text { no } \\
\text { no } \\
\text { no } \\
\text { no }\end{array}$ & $\begin{array}{c}\text { no } \\
\text { no } \\
\text { uncertain } \\
\text { probable } \\
\text { no }\end{array}$ \\
\hline Exterior postholes & no & no & uncertain \\
\hline $\begin{array}{l}\text { Probable type of } \\
\text { superstructure }\end{array}$ & wattle and daub & stone masonry & $\begin{array}{l}\text { very ephemeral, } \\
\text { jacal-like }\end{array}$ \\
\hline \multicolumn{4}{|c|}{$\begin{array}{l}\text { 'Depths represent minimum estimates of how deep the floors were excavated from the original ground surface } \\
{ }^{2} \text { No interior hearth was found, but a postabandonment subfloor burial in the center of the structure could have } \\
\text { destroyed a hearth. }\end{array}$} \\
\hline
\end{tabular}


TABLE 78

COMPARISON OF FAUNAL EVIDENCE FOR USE OF SPECIFIC FOOD RESOURCES AT PALO DURO COMPLEX SITES

\begin{tabular}{|c|c|c|c|c|c|c|c|c|c|c|c|}
\hline \multirow[b]{2}{*}{ Common Name } & \multicolumn{2}{|c|}{ Residential Bases } & \multicolumn{2}{|c|}{ Rockshelters } & \multicolumn{7}{|c|}{ Campsites } \\
\hline & $\begin{array}{l}\text { Kent } \\
\text { Creek }\end{array}$ & $\begin{array}{l}\text { Sam Wahl, } \\
\text { Early } \\
\text { Occupation }\end{array}$ & $\begin{array}{l}\text { Deadman's } \\
\text { Shelter }\end{array}$ & $\begin{array}{l}\text { Boren No. } 2 \text {, } \\
\text { Lower } \\
\text { Shelter }\end{array}$ & $\begin{array}{l}\text { Blue } \\
\text { Clay }\end{array}$ & $\begin{array}{l}\text { County } \\
\text { Line }\end{array}$ & $\begin{array}{l}\text { Cat Hollow, } \\
\text { Lower Zone }\end{array}$ & $\begin{array}{l}\text { Gobbler } \\
\text { Creek } \\
\text { Bridge }\end{array}$ & $\begin{array}{l}\text { Fatheree } \\
\text { Area } 1\end{array}$ & $\begin{array}{l}\text { South } \\
\text { Ridge, } \\
\text { East End }\end{array}$ & $\begin{array}{l}\text { South } \\
\text { Sage } \\
\text { Creek }\end{array}$ \\
\hline Deer & 2 & & 1 & & & ? & & & ? & ? & \\
\hline Antelope & 3 & $?$ & 3 & & & & & & $?$ & & \\
\hline Deer/Antelope & & & & & & & $?$ & & & & \\
\hline Bison & 3 & & 3 & & $?$ & $?$ & $?$ & & ? & $?$ & \\
\hline Canid & & & & $?$ & & & & & & & \\
\hline Coyote & & & ? & & & & & & & & \\
\hline Fox & & & $?$ & & & & & & & & \\
\hline Badger & & & $?$ & & & & & & & & \\
\hline Skunk & $?$ & & $?$ & & & & & & & & \\
\hline Raccoon & & & $?$ & & & & & & & & \\
\hline Ringtail & & & $?$ & & & & & & & & \\
\hline Rabbits & ? & $?$ & $?$ & 2 & $?$ & & $?$ & $\mathrm{x}$ & $?$ & $?$ & \\
\hline Rodents & & & ? & 2 & & $?$ & & & $?$ & & $?$ \\
\hline Birds & & & $?$ & $?$ & & $?$ & & & & & \\
\hline Water Turtle & $?$ & & & & & & & & & & \\
\hline Snakes & $\mathrm{x}$ & & ? & & & & & & & ? & \\
\hline Lizard & & & & ? & & & & & & & \\
\hline Toads/Frogs & & & $?$ & $?$ & & & & & & & \\
\hline Freshwater Fish & & 3 & 3 & & & & & & & $?$ & \\
\hline Freshwater Mussels & ? & $?$ & $?$ & $?$ & $?$ & $?$ & $?$ & $?$ & $?$ & $?$ & $?$ \\
\hline No. of Specimens & 627 & 29 & $3,000+$ & 482 & 342 & 188 & 16 & 4 & 291 & 833 & 1 \\
\hline Type of Analysis & $\mathrm{C}$ & $C^{*}$ & I & $\mathrm{C}$ & $\mathrm{C}$ & $\mathrm{C}$ & $\mathrm{C}^{*}$ & $\mathrm{C}^{*}$ & $\mathrm{C}$ & $\mathrm{C}$ & $C^{*}$ \\
\hline
\end{tabular}

Interpretations of the relative importance of resources are based on frequency of occurrence within class and evidence of modification: $1=$ intensive (probably represents a major food resource); $2=$ moderate (probably represents an important food resource); $3=10$ w (probably represents a minor food resource); ? = unknown (probably used as a food resource but importance is unknown); $\mathrm{x}=$ none (present in the assemblage but may not represent a food resource, e.g., burrowing rodents).

Type of Analysis: $\mathrm{C}=$ complete faunal analysis (noting evidence of burning, butchering, etc.); $\mathrm{I}=$ incomplete faunal analysis (selected specimen for species identification only).

*Poor preservation is noted as a possible source of bias. 
No. 2. The faunal assemblages at the other sites are either so meager that they are uninterpretable (they are likely to be biased by differential preservation), or they are just large enough to provide limited useful information on animals that may have been utilized. The remains from the Chalk Hollow site, although apparently a sizable and interesting assemblage, have not been analyzed at all.

Freshwatermussel shells are consistently present, and there is some evidence that they were utilized as food. For example, heated hinge fragments (presumably heated to cause the live mussel to open) were recovered from the South Sage Creek site. Mussel remains have not been found in sufficient quantities, however, to suggest that they were an important food resource. They certainly were never used by Palo Duro peoples to the extent that they were in other areas. Large accumulations of shells in the East Levee site, 41TG91 (Creel 1990), near San Angelo and at sites at Lake O. H. Ivie (Treece, Lintz et al. 1993a:519-523) indicate that mussels were an important food for peoples in the Colorado and Concho River valleys, but there is no such evidence for the Caprock Canyonlands. In fact, the relatively high frequency of modified mussel shells in Palo Duro complex habitation sites and burials suggests that the shells themselves may have been much more important than the mussels.

Palynological samples have been taken and analyzed from several sites (i.e., Kent Creek, Sam Wahl, and Gobbler Creek Bridge site), but the fossil pollen has consistently been found to be seriously degraded, and the data are generally considered unusable for economic (or paleoenvironmental) interpretations (Bryant 1993; Dering 1994; Dering and Bryant 1992; Jones 1990). Phytoliths have been extracted from feature sediments at Lake Alan Henry sites, but the resulting data are generally not useful for subsistence interpretations. Unlike pollen, phytoliths are well preserved, but the interpretations are limited primarily by the inability to recognize specific taxa and the lack of comparative collections. One notable exception is that calcium oxylate crystals found in sediments associated with a baking pit at the Gobbler Creek Bridge site are thought to be from prickly pear (Cummings 1990:541).

Macrobotanicalremainsrecoveredfrom sediment flotation provide the most useful evidence for interpreting the plants that probably were used as food resources (Table 79). Carbonized seeds of many different plants have been recovered from sediments in a variety of contexts, e.g., on pithouse floors, in storage pits and baking pits, and in nonfeature samples. In all cases, the charring is thought to be the result of human activities, as opposed to natural fires. The question, then, is which of the plants were used as food and which plants may have been burned accidentally or used as fuel. The data presented in Table 79 show various plant taxa as being either present or moderately abundant in charred form but do not attempt to make a judgment as to why the seeds were burned. Various analysts generally address these questions on a case by case basis, taking many factors into account (e.g., the nature of the plant, the frequency of charred seed occurrence in various contexts, or ethnographic evidence for utilization of plants).

While any of the taxa listed may represent food resources, those that are most abundant (in terms of the quantity of charred seeds from individual samples and the ubiquity of their occurrence in multiple samples from different types of features) are more likely to have been used for food. Of all the taxa listed, however, only the mesquite beans and shin oak acorns have been found in archeological contexts that strongly suggest that they were used for food. Dering (1994:335-341) provides an interesting discussion of the probable use of mesquite at the Sam Wahl site, and Cruse (1992:121) discusses shin oak acorns found at the Kent Creek site.

It also is notable that Chenopodium is much more abundant than any other taxon and is associated with three types of features (i.e., pithouse, storage pits, and baking pits) at the Sam Wahl site. Dering (1994:341) suggests that the ubiquity of charred goosefoot seeds coupled to its absence at other Lake Alan Henry sites is evidence that goosefoot was processed as food. While goosefoot was very abundant in one storage pit flotation sample, it was not found in sufficient quantities or consistency in other storage pit samples to indicate that it was the principal plant food being stored.

In addition to the evidence for food use, Dering (1994:340-341) observed that four species of grass seeds were consistently found in storage pits at the Sam Wahl site, but they were not recovered in any other type of feature. He speculated that this may be evidence that the pits had been lined with grass rather than that grass seeds were stored in the pits.

There is no definitive evidence for the range of plant foods processed in the baking pits (see Hines et al. [1994] for a detailed discussion of pit roasting) at 


\begin{tabular}{|c|c|c|c|}
\hline \multicolumn{4}{|c|}{$\begin{array}{c}\text { TABLE } 79 \\
\text { COMPARISON OF MACROBOTANICAL EVIDENCE FROM } \\
\text { PALO DURO COMPLEX COMPONENTS }\end{array}$} \\
\hline \multirow[b]{2}{*}{ Common and Scientific Name } & \multicolumn{2}{|c|}{ Residential Bases } & \multirow{2}{*}{$\begin{array}{l}\text { Rockshelter } \\
\text { Boren No. 2, } \\
\text { Lower Shelter }\end{array}$} \\
\hline & Kent Creek & $\begin{array}{l}\text { Sam Wahl, } \\
\text { Early Occupation }\end{array}$ & \\
\hline $\begin{array}{l}\text { Goosefoot (Chenopodium sp.) } \\
\text { Pigweed (Amaranthus sp.) } \\
\text { Prickly poppy (Argemone sp.) } \\
\text { Purslane (Portulaca sp.) } \\
\text { Bottle gourd (Cucurbitacaea) } \\
\text { Carpet weed (Mollugo verticillata) } \\
\text { Skullcap (Scutellaria } \text { sp.) } \\
\text { Mesquite (Prosopis glandulosa) } \\
\text { Oak (Quercus sp., probably shin oak) } \\
\text { Lotebush (Ziziphus obtusifolia) } \\
\text { Hackberry (Celtis reticulata) } \\
\text { Brome grass (Bromus sp.) } \\
\text { Paspalum (Paspalum } \mathrm{sp} .) \\
\text { Dropseed (Sporobolus sp.) } \\
\text { Panic grass (Panicum } \mathrm{sp} .)\end{array}$ & $?$ & $\begin{array}{l}\mathrm{x} \\
? \\
? \\
\mathrm{x} \\
? \\
? \\
\mathrm{x} \\
\\
? \\
\mathrm{x} \\
\mathrm{o} \\
\mathrm{o} \\
\mathrm{o} \\
\mathrm{o}\end{array}$ & $\begin{array}{l}? \\
? \\
\mathrm{x} \\
?\end{array}$ \\
\hline Number of flotation samples analyzed: & 4 & 14 & 10 \\
\hline \multicolumn{4}{|c|}{$\begin{array}{l}\text { Note: Macrobotanical evidence consists of carbonized seeds recovered from flotation (charred wood is not } \\
\text { included). A few flotation samples from the Gobbler Creek Bridge and South Sage Creek sites were analyzed, bu } \\
\text { no carbonized seeds were recovered. } \\
\mathrm{x}=\text { moderately abundant; found in multiple samples from different types of features. } \\
?=\text { presence noted in one or more samples. } \\
\mathrm{o}=\text { recovered only in storage pits; may be evidence of grass lining rather than food. }\end{array}$} \\
\hline
\end{tabular}

residential bases or specialized campsites, or the season(s) of the year that earth ovens might have been used. Some possibilities are that baking pits may have been used (1) during one time of the year for cooking a particular plant, (2) during one time of the year for cooking a variety of different plants, (3) during multiple seasons for cooking a few specific plants, or (4) during multiple seasons for cooking a wide variety of plant foods. It is likely that the baking pits were used primarily during the late spring, summer, and fall, when a full range of wild plant foods (e.g., seeds, beans, berries, tubers, tunas, and pads) were available.

Ethnographic evidence for arid and semiarid environments (e.g., Basehart 1960; Castetter and Opler 1936:35-38; Pennington 1963; Sonnichsen 1958) indicates that many different plants were cooked in pit ovens. The principal ones were agave, sotol, prickly pear, yucca, and corn. Agave is not found in the Caprock Canyonlands today and probably never ranged that far north, but sotol, although not found there today, may have been present in the past. Its current range has been seriously altered by modern ranching practices (see Boyd et al. 1994:264). Prickly pear and yucca are ubiquitous in the area today and probably were abundant in Palo Duro times as well. Although it is not known whether the Palo Duro peoples practiced horticulture, corn is one possible plant that was oven roasted.

Although their contemporaneity has been demonstrated by the radiocarbon dates from the Sam Wahl site, it is not known if grinding tools, baking pits, and storage pits were used together as an integrated process for some specific resource(s), or if they were used independently for different resources. Some foods may have been ground before being cooked, or vice versa, and these foods may or may not have then been stored for future use. It 
also is possible that many plants were ground, while only a few were cooked and/or stored.

Besides the possible oven-baked plant resources mentioned above, a wide range of other plants may have been important food resources (including but not limited to all of the plants listed in Table 79). Boyd et al. (1994:264-265) provide a detailed discussion of this for the Caprock Canyonlands and Rolling Plains. The plants and plant parts that may have been sufficiently abundant and nutritious to have been intensively utilized as food are, in no particular order, seeds of various grasses and flowering plants (e.g., dropgrass and Cheno-ams); various roots and tubers (e.g., buffalo gourds and prairie turnip); pads, stalks, fruits, and/or bulbs of desert succulents and cacti (e.g., yucca, sotol, prickly pear, and cholla); various cucurbits (e.g., bottle gourds); acorns of shin oak and possibly live oak (remnant groves of live oak are present at Lake Alan Henry); possibly pecan or hickory nuts (charred Carya sp. wood from a hearth at 41GR484 indicates that pecan or hickory was once in the Lake Alan Henry area); and mesquite beans. Many other plants might have been important, but they are perhaps less obvious in the ethnographic or archeological records. A variety of horticultural crops (e.g., corn, squash, and beans) should not be discounted as possible food resources despite their absence in the archeological record.

Of all the plants mentioned above, mesquite is particularly important because it is the only one for which good archeological evidence exists for its use by Palo Duro peoples. It also is well documented in the ethnographic literature as a staple resource for many peoples in the southwestern United States and northern Mexico (Bell and Castetter 1937:21-33), along the Texas Coast and in Central Texas (Covey 1961:66, 86-87, 100), and in the Rio Grande delta (Salinas 1990:117-119). Although direct archeological evidence is limited, mesquite has been suggested as an important resource throughout the Jornada Mogollon region (Brethauer 1979; Carmichael 1986: 220; Leslie 1979:186), and even the historic Comanche and Kiowa of the Texas Panhandle-Plains utilized mesquite beans as food (Carlson and Jones 1940:530; Galvin 1970:30-31; Vestal and Schultes 1939:33-34). Nutritional data compiled by Hiles (1993) indicate that mesquite pods and beans are very high in protein, carbohydrates, fiber, and sugar.

Boyd et al. (1994:265-266) dispute the claim that mesquite was not present or was rare in the Texas Panhandle-Plains prior to late-nineteenth- century ranching. The distribution of mesquite has certainly increased dramatically due to historic and modern ranching and agricultural practices (Flores 1990:60-61; Kirkpatrick 1992:141), and its rapid spread into new areas (such as uplands) that were once devoid of mesquite is the source for the common misconception that "there was no mesquite before ranchers came." However, early historic accounts (e.g., Bailey 1951:105, 121; Foreman 1937:97; Parker 1984:170-171, 184) clearly indicate that mesquite trees were abundant in riverine environments prior to cattle grazing (and overgrazing), root plowing and chaining, and control of range fires. The mid-nineteenth-century distribution of mesquite suggests that it was abundant throughout the Caprock Canyonlands in prehistory, and it is the best candidate for having been a staple resource (not necessarily the only one) for Palo Duro peoples. Charred mesquite beans should not be expected to be common in the archeological record even if they were extensively utilized. Most ethnographic accounts indicate that beans were crushed and ground before being cooked. If they were not cooked in pod or bean form, the chances of their being charred, and hence preserved in the archeological record, are low.

There are five main interpretations that may be derived from the subsistence data. First, bison hunting and use of bison as a food resource are poorly documented. That bison were present during Late Prehistoric I times is unquestionable since some bison remains dating to this time have been found. Bison remains are exceedingly rare, however, compared to the preceding late Archaic period. Even at sites where the artifactual evidence indicates that hunting was an important activity, the principal game animals appear to have been deer and smaller animals. In addition, no bison kill or butchering localities are known for the Palo Duro complex, and it appears unlikely that communal bison hunting occurred. From this, one may infer that bison were somewhat scarce, but never absent, from the Caprock Canyonlands and adjacent areas during Palo Duro times (this statement is based on the assumption that people would have hunted them much more if large populations were present). While a general scarcity of bison remains has been suggested for the Southern Plains between A.D. 500 and 1200 (Dillehay 1974), this does not preclude the possibility that bison were abundant in other areas at this time. Treece, Lintz et al. (1993b:523-524) note that 
bison remains dating to this time period are well represented in sites at Lake O. H. Ivie in westcentral Texas.

The second major point is that multiple lines of evidence indicate that the primary subsistence resources were plant foods. Although hunting activities are fairly well represented at some sites, some evidence for the use of plant foods is found at all Palo Duro sites, and it is overwhelmingly dominant in many components. The contemporaneous use of storage pits, baking pits, at least two kinds of portable grinding tool kits (i.e., mano/metate sets), and bedrock mortars/pestles at residential bases denotes intensive use of plant foods. The activities that occurred at these sites were often of sufficient duration to warrant the construction of pithouses, and it is likely that these residential villages were occupied on a seasonal basis.

Third, while a wide range of plant foods was probably utilized, it is hypothesized that mesquite beans, and to a lesser extent shin oak acorns, were extremely important food resources. Many campsites in the Eastern Jornada area may have been occupied by people harvesting these foods, and Leslie (1979:185-186) notes that "acorns and mesquite beans mature at about the same time (August-early September) but vary in different areas and different years; the two foods were possibly harvested at the same time when possible." The same may be true for peoples who lived in the Caprock Canyonlands.

The fourth point is that, in spite of the absence of domesticated plant remains or definite agricultural tools, it is possible that Palo Duro peoples practiced limited horticulture. The introduction of domesticated plants into the southwestern United States has been characterized as a "monumental nonevent" that had "little immediate impact on native human populations" (Minnis 1985:310). It was the intensification of agricultural production, rather than its mere introduction, that had significant and widespread impacts upon prehistoric economies. Following Bronson's (1977) terminology (cited in Minnis 1985:338), Palo Duro peoples were not agriculturalists ("those dependent upon cultivated plants"), but they could have been cultivators ("those for whom crops are not necessarily major economic items"). Lacking definitive evidence, it can only be suggested that limited plant cultivation may have been incorporated into a seasonal pattern of resource collection (Minnis 1985:331). Certainly, it is likely that Palo Duro peoples were at least aware of farming since agricultural systems were well established in the Southwest by A.D. 500-700 (Minnis 1985:310; Woodbury and Zubrow 1979:50-51), in the Central Plains by A.D. 900 (Adair 1988:114), and in southcentral Oklahoma (Vehik 1984:196) and northeast Texas (Perttula 1992:13; Perttula and Bruseth 1983:17) by A.D. 800 . Ford (1985:352, 362-364) suggests that the Southern Plains may have been a corridor for the continued eastward spread of cultigens (specifically maize and beans), and presumably farming technologies, from the American Southwest. If so, the Palo Duro complex may have even played some critical role in the diffusion process.

The final major point is that there is ample evidence for considerable variability in site function. This has been observed not only between different types of sites, but even within sites of a single type. The differences between the contemporaneous pithouse occupations at the Kent Creek and Sam Wahl sites are particularly notable. This diversity of site function is indicative of a high degree of residential mobility within the Palo Duro complex, which in turn is suggestive of a seasonal organization of subsistence activities.

\section{Seasonality, Residential Mobility, and Settlement Pattern}

Reconstructing the settlement pattern of the Palo Duro culture is a daunting task, given the paucity of definitive seasonality data and the constraints imposed by the small sample of sites that have been adequately investigated. Limited inferences may be made, but they are based largely on indirect and circumstantial evidence.

It can be stated with some degree of confidence that the Palo Duro complex peoples organized their subsistence activities on a seasonal basis. This interpretation is based in large part on the fact that the distribution, abundance, usefulness, and predictability of various plant and animal resources in the Caprock Canyonlands varies according to the seasons today and certainly did so in prehistoric times as well. When the residential bases, rockshelters, and campsites are considered together, the adaptive strategy of Palo Duro complex peoples must be viewed as extremely mobile and dominantly plant oriented.

Although the seasonality of their occupations is speculative, rockshelters and campsites probably represent habitation sites that were occupied at 
different times of the year than residential bases. Two types of rockshelters have been noted. Some, such as Boren Shelter No. 2, were used only on an ephemeral basis by small mobile groups while others, such as Deadman's Shelter, were intensively occupied. The material culture from Deadman's Shelter mimics that from the residential bases and denotes the considerable importance of grinding plant foods and hunting deer and smaller animals. There is no convincing direct evidence for seasonality. It is likely that there was winter or coldweather use of larger rockshelters as short-term residential bases and ephemeral use of smaller rockshelters by smaller groups (families or task groups?) during various seasons, perhaps as temporary havens from inclement weather.

Campsites range from multifunctional locations where hunting was important (e.g., the County Line site) to specialized activity areas where grinding and cooking of plant foods were nearly exclusive activities (e.g., the Cat Hollow and Gobbler Creek Bridge sites). It is likely that some of this variation is related to different seasons of occupation. Again, there is no good evidence for seasonality, but most of the plants that would have been cooked at the specialized plant processing localities ripen or are ready for harvest during the late spring to fall. The absence of storage pits at campsites suggests that they were not occupied during the winter. If the plant foods processed there were intended for storage, one might expect that some of these plant processing campsites would be located in close proximity to residential bases. This does seem to be the case at Lake Alan Henry, as evidenced by the close proximity of the Cat Hollow and Sam Wahl sites.

The two residential bases also appear to have functioned in different ways. At the Sam Wahl site, baking, grinding, and storage of plant foods were extremely important activities, while the use of animal resources appears to have been minimal. At Kent Creek, grinding, cooking, and storage of plant foods also are evident and represent important activities; however, hunting of deer and smaller animals was significantly more important than at Sam Wahl. The differences in storage techniques utilized at these sites probably relate to variations in site function. While pit storage is well represented at Sam Wahl, it is only minimally represented at Kent Creek, where aboveground storage may have been more common. As discussed below, however, it is difficult to translate the apparent functional differences between these sites directly into interpretations of the seasonality of the occupations.

The Kent Creek and Sam Wahl sites are, in many ways, more similar than they are different, however. The presence of permanent habitation structures and storage facilities at both provides evidence for speculating on the seasonal orientation of subsistence activities and settlement pattern of Palo Duro peoples. Pithouse dwellings generally imply some degree of residential mobility and seasonal organization of activities. Storage generally implies seasonal changes in resource availability, and subterranean food storage implies the use of plant foods.

In the southwestern United States, recent research has emphasized the importance of understanding residential mobility (e.g., Whalen and Gilman 1990). Shifting away from the view that pithouses are evidence of sedentism, most researchers now embrace the view that the pithouse period may have been characterized by considerable and varying degrees of residential mobility and an emphasis on food collecting rather than food producing (e.g., O'Laughlin 1980, 1993; Whalen 1977, 1978, 1980a, 1981b). Gilman (1987:548) states that "pithouse structures are the most adaptive and useful choice of habitation under conditions of biseasonal settlement systems, dependence upon stored foods, and cold season sedentism." Based on this idea, the pithouse occupations at the Kent Creek and Sam Wahl sites can be interpreted as having been at least seasonal, and possibly biseasonal, residences. The variability between these two residential bases is interpreted as evidence of different site functions and seasonality of occupations. It should not be assumed that the mere presence of pithouses is indicative of a single site function or a particular season of occupation. This assumption does not seem to be valid for the Jornada Mogollon region (Carmichael 1986:218), nor is it tenable for the Caprock Canyonlands. In fact, until data prove otherwise, it is probably safer to assume that differences in architectural styles, storage facilities, artifact assemblages, and macrobotanical remains could relate directly to variations in site function and/or the season of occupation.

Storage in general, and subterranean storage in particular, have been interpreted as evidence of seasonally oriented resource distributions and residential mobility (Binford 1990; DeBoer 1988; Goland 1983; Ingold 1983; O'Laughlin 1993; 
Raymer 1988; Ward 1985). Boyd et al. (1994:262) provide a detailed discussion of the implications of storage at the Sam Wahl site, including a few major ethnographic observations: (1) bulk food storage generally occurs at the locality where the resource is procured or harvested; (2) subterranean storage in temperate climates almost always involves storage of plant foods (both wild and domesticated); (3) one important function of pit storage is to conceal foodstuffs during periods of site abandonment; (4) stored foods are usually consumed at or near the storage locality; and (5) consumption of stored foods most often occurs during the winter-the lean season when most food resources are scarce.

Based on these observations, one possible scenario is that the Sam Wahl and Kent Creek sites were occupied between late summer and late fall when plant foods were harvested and stored. Archeological evidence for the use of mesquite beans (and possibly goosefoot) at Sam Wahl and shin oak acorns (and possibly goosefoot) at Kent Creek support this interpretation. Subterranean storage also implies that the sites may have been occupied during the middle to late winter, at which time the stored foods were consumed. It is more speculative, however, to infer whether the sites were occupied continuously from fall through winter, or whether they may have been abandoned during late fall to early winter and reoccupied during mid to late winter. Assuming that one function of subterranean storage was concealment, the predominant use of storage pits at Sam Wahl may be interpreted as evidence that the site was temporarily abandoned during late fall/early winter. In contrast, the predominant use of aboveground storage at Kent Creek could mean that this site was not temporarily abandoned during this time, perhaps because the inhabitants had greater access to other resources such as game animals. Thus, it is possible that differences in site abandonment could be at least partially responsible for some of the apparent functional differences between the Kent Creek and Sam Wahl sites.

Numerous ethnoarcheological and archeological case studies (e.g., Cameron and Tomka 1993) suggest that the caching of complete and fully functional metates (as at the Sam Wahl site) may be evidence of planned abandonment on an episodic or, more likely, seasonal basis. Schlanger $(1990,1991)$ notes that complete tools are often found in use contexts (i.e., cached or left in primary activity areas) within village sites, presumably because the last abandonment was perceived as temporary by the final inhabitants. The last inhabitants at Sam Wahl, who left the metates stored upside down on storage pits and inside the pithouse, probably left fully expecting to return.

In contrast, Structure No. 1 at the Kent Creek site may have been abandoned hastily, and its inhabitants left with no intention of returning. This pithouse was probably abandoned permanently upon the death and burial of one of its occupants. Cruse (1992:136, Figure 27) was able to define two distinct activity areas (a lithic work area and a food storage/processing area) based on the distribution of artifacts within the structure. Some of the tools that were left behind, including a mano and a side scraper, were complete. This does not necessarily mean that no usable artifacts were salvaged from the house, but it does suggest that the final abandoment was unplanned and disorderly. Brooks (1993) notes similarly well defined artifact patterning on the interior of a Washita River phase house that burned. The burning of the house could have been accidental, but it seems more likely that it was intentional upon the death of a child (occupant?) who was buried inside. In either case, the abandonment was unplanned and the house-floor artifacts, including a grinding basin and five manos, were left in their primary contexts reflecting the locations of household activities.

If limited horticulture was incorporated into their subsistence base, Palo Duro peoples might have occupied the villages on a biseasonal basis. The people may have occupied the villages during planting season in early spring, abandoned the sites while foraging and hunting during the summer, and returned in the late fall to harvest the crop and probably stayed through the winter. A simplistic model of prereservation Western Apache horticulture, as defined by Welch (1991), is useful for understanding one way in which subsistence activities might have been scheduled. No genetic affiliation with Athapaskan-speaking peoples is intended nor is it suggested that this model is a direct analog for Palo Duro culture adaptation. It is simply one possible scenario for how Palo Duro peoples might have organized a biseasonal adaptation involving limited horticulture.

According to Welch (1991:78), the prereservation Western Apaches' diet consisted of "roughly equal amounts of cultivated, gathered, and hunted 
foods." He states that:

Apache horticulturalists integrated cultivation with foraging through scheduling and resource procurement task groups (see Binford 1980). When a food source failed, greater emphasis could be placed on the other two, or on raiding. Family clusters based loosely on clan affiliations were the main settlement and subsistence units. These clusters contributed labor to the cultivation (mainly maize and cucurbits). . . . The cultivation cycle began as early as March and as late as July with digging out silted irrigation ditches and clearing and planting fields. The very old and young sometimes remained at the farmsteads to weed, protect, and irrigate the crops while others descended to harvest cactus fruits and other late spring and early summer foods. Additional gathering took place until the band reunited in early September to harvest and store food for late winter and early spring and to prepare for fall hunting [Welch 1991:78, 81].

The concentration of Palo Duro sites in the Caprock Canyonlands suggests that these people made this their home for most of the year because it offered abundant and predictable food resources and the widest range of other essential resources such as wood and water. When, why, and how often they moved about within the canyonland environment is still a mystery, however, because too many pieces of the puzzle, particularly good subsistence and seasonality data, are still missing.

\section{Geographic Range and Intercultural Relationships}

The vast majority of sites and components attributed to the Palo Duro complex are located in the escarpment breaks along the Prairie Dog Town Fork of the Red River and the Double Mountain Fork of the Brazos River. This constitutes the core area of the Palo Duro complex. Besides the sites that have already been discussed, other possible Palo Duro components that have not been tested may be present at Lake Alan Henry (41GR256 in Boyd et al. 1989:Table 12) and in Caprock Canyons State Park (41BI365 in Bagot and Hughes 1979:Figure 43, and 41BI265 in Etchieson et al. 1977:Figure 23). Since Palo Duro components have been found in all three of the intensively surveyed canyonland areas (i.e., Mackenzie Reservoir, Caprock Canyons State Park, and Lake Alan Henry), the complex appears to be well represented all along the Caprock Escarpment, including the intervening areas that have yet to be studied. Extrapolating data from these intensively studied areas suggests that there is likely to be a high density of Palo Duro complex sites in other areas of the canyonlands, particularly along all major tributaries.

As mentioned above, the northern boundary of the Palo Duro complex seems to overlap with the southern boundary of the Lake Creek complex. Couzzourt (1988:47) states that "Deadman points, characteristic to diagnostic of the Palo Duro Culture, are rare to absent in the northern Panhandle, though they do occur, as do some seemingly 'intermediate' types between corner-notched and base-notched types." Mogollon brownwares also are relatively rare in the Canadian River valley (as compared to the Caprock Canyonlands), but a few Palo Duro components are found in the upper headwaters of the Prairie Dog Town Fork (i.e., upstream of Palo Duro Canyon State Park as far as Buffalo Lake) and even into the Lake Meredith area of the Canadian River (see Figure 85). Thus, the area of overlap is the drainage divide between the Canadian and Prairie Dog Town Fork. It is this zone that has been proposed as a territorial border between Plains Woodland- and Southwestern-influenced cultures (Couzzourt 1982; Cruse 1992; J. Hughes 1991; Krieger 1946, 1978).

The evidence for violence and intercultural conflict seems to support the existence of such a boundary (see Figures 84 and 86). The Palo Duro woman who was buried, presumably by her relatives, in the pithouse at the Kent Creek hamlet was probably killed by non-Palo Duro peoples. The cultural identity of the two men who were killed and interred together in the Donley County Double Burial is uncertain, but they may have been killed by members of the Palo Duro group. Could they have been Lake Creek or Plains Woodland peoples? If so, the evidence argues for a cultural boundary somewhere in the vicinity of the Prairie Dog Town Fork of the Red River.

Other burials to the northwest of the Palo Duro area also have evidence of violence. Cemeteries at Lake Altus in Greer County, Oklahoma, contain 
Plains Woodland or Custer phase burials that include two clear cases of violence. One individual had been shot with an arrow, and a group of five were apparently killed and buried together in a single grave. A double burial at another western Oklahoma site (34RM668) contained dart points as the probable cause of death and is radiocarbon dated to the transitional Archaic period. This burial, which is roughly contemporaneous with the burial at the Sam Wahl site, confirms that intercultural conflicts took place immediately preceding or perhaps early in Palo Duro complex times.

Given the evidence for violence in the Palo Duro and Lake Creek/Plains Woodland culture areas, it may be postulated that these people were engaged in conflicts with each other and/or with other groups. If so, the locations of sites attributed to these complexes should reflect group territories to some extent, although territorial boundaries probably fluctuated through time.

The few Palo Duro components found along the Canadian River (i.e., the South Ridge, the Maintenance Barn, and Fatheree sites) are located well inside the area where Lake Creek occupations are common. Given the possibility of warfare between these cultures, this is somewhat difficult to explain. These sites seem to indicate that Palo Duro peoples ventured into the Canadian River valley, but it is not known if this represents an unusual occurrence or if there may have been consistent overlap and/or fluctuation in the territorial boundary. The presence of occasional brownware sherds in some Lake Creek components could indicate that there was some form of exchange between the two groups.

There are many possible explanations of the relationship between the Palo Duro and Lake Creek (and other Plains Woodland) peoples, and a few of them are offered here: (1) the Palo Duro and Lake Creek peoples were never enemies, their territories overlapped and they interacted frequently, and other groups were responsible for the violence; (2) the Palo Duro and Lake Creek peoples were long-time enemies who came from different cultural traditions, the territorial boundary between them fluctuated, and the Palo Duro culture extended into the Canadian River at some time; (3) the Palo Duro and Lake Creek peoples may have co-existed peacefully for some time, but hostilities developed near the end of the Late Prehistoric I period; or (4) the Palo Duro and Plains Woodland cultural traditions represent many different groups (rather than just two) who interacted with each other in various ways (as allies or enemies) at different times.

The extent of the Palo Duro complex to the east is uncertain. Diagnostic Palo Duro artifacts were not recovered in the surveys and testing at Truscott (Etchieson et al. 1978) and Crowell (Etchieson et al. 1979) Reservoirs, nor have they been reported elsewhere in the Texas Rolling Plains. Thus, it is not certain whether Palo Duro peoples avoided the Rolling Plains or perhaps ventured there occasionally but left behind no diagnostic residue that archeologists have recognized. It does seem unlikely that residential bases would be common in the Rolling Plains. Even if some riverine areas had sufficient fresh water and other resources to support such occupations, these areas would have been isolated oases within a sea of saline water and sparse resources. Being outside their primary territory, such isolated villages would have been much more vulnerable to attack.

It is not known whether the Palo Duro complex extends south into the canyonlands of the upper Colorado River drainage. Little archeological work has been reported immediately south of Lake Alan Henry, but one gets the impression that Deadman'slike points and Mogollon pottery are rare. No pottery or early stemmed arrow points were found during the recent survey and testing at Mitchell Reservoir, but Scallorn-like points indicate that some occupations occurred during Late Prehistoric I times (Lintz, Trierweiler et al. 1991; Quigg, Lintz, Oglesby, Earls et al. 1993). There are insufficient data to indicate whether the upper Colorado River (in Borden, Dawson, Howard, Mitchell, and Scurry Counties) was occupied by Palo Duro peoples. The Big Spring site (Sommer 1971) in Howard County, for example, has produced artifacts similar to those of the Palo Duro complex, but the age of these materials is not certain.

Immediately southeast of the Palo Duro complex is the aceramic Blow Out Mountain complex, but it is possible that the apparent absence of ceramics is due to inadequate archeological sampling. This poorly defined complex appears to be different from the Palo Duro complex in many ways, but the projectile points exhibit some similarities. While no true Deadman's points are reported in the area, the arrow points of the Blow Out Mountain complex include stemmed Bonham-like varieties that look like Deadman's with shorter barbs or without barbs (cf. Creel 1990:Figure 42; 
Wulfkuhle 1986:Figure 132), and they are quite similar to many of the Deadman's-like points found at Palo Duro sites. Not much is known about the Blow Out Mountain complex because the East Levee site (41TG91) is the only site that has been intensively investigated (Creel 1990), except for burials. Thus, it is speculative to comment on the relationship between the Palo Duro and Blow Out Mountain cultures at this time.

As discussed previously, there is considerable evidence for violence in burials of the Blow Out Mountain complex and in culturally unassigned burials south of the Caprock Canyonlands, such as at 41CC237. Perhaps the Palo Duro peoples were engaged in conflicts with peoples to the south and southeast, as well as with groups to the north and northeast. The taking of human jaws as war trophies attests to the intensity of the hostilities, which had perhaps escalated to the point of all-out warfare.

To the west and southwest of the Palo Duro complex are the Middle Pecos and Eastern Jornada Mogollon culture areas. Lying between is a sizable portion of the Llano Estacado which, one would think based on the paucity of published archeological data, was virtually uninhabited. While this perception may be true to an extent, there is evidence that people traversed the Llano using southeastwardflowing drainages as highways, and there is evidence for more-than-ephemeralLate Prehistoric occupations at some large playa and pluvial lakes on the southern Llano. The only well-documented Late Prehistoric playa lake site in the southern Llano Estacado is the Salt Cedar site (Collins 1968). Occupations at this residential base, which currently marks the easternmost edge of the Eastern Jornada Mogollon, are primarily post-A.D. 1100 but may have begun during Late Prehistoric I times.

Based on survey evidence alone, it may be speculated that the Palo Duro complex does extend up onto the eastern edge of the southern Llano Estacado. The possibility that a Palo Duro component may be present in Lynn County has been mentioned, and early stemmed arrow points and Jornada brownware pottery have been found at several playa lake sites in Lubbock County (Brown 1985, 1990a, 1990b, 1991a, 1991b, n.d.). The presence of Palo Duro occupations on the southern Llano has yet to be confirmed through excavations, but it is possible that at least a few components exist around playa and pluvial lakes.

Despite the geographic gap in the regional data, the Palo Duro complex contains definite evidence, in the form of brownware pottery, that there was some transfer of material culture from the Jornada Mogollon area across the southern Llano Estacado and into the Caprock Canyonlands. There also is other circumstantial evidence for cultural interaction and exchange of ideas between Jornada Mogollon and Palo Duro peoples. It is this author's opinion, apparently one that is shared by Brett Cruse (1992) and Jack Hughes (1991), that the interaction between these groups was direct, that the Jornada influence upon the Palo Duro culture was strong and consistent through time, and that it involved much more than just the acquisition of pots.

Pottery constitutes the only direct evidence for influence from the Jornada Mogollon area. Almost all of the potsherds found at Palo Duro sites are generically identified as some variety of Jornada Mogollon brownware. Most are tempered with crushed igneous rocks and are indisputably of nonlocal origin. The varieties that have been identified include Jornada Brown, Alma Plain, El Paso Brown, Roswell Brown, South Pecos Brown, Middle Pecos Micaceous, and McKenzie Brown. All of these wares were manufactured in the Jornada Mogollon or Middle Pecos areas, and very few brownware sherds have been identified as possibly being locally made wares. The consistent presence of small quantities of nonlocal brownwares in Texas sites indicates that Palo Duro peoples did maintain at least periodic contact with Jornada Mogollon peoples over a long period of time. Potsherds are not very abundant, but there are sometimes as many as four vessels represented at a single Palo Duro site. Pottery is sufficiently scarce to indicate that the supply of pots was limited, perhaps because Palo Duro groups did not make journeys to the Jornada region on an annual or regular basis. Perhaps their availability was limited because of the high labor cost involved in transporting large, fragile vessels over long distances on foot. Exactly how the pots made their way into the Panhandle-Plains region is not known. Although intermediary groups could have been involved, the relatively short distance between the Caprock Canyonlands and the Pecos River valley suggests that Palo Duro peoples acquired pots directly from Eastern Jornada groups.

Other evidence for the Palo Duro complex having been influenced by the Jornada Mogollon culture is circumstantial, but strong nonetheless. The architectural similarities between the Palo Duro and 
Eastern Jornada pithouses are particularly intriguing. Various researchers have noted similarities between the Palo Duro pithouses and those of the Jornada Mogollon area while noting the lack of similarities with houses of nearby Plains Woodland and Plains Village complexes (Boyd 1995; Boyd et al. 1994: 116-117, 260; Cruse 1992:127-129; J. Hughes 1991:26). Although rectangular and circular pithouses are found among many cultures and shape alone is not diagnostic, when the combination of traits is considered, the closest architectural parallels are clearly to the west and southwest rather than the north or east. Pithouses in the Jornada Mogollon area exhibit considerable architectural variability, and if the sample of three is any indication, so do the pithouses of the Palo Duro complex.

Rectangular structures, both surface structures and pithouses, are known for Southern Plains Woodland and Village complexes, but they are very different from those at the Kent Creek site (Boyd et al. 1994:116). In contrast, Cruse (1992:127-129) notes that many architectural traits observed for the Kent Creek pithouses are similar to those seen in Jornada Mogollon pithouses. Particularly diagnostic are the ramped entryways, which are a common feature in Jornada pithouses but are not seen in any Plains Woodland or Plains Village houses. Other architectural parallels between Kent Creek and Mogollon pithouses include small trough features/ steps just inside the entryway, comparable variability in interior floor area, the use of a single large roof support post, and the practice of subfloor burials inside houses.

One example shows a striking parallel between Kent Creek and the Jornada area. A rectangular pithouse (Pitroom R-2) excavated at the Merchant site in Lea County, New Mexico, is very similar in size, shape, and entry configuration to Structure 2 at Kent Creek (cf. Leslie 1965:Figure 3 with Cruse 1992:Figures 6 and 10). Unfortunately, there are no radiocarbon dates directly associated with either structure. Leslie's (1965) assessment that the Merchant site dates to the A.D. 1400s is based solely on a few decorated potsherds (which make up only a small percentage of the total ceramic assemblage). Cruse (1992:129) notes that the elongated trough features along the front and back walls of Structure 2 are unique to the Kent Creek pithouses.

Similarly, the ephemeral pithouse at the Sam Wahl site has no analogies in nearby Plains Woodland or Plains Village complexes, but very similar round to oval structures are present in the Keystone Dam area near El Paso (Carmichael 1985:142-149; O'Laughlin 1980:135-149) and at the Fox Place and King Ranch sites near Roswell (Wiseman 1981: 174-175, 1988:229, personal communication 1993). The Keystone Dam structures date earlier (ca. 550 B.C. to A.D. 150) than the Sam Wahl pithouse, while the King Ranch structures are later (ca. A.D. 1150-1300). Unpublished dates for the Fox Place pithouses indicate occupations in the 1200s and 1300s (Regge Wiseman, personal communication 1997). Southwestern pithouse occupations are continually being pushed back earlier in time, and Jornada Mogollon pithouses may prove to be the prototypes for those in the Caprock Canyonlands.

There also are broad similarities in the subsistence strategies and settlement patterns of the Palo Duro and Eastern Jornada peoples. Mesquite and shin oak have been identified as probable staple foods utilized by both groups. Except for a slightly lower rainfall and minor differences in plant and animal communities, the Mescalero Escarpment on the west edge of the Llano Estacado is in many ways similar to the Caprock Escarpment. Consequently, it should not be surprising that human populations adapted to these areas in a similar manner. Leslie (1979) notes that the QuerechoMaljamar phases are characterized by pithouse villages and seasonal campsites, a heavy dependence upon plant foods, the predominant use of oval-basin metates and convex-faced manos, and the dominant use of a variety of corner-notched arrow points.

The same amount of variability in arrow point morphology within the Palo Duro complex is evident in the arrow points of the pithouse period in the Eastern Jornada area (Leslie 1978). The corner- and basal-notched stemmed arrow points of the Palo Duro complex are very similar to, and exhibit the same range of variability as, Leslie's (1978) Types $3 \mathrm{~A}$ through $3 \mathrm{E}$, including occasional serrated blades. These points are associated with Leslie's (1978: Figure 13) Querecho phase, although the dates that he gives for this phase are probably far too young. Jelinek (1967:103-105, 110) also documents a similar variety of points in the Late Archaic through Late 18 Mile phases and notes that serration is most strongly associated with pithouse occupations of the Early 18 Mile through Early Mesita Negra phases (i.e., A.D. 800 to 1100 ).

Similarly, the most common points associated with Blow Out Mountain are a variety of stemmed 
points that do not fit neatly into a single type but are similar to, or typed as, Alba, Bonham, Moran, and Sabinal; blade serration is a common variation. These points are most similar to those of the Palo Duro complex and the Eastern Jornada area (i.e., Type 3D in Leslie 1978). Regardless of the names one assigns to them, there seems to be some morphological continuity between the stemmed arrow points of the Palo Duro and Blow Out Mountain complexes and those of the Eastern Jornada and Middle Pecos areas. While corner-notched dart points (i.e., Ellis-like) used by Late Archaic bison hunters may be the prototypes for ubiquitous Scallorn-like arrow points of the Lake Creek and Palo Duro complexes, the unusual Deadman's arrow points seem to have appeared suddenly and rather early (probably before A.D. 500). There is no precursor evident in Southern Plains Late Archaic points, but it is possible that the prototype for Deadman's points may be found in the Shumla dart points of the Lower Pecos and South Texas. Shumla-like dart points are present, but rare, throughout much of the Jornada area at least as far west as Las Cruces (MacNeish 1993:179). In addition, stemmed and sometimes serrated arrow points found in southern New Mexico, Trans-Pecos Texas, and northern Chihuahua, Mexico, are quite similar to the early stemmed arrow points found in the Caprock Canyonlands and west-central Texas. The Ahumada point, first identified in northern Chihuahua by Krone (1976), extends northward across the Rio Grande and into Trans-Pecos Texas (Prewitt 1995:Figure 2). Although Krone (1976:42) suggests that the Ahumada points date to ca. A.D. $750-900$, this assessment is speculative, and they may well be much earlier. MacNeish (1993: 183-184) found the same style of arrow point, which he named Pendejo, at several rockshelters in southern New Mexico. He suggests that this style is associated with Hueco (Late Archaic) and Mesilla phase deposits and dates from ca. 1000 B.C. to A.D. 500. Consequently, this point style predates, and may well be the prototype for, similar arrow points in the Palo Duro and Blow Out Mountain complexes.

The sudden shift in arrow point styles may signal the adoption of the bow and arrow by indigenous groups, or it may mark the appearance of new peoples in the Caprock Canyonlands (i.e., the Palo Duro complex) and in west-central Texas (i.e., the Blow Out Mountain complex). This author prefers the latter interpretation and suggests that strong evidence for the arrival of new peoples is found in the burials throughout the region. A growing amount of evidence, some definitive and some circumstantial, denotes the formation of territorial boundaries and increasingly widespread violence among many Southern Plains cultures during the first millennium A.D. These events set the stage for the escalating warfare seen during later Plains Village times (Brooks 1994).

If Palo Duro peoples were newcomers to the Caprock Canyonlands some time between A.D. 1 and 500 , where did they come from? Perhaps Krieger (1946:80-82) was on the right track some 50 years ago when he observed that there was virtually no difference in the archeology of the New Mexico and Texas portions of the southern Llano Estacado. $\mathrm{He}$ suggested that the southern High Plains had been "actually inhabited by Puebloans, if only seasonally" (Krieger 1946:80). Given the evidence for cultural influence from the west, one must look to the Jornada Mogollon region (including its eastern extension east of the Pecos River) as the most likely area of origin for peoples of the Palo Duro complex. It is not suggested that Palo Duro peoples were direct lineal descendants of Jornada Mogollon peoples. Although this certainly is one possibility, there is not enough evidence to support such a statement. There is sufficient evidence to suggest that Palo Duro peoples may have been descendants of hunter-gatherers who, having lived in close contact with Jornada Mogollon peoples (in what is now southeastern New Mexico and far western Texas), migrated east- or northeastward onto the Southern Plains.

What became of the Palo Duro complex is equally perplexing. The most logical theory is one that links the Palo Duro complex (and perhaps the Blow Out Mountain complex) with the Toyah phase of Central and South Texas. Shafer (1977) originally proposed that the Toyah culture was derived from Southern Plains bison hunting peoples who migrated southward. Elaborating upon this idea, Lee Johnson (1994:271-281) proposes that the classic Toyah phase retains enough subtle traits, primarily in pottery styles and manufacturing techniques, to link it to the Jornada Mogollon cultural tradition. While much of its material culture represents classic Plains bison hunting gear (i.e., the beveled Harahay skinning knives and Plains-style hafted end scrapers), the pointed-stemmed Perdiz point is distinctive, and 
its logical prototype is found in the stemmed arrow points of the Blow Out Mountain culture. Lee Johnson (1994) suggests that Toyah peoples are descendants of groups who made Jornada Mogollon tradition pottery, slightly modified their stemmed arrow points into the distinctive Perdiz style, and adopted a Plains bison hunting lifestyle. He also suggests that the Mogollon influence may have been indirect and that the earliest Toyah peoples could have come from the Southern Plains rather than from the Jornada Mogollon region.

I would further modify this theory and suggest that the Blow Out Mountain complex may be related to the Palo Duro complex. These manifestations may prove to be northern and southern variants of the same cultural tradition. The stemmed Bonhamlike arrow points that characterize the Blow Out Mountain complex are little more than modified Deadman's points, but the latter represent the earliest narrow-stemmed arrow point form in the Texas Panhandle-Plains. Consequently, the Deadman's point is the logical prototype for the stemmed Blow Out Mountain points and ultimately, if Lee Johnson (1994) is correct, for Perdiz points as well.

One possible scenario is that, as bison populations increased in the Southern Plains around A.D. 1100-1300, peoples of the Palo Duro and Blow Out Mountain complexes quickly adopted a Plains bison hunting lifestyle and material culture and began to migrate southward. This migration may have been spurred, in a domino effect, by pressures from southward-migrating Athapascan-speaking peoples who moved from the Central Plains into the Southern Plains by around A.D. 1300-1400. The wide geographic range and the extreme archeological variability that characterize the Toyah phase may be partially explained if these proto-Toyah peoples spread throughout Central and South Texas within one or two centuries and eventually displaced or assimilated, but adopted traits from, many of the indigenous groups.

\section{Summary of the Palo Duro Complex}

The Palo Duro complex has been redefined in light of recent archeological finds. It dates to the period between A.D. 500 and 1100-1200. A wide range of activities and site functions are inferred for the three types of habitation sites that are recognized. The Kent Creek and Sam Wahl sites are identified as residential bases where people lived in pithouses while procuring, processing, storing, and consuming a wide range of wild plant foods. Mesquite beans and shin oak acorns have been identified as possible staples, but other plants such as goosefoot and buffalo gourds also may have been important foods. Although no cultigens have been found, limited horticulture may have been practiced at residential sites. Occupations at these villages were at least seasonal (i.e., during late summer to fall harvest and into winter) and may have been biseasonal (i.e., during planting and then again during fall harvest and into winter).

Palo Duro peoples lived in rockshelters and open camps at various times of the year and for different reasons. Rockshelters were occupied on a sporadic and ephemeral basis or were used more intensively and may have served as relatively permanent bases. Some campsites were little more than specialized processing sites where baking and grinding of plant foods were the primary activities. Others were multifunctional bases where considerable hunting and processing of animals was done. Deer and small animals appear to have been the principal game animals. Bison were hunted, but they do not appear to have been a major food resource, and the evidence suggests that populations may have been relatively low.

Palo Duro culture is now viewed as representing semisedentary peoples who maintained a high degree of residential mobility in order to exploit a wide range of resources which were locally available and abundant on a seasonal basis. Sites of this complex are found mainly in the Caprock Canyonlands, an ecological subregion that offered the most predictable and widest range of subsistence resources (i.e., water, plants, and animals) within a relatively arid landscape. The home territory for Palo Duro peoples was in the upper drainages of the Red and Brazos Rivers. They may have ranged on occasion north into the Canadian River valley, east into the Rolling Plains, south into the upper Colorado River drainage, and west onto the Llano Estacado.

Human burials provide evidence of widespread violence in and around the Caprock Canyonlands during the Late Prehistoric I period. The Palo Duro culture may have come into periodic contact with enemy peoples to the north and east (i.e., Lake Creek or Plains Woodland groups) and to the south and southeast (i.e., Blow Out Mountain and other undefined groups). Palo Duro peoples did maintain some form of contact with the Jornado Mogollon 
peoples of southeastern New Mexico and western Texas over a long period of time. There appears to be a significant amount of Jornada Mogollon cultural influence across the southern Llano Estacado and into the Caprock Canyonlands. The Palo Duro complex exhibits many traits (e.g., imported brownware pottery and pithouse architectural styles) that were derived, whether directly or indirectly, from the Jornada Mogollon region. In addition, the similari- ties between the subsistence and settlement patterns proposed for the Palo Duro complex and those proposed for their Eastern Jornada Mogollon neighbors may be more than a mere coincidence. It is unclear whether the Palo Duro complex represents an actual migration of Jornada Mogollon or related peoples, or whether it simply represents indigenous Southern Plains people who came under the widespread influence of Jornada Mogollon culture. 



\section{LATE PREHIISTORIC III (A.D. 1100/1200-1541) AND PROTOHISTORIC (A.D. 1541-1750) PERIODS}

by Douglas K. Boyd

\section{INTRODUCTION}

Paleoenvironmental and archeological evidence suggests that changes in subsistence and settlement patterns that occurred during the transition to the Late Prehistoric II period were climate driven, or at least coincided with significant climatic shifts. A brief but intensive regionwide drying trend and significant increases in bison populations are thought to have occurred simultaneously in the Texas Panhandle-Plains around A.D. 1000-1200. While many of the details remain unclear, it seems likely that these factors played key roles in the cultural changes that took place. This interpretation corresponds with other archeological evidence indicating that Native Americans all across the Southern Plains and Southwestern United States underwent dramatic cultural changes around or just before A.D. 1200. Five major concurrent cultural events are prominent in the archeological record: (1) the appearance and widespread adoption of small side-notched arrow points, beveled knives, and Plains-style end scrapers; (2) a shift from Plains Woodland to Plains Village lifestyles that occurred among some local Southern Plains populations; (3) the appearance of immigrant populations of mobile bison hunters in the Panhandle-Plains; (4) the transition from pithouse to pueblo throughout the Southwest; and (5) the development of reciprocal exchange systems between Southern Plains bison hunters (both Plains Village and nomadic groups) and Southwestern agriculturalists.

The sudden appearance of small side-notched (and unnotched triangular) arrow points in the Southern Plains (typeable in Texas as Washita, Harrell, and Fresno) may represent the arrival of new bow and arrow technology that was considerably more efficient for hunting large game on the open plains. Distinctive forms of two- and fourbeveled bifacial knives (also called Harahay knives) and hafted, unifacial Plains-style end scrapers also appeared at approximately the same time. Together, these artifacts represent a specialized bison hunting tool kit (i.e., for killing, skinning, and butchering animals and working hides) that gradually spread from the northwestern Great Plains, southward across the Central Plains, and finally reached the Southern Plains around A.D. 1100 (J. Hughes 1991:30).

Some researchers favor the hypothesis that the side-notched arrow point in the Southern Plains was introduced by Athapaskan-speaking peoples and was derived from the Avonlea complex of the Northern Plains (e.g., J. Hughes 1991:30; Kehoe 1966; Wilcox 1981:222). The Avonlea complex marks the earliest arrival of the bow and arrow on the Great Plains during the first few centuries A.D. If Avonlea is the source, the appearance of side-notched points in the Southern Plains may signal the spread of the technology across cultural boundaries and/or the arrival of immigrant peoples. With respect to the latter hypothesis, it has most often been speculated that this new technology was brought by Athapaskanspeakers who later became known as Apaches. The timing of the arrival of Apachean peoples in the Southern Plains, then, becomes a critical question. Many researchers like the idea of a late arrival early 
in the sixteenth century, just prior to Coronado's entrada (e.g., Gunnerson 1956; Gunnerson and Gunnerson 1971; Perry 1980; Schaafsma 1981; Wilcox 1981). However, Brugge (1981) notes that this is not consistent with the arrival of the sidenotched arrow point complex in the Southern Plains prior to A.D. 1100. He contends that the Apachean peoples (including Navajos) in the Southwest were too numerous and diverse by the time of the first Spanish settlements (i.e., 1598) to have been late arrivals. Brugge (1981:286) suggests that Apachean peoples must have arrived in the Southwest several centuries prior to A.D. 1500 .

Regardless of one's views on ethnicity, it is clear that the side-notched arrow point and related bison hunting technology spread rapidly once it was introduced into the Southern Plains, and it was widely adopted by many indigenous groups. Although this triad of distinctive stone tools is temporally and functionally diagnostic, its adoption by many different cultures across a vast area means that these artifact types are almost useless as cultural indicators. Arrow points similar to, or typeable as, Washita, Harrell, and Fresno are found, for example, among all of the cultural complexes and phases discussed later in this chapter.

The archeological record also indicates that most peoples in the Southern Plains turned their attention to intensive bison hunting sometime between A.D. 1100 and 1300. Many groups gave up their mobile hunter-gatherer ways in favor of a more sedentary village lifestyle that incorporated intensive bison hunting and horticulture. This is evidenced by the development of Plains Village cultures, archeologically recognized as the Antelope Creek phase and Buried City complex in the Texas Panhandle and the Washita River phase in western Oklahoma. These cultures fit the classic model of the Plains Woodland into Plains Villager transition - a cultural evolutionary trend that is evident across most of the Great Plains. An emphasis on bison hunting is a common theme among all Plains Village peoples in the Southern Plains, but their diets were supplemented by "hunting of other game animals, fishing and the collection of shellfish, the collection of wild plant products, and growing of garden crops of various kinds" (Brooks 1989:75). It was the growing and tending of crops that most likely required a shift toward a more sedentary lifestyle. A drying trend that began after A.D. 700 and lasted several centuries has been proposed as the catalyst that initiated the shift from Woodland hunter-gatherers to Plains Village hunter-farmers in western Oklahoma. Drass (1988:84) states that

changes in resource availability resulting from dry conditions in conjunction with an increasingly high population during the Woodland period is suggested as a factor leading to the intensification of horticultural activity and the corresponding change in settlement patterns that mark the transitional period.

Not all of the Late Prehistoric II cultures in the Southern Plains fit the Plains Woodland-to-Plains Village model, however, and some groups never adopted the semisedentary Plains Village lifestyle. The Tierra Blanca and Garza complexes, which appeared in the archeological record by around A.D. 1300 , represent bison hunting peoples who maintained a higher degree of residential mobility. Despite equivocal evidence for these peoples having practiced limited horticulture, it is clear that it was never of sufficient intensity or importance to limit their mobility or other subsistence pursuits. It is likely that the Tierra Blanca and/or Garza complexes represent immigrant cultures into the PanhandlePlains, but where they came from is uncertain. Many researchers have suggested that these complexes represent the remains of nomadic bison hunting peoples who were documented at the time of European contact (e.g., Habicht-Mauche 1992; J. Hughes 1991; E. Johnson 1987; Runkles 1964; Spielmann 1983).

The pithouse-to-pueblo transition that occurred around A.D. 1200 among many peoples in the Southwest reflects increased sedentism and dependence upon agriculture (e.g., Minnis and Redman 1990). While the impetus for these changes is not well understood, it is generally agreed that they occurred quickly and simultaneously over a large area. These socioeconomic changes may have been the end result of increasing population pressures and competition for limited resources. There may also have been external environmental pressures that acted as catalysts to synchronize cultural events on such a widespread scale. A population explosion in the Southern Plains, perhaps exacerbated by the arrival of immigrants, must also be considered as a possible factor that further encouraged sedentism in parts of the Southwest and in the Southern Plains.

Archeological evidence in the Panhandle-Plains 
indicates that Plains Villagers (i.e., the Antelope Creek phase) and nomadic bison hunters (i.e., the Tierra Blanca and Garza complexes) interacted with various Southwestern agriculturalists. Thought to have been in the form of mutually beneficial exchange, these relationships primarily involved the trade of bison products for agricultural produce, although a wide range of products actually changed hands (e.g., Baugh 1991; Creel 1991; Lintz 1991; Spielmann 1983, 1991). Although much of the exchange involved perishable items, the most visible archeological evidence.in the Southern Plains is the abundance and diversity of Southwestern pottery types, along with small amounts of obsidian, turquoise, and Olivella shell beads. Corresponding evidence in the Southwest includes the appearance of Alibates agate and Plains-style artifacts and an increase in bison bones and bison bone tools in the middens of many agricultural villages, such as Pecos Pueblo and Gran Quivera (Spielmann 1982:294-307). The socioeconomic importance of the Plains-Pueblo exchange continued to increase throughout the Late Prehistoric II period. It eventually evolved into a complex network that has been characterized as being an intraregional macroeconomy or an extensive mutualistic exchange system (discussed extensively in Spielmann [ed. 1991]). By the time of European contact, the Panhandle-Plains bison hunting nomads had established themselves as trade intermediaries between Southwestern peoples west of the Llano Estacado and various Caddoan-related Plains Villagers to the east (Baugh 1982, 1986; Spielmann 1982:Figure 16).

Another form that the Plains-Pueblo relationships took, besides trading, was raiding. Ethnographic evidence indicates that conflicts between Plains nomads and sedentary Southwestern agriculturalists were common during the Protohistoric period (Spielmann 1991), but archeological evidence suggests that raiding of Puebloan villages by Plains bison hunters had begun several centuries before European contact. Raiding by enemy groups may have been a key factor leading to the ultimate abandonment of the southeastern Puebloan area (including the Sierra Blanca, Middle Pecos, and Jornada Mogollon regions) during the fourteenth century (Jelinek 1967:162-163; Kelley 1984:156158; Whalen 1980b:446-448). Pressure from hostile nomadic Plains groups also is cited as a primary cause in the demise of the Antelope Creek culture around A.D. 1450 (J. Hughes 1991:33).
The various factors mentioned above are probably responsible, collectively and interactively, for the wide range of sociocultural changes that occurred in the Southern Plains and Southwestern United States between A.D. 1100 and 1541. Climatic changes may have led to increased bison populations, and the appearance of new peoples who introduced moreefficient hunting and processing tools may have heightened the competition for bison hunting territory. Increased human populations probably led to increased sedentism and intensification of agricultural production associated with the Plains Woodland-toVillage and Southwestern pithouse-to-pueblo transitions. The development of reciprocal trade between various Southern Plains bison hunters and Southwestern agriculturalists was a logical response to such dynamic cultural conditions. Ultimately, the development of territorial boundaries and warfare may have been inevitable as increased human population density stretched the carrying capacity of the land to its limits. Although many details are not known, it is clear that Southwestern and Southern Plains peoples experienced substantial social, political, and economic changes during the centuries immediately prior to the coming of Europeans.

Coronado's entrada into what is now the Southwestern United States and Southern Plains in 1541 documented the existence of a well-entrenched system of Plains-Pueblo exchange. His harsh treatment of natives immediately established the precedent for violence and misunderstanding between the European and Native American worlds. The expedition came and went quickly, however, and it was not until after 1598, when the Spanish began to settle permanently along the Rio Grande in what is now northern New Mexico, that the true upheaval of Native American cultures began. The social changes that occurred among Native American peoples during more than 100 centuries of prehistoric occupation in North America are dwarfed by the magnitude of the changes that occurred to these cultures over the three centuries following European contact.

The Protohistoric period in the Southern Plains is particularly hard to define because the gradual process of European acculturation does not segment neatly into calendar years and archeological/cultural units over such a vast area. Not all groups experienced the same degree of influence at the same time, and archival records documenting European contact with Southern Plains peoples are woefully inadequate. Consequently, archeologists and culture 
historians must set rather arbitrary boundaries for the elusive Protohistoric period. Technically, the period should begin with the first contact made by the Coronado Expedition in 1541, when European items and ideas were first introduced to Native peoples on the Great Plains. More realistically, however, the Spanish presence in the Southwest did not have a serious impact until after 1598 when Spaniards became permanently established in New Mexico. By 1650 , European goods were regularly making their way into the Southern Plains through the PlainsPueblo trade. Metal knives, firearms, and horses were of particular importance to the Plains peoples, and bison hides were of great value to the Pueblo Indians and to the Spaniards, who became directly and indirectly involved in various aspects of the trade (e.g., Creel 1991; Kessell 1987; Spielmann 1991). It is likely that most Southern Plains groups made the transition to an equestrian lifestyle by around 1700, and those that had not were at a decided disadvantage (Secoy 1953; Worcester 1944). Between 1541 and ca. 1700, various Southern Plains native peoples (mainly Apaches, but also other groups such as Teyas and Jumanos) had only limited access to European goods. Coronado introduced some European material culture to the Southern Plains, but seventeenth-century Plains peoples obtained items either through indirect trade with other native peoples or by journeying long distances to obtain them directly from Spanish/Puebloan sources (i.e., mission-pueblos). Shortly thereafter, the French trade with the Caddo and Wichita nations (Perttula 1992:150) began to have an impact on the availability of European goods and technology in east Texas and, indirectly, in the Southern Plains. A date of 1750 is used to mark the end of the Protohistoric period and the beginning of the Historic period primarily because there were significant changes in the Panhandle-Plains between about 1720 and 1750. During this time, the fully equestrian Comanches arrived. They quickly displaced all of the prior occupants and established relatively unrestricted access to European goods, via the French trade, through their 1746-1747 alliance with the Wichita on the Red River (Newcomb 1961:249; Wallace and Hoebel 1952:288; Weddle 1964:22). Consequently, it was not until after A.D. 1750 that European goods become common in Native American society in the Texas Panhandle-Plains.

The Protohistoric period on the Southern Plains was, from a sociocultural perspective, a dynamic one. The trade-and-raid relationships between various Plains and Pueblo peoples intensified during this time, as did the direct and often violent contact between European and Native American cultures. From an archeological perspective, the Protohistoric period is a confusing one. Recognizing the degree of European acculturation represented in individual Native American archeological sites is a formidable task, and ethnohistoric records are replete with accounts mentioning hundreds of specific names for various Native American tribes, bands, clans, etc. In his summary of Southern Plains Protohistoric culture history, Hofman (1989b:91) states that

The rapidity of economic and technological changes during the period between A.D. 1550 and 1800 has presented keen problems for interpreting the "traditions" of cultural groups via the archeological record. ... It is especially difficult to convincingly assign particular assemblages of this age to specific cultural groups, even though this is a problem which has received considerable archeological and ethnohistorical attention.

The subjects of ethnicity and intercultural relationships are intertwined in the discussions throughout the remainder of this chapter because they cannot be overlooked when considering Late Prehistoric II and Protohistoric archeological remains in the Southern Plains. Interpreting the data is made more problematic because, far from being a simple static arrangement, intersocietal exchange involved a series of dynamic and continually changing relationships between many different peoples. The Garza and Tierra Blanca complexes, whose core areas are the southern and northern portions of the Caprock Canyonlands, respectively, are particularly important cultural groups in the contexts of Plains-Pueblo exchange and ethnic identity. These peoples appeared in the archeological record during the Late Prehistoric II period, and they became key players in the intensive commerce between the Southern Plains and Pueblo worlds in the centuries following European contact. To fully appreciate the complexity of the situation, a brief summary of the historical development and theoretical views of Plains-Pueblo interactions is necessary.

\section{OVERVIEW OF PLAINS-PUEBLO EXCHANGE}

Following Krieger's (1946) lead, Wilcox 
(1991:144-145) has identified three phases in the evolution of Plains-Pueblo exchange. The first phase, called the "late prehistoric period," is between A.D. 1250 and 1450 . Archeological data for this time period indicate that there are two distinct geographic zones where Plains-Pueblo exchange occurred. In the Texas Panhandle, Glaze A ceramics in Antelope Creek phase sites indicate trade with the Rio Grande pueblos. In contrast, Wilcox (1991) notes that ephemeral sites on the southern Llano Estacado commonly produce late Jornada Brownwares, El Paso Polychrome, and Chupadero Blackon-white pottery, providing evidence of trade with southern Puebloans (e.g., Gran Quivira, Middle Pecos, Sierra Blanca, and/or the Jornada Mogollon area). The archeological data are interpreted as evidence that two separate Late Prehistoric exchange systems were in operation.

While this assessment is essentially correct, it may be misleading to suggest that the peoples inhabiting the southern Llano Estacado during this time were simple hunter-gatherers who generated only ephemeral sites that contain a few temporally diagnostic tradewares. Most of the sites that contain significant amounts of Southwestern trade wares that date to this time period are concentrated around large playa and pluvial lakes on the southern Llano Estacado. Our understanding of these sites is very poor, and little scientific research has been done. As discussed later, there is a whole range of Late Prehistoric II archeological remains that may represent an undefined cultural complex(es) on the southern Llano Estacado, or perhaps be a further extension of the Eastern Jornada Mogollon area. Many of these pottery-producing sites may well represent semipermanent villages where bison hunting and horticulture were primary subsistence activities. It is postulated later that the southern Llano Estacado experienced a sudden increase in population between A.D. 1200 and 1500, perhaps even an influx of immigrants who had abandoned their former southeastern Puebloan or Palo Duro complex homelands in favor of bison hunting. If this hypothesis proves to be true, it would change how one views the nature of the Late Prehistoric Plains-Pueblo interaction on the southern Llano.

The second phase of Plains-Pueblo exchange identified by Wilcox (1991) is the "early protohistoric period" between A.D. 1450 and 1600 . It begins at A.D. 1450 because this is when many of the key players in the Late Prehistoric exchange disappeared from the archeological record. The Jornada Mogollon, Antelope Creek, Sierra Blanca, and Middle Pecos regions were simultaneously abandoned at about this time (Jelinek 1967; Kelley 1984; Lintz 1986; Whalen 1980b). The subsequent peoples inhabiting these areas, who may have included new immigrants and/or descendants of these agricultural villagers, were mobile foragers who specialized in bison hunting. As some Puebloan areas declined in prominence, others stepped in to fill the empty niches and serve as trading partners with the Plains bison hunters. The principal Southwestern pueblos and pueblo regions that became involved in the Plains-Pueblo trade after ca. A.D. 1450 were, from north to south, Taos/Picuris, Pecos Pueblo, the Galisteo Basin, and Gran Quivira (Spielmann 1982:Figure 16). Noting that individual pueblos or groups of pueblos operated as independent polities, Wilcox (1991:152) suggests that they competed with each other for alliances with various groups of Plains traders. There is evidence that changing alliances between various Plains and Pueblo entities were the cause of serious conflicts, including the ca. 1525 attacks on Pecos Pueblo and various Galisteo Basin pueblos by the Plains Teyas (Castañeda 1904:104; Hammond and Rey 1940:257-258), who may have been Caddoan peoples. One probable scenario is that the appearance of Apachean groups may have disrupted the Teya-Pueblo trade alliances, leading to retaliations by the Teyas (Baugh 1991: 121; Boyd et al. 1993:257; Wilcox 1981:227, 1991:152).

Wilcox (1991:145) notes that the intensity of the exchange continued to increase throughout the early protohistoric period and suggests that by the "late protohistoric period," A.D. 1600-1700, the system had developed into an extensive "PuebloSouthern Plains-Wichita-Caddoan macroeconomy." Various Plains peoples, principally the Apaches, Teyas, and/or Jumanos, became the middlemen in this vast exchange network, and annual trade fairs were held at various Puebloan and Caddoan villages. The Tierra Blanca and Garza complexes are particularly important in this regard and have been suggested as likely candidates for being Apachean and/or Teya/Jumano peoples (Baugh 1982, 1991; Boyd et al. 1993:260-270; Habicht-Mauche 1992; Hickerson 1994:228-229; J. Hughes 1991:36; Spielmann 1982, 1983). Many problems are encountered, however, when attempting to link these archeological complexes with the confusing and 
sometimes contradictory array of ethnographic accounts and ethnic groups.

The evolution of Plains-Pueblo interactions is an important research avenue for explaining the nature of the societies involved (Spielmann, ed. 1991:1-17). It seems that the relationships between the Plains Villagers (i.e., Antelope Creek phase) and Puebloan peoples may have been in the form of redundant exchange that served as a buffering mechanism to minimize the risks of environmental stresses for both groups (Lintz 1991). It has been proposed that subsequent interactions between nomadic Plains bison hunters and Puebloan peoples not only were much more intensive, but they may have been in the form of mutualistic exchange (Spielmann 1982, 1983). Mutualism, involving the production and exchange of complementary resources from different ecological zones, provided economic and nutritional benefits for the agriculturalists and bison hunters alike. Spielmann (ed. 1991:10) suggests that this "meat for corn" scenario is the key to understanding the relationship that developed between the hunters and farmers. Speth and Spielmann (1983) and Speth (1991) have suggested that the participants may have become so specialized in the harvesting and control of complementary foodstuffs that the societies became dependent upon the exchange system in order to meet nutritional needs. Speth (1991:34) notes that this dietary dependence upon traded foods may have intensified as Plains peoples adopted a fully equestrian lifestyle and gained more-complete control of bison hunting ranges.

The "buffering" and "mutualism" models are both variations of an ecological approach to interpreting intersocietal exchange between nonhierarchical societies (Spielmann, ed. 1991:4-5). Both of these models assume that the exchange of foods was of paramount importance. Baugh (1982, 1984, 1991), on the other hand, takes a different approach. Although he acknowledges that the trade involved the exchange of complementary staple resources from different ecological zones, Baugh puts somewhat less emphasis on the ecological conditions and economics of the exchange and more on sociocultural variables and dynamics. Using Wallerstein's (1974, 1979) World Systems Theory, Baugh (1991:122) contends that protohistoric Puebloan, Apachean, and Plains Caddoan peoples interacted within the context of an extensive and complex "Southern Plains Macroeconomy." The system would have been driven more by the desire to maintain social and economic ties than by dietary dependence upon trade for obtaining subsistence resources.

Most researchers would agree with Spielmann's (ed. 1991:15) assessment that "the evolution of Plains-Pueblo interaction is the result of a dynamic interplay between ecological and historical factors." Most researchers also seem to agree with the general concept that the interactions evolved into a mutualistic meat-for-corn exchange. However, there is much less agreement on the nature and details of the exchange systems or the ecological, economic, or social factors that acted as driving mechanisms. The picture becomes even more complex when one shifts from theory to the archeological data.

The most notable similarity between all of these theoretical perspectives is that they assume that the trade in perishable foodstuffs was of considerable importance. This interpretation seems well supported by a wealth of ethnohistoric data. Unfortunately, such resources are seldom preserved in the archeological record, and archeologists must reconstruct exchange systems based primarily on nonperishable items that may have been important, yet peripheral, components of the trade. For example, Vehik (1990) argues that the geographic and temporal distribution of archeological occurrences of FlorenceA chert (relative to its limited source area in northcentral Oklahoma and south-central Kansas) and Alibates agate (relative to its primary and secondary sources in the Canadian River valley) are evidence of a high degree of economic specialization in the Late Prehistoric trade in the Southern Plains. In the summaries of Late Prehistoric II and Protohistoric cultures that follow, the archeological evidence for interpreting intercultural relationships is discussed. Much of this evidence relates to the role that these cultures played within the context of Plains-Pueblo interactions. Other evidence suggests that intersocietal warfare between various Plains peoples, and often involving Puebloan peoples, may also have played a significant role in the Late Prehistoric II and Protohistoric culture history of the Southern Plains.

\section{LATE PREHISTORIC II CULTURAL COMPLEXES AND PHASES}

The Late Prehistoric II cultural manifestations discussed in this section are ones that seemingly begin and end entirely within this time period, 
between A.D. 1100 and 1541 (Figure 94). The manifestations relevant to this period are Antelope Creek phase, Buried City complex, Washita River phase, Zimms complex, McKenzie phase of the Middle Pecos, and the late Maljamar and Ochoa phases of the Eastern Jornada Mogollon region (Figure 95). An ill-defined post-Palo Duro phenomenon in the Caprock Canyonlands also is discussed, but its significance is not known. Archeological sites discussed in the text are listed in Table 80 .

\section{Antelope Creek Phase}

It has been proposed that the indigenous Plains Woodland tradition peoples in the Texas Panhandle gradually evolved into Plains Village peoples (e.g., Gustafson 1994a, 1994b; Lintz 1986:226-236), but this remains to be convincingly demonstrated. Jack Hughes (1991:33) suggests that

the Antelope Creek focus in the Texas Panhandle may have been rooted in the Lake Creek complex, just as Village cultures elsewhere in the Plains seem to have evolved out of local Woodland cultures. In the Panhandle, however, the development may have received some special stimuli, at first from the Mogollon, and later from Anasazi sources.

Using McKern's (1939) Midwestern Taxonomic System, Krieger (1946) originally proposed the Antelope Creek focus of the Panhandle aspect to account for the Plains Village sites found along the Canadian River in the Texas Panhandle. Lintz (1986) redefined the Panhandle aspect, using the Willey and Phillips (1958) taxonomic system, as the Upper Canark Variant, so named for the area encompassed by the upper drainages of the Canadian and Arkansas Rivers (also see Lintz 1982, 1984). Within the Upper Canark Variant, Lintz (1986) recognized two regional variations, the Antelope Creek phase of the northern Texas Panhandle and the Apishipa phase of southern Colorado. Hughes and Hughes-Jones (1987) have defined a third regional Plains Village variation as the Buried City complex (discussed below). The Antelope Creek phase generally dates between A.D. 1200 and 1500 .

As discussed by Lintz (1986) and J. Hughes (1991), the Antelope Creek phase had a huntinggathering-horticultural economy. A wide variety of subsistence resources was procured on a seasonal basis; but bison were the principal game animal, and corn, beans, and squash were cultivated. Bone chemistry studies of burial populations have been done, but the relative dietary importance of these resources is not known (Habicht-Mauche et al. 1994:301). Antelope Creek site types include villages/hamlets, farmsteads, field huts, campsites and lithic scatters where no structures are evident, and occasional bison kill/processing sites. Considerable architectural variability is evident, but the principal dwelling was a large, rectangular, semisubterranean house with vertical slabs of dolomite used to line the lower walls (hence the common descriptive name, "slab houses"). Borger Cordmarked pottery, made locally and generally tempered with crushed quartzitic rocks (probably Ogallala quartzite pebbles that were fractured by use as hearthstones or boiling stones), is common in most village sites. Other characteristic artifacts include bison hunting tools (Washita, Harrell, and Fresno points; beveled knives; and highly formalized end scrapers) and a wide range of other chipped and ground stone tools. Bison bones are generally abundant, and they were often used to manufacture horticultural tools such as scapula hoes, squash knives, and tibia digging sticks.

The heart of the Antelope Creek territory was in the Canadian River valley in the central portion of the Texas Panhandle. Not coincidentally, this core area includes the famous Alibates Flint Quarries, and Antelope Creek villagers apparently enjoyed exclusive control of this important resource. Hundreds of quarry pits denote intensive exploitation of the distinctive multicolored, banded agate. Most of the quarry pits are attributed to Antelope Creek peoples because Alibates agate is ubiquitous in their sites and was traded widely during Late Prehistoric II times.

Antelope Creek materials are not common south of the Canadian River, but a few sites are known in the northern Caprock Canyonlands. Although the evidence at the Greenbelt site in Donley County seems to represent transitional Plains Woodland to Plains Village occupations (see Chapter 10), a significant portion of the material culture is attributed to the Antelope Creek phase (Campbell 1983). Pithouse structures are present, but they do not exhibit typical Antelope Creek slab architecture, and they have not been radiocarbon dated. Based primarily on the presence of Borger Cordmarked sherds and slab house remains, the Antelope Creek phase is thought to have extended southward along 


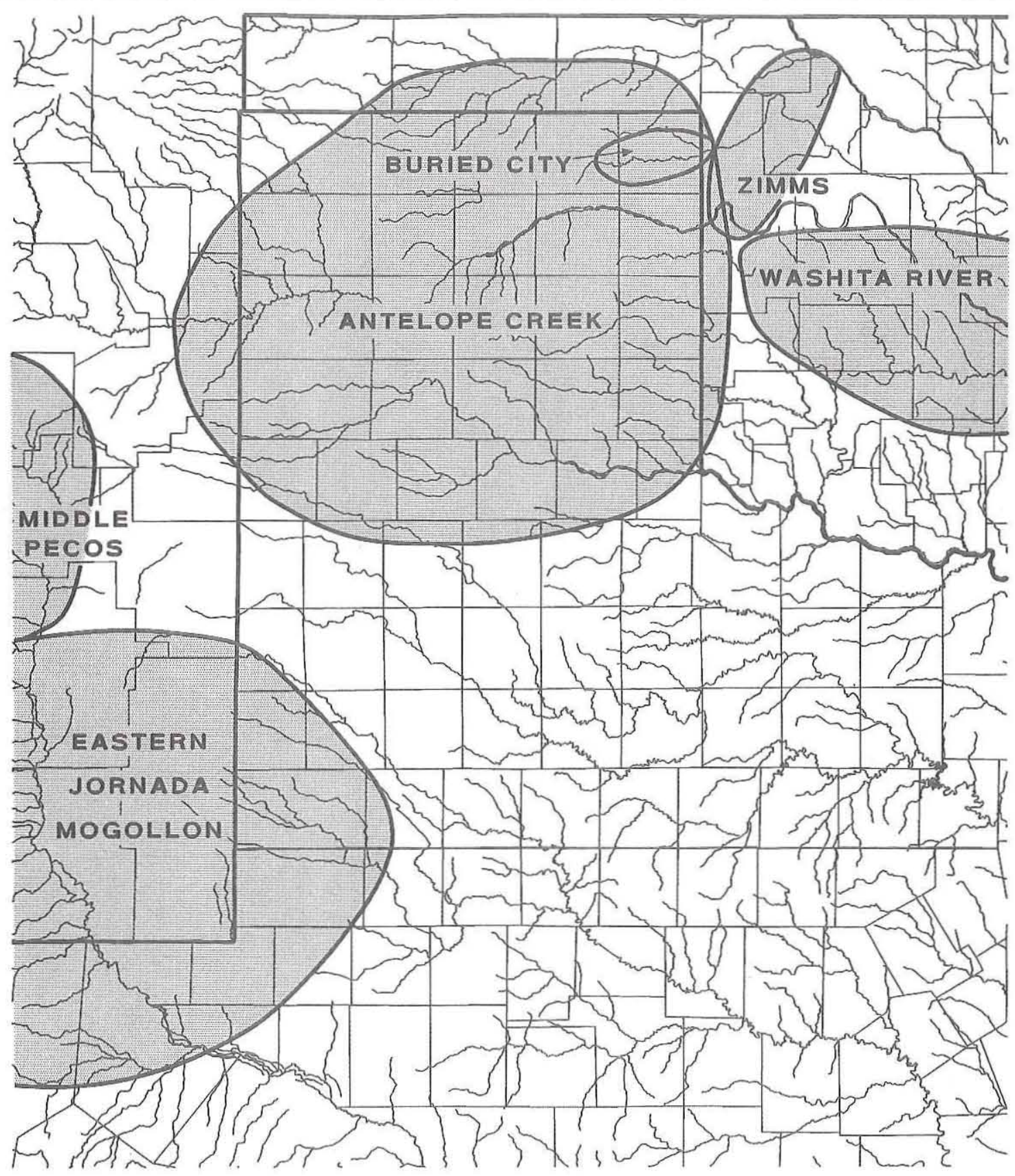

LEGEND

Cultural Complexes/Phases

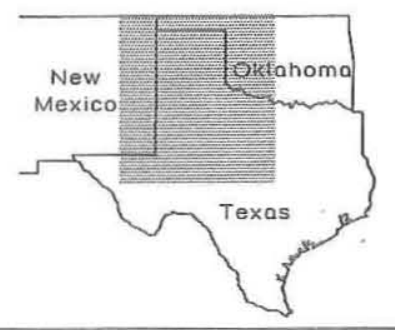

Figure 94. Map of Late Prehistoric II cultural complexes and phases in the Texas Panhandle-Plains and surrounding areas. 


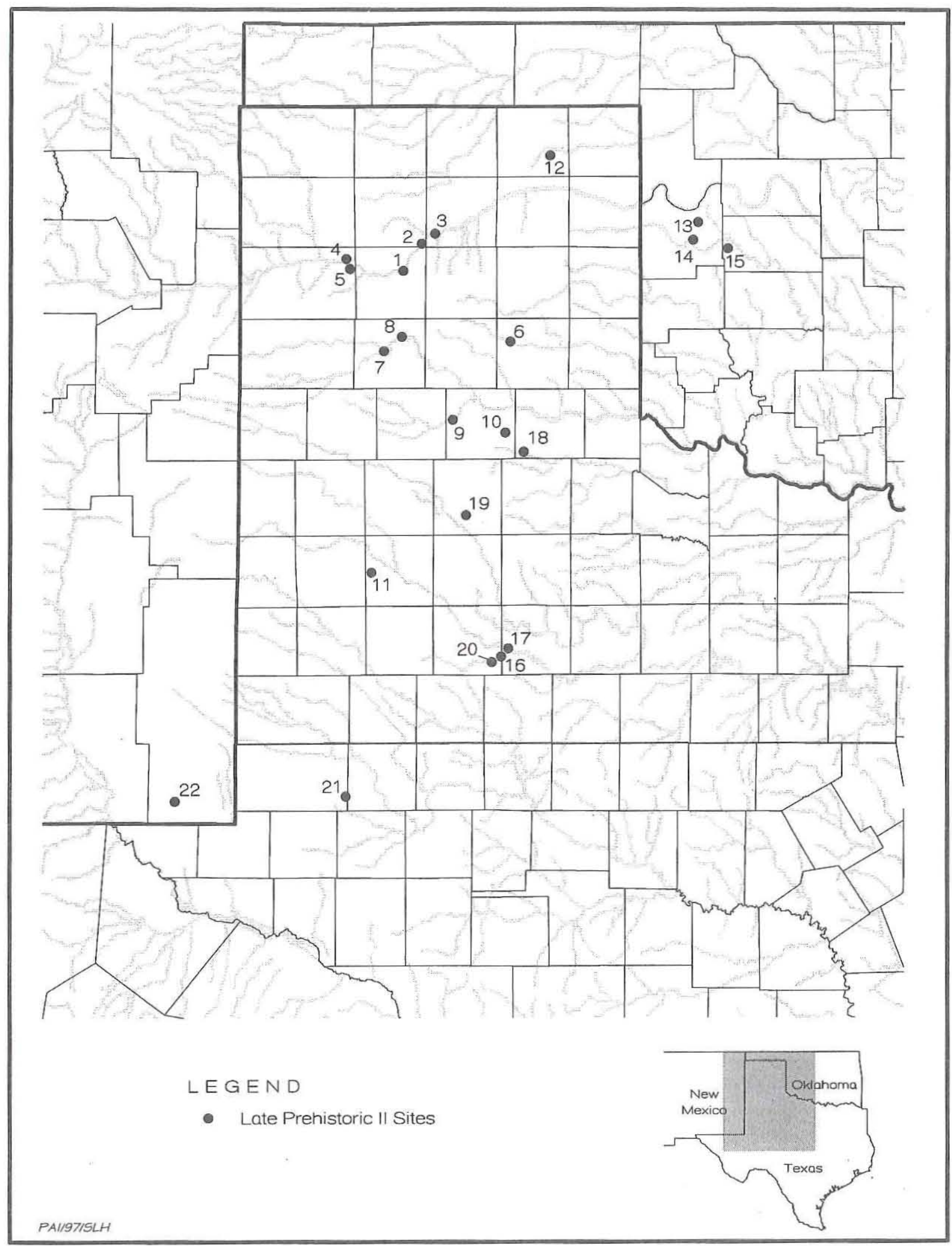

Figure 95. Map of Late Prehistoric II sites discussed in the text. 
TABLE 80

SELECTED LATE PREHISTORIC II SITES IN AND AROUND THE TEXAS PANHANDLE-PLAINS

\begin{tabular}{|c|l|l|}
\hline $\begin{array}{l}\text { Key to } \\
\text { Figure 95 }\end{array}$ & Site Name (Number) & Reference \\
\hline 1 & Footprint (41PT25) & Green 1986; Lintz 1986 \\
2 & Big Blue (PPHM-A678) & Lintz 1986 \\
3 & Tar Box (41HC2) & Lintz 1986 \\
4 & Tascosa Creek (PPHM-A2060) & Couzzourt 1985, 1988 \\
5 & Maintenance Barn (PPHM-A1543) & Couzzourt 1982 \\
6 & Greenbelt (41DY17) & Campbell 1983 \\
7 & Canyon City Club Cave (PPHM-A251) & Hughes 1969 \\
8 & Palisades (PPHM-A530) & Hughes 1978 \\
9 & Tule Canyon site 41BI20 & Malone 1970 \\
10 & Red Butte sites 41B1237/238 & Etchieson et al. 1977 \\
11 & SPAS-LU29 & Brown 1985 \\
12 & Handley Ruins (41OC1) & Lintz 1986; Hughes and Hughes-Jones 1987 \\
13 & Zimms (34RM72) & Drass and Moore 1987 \\
14 & Wickham \#3 (34RM29) & Wallis 1984 \\
15 & Heerwald (34CU27) & Shaeffer 1965 \\
16 & Reed Shelter (41GR54) & Riggs 1965a \\
17 & South Sage Creek (41KT33) & Boyd et al. 1992; this volume \\
18 & Kent Creek (41HL66) & Cruse 1992 \\
19 & Floydada Country Club (41FL1) & Word 1963, 1991a \\
20 & Sam Wahl (41GR292), late occupation & Boyd et al. 1994; this volume \\
21 & Salt Cedar (41AD2) & Collins 1968 \\
22 & Merchant (LCAS-E4) & Leslie 1965 \\
\hline
\end{tabular}

the Caprock Escarpment as far as the Red River drainage. Hughes (1969) reports an ephemeral Antelope Creek component at the Canyon City Club Cave in Randall County. Hughes (1978:43-44) notes several other Antelope Creek components, including a burial, in the Palo Duro Canyon area. The unreported excavation of a slab house in the Palisades, a commercial development just southeast of Amarillo, is the southernmost confirmed Antelope Creek structure. However, various researchers (Hughes 1978:43; Hughes and Willey 1978:30; Lintz 1986:30, Figure 1; Malone 1970:29-30) note that a site producing Borger Cordmarked pottery in Tule Canyon (41BI20, or PPHM-739) also contains possible slab house ruins and probably represents the southernmost occurrence of an Antelope Creek village. Etchieson et al. (1977:24-29, 71) recorded a probable Antelope Creek phase campsite (41BI238) and bison jump (41BI237) at Red Butte in Caprock Canyons State Park. The southerly distribution of Antelope Creek phase sites seems to mirror the southerly extent of their Woodland predecessors (i.e., sites of the Lake Creek complex).
Lintz (1991) has summarized the evidence for Texas Panhandle-Pueblo exchange for the period between A.D. 1200 and 1500 and notes that the Antelope Creek peoples were major participants in the interregional exchange. Antelope Creek phase sites have produced 19 Puebloan pottery types identified as having been manufactured in the northern Rio Grande pueblos (12 types represented at 11 sites), western pueblos (5 types represented at 4 sites), and southern pueblos (2 types represented at 3 sites) (see also Perttula and Lintz 1995). Most of the types are widespread in the Southwest, and Lintz (1991:95) suggests that the majority of these wares could have been obtained through trade with specific northern gateway pueblos (e.g., at Pecos Pueblo or in the Galisteo Basin). In addition, it is possible that Antelope Creek peoples obtained the southern Puebloan wares directly from villages of Jornada Mogollon origin/tradition peoples on the southern Llano Estacado. Borger Cordmarked sherds have been reported in surface collections from a small playa site in Lubbock County (SPAS-LU29), in association with Washita and Harrell arrow points 
and pottery identified as Jornada Brown, Chupadero Black-on-white, and Playas Red Incised (Brown 1985). If the cordmarked sherds have not been misidentified (noting the possibility that they could be a Puebloan corrugated ware), they represent the most southerly occurrence of the Borger type and suggest that Antelope Creek peoples ranged well into the southern Llano, perhaps to hunt bison and/or trade.

At least two sites - Tascosa Creek and Maintenance Barn-have yielded information relevant to understanding possible cultural interactions between Antelope Creek and Jornada Mogollon tradition peoples. An upper component at the Maintenance Barn site (PPHM-A1543) contains typical Antelope Creek phase materials (i.e., Borger Cordmarked pottery and side-notched arrow points), but it is also contains some brownware pottery identified (by Jack Hedrick) as Roswell Brown, Jornada Brown, and Middle Pecos Micaceous Brown (Couzzourt 1982). The Tascosa Creek site (PPHM-A2060), which has been suggested to be a good candidate for a transitional Woodland to Antelope Creek phase site, also has produced Mogollon brownware sherds (Couzzourt 1985, 1988). Although it is not well defined because it is mixed with earlier Woodland materials, the late component includes many typical Antelope Creek materials, but all of the pottery is Jornada tradition brownwares rather than Borger Cordmarked. The sherds have been identified (by Jack Hedrick) as Jornada Brown, Middle Pecos Micaceous Brown, McKenzie Brown, and an unidentified brownware of possible local manufacture. A thermoluminescence date of A.D. 1350-1450 was obtained on a Tascosa Creek sherd of Middle Pecos Micaceous Brown, a ware that was manufactured in the middle Pecos area from ca. A.D. 900 to at least A.D. 1250 (Jelinek 1967:Figure 9). Perhaps not coincidentally, middle Pecos peoples may have moved out onto the Southern High Plains to hunt bison between A.D. 1200 and 1350 (Jelinek 1967:154-156). Couzzourt (1988) suggests that the brownwares may have been obtained in trade or that middle Pecos peoples may have lived among the Antelope Creek peoples at that time. Gustafson (1994b) also reports that brownware pottery was recovered at the Duncan Ranch Site 1 in Hutchinson County.

Other nonperishable items found at Antelope Creek phase sites that come from the Puebloan world include obsidian (which is abundant at some sites, and some samples have been sourced to
Obsidian Ridge in the Jemez Mountains), turquoise beads and pendants, marine shell disc beads, Olivella shell beads, Conus shell tinklers, conch shell gorgets, and clay and stone tubular pipes. The Antelope Creek peoples presumably gave bison hides, dried meat, bois de arc (i.e., bow wood), salt, tobacco, and foodstuffs in exchange. Alibates agate probably also was traded to some extent, and Vehik (1990) proposes that the control of this resource was of considerable importance. In addition to the Puebloan items mentioned above, Antelope Creek peoples may well have obtained many perishable trade items such as cotton textiles and agricultural foodstuffs.

Lintz (1991) notes a marked increase in the intensity of the exchange through time. The Late Antelope Creek subphase (A.D. 1350-1500) is characterized by a much greater quantity and diversity of Puebloan artifacts and more abundant faunal remains. This is interpreted as evidence that Late subphase peoples increased their hunting range and activities concurrent with intensifying trading activities. Because many of the traded products were redundant in that similar products were already produced by each group, Lintz (1991:105) concludes that this intersocietal exchange "began as an environmental buffering strategy among sedentary groups with similar economies" and suggests that the exchange "evolved into a system of economic mutualism involving critical complementaryresources during the protohistoric period." Perhaps more correct is the idea, discussed below, that the redundant Antelope Creek-Pueblo exchange did not actually evolve into, but rather was replaced by, the mutualistic exchange between Plains bison-hunting nomads and sedentary Puebloan peoples.

There is ample evidence that intercultural warfare played a role in Antelope Creek society. Brooks (1994) concludes that violent conflicts were widespread in the Southern Plains during Late Prehistoric II times, particularly in the Antelope Creek phase, and to a lesser extent in the Zimms complex and Washita River phase. For the Antelope Creek phase, Brooks (1994:320) cites burned structures, defensive outposts on the eastern and western peripheries, combat-related injuries, and mutilation and decapitation as evidence of intensive warfare. Lintz (1986:248-251) notes indirect evidence for violence at numerous sites, and direct evidence has been found at several Antelope Creek phase sites. Occurrences of arrow points associated with skeletal 
remains as the probable cause of death are noted at the Big Blue Cemetery site, and a trophy skull was interred with a child burial at the Tarbox site (Bovee and Owsley 1994:Table 1; Lintz 1986:251). The most notable find is at the Footprint site (Green 1986), where the mutilated skeletal remains of as many as 32 individuals were found scattered on the floor and inside three subfloor pits within a burned structure. Lintz (1986:165-170, 251, Figure 25) interprets these as remains of Antelope Creek villagers who were killed during a raid. One of the subfloor pits contained 10 adult male skulls that may have been taken as war trophies. Lintz (1986:251) proposes that they represent enemies slain during a retaliatory raid by Antelope Creek peoples. Although the samples are small, Bovee and Owsley (1994:360) note that these crania are more closely affiliated with Washita River phase burial populations than with any Antelope Creek populations.

Brooks (1994:320) states that "the Antelope Creek phase represents the only case where both archaeological and bioarchaeological data support a context for moderate to large-scale conflict." The timing and nature of the conflicts are still in question. Antelope Creek peoples may have engaged in cultural conflicts throughout the existence of their society, but there is circumstantial evidence (e.g., the appearance of defensive lookouts and village fortification) that the intensity of violence increased through time. Antelope Creek villages may have come under intensive pressure from enemy raiding by A.D. 1400 . The enemy groups may have included Plains Village cultures, perhaps even former allies, but most researchers suggest that the appearance of Apache peoples was the cause for the increase in violence. J. Hughes (1991:33) suggests that the late Antelope Creek phase represents the last holdout of Caddoan peoples on the High Plains. Whatever pressures were involved, wholesale abandonment of their villages occurred between A.D. 1450 and 1500 . Antelope Creek peoples may have ultimately joined other Plains Caddoan relatives in fortified villages on the Arkansas and Platte Rivers (Hughes 1968).

\section{Buried City Complex}

Recent research in the Wolf Creek valley of the northeastern Texas Panhandle has led to the definition of the Buried City Complex by Hughes and Hughes-Jones (1987). While the complex is obviously related to the Antelope Creek phase, it is distinctive and warrants designation as a regional Plains Village variation.

The Buried City complex consists of numerous residential sites with architectural remains within an 8-km stretch of the Wolf Creek valley. David Hughes (1991:142-144) attributes the high site density to the fact that the Wolf Creek valley offered prehistoric residents abundant water from Ogallala springs, an abundance of wood and other riverine resources, and broad alluvial terraces suitable for farming. Bison herds on the High Plains also would have been easily accessible. The only other location in the Texas Panhandle that appears to have a comparable density of village sites is the core area of the Antelope Creek phase in the vicinity of Lake Meredith.

The Buried City complex is contemporaneous with the Antelope Creek phase, and both represent bison hunter-gatherers who also practiced horticulture. Material cultural assemblages and features are similar overall, but the primary differences are in architectural details and pottery. Compared to the Antelope Creek phase, the Buried City complex appears to have been less influenced by Southwestern cultures. Brooks (1989:83) suggests that the subterranean houses of the Buried City complex, which used caliche boulders as foundations rather than as vertical wall slabs, were similar to Apishipa phase architecture of southeastern Colorado. The Buried City pottery is particularly intriguing and is characterized by "chevron-incised plain and cordmarked wares" which exhibit considerable diversity in rim form and decoration, including "crenelated, filleted, pinched, gouged, incised, punctated, and fluted rims" (D. Hughes 1991:144). Strap handles and fabric- and corncob-impressed surfaces also are represented. Stylistically, this pottery is more closely akin to various Upper Republican pottery types in Kansas than to any Texas or Oklahoma types (Brooks 1989:84; D. Hughes 1991:144; Hughes and Hughes-Jones 1987:106). The Buried City ceramics are "thick, poorly fired, ... . and tempered with fine to very fine quartz sand" in contrast to the thin, hard, crushed rock-tempered wares of the Antelope Creek phase (D. Hughes 1991:143-144).

Buried City peoples utilized Alibates agate derived from Canadian River gravels rather than from the flint quarries, suggesting that their interaction with Antelope Creek peoples may have been minimal. Geographically, the Wolf Creek valley was as close to other Plains Village groups in 
Oklahoma and Kansas as it was to the core area of the Antelope Creek phase. Thus, it is not surprising that the Buried City complex exhibits evidence of cultural influence/interaction from the north and east.

There is only one case of direct evidence of violence within the Buried City complex, but two additional finds are suspect. In addition to burned structures, an arrow point embedded in a human bone was found at the Handley Ruin (41OC1) (Lintz 1986:247). At the Courson A site (410C27), an adult female was buried under a rock cairn inside an abandoned slab house. The cairn was constructed of rocks salvaged from the house at the time it was abandoned (an associated bone radiocarbon date is thought to have been contaminated). Because of the unusual position of the body, Hughes and HughesJones $(1987: 88,113)$ speculate that trauma/violence may have been involved. In addition, a mass burial of five individuals occurred inside a house at the Courson B site (410C28). The grave was covered by a large pile of rocks that had been robbed from the walls of at least two houses. The interment postdates A.D. 1350 and was approximately contemporaneous with the abandonment of one or both of the houses (Hughes and Hughes-Jones 1987:94, 96-97, 104). Although no definite evidence for violence was found, David Hughes (personal communication 1994) suggests that the unusual composition of the group (three adult females, a juvenile male, and a child) and the fact that it is a mass burial are suspect. He proposes that the grave may well represent a single episode of conflict that occurred late in the Plains Village occupational history of the Wolf Creek valley.

The Buried City complex seems to have disappeared suddenly, perhaps as early as A.D. $1350-1400$ based on the limited chronometric data currently available (Hughes and Hughes-Jones 1987:105). Like the Antelope Creek phase, intercultural conflicts could have played an important role in the demise of this culture.

\section{Washita River Phase}

A series of Plains Village sites in south-central and west-central Oklahoma have been designated as belonging to the Washita River phase (Bell 1984; Brooks 1989). Dating to A.D. $1250-1450$, the Washita River phase is thought to have evolved out of local Plains Woodland groups via the Custer phase (see Chapter 10). In many respects, the
Washita River phase is similar to the Antelope Creek phase, but there are some significant differences.

Washita River village sites generally include the remains of 5 to 20 square to rectangular houses along with associated middens, storage/trash pits, hearths, and cemetery areas. These surface houses, which were quite different from the slab-lined pithouses of the Antelope Creek phase, were of wattle-and-daub construction with upright wooden posts along the walls. They usually contain interior features such as postholes, fireplaces, and cache pits.

As with the Antelope Creek phase, the Washita River phase includes a range of tools and faunal and floral remains typical of hunting-gathering-horticultural pursuits. Bison and deer were the primary game hunted by Washita River peoples, and the most common hunting/processing tools are snubnosed end scrapers, beveled knives, and Fresno, Washita, and Harrell arrow points. Washita River ceramics are primarily plain (Nocona Plain and Lee Plain) and cordmarked (Stafford and Lindsay Cordmarked) utilitarian wares, but occasional appliquéd decorations and riveted handles are present. Cultivated plants include corn, beans, and gourds, and all known villages are located adjacent to suitable farmlands. A wide range of grinding tools is represented, but the presence of some Southwesternstyle trough metates and long oval manos suggests a greater intensity of plant processing than is evident for the Antelope Creek phase. The use of fish and shellfish as subsistence resources may have been more prevalent among Washita River peoples.

The importance of bison hunting within Washita River society depended largely upon geographic location. In their analysis of subsistence data for Oklahoma Plains Village sites (i.e., assigned to the Custer and Washita River phases), Drass and Flynn (1990) note two important trends. The exploitation of bison is much better represented in Plains Village sites located in the mixed-grass prairies that cover the western one-third of Oklahoma proper. In contrast, Plains Village peoples who lived in the tallgrass prairies and blackjack/post oak forests that cover the central one-third of the state depended more heavily on forest and riverine food resources and hunted less bison and more deer. They interpret these differences as reflecting the fact that bison were more numerous in western Oklahoma because they prefer mixed-grass prairies over forests and tallgrass prairies. The second trend is that bison 
hunting became better represented in Plains Village sites in western Oklahoma through time, with bison becoming a very significant food resource after A.D. 1200. This trend is attributed to several factors, including environmental change, increased bison populations, increased human populations and competition, and intersocietal trade.

The Washita River phase includes abundant evidence of mobility and/or interaction with other cultural groups. Nonlocal lithics include Frisco chert from Pontotoc County in south-central Oklahoma, Florence A chert from Kay County in north-central Okahoma, and Alibates agate. Much of the latter may have been obtained from secondary gravel sources in western Oklahoma rather than through trade with Antelope Creek peoples. Olivella shells and piñon nuts were obtained, whether directly or indirectly, from the west. Nonlocal pottery is from the east, as evidenced by occasional decorated Caddoan-style wares (e.g., engraved, incised, or slipped wares and an effigy vessel). Ear spools derived from the Caddoan area also have been found. Like the evidence for bison hunting, the direction of interaction evident in any particular Washita River phase site depends largely upon the geographic location of that site. Westernmost Washita River phase sites generally produce more nonlocal goods from Southwestern sources, and eastern sites produce more Caddoan-derived materials. The frequency of Florence A chert also increases from east to west along the Washita River valley.

Direct evidence of violence is found at three Washita River phase sites in Oklahoma, two in the west-central area and one in the south-central part of the state (Brooks 1994:319-320). The Heerwald site in Custer County includes a mass grave that contained a child and a young pregnant woman who had been shot with two arrows and scalped. Among the approximately 50 burials at the McLemore site cemetery in Washita County, a young female with an arrow wound was found. In south-central Oklahoma, 1 of the 15 individuals buried at the Grant site was an adult male with a probable combat injury, a nonfatal blow to the head.

The possibility that 10 skulls at the Footprint site in the Texas Panhandle were from Washita River peoples killed by Antelope Creek raiders has been mentioned. Equally intriguing evidence of Washita River violence was found at the Nagle site cemetery, outside the Washita River phase area, in central Oklahoma. Of the 20 individuals buried there, one adult male had been scalped and had four arrow points in his abdomen. Noting that all of the points are made of Alibates, Brooks (1994:319-320) speculates that the Nagle people represent a Caddoan group, perhaps a refugee population that immigrated from the Spiro site. He also suggests that they were perceived as invaders and that the individual had been killed by some Southern Plains Village group, most likely Washita River peoples. Schambach (1993:16) also thinks that the Nagle site skeletons represent Spiroan peoples, but he thinks the site was just one of many Spiroan trading outposts (entrepôts) in central Oklahoma and northeast Texas.

\section{Zimms Complex}

The Zimms complex is an odd variant of Southern Plains Village culture known primarily from sites in Roger Mills County of western Oklahoma (Brooks 1989; Drass and Moore 1987). The complex is recognized only at a few sites and remains poorly defined, but it appears to be a hybrid between the Antelope Creek and Washita River phases. Its location is such that this interpretation is reasonable. Although absolute chronological evidence is minimal, the Zimms complex is contemporaneous with the Antelope Creek and Washita River phases at ca. A.D. 1265-1425.

The Zimms complex is characterized by Antelope Creek-style architecture, minus the use of rock slabs, and Washita River-like material culture. Hunting seems to be the best-represented subsistence activity at most sites, and the Zimms complex settlement pattern appears to be rather dispersed. Relative to Antelope Creek and Washita River, Zimms peoples may have placed less emphasis on agricultural pursuits, and corn is the only cultigen that has been identified. Exotic material culture is rare but includes Florence A chert and some incised sherds of Caddoan derivation. One sherd of Southwestern pottery (i.e., Taos Black-on-white) also is reported.

Evidence for violence includes two individuals, one who had been scalped and one with fragmentary arrow points embedded in bones (Brooks 1994: 318-319). Regarding the latter, Wallis (1984:4-7) reports that Burial 1 at the Wickham \#3 site contained an untypeable arrow point tip in the chest cavity and a broken Washita point embedded in the sternum. At this time, it is difficult to place the 
Zimms complex violence in its proper perspective, but Brooks (1994:319) hints that Zimms peoples may have been enemies of Washita River phase peoples. Noting that more data are needed to accurately explain its cultural relationships, Flynn (1986:138-139) proposes three alternative hypotheses to explain the Zimms site: (1) an eastern extension of Antelope Creek groups coalescing with Washita River people; (2) a westward movement of Washita River groups interacting with Antelope Creek groups; or (3) an in situ development of a local culture in western Oklahoma. Lintz (1986:29-37) seems to favor the first hypothesis. Noting the architectural similarities, he originally included the Zimms site within the Antelope Creek phase. Drass and Moore (1987:417) also suggest that the Zimms complex is different from the Custer/Washita River phases and that it must represent an intrusive culture into western Oklahoma. At this time, the Texas Panhandle looks like the most likely area of origin for the Zimms complex.

\section{Eastern Jornada Mogollon: Late Maljamar and Ochoa Phases}

The eastern extension of the Jornada Mogollon (Corley 1965a, 1965b; J. Hughes 1991; Leslie 1979) includes two cultural phases that postdate A.D. 1100 - the Maljamar phase at A.D. $1100-1300$ and the Ochoa phase at A.D. 1300-1450. The Maljamar phase (see Chapter 10) represents a transitional phase characterized by a shift from corner- to side-notched arrow points and from pithouses to surface structures. Both of these changes are thought to have occurred at around A.D. 1200 , although there are no absolute chronological data to support this idea.

No mention is made of the earliest surface houses that appeared in the Eastern Jornada area during the late Maljamar phase, but at least four sites contain isolated surface houses or small room blocks attributed to the Ochoa phase. Residential sites have as many as $15-30$ rooms. The Ochoa phase is dominated by three varieties of locally made Ochoa ware (i.e., Plain, Corrugated, and Indented), and the primary intrusive pottery type is Chupadero Black-on-white. Shaft polishers, presumably for smoothing small arrow point shafts, appear in Ochoa phase sites, along with beveled knives, thumbnail end scrapers, and triangular side-notched and unnotched arrow points, often with notched or indented bases (Leslie 1979:192).

The Salt Cedar site, reported by Collins (1968), is a typical Ochoa phase residential base. Although a few Archaic points were found, it appears to represent a discrete component dating mainly from A.D. 1200 to 1500 , or perhaps a little earlier. Three radiocarbon dates were obtained, but they are not in agreement with their stratigraphic relationships. Hence, the age estimate relies heavily on known manufacturing dates for imported decorated pottery. Parts of 3, possibly 4, surface houses were encountered, along with numerous clay-lined and burned rock hearths, bone concentrations containing mostly bison remains, 10 (or 11) cache pits, and 4 burials. Although none were complete, the house remnants include sections of floors and stone and/or clay masonry walls, and they appear to represent simple jacal-like dwellings of variable shapes and sizes. Except for two manos, no other artifacts were definitely associated with the house floors. Several of the cache pits contained only chipped stone tools, flakes, or other debris, but six contained oval-basin metates and/or manos. One pit contained five metates and five manos.

The chipped stone assemblage from Salt Cedar includes arrow points, beveled knives, and an abundance of scrapers including snub-nosed end scrapers. A few Paleoindian and Archaic points may have been scavenged from nearby sites, but the collection is dominated by late arrow point styles174 Fresno, 101 Harrell, 12 Washita, 76 sidenotched fragments, 3 Perdiz, and 1 Garza. Ground stones include one-handed manos and oval-basin metates, and many complete specimens had been cached or stored. Tools such as awls, pins, and notched ribs (rasps?) were made from bison and deer/antelope bones. Unmodified bones, identified but not analyzed in detail, are dominated by bison (accounting for 84 percent of the 540 identifiable bones); all others are deer and/or antelope.

A few sherds of imported wares were found, but the dominant pottery type is Ochoa Indented Brown, accounting for 92 percent of the 486 sherds recovered by Collins (1968:Table 1). It is considered to be a locally made ware, and over 3,000 sherds of Ochoa Indented Brown, including surface collections, have been recovered. Two probable pottery-polishing stones, fragments of unfired modeled clay, and numerous "unfired sherds" support the idea that pottery was made on-site. Ochoa pottery 
is only found at late sites with surface houses (i.e., Ochoa phase), and Leslie (1979:Figure 4) suggests that this ware appeared around A.D. 1300. A few sherds of imported pottery indicate contact to the west and southwest (i.e., Agua Fria Glaze A, San Clemente Glaze A, Chupadero Black-on-white, and E1 Paso Polychrome), while a few sherds identified as Nocona Plain indicate contact with cultures to the east.

Four separate burials, three adult males and one infant, were found. All of the adult males, Burials $1-3$, were interred in flexed positions in oval pits. Burial 1 contained no offerings and the cause of death is unknown, but the other two males probably died of arrow wounds. Burial 2 contained several grave offerings (a bone awl and three modified bones, four unmodified flakes, a dart point fragment, an arrow point fragment, and three pieces of hematite/hematitic sandstone) that may have been inside a perishable container, but six side-notched arrow point fragments (Washita and Harrell) in the chest, neck, and stomach are interpreted as the cause of death. One of these was found lodged between two vertebrae. Burial 3 also contained grave offerings: 187 Olivella shell beads and a Canis claw may have been worn as bracelets, hematite and red ochre fragments, and an unidentified green pigment stone. Nine arrow points were associated and are interpreted as the cause of death. Two side-notched (Washita) fragments were found in the left wrist and near the sternum, and seven stemmed arrow points (Perdiz) were found in and around the vertebral column, with one being embedded in a vertebra and two lodged between vertebrae. Burial 4, a 2-monthold child, contained no associated artifacts. The stratigraphic positions of the burials relative to the midden led Collins (1968:119) to suggest that the interments took place late in the site's occupational history (i.e., probably after A.D. 1400).

Collins (1968:119-121, 158-162) interprets the Salt Cedar site as an Ochoa phase village occupied by Puebloan peoples who had spread onto the Llano Estacado out of southeastern New Mexico. The site appears to represent a blend of Plains and Puebloan traditions. Despite the lack of evidence for agriculture, it is acknowledged that the inhabitants may have done some farming. The nature of the grinding tools suggests some emphasis on plant foods, but there is ample evidence that the inhabitants were heavily involved in bison hunting. Besides the abundance of bison remains, a projectile point/ grinding tool index of 2.8 (105 arrow points/38 manos and metates) derived from Collins's (1968: Table 1) excavated materials denotes the overriding importance of hunting activities. The location of the site adjacent to a pluvial lake on the High Plains may have been intentionally selected because it provided immediate access to bison herds. Collins (1968:121) and Jack Hughes (1991:33-34) propose that the Ochoa phase may have been similar to the Antelope Creek phase in terms of subsistence, but there does not seem to have been any interaction between these two groups (and no Alibates agate is mentioned among the lithic materials at the Salt Cedar site).

Aside from the Salt Cedar site, little is known about the eastern Jornada Mogollon occupations that spread onto the southern Llano. It is possible that Ochoa peoples were bison hunter-gatherer-farmers, but the archeological data are too minimal at present to fully support such an inference. Hundreds of sites in southeastern New Mexico are attributed to this culture by Leslie (1979:Figure 3), but only a handful have been tested or excavated, published data are rare, and no radiocarbon dates have been reported. Most Eastern Jornada Mogollon sites were occupied during the Ochoa phase, but these late components are generally mixed with earlier occupations (J. Hughes 1991:34).

The only investigated site in southeastern New Mexico that has produced evidence of substantial occupations during the Ochoa phases is the Merchant site. Leslie (1965) reports both pithouses and surface rooms, indicating that occupations spanned a considerable length of time. The majority of the occupational debris, including side-notched arrow points and abundant Ochoa Indented pottery (some 96 percent of ca. 7,000 sherds), probably relates to the Ochoa phase. Based on the limited published data, however, it appears that there is considerable mixing with earlier materials and that discrete components cannot be defined.

Leslie (1979:191) proposed that the Ochoa phase may have evolved directly out of the Maljamar phase or that it might represent an influx of immigrants who replaced the Maljamar peoples. This latter theory is particularly appealing because there was a sudden increase and diversity in pottery types, and in the local manufacture of pottery, in the Eastern Jornada area after A.D. 1300. There also appears to be an increase in the number of sites and intensity of occupation, and, by inference, an 
increase in population.

Ochoa pottery may provide a clue to understanding the late Puebloan occupations on the southern Llano Estacado. Runyan and Hedrick (1987:42) define a single type, Ochoa Indented Brown, to include all variations of surface treatments from corrugated to indented. It is found only in southeastern Eddy and southern Lea Counties of New Mexico and as far east as Midland, Texas, and it is tempered with sand and/or crushed caliche of local origin (Collins 1968:101; Runyan and Hedrick 1987:42). Ochoa pottery is derived from the local Jornada tradition, and, except for the corrugated surface treatments, it is little different from other locally made brownwares in the Eastern Jornada area. If Leslie (1979:190) is correct, then the technique of manufacturing corrugated pottery appeared suddenly in the Eastern Jornada area during the late Maljamar Phase at ca. A.D. 1250-1350. Corrugated pottery seems to have spread out of the Anasazi area into southeastern New Mexico beginning around A.D. 1200. Corona Corrugated wares appeared at Gran Quivera after A.D. 1200 (Hayes et al. 1981:64-65), and corrugated brownwares appeared in the middle Pecos area in significant numbers during the Late McKenzie phase at A.D. 1250-1350 (Jelinek 1967:66, 69). They also appeared in the northern portion of the Sierra Blanca region during the Lincoln phase at about the same time (Kelley 1984:52-53, 126). Between A.D. 1300 and 1400 , large areas of southern and southeastern New Mexico (e.g., Tularosa Basin, Sierra Blanca, middle Pecos) were abandoned, perhaps under pressure from Plains bison hunters (Jelinek 1967: 162; Kelley 1984:156-158). Consequently, the sudden appearance of Southwestern-style corrugated/ indented pottery in pueblolike villages on the southern Llano Estacado may represent an influx of Puebloan peoples, as suggested by Collins (1968). One might suspect that the violent deaths at the Salt Cedar site were the result of hostilities between groups competing for control of the southern Llano Estacado bison hunting range. Because Perdiz and Washita points were found in Burial 3 at Salt Cedar, Lee Johnson (1994:89) speculates that "this adult male may have been the victim of Toyah-culture people using arrows tipped with more than one style of head."

Commenting on the ethnicity of the Ochoa peoples, Jack Hughes (1991:34) proposes that the McKenzie phase of the middle Pecos area (discussed below) is ancestral to the Ochoa phase and that the Ochoa phase is the likely progenitor of the Tanoanspeaking Kiowa. Jelinek (1967:162-163) first proposed that the Kiowa may have come from the Middle Pecos area, but Hughes notes that the timing of the decline and disappearance of the McKenzie phase coincides with the appearance of the Ochoa phase at A.D. 1300-1350. If the Ochoa phase does represent a sudden influx of new peoples, then the middle Pecos is a likely source area.

\section{Middle Pecos: McKenzie Phase}

Jelinek's (1967) cultural sequence for the middle Pecos River valley (see Chapter 10) includes the McKenzie phase at A.D. 1200-1350. The Early McKenzie phase is marked by the appearance of triangular, side-notched arrow points and rectangular surface houses between A.D. 1200 and 1250. During the Late McKenzie phase, contiguous rectangular surface rooms became common and side-notched arrow points almost completely replaced cornernotched varieties. A rise in grass pollen, along with a corresponding drop in the amount of maize and Cheno-am pollen, may provide evidence of a climatic change. A significant increase in the "quantity of animal remains, particularly bison, suggests drastic changes in the patterns of economic activity within the community" (Jelinek 1967:157). An increase in the frequency of arrow points and small end scrapers denotes the increased emphasis on hunting. The continuation of the ceramic tradition and peculiar form of end scrapers suggests that the middle Pecos peoples were adapting to a new lifestyle rather than being replaced or displaced by Plains bison hunting peoples. By A.D. 1250, people in the middle Pecos valley had begun to abandon their agricultural lifestyles in favor of bison hunting, and their sedentary lifestyle was completely abandoned by A.D. 1350. A post-McKenzie phase represents the period when middle Pecos peoples lived as nomadic hunter-gatherers, and they apparently abandoned the region completely during the late fourteenth or early fifteenth century. Jelinek (1967:162-164) suggests that the middle Pecos peoples were ancestral to the Kiowa, the only Southern Plains group known to speak a Tanoan language.

Kelley (1984:156-158) observed a similar phenomenon in that the Sierra Blanca region to the southwest apparently was abandoned at about the 
same time. A sudden increase in Plains bison hunting tools and bison remains immediately preceded the abandonment of the area. In addition, the village site of Bloom Mound, near Roswell, was attacked and burned at this time, and some of its inhabitants were killed. Who made the attack is not known, but hostility between Plains bison hunters and Puebloan villagers is a strong possibility. Kelley (1984:55-56) speculates that Bloom Mound may have been a regional trade center.

The presence of Middle Pecos Micaceous pottery at several Palo Duro complex sites (see Chapter 10) is evidence of a connection between the middle Pecos area and the Texas Panhandle-Plains at least as early as A.D. 1000 . It is likely that some form of cultural interaction was maintained for several hundred years. As mentioned above, the thermoluminescence date of A.D. $1350-1450$ on a Middle Pecos Micaceous sherd from the Tascosa Creek site is tantalizing evidence, particularly since it coincides with the end of the middle Pecos cultural sequence. Jelinek (1967:155-164) suggests that the inhabitants abandoned the middle Pecos area by A.D. 1350 and moved out onto the Plains to hunt bison. Couzzourt (1988:48-49) speculates that the late component at Tascosa Creek may represent middle Pecos peoples on bison hunting excursions into the Texas Panhandle.

\section{Post-Palo Duro Complex}

As mentioned in Chapter 10, the Palo Duro complex seems to have disappeared from the southern Caprock Canyonlands at about A.D. 1100-1200. The Palo Duro peoples were replaced by, or perhaps evolved into and/or converged with, a mobile huntergatherer culture whose dominant subsistence strategy was bison oriented. It is clear that Palo Duro culture, unlike its northern Plains Woodland counterpart, never developed into a Plains Village adaptation. There seems to have been a hiatus of some 200 years, from A.D. 1100 to 1300 , between the disappearance of the Palo Duro complex and the appearance of the next recognizable cultural group, the Garza complex. This hiatus may be more apparent than real, however, and it probably reflects the inability to separate, identify, date, and interpret discrete cultural occupations from this time period. The limited evidence that is available has a bearing on what happened to the Palo Duro complex and is briefly discussed here.
If the theory proposed by Lee Johnson (1994) is correct, then the Palo Duro complex should have disappeared as these people moved, or were pushed, southward. Assuming that the latest Palo Duro complex peoples did take up bison hunting sometime after A.D. 1100, the appropriate question is whether they became bison hunters before moving south out of the southern Caprock Canyonlands or whether they were displaced prior to becoming bison hunters.

A few components at Lake Alan Henry are relevant to this question. Since the late occupation period at the Sam Wahl site includes a possible ephemeral surface house that dates around A.D. 1250 (see Chapter 6), it is clear that something different had replaced the pithouse village by this time. Perhaps descendants of the Palo Duro occupants had adopted a new house form and were becoming more mobile before abandoning the site. Or, it is possible that the Palo Duro peoples suddenly abandoned the Sam Wahl site and that the subsequent occupations were by different peoples. A single multiple-sidenotched Huffaker-like arrow point associated with the late occupation period is unlike the other arrow points from the site.

A similar situation is evident at the South Sage Creek site (see Chapter 6), where a single Harrell point may indicate a post-Palo Duro occupation episode. Cruse (1992:79) also recovered a single Washita-like point from the Kent Creek site, although there is no other evidence for occupation after ca. A.D. 1100. Evidence at many other sites, such as the Floydada Country Club site and Reed Shelter (see Garza and Tierra Blanca complexes below), could represent occupations between A.D. 1100 and 1300, but aside from the late occupation period at the Sam Wahl site, no other post-Palo Duro components can be defined and dated anywhere in the southern Caprock Canyonlands.

The regional archeological data are too minimal to draw any firm conclusions, but two alternative hypotheses may be proposed. One is that transitional Palo Duro complex occupations, dating from A.D. 1100 to 1300 , should be expected to occur in the southern Caprock Canyonlands. Such sites/ components would reflect a culture undergoing a transformation to a more mobile hunting-oriented society. These archeological remains should reflect continuous occupation in the region and in situ cultural development. As at the Sam Wahl site, such components might occur immediately overlying Palo Duro occupations. 
The alternative hypothesis is that such transitional sites in the southern Caprock Canyonlands will reflect the disappearance of the Palo Duro culture and its sudden replacement by a different culture. This hypothesis is favored because the sudden shift in projectile point styles at these sites seems to represent a break in continuity rather than a gradual shift. If the appearance of the new bow and arrow technology represents new immigrants, it is possible that the violence evident during Palo Duro times (see Chapter 10) suddenly escalated. Perhaps the drying climate and raiding nomadic Plains bison hunters pressured the Palo Duro peoples into a hasty retreat southward. Alternatively, the aggressors may have been Plains Village peoples. If the interpretation of conflicts between Plains Woodland and Palo Duro peoples is correct, then Plains Village peoples of Woodland descent (i.e., the Antelope Creek or Washita River phases) are likely candidates for enemies of late or post-Palo Duro complex peoples.

\section{LATE PREHISTORIC II/ PROTOHISTORIC CULTURAL COMPLEXES AND PHASES}

The cultural complexes and phases discussed in this section are ones that either span the transition from Late Prehistoric II into Protohistoric times or begin in the Protohistoric period (Figures 96 and 97). It is often difficult to separate Native American occupations into Late Prehistoric II, Protohistoric, or Historic periods based on archeological remains. The age and duration of site occupations that have been extensively dated by absolute methods (e.g., radiocarbon, archeomagnetism, and obsidian hydration) are more confidently placed in time, but even these methods are often too imprecise. Relying solely on artifactual evidence has many pitfalls. An occupation may be dated by the presence of temporally diagnostic artifacts such as Southwestern trade pottery, but imported artifacts inherently have a lag time between their manufacture and cultural deposition. There also is a serious problem with assuming that a small percentage of imported artifacts is representative of the age of an entire occupation. For example, many sites with occupations over a long period of time were initially misinterpreted as representing short-term or singleevent occupations based on a few diagnostic specimens. For Protohistoric occupations, European-made artifacts are more-reliable chronological indicators, especially when the precise period of manufacture is known. In many cases, the presence, absence, or relative abundance of artifacts of European manufacture or origin often have been used as crude indicators of age. Because the process of acculturation was gradual, it is generally assumed that early Protohistoric sites will have fewer European goods than Historic Indian sites. While this is true in a general sense, interpreting the relative frequency of European artifacts in a Native American site also must take into account such factors as differential site function and level of sampling. Chronological problems such as these must be kept in mind throughout the remainder of this chapter.

Cultural manifestations that are relevant to the Late Prehistoric II/Protohistoric time periods are the Edwards complex, Wheeler complex and Protohistoric Wichita, Henrietta complex, and the Toyah phase. Archeological remains of unknown and multiple cultural affiliation on the southern Llano Estacado also are briefly discussed under the heading of undefined complexes. The Garza and Tierra Blanca complexes are particularly important and are discussed in detail in separate sections. Important sites attributed to these various cultural complexes are listed in Table 81.

\section{Edwards Complex}

Based primarily on archeological materials recovered from intensive investigations at the Edwards I (34BK2), Taylor (34GR8), Goodwin-Baker (34RM14), and Duncan (34WA2) sites, Hofman (1984b) defined the Edwards complex as an early Protohistoric manifestation in west-central Oklahoma. Baugh (1986) subsequently combined the Edwards complex, along with the related Wheeler complex, under the banner of the Wheeler phase. This author agrees with Hofman's (1989b:97) assessment that the Edwards and Wheeler complexes are characterized by distinctive assemblages and chronology and that they "merit taxonomic differentiation." As discussed later, Baugh's (1986) interpretation that the Garza complex is little more than a western extension of the Wheeler phase also is questioned.

As summarized by Hofman (1984b, 1989b), radiocarbon and obsidian hydration assays indicate that Edwards complex occupations generally date between A.D. 1500 and 1650, although occupations may be somewhat earlier at some sites. Unnotched 


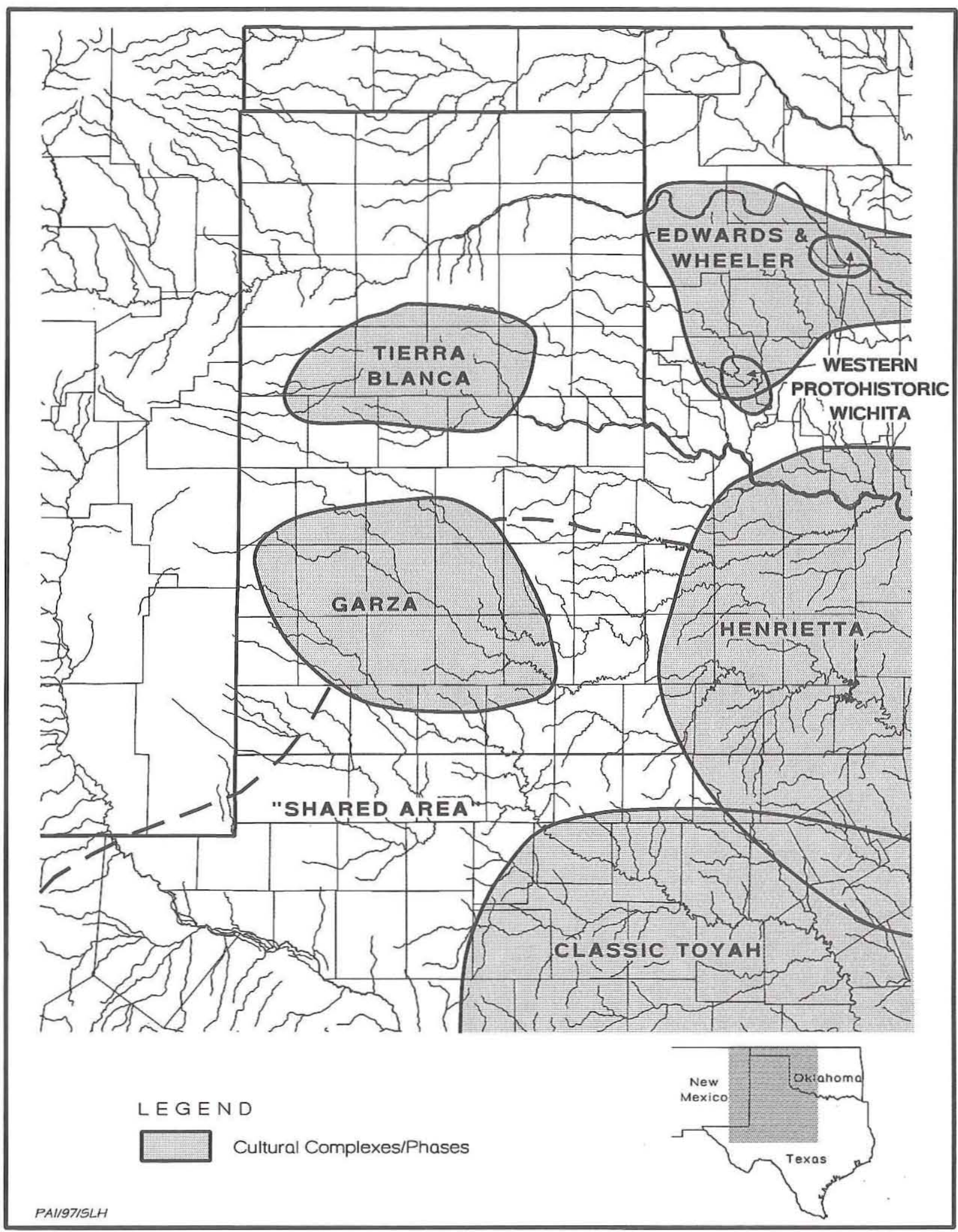

Figure 96. Map of Late Prehistoric II/Protohistoric culture complexes and phases in the Texas Panhandle-Plains and surrounding areas. Sources: Bell (1984:Figures 14.1, 16.1, and 17.1), Brooks (1989:Figure 15), and Lee Johnson (1994:Figure 105). 


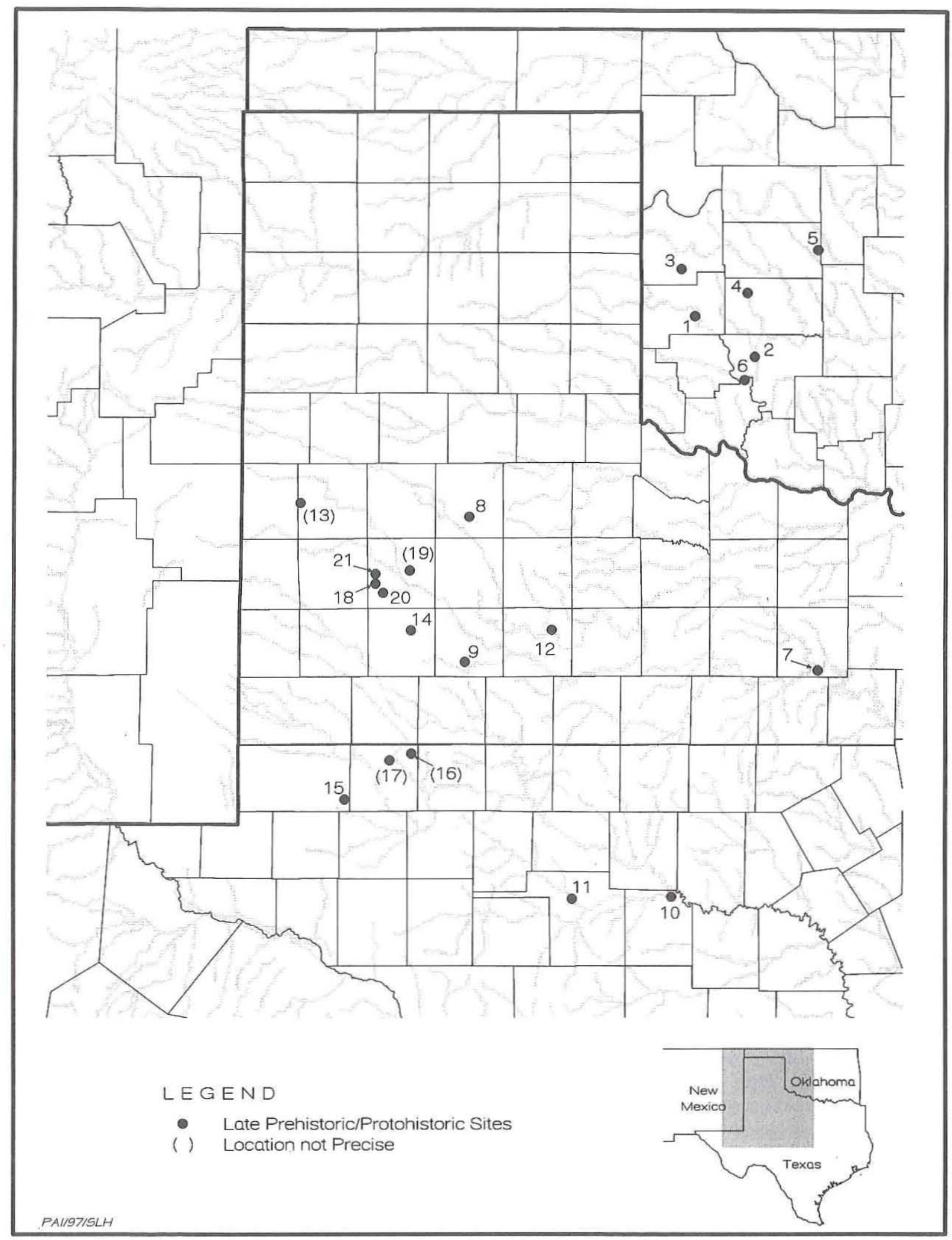

Figure 97. Map of Late Prehistoric II/Protohistoric sites discussed in the text. 


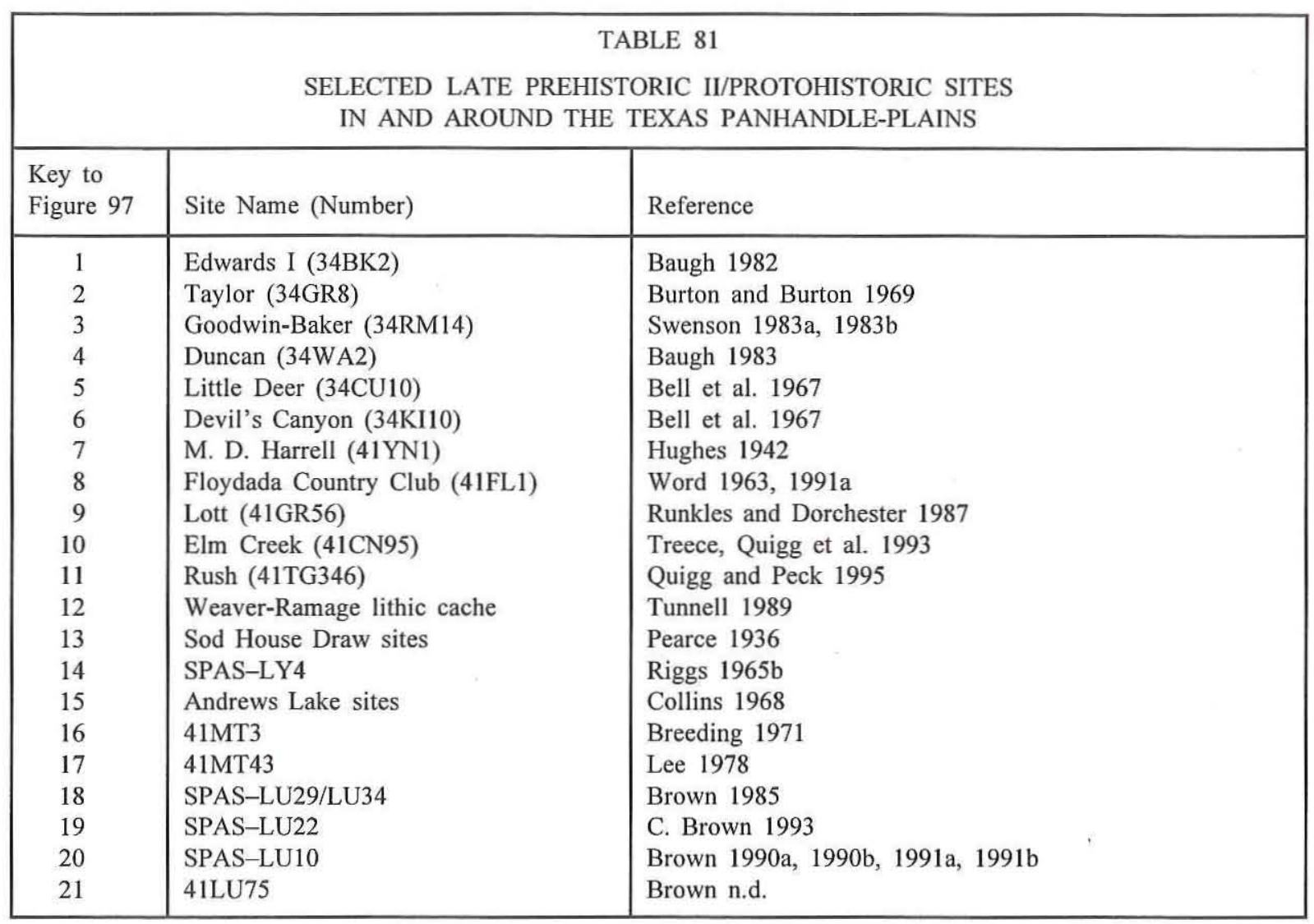

triangular Fresno arrow points are the dominant point type for the Edwards complex and generally make up about 70 percent of all arrow points. Sidenotched Washita and Harrell points are well represented, and a few Garza points are found. Other common lithic artifacts include end and side scrapers and drills. Ground stone manos and metates are common. Bone artifacts include awls, fleshers, squash knives, and scapula hoes. Ceramic assemblages are dominated by two types, Edwards Plain and Little Deer Ware, that are considered to have been locally made.

Extensive mobility and/or exchange is documented by a wide range of nonlocal items. Lithic materials are dominated (70 percent) by Texas materials (mainly Alibates agate, but also Tecovas jasper and Edwards cherts). Kay County chert from north-central Oklahoma is less frequent but still well represented (ca. 10 percent). Obsidian, most of which is traceable to sources in the Jemez Mountains, is relatively abundant at some sites but usually accounts for less than 10 percent of all materials.
Puebloan pottery makes up 2-5 percent of the ceramic assemblages from most Edwards components. Upper Rio Grande pueblos (probably Taos/ Picuris) and Pecos Pueblo are identified as the probable sources for late Glaze wares (IV, V, and VI), Plain Red Ware, micaceous utility wares, corrugated wares, and tubular Pecos-style pipe sherds. Other nonlocal pottery includes a wide range of Caddoan pottery types derived from the Red River area.

Hofman (1984b:353) concludes that the "economy of Edwards complex peoples was apparently based primarily on bison and trading." Some horticulture was practiced, but farming was probably less important to Edwards peoples than to Plains Village groups. Interaction between Edwards complex peoples and the Puebloan and Caddoan regions is well documented and probably involved "trading meats, hides, leather products, and salt for horticultural produce" (Hofman 1984b:353). Archeological evidence suggests that Edwards complex peoples may have served as trade emissaries between the Puebloan and Caddoan nations. Ethnographic 
evidence indicates that horses were used, at least in limited numbers, by western Oklahoma peoples by A.D. 1650. Increased mobility and access to European goods after A.D. 1650 probably had a significant impact on these peoples, as evidenced by the changes noted in the subsequent Wheeler complex. Of particular interest is the interpretation that at least two Edwards complex sites, Duncan and Edwards I, represent fortified villages. Possible evidence of violence and intercultural conflict includes four modified human bones from the Edwards I site (Owsley et al. 1994).

\section{Wheeler Complex}

The Wheeler complex was originally defined by Bell et al. (1967) based on materials recovered from the Wilson Springs (34CD5), Scott (34CN2), and Little Deer (34CU10) sites of west-central Oklahoma. As summarized by Hofman (1984b, 1989b), the Wheeler complex is a late Protohistoric manifestation that was immediately preceded by the Edwards complex. Although they are quite similar, Hofman (1989b:98) notes that Wheeler complex sites/components have artifact assemblages that are "easily distinguishable" from those of Edwards sites/components. The assemblages are similar in many respects, but four differences are notable for the Wheeler complex: (1) Puebloan pottery is less frequent and less variable; (2) Caddoan pottery is less frequent and less variable; (3) European-made or introduced items are much more prevalent; and (4) Kay County chert is the predominant lithic material, while Texas Panhandle-Plains lithic materials (i.e., Edwards chert and Alibates agate) and New Mexico obsidian are much rarer.

The Wheeler complex remains poorly defined because no Wheeler sites have been excavated. Hofman (1984b:355) states that "there is little information on houses, burials, fortifications, site structure, or settlement pattern for this cultural complex." The Wheeler phase is assigned to the period from A.D. 1650 to 1725 or 1750 , but the chronology was established almost entirely by associations with Puebloan ceramics (i.e., Glaze V Polychrome, Pecos-style pipes, and related seventeenth-century wares).

Most researchers seem to agree on two points: (1) the Edwards and Wheeler complexes represent a continuum of culture change (i.e., the same people at different times); and (2) the Late Prehistoric
Washita River phase represents peoples ancestral to the Protohistoric Wichita. Researchers do not agree, however, as to where the Edwards and Wheeler complexes fit into the bigger picture. Baugh (1982) contends that Edwards/Wheeler represents a cultural continuum of Caddoan-speaking peoples linking the Washita River phase with the Protohistoric Wichita. Hofman (1984b), on the other hand, thinks that the indigenous Edwards/Wheeler complex pottery is more closely related to Southwestern Puebloan and Athapaskan tradition wares than to any Caddoan/ Wichita ceramic tradition. This suggests that the Edwards and Wheeler complexes may represent Athapaskan-speaking intruders into a predominantly Caddoan area. Hofman (1984b:361) concludes that both theories warrant consideration but that "it is premature to assign the Edwards and Wheeler complexes to a specific ethnic group(s)." This author agrees with Hofman's statement and does not think that there is sufficient evidence to combine the Edwards and Wheeler complexes into the Wheeler phase defined by Baugh $(1986,1992)$. This author also disagrees with Baugh's suggestion that the Garza complex (described later in this chapter) is little more than a western extension of the Wheeler phase.

\section{Protohistoric Wichita}

The Wichita are briefly mentioned here because they were the major cultural group in central and western Oklahoma at the time of European contact, and they were heavily involved in the French trade during the late Protohistoric and Historic periods (Bell 1984; Hofman 1989b; Perttula 1992). The Wichita confederacy consisted of an extensive alliance of several Caddoan-speaking tribes and may have included peoples descended from Washita River phase groups. These peoples became increasingly involved in trading with the French during the early part of the eighteenth century. By around A.D. 1750 , they were concentrated in settlements along the Red River in southern Oklahoma, particularly in the Spanish Fort area, in order to facilitate trade. The significant increase in the frequency of European artifacts in Protohistoric Wichita sites dating between A.D. 1700 and 1760 is evidence of the increased intensity of the French trade (Bell 1984:376-377). Ultimately, it was the arrival of the Comanche Indians early in the 1700 s, and their access to the French trade through their 1746-1747 
alliance with the Wichita Indians, that radically changed the cultural complexity of the Southern Plains. The western extent of Wichita occupations is not known precisely, but an 1834 U.S. Army expedition encountered a Wichita village on the North Fork of the Red River at Devil's Canyon (Bell 1984:364; Bell et al. 1967:120-121).

\section{Henrietta Complex}

The Henrietta complex, initially defined by Krieger (1946), is the southernmost manifestation of Plains Village culture in Texas, but it also is the most poorly understood. The original definition utilized information from several sites but relied primarily on the archeological investigations at the M. D. Harrell site in Young County, Texas, which are reported by Hughes (1942). Additional investigations of Henrietta components are reported for sites near the Red River in the Spanish Fort area; the Coyote and Glass sites (Montague County) are reported by Bell et al. (1967), and the Chickenhouse site (Cooke County) is reported by Lorrain (1969). Recent investigations reveal that the Dillard site (Cooke County) is a Plains Village habitation site that is similar to, yet different from, those of the Henrietta complex (Martin 1994).

When summarized by Brooks (1989), the chronology of the Henrietta complex was not well known, and only one radiocarbon date was reported. Radiocarbon dates obtained for the Chickenhouse site are thought to be erroneous (Lorrain 1969:111) and perhaps were contaminated (Martin 1994:111). It is not clear how the radiocarbon dates from the Dillard site fit into the picture, and much work is needed to sort out the chronology of the complex. The Henrietta complex apparently spans the transition from Late Prehistoric II into Protohistoric times, and many habitation sites have substantial midden deposits that probably represent repeated occupations over long periods of time. Like many other Plainsinfluenced village cultures, the Henrietta complex may trace its ultimate origins to the Plains Woodland tradition. Prikryl (1990:80) notes an increase in Plains influence and evidence for bison hunting in north-central Texas after A.D. 1200.

Henrietta complex houses (at the Glass and Chickenhouse sites and probably at the Dillard site) are round or oval depressions, usually ca. 5-7 m in diameter or maximum length. They have three or four main interior postholes representing superstruc- ture supports, while smaller postholes along the perimeter represent walls. Storage pits also are common in these village sites. Fresno, Washita, Harrell, and Scallorn points are most common, but Alba, Bonham, Eddy, and Perdiz points also are found. Knives, scrapers, and drills also are common. Shell- and/or limestone-tempered Nocona Plain is the dominant pottery type. Gardening tools such as bison scapula hoes and other bone artifacts such as awls and bone beads are common. Bison and deer were the principal game animals, but fishing and use of mussels also are evident. A wide variety of animal remains and charred corn was found at the Dillard site (Martin 1994:Table 10, 193).

Mobility and intercultural relationships are not well known, but Henrietta complex sites contain abundant exotic materials. Alibates agate, obsidian, and occasional Southwestern sherds indicate interactions with groups to the west, while celts and other decorated potsherds indicate interactions with Caddoan peoples to the east. A variety of marine shell ornaments and evidence of copper (i.e., copper staining on human bones in a burial) were found at the Dillard site. Henrietta complex sites generally show stronger Plains influence to the west (and the presence of Nocona Plain in eastern Washita River phase sites may indicate that they interacted with Henrietta peoples) and stronger Caddoan influence to the east. Martin (1994:190) suggests that the Plains Village peoples in north-central Texas, including the Henrietta complex, were semisedentary, bison hunting horticulturists who acted as trade intermediaries between Caddoan peoples and Plains peoples.

Skeletal remains of 32 individuals were found in burials at the Harrell site (Hughes 1942:36-52). Although most of the burials were primary flexed or semiflexed interments of single individuals, three multiple burials were encountered. Two were cairncovered mass graves containing evidence of violence. One multiple burial consisted of three adults (one female and two indeterminate) with four arrow points that are interpreted as the cause of death. The mandibles were missing from two of the individuals, and their absence could not be attributed to postdepositional factors. Five arrow points interpreted as the cause of death were found in association with four adults (two females and two indeterminate) and an infant in a second mass grave. All of the arrow points in these multiple burials were of the "late type" (Hughes 1942:105), presumably side 
notched. A third mass burial consisted of the incomplete skeletal remains of six individuals (two were identified as adult males and one was a child), perhaps representing a secondary interment. It did not contain any definitive evidence of violence, but the nature of the remains is extremely suspect.

Eight graves containing the skeletal remains of 13 persons are clustered in one area of the Dillard site and represent a small cemetery (Martin 1994: 193). While osteological analysis of the skeletal remains (Albrecht 1994) provided only tantalizing hints but no definitive evidence of violence, the archeological contexts of the burials suggests even more that violence played a role in the deaths of five people in a mass grave: two young females (ca. 16-21 years old), two young males (ca. 27-34 years old), and an older female (ca. 35-44 years old). In his discussion of the mass grave (Burials 8-12), Martin (1994:136-147, 194) suggests that these five people were mutilated/dismembered after they died. While most of their remains were intact and articulated, several of the crania and long bones were displaced and some key elements were missing. At least three persons (one male, one young female, and the older female) apparently were decapitated, and they were each inexplicably missing several cervical vertebrae (probably explaining the absence of cut marks). The mandible of the other female was missing, and her arms were removed and apparently placed in a pile with two of the skulls at the top of the grave.

The violence in Henrietta society is not fully understood, but it must have been considerable if the Harrell and Dillard site cemeteries are any indication. Out of a burial population of 32 at the Harrell site, at least 7 people and perhaps as many as 13 (22-41 percent) were killed. At least 5 of the 13 people (38 percent) buried at the Dillard site may have been killed. The violent demise of over onefourth of these populations suggests that warfare was quite prevalent. The actual number of violent deaths may have been even higher at the Harrell site because Hughes (1942:51), referring to the site in general, notes that "bodies were occasionally buried without mandibles." This statement seems to imply that there may be other cases, besides the two individuals mentioned above, where mandibles were missing. Although mandibles could have been removed within the context of a mortuary ritual, this seems unlikely given the clear association of missing mandibles and violent deaths at the Harrell site.
Also notable is the evidence for the taking of human mandibles as war trophies in nearby Blow Out Mountain culture burials (see Chapter 10).

Like the Blow Out Mountain complex, the Henrietta complex has many problems related to the low number of investigated sites and inadequacy of chronological control. Similarities between the stemmed arrow points attributed to the Blow Out Mountain complex and those attributed to the Henrietta complex may denote some sort of genetic affiliation or cultural connection. Similarities in the nature and diversity of mortuary traits observed in Blow Out Mountain and Henrietta cemeteries also warrant investigation. Brooks (1989:85-86) suggests that the Henrietta complex also exhibits some similarities with archeological remains of the Sanders or Wylie phases to the east, but these relationships also are uncertain.

\section{Toyah Phase}

The Toyah culture was first defined as a focus by Kelley (1947) and was subsequently refined by Jelks (1962). Prewitt (1981) later introduced the Toyah phase and offered a clearer revision that is in widespread use today. The hallmark of the Toyah phase is its association with the distinctive pointedstemmed Perdiz arrow point that is found, almost literally, across the entire state of Texas, except for the Texas Panhandle (Prewitt 1995:126). It has long been recognized that Toyah phase components are most concentrated in Central and South Texas, but Toyah-like materials are found over a much broader area. The most recent and insightful summary of Toyah culture, by Lee Johnson (1994:241-287), introduces the concept of a core area of "Classic Toyah culture" that includes much of the inland Coastal Plain and South Texas. It extends northwestward through all of Central Texas and as far north and west as the Edwards Plateau and the San Angelo area. Classic Toyah culture is assigned to the period from A.D. 1300 to 1650 . Its material culture includes a range of tools that are typical of Plains Village occupations, including arrow points (Perdiz being the most common type), end scrapers, beveled knives, perforators, and grinding stones. While bifacial tools are represented, most of the chipped stone tools and debitage denotes a unifacial blade technology.

Lee Johnson (1994) acknowledges that Toyah peoples probably grew some maize, but current 
evidence suggests that their horticultural pursuits were limited. Toyah peoples are generally characterized as having been relatively mobile hunter-gatherers whose primary pursuit was bison. Toyah bison hunting techniques are thought to have been somewhat different from those of their traditional Plains counterparts. Many Plains peoples were large-scale bison collectors whose logistical strategy involved seasonal communal hunts and kills of relatively large numbers of animals. In contrast, Toyah peoples appear to have been bison foragers who hunted bison (as well as deer and other animals) intensively, but on a smaller scale or a more or less opportunistic basis.

Classic Toyah material culture, except for Perdiz points and pottery, is similar to that of the Southern Plains Village cultures. When, how, and from where the Plains-adapted tool kit made its way into Toyah culture is not known, but the Perdiz arrow point and classic Toyah ware are distinctive and originated from different sources. Lee Johnson (1994) proposes that classic Toyah pottery is poorly made but has many similarities with, and probably was derived from, pottery of the Jornada Mogollon tradition. He also proposes that the prototype for Perdiz points may be found in the stemmed arrow points of the Blow Out Mountain culture, and concludes that classic Toyah culture originated from the Southern Plains or Southwest, having evolved out of some Jornada Mogollon-influenced culture (L. Johnson 1994:268, 277). As proposed in Chapter 10, the Palo Duro complex fits the bill nicely. At the time of its disappearance from the Caprock Canyonlands between A.D. 1100 and 1300, this culture possessed an appropriate prototype arrow point style (i.e., Deadman's and similar stemmed variants), a connection with Mogollon potterymaking technology and styles, and the initial contact with Plains bison hunting tools and technology.

There is evidence for considerable regional cultural diversity within the vast classic Toyah area. Most notably, northern classic Toyah culture is different from southern classic Toyah culture. Bison remains and bison hunting technology (points, beveled knives, and end scrapers) are best represented in the northern sites nearest the Great Plains. The northernmost classic Toyah sites exhibit more Plains-like traits, such as four-beveled knives (instead of two-beveled) and sandstone shaft abraders. Regional diversity also is evident in classic Toyah ware. Some variability in composition is due to differences in local geology, but variations in vessel form and decorative style are due to geographic location and proximity to outside influences. Caddoan-like decorative techniques, for example, are more common on Toyah pottery in the eastern portion of the Edwards Plateau.

There is little evidence that classic Toyah peoples traded with Southwestern Puebloan cultures, although a few sherds of sandy paste pottery found in northern sites may have come from Puebloan and/or Plains (Apachean?) sources. Classic Toyah peoples living along the eastern margin of their homeland, however, apparently traded with Caddoan peoples on a more or less regular basis, with some Caddoan pottery even making its way as far west as Abilene and San Angelo. It is presumed that the Toyah-Caddo trade involved bison meat/hides for crops, but there is no hard evidence for this type of mutualistic exchange. What is clear is that classic Toyah peoples, unlike some of their Southern Plains contemporaries (i.e., Garza, Edwards, and Wheeler complex peoples), were not middlemen in any extensive Pueblo-Caddo interaction sphere. This may not be true, however, for the Toyah-like or Toyah-influenced cultures on the northern and western periphery of the classic Toyah area.

Nonclassic Toyah culture, which includes Perdiz arrow points, Toyah-like pottery, or other Toyah-like materials found outside the core area, is thought to represent "borrowing" of culture traits of other peoples. This appears to be the case all across Trans-Pecos Texas and southward into Mexico where some Toyah-like artifacts and traits are found in distinctly non-Toyah occupations. The northern extent of the Toyah sphere of activity, which extends up into the southern Panhandle-Plains, is different. The minimal evidence available for this area seems to indicate that classic Toyah peoples may have ventured northward periodically to hunt bison. The Weaver-Ramage lithic cache is of interest because it is affiliated with the Toyah phase but occurs in Kent County, well outside the traditionally recognized Toyah culture area (Tunnell 1978, 1989). It contained over 800 items of highquality Edwards chert, probably derived from the Callahan Divide some $100 \mathrm{~km}$ to the south. The cache, which weighs $11.5 \mathrm{~kg}$, consists of a Perdiz arrow point, a broken beveled knife and two other bifaces, a core, 8 tested cobbles, 24 scraping tools, 21 biface thinning flakes, 102 flakes and chips, and 652 blades or blade fragments. This collection may 
represent a cache of tools and raw materials left by a group of Toyah peoples on a hunting trip into the Lower Plains.

The consistency with which Perdiz points are found at sites in the Lower Plains and on the High Plains suggests that the area was frequented by Toyah phase peoples. Although Prewitt's (1995: Figure 40) statewide distribution of Perdiz points shows a concentration in Garza County (where the Lott site is located), only four other PanhandlePlains counties are shown to have produced any Perdiz points. There are additional sources, not consulted by Prewitt, that expand the distribution of Perdiz points (assuming that the identifications are correct) to include an additional 10 Panhandle-Plains counties. Table 82 lists references for finds of Perdiz points in 15 Panhandle-Plains counties.

In the Panhandle-Plains, Perdiz points almost always are found in conjunction with other arrow points and a variety of ceramic types, perhaps indicating the presence of two or more cultures. Word (1991a) suggests that three cultures are represented in three areas at the Floydada Country Club site in the southern Caprock Canyonlands. Perdiz points found in Area 3 may indicate the presence of a Toyah phase occupation. The Lott site in Garza County is particularly perplexing because excavations suggest the possibility that it may have been occupied simultaneously by two or three different groups, including Garza complex and Toyah phase peoples (Runkles and Dorchester 1987). Archeological findings at Lake $\mathrm{O}$. H. Ivie support the proposition that the northern Edwards Plateau was occupied/ utilized simultaneously by Toyah phase and Garza complex peoples. Lott and Perdiz points were found to co-occur in a discrete buried occupation at the Elm Creek site (discussed under Garza Complex below) in Coleman County.

Recent archeological work at the Rush site (41TG346), in Tom Green County, provides additional evidence for the co-occurrence of the Toyah phase and the Garza complex. This site contains stratified cultural deposits in an alluvial terrace of the North Concho River, just upstream from O. C. Fisher Reservoir at San Angelo. Testing and data recovery investigations in 1993 (Quigg 1997a; Quigg and Peck 1995) included backhoe trenching, followed by hand excavation of a $3-x-15-m$ block. Occupation 4, one of five discrete occupation zones, is characterized by a thin scatter of butchered and fragmented bison bones, abundant lithic debris including scrapers and arrow points, and potsherds from at least seven plainware vessels. Activity areas were well defined, and recognizable features include unlined hearths, ash piles and lenses, and burned rock concentrations.

The evidence recovered in the block excavation represents only a small sample of a much larger site,

TABLE 82

TEXAS PANHANDLE-PLAINS SITES PRODUCING PERDIZ ARROW POINTS

\begin{tabular}{|l|l|l|}
\hline Site & County & References \\
\hline various sites & Crosby, Gaines, Garza, and Lynn & Runkles 1962 \\
White site & Yoakum & Suhm 1962 \\
Montgomery site (41FL17) & Floyd & Word 1965; Northern 1979 \\
SPAS-LY4 near Tahoka Lake & Lynn & Riggs 1965b \\
Dockum Springs site (SMU-X41DK1) & Dickens & Parsons 1967 \\
Salt Cedar Site (41AD2) & Andrews & Collins 1968 \\
Greene Springs site & Scurry & Portis et al. 1968 \\
Canyon City Club Cave & Randall & Hughes 1969 \\
various sites & Lamb & Randall 1970 \\
Bull Hill site (41MD2) & Midland & Shawn 1975 \\
SPAS-LY42 & Lynn & Hart 1976 \\
SPAS-MT40 & Martin & Brown 1985 \\
SPAS-LU29 & Lubbock & Runkles and Dorchester 1987 \\
Lott site (41GR56) & Garza & Pope 1991 \\
Hogue site (41TY2) & Terry & Word 1991a \\
Floydada Country Club (41FL1) & Floyd & \\
\hline
\end{tabular}


but Occupation 4 is attributed to the Toyah phase based on the presence of numerous Perdiz points and fairly typical Toyah pottery. The age of this zone was determined by a single charcoal radiocarbon date of A.D. $1620 \pm 60$ (corrected date presented by Quigg and Peck [1995:Table 5.2]), which calibrates to A.D. $1484(1528,1558,1631) 1650$. This date corresponds well with other dates from occupation zones above and below. Quigg and Peck (1995: 163-184) interpret Occupation 4 as a bison processing campsite where secondary butchering and bone grease processing occurred. The activities are thought to represent a discrete, short-duration event that probably occurred in the late fall (November), ca. A.D. 1575. Of particular importance, a single complete Garza point (see Quigg and Peck 1995: Figure 5.18) was recovered in clear association with the Occupation 4 level. All of the arrow points (16 untypeable, 16 Perdiz, 2 Harrell, 1 Cliffton, and 1 Garza) in the Occupation 4 level are thought to have been used contemporaneously. Quigg and Peck (1995:88) suggest three alternative explanations: (1) Toyah peoples picked up and used non-Perdiz points or arrows that they found; (2) Toyah peoples made other styles of arrow points in addition to Perdiz; and/or (3) non-Perdiz points were made and used by non-Toyah peoples who lived or hunted with a Toyah group.

This co-occurrence of Garza and Perdiz points provides unequivocal evidence that these point styles were used simultaneously in west-central Texas. There is increasing evidence that Late Prehistoric II and Protohistoric archeological remains in the southern Panhandle-Plains and west-central Texas reflect the presence and interaction of at least two cultural groups. Much remains to be learned about these northernmost Toyah phase occupations, but Lee Johnson (1994:Figure 105, 268) suggests that the southern Panhandle-Plains (encompassing the upper Brazos and Colorado River drainages) was a "shared area" that was simultaneously occupied by two or more cultures. Perhaps "shared" is not the correct word, however, because arrow-riddled bodies at the Salt Cedar site in Andrews County (Collins 1968) and in the Spence Burial in Coke County (Collins and Caddell 1984) suggest that relationships were not always friendly. As Prewitt (1981:83) notes, "Perdiz and Cliffton arrow points frequently associated with [Toyah phase] burials appear to represent aggression which resulted in death rather than funeral offerings."

\section{Undefined Cultural Complexes on the Southern Llano Estacado}

In order to explain the abundance of Puebloan pottery in the Texas Panhandle-Plains, Krieger (1946:80) suggested that Puebloan peoples may have inhabited the Llano Estacado seasonally. Jelinek (1967:155) suggested that the post-A.D. 1200 archeological evidence on the southern Llano Estacado represents "an eastward extension of the Pecos Valley phases." Corley (1965a, 1965b) and Leslie (1979) also see the Eastern Jornada area as an extension of Puebloan culture onto the Llano Estacado, and, based on his work at sites around Andrews Lake, Collins (1968) favored this interpretation as well. Judging from the abundance and diversity of Puebloan pottery, it is not hard to see why all of these researchers came to this conclusion.

The distribution and frequency of nonlocal pottery indicates that the vast majority of Puebloan occupations or influence on the southern Llano Estacado occurred after A.D. 1200. Although the data are now over 30 years old, Watts's (1963) study of the distribution of Puebloan pottery types in the region provides some useful information (Table 83). Watts's data are from nonsystematic collections from over 50 localities on or adjacent to the Llano Estacado. The vast majority of typeable pottery on the High Plains (excluding occurrences in the Caprock Canyonlands) is of Puebloan origin, and Watts (1963:17) notes the scarcity of Woodland cordmarked sherds (only one sherd from one site) and the absence of "East Texas Wares" (i.e., Caddoan style). Although the numbers of sherds are not recorded, the relative frequency may be inferred from statements made by Watts and/or by the number of localities where a type is found. The data are far from complete, and many ceramic types that were not defined in 1963 are not noted (e.g., Ochoa Indented). Nevertheless, Watts's study is useful as a gross representation of the types and ages of pottery in the region. Wiseman et al. (1994) are currently conducting an update on the pottery on the Llano Estacado, concentrating on materials from private collections from Lubbock to Iraan, including petrographic and typological analyses, but no data have yet been published.

As discussed in Chapter 10, the dating of Mogollon-tradition brownwares is problematic, and such wares could have been manufactured any time between A.D. 100 and 1750 (Whalen 1981a). The 
TABLE 83

AGE AND RELATIVE FREQUENCY OF PUEBLOAN POTTERY TYPES FOUND ON THE SOUTHERN LLANO ESTACADO IN TEXAS ${ }^{1}$

\begin{tabular}{|c|c|c|c|c|c|c|c|c|}
\hline \multirow[b]{2}{*}{ Type } & \multicolumn{4}{|c|}{ Relative Frequency } & \multicolumn{4}{|c|}{ Age Estimate $^{2}$} \\
\hline & $\begin{array}{l}\text { Very } \\
\text { Common }\end{array}$ & Common & Rare & $\begin{array}{l}\text { Very } \\
\text { Rare }\end{array}$ & $\begin{array}{l}\text { Early } \\
\text { Ceramic }\end{array}$ & $\begin{array}{l}\text { Middle } \\
\text { Ceramic }\end{array}$ & $\begin{array}{l}\text { Late } \\
\text { Ceramic }\end{array}$ & Unspecified \\
\hline Undifferentiated brownware & $\mathrm{x}$ & & & & $\mathrm{x}$ & $\mathrm{x}$ & $\mathrm{x}$ & \\
\hline Jornada Brown & & $\mathrm{x}$ & & & $\mathrm{x}$ & $\mathrm{x}$ & $\mathrm{x}$ & \\
\hline Three Rivers Red-on-terracotta & & & $\mathrm{x}$ & & & $\mathrm{x}$ & $\mathrm{x}$ & . \\
\hline El Paso Polychrome & & $\mathrm{x}$ & & & & $\mathrm{x}$ & $\mathrm{x}$ & \\
\hline Chupadero Black-on-white & $\mathrm{x}$ & & & & & $\mathrm{x}$ & $\mathrm{x}$ & \\
\hline Rio Grande Glaze I/A & & $\mathrm{x}$ & & & & $\mathrm{x}$ & $\mathrm{x}$ & \\
\hline Rio Grande Glaze II/B & & & $\mathrm{x}$ & & & & $\mathrm{x}$ & \\
\hline Rio Grande Glaze III/C & & & $\mathrm{x}$ & & & & $\mathrm{x}$ & \\
\hline Rio Grande Glaze IV/D & & & $\mathrm{x}$ & & & & $\mathrm{x}$ & \\
\hline Rio Grande Glaze V/E & & $\mathrm{x}$ & & & & & , $\mathrm{x}$ & \\
\hline Rio Grande Glaze VI/F & & $\mathrm{x}$ & & & & & $\mathrm{x}$ & \\
\hline Tewa Polychrome/Tewa Red & & $\mathrm{x}$ & & & & & $\mathrm{x}$ & \\
\hline Los Lunas Smudged & & & & $\mathrm{x}$ & & & & $\mathrm{x}$ \\
\hline $\begin{array}{l}\text { Mimbres Black-on-white } \\
\text { (undifferentiated) }\end{array}$ & & & & $\mathrm{x}$ & $\mathrm{x}$ & $\mathrm{x}$ & & \\
\hline Kowina Black-on-white & & & & $\mathrm{x}$ & & & & $\mathrm{x}$ \\
\hline \multicolumn{9}{|l|}{${ }^{1}$ Based on Watts (1963). } \\
\hline
\end{tabular}

abundance and diversity of decorated late ceramic types, however, may indicate a substantial increase in human population and/or activities on the Llano Estacado after A.D. 1300. This inference seems to correlate with other archeological evidence from playa and pluvial lake sites summarized in Table 84 . These investigations suggest that the Late Prehistoric II/Protohistoric occupations in the region fall into two general categories. Components with little or no pottery and relatively low artifact density may represent temporary campsites where hunting activities occurred. Components with a high artifact density and an abundance of pottery represent morepermanent base camps and residential bases. Even at these sites, however, hunting activities are well represented.

In addition, Witte (1947) notes that sites with Pueblo pottery are most concentrated around key pluvial lakes (i.e., Silver, Yellow, Illusion, Bull, Soda, Coyote, and Government) northwest of Lubbock. Based on his brief inspections of these lakes during the summer of 1946 (along with E. H. Sellards of the Texas Memorial Museum in Austin), he suggested that the "Pueblo sherds, small points, 


\section{TABLE 84}

\section{SUMMARY OF INVESTIGATED SITES ON THE SOUTHERN LLANO ESTACADO PRODUCING EVIDENCE OF LATE PREHISTORIC II AND/OR PROTOHISTORIC OCCUPATIONS BY MULTIPLE AND/OR UNKNOWN CULTURAL GROUPS}

\begin{tabular}{|c|c|c|}
\hline Location & Description & Reference \\
\hline $\begin{array}{l}8 \text { sites in sand hills } \\
\text { along Sod House Draw, } \\
\text { Bailey and Lamb } \\
\text { Counties }\end{array}$ & $\begin{array}{l}\text { Surface collections only. Multiple occupations/components are } \\
\text { represented, but they are dominantly Late Prehistoric. Sites } \\
\text { probably represent base camps or residential bases. Points are not } \\
\text { described, but ceramics }(\mathrm{n}=226 \text { ) include Chupadero Black-on- } \\
\text { white (over } 50 \text { percent of all sherds), Lincoln Black-on-red, El } \\
\text { Paso Polychrome, Corona Rubbed-Ribbed, Puaray Glaze } \\
\text { Polychrome, and Cicuye Glaze Polychrome. Sites mentioned by } \\
\text { Pearce (1936) are not included in the ceramic distribution study } \\
\text { by Watts (1963). }\end{array}$ & Pearce 1936 \\
\hline $\begin{array}{l}\text { SPAS-LY } 4 \text { in sand dunes } \\
3 \text { miles from Tahoka } \\
\text { Lake (pluvial lake), } \\
\text { Lynn County }\end{array}$ & $\begin{array}{l}\text { Multiple components from Paleoindian to Late Prehistoric are } \\
\text { present. Points include } 4 \text { Paleoindian, } 56 \text { Archaic (primarily late), } \\
\text { and } 16 \text { arrow points ( } 8 \text { Washita, } 3 \text { Harrell, and } 1 \text { each of } \\
\text { Bonham, Garza, Perdiz, Scallorn, and Young). End scrapers and } \\
\text { beveled knives are present, and a turquoise bead was recovered. } \\
\text { No ceramics were found, but pottery has been recovered from } \\
\text { other sites near Tahoka Lake. }\end{array}$ & Riggs $1965 b$ \\
\hline $\begin{array}{l}\text { 41AD2, the Salt Cedar } \\
\text { site at Andrews Lake } \\
\text { (pluvial lake), } \\
\text { Andrews County }\end{array}$ & $\begin{array}{l}\text { Extensive surface collections and excavations by the Midland } \\
\text { Archeological Society and Collins produced evidence of a Late } \\
\text { Prehistoric II/Protohistoric residential base assigned to the Ochoa } \\
\text { phase of the Eastern Jornada Mogollon, but multiple components/ } \\
\text { occupations are likely. }\end{array}$ & Collins 1968 \\
\hline $\begin{array}{l}\text { 41AD3, the Adobe } \\
\text { Mound site at Andrews } \\
\text { Lake (pluvial lake), } \\
\text { Andrews County }\end{array}$ & $\begin{array}{l}\text { Minimal excavations by Collins revealed a residential base } \\
\text { occupation including a Puebloan-like adobe dwelling, } 10 \text { arrow } \\
\text { points (Fresno, Toyah, and untyped), } 7 \text { bifaces (one is a beveled } \\
\text { knife), } 10 \text { scrapers, an Olivella shell bead, } 2 \text { unidentified } \\
\text { potsherds, and a gunflint. A radiocarbon date (uncalibrated) of } \\
\text { A.D. } 1740 \pm 100 \text { indicates that the occupations date to the late } \\
\text { Protohistoric or early Historic period. }\end{array}$ & Collins 1968 \\
\hline $\begin{array}{l}41 \mathrm{AD} 8 \text { at Andrews Lake } \\
\text { (pluvial lake), } \\
\text { Andrews County }\end{array}$ & $\begin{array}{l}\text { Unreported excavations by Llano Estacado Archeological Society } \\
\text { produced numerous late arrow points (including Harrell, Fresno, } \\
\text { and Garza) and unidentified pottery. }\end{array}$ & Collins 1968 \\
\hline $\begin{array}{l}\text { 41MT3, the Gresham } \\
\text { Lake site (pluvial lake), } \\
\text { Martin County }\end{array}$ & $\begin{array}{l}\text { Limited South Plains Archeological Society excavations. Probable } \\
\text { Late Prehistoric II hunting campsite. Two Fresno arrow points } \\
\text { were recovered, but no ceramics were found. }\end{array}$ & Breeding 1971 \\
\hline $\begin{array}{l}41 \mathrm{MT} 43 \text { adjacent to a } \\
\text { small alkali lake, } \\
\text { Martin County }\end{array}$ & $\begin{array}{l}\text { Surface collections from a } 120-\mathrm{x}-20-\mathrm{m} \text { area. Multiple components } \\
\text { are likely. Various types of projectile points (types not specified) } \\
\text { and ceramics (prehistoric and historic, but types are not specified) } \\
\text { were found. }\end{array}$ & Lee 1978 \\
\hline
\end{tabular}


Table 84, continued

\begin{tabular}{|c|c|c|}
\hline Location & Description & Reference \\
\hline $\begin{array}{l}\text { SPAS-LU29 (Site B) } \\
\text { adjacent to a small playa } \\
\text { in Lubbock County }\end{array}$ & $\begin{array}{l}\text { Surface collections only. Repeated occupations of base camp or } \\
\text { residential base are likely. Late Archaic occupations are } \\
\text { represented, but Late Prehistoric component(s) dominate. Lithics } \\
\text { include } 7 \text { dart points, } 5 \text { early arrow points (Scallorn), and } 15 \text { late } \\
\text { arrow points ( } 8 \text { Harrell, } 4 \text { Fresno, and one each of Garza, Perdiz, } \\
\text { and Young). Ceramics include Jornada Brown ( } \mathrm{n}=14) \text {, } \\
\text { Chupadero Black-on-white }(\mathrm{n}=9) \text {, Playas Red Incised }(\mathrm{n}=8) \text {, } \\
\text { and Borger Cordmarked }(\mathrm{n}=35) \text {. It is possible that the Borger } \\
\text { Cordmarked are misidentified; if not, they represent the most } \\
\text { southerly occurrence of this type. Scrapers are very abundant. }\end{array}$ & Brown 1985 \\
\hline $\begin{array}{l}\text { SPAS-LU34 (Site A) } \\
\text { adjacent to a small playa } \\
\text { in Lubbock County }\end{array}$ & $\begin{array}{l}\text { Surface collections only. Repeated occupations of base camp or } \\
\text { residential base are likely. Components are Late Archaic through } \\
\text { Late Prehistoric II. Collections include } 5 \text { dart points, } 3 \text { early } \\
\text { arrow points (Scallorn and Deadman's), } 10 \text { late arrow points ( } 4 \\
\text { Fresno, } 3 \text { Harrell, } 2 \text { Young, and a Garza), } 70 \text { sherds of Jornada } \\
\text { Brown, and } 99 \text { sherds of unidentified brownware (perhaps locally } \\
\text { made). Scrapers are very abundant. }\end{array}$ & Brown 1985 \\
\hline $\begin{array}{l}\text { SPAS-LU10 near } \\
\text { Wolfforth in Lubbock } \\
\text { County; numerous playas } \\
\text { are in vicinity, but } \\
\text { precise site location is } \\
\text { not stated }\end{array}$ & $\begin{array}{l}\text { Surface collections only. Substantial Archaic component } \\
\text { (primarily Late) is represented by a variety of dart points, but } \\
\text { other occupations are Late Prehistoric. Diagnostics include pottery } \\
\text { (El Paso Brownware, Chupadero Black-on-white, unidentified } \\
\text { corrugated ware, and unidentified Rio Grande glazeware) and } \\
\text { arrow points (Deadman's, Scallom, Washita, and Fresno). }\end{array}$ & $\begin{array}{l}\text { Brown 1990a, } \\
1990 b, 1991 a, \\
1991 b\end{array}$ \\
\hline $\begin{array}{l}\text { 41LU75, adjacent to } \\
\text { small playa in Lubbock } \\
\text { County }\end{array}$ & $\begin{array}{l}\text { Surface collections and very limited testing. Repeated occupations } \\
\text { of base camp or residential base are likely. Components include } \\
\text { Late Archaic and Late Prehistoric, but most materials are of Late } \\
\text { Prehistoric II age. A few dart points and some early arrow points } \\
\text { are present, but Washita, Harrell, and Fresno are abundant. End } \\
\text { scrapers also are very abundant, and numerous bison bones and } \\
\text { bone tools are reported. Ceramics include Chupadero Black-on- } \\
\text { white ( } \mathrm{n}=1067) \text {, Casa Colorado ( } \mathrm{n}=435 \text { ), Pitoche Rubbed } \\
\text { Ribbed ( } \mathrm{n}=91 \text { ), White Mountain Redware ( } \mathrm{n}=11) \text {, Jornada } \\
\text { Brown ( } \mathrm{n}=237) \text {, and local/undifferentiated brownwares ( } \mathrm{n}= \\
850 \text { ). Brown felt that most of the brownwares were of local } \\
\text { manufacture, but this has not been confirmed. }\end{array}$ & Brown n.d. \\
\hline $\begin{array}{l}\text { SPAS-LU22 adjacent to } \\
\text { small playa in Lubbock } \\
\text { County }\end{array}$ & $\begin{array}{l}\text { Collections include five Washita and two Fresno arrow points and } \\
\text { many end scrapers. Edwards chert and Tecovas jasper are the } \\
\text { dominant lithic materials, but obsidian also is represented. Pottery } \\
\text { includes striated plainware }(\mathrm{n}=26) \text {, Jornada Brown }(\mathrm{n}=16) \text {, } \\
\text { Chupadero Black-on-white }(\mathrm{n}=1) \text {, and a variant of Puaray Glaze } \\
\text { E Polychrome }(\mathrm{n}=71) \text {. Decorated pottery types suggest multiple } \\
\text { occupations over a lengthy period of time. }\end{array}$ & C. Brown 1993 \\
\hline
\end{tabular}


small scrapers, four-edged and oval knives likely fall within the presumed heavy Pueblo occupation of the area during late prehistoric times." The abundance of Late Prehistoric materials suggests a fairly high population on the southern Llano.

Based on his work at the Salt Cedar site, Collins (1968:155-156) concluded that "various marginal Puebloan groups, related to, or similar to those which Corley and Leslie have recognized in southeastern New Mexico, spread eastward to temporarily occupy the Andrews Lake locality." The culture recognized by Corley (1965a, 1965b) and Leslie (1979) is the eastern extension of the Jornada Branch of the Mogollon. The concept of an Eastern Jornada Mogollon culture is appropriate for some, but not all, of the Late Prehistoric II and Protohistoric archeological evidence on the southern Llano Estacado, however. Other evidence, such as the diversity of pottery and arrow point styles, indicates that unknown and/or multiple cultural groups were responsible for much of the archeological remains dating to these periods.

The archeological data for the southern Llano Estacado are poor, and subsurface investigations are rare and often inadequately reported. The vast majority of the available data are derived from surface collections from sites extensively disturbed by modern agriculture. Diagnostic artifacts indicate that mixing of materials from multiple components is likely at most sites. These are but a few examples of problems that limit the interpretability of the data. Regardless of these limitations, the southern data seem to indicate that (1) relative to earlier time periods, there may have been an explosion in human population and/or activities on the southern High Plains after A.D. 1100-1200; (2) the Late Prehistoric II/Protohistoric peoples inhabited numerous small villages and campsites around prominent playas and pluvial lakes; (3) hunting and processing of animals, primarily bison, are the main activities represented at both residential bases and ephemeral campsites (i.e., bison is the only taxon for which substantial direct evidence for utilization exists); (4) the apparent increase in human population correlates in time with the onset of xeric conditions and increasing bison populations in the Southern Plains after A.D. 1100 (see Chapter 8); (5) the diversity of late arrow point styles and ceramic wares indicates that there were probably many different cultures or groups of people involved in the intensive bison hunting on the southern Llano Estacado after
A.D. 1100; and (6) Toyah phase peoples from westcentral Texas may have frequented the Llano Estacado and interacted in some manner with Garza complex peoples (Treece, Lintz et al. 1993b:391399, 442-444).

The southern Llano Estacado seems to have been utilized by several different cultural groups, but their origins are not altogether clear. Perhaps the diversity of archeological remains may be explained by a combination of in situ development and expansion of eastern Jornada Mogollon culture across the High Plains, expansion of other cultural groups out of their core areas (e.g., Toyah phase), and a sudden influx of various immigrant groups (e.g., Garza complex). The production of corrugated pottery on the Llano, as well as the probability that some brownwares were locally manufactured, indicates that the origins of at least some of these Plains people could be traced to the Jornada Mogollon or southern Puebloan area. Perhaps these peoples represent immigrant populations - refugees from the Jornada Mogollon heartland, the middle Pecos and Sierra Blanca regions, or other Puebloan areas that were partially or completely abandoned during the thirteenth through sixteenth centuries. It also is possible that some of these peoples were descendants of Palo Duro complex peoples who moved onto the Llano Estacado after A.D. 1100-1200. As currently defined, the late Maljamar and Ochoa phases do not adequately account for the diversity of points and pottery (perhaps representing a diversity of peoples) and the specialized nature of the bison hunting villages and campsites across the southern Llano Estacado.

\section{TIERRA BLANCA COMPLEX}

The Tierra Blanca complex is an ill-defined, misunderstood concept, although a number of sites have been attributed to it (Figure 98 and Table 85). The primary interpretive problems are that (1) too few sites have been adequately investigated, and those that have been are not adequately reported; (2) the absolute chronology (Table 86) is well defined at some sites but poorly defined at others; (3) the material culture is only vaguely defined and has never been adequately summarized; and (4) it is difficult to define discrete components at many sites where multiple, long-term occupations are likely. In addition, there has been a tendency to lump all archeological remains at such sites as representative 
of the complex, which may not be the case. Because published data derived from intensive investigations are minimal, it is important to critically evaluate each site attributed to the Tierra Blanca complex. Numerous sites have produced materials suggesting that Tierra Blanca complex occupations may be represented. However, only sites/components that can be attributed to the complex with some degree of confidence are discussed here. Whenever possible, information is drawn from published data, but useful archeological data are scarce for many of these sites. Consequently, the Panhandle-Plains Historical Museum collections and records for many Tierra Blanca sites were examined during this study.

One of the primary interpretive problems is that, unlike the Garza complex, there is no diagnostic artifact that is exclusive to the Tierra Blanca complex. The common projectile points are the ubiquitous Washita, Harrell, and Fresno points. In addition, some unnotched triangular points are long and narrow with straight to slightly concave blades and have been called Talco or Talco-like (e.g., J. Hughes 1991:35; Hughes et al. 1978:147). As discussed below, even these Talco-like points are found elsewhere in the region and in sites assigned to other cultural complexes (i.e., the Garza complex). Due to the lack of a culturally diagnostic artifact, geographic location has been an extremely important factor in assigning sites to the Tierra Blanca complex; geographic location is not a cultural variable and may have been overemphasized, however. It has generally been assumed that the Tierra Blanca culture has a restricted range confined to a single drainage (i.e., Prairie Dog Town Fork of the Red River), despite the fact that similar sites are found elsewhere in the Panhandle-Plains.

\section{Archeological Sites}

\section{Residential Bases and Base Camps}

\section{TIERRA BLANCA (41DF3)}

The Tierra Blanca site (PPHM-A264), on Tierra Blanca Creek in Deaf Smith County, is considered to be the type site of the Tierra Blanca complex. The site was first discovered around 1925 by a local amateur archeologist who reported finds of Puebloan glazeware pottery to H. P. Mera of the Laboratory of Anthropology at Santa Fe. At Mera's insistence,
Texas Technological College conducted the first intensive archeological investigation in 1930. Holden (1931:50-52) reports that the team spent four days excavating at the "Tierra Blanca Ruin" for the purpose of defining the nature of the Puebloan influence on the Texas Panhandle "slab-house culture," now recognized as the Antelope Creek phase. Holden (1931:50) observed that the site was located on the south rim of the valley at a point "commanding a view for miles up and down the valley" and adjacent to a "strong spring" in the creek. About a dozen ruins, vaguely defined by circular concentrations of stone, were observed, but the Texas Tech excavations concentrated on a single $23-\mathrm{x}-27-\mathrm{ft}(6.9-\mathrm{x}-8.1-\mathrm{m})$ structure. The dwelling was completely excavated in pie-shaped sections. The floor level was reached at about 12-18 inches below the surface. The excavations produced Puebloan redware and glazeware pottery (identified as Glazes II, IV, and V), black plainware sherds, at least one arrow point, flint flakes, some obsidian flakes, scrapers, a reamer, bison bones, and mussel shells. In the lowest level, three sherds of the "Canadian type" (presumably Borger Cordmarked) were found.

No architectural details were presented, but Holden (1931:51) felt that the ruin was "of typical Canadian architecture." It is considerably larger than most of the similar circular structures in the Antelope Creek phase (Lintz 1986), but the measurements may represent exterior dimensions rather than the interior size. Of particular importance is Holden's (1931:52) statement that "it is our opinion that Pueblo Indians much later made temporary camps at these old slab-stone ruins on the Tierra Blanca for the purpose of hunting buffalo." Although researchers now generally agree that it is unlikely that the site was ever occupied by a Puebloan group, this leaves little doubt that Holden recognized that there were two discrete components.

Additional testing and excavations at the Tierra Blanca and Blackburn (described below) sites in 1979-1980 provided Spielmann $(1982,1983)$ with a sample of Puebloan trade items for her doctoral research on the nature of Southern Plains-Pueblo interactions. Only a cursory summary of the findings and selected archeological data have been published, but it is clear that there are at least two separate (perhaps more) components or occupation periods at the site (Spielmann 1982:279-287). Few details of the features are presented, but three structures and a roasting pit were excavated. Six 


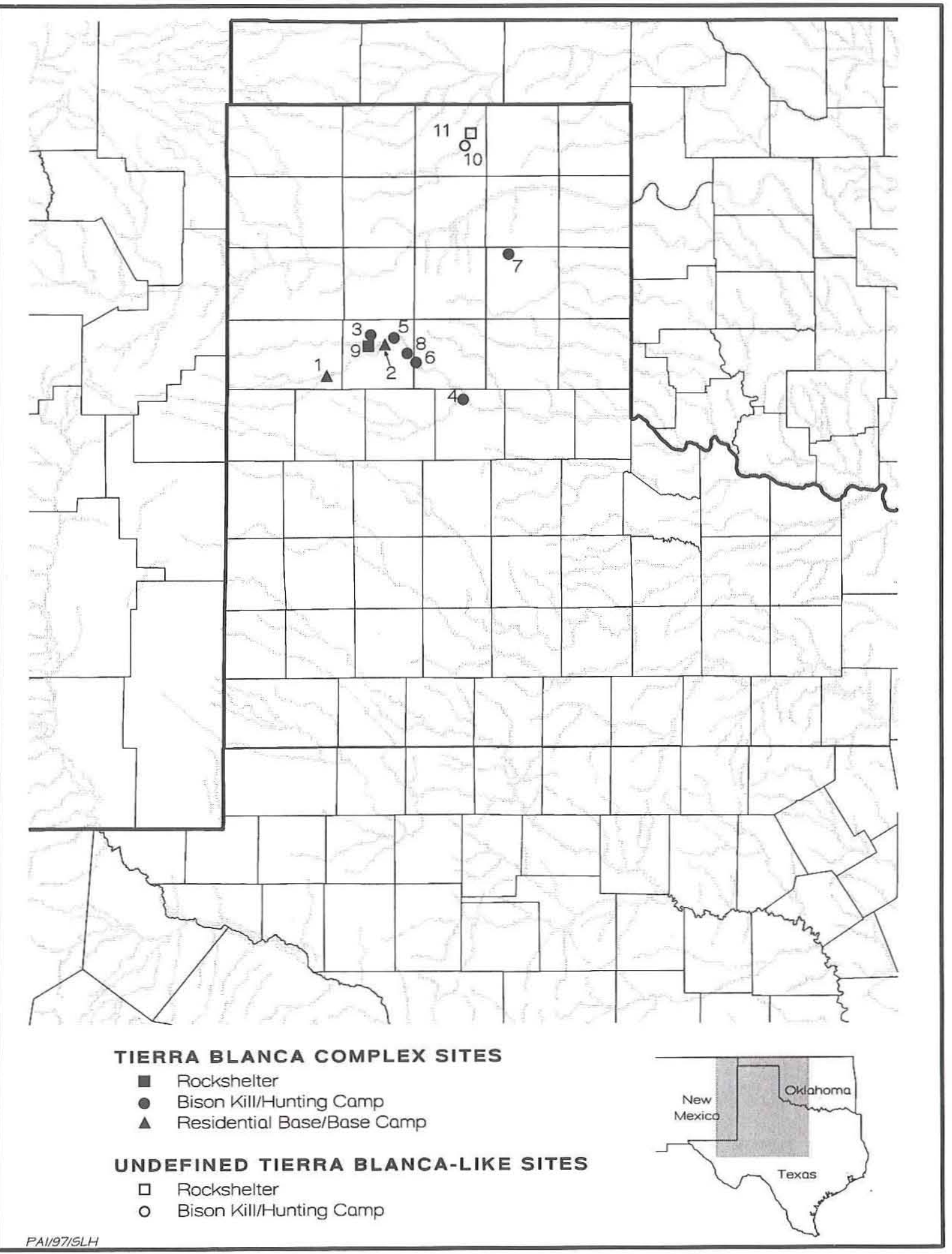

Figure 98. Map of Tierra Blanca complex sites discussed in the text. 
TABLE 85

TIERRA BLANCA COMPLEX SITES DISCUSSED IN THE TEXT

\begin{tabular}{|c|c|c|}
\hline $\begin{array}{l}\text { Key to } \\
\text { Figure } 98\end{array}$ & Site Name (Number) & Reference \\
\hline \multicolumn{3}{|c|}{ RESIDENTIAL BASES AND BASE CAMPS } \\
\hline $\begin{array}{l}1 \\
2\end{array}$ & $\begin{array}{l}\text { Tierra Blanca (41DF3) } \\
\text { Blackburn (41RD20) }\end{array}$ & $\begin{array}{l}\text { Holden 1931; Spielmann 1982, } 1983 \\
\text { Spielmann 1982, } 1983\end{array}$ \\
\hline \multicolumn{3}{|c|}{ BISON KILLS AND HUNTING CAMPS } \\
\hline $\begin{array}{l}3 \\
4 \\
5 \\
6 \\
7 \\
8\end{array}$ & $\begin{array}{l}\text { Fifth Green (PPHM-A1363) } \\
\text { Tule Mouth Sites (41B73, 81, and } 83 \\
\text { Palisades (PPHM-A530) } \\
\text { Cita Mouth (PPHM-A288) } \\
\text { Fatheree (41GY32) } \\
\text { Water Crossing No. } 2 \text { (PPHM-A148) }\end{array}$ & $\begin{array}{l}\text { Kalokowski } 1986 \\
\text { Katz and Katz } 1976 \\
\text { Unpublished } \\
\text { Unpublished } \\
\text { Hughes et al. } 1978 \\
\text { Unpublished }\end{array}$ \\
\hline \multicolumn{3}{|c|}{ ROCKSHELTER (with burial) } \\
\hline 9 & Canyon City Club Cave (PPHM-A251) & Hughes 1969 \\
\hline \multicolumn{3}{|c|}{ UNDEFINED TIERRA BLANCA-LIKE SITES } \\
\hline $\begin{array}{l}10 \\
11\end{array}$ & $\begin{array}{l}\text { Broken Jaw (41HF8) } \\
\text { Unnamed Shelter ( } 41 \mathrm{HF} 86)\end{array}$ & $\begin{array}{l}\text { Quigg, Lintz, Oglesby, Earls et al. } 1993 \\
\text { Quigg, Lintz, Oglesby, Earls et al. } 1993\end{array}$ \\
\hline
\end{tabular}

radiocarbon dates obtained on charcoal associated with these features support an interpretation of multiple components (see Table 86).

Structure 1 is described as an ephemeral dwelling (i.e., a brush hut or windbreak) consisting of a "hard-packed sand/clay floor ringed on the windward [southwest] side by a scatter of small boulders" (Spielmann 1982:282). This structure produced the majority of New Mexican trade items, but the ceramics associated with it are not specifically identified. No radiocarbon dates are associated.

Structure 2 is described as "a circular, slablined, semi-subterranean habitation with a central hearth" (Spielmann 1982:282). Judging from an illustration (Spielmann 1982:Figure 13a), this structure appears to have measured approximately $3.5 \times 4.5 \mathrm{~m}$, much smaller than the rock-lined structure excavated by Holden (1931) but similar in size and configuration to some of the circular Antelope Creek phase structures described as Unit Type 3 by Lintz (1986:107-110). When the three radiocarbon dates for Structure 2 are averaged and calibrated following Stuiver and Reimer (1993), the 1-sigma range and intercepts are A.D. 1293 (1303,
1372, 1383) 1392. Consequently, it is likely that Structure 2 dates to the fourteenth century or earlier (assuming that all of the charcoal samples are from the hearth or floor of the structure rather than from postoccupation fill).

The roasting pit feature is not described, but two radiocarbon dates obtained on charcoal from the pit indicate that it also dates to the fourteenth century. When the two dates are averaged and calibrated following Stuiver and Reimer (1993), the 1-sigma range with intercepts is A.D. 1296 (1326, $1353,1360,1367,1389) 1404$. This feature is approximately contemporaneous with Structure 2 .

The third excavated structure is a tipi ring defined by an irregular, 3-4-m-diameter scatter of rocks around a central, basin-shaped hearth. A single radiocarbon date from this hearth indicates that the tipi was used early in the fifteenth century (see Table 86).

The material culture is not described except for the New Mexican trade items, which are summarized by Spielmann (1983:262-267). Two pieces of turquoise (a bead and a fragment), 73 pieces of obsidian (including 2 arrow points), and 306 glazeware sherds were recovered. Of 49 pieces of 


\begin{tabular}{|c|c|c|c|c|}
\hline \multicolumn{5}{|c|}{ TABLE 86} \\
\hline \multicolumn{5}{|c|}{ SUMMARY OF RADIOCARBON DATES FOR TIERRA BLANCA COMPLEX SITES } \\
\hline $\begin{array}{l}\text { Site Name, Number, Sample } \\
\text { Provenience, and Reference }\end{array}$ & $\begin{array}{l}\text { Material and } \\
\text { Lab No. }\end{array}$ & $\begin{array}{l}\text { Uncorrected } \\
\text { Age, B.P. }\end{array}$ & $\begin{array}{l}\text { Corrected } \\
\text { Age, B.P. }{ }^{1}\end{array}$ & $\begin{array}{l}\text { Calibrated Date Range } \\
\text { and Intercepts, A.D. }\end{array}$ \\
\hline \multirow{3}{*}{$\begin{array}{l}\text { Tierra Blanca (41DF3), Structure } 2 \\
\text { Spielmann 1982:Table } 26\end{array}$} & Charcoal, Beta-2767 & - & $560 \pm 50$ & 1328 (1408) 1427 \\
\hline & Charcoal, Beta-2768 & - & $710 \pm 60$ & 1264 (1288) 1382 \\
\hline & Charcoal, Beta-2769 & - & $700 \pm 60$ & $1278(1290) 1386$ \\
\hline \multirow{2}{*}{$\begin{array}{l}\text { Tierra Blanca (41DF3), Roasting Pit } \\
\text { Spielmann 1982:Table } 26\end{array}$} & Charcoal, Beta-2772 & - & $540 \pm 50$ & $1331(1412) 1434$ \\
\hline & Charcoal, Beta-2773 & - & $740 \pm 60$ & 1259 (1282) 1295 \\
\hline $\begin{array}{l}\text { Tierra Blanca (41DF3), Tipi Ring } \\
\text { Spielmann 1982:Table } 26\end{array}$ & Charcoal, Beta-2770 & - & $480 \pm 60$ & 1412 (1436) 1449 \\
\hline $\begin{array}{l}\text { Tule Mouth Site (41BI83) } \\
\text { Katz and Katz 1976:Appendix II }\end{array}$ & Charcoal, BGS $284^{3}$ & $360 \pm 80$ & - & 1439 (1490) 1643 \\
\hline \multirow{2}{*}{$\begin{array}{l}\text { Canyon City Club Cave } \\
\text { (PPHM-A251), Level } 1 \\
\text { Hughes 1969:Table } 1\end{array}$} & Charcoal, WIS -410 & $400 \pm 60$ & - & 1435 (1449) 1620 \\
\hline & Charcoal, WIS-411 & $300 \pm 50$ & - & $\begin{array}{l}1439(1533,1541,1636) \\
1651\end{array}$ \\
\hline \multicolumn{5}{|c|}{$\begin{array}{l}{ }^{1} \text { Corrected ages are estimates for dates for which no } \delta^{13} \mathrm{C} \text { values were obtained. The corrected ages are based on } \\
\text { an estimated } \delta^{13} \mathrm{C} \text { value of }-24.00 \text { for fossil wood charcoal (from Stuiver and Polach 1977). } \\
{ }^{2} \text { All calibrations are done by CALIB version } 3.03 \text { according to Stuiver and Reimer (1993), using a 1-sigma range } \\
\text { for calibration data set } \# 2 \text {. Calibrations are based on the estimated } \delta^{13} \mathrm{C} \text { values. } \\
{ }^{3} \text { Brock University Geological Sciences, Catherines, Ontario, Canada. }\end{array}$} \\
\hline
\end{tabular}

obsidian subjected to trace element analysis for sourcing, 16 could not be sourced, 31 were identified as probably having come from the Jemez Mountains of northern New Mexico, and 2 were sourced to the Red Hill locality in west-central New Mexico (Sappington 1982). The glazeware sherds were identified by A. H. Warren as Glazes C through D wares, most of which were manufactured either at Tonque Pueblo or at various Galisteo Basin pueblos, including San Marcos. The assemblage is thought to date to approximately A.D. 1425-1525. In addition to the glazewares, other ceramics included 32 sherds of corrugated pottery of unknown Puebloan or possibly Plains origin, 7 sherds of Ocate Micaceous, and 117 sherds of Faint-Striated.

Spielmann (1983:264) states that no sherds originating at Pecos Pueblo were identified in the excavated sample. Notes on the ceramics by A. H. Warren (dated October 1980, on file at the PanhandlePlains Historical Museum) do indicate that a few sherds of glazeware and redware in the general site collection may be from Pecos Pueblo, however. They are tempered with sandstone and appear consistent with wares made at Pecos Pueblo after A.D. 1600. Warren also noted that "the faint striated or Perdido Plain sherds generally contain sandstone which could also be from the Pecos area, but not necessarily so." Based on a petrographic study that concluded that they were manufactured locally, these striated sherds were later typed as Tierra Blanca Plain by Habicht-Mauche (1988). Boyd and ReeceTaylor (1993) question this conclusion, however, and suggest that most of the striated plainware sherds from the Tierra Blanca site were Puebloan made. In either case, the decorated and striated wares are thought to date no earlier that about A.D. 1600, thus indicating seventeenth-century occupations. Historic ceramics and a metal point found on the surface may indicate even later occupations.

The Tierra Blanca site is important, but the lack of detailed published information on the features and material culture prevents any meaningful intrasite 
analysis and definition or comparison of components. It seems likely that the site may have been occupied by Antelope Creek villagers during the fourteenth century (i.e., Structure 2 and the roasting pit) and then reoccupied, probably repeatedly, by another cultural group during the fifteenth to seventeenth centuries (i.e., Structure 1 and the tipi ring). The later occupations represent the Tierra Blanca culture and contain ample evidence that these people interacted with sedentary Puebloan farmers. Alternatively, it is possible that there is no definable Antelope Creek phase component and that the earlier features (i.e., Structure 2 and the roasting pit) may represent early Tierra Blanca complex occupations.

\section{BLACKBURN (41RD20)}

Archeological investigations by the PanhandlePlains Historical Museum at the Blackburn site (PPHM-A152) in Randall County include surface collections over several decades and limited excavations in the 1950s. Much of this work is summarized in the field notes of Jack Hughes and Bill Harrison, but no analysis or reporting of these investigations has been done. Large amounts of glazeware and plainware pottery and arrow points have been collected from the site. In addition, Hughes (field notes, August 8, 1956) reports that structural features (either slab-lined walls and/or collapsed masonry walls of adobe/rock) were encountered during one dig.

Additional investigations were conducted in 1979-1980, but only minimal data have been reported (Spielmann 1982, 1983). The site, located on the south rim of Palo Duro Canyon, is described as being deflated, and most materials were found within $10-20 \mathrm{~cm}$ of the surface. Bone preservation was poor, no features were found, and no pollen or flotation samples have been analyzed. Only the imported artifacts are discussed by Spielmann (1982, 1983). Of 34 pieces of obsidian recovered, 7 were submitted for trace element sourcing (Sappington 1982). One could not be sourced with any confidence, but six were identified as probably having come from the Jemez Mountains of northern New Mexico. Spielmann (1983:265-266) summarizes the ceramic assemblage as being identical to the intermediate glaze assemblage at the Tierra Blanca site. Most of the 320 glazeware sherds were identified by A. H. Warren as having temper characteristic of Tonque Pueblo, San Marcos Pueblo, or other
Galisteo Basin pueblos.

The Blackburn site cannot be evaluated based on the published information, and no substantial inferences regarding subsistence and site function may be made. However, it is clear that the site represents a residential base and that the investigated area is only a small portion of an extensive site that has produced large amounts of various types of lithics and pottery. Its many similarities with the Tierra Blanca site are noteworthy, and it is possible that the Blackburn site also has an earlier occupation by Antelope Creek peoples and that only the later occupations relate to Tierra Blanca.

\section{Bison Kills and Hunting Camps}

\section{FIFTH GREEN (PPHM-A1363)}

An unpublished manuscript on file at the Panhandle-Plains Historical Museum (Kalokowski 1986) describes the findings of the 1976 surface collection and 1979 salvage excavations at the Fifth Green site, now part of the Canyon Country Club in Randall County. Excavations; conducted by West Texas State University and the Panhandle Archeological Society, exposed $36 \mathrm{~m}^{2}$ (isolated units and small excavation blocks) of shallowly buried cultural deposits in an alluvial terrace adjacent to Palo Duro Creek. The site is situated in the upper end of Palo Duro Canyon, about $5 \mathrm{~km}$ upstream from where Palo Duro and Tierra Blanca Creeks join to form the Prairie Dog Town Fork of the Red River.

The surface collections yielded an abundance of similar materials, and the excavated artifacts constitute a discrete assemblage attributable to the Tierra Blanca complex (Table 87). This assemblage consists of 554 artifacts that are largely related to hunting, butchering, and hide-processing activities or maintenance of the tools associated with these activities. Twelve arrow points included six specimens typeable as Fresno $(n=4)$, Talco, and Washita. A beveled knife, several bifacial tools, and edge-modified flakes were recovered, along with 10 unifaces, 7 of which are snub-nosed end scrapers. The only ground stone tools are two shaft smoothers and an awl smoother or whetstone. Pottery includes 139 sherds of thin, black micaceous plainware that is described as being similar to Perdido Plain or Puebloan utility wares (e.g., from Taos/Picuris). Faunal remains were not analyzed, except for a few hundred mussel shell fragments and a few rodent 


\begin{tabular}{|l|l|c|}
\hline \multicolumn{2}{|c|}{ TABLE 87 } \\
SUMMARY OF ARTIFACTS RECOVERED FROM \\
EXCAVATIONS AT THE FIFTH GREEN SITE \\
\hline \multicolumn{2}{|c|}{ Artifact Type } & $\begin{array}{c}\text { No. of Specimens } \\
\text { Recovered }\end{array}$ \\
\hline Chipped Stones & Arrow points & 12 \\
& Bifacial knife & 1 \\
& Beveled knife & 1 \\
& Other bifaces & 8 \\
& Keeled end scrapers & 7 \\
& Side scrapers & 3 \\
& Edge-modified flakes & 10 \\
& Unmodified debitage & 363 \\
\hline Ground and & Shaft smoothers & 2 \\
Battered Stones & Awl sharpener/whetstone & 1 \\
\hline Ceramics & Micaceous plainware sherds & 139 \\
\hline Bone Artifacts & Awl & 1 \\
\hline Historic Artifact & Stakes or wedges & 5 \\
\hline Total: & Iron awl & 1 \\
\hline
\end{tabular}

near the possible tipi ring, and a midden area (i.e., a concentration of cultural materials) was uncovered near the vertical bison bones.

Material culture, features, and activity areas found in the excavations strongly suggest that the Fifth Green site, covering an area of more than $40 \times 40 \mathrm{~m}$, represents a tipi encampment and secondary bison processing area. The deposits could represent multiple camping/ processing episodes, but the discreteness of the deposits and activity patterning suggest that it could represent a single event of relatively short duration. Judging by the amount of bison bones recovered, it is likely that the kill locality was somewhere nearby in the canyon. The site has not been radiocarbon dated, but most of the plainware pottery falls into the category of late-sixteenth-to-seventeenthcentury striated utility wares discussed by Habicht-Mauche (1988).

bones. Approximately 1,700 bones are reported to be almost exclusively bison bones.

The lithic debitage is heavily dominated by Alibates agate ( 90.4 percent) and Tecovas jasper (6.3 percent). These materials are not found in the immediate vicinity of the site, and the closest source areas are in the Canadian River valley more than $75 \mathrm{~km}$ away. Obsidian (1.4 percent) and Edwards chert ( 0.8 percent) came from much farther away (i.e., more than $300 \mathrm{~km}$ ) but are poorly represented in the assemblage. Potter chert, which may be found in the Ogallala gravels farther downstream in Palo Duro Canyon, was more readily available, but its low frequency of occurrence (1.1 percent) indicates that it was not a preferred material for making hunting/butchering tools.

Only three features are described, but two other activity areas are mentioned. Feature 1 is an unlined basin hearth. Feature 2 is a cluster of caliche rocks thought to represent a partial tipi ring. Feature 3 is a series of vertical bison limb bones, two isolated and three in one tight cluster, within a $3.5-\mathrm{m}$ area. The latter are interpreted as stakes or wedges for poles and may have helped support hidedrying racks. A bison processing area was noted
The metal awl would be consistent with a seventeenth-century occupation. In many ways, the site is reminiscent of the Longhorn site (see Chapter 6 and Garza Complex below), where similar evidence of a tipi encampment was uncovered. The primary difference is that the Longhorn site was a repeatedly occupied base camp with a much greater diversity of artifacts (including much decorated pottery) and activities represented, while the Fifth Green site appears to have been a short-term encampment where hunting/processing activities were predominant.

\section{TULE MOUTH SITES \\ (41BI73, 41BI81, AND 41BI83)}

Investigations at three sites located within $1 \mathrm{~km}$ of each other on the alluvial terraces on either side of Tule Creek at its confluence with the Prairie Dog Town Fork of the Red River are reported by Katz and Katz (1976:52-56). Surface collection and eight 2-x-2-m units $\left(32 \mathrm{~m}^{2}\right)$ at $41 \mathrm{BI} 73$, on the south bank of the Tule, produced a Fresno point, a point fragment, five scrapers, a drill, a sherd of Puebloan plainware, and at least one bison bone. A. H. Warren suggested that the potsherd dates to the 
seventeenth century and is stylistically similar to Pecos Faint Striated but notes that the crushed quartzite temper probably indicates that it was made at Picuris Pueblo or at one of the Salinas pueblos.

A continuous scatter of charcoal and bison bones was observed over a large area at 41BI83, on the north terrace. Surface collection and six 2-x-2-m units $\left(24 \mathrm{~m}^{2}\right)$ produced evidence of a bison processing station dating to the sixteenth century. Five units were excavated in areas where bone concentrations were observed, and the sixth unit was selected to expose a hearth. Charcoal from the hearth, which turned out to be an unlined basin filled with ash, charcoal, and some burned rocks, produced a calibrated date of A.D. 1439 (1490) 1643 (see Table 86). No points were recovered. Collected items include four scrapers, a drill, and sherds of unidentified brownware, probably made in eastern New Mexico (according to Warren). Faunal remains were found as discrete clusters of different elements in several different units, and 425 unworked bones were recovered. The bones are not identified, but bison is apparently well represented. The excavators felt that the "bone units" were "disappointing" because they yielded "very little artifactual material" (Katz and Katz 1976:55). The site appears quite promising, however, because it probably represents a discrete hunting/processing event.

Investigation of another site, 41BI81 (located just upstream from 41BI83), revealed "a stratum of bone, chipped stone flakes and charcoal in the north bank of Tule Creek" (Katz and Katz 1976:53). No excavation was done, but two scraping tools were recovered and bones from the cutbank were identified as bison.

All three sites appear to be of similar age and produced similar cultural materials. Katz and Katz (1976:55) suggest that they represent bison hunting and related activities by the same group, probably Apaches, during the sixteenth and/or seventeenth centuries. One other site in the vicinity, 41BI97, located about $7 \mathrm{~km}$ upstream on the north terrace of Tule Creek, also produced one potsherd, identified (by Warren) as Corona Plain made in the Salinas area between A.D. 1550 and 1675 .

\section{PALISADES (PPHM-A530)}

A series of archeological investigations at the Palisades site, which includes a collapsed rockshelter and an open campsite in Randall County, were conducted between 1962 and 1977 by West Texas State University and Amarillo College. No analysis or write-up of these investigations has been done, but field notes and site records are on file at the Panhandle-Plains Historical Museum. A possible wattle-and-daub structure (e.g., jacal-like dwelling) was excavated in 1963 (Jack Hughes field notes, May 19 and July 13-14, 1963). Hughes (1978:46) mentions that this feature is a "possible Apache dwelling" but presents no details. The structure consisted of a central, unlined basin hearth and a probable floor area where scattered grass-and-stickimpressed daub fragments, one with fingerprint impressions in it, and cultural debris were found. At least two Fresno arrow points and one sherd of plainware pottery were recovered. No definite postholes were found, but a line of vertical bison rib sections (several up to 6 inches long) was encountered along one edge of the structure. The excavators concluded that these ribs represented stakes, but they could not determine how they were related to the dwelling (i.e., whether they were inside or outside).

Although the Palisades and several other sites in the immediate vicinity (Hughes 1978:44-46) were occupied primarily by Antelope Creek peoples, the uppermost materials appear to represent ephemeral occupations by peoples of the Tierra Blanca complex (Jack Hughes, personal communication 1992). It is not known whether the occupations represent a residential base or a small hunting camp. The absence of glazeware pottery suggests the latter.

\section{CITA MOUTH (PPHM-A288)}

The Cita Mouth site has been attributed to the Tierra Blanca complex (Habicht-Mauche 1988:211; Hofman 1989b:99), but investigations consist solely of surface collections made over many years by the Panhandle-Plains Historical Museum. No report on the investigations or collections has been made. Cultural materials include arrow points (Fresno, Washita, and one Garza), unifacial scrapers, large Potter chert choppers, obsidian flakes, a few ground stones, and plainware ceramics. Habicht-Mauche (1988:Tables 5-1 and 7-2) conducted an attribute analysis on 132 plainware sherds and included 8 of these sherds in her Tierra Blanca plainware petrographic analysis.

Hughes (1978:46) notes that this is an extensive campsite located on an alluvial terrace in Cita 
Canyon at its junction with Palo Duro Canyon. In the absence of subsurface investigations, interpretations of site function are speculative. The materials recovered are most similar to artifacts from the Fifth Green and Tule Mouth sites. Consequently, it may be suggested that the Cita Mouth site represents an encampment where bison hunting/processing activities were conducted.

\section{FATHEREE (41GY32), AREA 2}

Surface collections and excavation of one 5-x-5-ft unit in Area 2 at the Fatheree site, along a tributary to Red Deer Creek in Gray County, yielded evidence of a Tierra Blanca complex occupation (Hughes et al. 1978:146-153). The deposits were very shallow (only about 3 inches thick), and no features were encountered. Collections consist of 23 stone artifacts, 79 bones (only 1 was identifiable as bison), and 241 sherds. The stone specimens include two arrow points (a Fresno and a Talco), a drill, an end scraper, and a metate fragment. All of the sherds appear to be from a single plainware pot that had "vertical loop handles between the neck and shoulder, probably two on opposite sides" (Hughes et al. 1978:152). Although the handles were considered unusual, the ware was tentatively identified (by James Gunnerson) as seventeenth-century Perdido Plain. The vessel fragments were later analyzed and typed as Tierra Blanca Plain by Habicht-Mauche (1988:Table 5-1).

WATER CROSSING NO. 2 (PPHM-A148)

Located on an alluvial terrace at the second water crossing in Palo Duro Canyon State Park, site PPHM-A148 is mentioned by Hughes (1978:43) but is known primarily through a surface collection at the Panhandle-Plains Historical Museum. Cultural materials recovered include flakes, bifaces, numerous scrapers, an untypeable obsidian arrow point with serrated edges, and striated plainware sherds (two with fingernail punctates). A few possible glazeware sherds and a small unidentified brass artifact also were found. Eight plainware sherds were included in the attribute analysis of Tierra Blanca plainwares by Habicht-Mauche (1988:Table 5.1). The scarcity of artifacts suggests that the site represents an ephemeral hunting camp, although test excavations might prove otherwise.

\section{Rockshelter and Burial}

\section{CANYON CITY CLUB CAVE (PPHM-A251)}

A short distance south of the Fifth Green site is a small rockshelter formed in the Ogallala caliche canyon rim in the vicinity of the Canyon Country Club (originally called the Canyon City Club). This Randall County rockshelter, called the Canyon City Club Cave, was excavated in 1956 by the Panhandle-Plains Historical Museum. An unpublished report by Hughes (1969) describes the findings. The uppermost deposits, designated as Level 1 , contained evidence of an ephemeral occupation consisting of a cultural zone of charcoal/ashy sediment and two small ash dumps or hearths. There is evidence of serious mixing of cultural deposits throughout the shelter, and Level 1 artifacts include two arrow points (typed as Fresno and Young), a corner-notched dart point, a biface, a drill, end scrapers, a paint stone fragment, metate fragments, and an awl sharpener and a bone awl. Although no pottery was found, Hughes (1969) suggested that Level 1 represents occupations by Apachean peoples. Based on its similarities to the nearby Fifth Green site, the Level 1 occupation is now tentatively attributed to the Tierra Blanca complex. Level 1 is radiocarbon dated to A.D. 1435-1651 (calibrated, see Table 86).

Hughes (1969) also reports that a burial was found in the Canyon City Club Cave in the spring of 1956, a few months prior to the museum's excavations. Called the Childer's burial, this interment was excavated by a local collector and no records were kept. Hughes (1969) was able to look at the skeletal materials and reconstruct the following scenario from information provided by the excavator. The skeleton, found tightly flexed inside a small oval pit, was nearly complete, although some elements were missing due to improper excavation and/or rodent activity. The remains are of an elderly person, probably female, but no grave offerings were associated. The skeleton was found at the same elevation as Level 4 , but the burial pit apparently had been dug down from Level 1. Based primarily on cranial measurements, Hughes (1969) noted that this individual has attributes different from those of Antelope Creek villagers or Apachean populations. He suggests that the woman may have been of Puebloan ancestry. The remains have not 
been radiocarbon dated. The burial's tentative association with Level 1 and its cultural affiliation are speculative, but it may well be affiliated with the Tierra Blanca complex.

\section{Isolated Ceramic Vessels}

Except for a partially reconstructed plainware vessel from the Fatheree site, only isolated sherds have been found at most Tierra Blanca sites. However, there are at least two isolated pots that are probably affiliated with the Tierra Blanca complex in the collections of the Panhandle-Plains Historical Museum. Both pots were found in contexts suggesting that they were deliberately cached in isolated hiding places.

Hughes (1978:46) reports that a large glazed polychrome olla was found underneath a caliche ledge not far from the Blackburn site in Palo Duro Canyon. It was identified (by A. H. Warren) as a Glaze C or D vessel manufactured at Tonque Pueblo or in the Galisteo Basin area between ca. A.D. 1425 and 1500 (Habicht-Mauche 1988:178; Spielmann 1983:264). This vessel is of the same ware type and from the same source area as most of the pottery from the Blackburn site.

About one-fifth of a plainware vessel was reconstructed from sherds found along the Prairie Dog Town Fork near Wayside in Armstrong County (Panhandle-Plains Historical Museum catalog no. 1988-120/2). It is a wide-mouthed bean pot-type jar with an everted rim and two horizontal rows of fingernail punctates around the widest portion of the body. Unlike the pot from the Fatheree site, this vessel does not have loop handles, but a repair hole is present on its neck. This vessel falls into the faint striated category described as Tierra Blanca Plain by Habicht-Mauche (1988).

\section{Undefined Tierra Blanca-like Sites}

Recent investigations at Palo Duro Reservoir north of the Canadian River in Hansford County have identified Late Prehistoric II/Protohistoric components that are similar to, but not definitely assignable to, the Tierra Blanca complex (Quigg, Lintz, Oglesby, Earls et al. 1993). The most intensively investigated one is the Broken Jaw site, but similar cultural deposits also were encountered in a small rockshelter, 41HF86. These occupations are dated primarily to the fifteenth through seventeenth centuries by radiocarbon and thermoluminescence techniques (Table 88). As discussed below, these occupations are perplexing when considering the geographic range of the Tierra Blanca complex.

\section{BROKEN JAW (41HF8)}

Investigations at the Broken Jaw site identified Tierra Blanca-like materials in excavation Blocks B and $\mathrm{C}$, located approximately $35 \mathrm{~m}$ apart on an alluvial terrace of Palo Duro Creek (Quigg, Lintz,

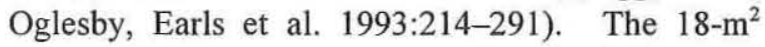
excavation Block B uncovered a buried, 12-to30 -cm-thick cultural zone and exposed two hearth features. The artifact assemblage includes a ferrous metal arrow point and three small sherds of late Pecos-like glazeware (identified by S. Peckham). Quigg, Lintz, Oglesby, Earls et al. (1993:241) state that the metal arrow point probably dates between A.D. 1750 and 1874 , but there is no reason why it could not date considerably earlier, perhaps even as early as A.D. 1650 . It is the only Euro-American artifact found, and it is handmade (rather than machine stamped) from a small iron fragment. There is ethnographic and archeological evidence (see Boyd et al. 1993:208) indicating the likelihood that some quantities of European items were obtained by Southern Plains nomads during the mid sixteenth century, and such objects would have been more abundant in New Mexico after the 1680 Pueblo Revolt.

Other artifacts from the Block B component include a Marcos dart point (probably scavenged from a nearby site), a Harrell and two Fresno arrow points, three scrapers, a biface, two ground stone pieces, a bone tool, and three Olivella shell beads. The artifacts are indicative of a hunting-based economy, and 814 animal bones were recovered. Over 95 percent of the identifiable faunal remains are bison (i.e., 124 of 130 specimens); some exhibit butchering marks, impact breaks, or evidence of burning. Quigg, Lintz, Oglesby, Earls et al. (1993:241) do not assign a cultural affiliation to the remains, but they note that the Tierra Blanca complex is a possibility.

The most extensive excavation area was Block $\mathrm{C}$ where two distinct cultural zones were identified. The upper zone, called Block $\mathrm{C} 1$, was buried at $290-310 \mathrm{~cm}$ below the surface and was investigated with $133 \mathrm{~m}^{2}$ of hand excavation. Immediately below this was a $10-\mathrm{cm}$-thick sterile zone, and then 
TABLE 88

SUMMARY OF RADIOCARBON AND THERMOLUMINESCENCE DATES FOR UNDEFINED TIERRA BLANCA-LIKE OCCUPATIONS AT PALO DURO RESERVOIR ${ }^{1}$

\begin{tabular}{|c|c|c|c|c|c|}
\hline \multirow{2}{*}{$\begin{array}{l}\text { Site Name } \\
\text { and Number }\end{array}$} & \multirow{2}{*}{$\begin{array}{l}\text { Material and } \\
\text { Lab No. }\end{array}$} & \multirow{2}{*}{$\begin{array}{l}\delta^{13} \mathrm{C} \\
\% \text { o }\end{array}$} & \multicolumn{2}{|c|}{ Corrected } & \multirow{2}{*}{$\begin{array}{l}\text { Calibrated Date Range } \\
\text { and Intercepts, A.D. }{ }^{2}\end{array}$} \\
\hline & & & Age, B.P. & Date, A.D. & \\
\hline \multicolumn{6}{|c|}{ RADIOCARBON DATES } \\
\hline \multirow{2}{*}{$\begin{array}{l}\text { Broken Jaw (41HF8) } \\
\text { Block C, lower } \\
\text { component }\end{array}$} & $\begin{array}{l}\text { Bison bone collagen } \\
\text { GX-16634-G }\end{array}$ & -8.4 & $460 \pm 75$ & $1490 \pm 75$ & $1413(1439) 1488$ \\
\hline & $\begin{array}{l}\text { Bison bone collagen } \\
\text { GX-16128-G }\end{array}$ & -10.0 & $725 \pm 80$ & $1625 \pm 80$ & $\begin{array}{l}1452(1530,1555,1633) \\
1658\end{array}$ \\
\hline $\begin{array}{l}\text { Unnamed rockshelter, } \\
\text { 41HF86 }\end{array}$ & $\begin{array}{l}\text { Charcoal } \\
\text { GX-16131 }\end{array}$ & -21.9 & $320 \pm 75$ & $1630 \pm 75$ & $\begin{array}{l}1480(1532,1547,1635) \\
1658\end{array}$ \\
\hline \multicolumn{6}{|c|}{ THERMOLUMINESCENCE DATES ${ }^{3}$} \\
\hline \multirow{3}{*}{$\begin{array}{l}\text { Broken Jaw (41HF8) } \\
\text { Block C, lower } \\
\text { component }\end{array}$} & Pottery Vessel \#1 & - & - & - & $1505-1805$ \\
\hline & Pottery Vessel \#2 & - & - & - & $1650-1770$ \\
\hline & Pottery Vessel \#3 & - & - & - & $1280-1570$ \\
\hline $\begin{array}{l}\text { Unnamed rockshelter, } \\
41 \mathrm{HF} 86\end{array}$ & Cordmarked sherd & - & - & - & $1365-1575$ \\
\hline \multicolumn{6}{|c|}{$\begin{array}{l}{ }^{1} \text { All dates are from Quigg, Lintz, Oglesby, Earls et al. 1993:Tables B1 and B2. } \\
{ }^{2} \text { All calibrations are done by CALIB version } 3.03 \text { according to Stuiver and Reimer (1993), using a 1-sigma range } \\
\text { for calibration data set } \# 2 \text {. }\end{array}$} \\
\hline \multicolumn{6}{|c|}{$\begin{array}{l}{ }^{3} \text { Thermoluminescence dates were obtained by the TL Laboratory, Department of Archaeology, University of Durham. } \\
\text { They are not calibrated. }\end{array}$} \\
\hline
\end{tabular}

another cultural zone at $320-340 \mathrm{~cm}$ below the surface. This lower zone, called Block C, was investigated with $157 \mathrm{~m}^{2}$ of hand excavation. Both of these cultural zones are interpreted as representing discrete, short-duration occupation episodes. The lower zone was the primary target of investigation and received the most intensive work.

The Block $\mathrm{Cl}$ component was encountered during mechanical stripping of overburden down to the target zone. Excavation revealed that this upper zone consists of a thin layer of sparse cultural materials and animal bones. Only 53 flakes, 3 cores, and 11 stone tools (2 Fresno arrow points, 4 scrapers, a biface, and 4 edge-modified flakes) were recovered. All of these materials are thought to be related to bison hunting, butchering, and processing. Faunal remains consist of 2,170 bones. Most are very fragmentary, but some exhibit evidence of burning or cut marks. Only 786 bones were identified, and 97.6 percent of these are bison. The bison remains represent at least four adults and one fetal animal (providing evidence of late fall-winter seasonality). The absence of hearths and ceramics suggests that the $\mathrm{C} 1$ occupations were of short duration. No radiocarbon dates were obtained, but $\mathrm{C} 1$ is thought to be stratigraphically equivalent to the cultural zone in Block B. The component is estimated to be ca. $200-400$ years old based on its stratigraphic relationship with the lower Block $\mathrm{C}$ cultural zone.

The Block C lower component is interpreted as representing a bison processing camp. The assemblage is dominated by over 5,000 bones, of which 2,871 , representing 98 percent of the identified specimens, are bison. Minimally, five animals are represented. The remains provide conclusive evidence that these animals were killed, probably 
nearby, and butchered on-site. Near-term fetal bison remains indicate that the kill/processing event probably occurred in late winter (January-February). A detailed faunal analysis provides interpretations of the bison processing sequence and suggests that bone grease processing was an important activity.

The chipped stone assemblage (9 projectile points, 2 bifaces, a drill, 12 scrapers, and 24 edgemodified flakes) indicates that killing/butchering of bison and processing of hides were primary activities. The points include an Ensor-like dart point, two indeterminate dart/arrow fragments, and six arrow points typeable as one Washita, one Harrell, and four Fresno. No ground stone tools were found.

Features indicate camping in addition to butchering/processing. One ephemeral unlined hearth (Feature 5) produced a Fresno point in a matrix of ashy sediment, charcoal flecks, burned and unburned bone fragments, and tiny resharpening flakes. The investigators identified a 3.2-x-1.9-m soil anomaly around the hearth and suggested that it represents a structure; subsequent analysis, however, concluded that a structure could not be positively identified. Although Feature 5 does not appear to have been heated as intensively, probably due to limited reuse, the contents of the fill (i.e., small bone fragments and microdebitage) mimic what was found in the interior fireplaces associated with tipis at the Longhorn site (Boyd et al. 1993:214-215, Table 25). A second feature (\#6) at Broken Jaw, also interpreted as an unlined shallow basin hearth, had a more intensively oxidized base but contained less bone and lithic debris.

All of the sherds from the Block C lower component are attributed to three plainware vessels. The 13 sherds of Vessel 1 represent a small bean pot with a variable (rough to burnished) surface finish. The 30 sherds of Vessel 2 represent a thickwalled jar with a rough to striated surface finish. Vessel 3 is a small, $10-\mathrm{cm}$-tall cup represented by 29 thin sherds with smooth to striated surfaces. Vessel 1 is interpreted as a cooking pot, and sherd interiors contained a significant build-up of organic residue. Vessel 2 could be either a cooking vessel or a storage container. Vessel 3 is an unusual form and is interpreted as a drinking cup. Petrographic analysis (Reese-Taylor 1993) indicates that the paste composition of all three vessels is similar in that quartz sand is the dominant temper (making up 79-94 percent of all nonplastics), but minor constituents and the size of the temper particles are variable.
Thermoluminescence dates obtained on sherds from all three vessels (see Table 88) suggest that Vessel 3 could be older than the other two. Only one of the three dates had been obtained at the time that the site interpretations were written (see Quigg, Lintz, Oglesby, Earls et al. 1993:258-261). Assuming that the two subsequent thermoluminescence dates (see Quigg, Lintz, Oglesby, Earls et al. 1993:Appendix B) are correct, they seem to contradict the interpretation that the Block $\mathrm{C}$ lower component represents a single event since the manufacture or last intensive heating of these vessels could be as much as 80 to 490 years apart.

The Block $\mathrm{C}$ lower component is most reliably dated by two bone radiocarbon assays (see Table 88). The radiocarbon dates place the time of the occupation between A.D. 1413 and 1658, most likely during the latter half of the fifteenth century or during the sixteenth century. Based on all lines of evidence, Quigg, Lintz, Oglesby, Earls et al. (1993:290) conclude that the Block C lower component cannot be assigned to the Tierra Blanca complex but note that it is contemporaneous and has many similarities. They specifically state that there are no diagnostic arrow points that could link the component to the complex and that the pottery does not resemble the Tierra Blanca plainwares described by Habicht-Mauche (1988). While paste characteristics are similar to some of the Tierra Blanca sherds, the lower component sherds are smoothed, lessprominently striated, and lack micaceous temper. Quigg, Lintz, Oglesby, Earls et al. (1993:290) suggest that Vessels 1 and 2 may have been made locally and note that local sediments in Palo Duro Creek may have been the source of the clay and temper.

\section{UNNAMED ROCKSHELTER, 41HF86}

Excavation of rockshelter 41HF86, located at the head of a small tributary drainage to Horse Creek about $1 \mathrm{~km}$ upstream from its confluence with Palo Duro Creek, also produced evidence of a brief occupation during the Protohistoric period (Quigg, Lintz, Oglesby, Earls et al. 1993:310-331). The $10-\mathrm{m}$-deep and 50-m-wide rockshelter is located in the Ogallala calcrete along the canyon rim. Thirteen $1-x-1-m$ units were excavated in the shelter. The deposits vary from 30 to $80 \mathrm{~cm}$ thick and contain evidence of multiple occupations, but considerable disturbance by wood rats and burning of wood rat 
nests was noted. Much of the disturbance is due to extensive use of the shelter during modern times (e.g., a rock-walled enclosure is attributed to Boy Scouts), but at least three prehistoric hearths were encountered.

The buried debris includes evidence of occupation by Antelope Creek phase or Buried City complex peoples, as indicated by cordmarked pottery and a thermoluminescence date of A.D. $1470 \pm 105$ obtained on one of these sherds. Two charcoal radiocarbon dates were obtained on samples from the same lower stratigraphic unit. While one date indicated that the shelter was occupied as early as 900 years ago, the other date produced a calibrated age of A.D. 1480-1658 (see Table 88) and provided evidence of a Protohistoric occupation that postdates the Plains Village period. Although the cultural materials cannot be separated into coherent assemblages, 10 Washita and Fresno arrow points are related to Late Prehistoric or Protohistoric occupations. Several historic artifacts also were recovered. Although most are modern (e.g., glass, plastic, and .22-caliber cartridges), a cuprous metal finger ring and a brass arrow point fragment (handmade) are thought to be from the Protohistoric occupation.

No meaningful interpretations may be made other than stating that the most intensive occupations of the shelter occurred during the Protohistoric period. These occupations were approximately contemporaneous with the bison hunting/processing activities that occurred at the Broken Jaw site, located about $4 \mathrm{~km}$ to the southwest. The Protohistoric activities were limited, and the total duration and intensity of occupations was quite low.

\section{GARZA COMPLEX}

Although it is much better known than the Tierra Blanca complex to the north, the Garza complex remains a vague concept. The data for the complex suffer from some of the same sampling and interpretive problems mentioned above for the Tierra Blanca complex. Overall, however, the published data for the Garza complex are generally more useful, and a greater number of investigated sites comprise a much more adequate sample (Figure 99, Table 89). In addition, the absolute chronology of the Garza complex is much better defined (Table 90).

Sites have been generally attributed to the Garza complex when they produce Garza and/or Lott arrow points, although there are some exceptions. The underlying assumptions, whether explicit or implicit, have been that Garza and Lott points are distinctive but related styles that were made by a single cultural group and that they were not made by other cultural groups. There is no reason to doubt these assumptions, but there is some evidence to suggest that there are minor temporal differences between Garza and Lott points and that both these forms became smaller and less distinctive through time.

\section{Archeological Sites}

\section{Residential Bases and Base Camps}

\section{LONGHORN (41KT53)}

The Longhorn site is the most intensively investigated and best reported Garza complex site with over $300 \mathrm{~m}^{2}$ of hand excavation. As described in Chapter 6, it is interpreted as a tipi encampment that was repeatedly reoccupied by bison hunting peoples during the fifteenth through eighteenth centuries, with most intensive use during the seventeenth century. Evidence of three separate tipis and numerous activity areas, along with an abundance of pottery and a diversity of other artifacts (e.g., beads, bone tools, and European trade items), indicate that the site was a residential base that may have served as a winter encampment. Activities may have been somewhat specialized in that an overrepresentation of scrapers and unifacial rejuvenation debitage is thought to represent intensive processing of bison hides. Although no Garza points were found, the site is included with the Garza complex because Lott and Lott-like specimens were recovered. However, these are diminutive points compared with classic Lott specimens, and projectile points are rare at the site. The paucity of points may be due to the fact that hunting was not a particularly important activity and/or because metal arrow tips and possibly firearms (as evidenced by Native-made gunflints) were commonly used instead of stone projectile points. In either case, most of the Longhorn site archeological evidence represents late Garza complex occupations.

\section{HEADSTREAM (41KT51)}

Archeological evidence indicates that the Headstream site, located just across Grape Creek 
from the Longhorn site, is an extension of the Longhorn site occupations. As described in Chapter 6 , the Headstream site produced an artifact assemblage that is nearly identical to that from Longhorn. The evidence is indicative of multiple reoccupations of a base camp or residential base, primarily during the seventeenth century. The absence of structural remains could mean that only nonhabitation activities took place there. Alternatively, the absence of structures may be due to limited archeological sampling (only $86 \mathrm{~m}^{2}$ of hand excavation), and it is possible that the site was a tipi encampment. Whether due to a lack of emphasis on hunting or the use of metal arrow tips, stone projectile points are not a prominent part of the assemblage. No Garza points were found, but a diminutive Lott point and four radiocarbon dates indicate that the Headstream site occupations represent late Garza complex peoples.

\section{SLATON DUMP (41LU6)}

Located on a bedrock bench just below the Caprock at the head of a small tributary along Yellowhouse Canyon, the Slaton Dump site was intensively investigated by the South Plains Archeological Society (SPAS) between 1965 and 1970. Riggs (1968) commented on an excavated pit feature with associated burned caliche rocks that seems to have been a baking pit. A few years later, Brown (1972) summarized the extensive SPAS excavations and noted three occupational levels and numerous features. The 0-6-inch level contained Garza, Fresno, Lott, and Harrell points along with other stone artifacts, bones, and fire-cracked rocks. The 6-12-inch level contained similar cultural materials and plainware sherds, but Brown (1972:n.p.) observed that the Garza and Fresno points in this level were "longer by a third than those found in the upper level" and that the "workmanship was much better also." The 12-18-inch level was relatively sterile, while the lower cultural level, at 18-24 inches, produced evidence of an earlier occupation that included both arrow points and "small late Archaic-like dart points."

Six years later, Booker and Campbell (1978) presented a cursory description and analysis of the artifacts recovered from the SPAS excavations. They noted that some flakes, bones, and ground stones were not recorded by level in the field records, but they sorted everything else into Level 1 at $0-12$ inches (above the sterile zone) and Level 2 at 18-24 inches (below the sterile zone). Level 1 contained 24 typeable arrow points (11 Fresno, 5 Garza, 4 Harrell, 2 Lott, and 2 Washita), a dart point (Matamoros ?), a drill, at least 2 beveled knives, and some scrapers. Level 2 contained 7 arrow points ( 5 Fresno and 2 Garza), a dart point (Ellis), a beveled knife, a few drills and scrapers, and a shell pendant.

The pottery includes 17 sherds of unidentified gray or red ware thought to be of Anasazi or possibly local origin. Pottery of definite Puebloan origin consists of 6 sherds of corrugated ware and 2 sherds of black-on-white, possibly Chupadero. Ground stone artifacts consist of 15 manos, 15 metates, and several shaft smoothers. Most of the metates are fragmentary, but they include both ovalbasin and slab types.

The faunal remains are only briefly mentioned; relative frequencies are presented, but actual numbers of specimens are not. Ninety percent of the identified remains are of bison, and long bones are the most common elements. Fragmented bones, possibly representing bone grease processing, and burned bones also were common, but few butchering marks were noted. Booker and Campbell (1978:31) mention that the distribution of the bones seemed to correlate with the distribution of scrapers and knives, and they suggest that bones were sparse in the areas around the hearths.

The features are only briefly described. There were "several saucer-shaped ash lenses found in all levels" and "seven firepits with vertical caliche rock lined walls" that are about 24 inches across and 18 inches deep (Brown 1972:n.p.). The former are analogous to the unlined hearths found at the Longhorn site, and the latter are probably baking pits. Booker and Campbell (1978:32) suggest that the rock-lined pits are a feature unique to the site, but similar features have been reported at many Late Prehistoric/Protohistoric sites in the region.

The SPAS excavations included one hundred forty 5 -x-5-ft units $\left(325 \mathrm{~m}^{2}\right)$ and covered a sizable portion $\left(3,500 \mathrm{ft}^{2}\right)$ of the total site area $\left(\mathrm{ca} .3,750 \mathrm{ft}^{2}\right)$. Although this is an important site, the published data are inadequate for comparative purposes. Based on the diversity and types of artifacts and features, the abundance of faunal remains, and the spatial distribution of discrete activities, it seems likely that the upper cultural zone represents an early Garza complex base camp or residential base. The 


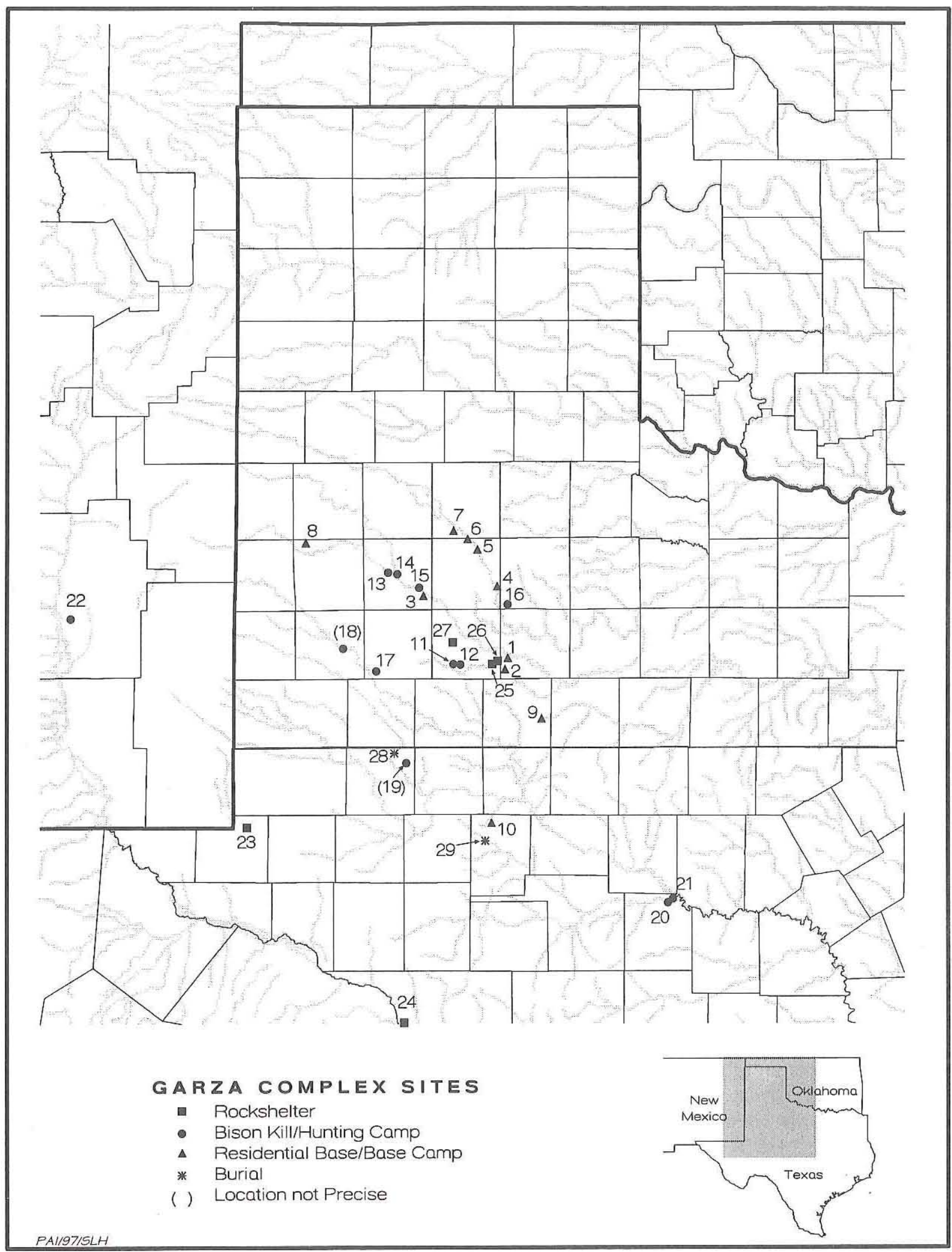

Figure 99. Map of Garza complex sites discussed in the text. 
TABLE 89

GARZA COMPLEX SITES DISCUSSED IN THE TEXT

\begin{tabular}{|c|c|c|}
\hline $\begin{array}{l}\text { Key to } \\
\text { Figure } 99\end{array}$ & Site Name (Number) & Reference \\
\hline \multicolumn{3}{|c|}{ RESIDENTIAL BASES AND BASE CAMPS } \\
\hline 1 & Longhorn (41KT53) & Boyd et al. 1993; this volume \\
\hline 2 & Headstream (41KT51) & Boyd et al. 1993; this volume \\
\hline 3 & Slaton Dump (41LU6) & Riggs 1968; Brown 1972; Booker and Campbell 1978 \\
\hline 4 & Pete Creek (SMU-X41CB1) & Parsons 1967 \\
\hline 5 & Bridwell (41CB27) & Parker 1982, 1990 \\
\hline 6 & Montgomery (41FL17) & Word 1965; Northern 1979 \\
\hline 7 & Floydada Country Club (41FL1) & Skinner 1975; Word 1963, 1991a \\
\hline 8 & Yellow Houses Ruins & Unpublished \\
\hline 9 & Greene Springs & Portis et al. 1968 \\
\hline 10 & Davis Hackberry Spring (41ST87) & Riemenschneider 1996 \\
\hline \multicolumn{3}{|c|}{ BISON KILLS AND HUNTING CAMPS } \\
\hline 11 & Garza (SPAS-41GA40) & Runkles 1964 \\
\hline 12 & Lott (41GR56) & Runkles and Dorchester 1987 \\
\hline 13 & Lubbock Lake (41LU1) & Green 1962b; Johnson et al. 1977; E. Johnson 1987 \\
\hline 14 & Canyon Lakes sites (41LU26/35) & Bandy et al. 1980 \\
\hline 15 & Johnson Creek (TTC 17-6) & Wheat 1955 \\
\hline 16 & Red Mud Creek (SMU-X41DK2) & Parsons 1967 \\
\hline 17 & Unnamed (41LY42) & Hart 1976 \\
\hline 18 & Hogue (41TY2) & Pope 1991 \\
\hline 19 & Mitchell Lake (41MT41) & Alvey 1978 \\
\hline 20 & Elm Creek (41CN95) & Treece, Quigg et al. 1993 \\
\hline 21 & Unnamed (41CN78) & Lintz, Treece et al. 1993 \\
\hline 22 & Garnsey Spring sites (LA-18399/18400) & $\begin{array}{l}\text { Speth and Parry 1978, 1980; Speth } 1983 \text {; } \\
\text { Parry and Speth } 1984\end{array}$ \\
\hline \multicolumn{3}{|c|}{ ROCKSHELTERS } \\
\hline 23 & Blue Mountain Rockshelter & Holden 1938 \\
\hline 24 & Red Bluff Shelter (SMU-X41CX8) & Lorrain 1968 \\
\hline 25 & Boren Shelters No. 1 and 2 (41GR546/559) & Boyd et al. 1994; this volume \\
\hline 26 & Reed Shelter (41GR54) & Riggs 1966 \\
\hline 27 & Garza County Cave (SPAS-GR269) & Harper and Shedd 1969 \\
\hline \multicolumn{3}{|c|}{ BURIALS } \\
\hline 28 & Garza Burial (SPAS-41MT40) & Gates and Hart 1977 \\
\hline 29 & Garza-U-Ranch Burial & Unpublished \\
\hline
\end{tabular}


TABLE 90

SUMMARY OF RADIOCARBON DATES FOR GARZA COMPLEX SITES

\begin{tabular}{|c|c|c|c|c|c|c|c|}
\hline \multirow{2}{*}{$\begin{array}{l}\text { Site Name, Number, } \\
\text { Component, and Reference }\end{array}$} & \multirow{2}{*}{$\begin{array}{l}\text { Lab No., Material, and } \\
\text { Provenience }\end{array}$} & \multirow{2}{*}{$\begin{array}{l}\text { Uncorrected } \\
\text { Age, B.P. }\end{array}$} & \multirow{2}{*}{$\begin{array}{l}\text { Uncorrected } \\
\text { Date, A.D. }\end{array}$} & \multirow[b]{2}{*}{$\delta^{13} \mathrm{C} \%$} & \multicolumn{2}{|c|}{ Corrected $^{1}$} & \multirow{2}{*}{$\begin{array}{l}\text { Calibrated Date Range } \\
\text { and Intercepts A.D. }{ }^{2}\end{array}$} \\
\hline & & & & & Age, B.P. & Date, A.D. & \\
\hline
\end{tabular}

Longhorn (41KT53)

Boyd et al. (1993:Table 14)

RESIDENTIAL BASES AND BASE CAMPS

\begin{tabular}{|l|l|c|c|l|l|l|}
\hline $\begin{array}{l}\text { Beta-51504, charcoal } \\
\text { Feature 11 }\end{array}$ & $120 \pm 40$ & - & -24.6 & $130 \pm 40$ & $1820 \pm 40$ & $\begin{array}{l}1679(1695,1727,1813, \\
1920,1954) 1955\end{array}$ \\
\hline $\begin{array}{l}\text { Beta-51505, charcoal } \\
\text { Feature 12 }\end{array}$ & $160 \pm 40$ & - & -26.0 & $140 \pm 40$ & $1810 \pm 40$ & $\begin{array}{l}1676(1690,1730,1811, \\
1923,1954) 1955\end{array}$ \\
\hline $\begin{array}{l}\text { Beta-51506, charcoal } \\
\text { Feature 19 }\end{array}$ & $440 \pm 80$ & - & -25.5 & $430 \pm 80$ & $1520 \pm 80$ & $1423(1440) 1662$ \\
\hline $\begin{array}{l}\text { Beta-51507, wood } \\
\text { Feature 44 }\end{array}$ & $540 \pm 60$ & - & -26.1 & $530 \pm 60$ & $1420 \pm 60$ & $1331(1410) 1438$ \\
\hline $\begin{array}{l}\text { Beta-52303, charcoal } \\
\text { Feature 27 }\end{array}$ & $170 \pm 50$ & - & -24.7 & $180 \pm 50$ & $1770 \pm 50$ & $\begin{array}{l}1663(1677,1776,1803, \\
1940,1954) 1954\end{array}$ \\
\hline $\begin{array}{l}\text { Beta-52304, charcoal } \\
\text { Feature 55 }\end{array}$ & $210 \pm 30$ & - & -24.2 & $220 \pm 30$ & $1730 \pm 30$ & $1655(1667) 1954$ \\
\hline $\begin{array}{l}\text { Beta-52305, charcoal } \\
\text { Feature 21 }\end{array}$ & $160 \pm 50$ & - & -23.7 & $190 \pm 50$ & $1760 \pm 50$ & $\begin{array}{l}1659(1674,1779,1801, \\
1943,1954) 1954\end{array}$ \\
\hline $\begin{array}{l}\text { Beta-52306, charcoal } \\
\text { Feature 10 }\end{array}$ & $300 \pm 50$ & - & -24.9 & $300 \pm 50$ & $1650 \pm 50$ & 1519 (1642) 1656 \\
\hline $\begin{array}{l}\text { Beta-52307, charcoal } \\
\text { Feature 39 }\end{array}$ & $260 \pm 60$ & - & -24.4 & $270 \pm 60$ & $1680 \pm 60$ & $1527(1650) 1952$ \\
\hline
\end{tabular}

${ }^{1}$ Corrected ages in brackets are estimates for the dates for which no $\delta^{13} \mathrm{C}$ values were obtained. The corrected ages are based on an estimated $\delta^{13} \mathrm{C}$ value of -24.00 for fossil wood charcoal (from Stuiver and Polach 1977) and estimated $\delta^{13} \mathrm{C}$ values of -3.3 for bison bone apatite and -9.4 for bison bone collagen based on the average of five Late Prehistoric bison bone samples from the Rush site (41TG346) by Quigg and Peck (1995:Table D-1).

${ }^{2}$ All calibrations are done by CALIB version 3.03 according to Stuiver and Reimer (1993), using a 1-sigma range for calibration data set \#2. Calibrations in brackets are based on the estimated $\delta^{13} \mathrm{C}$ values. 


\begin{tabular}{|c|c|c|c|c|c|c|c|}
\hline \multicolumn{8}{|l|}{ Table 90, continued } \\
\hline \multirow{2}{*}{$\begin{array}{l}\text { Site Name, Number, } \\
\text { Component, and Reference }\end{array}$} & \multirow{2}{*}{$\begin{array}{l}\text { Lab No., Material, and } \\
\text { Provenience }\end{array}$} & \multirow{2}{*}{$\begin{array}{l}\text { Uncorrected } \\
\text { Age, B.P. }\end{array}$} & \multirow{2}{*}{$\begin{array}{l}\text { Uncorrected } \\
\text { Date, A.D. }\end{array}$} & \multirow[b]{2}{*}{$\delta^{13} \mathrm{C} \%$} & \multicolumn{2}{|c|}{ Corrected } & \multirow{2}{*}{$\begin{array}{l}\text { Calibrated Date Range } \\
\text { and Intercepts A.D. }\end{array}$} \\
\hline & & & & & Age, B.P. & Date, A.D. & \\
\hline \multirow{8}{*}{ Longhorn (41KT53), continued } & $\begin{array}{l}\text { Beta-52308, charcoal } \\
\text { Feature } 48\end{array}$ & $280 \pm 50$ & - & -26.5 & $250 \pm 50$ & $1700 \pm 50$ & $1641(1655) 1953$ \\
\hline & $\begin{array}{l}\text { Beta-52309, wood } \\
\text { Feature } 9\end{array}$ & $300 \pm 50$ & - & -24.9 & $300 \pm 50$ & $1650 \pm 50$ & $1519(1642) 1656$ \\
\hline & $\begin{array}{l}\text { Beta-52310, charcoal } \\
\text { Feature } 32\end{array}$ & $250 \pm 50$ & - & -25.2 & $250 \pm 50$ & $1700 \pm 50$ & $1641(1655) 1953$ \\
\hline & $\begin{array}{l}\text { Beta-52311, charcoal } \\
\text { Feature } 35\end{array}$ & $190 \pm 50$ & - & -24.8 & $190 \pm 50$ & $1760 \pm 50$ & $\begin{array}{l}1659(1674,1779,1801, \\
1943,1954) 1954\end{array}$ \\
\hline & $\begin{array}{l}\text { Beta-51312, charcoal } \\
\text { Feature } 37\end{array}$ & $200 \pm 50$ & - & -25.2 & $200 \pm 50$ & $1750 \pm 50$ & $\begin{array}{l}1655(1671,1781,1799, \\
1945,1953) 1954\end{array}$ \\
\hline & $\begin{array}{l}\text { Beta-52314, sediment } \\
\text { Feature } 8\end{array}$ & $250 \pm 50$ & - & -20.1 & $330 \pm 50$ & $1620 \pm 50$ & $\begin{array}{l}1487(1528,1558,1631) \\
1648\end{array}$ \\
\hline & $\begin{array}{l}\text { Beta-52315, sediment } \\
\text { Feature } 4\end{array}$ & $780 \pm 50$ & - & -21.6 & $840 \pm 50$ & $1110 \pm 50$ & $1159(1215) 1262$ \\
\hline & $\begin{array}{l}\text { GX-14451, charcoal } \\
\text { Feature 1 }\end{array}$ & $280 \pm 80$ & - & -24.2 & $295 \pm 80$ & $1655 \pm 80$ & 1489 (1640) 1952 \\
\hline \multirow{4}{*}{$\begin{array}{l}\text { Headstream (41KT51) } \\
\text { Boyd et al. (1993:Table 4) }\end{array}$} & $\begin{array}{l}\text { Beta- } 51502 \text {, charcoal } \\
\text { Feature } 3\end{array}$ & $210 \pm 40$ & - & -26.6 & $190 \pm 40$ & $1760 \pm 40$ & $\begin{array}{l}1663(1674,1779,1801, \\
1943,1954) 1954\end{array}$ \\
\hline & $\begin{array}{l}\text { Beta- } 51503 \text {, charcoal } \\
\text { Feature } 3\end{array}$ & $280 \pm 40$ & - & -25.9 & $260 \pm 40$ & $1690 \pm 40$ & $1641(1653) 1667$ \\
\hline & $\begin{array}{l}\text { Beta-52301, charcoal } \\
\text { Feature } 9\end{array}$ & $290 \pm 60$ & - & -25.9 & $270 \pm 60$ & $1680 \pm 60$ & $1527(1650) 1952$ \\
\hline & Beta-52302, charcoal & $320 \pm 50$ & - & -25.9 & $300 \pm 50$ & $1650 \pm 50$ & 1519 (1642) 1656 \\
\hline
\end{tabular}




\begin{tabular}{|c|c|c|c|c|c|c|c|}
\hline \multicolumn{8}{|l|}{ Table 90, continued } \\
\hline \multirow{2}{*}{$\begin{array}{l}\text { Site Name, Number, } \\
\text { Component, and Reference }\end{array}$} & \multirow{2}{*}{$\begin{array}{l}\text { Lab No., Material, and } \\
\text { Provenience }\end{array}$} & \multirow{2}{*}{$\begin{array}{l}\text { Uncorrected } \\
\text { Age, B.P. }\end{array}$} & \multirow{2}{*}{$\begin{array}{l}\text { Uncorrected } \\
\text { Date, A.D. }\end{array}$} & \multirow[b]{2}{*}{$\delta^{13} \mathrm{C} \%$} & \multicolumn{2}{|c|}{ Corrected } & \multirow{2}{*}{$\begin{array}{l}\text { Calibrated Date Range } \\
\text { and Intercepts A.D. }\end{array}$} \\
\hline & & & & & Age, B.P. & Date, A.D. & \\
\hline \multicolumn{8}{|c|}{ BISON KILLS/HUNTING CAMPS } \\
\hline \multirow{3}{*}{$\begin{array}{l}\text { Lott (41GR56) } \\
\text { Runkles and Dorchester } \\
(1987: 107)\end{array}$} & $\mathrm{Tx}-4442$, charcoal & $450 \pm 70$ & $1500 \pm 70$ & - & {$[466 \pm 81]$} & - & {$[1410(1438) 1488]$} \\
\hline & $\begin{array}{l}\text { Tx-4600, charcoal } \\
\text { Feature } 4\end{array}$ & $510 \pm 60$ & $1440 \pm 60$ & - & {$[526 \pm 72]$} & - & {$[1330(1416) 1441]$} \\
\hline & Tx-4788, charcoal & $540 \pm 50$ & $1410 \pm 50$ & - & {$[556 \pm 64]$} & - & {$[1326(1409)$ 1433] } \\
\hline \multirow{6}{*}{$\begin{array}{l}\text { Lubbock Lake (41LU1) } \\
\text { Holliday et al. (1983:Table 1), } \\
\text { Johnson et al. (1977), and } \\
\text { E. Johnson (1987:Table 1.2) }\end{array}$} & $\begin{array}{l}\text { SI-2700, charcoal } \\
\text { upper FA8-6 }\end{array}$ & $380 \pm 40$ & $1570 \pm 40$ & - & {$[396 \pm 57]$} & - & {$\left[\begin{array}{llll}1440 & (1482) & 1627\end{array}\right]$} \\
\hline & $\begin{array}{l}\text { SI-2701, charcoal } \\
\text { lower FA8-6 }\end{array}$ & $505 \pm 55$ & $1445 \pm 55$ & - & {$[521 \pm 68]$} & - & {$[1332$ (1419) 1441] } \\
\hline & $\begin{array}{l}\text { SI-2703, charcoal } \\
\text { Feature FA15-1 }\end{array}$ & $285 \pm 60$ & $1665 \pm 50$ & - & {$[301 \pm 72]$} & - & {$[1490$ (1641) 1664] } \\
\hline & $\begin{array}{l}\text { SI-2704, charcoal } \\
\text { Feature FA14-1 }\end{array}$ & $315 \pm 50$ & $1635 \pm 50$ & - & {$[331 \pm 64]$} & - & $\begin{array}{l}{[1479(1527,1559,} \\
1630) 1651]\end{array}$ \\
\hline & $\begin{array}{l}\text { SMU-345, charcoal } \\
\text { upper FA8-6 }\end{array}$ & $300 \pm 60$ & $1650 \pm 60$ & - & {$[316 \pm 72]$} & - & $\begin{array}{l}{[1485(1533,1541} \\
1636) 1658]\end{array}$ \\
\hline & $\begin{array}{l}\text { SMU-546, charcoal } \\
\text { Area } 19 \text { hearth }\end{array}$ & $320 \pm 60$ & $1630 \pm 60$ & - & {$[336 \pm 72]$} & - & $\begin{array}{l}{[1451(1525,1562,} \\
1628) 1652]\end{array}$ \\
\hline \multirow{4}{*}{$\begin{array}{l}\text { Canyon Lakes } \\
\text { (41LU26/41LU35) } \\
\text { Bandy et al. (1980:Table 10) } \\
\text { (Excludes one erroneous } \\
\text { date from Area 4) }\end{array}$} & $\begin{array}{l}\text { Tx-2719, charcoal } \\
\text { Area } 1, \text { Feature } 1\end{array}$ & $440 \pm 60$ & $1510 \pm 60$ & - & {$[456 \pm 72]$} & - & [1414 (1440) 1489] \\
\hline & $\begin{array}{l}\text { RL-788, charcoal } \\
\text { Area 1, Feature } 1\end{array}$ & $210 \pm 100$ & $1740 \pm 100$ & - & {$[226 \pm 108]$} & - & {$\left[\begin{array}{llll}1526 & (1665) & 1954\end{array}\right]$} \\
\hline & $\begin{array}{l}\text { Tx-2721, bone apatite } \\
\text { Area 1, Feature } 1\end{array}$ & $270 \pm 100$ & $1680 \pm 60$ & - & {$[619 \pm 108]$} & - & $\begin{array}{l}{[1284(1327,1351,} \\
1363,1366,1390) 1426]\end{array}$ \\
\hline & $\begin{array}{l}\text { Tx-2720, charcoal } \\
\text { Area 2, Feature } 3\end{array}$ & $630 \pm 70$ & $1320 \pm 70$ & - & {$[646 \pm 81]$} & - & $\begin{array}{l}{[1284(1303,1372,} \\
1383) 1408]\end{array}$ \\
\hline
\end{tabular}




\begin{tabular}{|c|c|c|c|c|c|c|c|}
\hline \multicolumn{8}{|l|}{ Table 90 , continued } \\
\hline \multirow{2}{*}{$\begin{array}{l}\text { Site Name, Number, } \\
\text { Component, and Reference }\end{array}$} & \multirow{2}{*}{$\begin{array}{l}\text { Lab No., Material, and } \\
\text { Provenience }\end{array}$} & \multirow{2}{*}{$\begin{array}{l}\text { Uncorrected } \\
\text { Age, B.P. }\end{array}$} & \multirow{2}{*}{$\begin{array}{l}\text { Uncorrected } \\
\text { Date, A.D. }\end{array}$} & \multirow[b]{2}{*}{$\delta^{13} \mathrm{C} \%$} & \multicolumn{2}{|c|}{ Corrected } & \multirow{2}{*}{$\begin{array}{l}\text { Calibrated Date Range } \\
\text { and Intercepts A.D. }\end{array}$} \\
\hline & & & & & Age, B.P. & Date, A.D. & \\
\hline \multirow{6}{*}{$\begin{array}{l}\text { Canyon Lakes } \\
\text { (41LU26/41LU35), } \\
\text { continued }\end{array}$} & $\begin{array}{l}\text { RL-789, charcoal } \\
\text { Area 2, Feature } 3\end{array}$ & $420 \pm 100$ & $1530 \pm 100$ & - & {$[436 \pm 108]$} & - & [1411 (1444) 1632$]$ \\
\hline & $\begin{array}{l}\text { Tx-2722, charcoal } \\
\text { Area 2, Feature } 3\end{array}$ & $400 \pm 60$ & $1550 \pm 60$ & - & {$[416 \pm 72]$} & - & [1432 (1449) 1625$]$ \\
\hline & $\begin{array}{l}\text { Tx-2723, bone apatite } \\
\text { Area 2, Feature } 3\end{array}$ & $160 \pm 60$ & $1790 \pm 60$ & - & {$[509 \pm 72]$} & - & {$\left[\begin{array}{llll}1333 & (1426) & 1444]\end{array}\right.$} \\
\hline & $\begin{array}{l}\mathrm{Tx}-2727 \text {, bone apatite } \\
\text { Area 1, Feature } 5\end{array}$ & $360 \pm 50$ & $1590 \pm 50$ & - & {$[709 \pm 64]$} & - & [1264 (1288) 1385$]$ \\
\hline & $\begin{array}{l}\text { Tx-2728, bone apatite } \\
\text { Area 1, Feature } 5\end{array}$ & $440 \pm 70$ & $1510 \pm 70$ & - & {$[789 \pm 81]$} & - & [1165 (1261) 1289] \\
\hline & $\begin{array}{l}\text { RL-793, bone collagen } \\
\text { Area } 1 \text {, Feature } 5\end{array}$ & $570 \pm 100$ & $1380 \pm 100$ & - & {$[821 \pm 108]$} & - & $\begin{array}{l}{[1067(1221,1253,} \\
1255) 1288]\end{array}$ \\
\hline \multirow{7}{*}{$\begin{array}{l}\text { Elm Creek (41CN95), } \\
\text { Cultural Unit } 1 \text {, } \\
\text { Treece, Lintz et al. } \\
\text { (1993b:Table 5.13) } \\
\text { (Excludes } 2 \text { dates that were } \\
\text { rejected as erroneous) }\end{array}$} & $\begin{array}{l}\text { Tx-6757, charcoal } \\
\text { Feature } 20\end{array}$ & $453 \pm 65$ & - & -25.3 & $448 \pm 65$ & $1502 \pm 65$ & $1422(1441) 1489$ \\
\hline & $\begin{array}{l}\text { Beta-35874, charcoal } \\
\text { Feature } 20\end{array}$ & $540 \pm 60$ & - & -26.1 & $520 \pm 60$ & $1430 \pm 50$ & $1333(1419) 1440$ \\
\hline & $\begin{array}{l}\text { Tx-6766, charcoal } \\
\text { Feature } 20\end{array}$ & $497 \pm 70$ & - & -24.5 & $508 \pm 70$ & $1444 \pm 70$ & 1334 (1427) 1444 \\
\hline & $\begin{array}{l}\mathrm{Tx}-6515 \text {, charcoal } \\
\text { Feature } 12\end{array}$ & $300 \pm 100$ & - & -24.1 & $310 \pm 100$ & $1640 \pm 100$ & $1450(1638) 1952$ \\
\hline & $\begin{array}{l}\text { Beta-35873, charcoal } \\
\text { Feature } 21\end{array}$ & $310 \pm 50$ & - & -25.9 & $300 \pm 50$ & $1650 \pm 50$ & 1519 (1642) 1656 \\
\hline & $\begin{array}{l}\text { Tx-6501, charcoal } \\
\text { Feature } 11\end{array}$ & $490 \pm 200$ & - & -24.3 & $495 \pm 140$ & $1455 \pm 140$ & 1318 (1431) 1620 \\
\hline & $\begin{array}{l}\text { Tx-6516, charcoal } \\
\text { Feature } 11\end{array}$ & $530 \pm 70$ & - & -24.3 & $540 \pm 70$ & $1410 \pm 70$ & 1328 (1412) 1438 \\
\hline
\end{tabular}




\begin{tabular}{|c|c|c|c|c|c|c|c|}
\hline \multicolumn{8}{|l|}{ Table 90, continued } \\
\hline \multirow{2}{*}{$\begin{array}{l}\text { Site Name, Number, } \\
\text { Component, and Reference }\end{array}$} & \multirow{2}{*}{$\begin{array}{l}\text { Lab No., Material, and } \\
\text { Provenience }\end{array}$} & \multirow{2}{*}{$\begin{array}{l}\text { Uncorrected } \\
\text { Age, B.P. }\end{array}$} & \multirow{2}{*}{$\begin{array}{l}\text { Uncorrected } \\
\text { Date, A.D. }\end{array}$} & \multirow[b]{2}{*}{$\delta^{13} \mathrm{C} \%$} & \multicolumn{2}{|c|}{ Corrected } & \multirow{2}{*}{$\begin{array}{l}\text { Calibrated Date Range } \\
\text { and Intercepts A.D. }\end{array}$} \\
\hline & & & & & Age, B.P. & Date, A.D. & \\
\hline \multirow{4}{*}{$\begin{array}{l}\text { Elm Creek (41CN95), } \\
\text { continued }\end{array}$} & $\begin{array}{l}\text { Tx-6508, charcoal } \\
\text { Feature } 17\end{array}$ & $490 \pm 70$ & - & -25.1 & $500 \pm 70$ & $1450 \pm 70$ & $1406(1429) 1445$ \\
\hline & $\begin{array}{l}\text { Tx-6518, charcoal } \\
\text { Feature } 17\end{array}$ & $400 \pm 80$ & - & -24.2 & $410 \pm 80$ & $1540 \pm 80$ & $1431(1451) 1631$ \\
\hline & $\begin{array}{l}\text { Tx-6765, charcoal } \\
\text { Feature } 25\end{array}$ & $416 \pm 72$ & - & -26.0 & $398 \pm 72$ & $1552 \pm 72$ & $1437(1455,1480) 1633$ \\
\hline & $\begin{array}{l}\text { Tx-6519, charcoal } \\
\text { Feature } 18\end{array}$ & $380 \pm 120$ & - & -24.6 & $390 \pm 120$ & $1560 \pm 120$ & $1424(1486) 1650$ \\
\hline $\begin{array}{l}\text { 41CN78, Analytical Unit } 6 \\
\text { Lintz, Treece et al. } \\
\text { (1993:555, Table I.1) }\end{array}$ & Tx-6517, charcoal & $250 \pm 70$ & - & -23.6 & $270 \pm 70$ & $1680 \pm 70$ & $1523(1650) 1953$ \\
\hline $\begin{array}{l}\text { Garza Hearth at the Garnsey } \\
\text { Springs campsite (LA-18400) } \\
\text { Parry and Speth (1984:Table 1) }\end{array}$ & Beta-6693 charcoal & $320 \pm 50$ & $1630 \pm 50$ & -27.87 & $280 \pm 50$ & $1670 \pm 50$ & $1527(1648) 1664$ \\
\hline \multirow{2}{*}{$\begin{array}{l}\text { Red Bluff Shelter (or Sotol) } \\
\text { (SMU-X41CX8), Zone D } \\
\text { Lorrain (1968:26-27) }\end{array}$} & $\begin{array}{l}\text { Tx-649, charcoal } \\
\text { Hearth } 1\end{array}$ & $400 \pm 60$ & $1550 \pm 60$ & - & {$[416 \pm 72]$} & {$[1534 \pm 72]$} & [1432 (1449) 1625] \\
\hline & $\begin{array}{l}\text { Tx-650, charcoal } \\
\text { Hearth } 2\end{array}$ & $370 \pm 60$ & $1580 \pm 60$ & - & {$[386 \pm 72]$} & {$[1564 \pm 72]$} & [1439 (1487) 1637] \\
\hline $\begin{array}{l}\text { Boren No. } 1 \text { (41GR546) } \\
\text { Boyd et al. (1994:210) }\end{array}$ & $\begin{array}{l}\text { GX-14447, charcoal } \\
\text { Feature } 2\end{array}$ & $245 \pm 210$ & - & -23.4 & $275 \pm 210$ & $1675 \pm 210$ & $1433(1650) 1955$ \\
\hline $\begin{array}{l}\text { Boren No. } 2 \text { (41GR559), } \\
\text { talus area, Boyd et al. } \\
\text { (1994:Table 54) }\end{array}$ & $\begin{array}{l}\text { Beta- } 61502 \text {, bison } \\
\text { bone collagen } \\
\text { Features } 9 / 12\end{array}$ & $30 \pm 70$ & - & -9.7 & $280 \pm 70$ & $1670 \pm 70$ & 1519 (1650) 1952 \\
\hline
\end{tabular}


location provided the inhabitants immediate access to water, wood, and other resources in Yellowhouse Canyon and quick access to the bison hunting range on the adjacent High Plains.

\section{PETE CREEK (SMU-X41CB1)}

Investigations upstream from White River Lake in Crosby and Dickens Counties by Parsons (1967) produced evidence of Garza complex occupations at two sites. Limited excavations indicate that similar Late Prehistoric II/Protohistoric materials may be present at the Grape Creek (SMU-X41CB3), Collett Springs (SMU-X41CB4), and Dockum Springs (SMU-X41DK1) sites, but Garza points were only found at the Pete Creek and Red Mud Creek (described below) sites.

Investigations at Pete Creek consisted of a 92- $\mathrm{m}^{2}$ hand-excavated block (eighteen 2-x-2-m units and a $1-\mathrm{x}-20-\mathrm{m}$ trench) that revealed ca. $90 \mathrm{~cm}$ of cultural deposits on a bedrock terrace overlooking the creek. Six $15-\mathrm{cm}$ levels produced cultural materials concentrated in levels $2-5$, indicating repeated occupations. A few crude tools and two dart points found in levels 5 and 6 may indicate an ephemeral Archaic occupation, but the vast majority of the assemblage appears to represent a series of discrete Late Prehistoric II and Protohistoric occupations. Charcoal samples were taken, but no radiocarbon dates were obtained; consequently, chronology is based solely on diagnostic artifacts.

Excluding debitage (which was not quantified), the 1,156 artifacts included 176 arrow points (26 Washita; 22 Harrell; 15 untyped side notched; 8 Garza; 70 unnotched Fresno, Young, or preforms; and numerous unidentified specimens and fragments) and a variety of unifacial and bifacial tools (29 snub-nosed end scrapers and 12 beveled knives). While most of the stone artifacts are probably hunting/processing tools, mano and metate fragments $(n=44)$ indicate that plant processing also was done. Bone and shell artifacts $(n=19)$ also were recovered.

Pottery consisted of 322 sherds as follows: 190 micaceous plainware (possibly from Picuris); 67 faint striated plainware; 46 Rio Grande Glaze VI sherds, most of which may have been made at one of the Galisteo Basin pueblos; 8 unidentified plainware; and 11 Bullard Brushed. Except for the Caddoantradition brushed sherds and a few sherds of unknown origin, the majority of the pottery (ca. 94 percent) appears to be of Puebloan origin (these sherds were identified by Herbert Dick).

The cultural materials are tabulated by levels, but only weak chronological patterns are noted. Arrow points are common in levels $2-5$, but the Garza, Harrell, and Fresno points tend to be more common in the three or four upper levels. Almost all of the pottery and most of the obsidian artifacts are from the upper three or four levels. The Rio Grande Glaze VI pottery, probably manufactured during the late seventeenth century, is found only in the upper two levels. A glass bead from level 1, the only European-made artifact, may date to the early eighteenth century. Thus, it appears that the upper levels represent seventeenth- and early-eighteenthcentury Protohistoric occupations while the lower levels could represent earlier occupations dating to the fourteenth through sixteenth centuries.

The diversity of artifact types and features strongly suggests that the site represents a residential base or base camp. Faunal remains were not analyzed, but several concentrations of bison bones may represent secondary processing areas. Two large, partially trash filled pits are reported, but it is unclear whether they were used for storage, baking, or some other purpose. Five rock-lined hearths were encountered, and one circular hearth (Feature 6) appears to be a shallow, unlined basin similar to the tipi hearths at the Longhorn site. Another feature is a 2-m-long arc-shaped alignment of rocks that may represent "weights for the edges of tents" (Parsons 1967:16). It is not clear how much of the feature was excavated or if any other features (such as a hearth) were associated. It is possible, however, that the Pete Creek site represents a tipi encampment. Parsons (1967:78-79) suggests that the uppermost levels represent a winter encampment of bison hunters, perhaps Plains Apaches.

\section{BRIDWELL (41CB27)}

Surface collections and limited excavations at the Bridwell site, on a wide alluvial terrace of the White River in Blanco Canyon about $15 \mathrm{~km}$ downstream from the Montgomery site, have yielded an impressive assemblage of Late Prehistoric/ Protohistoric artifacts (Parker 1982, 1990). The site consists of a prominent circular ridge, approximately $50-55 \mathrm{ft}$ in diameter and 8-15 $\mathrm{ft}$ in width, that rises about $2 \mathrm{ft}$ above the surrounding terrace. Cultural materials are exposed along this circular ridge. A 
concentration of cultural materials was observed on a low circular mound, $15 \mathrm{ft}$ in diameter, located to the east of the circular ridge (between the ridge and the White River). No excavations were done to confirm what this mound is, but it is called a "refuse dump" by Parker (1982). Excavations consisted of 10 hand-dug trenches (each 2-5 ft wide and 8-15 $\mathrm{ft}$ long) bisecting the ridge for a total excavation area of $453 \mathrm{ft}^{2}\left(42 \mathrm{~m}^{2}\right)$. Although a large amount of cultural materials was recovered, the excavations were poorly controlled and no useful stratigraphic information was obtained. Consequently, this feature is poorly understood, and its function is open to interpretation.

In his summary of Protohistoric societies on the Southern Plains, Baugh (1986:175-176) suggested that the circular ridge represents the remnants of a fortification. This interpretation is based largely on the fact that low ridges of a similar size and shape found at two Edwards complex sites (i.e., the Edwards I and Duncan sites that Baugh classifies as Wheeler phase) in western Oklahoma are interpreted as fortifications. This interpretation is plausible for the Oklahoma features since excavations have revealed that the mounded sediments were overlying 2-m-wide trenches. Baugh speculates that the trenches were dug and the fill was mounded up to build a parapet and/or support a stockade of wooden posts. Baugh (1986:175) concludes that "no dwellings or other features are believed to be present inside these structures." This implies that the dwellings were located outside the defensive structures, but there is no archeological evidence to confirm this.

At this point, the similarities between the Bridwell site and Edwards complex features are only superficial since the Bridwell excavations failed to provide any evidence about the existence of an underlying trench. Rather than being a fortification, Jack Hughes (1991:36) suggests that the Bridwell ridge is an eolian accumulation that formed when sediments were trapped along a brush pile enclosing a winter encampment. This interpretation cannot be proven or disproven with the limited evidence currently available. Regardless of the varying interpretations, the extensive cultural residue found all along the ridge indicates that it probably served as a communal trash dump. In addition, the mounded "refuse dump" outside the enclosure may represent a large communal trash dump, but no such features have been reported at any other contempora- neous sites in the region.

Other features include four hearths (not described in detail) found in the ridge excavations by Parker and an unusual feature found by another digger. The latter feature, called the "Wallace Cache" by Parker (1982:14-16), consists of a bifacial oval-basin metate found upside down over two manos (one sandstone and one quartzite) and a cluster of 54 end and side scrapers made of Edwards chert. The excavation was uncontrolled, but the description suggests that these items were placed inside a shallow pit. The location of this feature within the site, and relative to the circular ridge, is not stated.

Diagnostic cultural materials recovered include 124 arrow points (58 Fresno, 48 Harrell, 13 Washita, 3 Perdiz, and 1 each of Garza and Lott), ca. 128 unifaces (including 43 end scrapers), and 53 bifaces (including 21 drills and 17 beveled knives). Ground stone tools include 14 manos, 11 metates, and 7 shaft smoothers. Modified shells $(n=60)$ and bones $(n=54)$ are well represented. Seven turquoise beads and pendants, a "spindle whorl" made from a potsherd, and five stone pipe sherds also are reported. Several artifacts of European origin (five glass beads, three brass buttons, a Civil War-era button, and an 1859 Canadian coin with suspension holes) were found in the upper few inches of sediment on the ridge.

The 683 vessel sherds represent a large number of pots and a wide range of ware types. Roughly 50 percent of the sherds are from Rio Grande glazeware ollas and bowls (ca. 337), and the other half are from plainware (probably cooking vessels) ( $\mathrm{n}=346$ ). Ninety-four decorated sherds of Puebloan origin were examined and identified by A. H. Warren as having been manufactured between A.D. 1350 and 1600 . The majority of these sherds were identified as Glaze $\mathrm{A}-\mathrm{F}$ wares made at Tonque Pueblo $(n=63)$ or at various pueblos in the Galisteo Basin, including San Cristobal $(n=6)$, San Marcos $(n=4)$, and unidentified pueblos $(n=14)$. Nine glazeware sherds were made at unknown Rio Grande pueblos, and one was from Pecos Pueblo. In addition, one sherd of Bandelier Black-on-gray (that was apparently counted as a glazeware) was made in the southern Pajarito Plateau region. Of the 346 plainware sherds, 158 were identified by Tim Baugh as being unidentified Puebloan corrugated ware $(n=26)$, Little Deer Ware from western Oklahoma $(n=28)$, unidentified plain sandy paste 
ware $(\mathrm{n}=28)$, and Perdido Plain $(\mathrm{n}=76)$.

Faunal remains are not described or quantified but Parker (1990:110) states that "broken buffalo bones" and "bone rubbish" are common. The density of artifacts in the excavation trenches is extremely high. When debitage $(n=1,630)$ is included, the total number of artifacts recovered from the $42-\mathrm{m}^{2}$ excavation is approximately 2,790 , for a total artifact density of 66 specimens per $\mathrm{m}^{2}$. The site was a favorite location for local pothunters for many years, and Parker (1982:57) notes that "several thousand sherds have been recovered from uncontrolled digs." Although only one Garza point was found by Parker, at least 10 others have been found during other uncontrolled digs at the site (Parker 1990:111).

The nature of the features and the diversity of cultural materials indicate that the Bridwell site is probably a residential base that was repeatedly occupied over a long period of time. The primary activities represented are hunting and processing of bison. All of the pottery, arrow points, and European artifacts are consistent with an interpretation of multiple occupations, possibly during two main periods. Parker (1990) concludes that the most intensive occupations were between A.D. 1350 and 1700 and probably represent Apachean peoples, while an ephemeral historic occupation, probably by Comanches, occurred between A.D. 1750 and 1875. Subsequent to Parker's work, nine obsidian hydration dates were obtained on surface-collected specimens, and they indicate that the occupations span the period from A.D. 1454 to 1703 (Baugh 1986:Table 7).

\section{MONTGOMERY (41FL17)}

Located in Blanco Canyon $11 \mathrm{~km}$ downstream from the Floydada Country Club site, the Montgomery site has produced cultural materials indicating substantial occupations during the Late Prehistoric II and Protohistoric periods. The site is situated on, and completely covers, a $165-\mathrm{x}-180-\mathrm{m}$ natural mound that rises $9 \mathrm{~m}$ above the alluvial terraces of the White River. Cultural materials are concentrated in the upper $30 \mathrm{~cm}$ but extend to $50 \mathrm{~cm}$ below the surface in some areas. The sandy loam containing the cultural deposits overlies a layer of river gravels and sand. Its geomorphic context is not discussed, but the mound is probably an erosional remnant that may have been preserved because it is underlain by bedrock. The site would have been a good camping spot, located in the canyon and close to the river but well above the floodplain. Because of the presence of numerous springs in Blanco Canyon, the White River flowed year-round until the water table dropped due to agricultural irrigation in the 1940 s (Northern 1979:13).

Two episodes of testing have been conducted. The South Plains Archeological Society held a field school at the site in 1965, and the results of these investigations are reported by Word (1965). They excavated an unspecified number of $5-\mathrm{x}-5-\mathrm{ft}$ test units along intersecting north-south and east-west transects across the crest of the mound. The recovered artifacts are summarized, but proveniences and distributions are not discussed. Word $(1965: 59,61)$ notes, however, that the density of artifacts, bone scraps, and burned rocks was extremely variable across the site.

Numerous features and activity areas were encountered. Word (1965:61) speculates that a linear single-course alignment of "limestone" (actually Ogallala caliche) rocks may have been structural, but the excavations were not expanded to follow the feature out. A bone bed, consisting mainly of bison remains, was encountered nearby and probably represents a butchering/processing area. In addition, an unspecified number of postholes were found, but they "did not appear to have any pattern, but were scattered throughout the tested area" (Word 1965:65). This is contradicted by the fact that two postholes and an unlined basin hearth filled with ashy sediment and charcoal were found in one 5-x5 - $\mathrm{ft}$ unit. The excavations were not expanded to determine how these features might be related, but it is possible that they represent a structure.

The site was investigated again in 1978 by Texas Tech University with cooperation and funding from the Floyd County Museum (Northern 1979). Although the site had been extensively surface collected for many years, it became well known after 1965, and relic collectors started digging there. Northern (1979:2) estimates that between 1965 and 1978 , as much as 75 percent of the cultural deposits had been disturbed by pothunters. Northern (1979) tried to re-locate the original grid and test units but was unable to do so. He notes that most of the 1965 field notes and artifacts were no longer available because they were kept by various individual excavators after the original analysis and report were completed. 
The 1978 investigations established a new site grid and laid out test units in the same general area as the 1965 testing. The new excavations consisted of twenty 1-x-1-m units (isolated or as 1-x-2-m units). Of these, 10 were completely excavated, 3 were partially excavated, and 7 were in totally disturbed areas. Northern (1979:20) encountered only one feature, a disturbed hearth, and speculates that many features had already been destroyed. The artifacts described by Northern (1979) include all of the surface-collected and excavated materials from 1978, all of the available materials from the 1965 investigations, and some materials from private collections. Excluding the materials from private collections, over 2,300 artifacts have been recovered from the two investigations of the Montgomery site (Table 91).

The ceramics represent several different source areas and ceramic traditions. The "Texas types" (identified by Jack Hughes) include Caddoan-style wares (called Bullard Brushed and Fugitive Red), wares of the Henrietta Focus of north-central Texas (i.e., Nocona Plain), plainwares of uncertain origin (i.e., Perdido Plain), and unidentified late Plains Village wares. Baugh (1986:Table 4) later identified the latter as being Edwards Plain and Little Deer ware from Oklahoma. Most of the Southwestern wares were identified by Stewart Peckham, and Northern (1979:61) notes that the majority of the southwestern sherds were manufactured in or west of the Galisteo Basin during Glaze $\mathrm{E}$ and $\mathrm{F}$ times. In addition, Northern (1979:74) notes that some of the Southwestern ceramics recovered in 1965 were identified as Pueblo III Indented, Sapawe Micaceous Washboard, Rio Grande Glaze IV and V, Puaray Glaze Polychrome, and Pecos Glaze Polychrome. Evidence of trade also is represented by 67 obsidian artifacts and 1 turquoise bead. The stone pipe appears to be a fragment of an elbow pipe made of catlinite that probably came from the northeast. The clay pipes include one complete specimen that conforms with the "Flattened Slim Type" (Class IB) identified at Pecos Pueblo by Kidder (1932:158, Figures $137 \mathrm{~b}$ and $138 \mathrm{a}-\mathrm{c}$ ). This pipe is made of fine clay with no apparent temper, and its composition is comparable to pipes that were made at Pecos Pueblo up through the end of Glaze I times (Kidder 1932:156, 181) at around A.D. 1450.

The precise chronology of the occupations is not known, but artifactual evidence suggests that the most intensive occupations occurred during the latter half of the Late Prehistoric II period and well into Protohistoric times. The Ellis and Scallorn points could indicate that Late Archaic and Late Prehistoric I components are present, or they may have been scavenged from other sites. No radiocarbon dates have been obtained, but 10 obsidian hydration dates were subsequently obtained on surface-collected specimens (Baugh 1986:Table 7). Nine of the dates cluster between A.D. 1559 and 1715 and indicate that the occupations were primarily during the Protohistoric period. The tenth date, A.D. 1207, is from an old flake scar on a reworked specimen that also produced a date of A.D. 1688 on a younger flake scar. It is not known whether the obsidian piece was picked up from an earlier component before it was reused.

Stratigraphic and feature evidence indicates that multiple occupations, and possibly discrete components, are represented. The density of cultural materials and the temporally diagnostic artifacts, particularly pottery, support an interpretation of multiple occupations over a long period of time. The postholes and one hearth are very reminiscent of tipi-related features at the Longhorn site (see Chapter 6). Northern (1979:98-114) interprets the Montgomery site as a seasonally occupied residential base camp, and he notes the possibility that the hearths might be associated with shelters. Northern notes that much of the evidence for structures has probably been destroyed by extensive potting. Based on the presence and diversity of nonlocal trade items, he speculates that the site was occupied between ca. A.D. 1525 and 1700 by Apachean peoples who served as middlemen in the exchange network between Puebloan and Caddoan peoples.

\section{FLOYDADA COUNTRY CLUB (41FL1)}

Located just off the Caprock Escarpment at the head of Blanco Canyon, the Floydada Country Club site was extensively surface collected and minimally tested (three 5-x-5-ft units) in the early 1960s by the South Plains Archeological Society (Word 1963). More-intensive excavations (one hundred eight 1-x-1-m units) were done in 1975 by the Texas Archeological Society (Word 1991a). This large site is situated on alluvial terraces on both sides of the White River immediately below Cochran's Mesa, which is the most prominent feature in this stretch of Blanco Canyon. "The White River was an active stream until 1944, when the lowering of the under- 
ground water table-a result of exploitation of the Ogalalla [sic] aquifer for irrigation purposes - dried up the springs that fed it" (Word 1991a:60). Archeological investigations at the site have produced materials of various ages, but the bulk of the occupational debris is related to the Late Prehistoric II and Protohistoric periods (Table 92).

Because there seemed to be some spatial differences in the distributions of various types of artifacts, one of the goals of the 1975 TAS Field School was to test several hypotheses proposed by Skinner (1975) regarding occupations by different cultural groups through time. Word (1991a:100102) later concluded that the site was "occupied intermittently" between about A.D. 1100 and 1750 by various groups. He proposes that three discrete areas were intensively occupied by different, but more or less contemporaneous, groups between ca. A.D. 1200 and 1500 . He speculates that Area 1 had been occupied by "Apachean people" who traded with Puebloan groups (i.e., Anasazi); Area 2 had been occupied by Jornada "Mogollon people" who maintained contact with their relatives in western Texas or southeastern New Mexico; and Area 3 had been occupied by "Caddoan people" who were perhaps related to Caddoan peoples of western Oklahoma. He further speculates that these groups came together at the site to trade. In addition, the site is thought to have been subsequently occupied by Comanches in the eighteenth century.

No radiocarbon dates have been obtained, but obsidian hydration dates on six surface-collected samples range from A.D. 1535 to 1662 (Baugh 1986:Table 7). The temporally diagnostic artifacts, particularly ceramics and historic items, suggest that the site was occupied both earlier and later than this time span. Consequently, it appears that the evidence does support Word's (1991a) hypothesis that the site was occupied by multiple groups over a long period of time. The diversity of artifacts, particularly arrow points and pottery, also suggests that occupations by multiple cultural groups are likely. However, the contention that there are discrete and horizontally separable components representing different ethnic groups is not well supported. The distributions of various pottery types, in fact, contradict this (see Table 92). Word's (1991a) Local Pottery Type 1, thought to be similar to Deer Creek Plain of Oklahoma, was recovered in Areas I and III, and sherds of unidentified Caddoan tradeware were recovered only in Area 1. Brownware pottery from the Jornada Mogollon region also was found in all three areas. In addition, Word (1963) reports that Garza points were found in two of the three original test units (i.e., Test Sites I and III), and when the maps are compared (cf. Word 1963:Map 1 with Word 1991a:Figure 3), it is clear that these points came from Word's (1991a) Area II and between Areas II and III. While no Garza points are reported in the hypothesized Apachean Area I, one Garza point and a sherd of Rio Grande Pueblo IV utility ware were found at the same level in Test Site III, within the proposed Mogollon Area II. The arrow point typed as Cuney (Word 1991a:Figure 7D) is more similar to an aberrant Lott point from the Lott site (Runkles and Dorchester 1987:Figure 7F) than to the eastern Texas Cuney points illustrated by Turner and Hester (1993:210) or Davis (1991:209). If so, then Lott points are present in all three areas as well. Thus, it appears that there is considerable spatial overlap in many types of diagnostic artifacts.

Stratigraphic evidence also indicates that occupations may be separated in time rather than space. No cultural stratigraphy was observed in Area I by Word (1991a), but the earlier investigation notes three thin occupation layers between 18 and 36 inches below the surface in Test Site III (Word 1963:Figure 4), which is located in Area I. Word (1991a:Tables 1-3) also notes that lithic debris is consistently present at $0-40 \mathrm{~cm}$ below the surface in all areas, and the stratigraphic description suggests that the alluvial deposits accumulated slowly over a long period of time.

Both investigations were geared more toward obtaining artifacts than identifying features and cultural activities through large block excavations. Despite the fact that no more than five contiguous units were dug in any one part of the site, a number of features and activities were identified. In one 5-x-5-ft unit, Word (1963:46) encountered a 6-inchthick bone bed that contained broken and butchered bones from at least two bison. Word (1991a) also reports bison remains from all three areas, along with several features. Five "hearths" were found in Area I, but none were completely excavated. One of the hearths, a large basin-shaped pit containing numerous burned caliche rocks, appears to have been a baking pit (see Word 1991a:Figure 10). A small hearth and a hearth dump were encountered in Area III. A concentration of burned daub fragments (over $8 \mathrm{~kg}$ total), many with grass impressions, was found in the upper $40 \mathrm{~cm}$ in 10 test units within a 


\begin{tabular}{|l|r|r|r|}
\hline Table 91, continued \\
\hline Artifact Class and Type & 1965 & 1978 & Totals \\
\hline Southwestern Ceramic Types & & & \\
Kotyiti Glaze-on-yellow (Glaze F) & 13 & 2 & 15 \\
Unnamed late glaze (I-VI) & 8 & - & 8 \\
Unnamed late types (6 & 5 & 31 \\
Unnamed black-on-brown & 14 & 5 & 19 \\
Unnamed black/red-on-yellow & - & 2 & 2 \\
Unnamed bichromes/polychromes & 9 & 5 & 14 \\
Unnamed black-on-white & 6 & 4 & 10 \\
El Paso Brown & 2 & 1 & 3 \\
Jornado Brown & 2 & - & 10 \\
Unnamed brownwares & 11 & 5 & 16 \\
Late Rio Grande micaceous (cf. Picuris Pueblo micaceous) & 1 & - & 1 \\
\hline Stone Pipes & 5 & 2 & 7 \\
\hline Clay Pipes & $454^{4}$ & 1,888 & $2,342+$ \\
\hline Totals: & & & \\
\hline${ }^{3}$ Other types that were not quantified are mentioned in the text. & & \\
${ }^{4}$ Total for 1965 excludes debitage. & & & \\
\hline
\end{tabular}

$5-\mathrm{x}-10-\mathrm{m}$ portion of Area II. These remains are interpreted as evidence of a structure. Probable postholes were noted by Jack Hughes, who stated that "excavators had inadvertently dug through remnants of a floor or living area" (Word 1991a:87).

Taking all of the feature and artifactual evidence into account, it appears that the Floydada Country Club site may represent a residential base that was repeatedly occupied over a period of several hundred years. Based on the relative abundance of arrow points, scrapers, and bison remains, bison hunting and processing were important activities during much of this time. While it is likely that different groups occupied the site, the evidence for discrete artifact assemblages associated with specific groups is not convincing. The site could contain discrete components that might be separable vertically and/or horizontally, but no such components can be defined with the evidence currently available. While occupations by Garza peoples are probably an important component, the Garza evidence may be mixed and inseparable from other material culture. Although the material culture is often discussed as if it were generated by a single Garza complex occupation, this is probably not the case. The proposition that the site represents a rendezvous locality that was simultaneously occupied by Apachean, Mogollon, and Caddoan peoples cannot be supported by the archeological evidence.

\section{YELLOW HOUSES RUINS, HOCKLEY COUNTY}

A unique spring-fed area near the head of Yellow House Draw was well known to the U.S. Cavalry in the nineteenth century as a permanent water source on the Llano Estacado. This small canyonlike segment of the draw is unusual in that it is deeply entrenched. Numerous springs once flowed from the Ogallala Formation into nearby Yellow and Illusion Lakes in the bottom of the valley. This area is located northwest of Lubbock in southwestern Lamb and northeastern Hockley Counties and is sometimes called Yellow House Draw Canyon. It should not be confused with the true Yellowhouse Canyon farther downstream southeast of Lubbock along the Caprock Escarpment (see Johnson Creek site discussion below). This area was originally called Casas Amarillas or Laguna de Casas Amarillas (Lake of the Yellow Houses) by early Spaniards and Mexicans, but Colonel Ranald S. Mackenzie consistently, but mistakenly, called it "Casa Maria" (Wallace 1965:50, 1966:183). Because of its dependable water supply, buffalo hunters set 
TABLE 92

TEMPORALLY DIAGNOSTIC ARTIFACTS FROM THE FLOYDADA COUNTRY CLUB SITE

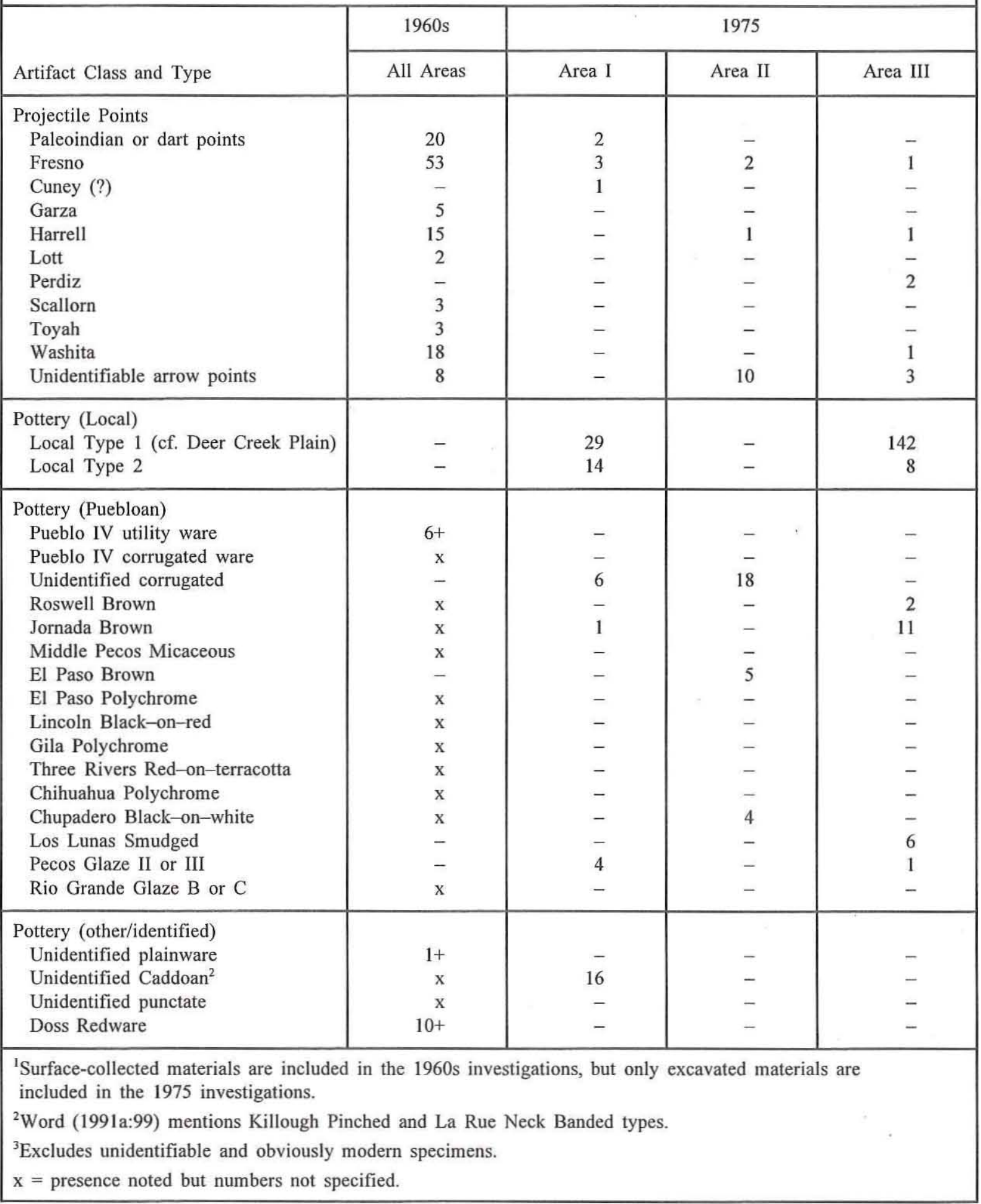




\begin{tabular}{|l|c|c|c|c|}
\hline \multicolumn{5}{|l|}{ Table 92, continued } \\
\hline \multirow{3}{*}{ Artifact Class and Type } & 1960 s & \multicolumn{3}{|c|}{1975} \\
\cline { 2 - 5 } & All Areas & Area I & Area II & Area III \\
\hline Historic Artifacts & & & & \\
German Ocarina (1819) & 1 & - & - & - \\
Glass beads & 7 & 1 & - & - \\
Rifle parts & 2 & - & - & - \\
Cartridge cases & 5 & 1 & - & - \\
Iron arrow point & 1 & - & - & - \\
Metal tinkler & - & 1 & - & - \\
Hand-forged ox-bow pin & - & 1 & - & - \\
Ceramics (nineteenth century) & - & 5 & - & \\
\hline
\end{tabular}

up camp at this location in 1877 , and the canyon eventually became the headquarters of the southern Yellow House division of the famous XIT Ranch (Nordyke 1949).

It has been suggested that the name Yellow Houses was derived from the presence of caves, once inhabited by Indians, along the yellowish caliche bluffs (Mabry 1938:48). More likely, however, the original Spanish name relates to the presence of masonry ruins on the canyon rim that were subsequently mentioned in the 1870 s by early buffalo hunters and soldiers (Sheffy 1938:14). These ruins are thought to have been built by Indians. Much of the canyon rim is disturbed by historic ranching activities, but Rio Grande glazeware and plainware pottery and arrow points have been found there. The site is tentatively affiliated with the Garza complex because a plainware vessel was found in an uncontrolled excavation in 1982 among the masonry ruins (Panhandle-Plains Historical Museum catalog no. 1982-78/1). Stylistically, the vessel falls into the striated plainware category, and it was included as an example of Tierra Blanca Plain from a possible Garza complex site in the attribute analysis by Habicht-Mauche (1988:Table 5.1). It probably dates to the Protohistoric period, and it is possible that the vessel had been cached inside a house. The precise age and cultural affiliation are not known. Its cultural implications are difficult to evaluate since no systematic archeological investigations have been reported for this or any other sites in the vicinity.

\section{GREENE SPRINGS, SCURRY COUNTY}

Portis et al. (1968) present a brief summary of surface collections from a site near the Clear Fork of the Brazos in eastern Scurry County. Although they do not name the site, the discussion implies that it is located at Greene Springs, which is described by Brune (1981:402) as emerging from the Ogallala Formation at the head of the Clear Fork. The Greene Springs site is an extensive campsite with surface artifacts and buried deposits observed in the creek bank. No subsurface testing has been done except for a single $5-\mathrm{x}-5$-ft square excavated to bedrock at 9 inches below the surface. A considerable amount of cultural material has been surface collected, and bedrock mortars and some petroglyphs are present near the site.

The artifact sample includes 213 scrapers, 465 broken blades and scrapers, 187 identifiable points, 164 unidentifiable points, a few bifacial tools including 2 four-beveled knives, 11 manos, 12 drills, and 1 graver. The point types are not quantified and include some early specimens (Darl, Frio, Marshall, Clovis, and Folsom), but the vast majority are apparently late arrow points typeable as Washita/ Harrell, Fresno, Garza, Lott, and Perdiz. Other artifacts recovered include bone and shell beads and ornaments, obsidian, an Olivella shell bead, and 151 potsherds that are not identified but apparently represent at least 12 different types. Historic artifacts are a blue glass trade bead and an ornamental brass side plate with a dragon design. The latter is identified as coming from a French trade gun dating to ca. A.D. 1730 (Portis et al. 1968:62).

Although Garza points seem to be fairly common (i.e., at least 15 of the illustrated specimens are Garza points), no discrete Garza occupations are defined. Like many other intensively occupied sites, such as Montgomery and the Floydada Country 
Club, the Greene Springs site probably represents a major residential base or base camp that was occupied repeatedly over a long period of time, probably by multiple groups.

\section{DAVIS HACKBERRY SPRING (41ST87)}

Garza occupations are documented by limited investigations at the Davis Hackberry Spring site in Sterling County, located about 15 miles north of Sterling City (Riemenschneider 1996). The site is situated on the Davis Ranch near Hackberry Spring, a perennial spring at the headwaters of Hackberry Creek, a southern tributary of the Colorado River. The site is on the Colorado side of the drainage divide between the Colorado and North Concho Rivers. The landowner has surface collected and dug at the site for many years and has a sizable collection of artifacts from excavations and surface collections.

Riemenschneider (1996) became interested in the site in 1991 and began recording the collections with the help of the Texas Historical Commission. The Concho Valley Archeological Society then conducted limited testing consisting of ten 1-x-1-m units at $30-\mathrm{m}$ intervals to determine the extent of the site. Site size was defined as being $330 \times 260 \mathrm{~m}$. Four contiguous units (called Test Area A) were then excavated to better define the cultural stratigraphy. A lower zone (at $50-120 \mathrm{~cm}$ below the surface) is defined as a Late Archaic component and produced a Marcos dart point, while the upper $50 \mathrm{~cm}$ produced a large number of bison bones, arrow points (Perdiz, Harrell, Garza, and Fresno), and other artifacts of Late Prehistoric II and/or Protohistoric age. No radiocarbon dates have been obtained, but the later occupation period is well represented in the uncontrolled collections. The results of the Concho Valley Society's testing have not been reported.

The Davis collection includes over a thousand arrow points, with the predominant types being Perdiz $(\mathrm{n}=570)$, Fresno $(\mathrm{n}=237)$, Harrell $(\mathrm{n}=$ 208), Garza $(n=126)$, Clifton $(n=76)$, and Lott (26). Also recovered were approximately 3,0005,000 scrapers, including many snub-nosed end scrapers; 106 beveled knives (83 four beveled, 13 two beveled, and 10 with only one beveled edge); and numerous drills and utilized flakes. Some manos, metates, and nutting stones are present along with a few shaft abraders and grooved stones. Unusual artifacts include tubular stone beads, shell disc beads and pendants, bone tools (awls and flaking tools), and incised bone and shell pieces.

Nonlocal items are common and include obsidian (ca. 30 specimens), a turquoise bead, Olivella shell beads, and a pendant fragment and bead probably made of kaolinite. The Davis collection contains thousands of potsherds that have not been analyzed or identified, but decorated sherds apparently represent both Southwestern and Caddoan sources. European artifacts include three blue glass beads, a mother-of-pearl button, a possible chain mail fragment, and a metal arrow point.

It appears that the upper component represents a large base camp or residential base repeatedly occupied over an extended period of time. Although some plant processing activities are represented by the ground stone tools, most of the stone artifacts are related to hunting, skinning, and hide processing. Faunal remains have not been quantified, but bison is clearly the most abundant. The dominance of Perdiz points indicates that the majority of the occupations are associated with the Toyah phase. Like at the Lott site, however, the evidence suggests that peoples of the Toyah phase and the Garza complex may have interacted at the Davis Hackberry Spring site, which is located within the "shared area" that Lee Johnson (1994:Figure 105) proposes was utilized by Toyah, Garza, and other cultures. Riemenschneider (1996) speculates that the site represents "a seasonal bison hunting camp" and/or "a central trade center."

\section{Other Possible Residential Bases/Base Camps}

There are probably many more unreported Garza complex sites in the Caprock Canyonlands (Frank Runkles, personal communication 1992), and at least two other sites may represent residential sites or base camps. Northern (1979:103-105) mentions that the Kirkpatrick Ranch site in Garza County was probably a seasonal base camp of bison hunting peoples. Artifact types represented (artifacts are not quantified, and it is unclear whether they were collected or only observed) include Fresno, Harrell, Garza, Perdiz, Scallorn, and Washita points; beveled knives; end and side scrapers; cut bones; manos, metates, and other ground stones; and Southwestern ceramics. Burned rocks and hearths also were 
noted. No other details regarding this site have been published.

The upper component at site 41BI528 is another good candidate for a Protohistoric base camp (Brett Cruse, personal communication 1993). The Briscoe County site is located on an upland peninsula, a remnant of the High Plains, that juts out into the valley of Rock Creek just above its confluence with Tule Creek in the vicinity of Mackenzie Reservoir. Surface artifacts are sparse over most of the site, but the landowner reports having found pottery and points around the eroding margins. Although no Garza points are known to have been found, three micaceous plainware sherds (similar to those from the Longhorn and Headstream sites) were found in the upper cultural zone in a single 1-x-1-m test unit, along with flakes and a mussel shell pendant. Like the Protohistoric occupational zone at the Longhorn site, the upper component at 41BI528 is shallowly buried and in good archeological context (the site is stratified and also contains a probable Archaic lower component). Situated on the edge of the escarpment, the site affords a commanding view of a large portion of the Rock Creek canyon. A semicircular low mound encloses a portion of the site, and the remainder is bounded by the escarpment edge. This is reminiscent of the circular ridge feature that may represent a fortification or village enclosure at the Bridwell site.

\section{Bison Kills and Hunting Camps}

\section{GARZA (SPAS-41GA40)}

The Garza arrow point type was first proposed in print by Runkles (1964) based on the 1959 salvage excavations at the Garza site by the South Plains Archeological Society. The Garza site subsequently became the type site for the Garza complex. Located in Garza County about 16 miles south of Post, the excavations were done because the site was threatened by highway construction. It is situated about 1 mile east of the Caprock Escarpment, on a low terrace of an unnamed tributary of the Double Mountain Fork of the Brazos River. A buried cultural zone was found across a large area. It was generally very thin (ca. 2 inches) but was between 6 and 14 inches thick in some areas. The top of the occupational level varied from 16 to 42 inches below the surface. After the vegetation was bulldozed off, extensive excavations were conducted in 10-x-10-ft units; 26 units were completely excavated, while 16 were partially excavated. A total occupation area of $3,734 \mathrm{ft}^{2}\left(347 \mathrm{~m}^{2}\right)$ was cleared, but the excavations were not well controlled since the excavators decided that the clayey sediment was "much too compact to be troweled" and had to be "chipped away by picks, shovels, and ice picks" (Runkles 1964:105). Screening of the matrix is not mentioned.

Ten features encountered in the cultural zone consist of six rock-lined hearths (three of which had ash dumps next to them), two bone fragment clusters or dumps (one was surrounded on three sides by stone alignments), a chipping station where arrow points were made, and a mano/metate set. Except for a single corner-notched dart point, all of the other diagnostics were late arrow points typed as Fresno $(n=27)$, Harrell $(n=15)$, Garza $(n=13)$, and unidentified $(\mathrm{n}=19)$. Other stone tools include 10 drills, 97 bifacial flake knives, a beveled knife, 5 cobble tools or choppers, 5 hammerstones, 30 scrapers, and 4 spokeshaves. No ceramics were recovered, but 8 modified bone specimens -2 awl fragments, 4 tubular bone beads, and 2 wolf teeth pendants - were found. Over 10,000 flakes were recovered, including 4 of obsidian. Unidentified bone fragments were ubiquitous, and almost all of the larger specimens were identified as bison $(\mathrm{n}=$ 2,093). Although the faunal remains were not analyzed, Runkles (1964:122) states that "the bison were clearly killed and partially butchered elsewhere, for among the thousands of bone fragments found, only leg bones and lower jaws were represented." Butcher marks were noted on some long bones, and most bones had been broken or smashed, probably to obtain marrow.

The Garza site represents a specialized campsite where secondary processing of bison was the principal activity. No detailed analyses of the spatial patterning of artifacts were done, but the evidence suggests that the site represents a single event, or at least occupations/activities of relatively short duration. No radiocarbon dates were obtained, so the precise age of the occupations is not known. Based on the occurrence of Garza points in the dated stratigraphic sequence at Lubbock Lake, Dr. Earl Green suggested that the Garza point dates prior to A.D. 1500 (Runkles 1964:123). Runkles (1964: 123-124) observed that Garza points are quite common at other sites in and around Garza County and that they are usually found along with Harrell 
and/or Washita points and occasionally with Lott points.

\section{LOTT (41GR56)}

The Lott site, located about 3 miles east of the Caprock Escarpment on the John Lott ranch in southern Garza County, was discovered in 1961 by Emmett Shedd and Frank Runkles. It is situated on a second terrace of Sand Creek, just north of the Double Mountain Fork of the Brazos River and is best known as the type site for Lott arrow points. Members of the South Plains Archeological Society investigated the site over an unspecified number of years, and the results of their work are reported by Runkles and Dorchester (1987). The site was initially gridded into a series of 10 - $\mathrm{ft}$ squares, and feature notes and surface collections were made periodically as cultural debris was exposed by sheet erosion. The investigators note that "reasonably good records were kept of the numbers, types, and locations of most of the artifacts, but many of them were kept by those who worked on the site" (Runkles and Dorchester 1987:91). Some limited excavations, apparently portions of six $10-\mathrm{x}-10-\mathrm{ft}$ units, confirmed that the exposed cultural materials had been buried within a single cultural zone in the upper $8 \mathrm{~cm}$ of deposits.

The reported artifacts, summarized in Table 93, may constitute a fairly representative assemblage, but the data should be used cautiously. The assemblage consists of surface-collected and excavated materials representing a single component, but no unmodified flakes are mentioned (except for a few made of obsidian), and they probably were not systematically collected. In addition, many artifact identifications are based on initial field observations since an unknown percentage of specimens were never analyzed. All of the materials kept by Runkles, including most of the ceramics, were examined, and selected specimens are illustrated. However, it is unclear how much material may have been removed from the site without having been adequately recorded.

The distributional data are not consistent for all artifact types, but different point styles reportedly cluster into three different parts of the site (Table 94). It is stated that Lott points were found only in the western and northeastern portions of the site, in Areas A and F; Garza points were found only in the central portion, in Areas C and D; and
Perdiz points were found only in the northern and north-central portion, in Areas B and E. Runkles and Dorchester (1987:87) interpret this as evidence that different cultural groups occupied the site. The Lott and Garza points are thought to belong to a single culture, with Lott slightly predating Garza, while the Perdiz points are attributed to other peoples.

Three sherds of Agua Fria, or Rio Grande Glaze I, were identified by A. H. Warren as probably having been manufactured in the vicinity of Albuquerque. Snow (1982) suggests that Glaze A pottery was made between A.D. 1300 and 1450 . The single Group I sherd, with an incised pattern of rectangles, is thought to be related to pottery attributed to the Edwards complex of southwestern Oklahoma. The Groups II, III, and IV sherds are tempered with fine burned bone fragments and are either plain or decorated with fingernail punctates (some with parallel rows in a chevron pattern) or incised parallel lines. Based on petrographic analyses of some of these sherds by Reid Ferring, Runkles and Dorchester (1987:103) suggest that these three types represent locally made pottery. Despite the fact that the decorations are Caddoan in style, the clay components were found to be consistent with local Triassic clays exposed along the Caprock, and they are unlike any east Texas clays. These bone-tempered wares could have been made anywhere in the Caprock Canyonlands area. All the sherds are reported to have come from the Garza and Lott areas of the site, and none were found in the Perdiz area. This tentative association suggests that the people who made and used Garza and Lott points also made and/or used the bone-tempered pottery.

Although no detailed information on lithic materials is presented, Runkles and Dorchester (1987:91) suggest that most of the chipped stone artifacts are made of local materials derived from the Triassic Dockum Group. A large percentage of the materials retained by Runkles (which were briefly examined by the author), however, are made of tan and gray Edwards cherts of Cretaceous origin and are not from Triassic sources. Some of these Edwards cherts may have been procured from Ogallala or Lingos gravel deposits somewhere in the vicinity of the site, but it is likely that some of these Edwards cherts, particularly the high quality gray and dark gray varieties from which many of the points are made, were procured from primary 


\begin{tabular}{|c|c|}
\hline $\begin{array}{c}\text { TABLE } 93 \\
\text { SUMMARY OF ARTIFACTS RECOVERED FROM }\end{array}$ & TT SITE \\
\hline Artifact Class and Type & Quantity \\
\hline $\begin{array}{l}\text { Lithics } \\
\text { Lott points } \\
\text { Garza points } \\
\text { Triangular preforms (cf. Fresno) } \\
\text { Perdiz points } \\
\text { Harrell points } \\
\text { Drills* } \\
\text { Gravers } \\
\text { Serrated flakes } \\
\text { Ovate and beveled knives } \\
\text { Snub-nosed end scrapers } \\
\text { Other scrapers } \\
\text { Modified flakes } \\
\text { Choppers and hammerstones } \\
\text { Shaft smoother }\end{array}$ & $\begin{array}{c}56 \\
49 \\
52 \\
58 \\
6 \\
35 \\
12 \\
2 \\
34 \\
41 \\
40 \\
\text { "several" from features } \\
\text { unspecified } \\
2\end{array}$ \\
\hline $\begin{array}{l}\text { Shell } \\
\text { Marine shell beads (possibly from Pacific coast Dentalium semipolitum) } \\
\text { Mussel shell pendant }\end{array}$ & $\begin{array}{c}\text { "about" } 13 \\
1\end{array}$ \\
\hline $\begin{array}{l}\text { Bone } \\
\text { Coyote or wolf bone beads } \\
\text { Bone awl fragment }\end{array}$ & $\begin{array}{l}2 \\
1\end{array}$ \\
\hline $\begin{array}{l}\text { Pottery } \\
\text { Group I, grog (sand temper, incised rectangular decoration) } \\
\text { Group II, (bone temper, fingernail punctate decoration) } \\
\text { Group III, (bone temper, parallel incised line decoration) } \\
\text { Group IV, (bone-tempered plainware) } \\
\text { Agua Fria/Rio Grande Glaze I }\end{array}$ & $\begin{array}{c}1 \text { sherd } \\
\text { "at least } 75 \text { sherds" } \\
\text { "at least } 60 \text { sherds" } \\
\text { "at least } 500 \text { sherds" } \\
3 \text { sherds }\end{array}$ \\
\hline
\end{tabular}

limestone outcrops or secondary gravels located along the Brazos/Colorado River drainage divide some $10-15 \mathrm{~km}$ south of the site.

Two of the Garza points and an unknown number of flakes are of obsidian. Both points and three flakes were submitted to the Lawrence Berkeley Laboratory, University of California, for trace element sourcing. The source of two of the specimens was identified as the Valles Caldera in the Jemez Mountains of northern New Mexico, while the source of the other three specimens could not be identified. Runkles and Dorchester (1987:92) note that an obsidian biface found at Blackwater Draw Locality No. 1 is from this same unknown source. No Alibates or other nonlocal materials are reported.

Thirteen features are mentioned, but none are described in any detail. One is a nearly complete skeleton of a young bison, 2 are chipping stations, and 10 are rock-lined hearths. The researchers state that "fire-hardened clay lumps that have impressions of grass and sticks and finger prints were found in and near two hearths." They suggest that the clay lumps could have come from "wattle-and-daub structures that caught fire" (Runkles and Dorchester 1987:106). Important evidence may have been overlooked, however, because the excavations were not expanded around the features.

Three charcoal radiocarbon dates (see Table 90) indicate that the occupations occurred between A.D. 1326 and 1488 , most likely during the first half of the fifteenth century since the three calibrated intercepts range from A.D. 1409 to 1438 . A Lott 


\begin{tabular}{|c|c|c|c|c|c|c|c|}
\hline \multicolumn{8}{|c|}{ TABLE 94} \\
\hline & Area A & Area B & Area $\mathrm{C}$ & Area D & Area E & Area $\mathrm{F}$ & Other \\
\hline Artifact Types ${ }^{1}$ & & & & & & & \\
\hline Lott points & $\mathrm{x}$ & - & - & - & - & $\mathrm{x}$ & - \\
\hline Garza points & - & - & $\mathrm{x}$ & $\mathrm{x}$ & - & - & - \\
\hline Triangular preforms & $\mathrm{x}$ & - & $\mathrm{x}$ & $\mathrm{x}$ & - & $\mathrm{x}$ & - \\
\hline Perdiz points & - & $\mathrm{x}$ & - & - & $\mathrm{x}$ & - & - \\
\hline Dual/beveled knives & $\mathrm{x}$ & $\mathrm{x}$ & - & $\mathrm{x}$ & - & - & - \\
\hline Pottery (individual types not specified) & $\mathrm{x}$ & - & $\mathrm{x}$ & $\mathrm{x}$ & - & $\mathrm{x}$ & - \\
\hline Features $(n=13)^{2}$ & & & & & & & \\
\hline Rock-lined hearths & 1(3) & - & 1 & (1) & - & - & 4 \\
\hline Chipping stations & (2) & - & - & - & - & - & - \\
\hline Bison skeleton & (1) & - & - & - & - & - & - \\
\hline
\end{tabular}

arrow point was found in situ in a hearth that produced a date $(\mathrm{Tx}-4600)$ of ca. A.D. 1416 (calibrated intercept). Based on this date, along with finds of Garza points from dated contexts, Runkles and Dorchester (1987:108) suggest that the Lott point was earlier than, and was the prototype for, the Garza point.

Summarizing the Lott site, Runkles and Dorchester (1987:109) conclude that

The large quantities of arrow points, chipping debris, and pottery strongly suggest that this site is more than a temporary or short-term campsite. Rather it is most likely a base camp for hunting expeditions in the area, used seasonally for making and repairing hunting equipment. Further investigation should be made of the pieces of fired-clay with imprints of grass and sticks, described earlier, to try to determine if they came from wattle-and-daub shelters. The writers believe there is a definite relationship between Caddoan and Plains cultures and that the Lott site is an important link in this relationship.

Runkles and Dorchester (1987:111) conclude that "the Lott site is a distinct manifestation of the movement of Caddoan traits to the southern High Plains and that the people used the site seasonally as a base camp for hunting, manufacturing stone tools, and perhaps for making pottery." They concede, however, that they "are unable to explain the large number of Perdiz points on this site" or the fact that their distribution "does not correspond to the distribution of Caddoan-style pottery." The hypothesis that the Lott site contains horizontally separable components representing different groups should be viewed very cautiously.

\section{LUBBOCK LAKE (41LU1)}

Garza components, all of which are stratigraphically correlated to Stratum 5 or $5 \mathrm{~A}$, are scattered throughout the Lubbock Lake site proper and appear to be present in adjacent sites as well. The most extensive Garza component investigation is reported by Green (1962b). This work is summarized, and additional testing is reported by Johnson et al. (1977) and Eileen Johnson (1987:133-139). Radiocarbon dates for the Garza complex and Stratum 5 at Lubbock Lake are summarized by Holliday et al. (1983, 1985), Baugh (1986:Table 6), and Eileen Johnson (1987:Table 1.2). Portions of the Lubbock Lake site that have occupations attributed to the Garza complex are Areas 4, 5, 8, 14, 15, and 19.

Two sequential living surfaces have been defined in Area 4, but the occupations are undated. Eileen Johnson (1987:113) states that a Lott point was recovered in association with one of these cultural zones. One hearth feature in Area 4 (FA4-3) is described as "an unlined basin filled with charcoal and ash" (E. Johnson 1987:136). 
In Area 5, Feature FA5-6 is described as "an area of secondary processing" (Johnson et al. 1977:95). After being killed elsewhere, but presumably not too far away, selected parts of various animals were brought to this area, butchered further, and their bones processed for marrow. The primary game animal represented is bison, but butchered remains of pronghorn, antelope, wolf, and coyote are also present. Although three-quarter-term fetal bison remains could be indicative of a spring kill/butchering event, Johnson et al. (1977:101) state that the possibility of "out of season" births makes this interpretation tentative. Expedient bone tools are associated, and the lithic artifacts from this feature include 4 arrow points (a Garza, a Harrell, a notched base fragment, and a midsection) a bifacial knife fragment, a unifacial flake tool, 2 scrapers (1 is a snub-nosed end scraper), a large chopper of Potter's chert (found next to a bison skull and pile of long bones), and 10 utilized flakes. In addition, 2 fragments of a broken metate, 18 expedient bison bone tools, and "one sherd of 'Apache' pottery, a thin-walled, mica-tempered blackware" were recovered (Johnson et al. 1977:99). Of 145 flakes from this feature, 73 percent are Edwards chert and 8 percent are an unidentified white chert. No radiocarbon dates are directly associated with Feature FA5-6.

The most intensively investigated Garza occupations are in Area 8, where excavations by Green (1962b) identified multiple living surfaces. Two of the four cultural zones are ephemeral, but the other two represent intensive-occupation surfaces littered with lithics and bone debris. Green's (1962b) work on the upper Garza zone, now designated as Feature FA8-2, produced 3 arrow points (a Garza, a Lott, and an unidentified fragment), an ovate biface, 6 scrapers (including 1 snub-nosed variety), 15 utilized flakes, 2 tubular bone beads, and potsherds of a "thick-walled, brushed, grit-tempered blackware" of possible "local origin" (Johnson et al. 1977:91). Additional testing by the Lubbock Lake Project produced a biface, a core, 6 utilized flakes, and an unspecified number of potsherds (Johnson et al. 1977:88-92). Of 255 flakes associated with this feature, 71 percent are Edwards chert and 22 percent are an unidentified white chert. Identifiable activity areas within Feature FA8-2 include chipping stations and butchering/processing areas.

The lower zone, designated as Feature FA8-4, is similar in that it also consists of scattered bones, primarily bison, and chipping stations, butchering areas, and a hearth. Green (1962b) recovered five arrow points (two Garza, a Harrell, and two midsections), a bifacial knife, four scrapers, five utilized flakes, and a bone awl. A cluster of 16 bison skulls may represent a specialized processing area, but Green suggests that it may have had some ritual significance. A butchered wolf skeleton was found in this area, and other animals that were apparently butchered and/or cooked include pronghorn, badger, and diamondback rattlesnake. The Lubbock Lake Project testing recovered additional bison remains and three utilized flakes from this feature (Johnson et al. 1977:93-95).

Also in Area 8, another living surface (FA8-7) produced a Garza point. Nearby, three charcoal radiocarbon dates (see Table 90) were obtained on double-hearth Feature FA8-6 (E. Johnson 1987:113). One date, from the lower deposits, is associated with early use prior to A.D. 1440 (perhaps ca. A.D. 1419 based on a single calibrated intercept). In contrast, the two dates from upper feature deposits suggest that later hearth use occurred between A.D. 1440 and 1651.

Excavated features in Areas 14 and 15 provide good contextual data because Garza points were found in close association. Feature FA14-1 is identified as an unlined, basin-shaped, ash-filled hearth. It is radiocarbon dated to A.D. 1479 (1527, 1559, 1630) 1651 (calibrated, see Table 90). A Garza point was found $10 \mathrm{~cm}$ above this hearth. Feature FA15-1, described as a "kettle-shaped pit" (Johnson et al. 1977:86, Figure 2), is analogous to baking pit features described at other Protohistoric sites. A charcoal radiocarbon date of A.D. 1490 (1641) 1664 (calibrated, see Table 90) was obtained on this feature. A Garza point was found in the lower fill.

While no Garza or Lott points are associated, a charcoal radiocarbon date indicates that the cultural activities in Area 19 occurred between A.D. 1451 and 1652 and were contemporaneous with the Garza occupations (see Table 90). One feature in Area 19 (FA19-2), described as a basin-shaped, ash-filled hearth similar to Feature FA14-1, was lined with caliche cobbles (E. Johnson 1987:136).

Most of the Protohistoric activities represented at the Lubbock Lake site are related to secondary processing of bison (including intensive marrow extraction, removal of brains, and perhaps bone grease production) and other animals, along with 
limited hide processing. Cultural materials are generally sparse, and all of the lithic tools (with the possible exception of two ground stones) are indicative of hunting and animal processing activities. The vast majority of the lithic debitage and tools are made of Edwards chert, but other nonlocal materials, including Alibates agate, Tecovas jasper, and obsidian, are consistently present in small frequencies.

Holliday et al. (1985:289) note that occupational evidence in Area 7, including another dated hearth, may also be associated with the Garza complex. More-recent work in other areas at Lubbock Lake (e.g., Areas 13B and 39) and at adjacent sites has produced evidence of additional Late Prehistoric II/ Protohistoric occupations; they cannot be assigned a particular cultural affiliation (Johnson 1993) but could be associated with Garza. It also is possible that some of the Historic period occupations in Stratum 5B of Areas 1, 5, 6, and 8 (particularly those in Area 6 where two mid-seventeenth-century radiocarbon dates were obtained) are associated with the late Garza complex. During the early Historic period, people at Lubbock Lake still hunted and butchered bison, wolf, and coyote, but they also utilized modern horses as a food resource.

\section{CANYON LAKES SITES 41LU26/41LU35}

The City of Lubbock initiated archeological studies in the early 1970s as part of a plan for developing a series of small lakes along Yellowhouse Draw within the city limits. Following a survey by Johnson and Stafford (1975), the Canyon Lakes Archeological District was listed on the National Register of Historic Places in 1976. Subsequent construction activities disturbed prehistoric remains in one area and ultimately led to intensive archeological investigations at two adjacent sites, 41LU26 and 41LU35. The work was done by Texas Tech University and is reported by Bandy et al. (1980).

With stratigraphy comparable to that of Lubbock Lake, these sites produced evidence of stratified cultural components dating from Paleoindian to modern times, with most of the diagnostic cultural evidence relating to Late Prehistoric/ Protohistoric occupations (Table 95). Buried cultural deposits were identified in four areas which stretch out over $250 \mathrm{~m}$ along Yellowhouse Draw. Intensive investigations were conducted primarily in Areas 1,
2 , and 4 , and several discrete features and/or activity areas were defined. Most of these features were encountered in backhoe trenches and subsequently tested with hand excavations. Ten radiocarbon dates on bone and charcoal (see Table 90) indicate that Areas 1 and 2 contain cultural deposits within Stratum 5 that probably date to the thirteenth through seventeenth centuries. Although undated, Area 4 also produced artifacts indicating that the cultural deposits there probably date to the same time period.

Area 1 was investigated by $49 \mathrm{~m}^{2}$ of hand excavation. Four activity areas or features were encountered. Two are undated: Feature 2 is an unidentified cluster of burned rocks, charcoal, and bone fragments, while Feature 6 is a scatter of bone and fire-cracked rocks. The other two features are better defined and are dated by radiocarbon assay (see Table 90). Feature 1, a large hearth or baking pit, probably dates to the fourteenth or fifteenth centuries based on two dates with overlapping 1sigma ranges (noting that a third date from this feature is much later, i.e., sixteenth to seventeenth century. Feature 5 , an extensive bone bed, may date to the thirteenth century (the range of the three calibrated dates is A.D. 1067-1385). Most of the faunal remains represent extensively butchered bison, but some butchered coyote bones also were recovered. Bandy et al. (1980:191) interprets Feature 5 as having been primarily a bison processing area where numerous animals were butchered. Early stage processing is represented, and expedient bone tools are common. The kill probably occurred on or very near the site, and the presence of "stacking piles" of specific elements and groups of elements is evidence that the initial butchering process was selective. Diagnostic artifacts include a Washita arrow point and 50 sherds of micaceous pottery. The sherds include at least two types (one with polished exteriors and one with punctate decorations) that are tentatively identified as Puebloan plainwares.

Four features were defined in Area 2. Of these, only Feature 3 is attributed definitely to the Late Prehistoric II period. It is an unlined basin hearth surrounded by a scatter of bison bones, firecracked rocks, chipped stone tools, and flake debris. Four radiocarbon assays on bone and charcoal (see Table 90) confidently date Feature 3 to the mid fifteenth century, and three of the dates have single calibrated intercepts that fall between A.D. 1426 and 1449. Diagnostic artifacts from Area 2 include a 
TABLE 95

SUMMARY OF CHIPPED STONE AND CERAMIC ARTIFACTS RECOVERED FROM CANYON LAKES SITES 41LU26/35 ${ }^{1}$

\begin{tabular}{|c|c|c|c|c|c|c|c|c|c|c|}
\hline \multirow[b]{2}{*}{ Artifact Class and Type ${ }^{2}$} & \multicolumn{2}{|c|}{ Area 1} & \multicolumn{2}{|c|}{ Area 2} & \multicolumn{2}{|c|}{ Area 3} & \multicolumn{2}{|c|}{ Area 4} & \multirow[b]{2}{*}{ Unspecified } & \multirow[b]{2}{*}{ Totals } \\
\hline & Excavated & Other & Excavated & Other & Excavated & Other & Excavated & Other & & \\
\hline
\end{tabular}

CHIPPED STONES

Projectile points

Point preforms

Thinned bifaces (i.e., beveled knives)

Irregular bifaces

End scrapers

Side scrapers

Irregular scrapers

Scraper fragments

Clear Fork gouge

Unifacial trimmed flakes

Bifacial trimmed flakes

Cores

Hammers

Unmodified flakes

Subtotals:

\begin{tabular}{r|r|r}
1 & - & 5 \\
- & - & 1 \\
- & - & - \\
- & 1 & - \\
- & 1 & 4 \\
- & - & 1 \\
- & - & 1 \\
- & 1 & 4 \\
- & 1 & - \\
2 & - & 10 \\
- & - & - \\
- & - & - \\
1 & - & - \\
68 & $\frac{17}{72}$ & $\frac{220}{246}$
\end{tabular}

\begin{tabular}{c|c|c|c|}
\hline 2 & - & 2 \\
- & - & - & - \\
- & - & - & - \\
- & - & - & - \\
- & - & 1 \\
1 & - & - \\
- & - & - \\
1 & - & - \\
- & - & - \\
2 & - & - \\
1 & - & - \\
- & - & 1 \\
- & 0 & 5 \\
28 & & - & \\
\hline 35 & &
\end{tabular}

\begin{tabular}{|l|l|}
- & \\
- & 1 \\
1 \\
1 \\
- \\
5 \\
- \\
- \\
6 \\
1 \\
2 \\
- \\
\hline 9 \\
\hline 26
\end{tabular}

\begin{tabular}{r|l|r}
\hline 1 & - & 11 \\
- & - & 1 \\
1 & - & 2 \\
3 & - & 5 \\
4 & - & 10 \\
1 & - & 4 \\
1 & - & 8 \\
2 & - & 8 \\
- & - & 1 \\
4 & - & 24 \\
- & - & 2 \\
- & - & 2 \\
1 & - & 2 \\
18 & - & 361 \\
\hline 36 & 0 & 441 \\
\hline
\end{tabular}

GROUND STONES

\begin{tabular}{|c|c|c|c|c|c|c|c|c|c|c|}
\hline $\begin{array}{l}\text { Metate fragments } \\
\text { Mano fragments }\end{array}$ & $\overline{1}$ & $\overline{-}$ & - & - & - & - & - & - & $\begin{array}{l}3 \\
-\end{array}$ & $\begin{array}{l}3 \\
1\end{array}$ \\
\hline \multicolumn{11}{|c|}{ CERAMICS } \\
\hline $\begin{array}{l}\text { Redware (probable Glaze IV or V) } \\
\text { Black Micaceous (probable Puebloan) }\end{array}$ & 50 & - & - & $\begin{array}{l}1 \\
-\end{array}$ & - & - & - & - & - & $\begin{array}{r}1 \\
50\end{array}$ \\
\hline Grand Totals: & 123 & 21 & 246 & 36 & 0 & 5 & 26 & 36 & 3 & 496 \\
\hline
\end{tabular}

${ }^{1}$ Data summarized from Bandy et al. (1980:121-157, Table 3).

${ }^{2}$ Artifacts are classed as described by Bandy et al. (1980), but there are discrepancies between numbers presented in tables and in the text. Numerous modified bones, and mostly expedient tools, were recovered but are excluded. 
sherd of Puebloan redware (probably Glaze IV or V), three Fresno points, and one each of Washita, Harrell, and Lott. Along with the bison remains, the abundance of scrapers and unifacially worked flakes suggests that butchering and hide processing activities occurred in Area 2.

Area 4, which had been extensively disturbed by construction activities, contained another bone bed similar to Feature 5. Although stone tools and debitage were less common, a Fresno arrow point, a reworked corner-notched dart point, two beveled knives, and numerous scrapers and utilized flakes were recovered. No radiocarbon dates were obtained, but the materials appear to be roughly contemporaneous with the dated events in Areas 1 and 2. Area 4 is interpreted as a primary bison processing area, and Bandy et al. (1980:64) suggest that the kill and initial processing occurred within a seasonal spring or marsh area. Such marshes undoubtedly served as watering holes for game animals and would have been important localities for nomadic hunter-gatherers.

The evidence suggests that there are several discrete Late Prehistoric and/or Protohistoric components in different areas of the Canyon Lakes sites, but all materials recovered were lumped for descriptive purposes. Numerous surface-collecteddart points and at least some of the excavated materials may relate to Late Archaic occupations. However, the bulk of the occupational evidence is more or less contemporaneous and is attributed to the later occupations. The data reported by Bandy et al. (1980) cannot be separated into discrete component samples (i.e., associated with particular areas or features) that are useful for comparative purposes. The faunal remains, for example, are described as a single assemblage although they were found in different areas (most are from Area 4 and Feature 5 in Area 1). In general, however, it appears that all of the faunal remains $(n=10,631)$ are attributed to the Late Prehistoric II and Protohistoric periods and that the combined materials constitute a representative assemblage for these times. The majority ( 88 percent) of the remains were identified as bison, and at least 67 specimens had been intentionally modified or used as expedient tools. The faunal remains were not analyzed to determine seasonality, but the discussion of Area 4 implies springtime hunting. Not all of the nonbison remains (see Bandy et al. 1980:Tables 8 and 9) were examined, but identified animals that probably represent food resources include coyote (which was unusually well represented), wolf, turtles and other amphibians, snakes, prairie dogs, muskrats and unspecified rodents, antelope, and birds (including duck and possibly turkey).

In conclusion, the archeological remains at the Canyon Lakes sites represent a series of Late Prehistoric II and Protohistoric occupations during the thirteenth through seventeenth centuries. There is no evidence that the locality served as a residential base, and it may be inferred that individual occupation/use episodes were of relatively short duration. In many ways, the activities are analogous to the Garza occupations at the Lubbock Lake site, located about $10 \mathrm{~km}$ upstream on Yellowhouse Draw. The Canyon Lakes area appears to have been a favorite hunting location, and the predominant cultural activities were bison hunting and initial butchering, along with some secondary processing (i.e., later stages of butchering) and hide working. The use of pottery appears to have been minimal, and almost all of the lithic reduction was related to tool maintenance. The relative paucity of stone tools and lithic debris indicates that people came to this locality already equipped with the necessary hunting/processing tools. Almost all of the stone materials had to be brought into the area, with the possible exception of silicified caliche and various Ogallala gravels, and the majority of the analyzed tools ( 66.7 percent) and debitage (75.4 percent) are of Edwards chert (Bandy et al. 1980:Tables 4 and 5). Obsidian $(n=5)$, Alibates agate $(n=9)$, and Tecovas jasper $(n=13)$ are present in low percentages, collectively making up 5.8 percent of the analyzed stone tools and debitage $(\mathrm{N}=466)$.

\section{JOHNSON CREEK (TTC 17-6)}

The Johnson Creek site is located near the head of a tributary to lower Yellowhouse Canyon about 3 miles north of Slaton, close to the Slaton Dump site described above. Several weak springs emerge from the Comanchean limestone (some of the northernmost Cretaceous remnants in Texas) at the head of Johnson Creek. Texas Technological College conducted limited excavations there in 1931, and again in 1939, as part of a Works Progress Administration archeological project $(\# 13,543)$. The results of these investigations are briefly reported by Wheat (1955). Three test pits of unspecified size (a rough estimate of total excavation size is $55 \mathrm{~m}^{2}$ 
based on the published maps) uncovered a buried cultural zone within an estimated $45-\mathrm{x}-15-\mathrm{m}$ area of the alluvial terrace. Materials were sparse in Pits A and $\mathrm{B}$, but Pit C (approximately $18 \times 30 \mathrm{ft}$ ) exposed a living surface littered with bison bones (including a complete pelvis with articulated vertebrae, a skull, and isolated fragmentary elements), three rock-lined hearths, and an ash dump or unlined basin hearth. The artifacts recovered in 1939 are 4 arrow points, 2 drills, 3 end scrapers, 3 side scrapers, 2 bone beads, a beveled knife, a flake knife, and a bone awl. A large canine (wolf ?) tooth was found with the beveled knife, and obsidian flakes were recovered during the 1931 investigations. The two points illustrated by Wheat (1955:Plate 11a and b) are typeable as Garza and Fresno.

The published information is sufficient to interpret the site as a bison kill and/or processing station associated with the Garza complex. The precise age of the occupation is not known. Runkles (1964:123) notes that the Johnson Creek site assemblage is very similar to that of the Garza site except that no Harrell points were found at the former. The absence of Harrell points could be due to limited sampling.

\section{RED MUD CREEK (SMU-X41DK2)}

Parsons (1967:98) reports that "a large number of Garza points" were surface collected, along with Harrell, Washita, and Fresno points, from the Red Mud Creek site in Dickens County. The site consists of a buried component exposed in a gully that produced beveled knives, snub-nosed scrapers, and a few unidentified potsherds (presumably plainwares). Although the investigations were limited and the materials recovered are not described, Parsons (1967:98) felt that this locality had the potential to be one of the more important Garza complex sites in the region.

\section{$41 \mathrm{LY} 42$}

Hart (1976) reports that several digs, some done independently and some by the Dawson County Archeological Society, were conducted at $41 \mathrm{LY} 42$ between 1967 and 1974. This large site is located on the southern Llano Estacado between two alkali lakes, one of which has a freshwater spring. No detailed data are presented, but the upper 6-12 inches of the site contained a substantial Late
Prehistoric/Protohistoric component. Although surface-collected artifacts included Paleoindian and Archaic materials, the temporally diagnostic specimens recovered in the excavations include large numbers of arrow points (Fresno, Washita, Harrell, Perdiz, and Garza-like), unidentified brownware and black-on-white pottery, and historic glass beads. A mano and metate were recovered, but the most common lithic tools are scrapers. Large bones and bone fragments, both burned and unburned, are ubiquitous. No faunal analysis was done, but the majority of the remains presumably are bison.

Scattered burned rocks and several burned rock features were observed. One of the features excavated is a rock-lined pit that Hart (1976:113) interpreted as a possible pottery kiln. There is no evidence to support this interpretation, however, and it most likely represents a food baking pit. It is quite similar to features that are interpreted as earth ovens at other sites, such as the Protohistoric pit features found in Sterling and Coke Counties (Riemenschneider 1994b; Shafer 1977:113-119). Despite some evidence of plant processing, 41LY42 appears to be a campsite where hunting/processing activities were predominant. The site's location, on the Llano Estacado upland between two prominent watering holes, was well suited for monitoring bison herds. The paucity of published data, uncertainties regarding field methods and data recording, and the possible presence of multiple but inseparable components limit interpretation of this site.

\section{HOGUE (41TY2)}

The Hogue site, located on a ridge along the east edge of a playa and in the vicinity of a draw in Terry County, has produced surface evidence of a probable Garza complex occupation (Pope 1991). Burned caliche and bison bones are scattered across the site, and diagnostic artifacts indicate that the occupations probably date between ca. A.D. 1200 and 1700. Collected artifacts include 4 Garza, 1 Lott, 2 Perdiz, 12 Harrell, 3 Washita, and 19 Fresno points, and sherds of Jornado and El Paso Brown $(n=5)$, corrugated plainware $(n=2)$, and San Lazaro Glaze D Polychrome $(n=15)$ identified by Steve Leckson. Other commonly recovered artifacts are scrapers, drills and gravers, and bifaces, including one beveled knife; manos and metates are mentioned, but numbers are not specified. Edwards chert is the dominant material, but two arrow points are obsidian. 
The Hogue site probably does not represent a single component, however, and three Marcos dart points and two Scallorn arrow points may indicate that earlier occupations are represented. In addition, five sherds of Jornada and El Paso Brown could predate the Garza occupations.

Since the surface evidence suggests the likelihood of multiple components, the interpretability of the artifact collection is limited. The majority of the stone artifacts, however, appear to be related to hunting/processing activities. Like many other sites on the southern Llano Estacado, the Hogue site probably represents an ephemeral hunting camp that was repeatedly occupied, perhaps by various cultural groups, over several hundred years. ${ }^{9}$

\section{MITCHELL LAKE (41MT41)}

The South Plains Archeological Society conducted limited excavations at 41MT41, adjacent to a small alkali lake in Martin County, during a society field school in 1977 (Alvey 1978). Surface collections indicate the likelihood of multiple occupations from different time periods, but the excavations (a total of 15 units scattered across a large area) produced only a single diagnostic, a Garza point base. Only a few other artifacts were recovered, and no discrete Garza component was defined. Hart (1980:2, Figure 4) interprets a rock-lined pit excavated in 1971 as a pottery kiln. However, this feature is quite similar to Protohistoric earth ovens in Coke and Sterling Counties described by Riemenschneider (1994b) and Shafer (1971:113119). Although the age of this feature is unknown, it may be contemporaneous with the Garza occupations. It is nearly identical to a rock-lined pit at 41LY42 (discussed above), where most of the occupations appear to have been Late Prehistoric II and/or Protohistoric (Hart 1976).

\section{ELM CREEK (41CN95)}

The Elm Creek site, located at the confluence of Elm Creek and the Colorado River $16 \mathrm{~km}$ downstream from the Colorado/Concho River confluence, was excavated by Mariah Associates in 1989

\footnotetext{
${ }^{9}$ Test excavations conducted at the Hogue site during the 1993 Texas Archeological Society field school are reported by Baxevanis et al. (1997).
}

(Treece, Quigg et al. 1993). The upper component of this stratified site, designated as Cultural Unit 1, was investigated with extensive hand excavations, $301 \mathrm{~m}^{2}$ in Block A and $29 \mathrm{~m}^{2}$ in Block B. A thin cultural zone, consisting of charcoal and ashy sediment between 20 and $70 \mathrm{~cm}$ below the surface in both areas, is described as a living surface. Cultural Unit 1 materials were sparse in Block B but abundant in Block A. Because activity patterning in Block A was so well defined and because the cultural zone occurred as a distinct layer within alluvial sediments that had accumulated rapidly, Cultural Unit 1 is interpreted as representing a single event or at least an occupation of very short duration. Eleven radiocarbon assays (excluding two dates that are thought to be erroneous) provide good chronological control (see Table 90). Their consistency generally supports the interpretation that Cultural Unit 1 represents a single event. Treece, Quigg et al. (1993:346-347) averaged the 11 corrected dates according to Long and Rippeteau (1974), resulting in a mean age of A.D. $1512 \pm 81$ and a weighted average (that places greater weight on samples with smaller standard deviations) age of A.D. $1511 \pm 21$. When these same dates are averaged by the CALIB (version 3.03) program according to Stuiver and Reimer (1993), the resulting weighted average age is A.D. $1519 \pm 23$ and the calibrated age is A.D. 1439 (1444) 1479. This calibrated date is perhaps a more realistic estimate of when the occupation actually occurred, and it is consistent with other dated occurrences of Lott points.

The lithic assemblage from Cultural Unit 1 consists of 31 bifaces, 77 unifaces, 3 hammerstones, 20 cores/tested cobbles, 2 ground stones, 5,577 unmodified debitage, and 23 projectile points. The latter consist of 4 large points (or preforms ?), 1 indeterminate point, and 18 arrow points. Most of the arrow points are untyped $(n=10)$, but the typed specimens are four Lott, three Fresno, and one Perdiz. At least one of the Fresno points (two refit fragments) appears to be a manufacturing failure, and three burned antler tines may have been used as pressure flaking tools. Eighteen body sherds from a single vessel of Leon Plain also were recovered.

Twenty features are associated with Cultural Unit 1 . The most numerous are eight basin-shaped hearths (Features 9, 15, 16, 17, 21, 25, 27, and 30) that generally had oxidized clay bases and ashy fill. Six ash/charcoal lenses (Features 11, 23, 24, 26, 29, 
and 31) are interpreted as dumps of hearth fill from the basin hearths (other minor ash/charcoal stains are mentioned but were not recorded as features). Other features include an angular rock hearth or cooking pit; a clay-lined pit; two knapping stations; an artifact concentration containing an end scraper, three utilized flakes, two ribs, and burned rocks; and a large limestone boulder that probably served as an anvil stone (Features 20,14, 13, 22, 12, 28, respectively). One additional basin-shaped hearth (Feature 18) found during mechanical stripping of an extension to Block A was not assigned to Cultural Unit 1. The 11 valid radiocarbon dates are associated with seven of these features (including the unassigned hearth).

Four archeomagnetic dates were attempted on burned sediment samples from four of the unlined basin hearths. One sample was undatable, but three samples each produced two or three different date options (based on different segments of the archeomagnetic curve intersected by the $\alpha_{95}$ values). In each case, the latest date option is the most likely: Feature 9 at A.D. $1400-1800$, Feature 15 at A.D. 1500-1800, and Feature 21 at A.D. 1425-1700. These results are consistent with the radiocarbon dating results, and the paired dates for Feature 21 overlap considerably.

The well-preserved faunal assemblage consisted of 2,980 specimens, of which 68.5 percent were unidentifiable. Of the remainder, 938 bones were identified as bison and 1 as deer. Only 200 bison bones were identified to element, and 4 teeth and a mandible were the only complete bones (representing a 1-year-old animal). Most of the bones had been broken and pulverized, apparently as part of the process of removing marrow and making bone grease. Nineteen freshwater mussel shells, of at least six different species, were recovered. Several of the shells exhibited evidence of burning, but clams probably were a minor food resource.

Treece, Quigg et al. (1993:367) summarize Cultural Unit 1 as a springtime bison processing campsite occupied around A.D. 1511 (or during the mid fifteenth century according to calibrated dates). The principal activities represented are tool manufacturing, bone processing, cooking (on open hearths, in pits, and presumably in pots), and hide processing. The artifact and bone patterning was well defined, and numerous discrete activity areas were identified. Most of the activities seemed to center around three basin hearths in Block A (Features 11, 15, and 27) and one basin hearth (Feature 25) in Block B. The repeated artifact patterning observed around each of these hearths (e.g., association of large and small bone processing areas, knapping stations, and stone tools) is suggestive of individual household units, perhaps reflecting family groups. In addition, one burned rock hearth (Feature 20) is tentatively interpreted as a cooking pit, perhaps something akin to an incipient burned rock midden. Pit roasting may have been the focus of communal activities. The clear association with Lott points suggests that the brief occupation was affiliated with the Garza complex.

\section{$41 \mathrm{CN} 78$}

Archeological investigations at $\mathrm{O}$. $\mathrm{H}$. Ivie Reservoir in 1988 and 1989 included limited testing of one Coleman County site, 41CN78, with evidence of a Protohistoric Garza occupation (Lintz, Treece et al. 1993:533-556). This site, which is located about $1 \mathrm{~km}$ northeast of the Elm Creek site, contains eight analysis units or components that were defined based on horizontal and vertical separation. Analysis Unit 6 , in the north-central part of the site, consists of surface-collected artifacts and excavated materials from shallowly buried (i.e., $0-20 \mathrm{~cm}$ below the surface) deposits in six 1-x-1-m test units. Although surface features are present nearby, no features are assigned to this analysis unit.

Collected from Analysis Unit 6 were 2 cores, 8 bifaces, 3 unifaces, 27 flakes, and a Garza arrow point. The latter was found on the surface but is thought to be associated with the buried deposits. A radiocarbon assay on charcoal from the cultural zone produced a calibrated date of A.D. 1523 (1650) 1953 (see Table 90). Although the association between the point and the deposits is not precise, a midseventeenth-century date corresponds well with other dated occurrences of Garza points.

\section{GARNSEY SPRING SITES \\ (LA-18399 AND LA-18400)}

Two seasons of archeological investigations at the Garnsey Spring sites, located $20 \mathrm{~km}$ southeast of Roswell in Chaves County, New Mexico, were conducted by the Museum of Anthropology, University of Michigan in 1977 and 1978. Extensive work was done at the Garnsey Spring Bison Kill site (LA-18399), while a moderate amount of work was 
done at the Garnsey Spring Campsite (LA-18400). Both date to the Late Prehistoric period, and it is thought that the occupations and activities at these localities might represent the same peoples. Investigations at the kill site are reported by Speth and Parry $(1978,1980)$ and Speth (1983), and the work at the campsite is reported by Parry and Speth (1984). The sites are adjacent to a tributary that cuts into the western Llano Estacado caprock, called the Mescalero Escarpment, and are located in the easternmost part of the Mescalero Pediment, a series of low rolling plains between the Pecos River and the Llano Estacado. The kill site is situated in the alluvial sediments of Garnsey Wash (or Arroyo), and the campsite is located on a terrace above an unnamed draw, informally called Spring Draw, about $0.5 \mathrm{~km}$ east of the kill site. Permanent fresh water is available at Garnsey Spring between the sites and in two deep spring-fed lakes located in large sinkholes less than $0.5 \mathrm{~km}$ from the kill site. Although Garnsey Spring is still active, the water seeps into the ground or is lost to evaporation, and water only flows in Garnsey Wash after large rains. Parry and Speth (1984:110) note that "The proximity of the campsite to the spring, one of the few along the east side of the Pecos Valley in the Roswell area, suggests that the availability of fresh water was indeed an important factor in the placement of the [camp] site."

The Garnsey Spring Campsite was completely surface collected, and the subsurface deposits were investigated with a 1-x-2-m test unit in 1977 and $48 \mathrm{~m}^{2}$ within eight small block areas in 1978. Two radiocarbon dates were obtained from mixed charcoal samples during the 1977 testing, but these dates are thought to be unreliable. During the intensive work in 1978, the deposits were found to be very shallow and disturbed, and bone preservation was poor. Small bone fragments were common, but identifiable bones were rare $(n=36)$. Species that probably represent food resources are bison $(\mathrm{MNI}=$ $1)$, deer/antelope $(\mathrm{MNI}=1)$, cf. Canis $(\mathrm{MNI}=1)$, and cottontail and jackrabbit $(\mathrm{MNI}=2$ each). The artifacts from the campsite (Table 96) include an abundance of arrow and dart points (precise numbers are not specified), bifacial knives, scrapers, and utilized/retouched flakes that are indicative of hunting, butchering, and hide processing.

The dart and arrow points indicate activities spanning a considerable amount of time, although the projectile point chronology for southeastern New
Mexico is poorly documented. The Carlsbad points are thought to predate A.D. 950 and be generally associated with preceramic occupations, while most of the Washita arrow points probably date after ca. A.D. 1200 . The 5 Garza points, which represent 12 percent of the 42 typeable arrow points, are thought to postdate A.D. 1400. The absence of Harrell points is notable because they are so common in the Texas Panhandle after A.D. 1200.

The ceramic assemblage (identified by Regge Wiseman) is quite variable and includes plain and decorated Puebloan wares thought to have been manufactured between A.D. 900 and 1400 . The most ubiquitous wares, which are commonly found well onto the southern Llano Estacado, are Jornadatradition brownwares (at least five varieties) and Chupadero Black-on-white. The dating of the brownwares in southeastern New Mexico is problematic, however, and Chupadero Black-on-white was manufactured as late as A.D. 1545 at Gran Quivira (Hayes et al. 1981:72).

Four features in the main campsite area are identified: (1) a 60-cm-diameter lens of ashy gray sediment, tentatively dated to before A.D. 1400 because a sherd of Chupadero Black-on-white was found in its fill; (2) a 30-cm-diameter circular basin with a black ashy fill containing tiny burned bone fragments; (3) a large concentration of fire-cracked rocks; and (4) a 34-cm-diameter circular basin with an oxidized base and ashy fill containing numerous small chert flakes. The latter feature is radiocarbon dated to around A.D. 850 .

A fifth feature, called the "Garza hearth," was located across Garnsey Wash from the main campsite. This shallow, unlined basin hearth was exposed on the surface, and 15 artifacts were surface collected from a 2-m radius: a Garza point, an unidentified arrow point fragment, 3 scrapers, 4 utilized flakes, and 6 unmodified flakes. Excavation obtained a charcoal sample that produced a calibrated radiocarbon date of A.D. 1527 (1648) 1664 (see Table 90). Parry and Speth (1984:29) note that "the association between hearth and Garza point is less than ideal," but they conclude that they most likely were associated. The absence of late Puebloan pottery types (e.g., late Rio Grande glazewares) may indicate that the seventeenth-century occupations were less frequent and/or more temporary than the earlier occupations.

The artifactual evidence indicates that the Garnsey Spring campsite was occupied as early as 
TABLE 96

COMPARISON OF ARTIFACTS RECOVERED FROM THE GARNSEY SPRING BISON KILL AND CAMPSITE

\begin{tabular}{|c|c|c|c|}
\hline Artifact Class and Type & $\begin{array}{l}\text { Bison Kill } \\
\text { Excavations }{ }^{1}\end{array}$ & $\begin{array}{l}\text { Campsite } \\
\text { Excavations }^{2}\end{array}$ & $\begin{array}{l}\text { Campsite Surface } \\
\text { Collections }^{3}\end{array}$ \\
\hline \multicolumn{4}{|l|}{ Arrow Points } \\
\hline Fresno & _- & 7 & 11 \\
\hline Garza & - & 2 & 3 \\
\hline Harrell & 2 & - & - \\
\hline Washita & 3 & 11 & 6 \\
\hline Harrell/Washita & 3 & - & - \\
\hline Corner-notched & - & 2 & - \\
\hline Untyped & - & ? & $?$ \\
\hline \multicolumn{4}{|l|}{ Dart Points } \\
\hline Maljamar & - & 1 & $2(?)$ \\
\hline Carlsbad & - & $14+$ & $12+$ \\
\hline Corner-notched & - & 6 & $4(?)$ \\
\hline Untyped & 1 & ? & $?$ \\
\hline Reworked & 1 & - & - \\
\hline \multicolumn{4}{|l|}{ Other Chipped Stones } \\
\hline Bifaces & 11 & 75 & - \\
\hline Scrapers & 6 & 58 & - \\
\hline Utilized/retouched flakes & 59 & 292 & - \\
\hline Cores & 3 & 72 & - \\
\hline Unmodified flakes & 459 & ca. 7,580 & - \\
\hline Resharpening flakes & 54 & - & - \\
\hline \multicolumn{4}{|l|}{ Pottery } \\
\hline Chupadero Black-on-white & 6 & 146 & - \\
\hline San Andres Red-on-terracotta & - & 12 & - \\
\hline Three Rivers Red-on-terracotta & - & 12 & - \\
\hline Three Rivers Ware & - & 20 & - \\
\hline Lincoln Black-on-red & - & 2 & - \\
\hline Redwash Brown & - & 5 & - \\
\hline Playas Incised (Sierra Blanca variety) & - & 6 & - \\
\hline Jornada Brown & 3 & 200 & - \\
\hline Roswell Brown & 1 & 72 & - \\
\hline South Pecos Brown & 4 & 245 & - \\
\hline McKenzie Brown & 2 & 112 & - \\
\hline El Paso Brown & - & 30 & - \\
\hline Corona (?) Corrugated & - & 1 & - \\
\hline Manges/Mimbres Black-on-white & - & 14 & - \\
\hline Red Mesa Black-on-white & - & 2 & - \\
\hline Galisteo Black-on-white & - & 2 & - \\
\hline St. Johns Polychrome & - & 4 & - \\
\hline Unidentified painted & - & 4 & - \\
\hline Unidentified brown & 1 & 10 & - \\
\hline El Paso Polychrome & 2 & - & - \\
\hline
\end{tabular}

${ }^{1}$ Eight arrow points typed as Harrell include some obviously misidentified specimens. These points are retyped in this table as 2 Harrell, 3 Washita, and 3 Harrell/Washita.

${ }^{2}$ Includes 62 projectile points, but the precise number of dart and arrow points is not specified.

${ }^{3}$ Includes 32 points collected by the University of Michigan and 50 points collected by local amateurs. The precise number of dart and arrow points is not specified. 
A.D. 900 and possibly as late as the seventeenth century. The campsite consists of multiple, spatially overlapping occupations over many centuries. The lack of "reliable stratigraphic and chronometric control" at the site, and the lack of similar dated cultural materials throughout the region, seriously limit the interpretability of the data (Parry and Speth 1984:29). With the exception of the "Garza hearth," no discrete components assignable to the Garza complex can be defined; nonetheless, a significant portion of the material culture could represent residue of the Garza culture.

The nearby Garnsey Bison Kill represents a series of separate bison kill/processing events that occurred mainly between A.D. 1450 and 1625 based on 18 bone radiocarbon dates (out of 26 samples submitted for analysis, 5 were too small and 3 produced modern dates). This age assessment, by Speth and Parry (1980:Fig. 18), is based on averages of $\delta^{13} \mathrm{C}$-corrected dates from the entire site and from discrete bone clusters. Calibration of these dates according to Stuiver and Reimer (1993) does not significantly alter their general assessment. It should be noted, however, that a few individual dates are earlier and later (see Speth and Parry 1984:Tables 4 and 5).

The kill site is not a single bone bed but consists of a series of discontinuous scatters and clusters of bones exposed for $300 \mathrm{~m}$ along Garnsey Wash. The investigations consisted of hand excavation of $120 \mathrm{~m}^{2}$ in 1977 and $227 \mathrm{~m}^{2}$ in 1978 . Bone preservation was quite good, and 6,937 bison bones were recovered in at least three distinct levels at $120-170 \mathrm{~cm}$ below the surface. A conservative estimate of the minimum number of individuals is 35 , and there are at least six clusters that may represent different kill events. Based on the geomorphic evidence, it was suggested that the entire 2to 4-m-thick alluvial sequence containing the bone layers "represents a comparatively short period, probably on the order of a few centuries or less" (Speth 1983:23). Anywhere from 4 to 15 animals were killed in individual kill events, but the "typical" kill appears to have involved only 6 to 8 animals. Some secondary butchering activities may have occurred in the upstream end of the site (i.e., toward the campsite), but the majority of the remains are indicative of early stage processing, and the hunters were apparently very selective in which animals they butchered and what parts of animals they transported away. Nonbison remains were rare and consist of canid $(n=40)$, antelope $(n=8)$, and deer $(n=1)$. A minimum of four canids, two antelopes, and one deer are represented. These animals were killed and butchered, and their remains were scattered in various bison processing areas. Among the nonbison remains is a complete canid skull identified as a wolf/dog hybrid.

According to Speth and Parry (1980:176), the Garnsey kill site

was the locus of recurrent, communal procurement activities, in which bison were either surrounded within the wash or driven over the edge of the wash into corrals. Although several different events are recorded in the Garnsey deposits, all took place during the same season of the year-the spring.

One of the critical questions is whether any of the campsite occupations were related to any of the bison kill episodes. Parry and Speth (1984:109) note the general contemporaneity of the two sites but conclude that they are not necessarily related. Five lines of evidence, however, suggest that the campsite occupations probably coincided with specific hunting and processing events.

First, it has been established that the sites are chronologically related. Despite the limited chronometric evidence for the campsite, the combined radiocarbon and artifactual evidence indicates that both sites represent multiple but contemporaneous occupations over a long period of time. Second, the sites produced very similar artifact assemblages. Although the intrasite proveniences and contexts of specific artifacts are not discussed, the kill site yielded the same types of arrow points, dart points, cutting and scraping tools, and pottery as the campsite (see Table 87). The most common diagnostics found at the kill site (i.e., Washita points, Jornada brownwares, and Chupadero Black-on-white) also are the most common types found at the campsite. Ground stone tools are missing from both assemblages, and the artifactual evidence indicates that the activities that occurred at the campsite were somewhat specialized and probably hunting oriented.

Third, the kill site does not contain any camping features (e.g., hearths), while such features are present at the campsite. Fourth, the site functions are complementary, as indicated by the differences in the assemblages (Table 97). At the kill site, utilized flakes, points, and bifacial skinning tools 
TABLE 97

COMPARISON OF ARTIFACT COLLECTIONS FROM EXCAVATIONS AT THE GARNSEY SPRING BISON KILL AND CAMPSITE

\begin{tabular}{|c|c|c|c|c|c|c|}
\hline \multirow[b]{2}{*}{ Artifact Class } & \multicolumn{2}{|c|}{ Bison Kill } & \multirow{2}{*}{$\begin{array}{l}\text { Adjusted Standardized } \\
\text { Residuals for Kill Site* }\end{array}$} & \multicolumn{2}{|c|}{ Campsite } & \multirow[b]{2}{*}{ Totals } \\
\hline & No. & $\%$ & & No. & $\%$ & \\
\hline Projectile points & 10 & 1.6 & +2.59 & 62 & 0.7 & 72 \\
\hline Bifaces & 11 & 1.8 & +2.42 & 75 & 0.8 & 86 \\
\hline Scrapers & 6 & 1.0 & +0.96 & 58 & 0.6 & 64 \\
\hline Utilized/retouched flakes & 59 & 9.5 & +8.08 & 292 & 3.2 & 351 \\
\hline $\begin{array}{l}\text { Unmodified flakes } \\
\text { (includes resharpening) }\end{array}$ & 513 & 82.6 & -0.80 & 7,580 & 83.9 & 8,093 \\
\hline Cores & 3 & 0.5 & -0.86 & 72 & 0.8 & 75 \\
\hline Pottery & 19 & 3.0 & -5.66 & 899 & 10.0 & 918 \\
\hline Totals: & 621 & 100 & & 9,038 & 100 & 9,659 \\
\hline
\end{tabular}

associated with killing and initial butchering activities are overrepresented. There are no significant differences in the frequencies of tools associated with lithic tool production and maintenance, while pottery is, as expected, overrepresented in the campsite. The ceramics, particularly the decorated wares, probably indicate some permanency of occupation, but the absence of ground stones and other rare artifact classes is indicative of a specialized hunting camp rather than a multifunctional residential base.

The fifth and final line of evidence is that the geographic settings of these sites are complementary and well suited to their specific functions. Spring waters in Garnsey Wash probably attracted bison, and small herds could have been easily ambushed as they moved upstream toward the spring. The kill site location, at a point where the draw first constricts, would have provided a prime location for such hunting activities, but it would not have been an ideal camping spot due to the potential for flash floods. The campsite location, just above Garnsey Wash and close to the spring, was the logical setting for establishing a camp while observing springtime bison herd movements downstream and on the Llano Estacado.

While Garza points are absent at the kill site, this does not necessarily mean that none of the kills were made by Garza peoples, as several of the dated kill episodes are contemporaneous with the dated Garza hearth. The absence of Garza points could be a sampling bias, given the small number of points from the kill site.

\section{OTHER POSSIBLE GARZA COMPLEX BISON KILLS/CAMPSITES}

A few other identified localities on the southern Llano Estacado may have been occupied temporarily by Garza peoples. Randall (1970:46, Figure 9e) notes that Garza points have been surface collected from sites in Lamb County but provides no specific details. Brown (1985:Figures 1 and 2) illustrates a Garza and a Lott point from two small campsites (41LU29 and 41LU29) near a small playa in westcentral Lubbock County. A variety of other diagnostic artifacts were recovered from these sites, so it is unlikely that discrete Garza components could be identified. At Palo Duro Reservoir in the northern Texas Panhandle, Peterson (1988:Figure 25, 241, 304-305) reports and illustrates a Garza point from Hansford County site 41HF107. This arrow point, along with a Fresno, was found in association with a $2-x-2.5-m$ ring of stones that may represent an ephemeral structure (e.g., tipi ring). The site is suggested as being affiliated with the Antelope Creek phase, but it more likely represents a later occupation.

Portales Spring, located along Boone Draw approximately 6 miles southwest of Portales in Roosevelt County, New Mexico, is a well-known locality and was of considerable importance in 
historic times. An archeological site in the vicinity of the spring, found by the landowners in 1957, was the scene of limited test excavations between 1962 and 1972. Word (1991b) subsequently completed a brief report that outlines the findings and what is known of their archeological contexts. Cultural deposits, buried at $60-90 \mathrm{~cm}$ below the surface in the alluvial terrace next to the draw, are characterized by a bison bone bed that covers an area of some $50-x-50 \mathrm{~m}$. The excavations (equivalent to fourteen $5-\mathrm{x}-5-\mathrm{ft}$ units, or $32.5 \mathrm{~m}^{2}$ ) revealed scattered bison bones and 15 bison skulls, along with several scrapers, a quartzite hammerstone, a core, a mano, a metate, and bone tools. The latter includes two antler tine scraper handles into which snubnosed end scrapers were once hafted. They are identical in form to others found in the Central Plains (cf. Word 1991b:Figure 6 with Wedel 1970a: Figures 1 and 2). Although the cultural deposits are undated, a horse skull and a grooved maul (a distinctive Historic period Plains Indian tool) indicate that the deposits probably date ca. A.D. 1650 or later. Lacking any projectile points, it is impossible to assign a cultural affiliation to this bison kill/ processing site, but its chronology and location suggest that it could be a late Garza component. The outline of a "bow," presumably of wood, is illustrated by Word (1991b:Figure 5). It is shown on a map as having been found under one of the bison skulls. If this does represent a Native American bow, it is a very rare find.

Three additional sites at Lake Alan Henry provide evidence of Protohistoric activities that may be associated with the Garza complex. Two are described as faunal localities and consist primarily of bison remains (Boyd et al. 1990:151-158). A flake tool and partial remains of a single male bison (10-11 years old) were recovered at $41 \mathrm{KT} 44$. Some of the bones exhibited cut marks and spiral fractures, and one bone was radiocarbon dated to A.D. 1432 (1491) 1653 (calibrated, see Appendix B). Partial remains of two bison (age and sex indeterminate) at 41KT96, Area A, are radiocarbon dated to less than 200 years (see Appendix B), but some of the bones exhibit probable green-bone breaks. Both of these may represent isolated kills contemporaneous with Garza complex activities in the area, but there are no diagnostic artifacts indicating cultural affiliation.

Scattered hearths in association with numerous ground stone tools but relatively sparse chipped stone tools were investigated at two open campsites on opposite terraces at the confluence of Grape Creek with the Double Mountain Fork of the Brazos. The Grape Creek Bench site, 41GR484, is interpreted as a special activity site in which plant processing was the dominant activity (Boyd et al. 1992:81-93). A charcoal radiocarbon date associated with a hearth (Feature 1) is calibrated to A.D. 1527 (1650) 1954 (see Appendix B). Across the creek at 41GR606, removal of fill for dam construction exposed a shallowly buried cultural zone containing over 20 discrete rock-lined hearths, over 20 grinding tools, numerous mussel shells, and very few chipped stones. Based on stratigraphic evidence and a radiocarbon date from a deeper stratum, plant processing activities at this site were determined to be approximately contemporaneous with those at 41GR484 (Boyd and Kibler 1993:238-239). Both of these sites hint that Garza complex peoples may have utilized plant resources intensively when they were not hunting bison.

\section{Rockshelters}

\section{BLUE MOUNTAIN ROCKSHELTER}

Blue Mountain Rockshelter, formed in the Cretaceous limestone canyon rim at the southern end of the Llano Estacado in Winkler County, was completely excavated in 1938 by Texas Technological College and the West Texas Museum of Lubbock. Holden's (1938) brief summary of this archeological investigation suggests that the shelter was occupied repeatedly during the Late Prehistoric II and/or Protohistoric periods. A former spring, which was said to have had a "strong and constant flow" early in the twentieth century, was located less than $50 \mathrm{ft}$ from the shelter (Holden 1938:208).

The small shelter enclosed a $45-\mathrm{m}^{2}$ area $(48 \times 20 \mathrm{ft})$ with deposits up to $4 \mathrm{ft}$ deep. The shelter had been dug into prior to 1938, but Holden's expedition removed the remainder of the deposits in three levels of approximately 6 inches each. Cultural evidence apparently was confined to the upper 18-20 inches, and the deposits produced 78 arrow points along with a wide range of other artifacts and materials, summarized in Table 98. Holden (1938) grouped most of the arrow points into five unnamed types that correspond to Fresno, Harrell/Washita, Perdiz, Lott, and Garza. The Fresno and Harrell/Washita points are most abundant (23 of each), followed by Garza $(n=21)$, Perdiz 
TABLE 98

CULTURAL MATERIALS RECOVERED FROM BLUE MOUNTAIN ROCKSHELTER

\begin{tabular}{|c|c|c|c|c|c|c|}
\hline Artifacts and Other Materials & $\begin{array}{l}\text { Surface or } \\
\text { Unspecified }\end{array}$ & $\begin{array}{l}\text { "Dump } \\
\text { Heap"1 }\end{array}$ & Level 1 & Level 2 & Level 3 & Totals \\
\hline $\begin{array}{l}\text { Arrow points: } \\
\text { Fresno } \\
\text { Harrell/Washita } \\
\text { Perdiz } \\
\text { Lott } \\
\text { Garza } \\
\text { Untyped } \\
\text { Folsom point fragment } \\
\text { Bifacial knives } \\
\text { End scrapers } \\
\text { Side scrapers } \\
\text { Utilized flakes } \\
\text { Flint awls (drills) } \\
\text { Bone awls } \\
\text { Bone beads } \\
\text { Paint stones (hematite/limonite) } \\
\text { Metate } \\
\text { Manos }{ }^{2} \\
\text { Shell beads } \\
\text { Worked shell } \\
\text { Decorated potsherds }{ }^{3} \\
\text { Plainware potsherds }{ }^{4} \\
\text { Yucca stem quids (?) } \\
\text { Horse teeth } \\
\text { Bison teeth } \\
\text { Carnivore teeth } \\
\text { Other bones }\end{array}$ & $\begin{array}{r}- \\
- \\
- \\
- \\
- \\
27 \\
- \\
1 \\
- \\
- \\
34 \\
- \\
- \\
- \\
- \\
- \\
- \\
- \\
- \\
3 \\
10 \\
2 \\
- \\
- \\
x \\
x\end{array}$ & $\begin{array}{l}- \\
- \\
- \\
- \\
- \\
- \\
- \\
1 \\
- \\
- \\
- \\
2 \\
2 \\
2 \\
- \\
- \\
- \\
2 \\
- \\
- \\
- \\
- \\
- \\
- \\
- \\
-\end{array}$ & $\begin{array}{r}15 \\
13 \\
8 \\
1 \\
10 \\
- \\
- \\
5 \\
- \\
- \\
- \\
5 \\
1 \\
4 \\
3 \\
1 \\
4 \\
- \\
- \\
- \\
- \\
- \\
- \\
- \\
- \\
x\end{array}$ & $\begin{array}{r}4 \\
10 \\
- \\
2 \\
9 \\
- \\
- \\
2 \\
4 \\
5 \\
- \\
2 \\
- \\
- \\
- \\
- \\
- \\
- \\
1 \\
- \\
- \\
- \\
- \\
- \\
- \\
\end{array}$ & $\begin{array}{r}4 \\
- \\
- \\
- \\
2 \\
- \\
1 \\
- \\
7 \\
4 \\
- \\
- \\
- \\
- \\
- \\
- \\
- \\
- \\
- \\
- \\
- \\
- \\
25 \\
x \\
- \\
x\end{array}$ & $\begin{array}{r}23 \\
23 \\
8 \\
3 \\
21 \\
27 \\
1 \\
9 \\
11 \\
9 \\
34 \\
7 \\
3 \\
6 \\
5 \\
1 \\
4 \\
2 \\
1 \\
3 \\
10 \\
2 \\
25 \\
\mathrm{x} \\
\mathrm{x} \\
\mathrm{x}\end{array}$ \\
\hline \multicolumn{7}{|c|}{$\begin{array}{l}\text { 1"Dump heap" is a pothunter's backdirt pile. } \\
{ }^{2} \text { One mano was found with the metate from Level } 1 . \\
{ }^{3} \text { Painted sherds include black-on-white, brown-on-gray, and red-on-orange. } \\
{ }^{4} \text { Two plainware sherds have "thumb print indentations" on exterior. } \\
x=\text { present but not quantified. }\end{array}$} \\
\hline
\end{tabular}

$(n=8)$, and Lott $(n=3)$. A Folsom fragment in Level 3 is undoubtedly a relic that was introduced during the Protohistoric period.

Holden's (1938:219) statement that "A considerable amount of crushed bone was found throughout all the layers" indicates that hunting activities were important. The abundance of arrow points, scrapers, and knives supports this assumption. Teeth identified as bison, carnivore (probably canid), and modern horse were recovered. Although the faunal remains were not analyzed in any detail, it is possible that all of these animals represent food resources. The presence of horse teeth indicates that some, perhaps most, of the occupations occurred after European contact.

Thirteen potsherds of at least four different types were found. Three sherds of painted ware are "definitely of Puebloan origin" (Holden 1938:216), while the plainware sherds are of unknown origin. These wares perhaps indicate that a variety of cooking, storage, and/or food consumption activities occurred in the shelter. Three mano fragments and a paired mano and metate suggest that plant food processing also occurred. The presence of other rare artifact types, such as bone awls, bone and shell beads, and paint stones, is further evidence of a 
wide variety of activities. In contrast to most small rockshelters in the region, which appear to have been used only as temporary camps, Blue Mountain Rockshelter seems to have been occupied intensively (i.e., more often and for longer periods of time) and perhaps served as a residential base. The nearby spring undoubtedly was an important reason for the intensive occupations.

No features were identified, but a red negative pictograph of a human hand was found on the ceiling. Approximately 30 additional pictographs were found on the rock face above the nearby spring. Images depicted in this group include a human hand with fingers missing, a "female figure" and a man, a quadruped (deer ?), a horse, and a "plumed serpent." The horse denotes contact with Europeans and suggests that these images could have been made by Protohistoric peoples who occupied the shelter. The plumed serpent, if that is what it is, could indicate contact with the Puebloan world, or perhaps authorship by a Puebloan person. Other Southwestern motifs, including another plumed serpent in Oldham County, have been documented at a few rock art sites in the Texas Panhandle-Plains (see Chapter 6).

Over 100 mortars were found in the bedrock limestone in the vicinity of the shelter. It is possible that Protohistoric peoples living in the shelter (or in nearby sites?) made and/or used some or all of these mortars, but there is no evidence to support this.

\section{RED BLUFF SHELTER (SMU-X41CX8)}

Excavations at Red Bluff Shelter (or the Sotol site) in Crockett County were conducted in 1967 by Southern Methodist University for the Texas State Building Commission (Lorrain 1968). The site consists of a series of protected overhangs along the base of a limestone bluff overlooking the Pecos River. An $18-\mathrm{m}^{2}$ area was excavated in and near the main shelter. A 1-x-6-m trench was located outside the dripline, and three contiguous $2-\mathrm{x}-2-\mathrm{m}$ units were located in the central portion of the shelter, both inside and outside the dripline. The excavated deposits consist of about 1-m-deep sediments that were separable into two to four natural stratigraphic zones. The lowermost Zone A was almost sterile (only 2 artifacts recovered), while the overlying Zone B contained only 5 specimens, 2 of which were dart points. Immediately above this, the Zone $\mathrm{C}$ stratum was subdivided into lower, middle, and upper cultural levels. Lower Zone $\mathrm{C}$ produced 16 dart points and 5 arrow points (2 Cliffton and 1 each of Toyah, Perdiz, and untyped); middle Zone $\mathrm{C}$ produced 6 dart points and 2 arrow points (Cliffton and Perdiz); and upper Zone C produced 6 dart points and 10 arrow points (5 Perdiz, 2 Cliffton, and 1 each of Washita, Toyah, and untyped). The dart points from Zone $\mathrm{C}$, which include specimens typed as 15 Ensor, 6 Frio, 4 Figueroa, and 1 each of Marcos, Marshall, Travis, Pedernales, Tortugas, Abasolo, and Paisano, decreased in frequency through time, while the relative number of arrow points increased.

The uppermost cultural level, Zone D, was mainly inside the dripline and can be defined as a Garza complex component. Thirteen artifacts associated with Zone D include 7 arrow points: 2 Garza, 2 Toyah, a Perdiz, a Fresno, and an untypeable fragment. Other associated artifacts are identified as 4 scrapers, a burin, and 1 untyped plainware potsherd. Lorrain (1968:33) describes the sherd as having a "dark gray paste with coarse rock and sand temper (including some mica particles)." This black micaceous sherd may be of Puebloan origin.

Two hearth features were found within Zone D and samples of charcoal from both were radiocarbon dated (see Table 90). Feature 1, a small $(60 \times 60 \times 25 \mathrm{~cm})$ basin-shaped pit lined with limestone rocks, is dated to A.D. 1432 (1449) 1625 (calibrated). Feature 2, a more extensive cluster $(125 \times 90 \times 25 \mathrm{~cm})$ of burned limestone and charred remains, is dated to A.D. 1439 (1487) 1637 (calibrated). A bundle of charred sotol or lechuguilla stalks, found below one of the larger rocks in Feature 2, is interpreted as fuel. Since charred remains were found primarily in and underneath the burned rocks, it is likely that both of these features were roasting pits. Mortar holes and grooved boulders were found in nearby overhang shelters along the same bluffline, but these features cannot be associated with any particular time period or occupation.

\section{BOREN SHELTERS NO. 1 AND 2} (41GR546 AND 41GR559)

Investigations at two adjacent rockshelters at Lake Alan Henry, originally reported by Boyd et al. (1994) and summarized in Chapter 6, provide 
evidence of Protohistoric occupations tentatively associated with the Garza complex. Minimal cultural evidence was found in the 1-m-deep deposits in the smaller Boren Shelter No. 1, and only two definite artifacts (a scraper and a hammerstone) were recovered. Two hearths were found in the upper fill and a third was found in the lower fill. A calibrated radiocarbon date of A.D. 1433 (1650) 1955 (see Table 90) on charcoal from one of the upperfill hearths indicates that at least one occupation occurred during the Protohistoric period.

The larger Boren Shelter No. 2, with deposits over $1 \mathrm{~m}$ thick, contained no definite evidence of occupation after about A.D. 1300. However, a hearth dump and multiple bone clusters in the talus area are dated to the Protohistoric period by a single calibrated bone radiocarbon date of A.D. 1519 (1650) 1952 (see Table 90). The bone clusters are interpreted as midden dumps of portions of animal carcasses that had been selectively butchered. Many of the animals (i.e., wolves and unidentified canids, fox, bobcat, and mink) are fur-bearing mammals that were probably killed close by, and their skulls and limbs were discarded in the midden. The lower hind leg of a single bison probably represents an animal that was killed some distance from the shelter, perhaps indicating that these people were bison hunters at other times. The 16 artifacts recovered from the talus area (5 hammerstones, 3 cores, 7 flakes, and an untyped arrow point) appear to be hunting/butchering tools.

Because the dates overlap considerably, it is possible that the brief occupation of Boren Shelter No. 1 coincided with the hunting and butchering activities at Boren Shelter No. 2. Although no diagnostic artifacts are associated, the simultaneous events at these two sites are tentatively affiliated with the Garza complex for the following reasons: (1) these shelters are well within the core area of the Garza complex; (2) the cultural activities were contemporaneous with well-dated Garza occupations at several nearby sites; (3) hunting and butchering of animals, particularly bison, wolves, coyotes, and other canids, is well documented at other nearby Garza components; and (4) Garza complex occupations of small rockshelters are documented at nearby Reed Shelter (discussed below).

\section{REED SHELTER (41GR54)}

Excavation of the tiny (ca. $6 \times 13 \mathrm{ft}$ ) Reed
Shelter was conducted by members of the South Plains Archeological Society in 1966 and is briefly reported by Riggs (1966). Located on Gobbler Creek, a tributary of the Double Mountain Fork of the Brazos River, Reed Shelter is within the Lake Alan Henry project area and is about $4 \mathrm{~km}$ northeast of the Boren Shelters. The SPAS investigations revealed sporadic cultural materials throughout the ca. 24-inch-thick sediments. All of the deposits inside the shelter were removed, and cultural materials were found to extend out into the creek terrace immediately in front of the shelter. Eleven 5-x-5-ft units (ca. $26 \mathrm{~m}^{2}$ ) excavated in 6-inch levels produced 22 artifacts and 209 chips of lithic debris. No buried features were found.

Diagnostic artifacts that are described and illustrated are four arrow points (a Harrell, a Garza, and two Fresnos), an untyped dart point fragment, an ovate knife, and three scrapers. Other artifacts specifically mentioned include an obsidian flake, a mano fragment, a complete oval-basin metate, a metate fragment, and several quartzite hammerstones.

Rock art images are present in and near the shelter, and bedrock mortars are present in the vicinity. A small group of petroglyphs (three parallel lines, a zigzag snake, a rectangular figure or headless human, and a rectangular human) and an isolated glyph (a deer) were found on the soft sandstone faces near the back of the shelter (see Riggs 1966:Figures 4 and 5). Riggs (1966:Figure 6) also reported a pictograph (a red/orange-painted human figure holding a shield) under a sandstone ledge across the creek from Reed Shelter. Similarly, the mortars were observed in bedrock near the shelter and on the ledge across the creek. These features may or may not be associated with the Reed Shelter occupations. The mortars and pictograph across the creek are documented as components within an extensive Late Prehistoric campsite, 41GR390, and a campsite adjacent to the shelter, 41GR396, has produced a Fresno arrow point and a sherd of El Paso Polychrome (Boyd et al. 1989: 485-488). Consequently, it appears that Late Prehistoric occupations in the immediate vicinity of Reed Shelter may have been intensive. Despite the absence of radiocarbon-dated remains, the occupational debris in Reed Shelter probably dates to the Late Prehistoric II and/or Protohistoric Periods, and at least one occupation was probably by Garza peoples. 


\section{GARZA COUNTY CAVE (SPAS-GR269)}

In the newsletter of the South Plains Archeological Society, Harper and Shedd (1969) present a onepage description of the excavation of a small $(5 \mathrm{ft}$ wide) shelter along the edge of the Ogallala Caprock in Garza County. Minimal cultural materials were found, but an unnotched triangular arrow point suggests that the occupation dates to the Late Prehistoric II or Protohistoric period. Other materials recovered include a few bones (not identified), a modified piece of gypsum, a few flakes, a biface fragment, and a Plainview point base (that was picked up by later peoples). The occupations are not definitely attributable to the Garza complex, but the large number of Garza complex sites in the vicinity suggest that this is likely. No features were present and the deposits are undated.

\section{Burials}

\section{GARZA BURIAL (SPAS-MT40)}

A single burial, at site SPAS-MT40 in Martin County, is tentatively attributed to the Garza complex. Members of the South Plains Archeological Society found the site and excavated the "Garza burial" in 1971. The investigations are briefly reported by Gates and Hart (1977). The site consists of lithic debris and burned bison bones scattered on the surface. Subsequent probing with a $30-$ inch rod located a concentration of buried bones. Six contiguous 4-x-4-ft units were excavated around this concentration, exposing $30 \mathrm{~cm}$ of deposits that represent a dark midden soil or cultural zone overlying bedrock caliche. Continued excavation exposed a tightly flexed skeleton of a 12-14-year-old girl at $14-30 \mathrm{~cm}$ below the surface. There is no mention of a burial pit; and burned rocks, burned bone fragments, and lithic debris and artifacts were scattered throughout the units. Only one artifact was found in direct association with the remains. It is an $8.7-\mathrm{x}-18.5-\mathrm{cm}$, thin slab of dark gray shale with three holes drilled through it and an incised geometric design on one side. The shale piece was found overlying the face as if it had been tied over the face like a mask. All other artifacts were found in the adjacent units and cannot be definitely attributed to the burial. These include 35 arrow points (9 Garza, 3 Harrell, 2 Perdiz, a Washita, a Scallorn, and 19 untyped specimens), an unidentified brownware sherd, 2 dart points, a bone bead, 2 manos, and a metate. Gates and Hart (1977:148) suggest that the human remains are associated with the Garza complex; although this is likely, the burial's age and cultural affiliation are somewhat questionable.

\section{GARZA-U-RANCH BURIAL}

An unreported burial in Sterling County was found in 1965 eroding out of a cutbank of the North Concho River, about 8 miles west of Sterling City and within ca. 15 miles of the Davis Hackberry Spring site (described above). The excavation of the "Garza-U-Ranch burial" was not controlled, and the skeletal remains, which were reburied soon after the excavation, were never examined. Few details are known, but it probably represents a primary interment that had been partially disturbed by erosion. The grave offerings were subsequently acquired by a local collector and made available for study by the Texas Historical Commission (Andy Cloud, personal communication 1995). The artifacts that accompanied the burial consist of eight complete Garza points, all unusually large and very well made, and three large ovate bifaces that appear to be earlystage beveled knives. There also may have been some greenish beads (perhaps turquoise?) associated with the burial, but this has not been confirmed. Although unreported and undated, this is the only interment that can be attributed to the Garza culture with confidence.

\section{Isolated Ceramic Vessels}

As with the Tierra Blanca complex, there are several cases where complete or partial pots associated with the Garza complex have been found. Excluding some cases where whole pots may have been broken in situ, three finds may represent vessel caches. Habicht-Mauche (1988:Table 5.1) reports two occurrences of isolated pots in the collections of the Panhandle-Plains Historical Museum. Both are globular bean pot-type jars with wide mouths and everted rims. Stylistically, they fall into the striated plainware category and were included in the Tierra Blanca Plain attribute analysis by Habicht-Mauche (1988:Table 5.1). One of these is the partial plainware vessel found in the masonry ruins at Yellowhouse Canyon (described above). It may 
represent a pot that was cached inside a structure at a residential site.

The Crow Springs vessel (Panhandle-Plains Historical Museum catalog no. 2779/1), found in Dickens County, is illustrated in Habicht-Mauche (1988:Figure 5.4). Its context suggests that it was an isolated cache, rather than having been cached at an occupational site. The vessel, which had been shattered by a bullet and subsequently reconstructed, is complete except for the bullet hole through it (entry and exit) and a small section missing from the rim. The striated plainware vessel is unusual in that it has two loop handles on opposite sides of the neck. Each handle is a single loop of clay riveted to the vessel body.

In addition to these finds, approximately onehalf of a Pecos Glaze V Polychrome bowl was reconstructed from sherds found at the Longhorn site (see Boyd et al. 1993:Figure 178). The sherds were isolated from the main portion of the site and were not associated with any dwellings or activity areas. Their context indicates that these sherds may represent a vessel that was cached along the margins of a residential site, perhaps during a period of site abandonment (Boyd et al. 1993:, 177-178, 229).

\section{DISCUSSION OF THE TIERRA BLANCA AND GARZA COMPLEXES}

Except for some southerly occurrences of Antelope Creek sites, the Garza and Tierra Blanca complexes are the only two cultural manifestations defined for the Caprock Canyonlands during the Late Prehistoric II and Protohistoric periods. The preceding site summaries illustrate how similar these two complexes are, and the remainder of this chapter concentrates on further defining them. The evidence suggests that they are nearly identical in most respects, especially in terms of subsistence and settlement strategies. The only significant differences that are visible in the archeological record are that (1) they occupy different geographic locations, (2) Alibates agate is the dominant lithic material in Tierra Blanca sites, while Edwards cherts dominate Garza assemblages, and (3) Garza and Lott points are only associated with the Garza complex and are not found (with few exceptions) in the Tierra Blanca complex area. Given the many similarities and few differences, one important research question is whether the Tierra Blanca and Garza complexes represent only minor variations of the same cultural group (i.e., related peoples) or different cultural groups who simply adopted similar lifestyles (i.e., unrelated peoples).

The remainder of this chapter takes the stance that the Tierra Blanca and Garza complexes were probably distinct groups of people who occupied different areas at the same time. In the discussions that follow, the paucity of empirical archeological data is noted, the similarities and differences between these complexes are emphasized, and some speculations about their relationships are offered.

The relationships that the Tierra Blanca and Garza peoples had with other peoples in surrounding areas also must be considered. That these groups were important players in the Plains-Pueblo exchange seems certain, but the precise nature of their relationships with various Puebloan peoples is a complex issue that is open to debate. Much of what we know about these intercultural relationships is revealed not through the archeological record, but in historic documents that record initial European encounters with Pueblo Indians and their Plains trading partners. Consequently, the ethnohistoric and archeological records must be integrated to fully decipher the story of Plains-Pueblo interactions.

\section{Chronology}

Table 99 illustrates the paucity of absolute dates associated with sites or components attributed to the Tierra Blanca complex, in contrast to the larger number of dates for the Garza complex. The absolute chronology of the Tierra Blanca complex is defined by only nine radiocarbon dates from three sites, and six additional radiocarbon and thermoluminescence dates are associated with the Tierra Blancalike components at Palo Duro Reservoir. The six dates from the Tierra Blanca site are from good contexts, but the investigations are not adequately reported and associated artifact assemblages have not been described. The investigations at the radiocarbondated Tule Mouth site 41BI83 were minimal (i.e., $24 \mathrm{~m}^{2}$ ), and the associated cultural materials have not been adequately analyzed and reported. In addition, the dates from the Canyon City Club Cave are associated with an ephemeral Tierra Blanca component in the disturbed level 1 deposits. The chronologies of many of the important sites attributed to the complex, such as the Blackburn and Fifth Green sites, are known only in gross terms 
TABLE 99

SUMMARY OF ABSOLUTE DATES FOR TESTED/EXCAVATED TIERRA BLANCA AND GARZA COMPLEX SITES/COMPONENTS

\begin{tabular}{|l|l|l|l|l|}
\hline \multirow{2}{*}{ Site } & \multicolumn{4}{|c|}{ Number of Dates } \\
\cline { 2 - 5 } & Radiocarbon & Thermoluminescence & Archeomagnetic & Obsidian Hydration \\
\hline
\end{tabular}

TIERRA BLANCA COMPLEX

\begin{tabular}{|c|c|c|c|c|}
\hline $\begin{array}{l}\text { Residential Bases/Base Camps } \\
\text { Tierra Blanca } \\
\text { Blackburn }\end{array}$ & $\begin{array}{l}6 \\
-\end{array}$ & - & - & - \\
\hline $\begin{array}{l}\text { Bison Kills/Hunting Camps } \\
\text { Fifth Green } \\
\text { Tule Mouth Sites } \\
\text { Palisades } \\
\text { Cita Mouth } \\
\text { Fatheree } \\
\text { Water Crossing No. } 2\end{array}$ & $\begin{array}{l}\overline{1} \\
- \\
- \\
- \\
-\end{array}$ & $\begin{array}{l}- \\
- \\
- \\
- \\
-\end{array}$ & $\begin{array}{l}- \\
- \\
- \\
- \\
-\end{array}$ & $\begin{array}{l}- \\
- \\
- \\
- \\
-\end{array}$ \\
\hline $\begin{array}{l}\text { Rockshelter } \\
\text { Canyon City Club Cave } \\
\text { (Level 1) }\end{array}$ & 2 & - & - & - \\
\hline $\begin{array}{l}\text { Undefined Tierra Blanca-like } \\
\text { Broken Jaw (Blocks B and C) } \\
\text { Unnamed Shelter 41HF86 }\end{array}$ & $\begin{array}{l}2 \\
1\end{array}$ & ${ }^{3}$ & - & - \\
\hline Total Tierra Blanca Dates: & 12 & 3 & 0 & 0 \\
\hline \multicolumn{5}{|c|}{ GARZA COMPLEX } \\
\hline $\begin{array}{l}\text { Residential Bases/Base Camps } \\
\text { Longhorn } \\
\text { Headstream } \\
\text { Slaton Dump } \\
\text { Pete Creek } \\
\text { Bridwell } \\
\text { Montgomery } \\
\text { Floydada Country Club } \\
\text { Yellow Houses Ruins } \\
\text { Green Springs } \\
\text { Davis Hackberry Spring }\end{array}$ & $\begin{array}{r}17 \\
4 \\
- \\
- \\
- \\
- \\
- \\
- \\
- \\
-\end{array}$ & $\begin{array}{l}2 \\
- \\
- \\
- \\
- \\
- \\
- \\
- \\
- \\
-\end{array}$ & $\begin{array}{l}4 \\
3 \\
- \\
- \\
- \\
- \\
- \\
- \\
- \\
-\end{array}$ & $\begin{array}{r}- \\
- \\
- \\
- \\
9 \\
10 \\
6 \\
- \\
- \\
-\end{array}$ \\
\hline $\begin{array}{l}\text { Bison Kills/Hunting Camps } \\
\text { Garza } \\
\text { Lott } \\
\text { Lubbock Lake } \\
\text { Canyon Lakes } \\
\text { Johnson Creek } \\
\text { Red Mud Creek } \\
\text { Unnamed 41LY42 } \\
\text { Hogue } \\
\text { Mitchell Lake } \\
\text { Elm Creek (Cultural Unit 1) } \\
\text { Unnamed 41CN78 }\end{array}$ & $\begin{array}{r}- \\
3 \\
6 \\
10 \\
- \\
- \\
- \\
- \\
- \\
11 \\
1\end{array}$ & $\begin{array}{l}- \\
- \\
- \\
- \\
- \\
- \\
- \\
- \\
- \\
- \\
-\end{array}$ & $\begin{array}{l}- \\
- \\
- \\
- \\
- \\
- \\
- \\
- \\
- \\
3 \\
-\end{array}$ & $\begin{array}{l}- \\
- \\
- \\
- \\
- \\
- \\
- \\
- \\
- \\
- \\
-\end{array}$ \\
\hline
\end{tabular}




\begin{tabular}{|c|c|c|c|c|}
\hline \multicolumn{5}{|l|}{ Table 99, continued } \\
\hline \multirow[b]{2}{*}{ Site } & \multicolumn{4}{|c|}{ Number of Dates } \\
\hline & Radiocarbon & Thermoluminescence & Archeomagnetic & Obsidian Hydration \\
\hline $\begin{array}{l}\text { Bison Kills/Hunting Camps } \\
\text { continued } \\
\text { Garnsey Springs Kill } \\
\text { Garnsey Springs Campsite } \\
\text { (includes Garza hearth) }\end{array}$ & $\begin{array}{r}18 \\
3\end{array}$ & $\begin{array}{l}- \\
-\end{array}$ & $\begin{array}{l}- \\
-\end{array}$ & $\begin{array}{l}- \\
-\end{array}$ \\
\hline $\begin{array}{l}\text { Rockshelters } \\
\text { Blue Mountain Shelter } \\
\text { Red Bluff Shelter } \\
\text { Boren Shelter No. 1 } \\
\text { Boren Shelter No. } 2 \text { (talus) } \\
\text { Reed Shelter } \\
\text { Garza County Cave }\end{array}$ & $\begin{array}{l}- \\
2 \\
1 \\
1 \\
- \\
-\end{array}$ & $\begin{array}{l}- \\
- \\
- \\
- \\
- \\
-\end{array}$ & $\begin{array}{l}- \\
- \\
- \\
- \\
- \\
-\end{array}$ & $\begin{array}{l}- \\
- \\
- \\
- \\
- \\
-\end{array}$ \\
\hline $\begin{array}{l}\text { Burials } \\
\text { Garza Burial } \\
\text { Garza-U-Ranch Burial }\end{array}$ & $\begin{array}{l}- \\
-\end{array}$ & $\begin{array}{l}- \\
-\end{array}$ & $\begin{array}{l}- \\
-\end{array}$ & $\begin{array}{l}- \\
-\end{array}$ \\
\hline Total Garza Dates: & 77 & 2 & 10 & 25 \\
\hline
\end{tabular}

from relative dating provided by a few temporally diagnostic artifacts such as late-style arrow points and imported pottery. Based strictly on the presence of such artifacts, one would conclude that the Tierra Blanca complex dates primarily to the fifteenth through seventeenth centuries. Puebloan Rio Grande glazewares, most representing the Glaze $\mathrm{C}$ and $\mathrm{D}$ periods, indicate that the residential occupations at the Tierra Blanca and Blackburn sites date to approximately A.D. $1450-1515$, according to Snow (1982:Tables 5 and 6).

Despite the problems, the dates for the Tierra Blanca sites and components indicate that the complex may have appeared early in the fourteenth century but that the majority of the occupations occurred during the fifteenth, sixteenth, and early seventeenth centuries (Figure 100). Thermoluminescence and radiocarbon dates indicate that the two undefined Tierra Blanca-like sites in the northern Panhandle were occupied contemporaneously with the Tierra Blanca complex sites in the Red River drainage.

The chronology of the Garza complex is relatively well established through 114 age assays from 14 different sites/components using the radiocarbon, thermoluminescence, archeomagnetic, and obsidian hydration techniques (see Table 99). Although the majority (i.e., 56 percent) of the tested/excavated sites have not been dated, the temporally diagnostic artifacts recovered from these sites suggest approximate contemporaneity with the dated occupations. The dates shown in Figure 101 indicate that the Garza complex may have appeared in the archeological record as early as the twelfth or thirteenth centuries. However, all of the pre-A.D. 1300 dates are from contexts that could predate the Garza complex (i.e., five radiocarbon dates from the Canyon Lakes sites and one from the Longhorn site) or are poorly defined and cannot be confidently associated with the complex (i.e., one obsidian hydration date from the Montgomery site). Since the accuracy of radiocarbon dating tends to decrease significantly for organics less than 300 years old, the ending dates for the complex also are tenuous, although it appears that the Garza complex faded from the record by about A.D. 1700. The vast majority of the dates indicate that Garza peoples appeared in the Southern Plains around or just before A.D. 1400 and that they continued to occupy the region throughout the fifteenth, sixteenth, and seventeenth centuries.

One of the key attributes diagnostic of Garza complex residential bases and base camps is that they yield, along with a wide variety of all types of 


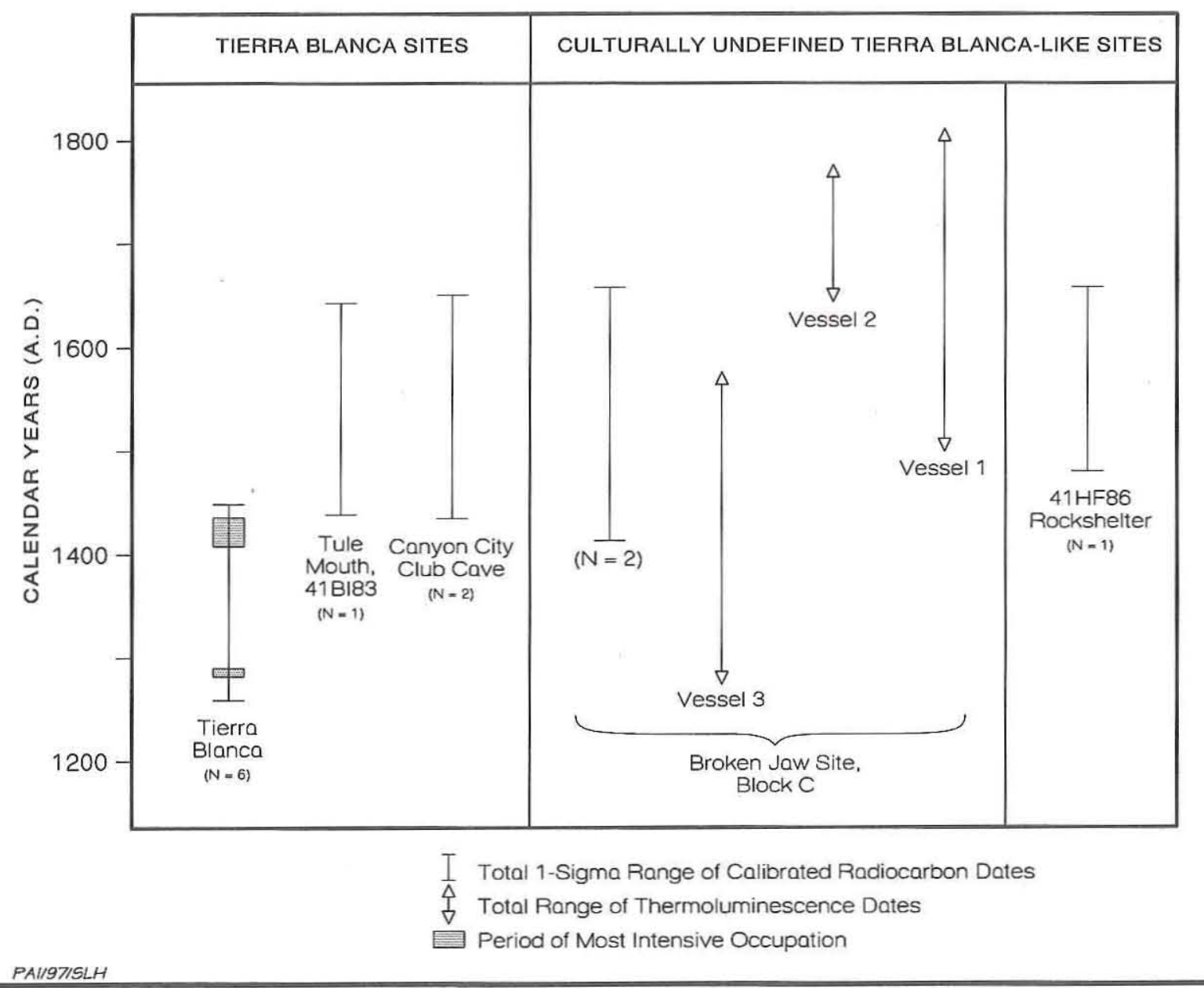

Figure 100. Graph of calibrated radiocarbon and thermoluminescence dates for Tierra Blanca complex sites/components.

artifacts, decorated imported Puebloan and/or Caddoan ceramics. The most temporally sensitive of these ceramics are the Rio Grande glazewares that were manufactured at various Pueblo villages between A.D. 1275 and 1700 (Table 100). These imported wares represent different time periods at different sites. The majority of glazeware sherds recovered from the Bridwell site are from the Glaze A-E periods and may represent a long period of continued occupations. The Floydada Country Club has produced mainly intermediate Glaze B or C sherds and lacks the late glazewares. In contrast, the Longhorn, Headstream, Pete Creek, and Montgomery sites have produced primarily late glazewares of the Glaze E and F periods. Excluding some of the other less temporally sensitive types of imported ceramics, the glazeware evidence could represent different periods of intensive occupation at different residential sites (i.e., sites were occupied at different times). Alternatively, the glazeware evidence could reflect changes in access to Rio Grande glazewares that varied through time and or space. As discussed later in more detail, the glazeware pottery found at Garza sites represents not only different time periods but also different Puebloan manufacturing source areas that apparently changed through time.

Only 5 of the 10 investigated Garza complex residential sites have been dated, and 3 of these are dated only by obsidian hydration on surface-collected artifacts (see Baugh 1986:Table 7). The resulting dates, shown in Figure 102, suggest that the obsidian hydration technique has considerable potential for addressing chronological problems relating to Garza 


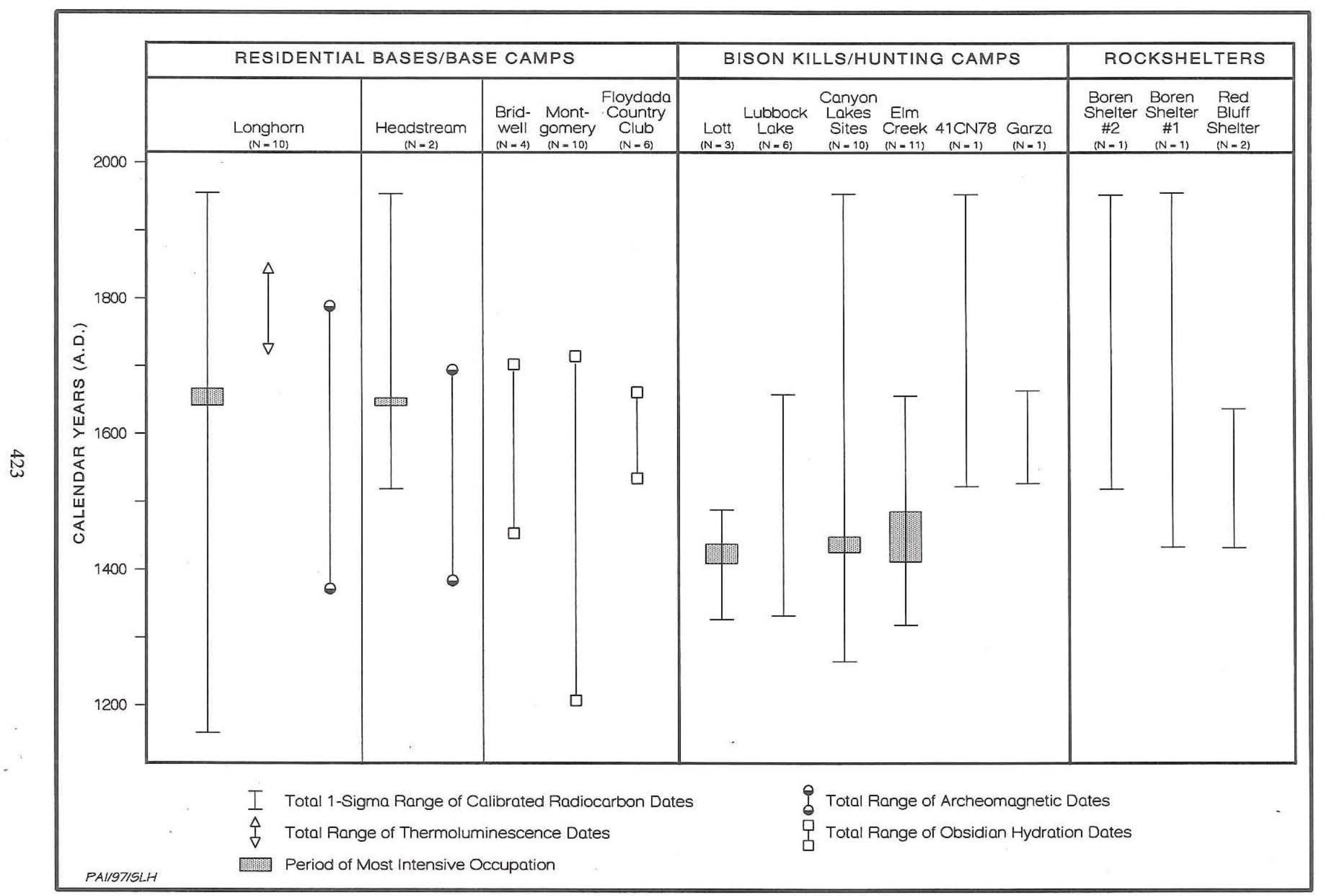

Figure 101. Graph of calibrated radiocarbon, thermoluminescence, and archeomagnetic dates for Garza complex sites/components. 


\begin{tabular}{|c|c|c|}
\hline \multicolumn{3}{|c|}{$\begin{array}{l}\text { CHRONOLOGY OF PUEBLOAN PRODUCTION OF } \\
\text { RIO GRANDE GLAZEWARE POTTERY }\end{array}$} \\
\hline \multirow[b]{2}{*}{ Glaze Group } & Northern District & Southern District \\
\hline & $\begin{array}{l}\text { Albuquerque to Taos, } \\
\text { including Pecos Pueblo } \\
\text { and Galisteo Basin }\end{array}$ & $\begin{array}{l}\text { Albuquerque to Socorro, } \\
\text { including Salinas and } \\
\text { Jornada Pueblos }\end{array}$ \\
\hline A & $1300-1450$ & $1275-1490$ \\
\hline B & $1400-1450$ & - \\
\hline $\mathrm{C}$ & $1450-1490$ & $1450-1490$ \\
\hline $\mathrm{C}$ & $1475-1515$ & $1490-1515$ \\
\hline $\mathrm{E}$ & $1515-1625$ & $1515-1625$ \\
\hline $\mathrm{F}$ & $1625-1700$ & $1625-1680$ \\
\hline \multicolumn{3}{|c|}{$\begin{array}{l}\text { Note: Adapted from Snow (1982:Tables } 5 \text { and 6). Glaze groups A-F } \\
\text { correspond with Pecos Glazes I-VI. }\end{array}$} \\
\hline
\end{tabular}

65 and Boyd et al. 1993:Figures 27 and 91). The two thermoluminescence dates on ceramics from the Longhorn site may be a century too late, and they do not correspond with the majority of the radiocarbon dates. In fact, the sherd that is thermoluminescence dated to A.D. 1765-1845 was identified as being from a Pecos Glaze $\mathrm{V}$ vessel that was probably manufactured no later than about A.D. 1700 (see Table 100). The glazeware bowl apparently served as a storage/serving vessel and was not used for cooking. If the vessel was never reheated after its initial firing, it would appear that the thermoluminescence date is in er-

(and Tierra Blanca) occupations. The obsidian hydration dates generally appear to correspond in age with temporally diagnostic artifacts recovered from excavations at each site, but they cannot be directly linked to discrete Garza components or occupations. At the Bridwell site, for example, it is likely that the Garza and Lott points $(n=2)$ are from the same time period as the Rio Grande glazewares (typologically dated to ca. A.D. 13501600 ) and the nine dated obsidian specimens (dating to A.D. 1454-1689). The association between these artifacts and dates is tenuous, however; nonetheless, the majority of the cultural materials are likely to date to the fifteenth to seventeenth centuries. The same is generally true for the Montgomery and Floydada Country Club sites, both of which contain evidence of intensive occupations but lack discrete components and artifact assemblages to go along with the surface obsidian hydration dates. The principal factor limiting an evaluation of the obsidian hydration dates for the Bridwell, Montgomery, and Floydada Country Club sites is the absence of radiocarbon dates. Paired radiocarbon and obsidian hydration dates from associated excavated contexts would be most helpful for evaluating obsidian hydration dating results.

Excluding the obsidian hydration dates, only two residential base sites have occupational zones that have been adequately dated. Archeomagnetic and radiocarbon dates indicate that the most intensive occupations at the Headstream and Longhorn sites were during the seventeenth century (see Figure ror. Alternatively, since the sherds were found around a burned tree stump, the vessel may have been reheated in a postoccupational fire during the late 1800 s that left several burned tree stumps at the site (Boyd et al. 1993:128, 229).

Also found at residential base sites are items of European manufacture or introduction. Although some sites have yielded European artifacts that are probably associated with nineteenth-century Plains Indian (e.g., Comanche) occupations (e.g., the 1859 Canadian coin from the Bridwell site and the 1819 German ocharina from the Floydada Country Club site), many other sites have produced European artifacts that are likely to be associated with lateseventeenth-to-early-eighteenth-century occupations by Garza peoples. Examples of such artifacts include Native-made gunflints and a lead ball, majolica sherds, and horse and cow bones from the Longhorn site; glass beads from the Headstream and Pete Creek sites; glass beads, iron arrow points, metal tinklers, and a hand-forged ox-bow pin from the Floydada Country Club site; and chain mail fragments, glass beads, and a metal arrow point from the Davis Hackberry Spring site. Such artifacts, generally found in very low frequencies, probably reflect the acquisition of European items and technologies through limited contact, whether direct or indirect. As mentioned previously, it appears that the initial European influence was indirect, in the form of intersocietal trade alliances that developed in the seventeenth century between the Southern Plains nomads and the Puebloan 


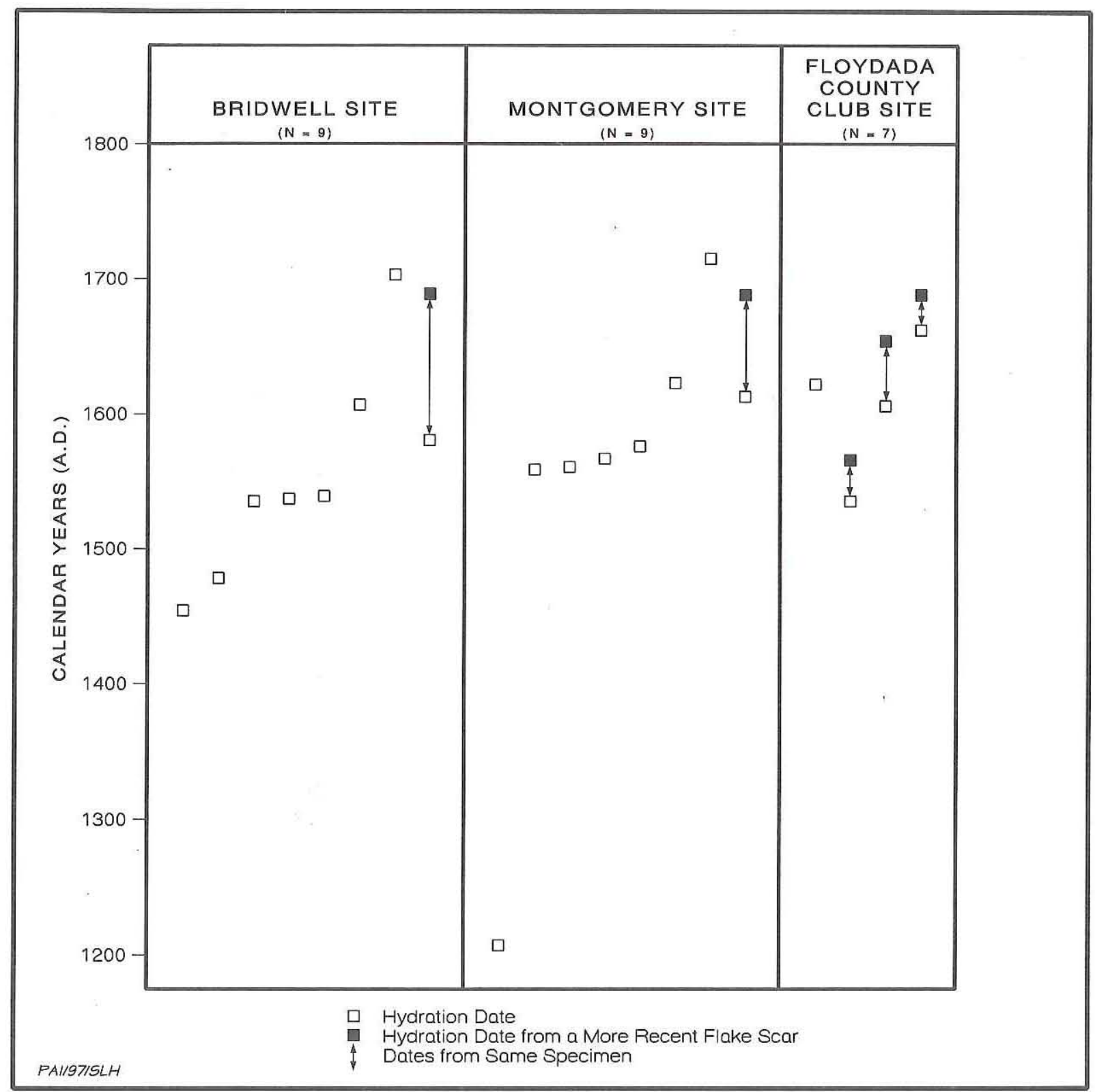

Figure 102. Graph of obsidian hydration dates from Garza complex sites. The data are from Baugh (1986:Table 7) and consist of 25 dates on 20 surface-collected specimens by the Oklahoma University Hydration Laboratory (OUHL sample nos. 1048-1067). A.D. dates are based on the hydration curve by Russell (1981).

farmers at Spanish missions in New Mexico.

Except for the occupations suggested by the questionable early dates (i.e., pre-A.D. 1300) from the Canyon Lakes sites, the Garza complex cultural activities at bison kills, hunting camps, and rockshelters date to the fourteenth through mid seventeenth centuries. None of the artifactual evidence contradicts this assessment, and these sites were occupied/utilized during the same time frame as the residential bases and base camps. Unlike many of the base camps, Garza and/or Lott points have been found in better archeological contexts (i.e., associated with more clearly definable artifactual assemblages and features) in bison kill/hunting camps.

The combined evidence reflects intensive Garza occupations during the fifteenth through mid seventeenth centuries. The beginning and ending dates for the complex are less certain, and, as discussed 
later, the interpretive potential of the chronometric data are limited by the paucity of discrete associated artifact assemblages.

\section{Geographic Range}

Most of the known Tierra Blanca sites are clustered in a small area along the main branch of the Prairie Dog Town Fork of the Red River. These sites are situated in canyons that cut into the Llano Estacado, primarily along Palo Duro and Tierra Blanca Creeks. With one exception, the Tierra Blanca sites discussed below are in Briscoe, Armstrong, Randall, and Deaf Smith Counties (see Figure 98). Sites have been attributed to the Tierra Blanca complex based in part on the nature of the cultural remains they contain, but location also is an important factor. Many sites found elsewhere in the Panhandle-Plains are similar but are not attributed to the complex because they are not located in the Red River drainage.

The primary exception to the limited distribution is the Fatheree site in Gray County, which includes a probable Tierra Blanca complex component. Situated along Red Deer Creek, a southern tributary of the Canadian River, the site is actually much closer to the North Fork of the Red River than it is to the Canadian. It is unclear whether the Tierra Blanca component is an isolated outlier, or whether the Tierra Blanca complex extends northward into the Canadian River valley or beyond. Some surveys have reported sites with similar occupations, but they cannot be attributed to the Tierra Blanca complex with confidence. One example in the Canadian River valley is 41OL24, found during an archeological reconnaissance of Alamosa Creek, a southern tributary of the Canadian River in eastern Oldham County (Marmaduke and Whitsett 1975:91-92). This site produced triangular Fresno-like arrow points, described as being "similar in design" to the northeast Texas Maud type, and striated utility ware. Based on the meager evidence, the site is considered to be similar to Apache sites in New Mexico. While late occupations (i.e., Protohistoric or Historic Indian) are often superimposed on Antelope Creek phase sites in the Canadian valley (Marmaduke and Whitsett 1975:97; Studer 1931:73), none of these late components has been investigated.

The highest density of documented Garza sites/components is in the upper headwaters of the
Brazos River in Crosby, Dickens, Floyd, Garza, Kent, and Lubbock Counties. This is skewed somewhat by the fact that there have been more archeological investigations in these counties than in any other portion of the Caprock Canyonlands or adjacent Llano Estacado, but numerous base camps/ residential bases in this portion of the Caprock Canyonlands (i.e., the Longhorn, Headstream, Montgomery, Floydada Country Club, Slaton Dump, and Pete Creek sites) suggest that this was the heartland of the Garza culture. This assessment is in general agreement with Runkles (1964:123-125), who noted that Garza points are most common in surface collections from in and around Garza County and are rare or absent in collections from other areas. The presence of numerous residential sites and base camps in this area is undoubtedly due to the high density of springs and other resources found in the canyonlands.

If one looks only at the distribution of investigated Garza components, the complex extends south and westward, beyond the core area in the canyonlands, at least as far as the Pecos River. While no residential sites or base camps have been found outside the core area, these far-flung components indicate that Garza peoples ranged over a broad area. If one looks at the total distribution of Garza points, including surface finds, as representative of the maximum geographic range of the Garza complex, then it appears that Garza peoples covered an even larger territory. While Lott points seem to be confined to the upper Brazos and Colorado drainage basins, Runkles (1964:Figure 12) shows the distribution of Garza points extending in a band westward as far as El Paso following the boundary between southeastern New Mexico and western Texas. Garza points have been reported across the Llano Estacado as far west as Lamb County (Randall 1970:46, Figure 9). A Garza point also is reported in eastcentral New Mexico from a site at Santa Rosa Lake in Guadalupe County (Levine and Winter 1987: Figure 4.13, 293). In addition, Hedrick (1989: Table 6) reports that 1 Garza point was found in the Van Horn area of Culberson County, and at least 13 others have been documented in the vicinity (Jack Hedrick, personal communication 1990): Heartfield (1975) reports a Garza point from southwestern Coahuila, and Mallouf (1992) notes that Garza points are found with some regularity in the $\mathrm{La}$ Junta area of the Big Bend region of Texas and in northern Chihuahua, Mexico. 
Besides Garza points, Mallouf (1992) also notes that a similar style of basal-notched arrow point called Soto is found throughout the La Junta region and northern Chihuahua. Because the Soto and Garza points are so similar, there is some confusion and uncertainty as to what or who these styles represent. Phelps (1964) first defined the Soto type based on earlier work by Krone (1978) at the Soto Ranch site southeast of El Paso in Chihuahua, applying the name Soto to the basal-notched points that Krone (1978:41) had originally identified as Garza points. Two subsequent reports by Phelps (1968, 1987) further define the Soto point and illustrate numerous examples. Many of the illustrated specimens are indistinguishable from Garza points, however, and Phelps (1968:20-21, 1987: 18-20) notes the strong similarities between the two styles. It does appear that classic Soto points are distinctive from classic Garza points, but there is considerable morphological/stylistic overlap between the nonclassic variations. Geographic location has been one of the important factors in differentiating between Soto and Garza points. Soto points are a northern Mexican type that extends north into western Texas, while Garza is a Panhandle-Plains type that extends southwest into western Texas. The Trans-Pecos region of Texas is the area where the two styles overlap considerably. Further compounding the confusion are the unnamed Garza-like points in the Bravo Valley aspect (Kelley 1986:88-89, Plate III) and the relatively unknown Cienegas type defined for northern Chihuahua and Coahuila (Taylor 1966:84). Because the chronology and cultural implications of these styles are not well understood, it is difficult to pinpoint the western and southwestern boundaries of the Garza complex.

The eastern limit of Garza complex influence appears to be in westernmost Oklahoma. Garza points are quite rare out in the Texas Rolling Plains, but they are found consistently in low frequencies in Edwards and Wheeler complex sites (Hofman 1984b: 352 , 357). Garza points appear to decrease in frequency in direct relation to the distance east of the Caprock Escarpment core area. The presence of a few Garza points in western Oklahoma does not necessarily mean that this area was commonly utilized by Garza peoples. Rather, it may only indicate that they occasionally journeyed to the area, perhaps to trade with the Edwards or Wheeler complex peoples.

The northern extent of the Garza complex is more clearly defined, assuming that the northern limit of the common occurrence of Garza points represents a cultural boundary. While Garza points are common in many parts of the Brazos River drainage, they are quite rare in or north of the Red River drainage. The only exception to the welldefined northern extent of Garza points is that Peterson (1988:304, Figure 25) reports and illustrates a Garza point base that was surface collected from 41HF107 at Palo Duro Reservoir in Hansford County. This appears to be an isolated occurrence some $100 \mathrm{~km}$ north of the North Fork of the Red River.

Based on the distribution of Garza points, it appears that Garza peoples roamed freely in the southern Panhandle-Plains, to the west and southwest throughout Trans-Pecos Texas, and in parts of northern Chihuahua and southeastern New Mexico. The Garza complex has a rather abrupt northern boundary somewhere along the drainage divide between the Brazos and Red River areas. This area also is perceived as the southern boundary of the Tierra Blanca complex.

\section{Arrow Points as Cultural and Chronological Indicators}

The arrow points found at Tierra Blanca and Garza complex sites are of particular significance for defining these cultural manifestations. They also are important for dating components within the Garza complex. While small unnotched, side-notched, and side/base-notched triangular arrow points, generally typeable as Fresno, Washita, and Harrell, are commonly found at Tierra Blanca and Garza complex sites, they are not culturally distinctive and these types are not discussed individually. Three reported types are discussed in terms of their cultural and/or temporal significance: Talco points for the Tierra Blanca complex and Garza and Lott points for the Garza complex.

The most common arrow points at Tierra Blanca complex sites are generally typed or described as Washita, Harrell, and Fresno, but some long slender points with straight to slightly concave blades have been called Talco or Talco-like (e.g., Hughes et al. 1978:147; J. Hughes 1991:35). The unnotched Talco-like points are considered to be a distinctive hallmark of the complex (J. Hughes 1991:35), but there are no published descriptions and few specimens are illustrated. A Talco point from 
the Fatheree site (Area 2) is illustrated by Hughes et al. (1978:Figure 17b), but none of the Talco specimens from the Fifth Green site are illustrated in the site report (Kalokowski 1986). Many Tierra Blanca site arrow points are very similar to Talco points, but this type name was originally proposed for Caddoan arrow points of the Titus phase of northeastern Texas (Suhm and Jelks 1962:289). Although it was never intended to imply any cultural connection, the use of the Talco type for unnotched triangular points in the Panhandle-Plains is misleading. In addition, the use of the name Talcolike for points in the Tierra Blanca complex, but not for similar points in the Garza complex, is inconsistent. For example, some "Fresno" points found at the Pete Creek (Parsons 1967:Figure 7Q), Montgomery (Northern 1979:Figure 1D), Bridwell (Parker 1982:19), and Slaton Dump (Booker and Campbell 1978:Figure 3G) sites would have been called Talco-like if they had been found in a Tierra Blanca site. These unnotched triangular points may, or may not, be distinctive enough to warrant their own type name specific to the Texas PanhandlePlains, and a thorough morphological/technological study of these late arrow points is sorely needed. Continued use of Talco for unnotched arrow points in the Panhandle-Plains will only cause more confusion.

One of the key problems in defining the material culture for the Tierra Blanca complex is that two of the principal sites, Tierra Blanca and Blackburn, have multiple occupations over long periods of time, perhaps even representing occupations by different groups of people. Given the limited data, it is not certain that the Talco-like points attributed to the complex are contemporaneous with the Puebloan trade pottery of the thirteenth to fifteenth centuries (i.e., the early glaze periods). These points may actually be associated with later sixteenth- and seventeenth-century occupations. There are no cases where these points have been found in close association with temporally diagnostic artifacts or with independently dated materials. The bison processing event at the Fifth Green site has perhaps the best potential among all of the known Tierra Blanca sites for producing reliable chronological data on the use of these arrow points, but no radiocarbon dates are available.

The Garza point and its closely related cousin, the Lott point, are considered to be the diagnostic hallmarks of the Garza complex. The Garza point is a distinctive variety of triangular point with a single basal notch (Davis 1991:220-221; Perino 1968:22-23; Turner and Hester 1993:215). Without the notches, these points would be typed as Fresno, or perhaps Talco-like, and they would probably be typeable as Toyah points if side notches were added. Turner and Hester (1993:215) suggest that Garza points in the El Paso area may be variants of Toyah points. As noted above, similar points in west Texas and northwestern Mexico have been typed as Cienegas (Taylor 1966) and Soto (Phelps 1987).

The chronological evidence now at hand indicates that Lott points may predate Garza points by some 100 years or more. Using only the occurrences of Lott and Garza points in reasonably well dated contexts, as shown in Table 101, calibrated radiocarbon dates suggest that the Lott points are from the fifteenth century or earlier. The calibrated dates suggest that Garza points could date as early as the mid fifteenth century, while most occurrences date from the mid sixteenth to mid seventeeth centuries. This limited sample does not rule out the possibility that these points were made at other times, but it does support the Runkles and Dorchester (1987:108) hypothesis that the Lott point predates and was the prototype for the Garza point. If this is correct, one would expect that there was a transition period, perhaps around the mid fifteenth century, when both styles were in use. It also is likely that there may be a transitional form that bridges the morphological gap between Lott and Garza. One of the Lott points illustrated by Davis (1991:233, third row, center) may be such a transitional form.

One problem relating to the recognition of pure Garza complex components is that few sites yield a high frequency of Garza and/or Lott points. The Garza and Lott sites, both bison processing campsites, are the rare exception where Garza and Lott points are predominant. Garza points account for 18 percent of the 74 arrow points recovered from the Garza site, while the 221 arrow points reported for the Lott site include 25 percent Lott and 22 percent Garza. Many ephemeral hunting/processing camps and rockshelters produce very few Garza or Lott points, and these are sometimes found along with other types (e.g., Washita/Harrell and Fresno). The paucity of points at some of these sites may relate to site function, but Garza and/or Lott points often make up only a very small percentage of the total arrow points recovered at residential bases and base 


\begin{tabular}{|c|c|c|}
\hline \multicolumn{3}{|c|}{ TABLE 101} \\
\hline Site & Provenience/Context & $\begin{array}{l}\text { Corrected and Calibrated } \\
\text { Radiocarbon Dates, A.D.* }\end{array}$ \\
\hline \multicolumn{3}{|c|}{ LOTT POINTS } \\
\hline Lott & $\begin{array}{l}\text { Single point directly associated with dated } \\
\text { hearth, Feature } 4\end{array}$ & $1424 \pm 72 ; 1330(1416) 1441$ \\
\hline Elm Creek & $\begin{array}{l}\text { Multiple points associated with Cultural Unit } 1 \text {, } \\
\text { a discrete Lott component representing a short- } \\
\text { term occupation }\end{array}$ & $\begin{array}{l}1502 \pm 65 ; 1422(1441) 1489 \\
1430 \pm 50 ; 1333(1419) 1440 \\
1444 \pm 70 ; 1334(1427) 1444 \\
1640 \pm 100 ; 1450(1638) 1952 \\
1650 \pm 50 ; 1519(1642) 1656 \\
1455 \pm 140 ; 1318(1431) 1620 \\
1410 \pm 70 ; 1328(1412) 1438 \\
1450 \pm 70 ; 1406(1429) 1445 \\
1540 \pm 80 ; 1431(1451) 1631 \\
1552 \pm 72 ; 1437(1455,1480) 1633 \\
1560 \pm 120 ; 1424(1486) 1650\end{array}$ \\
\hline Canyon Lakes & $\begin{array}{l}\text { Single point associated with dated Feature } 3 \\
\text { cultural zone in Area } 2\end{array}$ & $\begin{array}{l}1304 \pm 81 ; 1284(1303,1372,1383) 1408 \\
1514 \pm 108 ; 1411(1444) 1632 \\
1534 \pm 72 ; 1432(1449) 1625 \\
1441 \pm 64 ; 1333(1426) 1444\end{array}$ \\
\hline \multicolumn{3}{|c|}{ GARZA POINTS } \\
\hline Lubbock Lake & $\begin{array}{l}\text { Single point } 10 \mathrm{~cm} \text { above dated hearth, FA14-1 } \\
\text { Single point in fill of dated pit feature FA15-1 }\end{array}$ & $\begin{array}{l}1619 \pm 64 ; 1479(1527,1559,1630) 1651 \\
1649 \pm 72 ; 1490(1641) 1664\end{array}$ \\
\hline Rush & $\begin{array}{l}\text { Single point from Occupation } 4 \text {, a discrete } \\
\text { Toyah phase component }\end{array}$ & $1620 \pm 60 ; 1484(1528,1558,1631) 1650$ \\
\hline $\begin{array}{l}\text { Garnsey Spring } \\
\text { Campsite }\end{array}$ & $\begin{array}{l}\text { Single point found on surface near dated "Garza } \\
\text { hearth" }\end{array}$ & $1670 \pm 50 ; 1527(1648) 1664$ \\
\hline $41 \mathrm{CN} 78$ & $\begin{array}{l}\text { Single point found on surface but apparently } \\
\text { associated with dated cultural zone }\end{array}$ & $1680 \pm 70 ; 1523(1650) 1953$ \\
\hline Red Bluff Shelter & $\begin{array}{l}\text { Two points from Zone D tentatively associated } \\
\text { with two dated features }\end{array}$ & $\begin{array}{l}1534 \pm 72 ; 1432(1449) 1625 \\
1564 \pm 72 ; 1439(1487) 1637\end{array}$ \\
\hline
\end{tabular}

camps. This is particularly problematic since many of these sites were probably reoccupied numerous times over many centuries. The question, then, is whether all or only a small portion of the occupational debris at these sites was deposited by Garza peoples. Two hypotheses may be offered to explain residential sites with multiple point types: (1) such sites were occupied primarily or exclusively by Garza peoples who used other styles of arrow points in addition to Garza and Lott; and (2) such sites were primarily or exclusively occupied by non-Garza peoples who occasionally used Garza/Lott points. If Garza peoples made and used only Lott and Garza points and other cultures did not, a third hypothesis 
may be preferred: (3) residential sites and base camps may have been occupied primarily by other groups of people, and Garza peoples were only there periodically. It is not known, and will be very difficult to determine archeologically, whether such sites were occupied simultaneously by Garza and other peoples (e.g., sharing of residential localities to facilitate trade or cooperative hunting efforts), or whether different groups occupied the sites at different times (depending upon which group controlled the territory at that time).

\section{Subsistence and Site Function}

Previous researchers have noted that four primary site types are attributed to the Tierra Blanca and Garza complexes: residential bases and/or base camps, short-duration hunting camps, kill sites, and rockshelters. The primary distinctions between the open sites have been that (1) decorated pottery is commonly found on residential bases and base camps, while no pottery or only plainware is found at hunting camps (J. Hughes 1991:35; Spielmann 1983:264), and (2) bison remains and hunting/ processing implements are the exclusive or dominant tool types found at kill sites and hunting camps. While these distinctions are overly simplified in that there are likely to have been a wide range of functionally distinctive site types representing a much broader range of human activities, they are appropriate at a regional level of comparison.

For comparative purposes, this study lumps residential bases with base camps, and bison kills are lumped with hunting camps. Although habitation structures have been identified at some residential bases and base camps and not others, these types of sites are very similar in terms of other features and material culture. The reason for this lumping is that structural remains probably have gone unrecognized due to limited sampling and the methods and quality of archeological investigations. The same is true for bison kills and hunting camps, which represent similar activities except that hunting camps have a slightly greater range of activities represented by different types of features. The problem is compounded because camping activities may be represented at kills, while early-stage butchering at some campsites may mimic the butchering patterns found at kills. It is not surprising, then, that it is often difficult to distinguish between these two types of sites archeologically, especially when most of the excavated samples are very small.

\section{Material Culture}

The material culture of the Tierra Blanca complex is poorly known because so little data have been published, even though several sites/components have been scientifically investigated (Table 102). A reasonably discrete artifact assemblage that is attributable to the Tierra Blanca complex has been described for only one locality, the Fifth Green site. The data are only available in an unpublished manuscript that is incomplete and largely inaccessible, however. This single assemblage is not particularly useful for comparative purposes, but a few meaningful inferences of a general nature may be made.

The assemblage from the Fifth Green site (see Table 87) is sparse but generally similar to the assemblages found at Garza complex kill sites/ hunting camps discussed later. The abundance of Alibates agate, accounting for over 90 percent of the lithic debitage, suggests that these peoples ranged northward into the Canadian River valley. The Tecovas jasper may have been obtained from Canadian River sources or perhaps from the Rolling Plains to the east. In contrast, Edwards chert derived from the south is not well represented. Although comparable data are not available for any other sites, it has been generally observed that Alibates agate is the dominant lithic material at most Tierra Blanca sites. This observation supports the interpretation that a southern cultural boundary may have existed in the vicinity of the Red River. Though poorly documented, the material culture from other Tierra Blanca complex bison kills/hunting camps appears generally similar to the material culture from Garza complex kills and hunting camps, and the materials mentioned for Tierra Blanca residential bases/base camps generally correspond in type and diversity to those from residential bases and base camps of the Garza complex.

Material culture assemblages from Garza complex components, reviewed in Table 103, provide considerably better data than are available for the Tierra Blanca complex. Many of the sites have produced artifact assemblages that are sufficiently large for intersite comparisons and are from reasonably good archeological contexts. Some inconsistencies in artifact typology are apparent and undoubtedly introduce some bias. The artifact classes that 


\begin{tabular}{|c|c|c|}
\hline \multicolumn{3}{|c|}{$\begin{array}{l}\text { TABLE } 102 \\
\text { REVIEW OF MATERIAL CULTURE ASSEMBLAGES ASSOCIATED } \\
\text { WITH TIERRA BLANCA COMPLEX SITES/COMPONENTS }\end{array}$} \\
\hline Site Name & $\begin{array}{l}\text { Definable } \\
\text { Assemblage* }\end{array}$ & Comment \\
\hline Tierra Blanca & no & Excavation data unanalyzed and unpublished. \\
\hline Blackburn & no & Excavation data unanalyzed and unpublished. \\
\hline Fifth Green & yes & Artifacts described in unpublished manuscript. \\
\hline Tule Mouth & no & Minimal testing produced inadequate artifact sample. \\
\hline Palisades & no & Excavation data unanalyzed and unpublished. \\
\hline Cita Mouth & no & Surface collections only; artifacts not analyzed or published. \\
\hline Fatheree & no & Minimal testing produced inadequate artifact sample. \\
\hline Water Crossing & no & Surface collections only; artifacts not analyzed or published. \\
\hline Canyon City Club Cave & no & $\begin{array}{l}\text { Tierra Blanca cultural zone is severely mixed and artifact sample is } \\
\text { inadequate. }\end{array}$ \\
\hline \multicolumn{3}{|c|}{$\begin{array}{l}\text { *Indicates whether a discrete Tierra Blanca complex artifact assemblage has been identified and adequately } \\
\text { described. "No" does not indicate that no such assemblage has been recovered, only that no useful published } \\
\text { data are available. }\end{array}$} \\
\hline
\end{tabular}

seem to be used most inconsistently from site to site are cobble tools/choppers, cores, and edge-modified flakes. In addition, it is likely that not all researchers were equally rigorous in the use of some classes of tools or equally adept in the recognition of fragmentary specimens of some artifacts. This seems to be particularly true for tools such as beveled knives, distinctive varieties of scrapers, and various types of ground stones.

Generally comparable artifact data are available for 14 sites: 6 residential bases/base camps; 6 bison kills/hunting camps; and 2 rockshelters (Table 104). With one exception, these samples represent assemblages from excavated contexts. The sample from the Lott site was derived from repeated systematic surface collection over a period of many years. Although the collection methods and recording are questionable, continuous erosion and exposure of the shallowly buried cultural zone apparently provided a representative sample of materials. Despite the fact that edge-modified and unmodified flakes were not quantified, the assemblage is thought to be roughly analogous to the excavated assemblages from the other sites, and the excavations confirmed that the
Lott site deposits represent a single component.

A comparative summary of Garza complex artifact assemblages is presented in Table 105. The activity diversity index, a measure of the variability in activities that occurred on-site, is figured by summing the number of artifact classes represented at each site (see Table 104). To ensure that the values for the Garza sites are compatible with those for the Late Prehistoric I occupations (cf. Table 73), the following criteria were employed: (1) the dart point class is excluded; (2) the end scraper, side scraper, and other uniface classes are combined as a single category; (3) the bone awl, bone bead, and other modified bone classes are combined as a single category; and (4) the miscellaneous artifact class is excluded. The resulting activity diversity indexes for Garza complex sites range from 6 to 21, out of a possible score of 24 . Not surprisingly, the residential bases/base camps have the highest values, ranging from 16 to 21 . In contrast, the indexes for bison kills/hunting camps and rockshelters range only from 6 to 13 .

The total artifact density in Table 105 is calculated as the number of artifacts per $\mathrm{m}^{2}$ of 
TABLE 103

REVIEW OF MATERIAL CULTURE ASSEMBLAGES ASSOCIATED WITH GARZA COMPLEX SITES/COMPONENTS

\begin{tabular}{|c|c|c|}
\hline Site Name & $\begin{array}{l}\text { Definable } \\
\text { Assemblage }^{1}\end{array}$ & Comment $^{2}$ \\
\hline \multicolumn{3}{|c|}{ RESIDENTIAL BASES/BASE CAMPS } \\
\hline Longhorn & yes & Good representative assemblage; see Chapter 6 . \\
\hline Headstream & yes & Good representative assemblage; see Chapter 6 . \\
\hline Slaton Dump & no & $\begin{array}{l}\text { The entire assemblage is not quantified and described; only selected } \\
\text { artifact classes are discussed in site investigation report. }\end{array}$ \\
\hline Pete Creek & yes & All artifacts except lithic debitage were analyzed and described. \\
\hline Bridwell & yes $^{3}$ & $\begin{array}{l}\text { Some inconsistencies in the artifact typology and quantifications were } \\
\text { noted. }\end{array}$ \\
\hline Montgomery & yes & $\begin{array}{l}\text { Excavated sample includes materials from } 1965 \text { and } 1978 \text { seasons. } \\
\text { Some inconsistencies in the artifact typology and quantifications were } \\
\text { noted. Not all debitage was analyzed. }\end{array}$ \\
\hline Floydada Country Club & yes & $\begin{array}{l}\text { Excavated sample includes materials from } 1975 \text { TAS field school only. } \\
\text { Some inconsistencies in the artifact typology and quantifications were } \\
\text { noted. Not all debitage was analyzed. }\end{array}$ \\
\hline Yellow Houses Ruins & no & $\begin{array}{l}\text { Unsystematic surface collection only. Association with Garza complex } \\
\text { is questionable. }\end{array}$ \\
\hline Greene Spring & no & Unsystematic surface collection only. \\
\hline Davis Hackberry Spring & no & Unsystematic surface collection only. \\
\hline \multicolumn{3}{|c|}{ BISON KILLS/HUNTING CAMPS } \\
\hline Garza & yes & Some inconsistencies in the artifact typology were noted. \\
\hline Lott & $\operatorname{yes}^{3}$ & $\begin{array}{l}\text { Assemblage is primarily a systematic surface collection but includes } \\
\text { materials from limited excavation. Some inconsistencies in the artifact } \\
\text { typology were noted. }\end{array}$ \\
\hline Lubbock Lake & yes & $\begin{array}{l}\text { Excavated samples are from Areas } 5,8,14 \text {, and } 15 . \text { Some } \\
\text { inconsistencies in the artifact quantifications were noted. }\end{array}$ \\
\hline Canyon Lakes & $\mathrm{yes}^{3}$ & $\begin{array}{l}\text { Some inconsistencies in the artifact typology and quantifications were } \\
\text { noted. Excavated sample is from Areas 1, 2, and } 4 \text {. }\end{array}$ \\
\hline Johnson Creek & yes & Artifact analysis was minimal, and lithic debitage was not quantified. \\
\hline Red Mud Creek & no & No subsurface investigations. \\
\hline 41LY42 & no & $\begin{array}{l}\text { Unsystematic surface collection and minimal excavations; only selected } \\
\text { artifact classes were quantified. }\end{array}$ \\
\hline Hogue & no & Unsystematic surface collection. \\
\hline Mitchell Lake & no & Minimal excavations produced an inadequate sample. \\
\hline
\end{tabular}




\begin{tabular}{|c|c|c|}
\hline \multicolumn{3}{|l|}{ Table 103, continued } \\
\hline Site Name & $\begin{array}{l}\text { Definable } \\
\text { Assemblage }\end{array}$ & Comment \\
\hline Elm Creek & yes & $\begin{array}{l}\text { Excavated sample designated as Cultural Unit } 1 \text {. Good representative } \\
\text { assemblage. }\end{array}$ \\
\hline $41 \mathrm{CN} 78$ & yes & Minimal excavations produced a definable but inadequate sample. \\
\hline $\begin{array}{l}\text { Garnsey Spring Kill } \\
\text { and Campsite }\end{array}$ & no & $\begin{array}{l}\text { Discrete components not definitely attributable to Garza complex, } \\
\text { except for inadequate "Garza hearth" sample. }\end{array}$ \\
\hline \multicolumn{3}{|r|}{ ROCKSHELTERS } \\
\hline Blue Mountain Rockshelter & yes $^{3}$ & Some inconsistencies in artifact typology. \\
\hline Red Bluff Shelter & no & Garza complex Zone D sample is inadequate. \\
\hline Boren Shelter No. 1 & no & Artifact sample is inadequate. \\
\hline Boren Shelter No. 2 & no & Artifact sample is inadequate. \\
\hline Reed Shelter & yes & Artifact sample is small. \\
\hline Garza County Cave & no & $\begin{array}{l}\text { Artifact sample is inadequate, and association with Garza complex is } \\
\text { questionable. }\end{array}$ \\
\hline \multicolumn{3}{|c|}{$\begin{array}{l}\text { "Indicates whether a discrete Garza complex artifact assemblage has been identified and adequately described. } \\
\text { "No" does not indicate that no such assemblage has been recovered, only that no useful published data are } \\
\text { available. }\end{array}$} \\
\hline \multicolumn{3}{|c|}{${ }^{2}$ All assemblages are from excavated contexts unless otherwise noted. } \\
\hline \multicolumn{3}{|c|}{${ }^{3}$ Representativeness of artifact assemblage is questionable due to problems with collection and/or analysis methods. } \\
\hline
\end{tabular}

excavation, while the adjusted artifact density is calculated as the number of nondebitage artifacts per $\mathrm{m}^{2}$ of excavation. Both are crude measures of the total intensity and/duration of occupations. The total artifact density at Garza complex sites ranges from 8.7 to 66.7 , with the residential sites generally having high densities (i.e., all are above 25). This pattern holds when the debitage is factored out and the adjusted artifact densities are compared. One notable shift for the Garza site is seen using adjusted densities. For a hunting camp, the Garza site has an unusually high total artifact density at 30.9 , which is comparable to some of the residential sites. The adjusted density, at 0.8 , is much more in line with the adjusted densities for other hunting camps and at least one of the rockshelters. The simplest interpretation of these data is that lithic reduction, or manufacture/maintenance of tools, was an extremely important activity at the Garza site and that the relative intensity of occupations appears to be much less when the lithic reduction activities are factored out. This interpretation is supported by the fact that 98 percent of the total artifact assemblage from the Garza site is debitage, while the percentages for most of the other sites are much lower (Longhorn, 67 percent; Headstream, 77 percent; Bridwell, 58 percent; Floydada Country Club, 85 percent; Canyon Lakes, 73 percent; Elm Creek, 97 percent; and Reed Shelter, 90 percent). The presence of so much debitage at the Garza site probably can be explained by Runkles's $(1964: 109,113)$ statement that all of the debitage and most of the tools are of local cherts that "are abundant at the site" in the form of stream gravels, resulting in a greater amount of lithic reduction and discard of waste debris.

Reasonable estimates of the total duration of occupations cannot be made for most sites, but crude estimates are available for four sites (Table 106). The most reliable estimates are for the Elm Creek (Cultural Unit 1) and Longhorn sites, each with over $300 \mathrm{~m}^{2}$ of hand excavation and 12 or more radiocarbon dates. The estimates for the Headstream and 
TABLE 104

SUMMARY OF ARTIFACT ASSEMBLAGES ATTRIBUTED TO GARZA COMPLEX COMPONENTS

\begin{tabular}{|c|c|c|c|c|c|c|c|c|c|c|c|c|c|c|}
\hline \multirow[b]{2}{*}{ Artifact Class/Category } & \multicolumn{6}{|c|}{ Residential Bases/Base Camps } & \multicolumn{6}{|c|}{ Bison Kills/Hunting Camps } & \multicolumn{2}{|c|}{ Rockshelters } \\
\hline & Longhom & Headstream & $\begin{array}{l}\text { Pete } \\
\text { Creek }\end{array}$ & Bridwell & Montgomery & $\begin{array}{l}\text { Floydada } \\
\text { Country } \\
\text { Club }\end{array}$ & Garza & Lott & $\begin{array}{l}\text { Lubbock } \\
\text { Lake }\end{array}$ & $\begin{array}{l}\text { Canyon } \\
\text { Lakes }\end{array}$ & $\begin{array}{l}\text { Johnson } \\
\text { Creek }\end{array}$ & $\begin{array}{l}\text { Elm } \\
\text { Creek }\end{array}$ & $\begin{array}{l}\text { Blue } \\
\text { Mountain }\end{array}$ & $\begin{array}{l}\text { Reed } \\
\text { Shelter }\end{array}$ \\
\hline Chipped Stone Tools & & & & & & & & & & & & & & \\
\hline Arrow points & 29 & 21 & 176 & 124 & 81 & 25 & 74 & 221 & 17 & 7 & 5 & 19 & 105 & 4 \\
\hline Dart points & 1 & - & 3 & - & 2 & 2 & 1 & - & - & - & - & 4 & 1 & 1 \\
\hline Perforators/drills & - & 3 & 8 & 21 & 13 & 3 & 10 & 35 & 1 & - & 2 & 4 & 7 & - \\
\hline Beveled knives & 2 & - & 12 & 17 & 10 & - & 1 & 34 & - & 1 & 1 & 1 & - & 1 \\
\hline Other bifaces & 20 & 6 & 92 & 15 & - & 12 & 97 & - & 11 & 1 & 1 & 26 & 9 & - \\
\hline Cobble tools/choppers & 1 & - & 8 & - & - & - & 5 & NQ & 1 & - & - & - & - & - \\
\hline End scrapers & 53 & 15 & 29 & 43 & 30 & 11 & 21 & 41 & 1 & 5 & 3 & 5 & 11 & 2 \\
\hline Side scrapers & 10 & 7 & 3 & 39 & 86 & 3 & 9 & - & 18 & 1 & 3 & 3 & 9 & 1 \\
\hline Other unifaces & 56 & 14 & 17 & 46 & 6 & 4 & 4 & 54 & - & 10 & - & 69 & - & - \\
\hline Cores & 8 & 1 & 168 & - & - & 3 & 26 & - & 1 & 2 & - & 20 & - & - \\
\hline Edge-modified flakes & 89 & 33 & 240 & - & 236 & 26 & - & NQ & 50 & 19 & - & - & 34 & - \\
\hline Unmodified debitage & 6,026 & 3,476 & NQ & 1,630 & NQ & 2,356 & 10,444 & NQ & NQ & 297 & - & 5,216 & NQ & 209 \\
\hline Subtotals: & 6,295 & 3,576 & $756+$ & 1,935 & $464+$ & 2,445 & 10,692 & $385+$ & $100+$ & 343 & 15 & 5,367 & 1,764 & 218 \\
\hline $\begin{array}{l}\text { Battered and Ground } \\
\text { Stone Tools }\end{array}$ & & & & & & & & & & & & & & \\
\hline Hammerstones & 3 & 1 & 12 & - & - & - & 5 & 1 & - & 1 & - & 3 & - & 2 \\
\hline Manos & 9 & 6 & 14 & 14 & 7 & 5 & 1 & - & - & 1 & - & - & 4 & 2 \\
\hline Metates & 39 & 5 & 15 & 11 & 39 & 2 & 1 & - & 2 & - & - & - & 1 & 2 \\
\hline Shaft smoothers & 3 & - & 3 & 7 & - & - & - & 2 & - & - & - & - & - & - \\
\hline Other ground stones & 60 & 9 & 14 & - & 1 & 3 & - & - & - & - & - & 2 & - & - \\
\hline Subtotals: & 114 & 21 & 58 & 32 & 47 & 10 & 7 & 3 & 2 & 2 & $\mathbf{0}$ & 5 & 5 & 6 \\
\hline Ceramics & & & & & & & & & & & & & & \\
\hline Plainware sherds & 2,167 & 742 & 276 & 346 & 151 & 276 & - & $575+$ & NQ & 50 & - & 18 & 10 & - \\
\hline Decorated sherds & 409 & 137 & 46 & 337 & 99 & 9 & - & $63+$ & - & - & - & - & 3 & - \\
\hline Pipe sherds & 19 & 8 & - & 14 & 8 & - & - & - & - & - & - & - & - & - \\
\hline Subtotals: & 2,595 & 887 & 322 & 697 & 258 & 285 & $\mathbf{0}$ & $638+$ & ? & 50 & 0 & 18 & 13 & $\mathbf{0}$ \\
\hline
\end{tabular}




\begin{tabular}{|c|c|c|c|c|c|c|c|c|c|c|c|c|c|c|}
\hline \multirow[b]{2}{*}{ Artifact Class/Category } & \multicolumn{6}{|c|}{ Residential Bases/Base Camps } & \multicolumn{6}{|c|}{ Bison Kills/Hunting Camps } & \multicolumn{2}{|c|}{ Rockshelters } \\
\hline & Longhom & Headstream & $\begin{array}{l}\text { Pete } \\
\text { Creek }\end{array}$ & Bridwell & Montgomery & $\begin{array}{l}\text { Floydada } \\
\text { Country } \\
\text { Club }\end{array}$ & Garza & Lott & $\begin{array}{l}\text { Lubbock } \\
\text { Lake }\end{array}$ & $\begin{array}{l}\text { Canyon } \\
\text { Lakes }\end{array}$ & $\begin{array}{l}\text { Johnson } \\
\text { Creek }\end{array}$ & $\begin{array}{l}\text { Elm } \\
\text { Creek }\end{array}$ & $\begin{array}{l}\text { Blue } \\
\text { Mountain }\end{array}$ & $\begin{array}{l}\text { Reed } \\
\text { Shelter }\end{array}$ \\
\hline $\begin{array}{l}\text { Other Materials } \\
\text { Stone Pipes } \\
\text { Modified hematite/ }\end{array}$ & - & - & - & 3 & 1 & - & - & - & - & - & - & - & - & - \\
\hline limonite & 6 & - & - & - & - & 6 & - & - & - & - & - & - & 5 & 1 \\
\hline Turquoise beads/ & & & - & & - & - & - & 1 & 2 & - & - & - & - & - \\
\hline pendants & 1 & - & $\bar{c}$ & 7 & - & $\overline{-}$ & $\bar{c}$ & - & - & - & - & - & $\overline{0}$ & - \\
\hline Bone awls & - & - & 6 & 27 & 12 & 1 & 2 & 1 & - & - & 1 & - & 3 & - \\
\hline Bone beads & - & - & - & 13 & 9 & - & 4 & 2 & 2 & - & 2 & - & 6 & - \\
\hline Other modified bones & 5 & - & 1 & 14 & 1 & 4 & 2 & - & 19 & - & - & - & - & - \\
\hline Nonlocal shell artifacts & - & - & - & 29 & 2 & - & - & 13 & 1 & - & - & - & - & - \\
\hline Other modified shells & 1 & 4 & 12 & 31 & 1 & 2 & - & 1 & - & - & - & - & 2 & - \\
\hline Misc. artifacts & - & - & - & 3 & - & - & - & - & - & - & - & - & - & - \\
\hline Subtotals: & 13 & 4 & 19 & 127 & 26 & 13 & 8 & 18 & 24 & 0 & 3 & 0 & 16 & 1 \\
\hline European Artifacts & & & & & & & & & & & & & & \\
\hline $\begin{array}{l}\text { Glass beads } \\
\text { Gunflints. }\end{array}$ & $\overline{4}$ & 2 & 1 & & - & 1 & - & - & - & - & - & - & - & - \\
\hline $\begin{array}{l}\text { Gunntinis } \\
\text { Lead ball }\end{array}$ & 1 & - & - & & - & _- & - & - & - & _- & _- & _- & - & - \\
\hline Iron artifacts/fragments & 1 & - & - & - & - & 2 & - & - & - & - & - & - & - & - \\
\hline Majolica sherds & 5 & - & - & - & - & - & - & - & - & - & - & - & - & - \\
\hline Buttons/coins & - & - & - & 5 & - & - & - & - & - & - & - & - & - & - \\
\hline Subtotals: & 11 & 2 & 1 & 10 & 0 & 3 & 0 & 0 & 0 & 0 & 0 & 0 & 0 & 0 \\
\hline GRAND TOTALS: & 9,028 & 4,490 & $1,156^{*}$ & 2,801 & $795^{*}$ & 2,756 & 10,707 & $1,044+*$ & $126^{*}$ & 395 & 18 & 5,390 & 201* & 225 \\
\hline \multicolumn{15}{|l|}{ *Total excludes debitage } \\
\hline
\end{tabular}




\section{TABLE 105}

COMPARISON OF ARTIFACT ASSEMBLAGES ATTRIBUTED TO GARZA COMPLEX COMPONENTS

\begin{tabular}{|c|c|c|c|c|c|c|c|c|c|c|c|c|c|c|}
\hline & \multicolumn{6}{|c|}{ Residential Bases/Base Camps } & \multicolumn{6}{|c|}{ Bison Kills/Hunting Camps } & \multicolumn{2}{|c|}{ Rockshelters } \\
\hline & Longhom & Headstream & $\begin{array}{l}\text { Pete } \\
\text { Creek }\end{array}$ & Bridwell & Montgomery & $\begin{array}{l}\text { Floydada } \\
\text { Country } \\
\text { Club }\end{array}$ & Garza & Lott & $\begin{array}{l}\text { Lubbock } \\
\text { Lake }\end{array}$ & $\begin{array}{l}\text { Canyon } \\
\text { Lakes }\end{array}$ & $\begin{array}{l}\text { Johnson } \\
\text { Creek }\end{array}$ & Elm Creek & $\begin{array}{l}\text { Blue } \\
\text { Mountain } \\
\text { Rockshelter }\end{array}$ & $\begin{array}{l}\text { Reed } \\
\text { Shelter }\end{array}$ \\
\hline Total Artifacts & 9,028 & 4,490 & $?$ & 2,801 & $?$ & 2,756 & 10,707 & $?$ & $?$ & 496 & $?$ & 5,390 & $?$ & 225 \\
\hline $\begin{array}{l}\text { Total Artifacts } \\
\text { (excluding debitage) }\end{array}$ & 3,002 & 1,014 & 1,156 & 1,171 & 793 & 400 & 263 & $1,043+$ & $124+$ & 135 & 18 & 174 & 201 & 16 \\
\hline $\begin{array}{l}\text { Activity Diversity } \\
\text { Index' }\end{array}$ & 21 & 16 & 19 & 18 & 16 & 16 & 12 & 13 & 12 & 10 & 6 & 10 & 13 & 8 \\
\hline Total Artifact Density ${ }^{2}$ & 26.6 & 50.5 & - & 66.7 & - & 25.5 & 30.9 & - & - & - & - & 10 & - & 8.7 \\
\hline $\begin{array}{l}\text { Adjusted Artifact } \\
\text { Density }{ }^{3}\end{array}$ & 8.9 & 11.4 & 12.6 & 27.9 & 14.4 & 3.7 & 0.8 & - & - & - & 0.3 & 0.3 & 4.5 & 0.6 \\
\hline $\begin{array}{l}\text { Projectile Point/ } \\
\text { Grinding Tool Index }\end{array}$ & $0.6^{5}$ & 1.9 & 6.1 & 5.0 & 1.8 & 3.6 & 37.0 & 221 & 8.5 & 7.0 & $5.0 *$ & 19.0 & 21.0 & $1.0 *$ \\
\hline
\end{tabular}

${ }^{1}$ Number of artifact categories.

${ }^{2}$ Number of artifacts $/ \mathrm{m}^{2}$.

${ }^{3}$ Number of nondebitage artifacts $/ \mathrm{m}^{2}$

${ }^{4}$ Number of arrow points/number of manos, metates, and pestles.

${ }^{5} 18$ of 39 metate fragments refit into a single metate. Thus, a more-realistic projectile point/grinding tool index would be 1.0 .

*Validity of index is questionable due to small sample size. 
TABLE 106

COMPARISON OF ADJUSTED ARTIFACT DENSITIES AND ESTIMATED DURATION OF OCCUPATIONS FOR GARZA COMPLEX COMPONENTS

\begin{tabular}{|l|c|c|}
\hline Sites & Adjusted Artifact Density & Estimated Duration of Occupation (in years) \\
\hline Bridwell & 27.9 & none, but presumably lengthy \\
Montgomery & 14.4 & none, but presumably lengthy \\
Pete Creek & 12.6 & none \\
Headstream & 11.4 & $200^{1}$ \\
Longhorn & 8.9 & $350^{1}$ \\
Blue Mountain Rockshelter & 4.5 & none \\
Floydada Country Club & 3.7 & none, but presumably lengthy \\
Garza & 0.8 & $<100^{2}$ \\
Reed Shelter & 0.6 & none \\
Elm Creek & 0.3 & single event \\
Johnson Creek & 0.3 & none \\
\hline 'Interpretation based on geoarcheological context and radiocarbon dates. \\
'Interpretation based on geoarcheological context only. \\
\hline
\end{tabular}

Garza sites are less certain. Notably, the Elm Creek and Garza sites are interpreted as representing shortterm occupations or single events, and they have correspondingly low adjusted artifact densities. In contrast, the Longhorn and Headstream sites, each thought to have been repeatedly reoccupied over a period of several centuries, have moderately high densities. By inference, the density data suggest that the Pete Creek, Montgomery, and Bridwell sites may have been occupied even more intensively or for longer periods of time, and this is consistent with the nature and diversity of the features and artifacts at these sites.

The projectile point/grinding tool index (see Table 105) is another crude measure that is used to infer site function. Based on the assumptions that manos and metates were implements primarily used in processing plant foods and arrow points were used primarily for hunting, the index measures the relative importance of hunting vs. plant processing. The indexes for Garza components range from a low of 0.6 , indicating that plant processing was the dominant subsistence activity at the Longhorn site, to a high of 221, indicating that hunting was the exclusive subsistence activity at the Lott site. The data show that plant processing is well represented at all residential bases (which range from 0.6 to 6.1), while hunting activities are dominant at kills/ hunting camps (which range from 7.0 to 221 , excluding the small sample from Johnson Creek).
The small artifact samples from rockshelters show that plant processing and hunting were of equal importance at Reed Shelter, while hunting was dominant at Blue Mountain Rockshelter.

When the adjusted artifact densities are compared with the projectile point/grinding tool indexes, the components display considerable variability that appears to correlate with differential site function and use intensity. In Figure 103, all of the residential bases are clustered along the bottom axis, and all but one (i.e., the Floydada Country Club) may be characterized as locations where intensive plant processing and repeated and/or intensive occupations occurred. In contrast the three bison kill/campsites are clustered along the left axis and may be characterized as representing relatively short duration events/occupations. The relative importance of hunting activities varies from minimal at Johnson Creek to very high at the Garza site. Three other bison kill/campsites are not shown on the graph because the sizes of their excavated areas were not specified, and no adjusted artifact density could be calculated. Regardless, the Lott site would be off the top end of the graph because of its very high projectile point/grinding tool index (221). The Lubbock Lake and Canyon Lakes sites both have moderate projectile point/grinding tool indexes (7.0 and 8.5 , respectively), and since they apparently have relatively low artifact densities, it is safe to assume that they also would cluster somewhere 


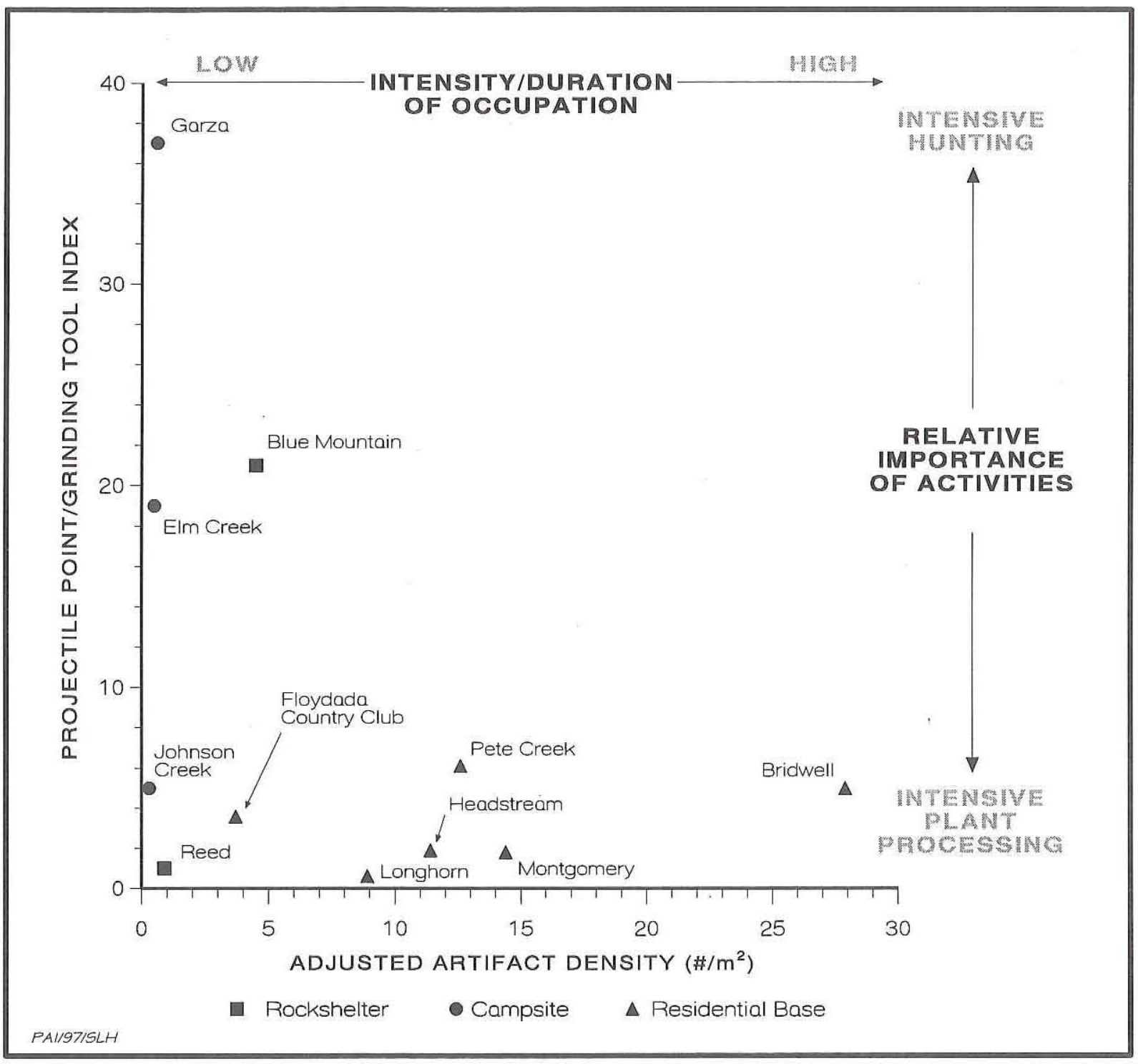

Figure 103. Comparison of adjusted artifact densities and projectile point/grinding tool indexes for Garza components.

along the left axis just above Johnson Creek.

The rockshelters are the most variable site type in terms of subsistence activities and duration of occupation. Reed Shelter appears to have been little more than a temporary refuge where plant processing dominated. Blue Mountain Rockshelter may be characterized as a rather intensively occupied hunting camp.

\section{STONE TOOLS}

A triad of functionally diagnostic tools - small triangular arrow points, beveled knives, and snub- nosed or Plains-style end scrapers - characterizes the stone tool assemblages of the Tierra Blanca and Garza complexes. These tools fit nicely into the "Plains Apache" model that hypothesizes that Tierra Blanca and Garza peoples were mobile huntergatherers whose primary subsistence pursuit was procuring bison (J. Hughes 1991:34-36). Beyond this gross generalization, however, the diverse array of stone tools found at these sites has been given little serious attention.

Complete lithic assemblages are not described for most Tierra Blanca complex sites, and detailed information is only available for the discrete compo- 
nent at the Fifth Green site. The Fifth Green site stone artifact assemblage is characteristic of an ephemeral hunting camp and consists of arrow points, bifacial knives, unifacial scrapers, expedient flake tools, and debitage resulting from tool manufacture and maintenance (see Table 87). Although the assemblage consists predominantly of chipped stones, a few ground stone tools were recovered. No comparisons with other Tierra Blanca assemblages can be made because insufficient data are available.

The data available for defining stone tool assemblages are much better for the Garza complex (see Table 104). As shown in Table 107, there are some striking differences between the stone tool assemblages from residential sites and those from bison hunting sites. The two rockshelters are not compared with these site types because of the small sizes of the artifact samples. By comparing the combined artifact samples for these site types using adjusted standardized residuals, two main functional inferences may be made. The primary observation is that the stone tool data support the idea that the residential sites are functionally distinct from the bison kills and hunting camps. A second observation is that there is a statistically significant inverse relationship between projectile points and manos/ metates. Projectile points are underrepresented at residential sites, while manos and metates are overrepresented. The opposite is true for bison hunting sites. This distinction highlights the fact that plant processing activities are fairly well represented at residential sites, while animal hunting and processing are essentially exclusive subsistence activities at bison kills/hunting camps.

\section{Chipped Stone Tools and Debitage}

The amount of chipped stone debitage relative to the total number of tools deposited in a site may be controlled in part by the proximity of sources of good-quality cherts. However, there also appears to be some connection between the amount of chipped stone tools and debitage and the activities that occurred at specific sites. Chipped stones, both tools and debitage, account for the vast majority of all artifacts recovered from bison hunting sites and rockshelters (Table 108). While chipped stones comprise 86-99 percent of the total artifact assemblages from these sites, they are somewhat less predominant at residential sites, making up between 70 and 89 percent of the total assemblages.

There do not seem to be many meaningful differences between sites in terms of the relative amounts of debitage and chipped stone tools. This can be seen by comparing the ratios of chipped stone debitage to tools (see Table 108). Five of the sites have mid-range ratios of 23.1 to 39.8 . Three other sites deviate from this cluster with ratios that are either higher or lower. The chipped stone

TABLE 107

COMPARISON OF STONE TOOL ASSEMBLAGES FROM GARZA COMPLEX RESIDENTIAL SITES AND BISON HUNTING SITES

\begin{tabular}{|l|c|c|r|r|}
\hline Artifact Class & $\begin{array}{c}\text { Residential } \\
\text { Sites }(\mathrm{n}=6)\end{array}$ & $\begin{array}{c}\text { Adjusted Standardized Residuals } \\
\text { for Residential Sites* }\end{array}$ & $\begin{array}{r}\text { Bison Hunting } \\
\text { Sites (n=6) }\end{array}$ & Totals \\
\hline Arrow points/dart points & 464 & $-\mathbf{8 . 9 2}$ & 348 & 812 \\
Nonpoint bifaces & 186 & -7.81 & 174 & 360 \\
Perforators & 44 & $-\mathbf{5 . 1 1}$ & 96 \\
Unifaces & 472 & -2.54 & 6 & 719 \\
Cobble tools/choppers & 9 & -0.80 & 69 & 15 \\
Edge-modified flakes & 624 & $+\mathbf{1 3 . 4 2}$ & 10 & 693 \\
Hammerstones & 16 & -0.88 & 5 & 26 \\
Manos/metates & 96 & $+\mathbf{8 . 0 8}$ & 4 & 171 \\
Other ground stones & $\mathbf{+ 5 . 9 8}$ & & 915 \\
\hline TOTALS: & 2,080 & & 2,995 \\
\hline *Numbers above +1.95 or below & -1.95 are statistically significant at the 0.5 level of confidence. \\
\hline
\end{tabular}


TABLE 108

SUMMARY OF CHIPPED STONE ASSEMBLAGES FOR SELECTED GARZA COMPLEX SITES

\begin{tabular}{|c|c|c|c|c|c|c|c|c|}
\hline \multirow[b]{2}{*}{ Site } & \multirow{2}{*}{$\begin{array}{c}\text { Total } \\
\text { Artifacts }\end{array}$} & \multicolumn{2}{|c|}{ Debitage } & \multicolumn{2}{|c|}{$\begin{array}{c}\text { Chipped Stone } \\
\text { Tools* }\end{array}$} & \multirow{2}{*}{$\begin{array}{c}\text { Debitage/ } \\
\text { Tools }\end{array}$} & \multicolumn{2}{|c|}{$\begin{array}{l}\text { All Chipped } \\
\text { Stones }\end{array}$} \\
\hline & & $\#$ & $\%$ & $\#$ & $\%$ & & $\#$ & $\%$ \\
\hline \multicolumn{9}{|c|}{ RESIDENTIAL SITES } \\
\hline Longhorn & 9,028 & 6,026 & 66.7 & 261 & 2.9 & 23.1 & 6,287 & 69.6 \\
\hline Headstream & 4,490 & 3,476 & 77.4 & 99 & 2.2 & 35.1 & 3,575 & 79.6 \\
\hline Bridwell & 2,801 & 1,630 & 58.2 & 305 & 10.9 & 5.3 & 1,935 & 69.1 \\
\hline Floydada Country Club & 2,756 & 2,356 & 85.5 & 86 & 3.1 & 27.4 & 2,442 & 88.6 \\
\hline \multicolumn{9}{|c|}{ BISON HUNTING SITES } \\
\hline Garza & 10,707 & 10,444 & 97.5 & 222 & 2.1 & 47.0 & 10,666 & 99.6 \\
\hline Canyon Lakes & 395 & 297 & 75.2 & 44 & 11.1 & 6.7 & 341 & 86.3 \\
\hline Elm Creek & 5,390 & 5,216 & 96.8 & 131 & 2.4 & 39.8 & 5,347 & 99.2 \\
\hline \multicolumn{9}{|c|}{ ROCKSHELTER } \\
\hline Reed Shelter & 225 & 209 & 92.9 & 9 & 4.0 & 23.2 & 218 & 96.9 \\
\hline
\end{tabular}

debitage to tool ratios do not correlate with functional site types, and they seem to correlate more to site-specific factors. Debitage is slightly overabundant at the Garza site, with a debitage to tool ratio of 47.0. As noted, the site occupants may have done more stone tool manufacturing or maintenance there because of the local abundance of high-quality stream gravel cherts.

Chipped stone tools are overabundant at the Bridwell and Canyon Lakes localities, with debitage to tool ratios of 5.3 and 6.7, respectively. The low value for the Bridwell site, indicating that less lithic reduction took place relative to other residential sites, may be related to the presence of a circular fortification ridge or brush enclosure there (see Features). No such features are present at any of the other residential sites, and the activities at Bridwell may have been different from those at the other sites. In addition, the abundance of tools at Bridwell could be related, at least in part, to differential archeological sampling and/or differences in refuse disposal behavior. While the dispersed excavations at the Longhorn, Headstream, and Floydada Country Club sites sampled a broad spectrum of living/activity areas, the excavations at Bridwell concentrated solely on the mounded ridge.
Presumably, the cultural materials from these deposits represent refuse that was discarded along a fortification wall or a brush enclosure. In either case, the circular feature would have been a major factor controlling where lithic reduction occurred and/or when and where refuse was disposed. Perhaps the ratio would be much different if the sample also had included areas inside and outside the circular ridge.

For the Canyon Lakes sites, the most likely explanation for an abundance of chipped stone tools is that the locality primarily represents a series of bison kills and primary butchering areas. In contrast, the greater abundance of debitage at the Garza and Elm Creek sites should reflect more secondary processing and/or camping activities. These interpretations are supported by the faunal evidence discussed earlier in this chapter.

One other aspect of lithic technology may be examined by comparing the frequencies of bifacial tools and debitage generated by bifacial reduction with the numbers of unifacial tools and debitage generated by unifacial reduction. Using a ratio of nonprojectile point bifacial tools to unifacial tools, the relative frequencies are clearly different for the three different site types (Table 109). Unifaces are 


\begin{tabular}{|c|c|c|c|}
\hline \multicolumn{4}{|c|}{$\begin{array}{c}\text { COMPARISON OF BIFACIAL TOOL TO UNIFACIAL } \\
\text { TOOL RATIOS FOR RESIDENTIAL SITES, } \\
\text { BISON HUNTING SITES, AND ROCKSHELTERS } \\
\text { OF THE GARZA COMPLEX }\end{array}$} \\
\hline Site Type & $\begin{array}{l}\text { Number of } \\
\text { Nonprojectile } \\
\text { Point Bifaces }\end{array}$ & $\begin{array}{l}\text { Number of } \\
\text { Unifaces }\end{array}$ & $\begin{array}{l}\text { Bifaces/ } \\
\text { Unifaces }\end{array}$ \\
\hline Residential sites $(n=6)$ & 234 & 472 & 0.50 \\
\hline Bison hunting sites $(n=6)$ & 226 & 247 & 0.91 \\
\hline Rockshelters $(\mathrm{n}=2)$ & 17 & 23 & 0.74 \\
\hline
\end{tabular}

cutting occurred most commonly at bison hunting sites, presumably during butchering activities, while scraping, presumably of hides, was most common at residential sites.

As was suggested for the Longhorn site (see Chapter 6), it is hypothesized that staged processing of animal hides accounts for the abundance of scrapers at all of the residential sites except Pete Creek (Table 110). Scrapers constitute 21-46 percent of the chipped stone tools at the other five residential sites. Since these sites have very low arrow point-grinding tool in-

twice as abundant as nonpoint bifaces at residential sites, while bifaces are relatively more common in rockshelters and especially in bison hunting sites. Except for preforms and manufacturing failures, most nonpoint bifaces are considered to be cutting tools, while most unifaces are scraping tools. Thus, dexes (ranging from 0.6 to 5.0, see Table 105), huntingactivities per se seem to have been infrequent. The high frequency of unifaces indicates common hide scraping, however, and it appears that bison hides had been acquired previously, stored temporarily, and then transported to the residential

\begin{tabular}{|c|c|c|c|c|c|c|c|}
\hline \multicolumn{8}{|c|}{$\begin{array}{c}\text { FREQUENCY OF UNIFACIAL SCRAPERS IN ASSEMBLAGES } \\
\text { FROM GARZA COMPLEX SITES }\end{array}$} \\
\hline \multirow[b]{2}{*}{ Site } & \multirow{2}{*}{$\begin{array}{l}\text { Total No. } \\
\text { of Chipped } \\
\text { Stone Tools }\end{array}$} & \multicolumn{2}{|c|}{ End Scrapers } & \multicolumn{2}{|c|}{ Other Scrapers } & \multicolumn{2}{|c|}{ All Scrapers } \\
\hline & & \# & $\%$ & \# & $\%$ & \# & $\%$ \\
\hline \multicolumn{8}{|c|}{ RESIDENTIAL SITES } \\
\hline Longhorn & 261 & 53 & 20.3 & 66 & 25.3 & 119 & 45.6 \\
\hline Headstream & 99 & 15 & 15.2 & 21 & 21.2 & 36 & 36.4 \\
\hline Pete Creek & 588 & 29 & 4.9 & 20 & 3.4 & 49 & 8.3 \\
\hline Bridwell & 305 & 43 & 14.1 & 85 & 27.9 & 128 & 42.0 \\
\hline Montgomery & 464 & 30 & 6.5 & 92 & 19.8 & 122 & 26.3 \\
\hline Floydada Country Club & 86 & 11 & 12.8 & 7 & 8.1 & 18 & 20.9 \\
\hline \multicolumn{8}{|c|}{ BISON HUNTING SITES } \\
\hline Garza & 222 & 21 & 9.5 & 13 & 5.9 & 34 & 15.3 \\
\hline Lott & 385 & 41 & 10.6 & 54 & 14.0 & 95 & 24.7 \\
\hline Lubbock Lake & 99 & 1 & 1.0 & 18 & 18.2 & 19 & 19.2 \\
\hline Canyon Lakes & 44 & 5 & 11.4 & 11 & 25.0 & 16 & 36.4 \\
\hline Johnson Creek & 15 & 3 & 20.0 & 3 & 20.0 & 6 & 40.0 \\
\hline Elm Creek & 151 & 5 & 3.3 & 72 & 47.7 & 77 & 51.0 \\
\hline \multicolumn{8}{|c|}{ ROCKSHELTERS } \\
\hline Blue Mountain & 167 & 11 & 6.6 & 9 & 5.4 & 20 & 12.0 \\
\hline Reed Shelter & 218 & 2 & 0.9 & 1 & 0.5 & 3 & 1.4 \\
\hline
\end{tabular}


sites for later processing, perhaps during nonbisonhunting seasons.

Of all of the residential sites, Pete Creek is the most unusual in this regard. Despite its relatively high arrow point-grinding tool index of 6.1, scraping tools are relatively rare, making up only 8 percent of the chipped stone tools. Thus, relative to other residential sites, it appears that more hunting and less hide processing occurred at Pete Creek.

The debitage from the Longhorn and Headstream sites also supports an interpretation of staged hide processing. Significant amounts of the lithic debris (ca. 35-40 percent) at these sites appear to have been generated as a result of resharpening unifacial tools such as end scrapers (Table 111). The Montgomery site is the only other Garza complex site for which comparable data are available; the amount of unifacial flakes recovered there is significantly less, though. This could reflect, at least in part, methodological differences between the debitage analyses. Only 7.6 percent of the Montgomery site debitage could be identified to flake type, while 42 percent of the Longhorn site debitage and 44 percent of the Headstream site debitage were identified as unifacial or bifacial flakes. Notably, the 8.9 to 1 ratio of unifacial to bifacial flakes at the Montgomery site, which is even higher than the 4.9 to 1 ratio at the Longhorn site and the 8.6 to 1 ratio at the Headstream site, also suggests a heavy reliance on unifacial tools. There are no comparable debitage analysis data for other Garza complex sites, and it is not possible to determine whether resharpening of unifaces was equally important at bison hunting localities.
Scrapers are relatively rare at Reed Shelter but are much more common at Blue Mountain Rockshelter (see Table 110), accounting for 1 and 12 percent of the chipped stone tools at these sites, respectively. This variability suggests that these two rockshelters were used by Garza peoples in different ways. This interpretation is consistent with variations in artifact densities and arrow point-grinding tool indexes for these rockshelters (see Table 105). This is similar to the situation for rockshelters of the Late Prehistoric I period, which also were used in different ways depending upon a variety of factors (see Chapter 10).

The frequency of scrapers at bison hunting sites also is quite variable (see Table 110). Scrapers constitute 15-51 percent of the chipped stone tool assemblages at the six bison hunting sites. This suggests that a significant amount of scraping and processing of hides was done at bison kill and primary processing locations. The scraping tools found at these locations presumably were used in connection with processing of fresh hides.

When viewed in light of circumstantial evidence and other material culture data (discussed below), the chipped stone data seem to support two complementary hypotheses: (1) bison hunting sites are characterized by evidence of intensive hunting, cutting and butchering of animal carcasses, and early-stage hide working, primarily involving fresh hides; and (2) residential sites are characterized by minimal evidence of hunting and considerable evidence of late-stage hide processing, primarily involving dry (i.e., stored) hides. Systematic usewear studies of large samples of stone tools (edge-

\begin{tabular}{|c|c|c|c|c|c|}
\hline \multicolumn{6}{|c|}{$\begin{array}{l}\text { SUMMARY OF UNIFACIAL VS. BIFACIAL LITHIC REDUCTION REPRESENTED IN THE } \\
\text { LITHIC DEBITAGE ASSEMBLAGES FROM SELECTED GARZA COMPLEX SITES }\end{array}$} \\
\hline \multirow[b]{2}{*}{ Site } & \multirow{2}{*}{$\begin{array}{l}\text { Total Unmodified } \\
\text { Flakes }\end{array}$} & \multicolumn{2}{|c|}{$\begin{array}{l}\text { Unifacial Flakes } \\
\text { (Single-Facet Platforms) }\end{array}$} & \multicolumn{2}{|c|}{$\begin{array}{l}\text { Bifacial Flakes } \\
\text { (Multiple-Facet Platforms) }\end{array}$} \\
\hline & & $\#$ & $\%$ & $\#$ & $\%$ \\
\hline Longhorn & 6,026 & 2,080 & 34.5 & 428 & 7.1 \\
\hline Headstream & 3,476 & 1,373 & 39.5 & 160 & 4.6 \\
\hline $\begin{array}{l}\text { Montgomery } \\
\text { (1978 excavations only) }\end{array}$ & 1,440 & 98 & 6.8 & 11 & 0.8 \\
\hline
\end{tabular}


modified flakes, bifacial cutting tools, and scrapers, particularly formal end scrapers) from good excavated contexts in residential and bison hunting sites is the most expedient means of testing these hypotheses. A third hypothesis is that scraping tools were used more intensively (i.e., resharpened more often and reused until exhausted) at residential sites than at bison hunting sites. This hypothesis could be tested by detailed and comparative attribute analyses of lithic debitage and unifaces from both types of sites.

There is undoubtedly much to be learned from detailed comparative technological, use-wear, and residue studies aimed at defining tool functions more precisely. A case in point is a subclass of unifacial tools that have prominent concave working edges and have been called spokeshaves. These tools are reported for several Garza complex sites such as Floydada Country Club (Word 1991a:Figure 8A), Montgomery (Northern 1978:35, Figure 2E; Word 1965:73), Pete Creek (Parsons 1967:36, Figure 11A and B), and Garza (Runkles 1964:112-113). In some cases, the notch is the only modified edge, but others are scrapers that also have modified notches. Some notches are relatively shallow while others are deep. The name implies a reasonable functional inference and suggests that these tools were used to plane wooden shafts. Lacking any detailed functional analyses, however, this interpretation must be considered tentative.

\section{Grinding Tools}

No ground stone tools are described from Tierra Blanca complex sites, and only a few assemblages have been sufficiently quantified to even determine whether manos or metates were present. No manos or metates are reported from the Fifth Green site in either the uncontrolled surface collections or the excavated artifact assemblage (Kalokowski 1986). One mano and six metate fragments were recovered from Levels 1 and 2 of the Canyon City Club Cave, and these specimens may be associated with the Tierra Blanca complex. Katz and Katz (1976:83) mention one quartzite mano from the Tule Mouth site 41BI81. No manos or metates are mentioned by Spielmann (1982) from excavations at the Tierra Blanca and Blackburn sites, but some may have been recovered. While the evidence is too skimpy to determine the role of grinding tools within the Tierra Blanca complex, the many similarities be- tween the Tierra Blanca and Garza complexes suggest that manos and metates are probably present with some consistency but in varying frequencies at Tierra Blanca sites.

Grinding stone data for Garza complex sites are considerably better in terms of presence/absence, but few manos and metates have been adequately described. Table 112 shows that manos and metates are relatively common but complete specimens are quite rare. Not surprisingly, manos and metates are more common in residential sites (average of 10 manos and 21 metates per site) than in bison hunting sites (average of less than 1 mano and 1 metate per site), and more broken specimens occur at residential sites.

As shown in Table 113, the materials most commonly used by Garza peoples for making manos and metates are sandstones and quartzites. The same may be said for all cultures and time periods over much of the Texas Panhandle-Plains (except along the Canadian River where dolomite is common and in the southern end of the region where limestones are common). In all areas where abundant Triassic deposits are exposed, sandstones are ubiquitous and were the preferred material for making grinding tools. Quartzites derived from Ogallala or Lingos Formation gravels were commonly used for manos, and limestones were occasionally used for both manos and metates.

For the Garza complex, sandstone was the favored material for metates ( 85 percent of the 99 identified specimens), while limestone accounts for only 14 percent. That the Montgomery site yielded the highest number of limestone metates is of interest since the nearest mapped outcrops of Cretaceous limestones are some $40 \mathrm{~km}$ to the southwest in Yellowhouse Canyon (see Barnes 1967). However, Northern (1979:50-51) hints that limestone does crop out in the vicinity of the site by stating that 12 metates are made of "native limestone." Also from the Montgomery site, a single metate made of volcanic pumice is obviously nonlocal. Except for this specimen, it appears that metates were made of the most readily available material, and there is no evidence suggesting that there may have been functional differences between metates made of sandstone or limestone.

A few observations may be made regarding the morphology and size of Garza complex metates. Complete metates are very rare, but most of the fragments appear to be of the oval-basin type. 


\begin{tabular}{|c|c|c|c|c|c|c|}
\hline \multicolumn{7}{|c|}{$\begin{array}{c}\text { SUMMARY OF OCCURRENCE AND COMPLETENESS OF MANOS AND METATES } \\
\text { FROM GARZA COMPLEX SITES }\end{array}$} \\
\hline & \multicolumn{3}{|c|}{ Manos } & \multicolumn{3}{|c|}{ Metates } \\
\hline Site & $\begin{array}{l}\text { Total \# of } \\
\text { Specimens }\end{array}$ & $\begin{array}{l}\text { \# of Complete } \\
\text { Specimens }\end{array}$ & $\begin{array}{l}\% \text { Complete } \\
\text { Specimens }\end{array}$ & $\begin{array}{l}\text { Total \# of } \\
\text { Specimens }\end{array}$ & $\begin{array}{l}\text { \# of Complete } \\
\text { Specimens }\end{array}$ & $\begin{array}{l}\text { \% Complete } \\
\text { Specimens }\end{array}$ \\
\hline \multicolumn{7}{|c|}{ RESIDENTIAL SITES } \\
\hline $\begin{array}{l}\text { Longhorn } \\
\text { Headstream } \\
\text { Slaton Dump } \\
\text { Pete Creek } \\
\text { Bridwell } \\
\text { Montgomery } \\
\text { Floydada Country } \\
\text { Club } \\
\text { Subtotals: }\end{array}$ & $\begin{array}{r}9 \\
6 \\
15 \\
14 \\
14 \\
7 \\
\frac{5}{70}\end{array}$ & $\begin{array}{l}2 \\
0 \\
? \\
? \\
3 \\
0 \\
\frac{1}{6+}\end{array}$ & $\begin{array}{r}22 \\
0 \\
? \\
? \\
21 \\
0 \\
\frac{20}{>8}\end{array}$ & $\begin{array}{r}39 \\
5 \\
15 \\
15 \\
11 \\
39 \\
\frac{2}{126}\end{array}$ & $\begin{array}{l}2 \\
0 \\
? \\
0 \\
4 \\
0 \\
\frac{0}{6+}\end{array}$ & $\begin{array}{r}5 \\
0 \\
? \\
0 \\
36 \\
0 \\
-\overline{75}\end{array}$ \\
\hline \multicolumn{7}{|c|}{ BISON HUNTING SITES } \\
\hline $\begin{array}{l}\text { Garza } \\
\text { Lubbock Lake } \\
\text { Canyon Lakes } \\
\text { Subtotals: }\end{array}$ & $\begin{array}{l}1 \\
0 \\
\frac{1}{2}\end{array}$ & $\begin{array}{l}1 \\
0 \\
0 \\
1\end{array}$ & $\begin{array}{r}100 \\
0 \\
0 \\
50\end{array}$ & $\begin{array}{l}1 \\
2 \\
0 \\
3\end{array}$ & $\begin{array}{l}1 \\
0 \\
0 \\
1\end{array}$ & $\begin{array}{r}100 \\
0 \\
0 \\
33\end{array}$ \\
\hline \multicolumn{7}{|c|}{ ROCKSHELTERS } \\
\hline $\begin{array}{l}\text { Blue Mountain } \\
\text { Reed Shelter } \\
\text { Subtotals: }\end{array}$ & $\begin{array}{l}4 \\
\frac{2}{6}\end{array}$ & $\begin{array}{l}1 \\
\frac{0}{1}\end{array}$ & $\begin{array}{r}25 \\
\frac{0}{17}\end{array}$ & $\begin{array}{l}1 \\
\frac{2}{3}\end{array}$ & $\begin{array}{l}1 \\
\frac{1}{2}\end{array}$ & $\begin{array}{r}100 \\
\frac{50}{66}\end{array}$ \\
\hline GRAND TOTALS: & 78 & $8+$ & $>10$ & 132 & $9+$ & $>6$ \\
\hline
\end{tabular}

Booker and Campbell (1978:30) note that of 15 metates from the Slaton Dump site, 14 are of the slab type while only 1 is a basin metate. A complete bifacial, oval-basin metate was found at the Bridwell site, along with 2 complete manos (one sandstone and one quartzite) and 54 scrapers (Parker 1982:15-16). This find, called the Wallace cache, was excavated by relic collectors, and precise contextual information is lacking (these specimens are excluded from the quantified assemblage in Tables 104 and 112). Three of the four complete metates from the Bridwell site are described as having "bowls on both surfaces" and showing "extensive use" (Parker 1982:46). Parsons (1967:47) notes that the metates from the Pete Creek site are fragments of small sandstone slab metates with oval grinding basins on one or both faces. Two complete unifacial sandstone metates were recovered from the
Longhorn site. Both are relatively small (under $30 \mathrm{~cm}$ in maximum length); one is of the slab type while the other has a grinding basin. The fragmentary metates from the Longhorn and Headstream sites include pieces of both slab and oval-basin metates.

Because complete specimens are so rare and so few are adequately described, maximum thickness is the only size measurement useful for comparing a sizable sample of metates. The total range of thicknesses for 89 individually measured specimens is $13-75 \mathrm{~mm}$, while the mean thickness of metates from four separate sites ranges from 21.5 to $63.5 \mathrm{~mm}$ (Table 114). In comparison with metates from the Late Prehistoric I period, the Garza metates are generally much thinner. For the Late Prehistoric I period, only the early occupation assemblage from the Sam Wahl site produced an adequate sample of 


\begin{tabular}{|c|c|c|c|c|c|c|c|c|}
\hline \multicolumn{9}{|c|}{$\begin{array}{l}\text { SUMMARY OF MATERIAL TYPES FOR MANOS AND METATES } \\
\text { FROM GARZA COMPLEX SITES }\end{array}$} \\
\hline \multirow[b]{2}{*}{ Site } & \multicolumn{4}{|c|}{ Number of Manos $(\mathrm{n}=78)$} & \multicolumn{4}{|c|}{ Number of Metates $(n=132)$} \\
\hline & Sandstone & Quartzite & Limestone & Unspecified & Sandstone & Limestone & Other & Unspecified \\
\hline \multicolumn{9}{|c|}{ RESIDENTIAL SITES } \\
\hline Longhorn & 6 & 3 & - & - & 39 & - & - & - \\
\hline Headstream & 6 & - & - & - & 5 & - & - & - \\
\hline Slaton Dump & - & - & - & 15 & - & - & - & 15 \\
\hline Pete Creek ${ }^{1}$ & 9 & 4 & 1 & - & $?$ & - & - & 15 \\
\hline Bridwell $^{2}$ & $?$ & $?$ & - & 14 & 11 & - & - & - \\
\hline Montgomery & - & 2 & - & 5 & 26 & 12 & $1^{3}$ & - \\
\hline \multicolumn{9}{|l|}{ Floydada } \\
\hline Country Club & 1 & $\underline{3}$ & $=$ & 1 & $=$ & 1 & $=$ & 1 \\
\hline Subtotals: & $22+$ & $12+$ & 1 & 35 & $81+$ & 13 & 1 & 31 \\
\hline \multicolumn{9}{|c|}{ BISON HUNTING SITES } \\
\hline Garza & - & 1 & - & - & - & 1 & - & - \\
\hline Lubbock Lake & - & - & - & - & - & - & - & 2 \\
\hline Canyon Lakes & 1 & $=$ & $=$ & $=$ & $=$ & $=$ & $=$ & $=$ \\
\hline Subtotals: & $\overline{1}$ & $\overline{1}$ & $\overline{0}$ & $\overline{0}$ & $\overline{0}$ & $\overline{1}$ & $\overline{0}$ & $\overline{2}$ \\
\hline \multicolumn{9}{|c|}{ ROCKSHELTERS } \\
\hline Blue Mountain & 4 & - & - & - & 1 & - & - & - \\
\hline Reed Shelter & $\underline{2}$ & $=$ & $=$ & $=$ & $\underline{2}$ & $=$ & $=$ & $=$ \\
\hline Subtotals: & $\overrightarrow{6}$ & $\overline{0}$ & $\overline{0}$ & $\overline{0}$ & 3 & $\overline{0}$ & 0 & $\overline{0}$ \\
\hline GRAND TOTALS: & $29+$ & $13+$ & 1 & 35 & $84+$ & 14 & 1 & 33 \\
\hline \multicolumn{9}{|c|}{$\begin{array}{l}\text { 'An unspecified number of metates are made from sandstone, and no other materials are mentioned; the } 15 \\
\text { specimens of unspecified materials may be sandstone. }\end{array}$} \\
\hline \multicolumn{9}{|c|}{${ }^{2}$ Manos are all made from sandstone and quartzite, but numbers are not specified. } \\
\hline
\end{tabular}

measured metates. Of 46 metates that were measured, the mean thickness is 56.3 , and the thickness of individual metates ranges from 17 to $102 \mathrm{~mm}$. Eight of the 46 Sam Wahl site specimens are thicker than the thickest Garza complex metate (i.e., $>75 \mathrm{~mm}$ ).

Sandstone is the dominant material for manos, accounting for 67 percent of the 43 identified specimens; quartzite accounts for only 30 percent (see Table 113), and only 2 percent are of limestone. Because of the differences in these materials, sandstone and quartzite manos may have been functionally distinctive tools. One possibility is that the sandstone manos were used to grind different materials (presumably different types of plant remains) than quartzite manos. A second possibility is that manos of both materials were used to process the same materials, but that they were used during different stages of processing (i.e., sandstone for coarse grinding, quartzite for fine grinding). However, there is no good evidence supporting such functional distinctions.

In terms of mano size variability, very limited data are available for the Garza complex (Table 115). The sample of measurable complete manos from Garza sites includes an unknown number (but less than 14) of specimens from Pete Creek and 6 specimens from four other sites. They exhibit a 
TABLE 114

COMPARISON OF THICKNESS MEASUREMENTS FOR METATES FROM GARZA COMPLEX RESIDENTIAL SITES

\begin{tabular}{|l|c|c|c|}
\hline Site & \# of Metates Measured $^{1}$ & Thickness Range $(\mathrm{mm})^{\text {Mean Thickness (mm) }}$ \\
\hline Longhorn & 31 & $13-75$ & 33.4 \\
Headstream & 4 & $15-36$ & 21.5 \\
Pete Creek & 15 & $27-60$ & 63.5 \\
Bridwell & $4^{2}$ & - & - \\
Montgomery & 39 & $41-63$ & 34.0 \\
Floydada Country Club & 1 & - & $35.2^{4}$ \\
\hline Total: & 94 & $13-75^{3}$ & \\
\hline
\end{tabular}

${ }^{1}$ Includes complete and fragmentary specimens unless otherwise stated.

${ }^{2}$ Complete only.

${ }^{3}$ Total range based on 89 specimens from four sites.

${ }^{4}$ Total mean based on 41 specimens from four sites.

\begin{tabular}{|c|c|c|c|c|c|}
\hline \multicolumn{6}{|c|}{$\begin{array}{c}\text { TABLE } 115 \\
\text { COMPARISON OF SIZE DATA FOR COMPLETE MANOS } \\
\text { FROM GARZA COMPLEX SITES }\end{array}$} \\
\hline Attributes & Longhorn & Pete Creek & Bridwell & $\begin{array}{l}\text { Floydada } \\
\text { Country Club }\end{array}$ & Garza \\
\hline Sample Size & 1 & $?$ & 3 & 1 & 1 \\
\hline $\begin{array}{l}\text { Size Range }(\mathrm{cm}) \\
\text { Length } \\
\text { Width } \\
\text { Thickness }\end{array}$ & $\begin{array}{l}- \\
- \\
-\end{array}$ & $\begin{array}{l}7.2-13.5 \\
7.3-11.5 \\
2.7-6.0\end{array}$ & $\begin{array}{l}- \\
- \\
-\end{array}$ & $\begin{array}{l}- \\
- \\
-\end{array}$ & $\begin{array}{l}- \\
- \\
-\end{array}$ \\
\hline $\begin{array}{l}\text { Mean Size }(\mathrm{cm}) \\
\text { Length } \\
\text { Width } \\
\text { Thickness }\end{array}$ & $\begin{array}{c}19.3 \\
10.2 \\
3.9\end{array}$ & $\begin{array}{l}11.3 \\
9.4 \\
3.6\end{array}$ & $\begin{array}{c}13.0 \\
9.0 \\
3.0\end{array}$ & $\begin{array}{c}11.7 \\
8.3 \\
2.8\end{array}$ & $\begin{array}{c}10.2 \\
7.6 \\
5.0\end{array}$ \\
\hline Mean Length/Width Ratio & 1.89 & 1.20 & 1.44 & 1.41 & 1.34 \\
\hline $\begin{array}{l}\text { Mean Grinding Surface Area } \\
\left(\mathrm{cm}^{2}\right)^{*}\end{array}$ & 196.9 & 106.2 & 117.0 & 97.1 & 77.5 \\
\hline
\end{tabular}

considerable range of sizes and vary in length from 7.2 to $19.3 \mathrm{~cm}$. The grinding surface area for all specimens is not known, but the mean grinding surface area for each site assemblage ranges from 77.5 to $196.9 \mathrm{~cm}^{2}$. Compared with the manos from Late Prehistoric I residential bases, the manos from the four Garza complex residential sites are more variable in size and grinding surface area (cf. Tables 115 and 75$)$.

Specific functional inferences for manos of various sizes and materials are not supported by any hard evidence. It is possible that some manos may 
have been used in hide processing/preparation, but most are thought to have been used in conjunction with metates for grinding plant foods. Compared with the grinding tool assemblages from Late Prehistoric I period sites of the Palo Duro complex (see Chapter 10), observations and inferences regarding the Garza complex can be summarized as follows: (1) metates of the Garza complex are quite variable in thickness, but they are generally thinner and were probably more portable than the largest metates of the preceding period; and (2) manos of the Garza complex are more variable in size than Palo Duro manos, and they may have been used for a wider variety of tasks.

Grinding tools other than manos and metates also have been found. A mano/pestle at the Longhorn site was found inside a shallow pit. This unusual grinding implement (see Boyd et al. 1993: Figure 69a) is unlike typical unifacial and bifacial manos. Based on its archeological context and ethnographic evidence, Boyd et al. (1993:113) suggested that this specialized grinding tool was used in conjunction with a rawhide mortar (i.e., the pit was lined with a dry hide). Except for a small mortar (67 mm in diameter) pecked into a limestone slab at the Pete Creek site (Parsons 1967:50), no other portable rock mortars are known for the Garza complex. Ovate bedrock mortars are reported near two Garza complex rockshelters, but there is no evidence linking them with the Garza occupations. No pestles suitable for use in bedrock mortars have been found at any Garza sites.

Another type of ground stone tool, called the shaft smoother or shaft straightener, consistently occurs in low frequencies at Plains sites associated with bison hunting peoples. It is presumed that these sandstone or limestone tools, sometimes found as matching pairs, functioned as abraders to grind and smooth spear, dart, and arrow shafts. They are occasionally found in sites from earlier periods but are much more common in the Late Prehistoric II and Protohistoric periods. Two specimens are reported from the Fifth Green site for the Tierra Blanca complex (Kalokowski 1986), and 13 specimens are reported from Garza complex sites (see Table 104). Booker and Campbell (1978:30) mention that a number of shaft smoothers were found at the Slaton Dump site. Several Garza complex specimens are illustrated by Boyd et al. (1993:Figure 70e and f), Parker (1982:43), and Runkles and Dorchester (1987:Figure 15C). The groove sizes on these specimens indicate that they would have worked well for sanding and smoothing arrow shafts. It is likely that these specialized tools became popular along with the spread of the small sidenotched arrow point tradition, since lighter arrow shafts probably required more-elaborate finishing than larger, heavier arrow or dart shafts.

Similar grinding tools from Garza complex sites have been called awl sharpeners (or needle sharpeners) and presumably were used to grind and sharpen bone awls (Northern 1979:51; Parker 1982:45). These sandstone tools differ from shaft smoothers in that the grooves are not parallel but taper slightly, and they often do not extend across the entire face of the tool (see Parsons 1967:Figures 16A and C). It is often difficult to distinguish between shaft smoothers and awl sharpeners. While the inferred uses seem logical, no detailed technological, experimental, or use-wear analyses have been done to specifically address the functions of these tools.

\section{CULINARY CERAMICS}

Plainware and decorated ceramics are plentiful in sites attributed to the Tierra Blanca and Garza complexes, but quantifiable data are available only for the latter (see Table 104). Overall, pottery sherds are abundant at Garza complex residential bases, where they constitute between 28 and 88 percent of all nondebitage artifacts (Table 116). Except for the Lott site, which has an unusually high percentage of ceramics, pottery is relatively rare at most bison hunting sites and at rockshelters. Decorated sherds (i.e., painted or incised/engraved) are found occasionally at bison hunting sites and rockshelters, but they are much more common at residential sites. This is especially true for painted pottery. Except for three sherds at one rockshelter, all of the other painted sherds are from residential sites, and none are reported for bison hunting sites. The presence of painted pottery representing imported Puebloan wares is one of the diagnostic attributes of Garza complex residential bases. The relative frequency of painted pottery at residential sites is quite variable, ranging from 1 to 29 percent of all nondebitage artifacts.

Besides their utility as chronological indicators (discussed earlier in this chapter) and for inferring cultural interactions and group mobility (discussed later in this chapter), the ceramics from Tierra Blanca and Garza complex sites reveal much about 


\begin{tabular}{|c|c|c|c|c|c|c|c|}
\hline \multicolumn{8}{|c|}{$\begin{array}{c}\text { COMPARISON OF FREQUENCY OF CERAMIC OCCURRENCE } \\
\text { AT GARZA COMPLEX SITES }{ }^{1}\end{array}$} \\
\hline \multirow[b]{2}{*}{ Site } & \multirow{2}{*}{$\begin{array}{l}\text { Total \# of } \\
\text { Nondebitage } \\
\text { Artifacts }\end{array}$} & \multicolumn{2}{|c|}{ Total Sherds } & \multicolumn{2}{|c|}{ Painted Sherds ${ }^{2}$} & \multicolumn{2}{|c|}{ Incised/Engraved Sherds } \\
\hline & & $\#$ & $\%$ & $\#$ & $\%$ & $\#$ & $\%$ \\
\hline \multicolumn{8}{|c|}{ RESIDENTIAL SITES } \\
\hline Longhorn & 3,002 & 2,576 & 85.8 & 392 & 13.1 & 17 & 0.6 \\
\hline Headstream & 1,014 & 879 & 86.7 & 137 & 13.5 & 0 & 0 \\
\hline Pete Creek & 1,156 & 322 & 27.9 & 46 & 4.0 & 0 & 0 \\
\hline Bridwell & 1,171 & 683 & 58.3 & 337 & 28.8 & 0 & 0 \\
\hline Montgomery & 794 & 250 & 31.5 & 99 & 12.5 & 0 & 0 \\
\hline Floydada Country Club & 400 & 285 & 71.3 & 4 & 1.0 & 0 & 0 \\
\hline \multicolumn{8}{|c|}{ BISON HUNTING SITES } \\
\hline Garza & 263 & 0 & 0 & 0 & 0 & 0 & 0 \\
\hline Lott & 1,043 & 638 & 61.2 & 0 & 0 & 63 & 6.0 \\
\hline Lubbock Lake & 124 & ? & (low) & 0 & 0 & 0 & 0 \\
\hline Canyon Lakes & 395 & 50 & 12.7 & 0 & 0 & 0 & 0 \\
\hline Johnson Creek & 18 & 0 & 0 & 0 & 0 & 0 & 0 \\
\hline Elm Creek & 174 & 18 & 10.3 & 0 & 0 & 0 & 0 \\
\hline \multicolumn{8}{|c|}{ ROCKSHELTERS } \\
\hline Blue Mountain & 201 & 13 & 6.5 & 3 & 1.5 & 0 & 0 \\
\hline Reed Shelter & 16 & 0 & 0 & 0 & 0 & 0 & 0 \\
\hline
\end{tabular}

site function and activities. Many functional inferences are based on the archeological contexts of ceramic finds, vessel forms represented within various ceramic types, and residues or use wear on sherds. A clear pattern of correlation between ceramic type, vessel form, and function has emerged for both the Tierra Blanca and Garza complexes. The two most common ceramic types are painted Puebloan wares, specifically Rio Grande glazewares (noting that many unpainted sherds of unslipped or red- or cream-slipped redware are probably from glazeware vessels also), and a variety of gray to black plainwares that have unfinished or striated exteriors and varying amounts of mica in their pastes. The typical glazeware vessel forms are bowls and ollas, and the typical plainware form is the bean pot jar (Figure 104). The absence of exterior smudging or accumulations of carbonized materials, or interior residues of carbonized organics, indicate that the glazeware vessels probably were not used for cooking. Some of the bowls, such as the partially reconstructed bowl from the Longhorn site (see Boyd et al. 1993:Figure 78), exhibit interior scarring, probably from use as serving vessels. This nearly complete glazeware bowl, apparently made during Glaze V times at Pecos Pueblo, is identical in form to the Figure 104a illustration. Ollas, on the other hand, most likely were used as storage containers. Such vessels probably were used to store a variety of necessities such as water and foodstuffs, as was suggested earlier for an olla cached in a rock ledge near the Blackburn site. This vessel is identified as an intermediate period glaze vessel that was manufactured somewhere in the Galisteo Basin. Its form approximates that shown in Figure $104 b$.

Plainwares found at Tierra Blanca and Garza complex sites represent utilitarian wares, many of which served as cooking vessels. Sherds often contain remnants of charred materials that accumulated on their exteriors from having been placed 

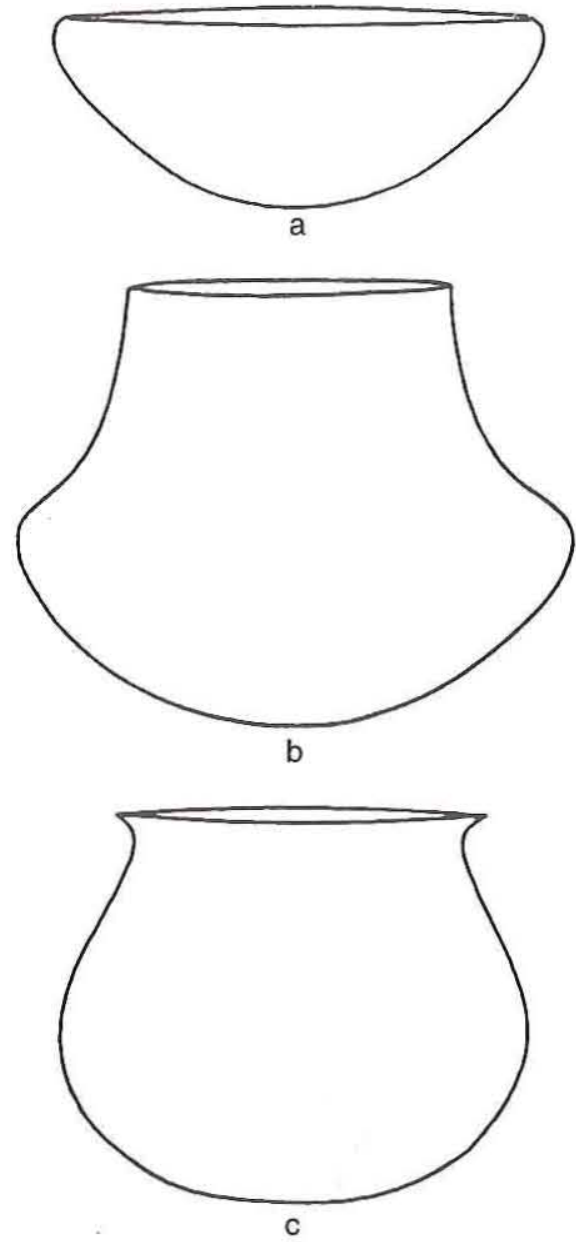

Figure 104. Generalized vessel forms represented in Tierra Blanca and Garza complex ceramic assemblages. The bowl $(a)$ and olla $(b)$ are Pecos Glaze V forms illustrated by Kidder and Shepard (1936:Figure 185c and h). (c) The bean pot jar is a Faint Striated jar form of the Glaze V period illustrated by Kidder and Shepard (1936:Figure 272b) and Habicht-Mauche (1988:Figure 5.5).

close to, or directly in, fires during cooking. Organic residues are frequently are found on sherd interiors and presumably represent accumulations of food residues. A gas chromatograph lipid analysis of organic remains recovered from the interior of a sherd from the Longhorn site revealed a mixture of plant and animal residues, thereby confirming that Plainware Vessel 1 had been a cooking pot (Marchbanks and Quigg 1990).

The only vessel form identified for the unfinished, striated, and/or micaceous plainwares is the globular jar commonly called a bean pot. Numerous examples of partially reconstructed and complete plainware pots are known, and all are of the same basic bean pot form illustrated in Figure 104c. As discussed earlier, several partially reconstructed bean pots have been recovered from Garza complex sites, and a few complete or nearly complete bean pots have been found at isolated locations near Tierra Blanca or Garza complex sites. The presence of plainware sherds at many bison processing localities and hunting camps where pulverized bones are ubiquitous provides circumstantial evidence that these pots were probably used for boiling water to obtain bone grease.

\section{NONCULINARY CERAMICS}

At least 13 ceramic pipes (and 4 or 5 stone pipes that are discussed later) have been found at four Garza complex residential sites (Table 117). These include both elbow and tubular pipes. Six of the tubular pipes, found at three different sites, are identified as Pecos-style pipes that may have been manufactured at Pecos Pueblo. The source of manufacture for the others is not known. Pecos pipes have been found over a large portion of the Southern Plains and are reported at the Pavo site in Coke County (Shafer 1969:58-59, Figure 39j); the Edwards I (Baugh 1982:108, Figure 31j), Little Deer, and Taylor sites (Hofman 1978b:64-65, Figure 28) in western Oklahoma; and at Dismal River sites in Nebraska and Kansas (Gunnerson 1968:180; Hill and Metcalf 1942:185-188; Wedel 1959:445-448, 1986:144).

These pipes were used as smoking implements, and it is suspected that smoking tobacco may have been traded as widely as the pipes. Beyond this, however, their significance is not well understood. Pipe smoking may have been done strictly for pleasure, only at specific times within some ritual/ ceremonial context, or perhaps both. Many cultures around the world incorporate some form of smoking into ritual/ceremonial events, and this seems to have been particularly true among nomadic Plains societies. Among the Comanches, for example, Wallace and Hoebel (1952:180) note the extreme importance of pipe smoking and state that it was always "a ceremonious act" that was "never done casually."

Other nonculinary uses of ceramics include the manufacture of broken pot fragments into new tools. Three refit glazeware potsherds at the Longhorn site exhibited groove and snap breaks that were clearly the result of an attempt to transform a broken pot fragment into some other type of utensil (Boyd et al. 
TABLE 117

SUMMARY OF CERAMIC AND STONE PIPES FOUND AT GARZA COMPLEX SITES

\begin{tabular}{|l|l|}
\hline Site & \multicolumn{1}{|c|}{ Description of Pipes } \\
\hline Longhorn & $\begin{array}{l}\text { Nineteen sherds representing four ceramic pipes. Two pipes of unknown form are each represented } \\
\text { by a single sherd. The other two are partially reconstructed Pecos-style tubular pipes of the "elaborate } \\
\text { rectangular" form described by Kidder (1932:156-182). These latter specimens are illustrated by Boyd } \\
\text { et al. (1993:Figure 82). }\end{array}$ \\
\hline Headstream & $\begin{array}{l}\text { Eight sherds representing three ceramic pipes. One sherd is of a Pecos-style tubular pipe similar to } \\
\text { the "elaborate rectangular" form described by Kidder (1932:156-182). The other two pipes are of } \\
\text { unknown form. }\end{array}$ \\
\hline Bridwell & $\begin{array}{l}\text { Twelve pipe sherds representing an unknown number of ceramic pipes, plus five complete pipes. Two } \\
\text { are ceramic elbow pipes, one is a ceramic tubular pipe, and two are stone tubular pipes (one with an } \\
\text { incised decoration). The five complete pipes are illustrated by Parker (1982:50). }\end{array}$ \\
\hline Montgomery & $\begin{array}{l}\text { Seven sherds representing an unknown number of ceramic pipes, plus four pipes of identifiable form. } \\
\text { One is a partially reconstructed stone elbow pipe. One complete and two fragmentary ceramic pipes } \\
\text { have been identified as Pecos-style tubular pipes of the "flattened slim type" described by Kidder } \\
\text { (1932:158). The complete specimen is illustrated by Northern (1979:Figure 4D). In addition, one } \\
\text { partial stone (possibly Catlinite) elbow pipe and one complete ceramic elbow pipe may have come } \\
\text { from this site. The former is mentioned by Northern (1979:81), and the latter is mentioned and } \\
\text { illustrated by Parker (1982:50, 53). }\end{array}$ \\
\hline
\end{tabular}

1993:183, Figure 80). It is not known whether the piece was broken during the cutting process, or whether it was broken after it had been altered and reused.

One potsherd from the Bridwell site is identified as a possible spindle whorl (Parker 1982:5254). It is a Puebloan-made sherd that was ground into a round disc with a hole drilled through its center. The specimen is virtually identical to modified sherds from Pecos Pueblo that Kidder (1932:Figure 135) identifies as possible spindle whorls used for weaving.

\section{BONE, SHELL, AND OTHER ARTIFACTS}

Artifacts made of chipped siliceous stones and fired clay are dominant in all Tierra Blanca and Garza complex assemblages. With the exception of the pipes, these artifacts generally represent utilitarian tools whose functions are thought to relate primarily to mundane subsistence activities (e.g., procuring, processing, storage, and consumption of food; manufacture of other tools, clothing, shelter, etc.). Artifacts made of other materials, such as bone, shell, and certain kinds of stone, apparently served a wider variety of functions. Some artifacts, such as bone awls, may have served only utilitarian functions, but these other material classes also include nonutilitarian artifacts. For example, beads, pendants, and other items made of bone, shell, and turquoise were used as ornamentation (Table 118). They may have been worn as necklaces, tied into hair, integrated into clothing, or attached as decorations to other items (e.g., hide bags or pipes). The true role that such ornaments played in Tierra Blanca and Garza societies may never be fully understood, but these artifacts provide a glimpse at something other than subsistence activities.

Four, possibly five, stone pipes are reported from two residential sites (see Table 117). Parker (1982:49-53) reports and illustrates three examples from the Bridwell site. One is a complete tubular pipe made of a "cream-colored limestone material." The second specimen, a tubular pipe fragment made of "a white limestone material," is unusual because it has an incised decoration around the bowl. Parker (1982:49) suggests that it is similar to incised Caddoan pipes from East Texas. The third specimen is an elbow pipe fragment made of "a greenish tan limestone material."

A partially reconstructed bowl of an elbow pipe from the Montgomery site is made of an unidentified fine-grained, pink siltstone (Word 1965:77). This material is not as red, nor as fine grained, as 


\begin{tabular}{|c|c|c|c|}
\hline \multicolumn{4}{|c|}{$\begin{array}{l}\text { TABLE } 118 \\
\text { UMMARY OF ORNAMENTAL STONE, BONE, AND SHELL ARTIFACTS } \\
\text { AT GARZA COMPLEX SITES }\end{array}$} \\
\hline Site & Bone Ornaments & Shell Ornaments ${ }^{2}$ & Stone Ornaments \\
\hline \multicolumn{4}{|c|}{ RESIDENTIAL SITES } \\
\hline Longhorn & & 1 Olivella bead & 1 turquoise bead \\
\hline Headstream & & 2 mussel beads & \\
\hline Pete Creek & & 4 mussel beads & \\
\hline Bridwell & $\begin{array}{l}13 \text { turkey or bird tubular } \\
\text { beads }\end{array}$ & $\begin{array}{l}22 \text { Olivella beads } \\
14 \text { Conus and Oliva tinklers } \\
3 \text { mussel beads } \\
10 \text { mussel pendants }\end{array}$ & $\begin{array}{l}4 \text { turquoise beads } \\
3 \text { turquoise pendants } \\
1 \text { fossil bead }\end{array}$ \\
\hline Montgomery & 11 tubular beads & $\begin{array}{l}2 \text { Olivella beads } \\
2 \text { mussel blanks } \\
1 \text { mussel pendant }\end{array}$ & 1 turquoise bead \\
\hline $\begin{array}{l}\text { Floydada Country } \\
\text { Club }\end{array}$ & $\begin{array}{l}1 \text { tubular bead } \\
1 \text { disc bead }\end{array}$ & $\begin{array}{l}1 \text { Olivella bead } \\
1 \text { Oliva bead } \\
2 \text { mussel beads or blanks }\end{array}$ & \\
\hline \multicolumn{4}{|c|}{ BISON HUNTING SITES } \\
\hline Garza & $\begin{array}{l}4 \text { tubular beads } \\
2 \text { wolf teeth pendants }\end{array}$ & & \\
\hline Lott & $\begin{array}{l}2 \text { coyote or wolf tubular } \\
\text { beads }\end{array}$ & $\begin{array}{l}13 \text { Dentalium beads } \\
1 \text { mussel pendant }\end{array}$ & \\
\hline Lubbock Lake & 2 tubular beads & & \\
\hline Johnson Creek & 2 tubular beads & & \\
\hline \multicolumn{4}{|c|}{ ROCKSHELTERS } \\
\hline $\begin{array}{l}\text { Blue Mountain } \\
\text { Rockshelter }\end{array}$ & 6 tubular beads & $\begin{array}{l}1 \text { mussel bead } \\
1 \text { mussel pendant } \\
1 \text { gastropod bead }\end{array}$ & \\
\hline \multicolumn{4}{|c|}{$\begin{array}{l}{ }^{1} \text { Includes some specimens known to have been recovered from sites but not included in the quantified artifa } \\
\text { assemblages. } \\
{ }^{2} \text { Genus is identified for imported marine shell artifacts; all other artifacts are presumed to be of local shell. }\end{array}$} \\
\hline
\end{tabular}

catlinite. In addition, Northern (1979:81) discusses a catlinite elbow pipe found by Wayne Parker, but how or by whom the identification was made is not mentioned. This specimen may be from the Montgomery site. If so, it is the only possible catlinite pipe known to have come from a Garza complex site.

Limonite and hematite are naturally occurring ferrous minerals that are common in the Triassic deposits and residual gravels along the Caprock Escarpment. Modified hematite and limonite are generally thought to represent materials that were used as a source of pigment for making paints. Modified specimens in archeological sites typically have one or more faces that exhibit striations that were ground flat. Limonite is a yellowish mineral 
that naturally alters through time into a reddish form called specular hematite (Pough 1960:124). Modified limonite is less common in archeological deposits because it is not as durable as hematite. Modified hematite pieces are found in Late Prehistoric and Protohistoric sites with some consistency, although never in any great quantities. Its absence in many assemblages, however, particularly those from residential sites, may be due to the fact that small modified fragments are not recognized by archeologists or are not quantified in artifact counts. Northern (1979:22), for example, mentions finding hematite at the Montgomery site but does not quantify the specimens or state whether any are modified.

The red pigment derived from hematite may have been used in many different ways. Red-painted petroglyphs and red pictographs are fairly common throughout the region (see Chapter 6), and the author also has seen red-painted images on ground stones in collections from Garza County. It is assumed, but has not been proven, that some of these red pigments were derived from hematite. In all likelihood, hematite pigments were used to paint a number of perishable items, such as buffalo robes, tipi covers, containers such as hide bags and baskets, and clothing. In addition, powdered hematite could have been used for body tattooing. Tattooing was common among Caddoan-speaking peoples including the Protohistoric Wichita (Newcomb 1961:250-251, 289-290), a number of unknown striped and painted Plains peoples generically called "Rayados" (Hickerson 1994:XX; Sauer 1934:66; Scholes and Mera 1940:275), and possibly the enigmatic Plains peoples called Jumanos.

Turquoise beads and pendants have only been found at residential sites. Spielmann (1982:Table 34) reports a turquoise fragment and a bead from the Tierra Blanca site, and nine turquoise beads and pendants have been found at three Garza complex sites. A turquoise bead from the Longhorn site is illustrated by Boyd et al. (1993:Figure 90), a turquoise bead from the Montgomery site is illustrated by Word (1965:Figure 10N), and three pendant fragments recovered from the Bridwell site are illustrated by Parker (1982:42). The frequency of turquoise artifacts from Garza complex sites probably underrepresents their actual occurrence because some specimens found by collectors do not show up in the artifact counts for archeologically recovered assemblages (see Table 104). The Montgomery site is a case in point. No turquoise is present in the artifacts recovered during the 1965 or 1978 investigations, but another collector found a turquoise bead on the surface (Word 1965:77). In addition, many small specimens have probably been missed in excavations because no fine screening or flotation was done. The tiny bead from the Longhorn site was found in a flotation sample from a basin hearth. In reference to small turquoise and shell beads at the Bridwell site, Parker (1982:38) acknowledged that many small beads were probably "lost while screening with the quarter inch wire."

Most researchers have generally assumed that the turquoise objects found in Protohistoric sites in the Texas Panhandle-Plains and western Oklahoma ultimately were derived from New Mexican turquoise sources via the Puebloan trade. While this is likely to be true in most cases, it is noteworthy that a turquoise source has been identified in the Ouachita Mountains of Arkansas and was exploited by Late Prehistoric and Historic Caddoan peoples (Early 1978, 1988). The possibility that Arkansas turquoise was traded into the Panhandle-Plains during Late Prehistoric and Protohistoric times should not be discounted. Preliminary trace element analyses using x-ray fluorescence and neutron activation techniques provide promising results indicating that the Arkansas turquoise is distinctive from New Mexican turquoise (Early 1988:131).

At least 44 bone beads have been found at eight Garza complex sites, including both disk and tubular varieties (see Table 118). Most of the tubular beads are not identified to species, but some are identified as being made of turkey or bird and coyote or wolf bones. At least one tubular bone bead from the Montgomery site is engraved with a geometric design (Word 1991a:Figure 12K). Word (1965:43) notes that Canis toe bones exhibited a variety of modifications that probably represent various stages of bone bead manufacture.

Runkles (1964:106-107, Figure 3A and B) describes and illustrates two wolf-tooth pendants from the Lott site. Wolf or canine teeth are reported at other Garza complex sites (e.g., Lubbock Lake, Canyon Lakes, and Johnson Creek), but the two Garza site specimens have shallow grooves engraved around the end of the root, presumably for suspension.

Bone awls are reported for eight Garza complex sites and appear to be found with equal regularity in residential sites, bison kill/processing sites, and 
rockshelters (see Table 104). The best sample is from the Bridwell site where 27 specimens are reported by Parker (1982:36-37). Five are illustrated, and they represent two different types: single-pointed awls made from split deer metapodials and double-pointed awls made from unidentified animal bones. Other bone awls are illustrated by Parsons (1967:Figure 17B and C), Runkles (1964: Figure 3C and D), and Runkles and Dorchester (1987:Figure 17B). It is usually suggested that bone awls are related to hide and leather working, but they may have been used for a wider variety of tasks.

Other modified bones include a range of different tools of unknown function. Parker (1982:33-36) and Parsons (1967:Figure 17) illustrate several types of bone tools of unknown or speculative functions recovered at the Bridwell and Pete Creek sites, including a flat bone tablet of unknown function, bone rasps used as musical instruments, a bone piece used as a knife handle, perforated bones with small drilled holes that may have been used as sewing needles, perforated bones with larger drilled holes that may have been used as shaft wrenches, and bone expedient tools used in bison butchering tasks.

Bone weaving tools are reported from the Bridwell site $(\mathrm{n}=7)$ by Parker $(1982: 36-37)$ and the Montgomery site $(n=3)$ by Word $(1965: 82$, Figure 10B) and Northern (1979:44-47, Figure 3A). Northern (1979:46) notes that the possible weaving tools from the Montgomery site are similar to those from Pecos Pueblo, as described and illustrated by Kidder (1932:225-227, Figure 190a-c).

Modified freshwater mussel shells are well represented in some Garza complex residential sites, and they apparently were a favored material from which jewelry was made. At least 24 beads, pendants, and blanks are reported from eight sites (see Table 118). Based on the variety of modified mussel shells from the Bridwell site, Parker (1982: 46-48) suggests that the full sequence of shell ornament manufacture is represented. Numerous small oval pieces, or "buttons," were found. Most had two holes drilled in them and small notches along their edges. One was an unfinished oval blank. Two modified valves were discarded in the process of being carved into oval blanks. One of these had two oval outlines etched into it, while a second had two oval blanks already removed from it. The latter specimen was found along with a flint tool that Parker (1982:14) confidently states was used to engrave mussel shells. In addition, 16 complete and unmodified mussel valves probably represent shells intended for manufacture into jewelry but never used.

Two ovate shell blanks from the Montgomery site are described and illustrated by Word (1965: $77-79$, Figure $10 \mathrm{o}$ and $\mathrm{p}$ ). Noting that mussel shell fragments were fairly common at the site, he suggested that they represent source materials for, and byproducts of, the manufacture of shell ornaments. Other mussel shell ornaments are illustrated by Boyd et al. (1993:Figure 25a and b), Parsons (1967:Figure 17F-H), Runkles and Dorchester (1987:Figure 16), and Word (1965:Figure 7X).

Mussel shell valves also appear to have been used occasionally by Garza peoples as functional tools. Parsons (1967:53-56) described seven specimens (as Forms I and V) that exhibit ground edges that may be the result of use wear. He speculated that these mussel valves had been used as scrapers.

Ornaments made from nonlocal marine shells are reported for five sites (see Table 118). These are identified as being of the following families or genera: Conus and Oliva $(\mathrm{n}=15)$, Dentalium $(\mathrm{n}=1)$, and Olivella $(\mathrm{n}=26)$. The Dentalium and Olivella specimens are identified as Pacific Coast shells, and Garza peoples probably obtained them indirectly through the Pueblo trade.

Although they have not been counted as artifacts in most cases, many unusual stones, concretions, and fossils found at Garza complex residential sites are from contexts indicating that they are manuports. Parker (1982:44) notes that two spherical "sandstone balls," apparently naturally occurring concretions, were found at the Bridwell site. Boyd et al. (1993:190-193, Figures 83-86) discuss a range of unusual unmodified specimens, grouped as oddshaped stones (round sandstone concretions and cylindrical and disk-shaped stream cobbles), fossils (Cretaceous gastropods and pelecypods), and hematite and limonite concretions (very symmetrical round balls). That all of these specimens were brought onto the sites is certain; their functions, however, are speculative. These oddities may have served as gaming pieces, children's toys, or simply novelty items. It also is possible that some were used in a ceremonial fashion. Kidder (1932:106109) noted that hundreds of fossils were found in "medicine outfits" associated with burials at Pecos Pueblo.

A few artifacts found at Garza complex sites 
could represent pottery-smoothing or polishing tools. These include a small polished river pebble from the Bridwell site (Parker 1982:44) and two small multifaceted sandstone pieces from the Longhorn site (Boyd et al. 1993:159-160, Figure 70c and d). This tentative identification suggests that some manufacture of pottery might have occurred at these sites.

A ground stone disk with a hole through its center was recovered from the Bridwell site. Like its ceramic counterpart mentioned above, this artifact is interpreted as a possible spindle whorl by Parker (1982:52-54).

One unusual artifact type within the ground stone class is pipe plugs. Only two of these artifacts have been reported; both are from the Longhorn site (Boyd et al. 1993:159, Figure 70a and b). They are small sandstone pieces that were intentionally ground into cylindrical shapes, and they exhibit considerable heat discoloration. Because of their small size and shape and thermal alteration, these specimens are interpreted as plugs used inside large-bore tubular pipes like the Pecos-style pipes found at the site. Similar pipe plugs, two of sandstone and one of clay, were found in the smoke passages of three pipes at Pecos Pueblo (Kidder 1932:156).

\section{ARTIFACTS OF EUROPEAN MANUFACTURE OR INTRODUCTION}

Items of European manufacture or introduction are of particular importance because they denote some form of contact, direct or indirect, with European peoples. Since a few such items have been found at five of the residential base sites (Table 119), it may be speculated that Garza complex peoples had come under limited influence from Europeans by the mid to late seventeenth century. Three consistent problems arise, however, when interpreting the age and cultural significance of European artifacts found in these sites. First, the precise time of manufacture or introduction of many of the artifacts cannot be determined. The glass beads, for example, are virtually unknown in terms of when and where they were manufactured. The second problem is that, even if the precise age of manufacture is known, it is uncertain how much lag time might have been involved between the item's manufacture, its acquisition by Plains peoples, and its deposition at the site. The third problem, which is particularly obvious in the Floydada Country Club and Bridwell site assemblages, is that some sites produce European artifacts that were manufactured some time after the presumed disappearance of the Garza complex. The extent to which such sites may have been reoccupied by subsequent peoples is difficult to determine, especially for sites where few features have been excavated and radiocarbon dated. Despite these problems, the evidence does suggest that Garza peoples were beginning to obtain significant amounts of European trade items just prior to their disappearance from the archeological record.

\begin{tabular}{|l|l|}
\hline \multicolumn{2}{|c|}{ TABLE 119 } \\
SUMMARY OF EUROPEAN-MANUFACTURED \\
OR -INTRODUCED ARTIFACTS RECOVERED \\
FROM GARZA COMPLEX SITES
\end{tabular}




\section{Features}

A limited number and range of features have been investigated and reported for Tierra Blanca complex sites (Table 120). The diversity of features is low because few sites have been investigated. In addition, many of the investigations have not been analyzed and published, and most of the reported features have only been mentioned, but not described, in the publications. A greater number of features and broader range of feature types, and several types of activity areas, are reported for the Garza complex (Table 121). While many of the features are not adequately reported, others have been described in detail and associated organic remains have been radiocarbon dated.

The recognition of domestic structures is critical for interpreting the remains of the Tierra Blanca and Garza complexes. Based on associations between archeological features, the presence of ephemeral houses, such as tipis, wickiups, or wattle and daub (i.e., jacal-like huts), has been inferred at several sites (Table 122). Most of these structures have a central firepit, and the association between structures and firepits is discussed in more detail below. These structures represent houses that were either extremely portable, as in the case of tipis, or easy to construct and made of immediately local materials, as is the case with small brush and/or mud enclosures. Except for the manufacture of hide tipi covers, it is unlikely that any of these dwellings represent a significant investment of labor. The only possible exception is that masonry structures, perhaps constructed of caliche rocks and mud, are rumored to be present at the Yellow Houses Ruins. This interpretation is tenuous, however, because no scientific investigations have been done and the site's association with the Garza complex is questionable at best.

TABLE 120

COMPARISON OF FEATURES ASSOCIATED WITH TIERRA BLANCA COMPLEX COMPONENTS

\begin{tabular}{|c|c|c|c|c|c|}
\hline \multirow[b]{2}{*}{ Feature Type } & \multirow{2}{*}{$\begin{array}{l}\text { Residential Sites } \\
\text { Tierra Blanca }\end{array}$} & \multicolumn{3}{|c|}{ Bison Hunting Sites } & \multirow{2}{*}{$\begin{array}{l}\text { Rockshelter } \\
\text { Canyon City } \\
\text { Club Cave }\end{array}$} \\
\hline & & Fifth Green & $\begin{array}{l}\text { Tule Mouth } \\
\text { Site } 41 B I 83\end{array}$ & Palisades & \\
\hline Unlined basin hearth & - & 1 & 1 & - & - \\
\hline $\begin{array}{l}\text { Ash dump or ephemeral unlined } \\
\text { hearth }\end{array}$ & - & - & - & $1 ?$ & - \\
\hline Debris midden & - & 1 & - & - & - \\
\hline Bison processing area & - & $\mathrm{x}$ & $\mathrm{x}$ & - & - \\
\hline Bison bone stakes & - & 5 & - & $\mathrm{x}$ & - \\
\hline $\begin{array}{l}\text { Undefined circular rock ring } \\
\text { (semisubterranean?) }\end{array}$ & $1 ?$ & - & - & - & - \\
\hline $\begin{array}{l}\text { Tipi ring (with central, unlined } \\
\text { basin hearth) }\end{array}$ & 1 & - & - & - & - \\
\hline $\begin{array}{l}\text { Partial tipi ring or ephemeral } \\
\text { structure }\end{array}$ & 1 & $1 ?$ & - & - & - \\
\hline $\begin{array}{l}\text { Wattle-and-daub structure (with } \\
\text { central unlined basin hearth) }\end{array}$ & - & - & - & $1 ?$ & - \\
\hline Human burial & - & - & - & - & 1 \\
\hline
\end{tabular}




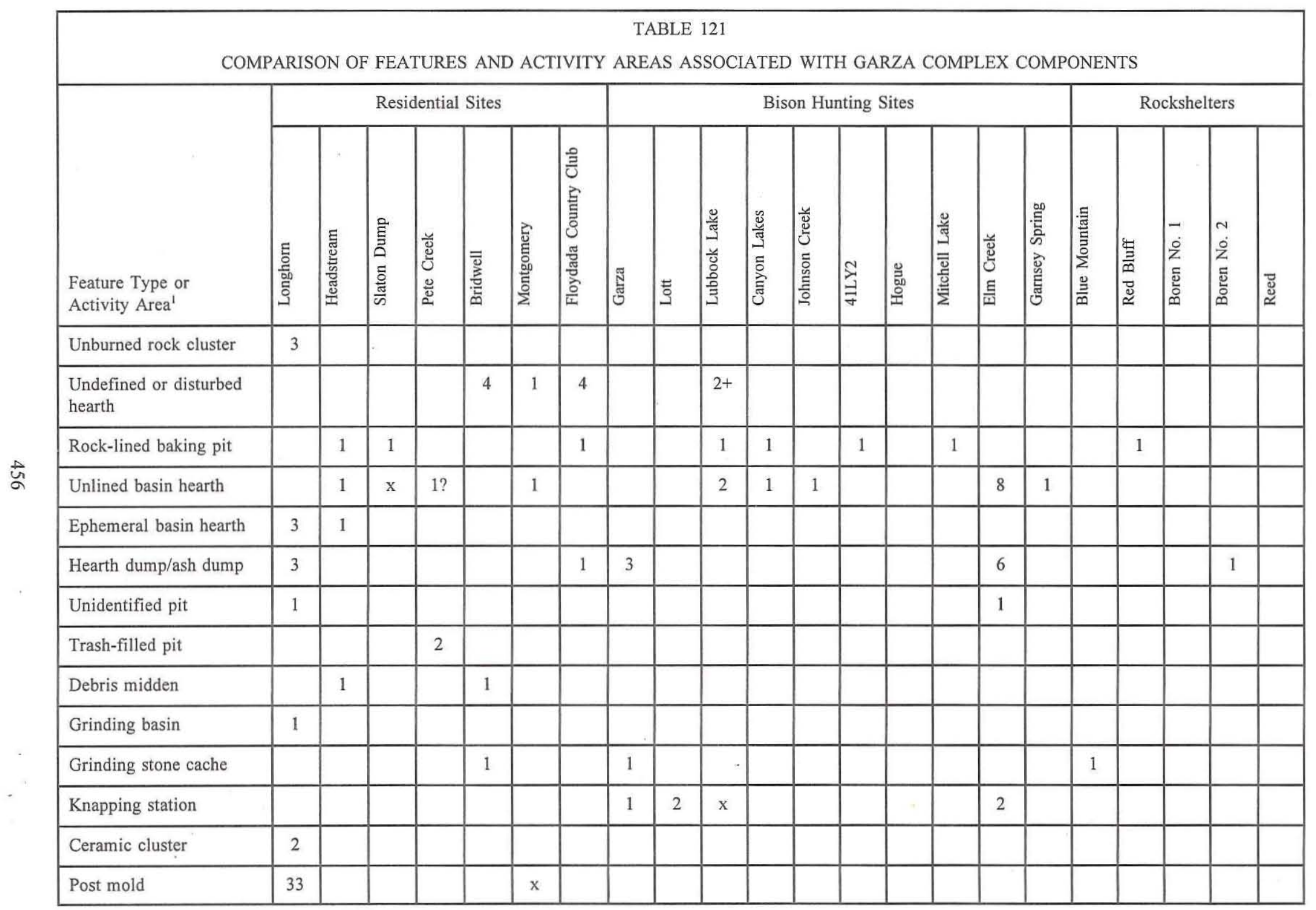




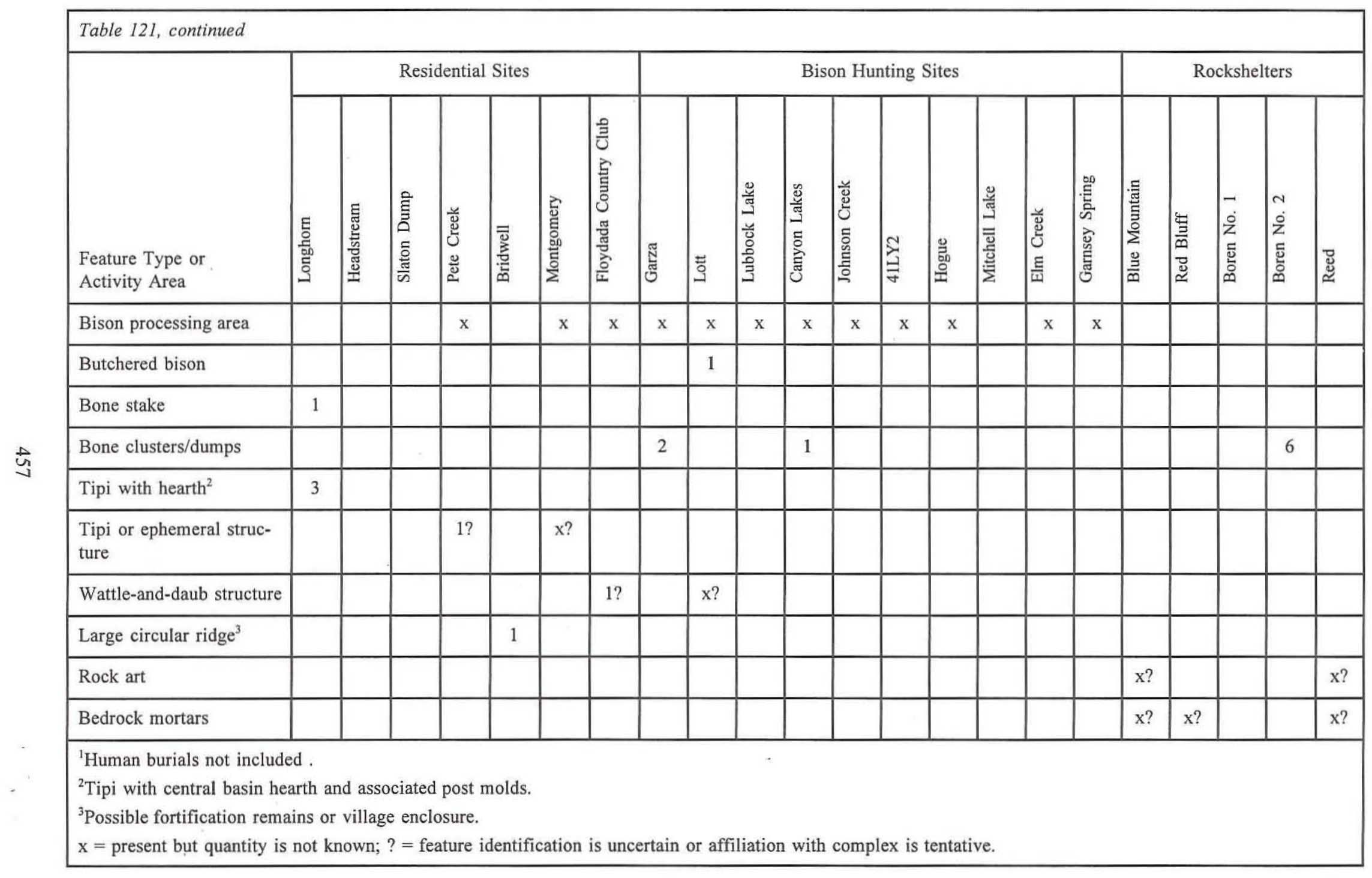




\begin{tabular}{|c|c|c|c|}
\hline \multicolumn{4}{|c|}{$\begin{array}{c}\text { SUMMARY OF STRUCTURES ASSOCIATED WITH TIERRA BLANCA } \\
\text { AND GARZA COMPLEX OCCUPATIONS }\end{array}$} \\
\hline Site & $\begin{array}{l}\text { Structure } \\
\text { Designation }\end{array}$ & Structure Type and Description & $\begin{array}{l}\text { No. of } \\
\text { Radiocarbon Dates }\end{array}$ \\
\hline \multicolumn{4}{|c|}{ TIERRA BLANCA COMPLEX } \\
\hline Tierra Blanca & "tipi ring" & $\begin{array}{l}\text { Tipi inferred from rock ring and associated central } \\
\text { unlined basin hearth. }\end{array}$ & 1 \\
\hline \multicolumn{4}{|c|}{ GARZA COMPLEX } \\
\hline \multirow[t]{3}{*}{ Longhorn } & Block 1 tipi & $\begin{array}{l}\text { Tipi inferred by association of unlined basin hearth, } \\
\text { bone tie-down stake, and other postholes. }\end{array}$ & 1 \\
\hline & Block 3 tipi & $\begin{array}{l}\text { Tipi inferred by association of unlined basin hearth, } \\
\text { tie-down stake hole, and other postholes. }\end{array}$ & 1 \\
\hline & Block 4 tipi & $\begin{array}{l}\text { Tipi inferred by association of unlined basin hearth, } \\
\text { tie-down stake hole, and other postholes. }\end{array}$ & 1 \\
\hline Pete Creek & none & $\begin{array}{l}\text { Possible tipi inferred by arc-shaped rock alignment; } \\
\text { no hearth associated. }\end{array}$ & - \\
\hline Montgomery & none & $\begin{array}{l}\text { Possible tipi inferred by association of unlined } \\
\text { basin hearth and nearby postholes. }\end{array}$ & - \\
\hline $\begin{array}{l}\text { Floydada } \\
\text { Country Club }\end{array}$ & $\begin{array}{l}\text { "daub } \\
\text { concentration" }\end{array}$ & $\begin{array}{l}\text { Possible wattle-and-daub house; the area was only } \\
\text { partially excavated, but no associated hearth was found. }\end{array}$ & - \\
\hline
\end{tabular}

The most temporally diagnostic type of feature at Tierra Blanca and Garza sites is the unlined basin hearth (see Figure 62). Unlined basin hearths are circular to ovate in plan view and planoconvex in cross section. These shallow basins typically range in maximum diameter from about $40 \mathrm{~cm}$ to just under $100 \mathrm{~cm}$ and from 10 to $15 \mathrm{~cm}$ in depth. The basins are filled with gray or white ashy sediment and occasional charcoal flecks, and large chunks of carbonized materials are rare. The fill may or may not contain small artifacts (e.g., flakes and bone fragments) or even a few burned rocks, but, unlike most hearth features, these basins are not lined with rocks. They typically have smooth bottoms, and they may have a well-defined basal rind of reddish orange oxidized sediment. Some appear to have been intensively heated, probably from being reused many times, while others appear to have been used relatively little.

All of the dated unlined basin hearths in the Texas Panhandle-Plains are from the Late Prehistoric I or Protohistoric periods. Twenty-eight of these features have been reported in association with Tierra Blanca or Garza complex components, and 12 of these have been radiocarbon dated (Table 123). Very few features from earlier time periods are similar to these distinctive hearths, and the author knows of no similar features in Texas that can definitely be attributed to any pre-A.D. 1200 occupations. In eastern New Mexico, one basin hearth at the Garnsey Spring site produced a corrected charcoal radiocarbon date of A.D. $855 \pm 55$ (uncalibrated). The site contains a variety of Late Prehistoric artifacts and the date may be valid, but the nearby "Garza hearth" is nearly identical and is radiocarbon dated to the seventeenth century (see Garnsey Spring site in Table 123). Based on Table 123, the earliest unlined basin hearth dates to the first half of the thirteenth century. This date, associated with Feature 4 at the Longhorn site, is questionable, however, because it was obtained on sediment (rather than charcoal) and is much earlier than the other dates associated with the same occupational zone. The next earliest date, on Feature 3 at Canyon 
Lakes, is from the fourteenth century. Since this is one of three dates on the same feature, however, and since the other two assays produced mid-fifteenthcentury dates, it also is questionable. If these two early dates are excluded, 11 of the features are radiocarbon dated to the fifteenth, sixteenth, and seventeenth centuries.

Compared to the larger rock-lined hearths that are common in earlier periods, these smaller unlined basin hearths represent carefully controlled fires that may have been used in conjunction with ceramic vessels. Cooking in pots required less fuel, and it could be concentrated in a smaller area because the vessel could be placed just above or directly into the fire. It is probably not a coincidence that these features are almost always found on sites where sherds of plainware pottery are found. There is considerable evidence indicating that many of these features were associated with structures at residential bases. At the Longhorn site, three of these features were found in contexts indicating that they were fireplaces inside tipis. These hearths would have been well suited for heating and cooking in tipis or wickiups because smaller fires in shallow basins would have been easier to control, they would have made more-efficient use of limited fuel, and they would have created less smoke. All of these factors would have been important inside dwellings and at residential bases where larger numbers of people used more firewood over longer periods of time.

While some of the unlined basin hearths are definitely associated with features interpreted as structures, others are not. In many cases, however, the excavated areas around hearths were relatively small (e.g., only a few test units), and associated structural evidence could have been missed. At least threeephemeral basin hearths at the Longhorn site appear to represent outdoor fireplaces. They were found in large excavation blocks, and there was no evidence that they were associated with other features that might represent tipis or ephemeral enclosures (although it is possible that these hearths could have been associated with tipis where tie-down stakes were not needed, such as at short-term encampments during periods when high winds were not expected). At the Longhorn site, detailed study of the feature fill helped define diagnostic characteristics that seem to distinguishing tipi hearths from the more ephemeral outdoor hearths. Boyd et al. (1993:215-216) observed that, relative to the ephemeral basin hearths, the basin hearths inside tipis have a more intensively burned/oxidized base. The fill within the tipi hearths also contains (1) a greater amount of completely oxidized white ash, (2) a greater frequency of small bone fragments, including burned specimens, and (3) a greater frequency of debitage, including microdebitage and burned specimens. These characteristics suggest that the central fireplaces inside structures were used more frequently and for longer periods of time, and that they served as temporary receptacles for debris that was generated inside the house.

Mounded concentrations of ashy sediment are often found at sites where unlined basin hearths occur, but they lack evidence of in situ burning and have flat bottoms. Three such features were found at the Longhorn site, and their fill is virtually identical to that found in the tipi-related and ephemeral basin hearths. These features are interpreted as ash dumps resulting from occasional cleaning of unlined hearths.

Unlined basin hearths also are thought to be associated with a tipi at the Tierra Blanca site and with a possible wattle-and-daub house at the Palisades site. Word (1991a:87, Figure 13) notes that a probable wattle-and-daub structure was encountered at the Floydada Country Club site, but since the excavators inadvertently dug through the floor level and only a portion of the area was excavated, it is not known whether a basin was associated.

An unlined basin hearth also was found in a possible structural context at the Pavo site (41CK120) in Coke County. Reported by Shafer (1969:58-59), charcoal from this feature was radiocarbon dated to the seventeenth or eighteenth century (Table 124). A Pecos-style cloudblower pipe, very similar to those found at the Longhorn site, was found in the fill and confirms the late age of the feature (see Shafer 1969:Figure 39J). Of particular interest are three small soil anomalies, thought to be post molds, found in close proximity to the hearth and perhaps representing central tie-down stakes inside tipis. Since this is a multicomponent site that yielded Perdiz points, the basin hearth could be affiliated with the Toyah phase. No Perdiz points were found in direct association with this feature, however, and it is possible that this feature represents a Garza complex occupation. Garza points are common in the area, and one was recovered from the nearby Airoso site (Shafer 1969: 31, Figure 22L). Shafer (1971:136) speculated that the late occupations at the Pavo site could represent Apachean peoples. 


\begin{tabular}{|c|c|c|c|}
\hline \multicolumn{4}{|c|}{$\begin{array}{l}\text { SUMMARY OF UNLINED BASIN HEARTHS ASSOCIATED WITH } \\
\text { TIERRA BLANCA AND GARZA COMPLEX OCCUPATIONS }\end{array}$} \\
\hline Site & $\begin{array}{l}\text { Feature } \\
\text { Designation }\end{array}$ & Archeological Context & $\begin{array}{l}\text { Calibrated Radiocarbon Date } \\
\text { Range and Intercepts, A.D. }{ }^{1}\end{array}$ \\
\hline \multicolumn{4}{|c|}{ TIERRA BLANCA COMPLEX } \\
\hline Tierra Blanca & none & $\begin{array}{l}\text { associated with "tipi ring" at residential } \\
\text { base }\end{array}$ & $1412(1436) 1449$ \\
\hline Fifth Green & $\mathrm{F} 1$ & associated with bison processing area & - \\
\hline $\begin{array}{l}\text { Tule Mouth } \\
\text { Site } 41 \text { BI } 83\end{array}$ & F1 & associated with bison processing area & $1439(1490) 1643$ \\
\hline Palisades & none & $\begin{array}{l}\text { associated with possible wattle-and-daub } \\
\text { house }\end{array}$ & - \\
\hline \multicolumn{4}{|c|}{ GARZA COMPLEX } \\
\hline \multirow[t]{6}{*}{ Longhorn } & F4 & associated with tipi at residential base & $1159(1215) 1262 ;$ sediment $^{2}$ \\
\hline & F8 & associated with tipi at residential base & $1487(1528,1631) 1648$; sediment $t^{2}$ \\
\hline & F39 & associated with tipi at residential base & $1527(1650) 1952^{2}$ \\
\hline & F9 & associated with residential base & $1519(1642) 1652$ \\
\hline & F16 & associated with residential base & - \\
\hline & F30 & associated with residential base & - \\
\hline \multirow[t]{2}{*}{ Headstream } & F7 & associated with residential base/base camp & - \\
\hline & F8 & associated with residential base/base camp & -3 \\
\hline Slaton Dump & none/multiple & $\begin{array}{l}\text { unspecified number of hearths associated } \\
\text { with residential base/base camp }\end{array}$ & - \\
\hline Pete Creek & none & associated with residential base/base camp & - \\
\hline Montgomery & none & associated with residential base/base camp & - \\
\hline \multirow[t]{2}{*}{ Lubbock Lake } & FA4-3 & associated with bison processing area & - \\
\hline & FA14-1 & associated with bison processing area & $1479(1527,1559,1630) 1651$ \\
\hline Canyon Lakes & F3 & associated with bison processing area & $\begin{array}{l}1284(1303,1372,1383) 1408 \\
1411(1444) 1632 \\
1432(1449) 1625\end{array}$ \\
\hline Johnson Creek & none & associated with bison processing area & - \\
\hline \multirow[t]{3}{*}{ Elm Creek } & F9 & associated with bison processing area & -4 \\
\hline & F15 & associated with bison processing area & -4 \\
\hline & F16 & associated with bison processing area & - \\
\hline
\end{tabular}




\begin{tabular}{|c|c|c|c|}
\hline Site & $\begin{array}{l}\text { Feature } \\
\text { Designation }\end{array}$ & Archeological Context & $\begin{array}{l}\text { Calibrated Radiocarbon Date } \\
\text { Range and Intercepts, A.D. }\end{array}$ \\
\hline \multirow[t]{5}{*}{$\begin{array}{l}\text { Elm Creek, } \\
\text { continued }\end{array}$} & F17 & associated with bison processing area & $\begin{array}{l}1406(1429) 1445 \\
1431(1451) 1631\end{array}$ \\
\hline & F21 & associated with bison processing area & $1519(1642) 1656^{5}$ \\
\hline & F25 & associated with bison processing area & $1437(1455,1480) 1633$ \\
\hline & F27 & associated with bison processing area & - \\
\hline & $\mathrm{F} 30$ & associated with bison processing area & - \\
\hline Garnsey Spring & $\begin{array}{l}\text { "Garza } \\
\text { hearth" }\end{array}$ & $\begin{array}{l}\text { isolated hearth associated with bison } \\
\text { kill and processing area }\end{array}$ & $1527(1648) 1664$ \\
\hline $\begin{array}{l}{ }^{1} \text { All dates are ol } \\
{ }^{2} \text { These three fea } \\
\text { F39, A.D. } 1684- \\
{ }^{3} \mathrm{~F} 8 \text { is dated by } \\
{ }^{4} \text { These two featl } \\
{ }^{5} \mathrm{~F} 21 \text { is dated by }\end{array}$ & $\begin{array}{l}\text { harcoal unles } \\
\text { es also are de } \\
189 \text {. } \\
\text { cheomagnetic } \\
\text { s are dated by }\end{array}$ & $\begin{array}{l}\text { therwise specified. } \\
\text { by archeomagnetic assay: F4, A.D. } 13 \\
\text { ay to A.D. } 1518-1686 \text {. } \\
\text { rcheomagnetic assay: F9, A.D. } 1400-18 \\
\text { ssay to A.D. } 1425-1700 \text {. }\end{array}$ & 1562; F8, A.D. 1378-1632; and \\
\hline
\end{tabular}

The second interesting type of feature associated with the Tierra Blanca and Garza complexes is the circular baking pit. Whether rock-lined or filled with rocks, ashy sediment, and charcoal, circular baking pits are present at several Garza complex sites; none are definitely associated with Tierra Blanca occupations. Two radiocarbon dates on a roasting pit at the Tierra Blanca site indicate that the feature dates to the thirteenth to fifteenth centuries (see Table 86). This feature could be associated with either the Antelope Creek phase or the Tierra Blanca complex. Because the current sample of excavated features is so small, the use of baking pits by Tierra Blanca peoples is uncertain.

At least eight features attributed to the Garza complex are defined as, or can be reinterpreted as, baking pits or earth ovens, although some were called hearths or pottery kilns by the original investigators (Table 125). Four of these features have been radiocarbon dated, and the resulting calibrated ages cluster into two groups: one in the fifteenth century (two dates on two features) and one in the seventeenth century (four dates on three features). Circular baking pits associated with Garza complex occupations generally range from 50 to $120 \mathrm{~cm}$ in diameter and 20 to $40 \mathrm{~cm}$ in depth. Depending upon where the feature is located, the associated burned rocks may be exclusively caliche (e.g., Canyon Lakes and Lubbock Lake), sandstone (e.g., Headstream), or limestone (i.e., Red Bluff Shelter). These features are generally assumed to be earth ovens for cooking plant foods, but no macrobotanical evidence has come to light to provide definitive evidence of what foods were cooked in these pits.

Many circular baking pits have been found in the southern end of the geographic range of the Garza complex, but they cannot be attributed to any specific culture or complex. Eight similar features were found at the Walker No. 2 site (41CK137) at Robert Lee Reservoir in Coke County (Riggs 1971; Shafer 1971:113-122), and one such feature is reported at site 41ST80 in Sterling County (Riemenschneider 1994b). All are interpreted as having been cooking pits, and three produced charcoal samples that have been radiocarbon dated to the seventeenth and/or eighteenth centuries (see Table 124). No Perdiz or Garza points have been found in direct association with any of these features, but both styles are found in the area. At Robert Lee Reservoir, Shafer (1971:136) notes that bison hunting was the primary activity represented in the Protohistoric component at the Agarita site, while the contemporaneous baking pits at the Walker No. 2 site are interpreted as evidence for plant-oriented subsistence 


\section{TABLE 124}

\section{SUMMARY OF RADIOCARBON DATES ON AN UNLINED BASIN HEARTH AND BAKING PITS ASSOCIATED WITH UNDEFINED PROTOHISTORIC OCCUPATIONS IN WEST-CENTRAL TEXAS}

\begin{tabular}{|c|c|c|c|c|c|}
\hline $\begin{array}{l}\text { Site Name } \\
\text { and Number }\end{array}$ & Reference & $\begin{array}{l}\text { Material and } \\
\text { Lab No. }\end{array}$ & $\begin{array}{l}\text { Uncorrected } \\
\text { Age, B.P. }\end{array}$ & $\begin{array}{l}\text { Corrected } \\
\text { Age, B.P. }{ }^{1}\end{array}$ & $\begin{array}{l}\text { Calibrated Date Range } \\
\text { and Intercepts, A.D. }{ }^{2}\end{array}$ \\
\hline \multicolumn{6}{|c|}{ UNLINED BASIN HEARTH } \\
\hline $\begin{array}{l}\text { Pavo } \\
41 \mathrm{CK} 120\end{array}$ & Shafer 1969:58-59 & $\begin{array}{l}\text { Charcoal, } \\
\text { Tx }-679\end{array}$ & $190 \pm 80$ & $206 \pm 90$ & $\begin{array}{l}1643(1670,1782,1798,1947, \\
1953) 1954\end{array}$ \\
\hline \multicolumn{6}{|c|}{ BAKING PITS } \\
\hline \multirow[t]{2}{*}{$\begin{array}{l}\text { Walker No. } 2 \\
41 \mathrm{CK} 137\end{array}$} & \multirow[t]{2}{*}{$\begin{array}{l}\text { Riggs 1971; } \\
\text { Shafer 1971:120 }\end{array}$} & $\begin{array}{l}\text { Feature } 4 \\
\text { charcoal, } \\
\text { Tx-892 }\end{array}$ & $110 \pm 70$ & $126 \pm 81$ & $\begin{array}{l}1670(1697,1726,1814,1919, \\
1954) 1955\end{array}$ \\
\hline & & $\begin{array}{l}\text { Feature } 5 \\
\text { charcoal, } \\
\text { Tx-893 }\end{array}$ & $240 \pm 70$ & $256 \pm 81$ & 1525 (1654) 1954 \\
\hline 41ST80 & $\begin{array}{l}\text { Riemenschneider } \\
1994 \mathrm{~b}: 28\end{array}$ & $\begin{array}{l}\text { Feature } 1 \\
\text { charcoal, } \\
\text { Tx-7257 }\end{array}$ & $150 \pm 50$ & $166 \pm 64$ & $\begin{array}{l}1664(1681,1739,1806,1936, \\
1954) 1954\end{array}$ \\
\hline \multicolumn{6}{|c|}{$\begin{array}{l}{ }^{1} \text { Corrected ages are estimates for dates for which no } \delta^{13} \mathrm{C} \text { values were obtained. The corrected ages are based on } \\
\text { an estimated } \delta^{13} \mathrm{C} \text { value of }-24.00 \text { for fossil wood charcoal (from Stuiver and Polach 1977). }\end{array}$} \\
\hline
\end{tabular}

activities during a different season. A similar interpretation is offered for the cooking pit at 41ST80, and both Shafer (1971:124-125) and Riemenschneider (1994b:31-32) suggest that these features are analogous to earth ovens made by historic Apaches. The circular baking pits of westcentral Texas range from ca. 100 to $150 \mathrm{~cm}$ in diameter and 30 to $80 \mathrm{~cm}$ in depth. Except for the fact that the burned rocks associated with these features are exclusively limestone, they are little different from their northern counterparts.

The activities best represented by features at Tierra Blanca and Garza complex sites are related primarily to hunting bison and processing of bison products. Bison processing areas, archeologically evident as concentrations of bones, are found at many sites (see Table 121), although few have been adequately analyzed and reported. Detailed information on Late Prehistoric II/Protohistoric bison hunting/butchering technologies has been obtained from analyses of faunal remains from bison processing areas at Lubbock Lake (E. Johnson 1987:133-
139), Canyon Lakes (Bandy et al. 1980:159-193), and the Garnsey Spring kill site (Speth and Parry 1978:26-29, 1980:67-80). From the available data, it may be inferred that bison processing areas actually represent a variety of different activities and may encompass the kill locality and/or early- to middle-stage processing loci. Late-stage processing is sometimes represented by abundant small bone fragments scattered throughout sites or by small piles of bone splinters, such as found at the Garza site, that probably represent dumps of bones that had been boiled in pots for extracting bone grease.

Grinding activities are not particularly well represented by Garza complex features. Caches of grinding stones reported at a few sites may indicate that specialized tools were stored during periods of site abandonment. Although bedrock mortars are found at some rockshelters containing Garza occupations, their association with these occupations is tentative. As mentioned earlier, the grinding basin at the Longhorn site consists of a mano/pestle found inside a small circular pit. Based on ethnographic 


\begin{tabular}{|l|c|l|l|}
\hline \multicolumn{5}{|c|}{ SUMMARY OF CIRCULAR BAKING PITS ASSOCIATED WITH } \\
GARZA COMPLEX OCCUPATIONS
\end{tabular}

analogies, it was suggested that this feature was a hide-lined pit for grinding foods.

Rock art images found inside Reed Shelter and at the spring near Blue Mountain Rockshelter could be associated with the Garza complex. Among the motifs found on a rock face above Blue Spring is an image of a horse, clearly dating some of the rock art to the postcontact period. Rock art images at Huddleston Shelter in Garza County appear to represent the early European contact period and are located only ca. $3 \mathrm{~km}$ from the Longhorn and Headstream sites. Among the painted petroglyphs at this site are a longhorn, a Spanish priest, and several human figures wearing brimmed hats, presumably representing European dress (see Figure $35 b$ and $g$ ). While most of the images produced by historic Native Americans in the region are classified as Late Biographic Style, the simpler stoic motifs at Huddleston Shelter apparently represent an Early Biographic Style that was done during the initial period of European contact (see Chapter 6). These images cannot be attributed to any specific cultural group with any certainty, but they appear to be in the right place at the right time to have been made by Garza peoples.

Protohistoric burials are rare in the Texas Panhandle-Plains, and only three are candidates for possibly being affiliated with the Tierra Blanca $(n=1)$ or Garza $(n=2)$ complexes. Except for the Garza-U-Ranch burial, which yielded eight Garza arrow points in unquestionable association, the hypothesized cultural affiliation of the other two is tentative. The Childer's burial at the Canyon City Club Cave was removed by artifact collectors, and its context and associations are essentially undocumented. The Garza burial from Martin County was excavated many years ago by local avocational archeologists and has never been adequately analyzed or reported. Its association with surface-collected Garza points should be viewed cautiously. The 
Garza-U-Ranch burial from Sterling County was not excavated using archeological techniques, the human remains may have been reburied and were never examined, and the precise contexts of the burial associations are vaguely known. The associated artifacts were collected and have been analyzed, but they have yet to be reported (Andy Cloud, personal communication 1995).

Given these limitations, little can be said about mortuary traits of Tierra Blanca or Garza peoples. Of possible significance, however, are the bifacial knives and large complete Garza points associated with the Garza-U-Ranch burial. Without knowing their contexts, one can only speculate whether the points represent detached projectiles, perhaps placed inside a perishable container such as suggested for Perdiz points associated with the Las Haciendas burial (Mallouf 1987:15), or complete arrows. Complete arrows might have been included in the grave as personal possessions of the individual or perhaps as ceremonial offerings by persons who buried the individual.

In conclusion, the features recognized for the Tierra Blanca and Garza complexes seem to be quite similar in terms of feature types and activities represented. However, the sample of excavated and adequately reported features for the Tierra Blanca complex is far too small to support any meaningful interpretations regarding intercultural differences. From the limited data, one must conclude that the subsistence pursuits and lifestyles of these two cultures were similar.

\section{Faunal and Botanical Remains}

There are no described faunal assemblages from any Tierra Blanca sites, but use of bison is well established. The Fifth Green site is called the type site for Tierra Blanca complex bison hunting camps by Jack Hughes (1991:35), and the recovered faunal remains are briefly summarized in the unpublished manuscript by Kalokowski (1986). The unmodified bone assemblage consists of 1,979 specimens, of which 1,702 (86.0 percent) are tentatively identified as bison/cow. The remainder consists of 231 unidentifiable bones (11.7 percent), 14 small animal/ rodent bones ( 0.7 percent), and 32 burned fragments (1.6 percent). Since no detailed analysis was done, the numbers may overestimate the frequency of bison remains, but it is clear that bison was the dominant animal hunted and processed.
Faunal remains from Garza complex sites indicate that these people were primarily bison hunters, but the data summarized in Table 126 indicate that they also exploited a wide range of other animals. Deer and antelope were utilized, but it appears that they may have been hunted on an opportunistic basis. Compared with the ubiquitous bison remains, deer and antelope are sparse at Garza complex sites. This relationship is opposite that observed for Late Prehistoric I sites of the Palo Duro complex (see Chapter 10), where deer and antelope were well represented but bison bones were scarce.

Minimal evidence indicates that cattle and horses were utilized by Garza complex peoples. There is no evidence for the use of longhorn cattle as a food resource, but a horn core was used as a tie-down stake inside a tipi at the Longhorn site. This item may have been transported to the site specifically to serve as a stake, but this does not preclude the possibility that cattle were occasionally killed and eaten by Garza peoples. Horse remains are reported at three sites. Butchered horse remains at the Lubbock Lake site are probably, but not definitely, associated with the Garza complex. These finds indicate that horses were utilized as a food resource by Protohistoric peoples, but it is likely that horses were valued primarily as a means of transportation. Keeping horses solely for transportation is not easily recognizable in the archeological record, however. If people ate horses only during hard times, one might expect few horse bones in the faunal assemblages. The horse remains reported from the Longhorn site and Blue Mountain Rockshelter are teeth-elements that are more likely to be preserved.

The ethnographic record suggests that Spanishintroduced horses were acquired by Southern Plains peoples as early as 1608 , and that horses became increasingly common after that (Bloom 1937:397398; Kessell 1987:137; Secoy 1953:23-27; Worcester 1944:226-227). Spanish accounts also indicate that thousands of cattle were stolen from Spanish missions and settlements during the late seventeenth century (e.g., Kessell 1987:217-228), and it is likely that small herds of wild cattle may have been encountered on the Southern Plains. Newcomb (1961:87) suggests that the number of horses and cattle available to Plains Indians increased substantially after virtually all Spanish livestock fell into Indian hands during the Pueblo Revolt of 1680 . 
Horses were apparently so common among Southern Plains peoples by the end of the seventeenth century that any group without horses would have been at the mercy of mounted tribes.

Large canids - wolves, coyotes, and dogs - are particularly well represented in Garza complex faunal assemblages. Of interest are Canis remains found in bison processing areas at several sites, including butchered wolf and coyote remains from the Lubbock Lake (Johnson et al. 1977:95), butchered coyote bones from the Canyon Lakes sites (Bandy et al. 1980:41), and wolf and canid remains from the Garnsey Spring Bison Kill (Speth and Parry 1980:134). Wolf and unidentified canid remains also were recovered from the talus area bone dump at Boren Shelter No. 2 (Boyd et al. 1994:243-244, 315-321). There is ample evidence that canids were hunted for food. Based on the Garnsey site evidence, Speth and Parry (1980:134) suggest that "bison carcasses may have been used as secondary traps for scavenging carnivores." As described previously, beads made of canid bones are reported at the Lott site, and wolf-teeth pendants were found at the Garza site.

Some of the canid bones from Garza complex sites are definitely identifiable as wolf and coyote, while others are not. Of particular note, doglike bones were found at Boren Shelter No. 2 (Peck et al. 1994:243), and a butchered canid skull from the Garnsey site is identified as a hybrid cross between a wolf and a large dog (Walker 1980). It is unclear whether any of these remains represent domesticated animals, but this could be the case since latesixteenth- and early-seventeenth-century Spanish accounts report Plains Apaches using dogs to pull travois (e.g., Castañeda 1904:195; Hammond and Rey 1953:660).

Other animals that were exploited include several species of mammals - fox, bobcat, badger, skunk, raccoon, mink, and muskrat-that might have been exploited primarily for furs. This hypothesis was originally proposed by Brian Shaffer and Jay Peck to account for the unusual faunal assemblage in the talus slope bone dump at Boren Shelter No. 2 (see Chapter 6). It is possible that the Spanish and/or Pueblo demand for exotic hides and furs (i.e., other than bison and deer) may have influenced hunting patterns among Garza peoples.

Remains of many small animals from Garza complex sites may represent food resources or noncultural introductions. Rabbits, turkeys, and snakes were apparently used as food (i.e., remains are butchered or burned), while it is uncertain whether prairie dogs, various rodents and birds, lizards, toads/frogs, and fish were actually taken to be eaten. Turtle remains, particularly shell fragments, are common and may represent a food resource. It also is likely that turtle shells were used as containers, although no such artifacts have been identified archeologically.

Freshwater mussel valves and shell fragments are commonly found in low frequencies in Garza complex sites. Modified specimens and pieces of shell represent various stages of ornament manufacture (i.e., blanks to finished products), and it is doubtful that mussels were considered a significant food resource. The one possible exception is the Elm Creek site in Concho County. Of 19 mussel shells recovered from Cultural Unit 1, 15.7 percent exhibited thermal alteration. Mussel shells found at sites in the Concho and Colorado River basins are much larger and more frequent than at sites in the Brazos and Red River basins. This suggests that Garza peoples living in the Concho/Colorado area may have considered mussels to be a much more viable food resource than in areas to the north.

The faunal data from most sites clearly indicate that bison were the single most important resource for Garza peoples. Bison processing activities at residential sites primarily reflect late-stage processing, while early- and middle-stage butchering and processing are well represented at bison kills and hunting camps. The Longhorn site is particularly notable because no bison processing areas were found, and no bones were definitely identifiable as bison despite an abundance of small bone fragments. The data are interpreted as evidence that animal bones were commonly crushed and pulverized, presumably to extract grease (Shaffer 1993:416). Boyd et al. (1993:272-274) suggested that the Longhorn and Headstream sites were residential bases from which little actual hunting was done, while the faunal evidence indicates that a fair amount of late-stage bone processing occurred. Approximately 79 percent of the unmodified bones exhibited evidence of burning, presumably representing bone debris that was discarded into fires.

No bison processing areas are mentioned for the Slaton Dump site, but abundant bison remains were recovered. The analysis of the faunal remains consisted of classification "according to bone type, age, and treatment or utilization." Although no 


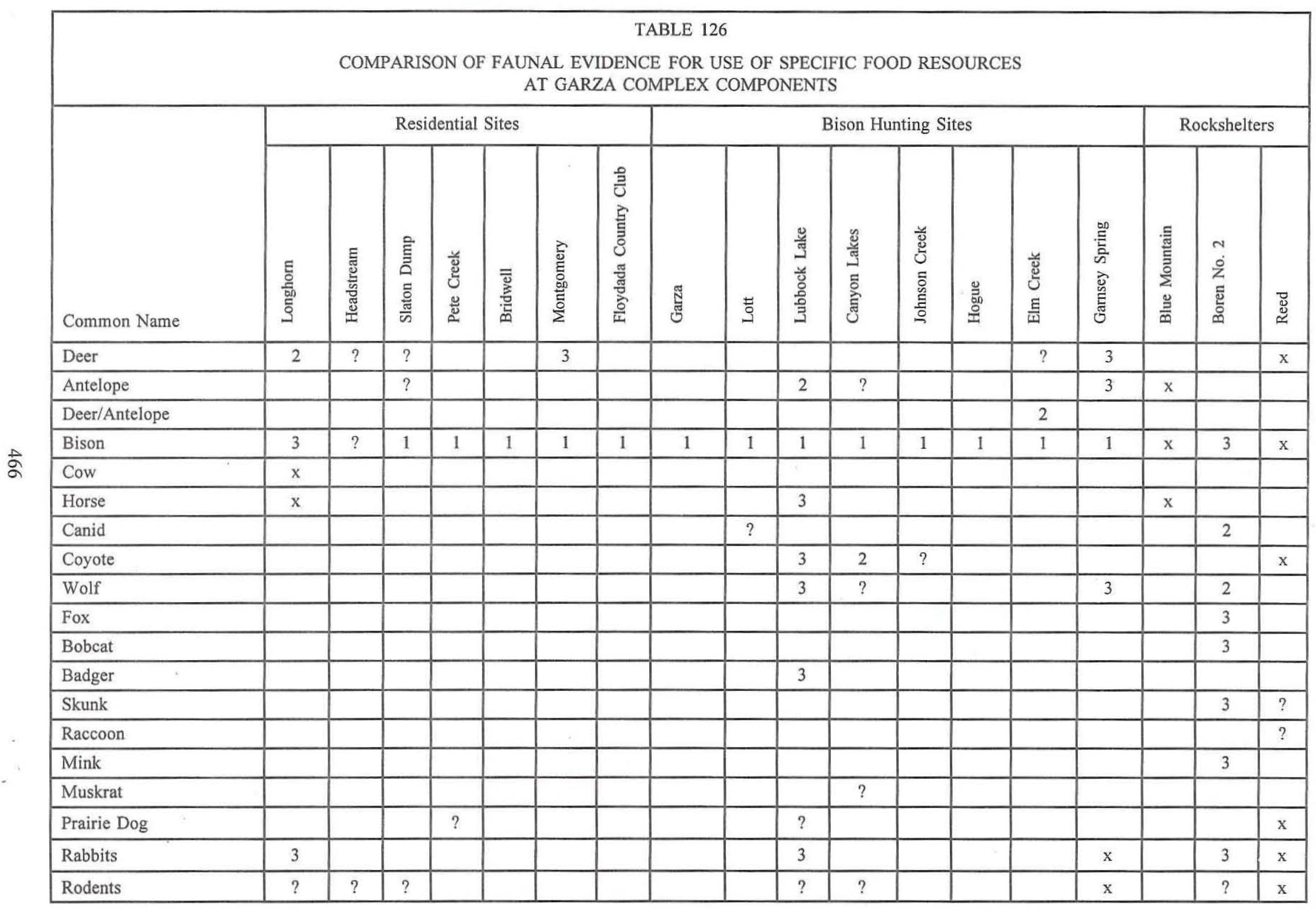




\begin{tabular}{|c|c|c|c|c|c|c|c|c|c|c|c|c|c|c|c|c|c|c|}
\hline \multicolumn{19}{|l|}{ Table 126, continued } \\
\hline \multirow[b]{2}{*}{ Common Name } & \multicolumn{7}{|c|}{ Residential Sites } & \multicolumn{8}{|c|}{ Bison Hunting Sites } & \multicolumn{3}{|c|}{ Rockshelters } \\
\hline & 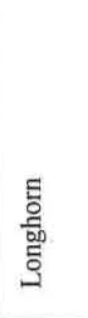 & 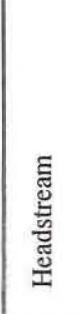 & 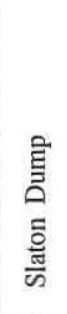 & 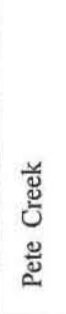 & 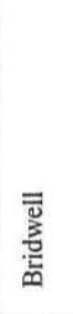 & 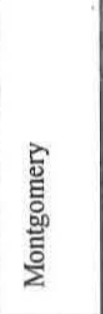 & 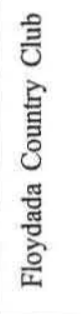 & 苞 & 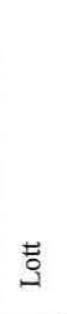 & 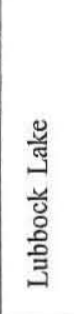 & 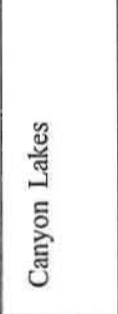 & 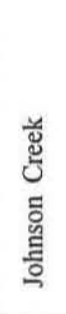 & 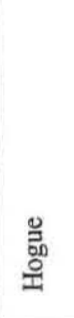 & $\begin{array}{l}\text { 플 } \\
\text { U } \\
\text { E }\end{array}$ & 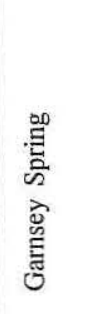 & 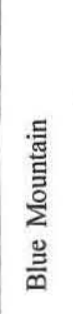 & $\begin{array}{l}N \\
\dot{0} \\
\dot{z} \\
\text { s. } \\
\dot{0}\end{array}$ & 芯 \\
\hline Birds & & & & $?$ & & & & & & & $?$ & & & & & & $?$ & \\
\hline Turkey & & & & & & 3 & & & & & & & & & & & & \\
\hline Turtles & 2 & $?$ & $?$ & $?$ & & & & $?$ & & $?$ & $?$ & & & & & & & \\
\hline Snakes & & $\mathrm{x}$ & & & & & & & & 3 & $?$ & & & & & & $?$ & $\mathrm{x}$ \\
\hline Lizards & & & & & & & & & & $?$ & & & & & & & & \\
\hline Toads/Frogs & & & & & & & & & & $?$ & $?$ & & & & & & & \\
\hline Freshwater Fish & & & & & & & & & & & $?$ & & & & & & & \\
\hline Freshwater Mussels & $\mathrm{x}$ & $\mathrm{x}$ & & $\mathrm{x}$ & $\mathrm{x}$ & $\mathrm{x}$ & $\mathrm{x}$ & & $\mathrm{x}$ & & & & & 3 & $\mathrm{x}$ & $\mathrm{x}$ & & $\mathrm{x}$ \\
\hline No. of Specimens & 3,815 & 411 & $?$ & $?$ & $?$ & 2,601 & 285 & $>2,100$ & $?$ & $?$ & 10,631 & $?$ & $?$ & 2,980 & 7,967 & $?$ & 3,033 & $?$ \\
\hline Type of Analysis & $\mathrm{C}$ & $\mathrm{C}$ & I & $\mathrm{I}$ & $\mathrm{N}$ & I & $\mathrm{I}$ & $\mathrm{I}$ & $\mathrm{N}$ & $\mathrm{C}$ & $\mathrm{C}$ & $\mathrm{N}$ & $\mathrm{N}$ & $\mathrm{C}$ & $\mathrm{C}$ & $\mathrm{N}$ & $\mathrm{C}$ & $\mathrm{N}$ \\
\hline $\begin{aligned} & \text { Interpretations of the } \\
& 1=\text { intensive (pro } \\
& 2=\text { moderate (pro } \\
& 3=\text { low (probably } \\
& ?=\text { unknown (pro } \\
& \text { x }=\text { none (present } \\
& \\
& \text { Type of Analysis: } \\
& \text { C }=\text { complete anal } \\
& \text { I }=\text { incomplete } \\
& \text { N }=\text { no systemati }\end{aligned}$ & $\begin{array}{l}\text { ve imp } \\
\text { represe } \\
\text { repres } \\
\text { sents a } \\
\text { used as } \\
\text { assem }\end{array}$ & $\begin{array}{l}\text { tance } \\
\text { ts a m } \\
\text { ths an } \\
\text { minor } \\
\text { a food } \\
\text { lage bu }\end{array}$ & $\begin{array}{l}\text { f resc } \\
\text { jor fo } \\
\text { mport } \\
\text { ood r } \\
\text { resou } \\
\text { t may }\end{array}$ & $\begin{array}{l}\text { ource } \\
\text { not bu } \\
\text { not re }\end{array}$ & $\begin{array}{l}\text { e base } \\
\text { arce) } \\
\text { resou } \\
\text { impor } \\
\text { resent }\end{array}$ & $\begin{array}{l}\text { on frec } \\
\text { ce) } \\
\text { ance is } \\
\text { food re }\end{array}$ & on onl & of occurr & nce & thin $\mathrm{c}$ & ass and $\mathrm{e}$ & idenc & of $\mathrm{mc}$ & ification & & & & \\
\hline
\end{tabular}


quantified data are presented, Booker and Campbell (1978:31) summarize their observations as follows: (1) 90 percent of the assemblage is bison, and most of the animals were adults; (2) few complete bones were found, and the vast majority are fragmentary; (3) a significant portion of the assemblage is charred (i.e., 13.4 percent); (4) very few butchering marks were observed; (5) limb bones are the most abundant identifiable elements; (6) many ulnas exhibiting use wear may have been used as "flesh separators" in the butchering process; and (7) the greatest butchering activity was "in the southeastern portion of the site with no fire pits in close association." All of these observations are consistent with the interpretation that the Slaton Dump site was a residential base where secondary butchering and late-stage bone processing occurred. Its faunal assemblage is similar to that of the Longhorn site in that so much of the bone seems to represent residue generated by bone grease processing.

For the Montgomery site, Northern (1979:41) notes that the unmodified faunal assemblage consists of 2,601 specimens that are "so fragmentary in nature that it was impossible to identify the majority of them." The only identifiable bones are bison, and the highly comminuted assemblage is probably the result of bone grease processing. Like the assemblage from the Slaton Dump site, approximately 13 percent $(n=349)$ of the unmodified bones exhibited evidence of burning, probably as a result of bone debris being discarded into fires.

Faunal remains from only a few Garza complex bison processing sites have been analyzed or reported in detail. The assemblage from many important sites, like the Garza site where bison bones $(n=2,093)$ are so frequent, were never analyzed. However, detailed studies of bone debris from the Lubbock Lake, Canyon Lakes, and Garnsey Spring sites provide reliable information on Late Prehistoric II/Protohistoric bison hunting and butchering techniques.

Eileen Johnson (1987:133-142) provides precise descriptions of Protohistoric animal butchering and processing activities at Lubbock Lake. Staged processing, primarily of bison but also including antelope, wolf, and coyote, is evident at Lubbock Lake (see Table 126). Some of the distinctive bison butchering techniques and behaviors recognized for the Protohistoric period are (1) breakage of long bones for marrow extraction; (2) use of large choppers to smash skulls for brain extraction; (3) stock- piling of long bones and skulls prior to marrow and brain extraction; (4) selective discard of various body parts in different areas; (5) common use of expedient tools, both bone and stone; (6) resharpening and maintenance of stone tools such as butchering knives and keeled hide (end) scrapers; and (7) spatial separation of various butchering, discard, and tool maintenance activities. Most of these observations relate to the processing area designated as Feature FA5-6 (E. Johnson 1987:137-139; Johnson et al. 1977:95-101).

Bandy et al. (1980:159-193) present interpretations based on a detailed analysis of 10,631 bones from the Canyon Lakes sites. Of the entire assemblage, 88.2 percent $(n=9,376)$ were identified as bison, including at least 67 bone tools. Some specimens were classified as formal tools because they had been intentionally modified by flaking or grinding; others were identified as expedient tools that exhibited use wear only. At least nine different elements - metapodial, ulna, tibia, radius, pelvis, rib, scapula, humerus, and femur-were used as choppers, hammers, scrapers, wedges, knives, and other tools during processing. Throughout the investigated areas, concentrations of different types of bones were identified as spatially discrete activity areas. The discussion of Feature 5 is particularly enlightening because it provides evidence used to outline a primary butchering sequence that resulted in numerous activity stations where different body parts were processed (Bandy et al. 1980:33-43, 191-193, 196). Five subareas are interpreted as bone dumps or stacking piles that represent discrete butchering activities.

At the Elm Creek site, butchered remains of a single bison in Cultural Unit 1 are interpreted as a mid-to-late-stage processing event (Treece, Quigg et al. 1993:367). Four activity areas, each consisting of two or more subareas containing shattered bone fragments, knapping stations, scattered debitage, and chipped stones, were centered around three hearths. Well-defined spatial patterning of artifacts and debris suggests that butchering activities were structured, and the following observations and interpretations were made: (1) butchering was a specialized process involving transport and reduction of selected body parts only; (2) 22 percent of the total assemblage was burned; and (3) the highly fragmented bone assemblage indicates that bone grease processing was an important activity (Treece, Quigg et al. 1993:343-345). 
Bison butchering activities also are described in detail based on faunal remains recovered from the Garnsey Spring Bison Kill (Speth 1983; Speth and Parry 1978:26-29, 1980:67-80). Of 6,986 bones (excluding microfauna) recovered from two seasons of excavation, 99.3 percent $(n=6,937)$ are identified as bison. Numerous kill events occurred at the site, and staged processing of bison carcasses is evident in many processing areas. It also appears that male animals were intentionally selected during many of the kills. The primary kill technique is thought to have been an entrapment (i.e., a corral) or surround in the floor of the wash (Speth and Parry 1980: 130-132). Similar kill methods may have been employed at the Lubbock Lake and Canyon Lakes localities along Yellowhouse Draw, both located in similar settings.

The data available for interpreting the wild plant foods that may have been utilized by Tierra Blanca and Garza peoples is limited, and interpretations are problematic. Summarizing the results of analyses of 9 pollen and 16 macrobotanical sediment samples from the late occupation component at the Tierra Blanca site, researchers note that the occupants may have used several different plants in a variety of ways. Gish (1982:400) tentatively interprets pollen remains as evidence that cattail, various grasses and chenopodiaceous species, and high-spine composites could represent food resources. Smart (1982:416-417) suggests that charred grass seeds from a tipi hearth (associated with Structure 1) represent use of bison dung as fuel, while charred grass seeds from a roasting pit (Feature 4) may represent accidental or incidental noncultural inclusions or intentional use of grass fuel or grass layers inside the pit. Charred seeds from weedy plants, especially goosefoot and knotweed, could represent food plants.

The only substantive archeological data available for inferring plant use by Garza complex peoples is derived from macrobotanical analysis of 76 flotation samples from the Headstream and Longhorn sites (Boyd et al. 1993:217-219; Dering 1993a). The charred seeds from these two sites indicate that a range of wild plants may have been exploited. Any of the plants listed in Table 127 could represent food resources, but Dering (1993a:429-430) suggests that the most likely candidates are grape, prickly pear, wild plum, cocklebur, and hackberry.

Based on the contexts of charred seeds at the Longhorn site and their relative frequencies by feature type (Table 128), Boyd et al. (1993:218-219) present further observations on subsistence resources. Because they occurred primarily in post molds and not in any of the cooking features (i.e., hearths and hearth dumps), it is suggested that the occurrence of some plant taxa (i.e., maygrass, dropseed, lotebush, and purslane) was incidental. These plants are not thought to have been of any economic importance. Taxa found in post molds and in other types of features (i.e., Poaceae) may have been of some economic importance. Some taxa found exclusively or dominantly in the cooking features are thought to be the most likely candidates for having been important plant foods. These include grape, cocklebur, prickly pear, plum, needlegrass, panicgrass, and ground cherry. In particular, prickly pear seeds are found in relatively high numbers in the cooking features.

Archeological pollen from 16 Longhorn site sediment samples was analyzed by Bryant (1993), but these samples consisted primarily of fossil pollens that are extremely durable. Thus, it appears

\begin{tabular}{|l|l|c|c|}
\hline \multicolumn{3}{|c|}{ TABLE 127 } \\
IDENTIFIED CHARRED SEEDS RECOVERED \\
FROM FLOTATION SAMPLES FROM THE \\
HEADSTREAM AND LONGHORN SITES \\
\hline Scientific Name & Common Name & Headstream & Longhorn \\
\hline Cenchrus incertus & Sandbur & $\mathrm{x}$ & $\mathrm{x}$ \\
Panicum sp. & Panic grass & $\mathrm{x}$ & $\mathrm{x}$ \\
Phalaris carolinensis & Maygrass & & $\mathrm{x}$ \\
Poaceae & Grass Family & $\mathrm{x}$ & $\mathrm{x}$ \\
Sporobolus sp. & Dropseed & $\mathrm{x}$ & $\mathrm{x}$ \\
Stipa leucotricha & Needlegrass & $\mathrm{x}$ & $\mathrm{x}$ \\
Polygonum sp. & Knotweed & $\mathrm{x}$ & $\mathrm{x}$ \\
Portulacaceae & Purslane Family & & $\mathrm{x}$ \\
Physalis sp. & Ground cherry & $\mathrm{x}$ & $\mathrm{x}$ \\
Xanthium sp. & Cocklebur & $\mathrm{x}$ & $\mathrm{x}$ \\
Celtis sp. & Hackberry & $\mathrm{x}$ & $\mathrm{x}$ \\
Condalia sp. & Lotebush & $\mathrm{x}$ & $\mathrm{x}$ \\
Opuntia sp. & Prickly pear & $\mathrm{x}$ & $\mathrm{x}$ \\
Prunus sp. & Wild plum & $\mathrm{x}$ & $\mathrm{x}$ \\
Vitis sp. & Grape & & \\
\hline
\end{tabular}


TABLE 128

FREQUENCY OF CHARRED SEEDS IN FLOTATION SAMPLES FROM THE LONGHORN SITE BY FEATURE TYPE

\begin{tabular}{|c|c|c|c|c|c|c|}
\hline Charred Seeds & $\begin{array}{c}\text { Basin Hearths } \\
\text { (3 samples) }\end{array}$ & $\begin{array}{c}\text { Ephemeral Hearths } \\
\text { (2 samples) }\end{array}$ & $\begin{array}{c}\text { Hearth Dumps } \\
\text { (3 samples) }\end{array}$ & $\begin{array}{l}\text { Unidentified } \\
\text { Pit (1 sample) }\end{array}$ & $\begin{array}{l}\text { Post Molds } \\
\text { (30 samples) }\end{array}$ & $\begin{array}{c}\text { Totals } \\
\text { (39 samples) }\end{array}$ \\
\hline Prickly pear & 6 & 2 & 16 & 2 & 10 & 36 \\
\hline Hackberry & - & 1 & 1 & - & 6 & 8 \\
\hline Poaceae (grasses) & 4 & 7 & - & 15 & 29 & 55 \\
\hline Ground cherry & 4 & 1 & - & - & 4 & 9 \\
\hline Cocklebur & 2 & 2 & 7 & - & - & 11 \\
\hline Grape & - & - & 5 & - & - & 5 \\
\hline Maygrass & - & - & - & - & 12 & 12 \\
\hline Needlegrass & 8 & 4 & - & - & 10 & 22 \\
\hline Dropseed & - & - & - & - & 22 & 22 \\
\hline Sandbur & - & 11 & - & - & 4 & 15 \\
\hline Knotweed & - & - & 5 & - & 2 & 7 \\
\hline Panicgrass & - & 9 & - & - & 5 & 14 \\
\hline Plum & 1 & - & 1 & - & 1 & 3 \\
\hline Lotebush & - & - & - & - & 1 & 1 \\
\hline Purslane & - & - & - & - & 1 & 1 \\
\hline Totals: & 25 & 37 & 35 & 17 & 107 & 221 \\
\hline
\end{tabular}

that the samples are seriously biased through selective pollen loss. Both cultural and paleoenvironmental interpretations based on such skewed pollen data would be questionable.

A principal research question is whether horticulture was practiced by either Tierra Blanca or Garza peoples. The only evidence of cultigens associated with the Tierra Blanca complex is from the Tierra Blanca site. The recovery of Zea pollen and charred maize fragments (cupule and rachis) from Structure 1 indicates that 12-row maize was used as a food resource, probably during both the early and late occupation periods (Gish 1982; Smart 1982). However, the question of whether corn was grown at the Tierra Blanca site is open to debate. Gish (1982) notes that the relatively low frequency of Cheno-am pollen is evidence that corn was not grown in the immediate vicinity of the site because these plants are generally abundant in areas disturbed by agriculture. Spielmann (1982:296-297) suggests that minimal recovery of maize indicates that "the corn recovered at Tierra Blanca was not grown there, and that it probably was acquired in trade." This interpretation is supported by an ethnographic account made by the Spanish expedition of Castaña de Sosa in 1590. Near a spring along the Pecos River, the expedition found an olla filled with recently shelled corn (Hammond and Rey 1966:262) that had apparently been obtained in trade and subsequently cached. If Habicht-Mauche (1988:178) is correct that this area was occupied by nomadic bands of Apaches at that time, this example provides conclusive evidence that the interregional PlainsPueblo trade did involve shelled corn.

On the other hand, the minimal recovery of maize associated with the later occupations at the Tierra Blanca site cannot be taken as conclusive evidence that corn was not grown by Tierra Blanca peoples. Corn remains should not be expected to be common in all sites attributed to corn-growing peoples. Corn is quite rare, for example, in the archeological record at many Antelope Creek phase sites. In contrast to Spielmann, other researchers have suggested that Tierra Blanca peoples probably did some farming (e.g., J. Hughes 1991:35).

For the Garza complex, there is no firm archeological evidence for horticulture. While Garza peoples were surrounded by sedentary agricultural peoples, no cultigen remains have been recovered from any Garza complex site or component. Perhaps the absence of such remains should be taken as evidence against the practice of horticulture: Alternatively, the absence of cultigens may reflect inadequate sampling and analysis. Even if cultigens are found at Garza complex sites, the evidence could be interpreted as representing acquisition of crops 
through trade, rather than local farming.

The combined archeological evidence supports the supposition that, if horticulture was practiced, it would have been of a very limited nature. The absence of traditional agricultural tools in Tierra Blanca and Garza complex sites (although Baugh [1986:180] mentions that a bison tibia digging stick and a bison scapula hoe may have been found by collectors at the Montgomery site) is in direct contrast to their frequent use by nearby agricultural peoples. This, along with the abundant evidence for bison hunting, suggests that if any farming was done, it probably only involved sowing of seeds and a subsequent return to harvest whatever survived to maturity. There is no evidence, archeological or ethnographic, suggesting that Tierra Blanca or Garza peoples put forth any substantial amount of labor in tending crops.

\section{Seasonality, Residential Mobility, and Settlement Pattern}

It is clear that Tierra Blanca and Garza peoples were mobile, ranged over a large area, and organized their movements and use of the landscape on a seasonal basis. This section attempts to get beyond this generalized statement to look at the specifics of when and why these peoples moved across the landscape. Using a combination of archeological and ethnographic data, an attempt to reconstruct the land-use patterns of these societies is made. $\mathrm{Al}$ though the bulk of the archeological data from which these inferences are drawn relates primarily to the Garza complex, the following discussions of seasonality and residential mobility may generally apply to both complexes.

Seasonality data for bison kill sites are not particularly robust. No detailed analyses of faunal remains have been done for many sites where one or more single processing events and/or short-term occupations occurred. Such is the case with the Fifth Green, Garza, Lott, and Johnson Creek sites. Faunal assemblages from the Canyon Lakes sites were analyzed, but no seasonality data or interpretations are presented. Minimal data and tentative seasonality interpretations are available for three bison hunting sites - Lubbock Lake, Elm Creek, and the Garnsey Bison Kill.

Lubbock Lake was the scene of numerous Protohistoric bison hunting and processing events, but seasonality evidence is available only for one such episode. A minimum of six bison were butch- ered in the processing station designated as Area 5, Feature FA5-6. Because one of the animals was a three-quarter-term fetus, the episode may have occurred during the spring (e.g., March-April). Johnson et al. (1977:101) caution, however, that an interpretation based on a single individual is tenuous because "out-of-season" births are possible.

A single event in which at least one bison was butchered occurred at the Elm Creek site (Cultural Unit 1). Using April 15 as a midpoint in the calving season, and aging the animal at 2.9 years based on dental eruption, Treece, Quigg et al. (1993:343, 367) cautiously suggest that the kill occurred in late winter to early spring (e.g., March).

Multiple bison kill events occurred at the Garnsey Spring site. Based on an analysis of dental eruption and tooth wear for the entire population, Wilson (1980:119-124) speculates that most of the kills occurred during the spring calving season, or late March to early April. This is supported by numerous fetal and neonatal bison elements found in several different areas and by the relatively high frequency of males in the population, which Speth (1983:70-73) suggests is evidence that bull groups were hunted during the calving season.

While the interpretations of seasonality for an individual kill episode should not be extrapolated for the region, a pattern of springtime bison hunting in the Southern Plains seems to prevail. Bison herds congregate in large numbers during the calving season, and it is reasonable to assume that communal bison hunters would have taken advantage of this. This is especially true since hunting societies probably needed to replenish their supply of meat after each winter.

Definitive seasonality data for inferring the timing of occupations at residential sites are even more sparse and difficult to interpret. It was speculated that the Longhorn and Headstream sites served primarily as winter encampments where nonbison hunting activities (including staged processing of stored bison hides) were carried out. However, there is no incontrovertible evidence to support this, and the only firm seasonality data seemingly contradicts a winter occupation hypothesis. Most of the charred seeds recovered by flotation represent plants that mature in the summer to late fall (Boyd et al. 1993:Table 39). These botanical finds are less convincing as seasonality evidence when one considers the fact that large amounts of food, including a variety of seeds, probably were stored and utilized in winter camps. Also, winter occupations would 
have left little definitive seasonality evidence in the archeological record.

Several lines of indirect evidence support the hypothesis of predominantly winter occupations at the Longhorn and Headstream sites. These are discussed in detail by Boyd et al. (1993:279-281), and their interpretations are as follows: (1) the nature of the lithic assemblage, particularly the overrepresentation of scrapers and unifacial resharpening flakes, suggests that these sites were occupied by bison hunting peoples during nonbison hunting periods; (2) the near absence of identifiable bison bones suggests that the occupations occurred during nonbison hunting periods; (3) winter is the primary season in which organized communal bison hunting (i.e., anything other than purely incidental hunting) did not commonly occur, primarily because bison tend to disperse into small groups and take shelter in river valleys during extremely cold weather; (4) the pulverized condition of the faunal remains suggests intensive processing of all large bones for bone grease as might be expected during a long winter occupation; (5) some Southern Plains bison hunting groups traveled to the pueblos in the fall to trade but returned home to the Plains for the winter; and (6) the diversity of seasonality indicated by botanical evidence (i.e., a variety of charred seeds from spring-, summer-, and fall-maturing plants) could be evidence of biseasonal occupation, or perhaps evidence of storage and use of a variety of plant resources through the winter.

While substantive data on the seasonal organization of prehistoric bison hunting activities are not available, some inferences may be made based on ethnographic accounts of Native American bison hunters on the Southern Plains. Most Plains peoples conducted communal bison hunts during the late spring to late fall. The general pattern was to conduct a large hunting venture during the late spring or summer to coincide with the calving or rutting season, and then to follow up with other major hunts in the summer, late fall, or early winter. Adapting to bison behavior and migration patterns, Plains hunters utilized the late spring/summer hunts to meet their need for fresh meat after the long winter and the late fall (or early winter) hunts to stock up on meat and hides for the winter (Boyd et al. 1993:280; McHugh 1972:157; Newcomb 1961: 112, 160, 197; Roe 1972:94-118; Verbicky-Todd 1984:4-9). Although bison were hunted year-round, kill sites and processing camps generated by commu- nal bison hunters should be much more evident in the archeological record than small kills or camps associated with small groups conducting only smallscale or opportunistic hunts.

The hypothesis that at least some of the occupation episodes at residential bases and base camps occurred during the winter months is supported by ethnographic evidence indicating that nomadic tribes on the Great Plains migrated seasonally and, as a general rule, dispersed into bands and moved into protected river valleys during the coldest part of the year (Lowie 1954:31). The primary reason was protection from the elements, but the proximity of camps to riparian woodlands provided ample fuel for fires and other resources. In addition, the need for winter forage and confined spaces for grazing became a major concern after the acquisition of the horse (Wallace and Hoebel 1952:14). All of the Garza complex residential bases, i.e., the Longhorn, Headstream, Slaton Dump, Pete Creek, Bridwell, Montgomery, and Floydada Country Club sites, are located in canyon valley bottoms. Parsons (1967: 78-79) also observed that the sheltered location of the Pete Creek site made it an especially suitable spot for a winter encampment of bison hunters. In contrast to their obviously favorable locations as cold-weather base camps, none of the abovementioned sites is particularly well suited for observing bison herd movements.

The material culture associated with Tierra Blanca and Garza complex sites provides particularly useful information for defining residential mobility and land-use patterns, although comparable samples are not available for all sites (especially for the Tierra Blanca complex). The consistent presence of obsidian, turquoise, Olivella shell beads, and pottery imported from the Pueblo world and the occasional presence of Caddoan-style pottery are recognized as evidence that Tierra Blanca and Garza peoples roamed over a vast area and were participants in a substantial interregional exchange network. The precise degree of their mobility and the nature and intensity of the exchange are open to considerable debate, however.

Published data on lithic material types in Tierra Blanca complex sites are minimal. It has been generally observed that Alibates agate makes up a substantial portion of the lithic materials at most Tierra Blanca sites, but quantified data are not available in most cases. Of the quantified lithic assemblage from Fifth Green, 90.4 percent of the 
debitage is Alibates while 1.4 percent is obsidian. Spielmann (1982:Table 34) notes that less than 1 percent of the lithics at the Tierra Blanca and Blackburn sites was comprised of obsidian, but no other materials are quantified. Two turquoise specimens also are noted from the Tierra Blanca site.

Lithic debitage assemblages are quantified for several Garza complex sites in Table 129. The relative abundance of Edwards cherts is of interest since all of these sites are located north of the northernmost widespread outcrops of Edwards limestones and cherts (i.e., the Callahan Divide) as illustrated by Frederick and Ringstaff (1994:Figures 6.1 and 6.3). Such high frequencies are not unexpected in the northern Garza complex components, though, since Garza peoples frequently ranged much farther south. The southernmost components of the Garza complex, i.e., the Elm Creek site in Concho County, the Davis Hackberry Spring site in Sterling County, and Red Bluff Shelter in Crockett County, are all located in the northern part of the Edwards Plateau where Edwards cherts are ubiquitous. The entire chipped stone assemblage from Elm Creek, including debitage and tools, is made of locally abundant Edwards chert.

Also of interest in terms of group mobility are the frequencies of obsidian and Alibates agate. Imported obsidian is present but rare in all but one of the sites shown in Table 129. Trace element analysis of 22 specimens from four sites indicates that the vast majority of the obsidian used by Garza peoples was from sources in the Jemez Mountains region of northern New Mexico (Table 130). Obsidian was probably obtained in trade at various eastern frontier Anasazi pueblos located less than $400 \mathrm{~km}$ from most Garza complex sites.

Despite being much closer to the source area, obsidian makes up only 0.6 percent of the total chipped stone assemblage (51 of 8,140 tools and debitage) from the Garnsey Spring campsite (Parry and Speth 1984:43). Obsidian is equally rare at the kill site (Speth and Parry 1980:145). The low frequency of obsidian mirrors that noted for Garza complex sites farther east, and the Garnsey Spring specimens are from the same sources. Fifteen Garnsey Spring obsidian flakes were analyzed by trace element analysis, and all are from three localities-Obsidian Ridge $(\mathrm{n}=9)$ ), Polvadera Peak $(\mathrm{n}=1)$, and Cerro del Medio $(\mathrm{n}=5)$-in the Jemez Mountains region (Parry and Speth 1984:
64-72).

The use of Tecovas jasper by Garza peoples appears to have been very localized. Tecovas is fairly abundant at three sites located nearest to the known source area-Bridwell, Montgomery, and Floydada Country Club (accounting for 6.4 percent to 19.9 percent of the chipped stone debitage and/or tools from these sites). Tecovas is much rarer in the Headstream and Longhorn site assemblages, probably because these sites are located a greater distance from the sources.

Alibates agate is either absent or infrequent in all but two assemblages shown in Table 129. It is absent or makes up less than 1 percent of the debitage at three major Garza complex sites (i.e., Longhorn, Headstream, and Bridwell). It probably occurs only in very low frequencies, if at all, in two other debitage assemblages that were never fully analyzed (i.e., Garza and Lott). Relative to these sites, Alibates is abundant at the Floydada Country Club site (accounting for 16 percent of debitage) and very abundant at the Montgomery site (accounting for 37 percent of debitage and tools). Perhaps the latter frequency is inflated somewhat since chipped stone tools also are included in the Montgomery site sample, but even this probably would not alter the figures significantly because material type frequencies for debitage are usually consistent with the material breakdown for tools (i.e., this is true for the Headstream and Longhorn sites). Part of the explanation for why so much more Alibates was used at these two sites probably lies in the fact that they are two of the northernmost sites of the Garza complex (see Figure 99). There are several possibilities that might explain how Alibates material was obtained. The inhabitants might have (1) ranged northward and procured Alibates directly from the source area, or perhaps scavenged lithic materials from Alibates-rich sites located along the Prairie Dog Town Fork of the Red River, (2) ranged north or northeastward and obtained Alibates in trade with other peoples who regularly used Alibates (e.g., Tierra Blanca or Wheeler complexes), or (3) obtained Alibates from other peoples (e.g., Tierra Blanca or Wheeler complexes) who came to the Floydada Country Club and Montgomery sites to trade. The relative paucity of Alibates at other sites suggests that most Garza peoples seldom ranged northward as far as the Canadian River (see earlier discussion of Geographic Range).

In terms of the origins of the pottery in Tierra 


\begin{tabular}{|c|c|c|c|c|c|c|c|c|c|c|c|c|c|c|c|c|}
\hline \multicolumn{17}{|c|}{$\begin{array}{c}\text { SUMMARY OF MATERIAL TYPES REPRESENTED IN CHIPPED STONE DEBITAGE } \\
\text { FROM SELECTED GARZA COMPLEX SITES }{ }^{1}\end{array}$} \\
\hline \multirow[b]{2}{*}{ Material Type } & \multicolumn{2}{|c|}{ Longhorn } & \multicolumn{2}{|c|}{ Headstream } & \multicolumn{2}{|c|}{ Bridwell } & \multicolumn{2}{|c|}{ Montgomery } & \multicolumn{2}{|c|}{$\begin{array}{l}\text { Floydada } \\
\text { Country Club }\end{array}$} & \multicolumn{2}{|c|}{ Slaton Dump } & \multicolumn{2}{|c|}{ Garza } & \multicolumn{2}{|c|}{ Lott } \\
\hline & \# & $\%$ & \# & $\%$ & \# & $\%$ & \# & $\%$ & \# & $\%$ & $\#$ & $\%$ & $\#$ & $\%$ & & $\%$ \\
\hline Edwards chert & 4,572 & 75.9 & 2,797 & 80.5 & 1,436 & 88.1 & 690 & 38.1 & 775 & 32.9 & $\mathrm{x}$ & 73.0 & $?$ & 3 & $\mathrm{x}$ & $\mathrm{H}$ \\
\hline Alibates agate & 6 & $<0.1$ & - & - & 14 & 0.9 & 676 & 37.3 & 380 & 16.1 & $\mathrm{x}$ & $?^{2}$ & - & - & - & - \\
\hline Tecovas jasper & 2 & $<0.1$ & - & - & 105 & 6.4 & 361 & 19.9 & 842 & 35.7 & $\mathrm{x}$ & $?^{2}$ & - & - & $\mathrm{x}$ & M \\
\hline $\begin{array}{l}\text { Obsidian } \\
\text { Potter chert/ }\end{array}$ & - & - & 3 & $<0.1$ & 18 & 1.1 & 67 & 3.7 & 30 & 1.3 & $\mathrm{x}$ & $<1.0$ & 4 & VL & $\mathrm{x}$ & VL \\
\hline Ogallala chert & - & - & 2 & $<0.1$ & 46 & 2.8 & 19 & 1.0 & 4 & 0.2 & - & - & - & - & - & - \\
\hline Quartzite & 43 & 0.7 & 8 & 0.2 & 3 & $<0.2$ & - & - & 27 & 1.1 & $\mathrm{x}$ & 2.5 & - & - & - & - \\
\hline Other local & 746 & 12.4 & 462 & 13.3 & 4 & 0.2 & - & - & 205 & 8.7 & $\mathrm{x}$ & 4.0 & $\mathrm{x}$ & $\mathrm{H}^{3}$ & - & - \\
\hline Other nonlocal & 156 & 2.6 & 66 & 1.9 & - & - & - & - & 3 & 0.1 & - & - & - & - & - & - \\
\hline Unknown & 501 & 8.3 & 138 & 4.0 & 4 & 0.2 & - & - & 90 & 3.8 & $\mathrm{x}$ & 6.0 & $\mathrm{x}$ & $?$ & $\mathrm{x}$ & - \\
\hline Totals: & 6,026 & 100 & 3,476 & 100 & 1,630 & 100 & $1,813^{4}$ & 100 & 2,356 & 100 & 4,172 & 100 & 10,444 & 100 & $?$ & - \\
\hline \multicolumn{17}{|c|}{$\begin{array}{l}x=\text { present but number not specified } \\
H=\text { high percentage } \\
M=\text { moderate percentage } \\
V L=\text { very low percentage }\end{array}$} \\
\hline \multicolumn{17}{|c|}{$\begin{array}{l}\text { 'Except for the Montgomery site, all samples are of lithic debitage only. Data are from Boyd et al. (1993:61-63, 154-155), Parker (1982:Table 1), } \\
\text { Northern (1979:Table 1), Booker and Campbell (1978:27), Runkles (1964:113), Runkles and Dorchester (1987:91), and Word (1991a:Tables 1-3). }\end{array}$} \\
\hline \multicolumn{17}{|c|}{${ }^{2}$ Alibates agate and Tecovas jasper combined make up 13.5 percent. } \\
\hline \multicolumn{17}{|c|}{${ }^{3}$ The "local" materials are described as stream gravels but may include Edwards cherts. } \\
\hline \multicolumn{17}{|c|}{${ }^{4}$ Sample is not totally comparable because it includes 1,440 unmodified flakes, 264 chipped stone tools, } \\
\hline
\end{tabular}




\begin{tabular}{|l|c|l|}
\hline \multicolumn{3}{|c|}{ TABLE 130 } \\
SUMMARY OF TRACE ELEMENT OBSIDIAN \\
SOURCE DETERMINATIONS ON SPECIMENS \\
FROM GARZA COMPLEX SITES
\end{tabular}

Blanca and Garza complex sites, in some cases the general area of origin is obvious, and it is the specific place of manufacture that is less certain or unknown. Such is the case with many of the Puebloan-made decorated wares. Although there may be some uncertainty as to whether a specific glaze-painted vessel sherd was made at Pecos Pueblo or in one of the Salinas District pueblos, there is no doubt that these wares were manufactured in the Puebloan Southwest. The origins of other decorated wares, such as the engraved or incised sherds found at a few sites, are not known. While researchers agree that these ceramic decorative techniques were probably derived from the east, little is known about possible areas of manufacture, and almost nothing is known about specific manufacturing localities.

Identifying ceramic sources becomes more problematic when considering the plainwares, and a controversy has emerged regarding whether certain Tierra Blanca and Garza complex plainwares are of Plains or Pueblo origin (see Chapter 7). Based on her petrographic work on plainware sherds from Tierra Blanca and Garza sites, Habicht-Mauche $(1987,1988,1991)$ proposed that the majority of striated plainwares - specifically those with polished interiors and faint to deeply striated exteriorsrepresent Puebloan-like pottery that was made locally on or near the Llano Estacado by Plains peoples. In contrast, Boyd and Reese-Taylor (1993) presented a different interpretation based on their petrographic study of similar plainwares and decorated Puebloan wares from Lake Alan Henry. They contend that the Lake Alan Henry petrographic data, and even the petrographic data generated by HabichtMauche (1988), may be interpreted as evidence that various pueblos are the most likely sources of manufacture for most of the striated and unfinished plainwares. The controversy is not about whether Tierra Blanca or Garza peoples made an occasional pot, perhaps because they adopted a few Puebloan women into their society. Nor is it about whether a few Tierra Blanca or Garza individuals learned how to make pottery from their Puebloan trade partners. Either of these scenarios is possible. The more important question with respect to understanding group mobility and cultural behavior is whether these peoples incorporated a widespread pottery-making tradition into their lifestyles. In the author's view, such a hypothesis is incongruous with the interpretation that Tierra Blanca and Garza peoples were mobile bison huntergatherers who obtained numerous kinds of material goods, including at least their decorated pottery, from various Puebloan trade partners. Why would nomadic Plains groups suddenly have begun making large amounts of plainware pottery when they obviously had access to Puebloan pottery, obsidian, shell ornaments, turquoise, etc.? The issue may not be resolved at this time, but there is not a convincing body of data, petrographic or otherwise, supporting the interpretation that Tierra Blanca or Garza peoples made most or even much of their own plainware pottery.

Tables 131 and 132 show the abundance of Puebloan-made pottery in Tierra Blanca and Garza complex sites. Puebloan-made pottery accounts for at least 69 percent of the pottery at the Tierra Blanca site and at least 77 percent of the pottery at the Blackburn site. If any of the plainwares of undetermined origin are in fact Puebloan, then the percentages are much higher, perhaps as high as 95 percent. The plainware sherds found at bison kills/hunting camps are of unknown origin, but they also could represent Puebloan-made pottery. 


\begin{tabular}{|c|c|c|c|c|}
\hline \multicolumn{5}{|c|}{$\begin{array}{c}\text { SUMMARY OF PUEBLOAN AND SELECTED PLAINWARE CERAMICS } \\
\text { FROM TIERRA BLANCA COMPLEX SITES }\end{array}$} \\
\hline Ceramic Types & Tierra Blanca & Blackburn & Fifth Green & Fatheree, Area 2 \\
\hline \multicolumn{5}{|c|}{ PUEBLOAN WARES } \\
\hline $\begin{array}{l}\text { Intermediate to Late Rio Grande Glazes (C-E) } \\
\text { Blind Indented Corrugated }\end{array}$ & $\begin{array}{c}306 \\
32\end{array}$ & $\begin{array}{c}319 \\
\mathrm{x}\end{array}$ & - & \\
\hline $\begin{array}{l}\text { Subtotals: } \\
\text { Percents of Totals: }\end{array}$ & $\begin{array}{l}338 \\
69.1\end{array}$ & $\begin{array}{l}319+ \\
>77.1\end{array}$ & $\begin{array}{l}0 \\
-\end{array}$ & $\begin{array}{l}0 \\
-\end{array}$ \\
\hline \multicolumn{5}{|c|}{ PLAINWARES OF UNDETERMINED ORIGIN } \\
\hline $\begin{array}{l}\text { Striated/Unfinished Plainware } \\
\text { Micaceous Plainware }\end{array}$ & $\begin{array}{c}117 \\
7\end{array}$ & $\mathrm{x}$ & 139 & 241 \\
\hline $\begin{array}{l}\text { Subtotals: } \\
\text { Percents of Totals: }\end{array}$ & $\begin{array}{r}124 \\
25.4\end{array}$ & $\begin{array}{l}? \\
-\end{array}$ & $\begin{array}{l}139 \\
100\end{array}$ & $\begin{array}{l}241 \\
100\end{array}$ \\
\hline Total No. of Sherds in Analyzed Assemblage & 489 & 414 & 139 & \\
\hline Estimated Percentage of Puebloan Ceramics & 69.1 to 94.5 & $>77.1$ & 0 to 100 & 0 to 100 \\
\hline
\end{tabular}

The residential sites of the Garza complex also contain significant amounts of Puebloan-made pottery, even if one favors the view that all plainwares are of local (i.e., Plains) manufacture. For the six residential sites that have analyzed samples of more than 200 sherds, sherds of definite Puebloan origin account for at least 12 to 42 percent of the assemblage. If any of the plainwares of undetermined origin are Puebloan made, then the percentages could be as high as 70 to 100 percent at some residential sites. The same may be true for most of the bison hunting camps and rockshelters.

Also shown in Table 132 is another group of non-Puebloan ceramics designated as other wares. This category includes some Caddoan-style incised/ engraved or slipped wares and wares specifically identified as Nocona Plain, Little Deer ware, and Doss Redware. All of these are considered to be of nonlocal origin, and Garza peoples may have obtained them through raiding or trading with Plains Village peoples living in north-central Texas and southwestern Oklahoma. The specific manufacturing sources of these wares cannot be identified.

Plainwares with bone or shell temper also are included in the other ware category. Both are rare in the Texas Panhandle-Plains and presumably represent the westward spread of eastern ceramic traditions. The few shell-tempered sherds from the Floydada Country Club site were found along with Caddoan-style potsherds, strengthening the assumption that the shell-tempered wares could be from eastern sources. Bone-tempered sherds are only reported for the Lott site. The use of fingernail punctates and Caddoan-style incised decorations on many of the bone-tempered sherds is suggestive of an eastern origin. Runkles and Dorchester (1987) suggest that this pottery was locally made of Triassic clays (an inference based on an unpublished petrographic study by Reid Ferring). If this interpretation is correct, then the bone-tempered wares from the Lott site could have been made anywhere within the Caprock Canyonlands region.

One might expect the bone-tempered pottery from the Lott site to be associated with the hypothesized occupation(s) of Perdiz arrow point makers, since bone tempering is a common trait of the Toyah phase (L. Johnson 1994:273-274). However, this interpretation seems to be contradicted by the spatial distributions. None of the Lott site pottery was found in the subareas where Perdiz points 
reportedly were found, and the spatial association between bone-tempered pottery and Garza and Lott points appears much stronger (see Table 94). Because of the methodology employed in surface collecting the site, there is uncertainty as to what artifacts are associated with different components, if indeed different components are represented. Regardless, bone-tempered pottery from the Lott site is distinctive from the pottery at all other Garza complex sites.

Two traits found on striated plainware vessels of the Tierra Blanca and Garza complexes are riveted handles and fingernail punctate decorations. Lee Johnson (1994:275-276) suggests that use of riveted loop handles developed in the east and spread westward via the Missouri River valley. This type of tenoned handle also is found with some consistency in the Southern Plains and is specifically noted for the Garza and Tierra Blanca complexes, the Toyah phase, and the Protohistoric Wichita. Kidder and Shepard (1936:262-264, 334-338) note that vertical loop handles, attached by the rivet method, appeared on Pecos-made corrugated pots as early as Glaze III or IV times and became more prevalent, although never common, on glazewares and striated plainwares during the Glaze V period. The use of riveted handles was widespread by the Protohistoric period, so the trait itself is not indicative of manufacture by any particular group or in any particular area.

Tenoned handles are represented on several glazeware and striated plainware vessels associated with the Tierra Blanca and Garza complexes. For the Tierra Blanca complex, vertical loop handles are reported on striated plainware sherds from the Fatheree site (Habicht-Mauche 1988:Table 5.1). Garza complex examples include an isolated striated bean pot jar found at Crow Springs in Dickens County and fragments of a striated plainware jar found at the Yellow Houses Ruins site (HabichtMauche 1988:Table 5.1, Figure 5.46). One sherd of a small Glaze VI jar with horizontal loop handles was found at the Bridwell site (Parker 1982:65). Two handle fragments from the Longhorn site are identified as being from a probable Glaze $\mathrm{E}$ jar and a Glaze V olla. The glazeware examples clearly indicate that the technique of riveting loop handles to vessel bodies was adopted by Puebloan pottery makers during Protohistoric times.

The occurrence of fingernail punctates on striated utility wares is not well understood. Kidder and Shepard (1936:318-320, 335) state that "nailmarked" decorations are present, but not very common, on Pecos-made striated utility jars. They are found only on small portions of vessels and usually occur as horizontal rows of punctates. Since the trait appears very late in the Southwest, it is speculated that its ultimate origins may have been from Plains Woodland or Village sources.

This same style of fingernail decoration is consistently present on small percentages of plainware sherds from sites in the Southern Plains. Habicht-Mauche (1988:235, Table 5.10) states that fingernail decorations are present on only 3.5 percent of the plainwares from Tierra Blanca and Garza complex and Wheeler phase sites, but the trait is represented at 9 of the 14 sites or sample groups. More recently, fingernail punctate sherds were recovered in low frequencies (i.e., less than 3.5 percent) at the Headstream and Longhorn sites (Boyd et al. 1993:67-68, 167-168). Like most of the plainwares found at Tierra Blanca and Garza sites, the source of manufacture for the fingernail punctated varieties is not known. Fingernail punctate-decorated pots in ,Protohistoric Texas Panhandle-Plains sites may represent Puebloan-made wares, locally made wares, or perhaps a mix of both.

Caching of pots seems to have been a fairly widespread practice among Protohistoric nomads in the Texas Panhandle-Plains (Spielmann 1982:318). Five occurrences of whole or nearly complete pots found in or near Tierra Blanca and Garza complex areas were mentioned earlier in this chapter. These finds are thought to represent deliberate caching of vessels in isolated hiding places and at residential sites. Archeological and ethnographic examples of vessel caching in the Southwest, summarized by Wolley and Osborn (1991:37-58, Appendixes D and E), have many implications for defining the function of caching behavior within cultural systems. Wolley and Osborn (1991:56) conclude that such behavior in general, and caching of foodstuffs in vessels in particular, is most often associated with logistical collectors rather than foragers. While empty pots were sometimes cached or stored (i.e., a cache of tools), cached vessels more often than not contained some bulk food resource, and the intent was to store the food rather than the vessel. While dried meat could have been stored for short periods in pots, most evidence suggests that vessels were used to store plant foods, both wild and domesticated, in arid climates. 
TABLE 132

SUMMARY OF CERAMIC TYPES RECOVERED FROM GARZA COMPLEX SITES ${ }^{1}$

Ceramic Types

\begin{tabular}{|c|c|c|c|c|c|c|c|c|c|c|c|}
\hline $\begin{array}{l}\text { E } \\
\text { 品 } \\
\text { ఏँ }\end{array}$ & 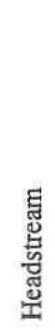 & 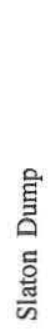 & 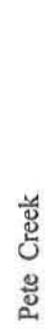 & 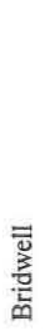 & 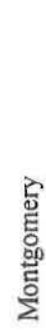 & 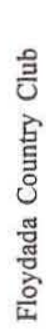 & 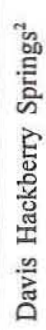 & : & 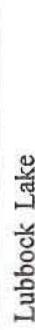 & 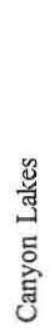 & 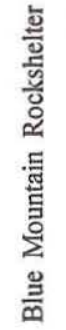 \\
\hline
\end{tabular}

PUEBLOAN WARES

Early Rio Grande Glazes-A\&B

Intermediate Rio Grande Glazes-C\&D

Late Rio Grande

Glazes-E\&F

Indeterminate Rio Grande Glazes

Tewa matte paint/redwares

Puebloan redwares

Chupadero Black-on-white

Puebloan Micaceous utility

Pueblo III/IV utility

Puebloan corrugated

Other Puebloan painted

wares

Pecos-style pipe

Subtotals:

Percents of Totals:

\begin{tabular}{r|r|r}
- & - & \\
- & - & \\
175 & 7 \\
- & - & \\
10 & 26 \\
207 & 104 \\
- & - & - \\
668 & - & - \\
- & - & 6 \\
- & - & \\
\hline 17 & 1 & \\
& & \\
\hline 1,077 & 138 & \\
41.5 & 15.6 &
\end{tabular}

\begin{tabular}{c|c|c|c|c|c|c|c|c|c|}
- & - & $\mathrm{x}$ & - & - & - & 3 & - & - & - \\
- & - & $\mathrm{x}$ & - & $4+$ & - & - & - & - & - \\
- & 46 & $\mathrm{x}$ & 89 & - & - & - & - & - & - \\
- & - & $337+$ & - & - & $\mathrm{x}$ & - & - & - & - \\
- & - & - & - & - & - & - & - & - & - \\
34 & - & - & - & - & - & - & - & 1 & - \\
2 & - & - & 10 & $\mathrm{x}$ & - & - & - & - & - \\
- & - & - & - & - & - & - & - & - & - \\
- & - & - & - & $6+$ & - & - & - & - & - \\
6 & - & $26+$ & - & $24+$ & - & - & - & - & - \\
18 & - & $\mathrm{x}$ & - & $\mathrm{x}$ & $\mathrm{x}$ & - & - & - & 3 \\
- & - & - & 1 & - & - & - & - & - & - \\
& & & & & & & & & \\
\hline 60 & 46 & $363+$ & 100 & $34+$ & - & 3 & - & 1 & 3 \\
- & 14.3 & $>52.1$ & 38.9 & 11.9 & - & $<0.5$ & - & 2.0 & 23.1 \\
\hline
\end{tabular}

PLAINWARES OF UNDETERMINED ORIGIN

\begin{tabular}{|l|c|c|c|c|c|c|c|c|c|c|c|c|}
\hline $\begin{array}{l}\text { Striated/unfinished plainware } \\
\text { Micaceous plainware }\end{array}$ & $\begin{array}{r}1,239 \\
243\end{array}$ & $\begin{array}{r}738 \\
4\end{array}$ & - & $\begin{array}{r}67 \\
190\end{array}$ & $\begin{array}{c}\mathrm{x} \\
-\end{array}$ & $\begin{array}{r}23 \\
16\end{array}$ & $\begin{array}{c}\mathrm{x} \\
-\end{array}$ & - & - & $\mathrm{x}$ & $\begin{array}{c}- \\
\mathbf{5}\end{array}$ & $\begin{array}{c}10 \\
-\end{array}$ \\
\hline Subtotals: & 1,482 & 742 & - & 257 & $?$ & 39 & $?$ & - & - & $?$ & 50 & 10 \\
Percents of Totals: & 57.1 & 83.7 & - & 79.8 & - & 15.2 & - & - & - & - & 98.0 & 76.9 \\
\hline
\end{tabular}

OTHER WARES

\begin{tabular}{|c|c|c|c|c|c|c|c|c|c|c|c|c|}
\hline Caddoan-style ware ${ }^{3}$ & 17 & - & - & 11 & - & 26 & $\mathrm{x}$ & $x$ & - & - & - & - \\
\hline Shell-tempered ware & - & - & - & - & - & - & 25 & - & - & - & - & - \\
\hline $\begin{array}{l}\text { Bone-tempered ware (plain, } \\
\text { incised, punctated) }\end{array}$ & - & - & - & - & - & - & - & - & $635+$ & - & - & - \\
\hline Nocona plain & - & - & - & - & - & 67 & - & - & - & - & - & - \\
\hline Little Deer ware & - & - & - & - & - & - & 29 & - & - & - & - & - \\
\hline Doss Redware & - & - & - & - & $28+$ & - & $10+$ & - & - & - & - & - \\
\hline Subtotals: & 17 & - & - & 11 & $28+$ & 93 & $64+$ & - & $635+$ & - & - & - \\
\hline Percents of Totals: & 0.7 & - & - & 3.4 & 4.0 & 36.2 & 22.5 & - & 99.5 & - & - & - \\
\hline $\begin{array}{l}\text { Total No. of Sherds in } \\
\text { Analyzed Assemblage }\end{array}$ & 2,595 & 887 & ? & 322 & 697 & 257 & 285 & $?$ & $638+$ & $?$ & 51 & 13 \\
\hline
\end{tabular}




\begin{tabular}{|c|c|c|c|c|c|c|c|c|c|c|c|c|}
\hline \multicolumn{13}{|l|}{ Table 132, continued } \\
\hline Ceramic Types & 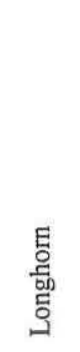 & 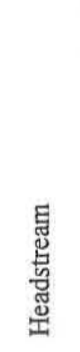 & 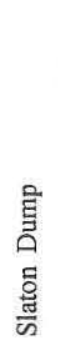 & 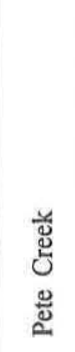 & 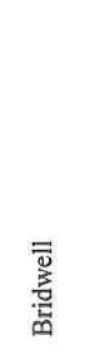 & 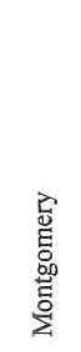 & 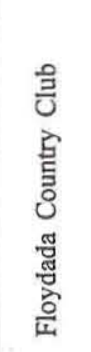 & 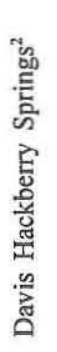 & Е艹 & 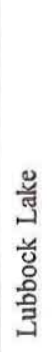 & 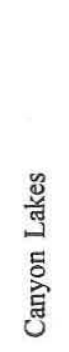 & 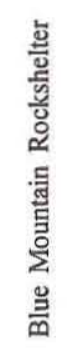 \\
\hline $\begin{array}{l}\text { Estimated Percentage of } \\
\text { Nonlocal Ceramics }\end{array}$ & $\begin{array}{c}42.2 \\
\text { to } \\
99.3\end{array}$ & $\begin{array}{c}15.6 \\
\text { to } \\
99.2\end{array}$ & ? & $\begin{array}{c}17.7 \\
\text { to } \\
97.5\end{array}$ & $>56.1$ & $\begin{array}{c}75.1 \\
\text { to } \\
90.3\end{array}$ & $>34.4$ & ? & $\begin{array}{c}<0.5 \\
\text { to } \\
100\end{array}$ & ? & $\begin{array}{c}2.0 \\
\text { to } \\
100\end{array}$ & $\begin{array}{c}23.1 \\
\text { to } \\
100\end{array}$ \\
\hline \multicolumn{13}{|c|}{$\begin{array}{l}\text { 'Includes excavated samples and surface collections; sherds from the Greene Springs site }(n=151) \text { are excluded from this table, } \\
\text { but at least } 12 \text { types are reported. }\end{array}$} \\
\hline \multicolumn{13}{|c|}{${ }^{2}$ Ceramics from Davis Hackberry Springs are not identified except for selected specimens. } \\
\hline \multicolumn{13}{|c|}{${ }^{3}$ Engraved, incised, red-slipped, or brushed wares. } \\
\hline
\end{tabular}

Among Southwestern peoples who intensively exploited wild plant foods or practiced horticulture, caching of foodstuffs was done in villages and in isolated locations throughout their territory. In both cases, the behavior was a deliberate attempt to store foods for future use and is viewed as an adaptive strategy associated with seasonal differences in the availability of food resources. In order to prolong the life of the stored food, vessels were usually carefully sealed with clay, lac (tree resin), or wooden lids. Food storage vessels were often old or worn-out pots that no longer served their original function. For example, broken and repaired vessels or water ollas that had lost their porosity commonly were used as dry storage containers.

Using the analogies from the Southwest, several inferences may be made regarding the caching of vessels in Tierra Blanca and Garza societies: (1) it is likely that whole vessels were stored in or adjacent to residential sites when they were abandoned temporarily (i.e., seasonally); (2) although some vessels may have been left empty, it is likely that many contained foodstuffs; (3) whole vessels containing foodstuffs were probably cached in isolated locations throughout their territory to store foods for use at a later time when they knew that they would be in the vicinity, or to serve as a general buffering mechanism in case of shortages or losses of resources in other areas (it probably was prudent to have several food caches in various locations at any one time); (4) it appears that some of the isolated storage vessels were old or worn-out pots that were recycled from their original use; and (5) this type of caching may indicate that Tierra Blanca and Garza peoples were logistically oriented collectors during part of the year, with caching reflecting differential seasonal mobility related to resource availability. These interpretations are supported by one ethnographic account of vessel caching on the margins of the Southern Plains. An olla filled with shelled corn found near the Pecos River by the de Sosa expedition in 1590 (Hammond and Rey 1966:262) confirms that a season-specific plant food, a cultigen in this case, was stored in pots by nomadic peoples during the early Protohistoric period.

In sum, multiple lines of evidence indicate that the Tierra Blanca and Garza complexes represent mobile groups whose movements and activities were dictated by seasonal variations in subsistence resources. The archeological evidence clearly indicates that these groups were primarily bison hunters and secondarily small-game hunters and wild-plant foragers. It is not known whether these peoples grew any domesticated crops, but even if they did, their farming efforts were probably minimal.

The three site types identified for the complexes-bison hunting sites, residential sites, and rockshelters - are characterized by different archeological attributes that represent broad differences in site function and perhaps seasonality of use. Collec- 
tively, these sites help define the subsistence modes, yearly cycles, and land-use patterns of these nomadic hunter-gatherers.

Bison hunting sites include kill localities where primary butchering occurred and campsite/processing localities which represent overnight or short-duration occupations where secondary butchering and processing occurred. The latter sites are characterized by ephemeral hearths and discrete spatial patterning indicating that different body parts were systematically separated and further butchered in special activity areas. Activities at these camps also involved some hide processing and crushing of selected bones into small fragments, presumably to boil them in pots to render bone grease. The material culture at bison hunting sites is characterized by low diversity and is dominated by specialized tools for bison killing (arrow points), skinning and butchering (bifacial knives, expedient edgemodified flake tools, and expedient bone tools), hide processing (unifacial scrapers), and bone-grease production (stone and bone choppers and plainware pottery). Although bison were clearly the focus of the hunt, antelope and/or deer and large carnivores were occasionally killed and butchered at these locations. Butchered wolf and coyote remains are common in some sites, and Speth and Parry (1980: 134) hypothesize that hunters may have intentionally returned to bison kills and processing areas to hunt carnivores that came to scavenge the carcasses. Minimal seasonality data suggest that some communal bison hunting was done during the spring (i.e., around calving season). Large hunts may have occurred during the summer, fall, and early winter as well, but it is unlikely that organized communal hunts occurred during the coldest winter months (i.e., late December to early February). Opportunistic bison hunting (i.e., killing of one or two animals in chance encounters) probably occurred year round.

Residential sites or base camps are localities that were occupied for longer periods of time (e.g., several days to months) and where a wide variety of cultural activities occurred. The diversity of features provides evidence of varying activities, and tipis or ephemeral huts (e.g., wickiups) were used for shelter at some locations. Activity diversity is further indicated by diversified material culture assemblages that include a variety of chipped stone tools; abundant debitage; manos and metates; specialized grinding tools such as shaft straighteners; decorated ollas and bowls; plainware cooking pots; stone and ceramic smoking pipes; ornaments made of stone, bone, and shell; and items of European manufacture or introduction. Ethnographic and indirect archeological evidence indicate that residential occupations may have occurred at any time of the year and perhaps during two or more seasons. It is hypothesized that these localities were especially suitable for winter occupations during extremely cold weather.

Rockshelters were occupied on a sporadic basis by Tierra Blanca and Garza peoples. Limited activities took place in rockshelters, and they appear to have functioned primarily as short-term camps, probably used during inclement weather.

A precise reconstruction of the yearly cycle of activities and movements of Tierra Blanca and Garza peoples is impossible given the limitations of the data. A gross reconstruction may be offered based on a combination of archeological and ethnographic evidence on Southern Plains bison hunters, particularly groups that now fall under the banner of Plains Apaches. Cultural groups that appear in Spanish documents as Querechos, Vaqueros, Faraónes, Cipayne, Limitas, Trementina, Carlanas, and Lipan Apache, are now generally considered to have been Plains Apaches (Perry 1991:58; Schlesier 1972:111). Using accounts of how these peoples lived, a model of seasonal bison hunting and trading may be proposed as a reasonable interpretation of the resource procurement strategies and annual migrations of Garza peoples. The same model may be broadly applicable for the Tierra Blanca complex, but there are considerably less archeological data to support this interpretation.

The Garza model discussed below is based primarily on Spanish accounts of Plains Apache lifeways during the seventeenth century. Whether the Garza complex actually represents Apachean peoples is another issue altogether (see discussion of ethnicity in the following section). The model simply makes note of the strong parallels between the Plains Apache lifeways and inferred behavior of Garza peoples. The model is derived primarily from summaries of ethnographic accounts of the PlainsPueblo trade presented by Baugh (1991), Boyd et al. (1993), Speilmann (1982, ed. 1991), and Wilcox (1981, 1991). Regardless of the social or economic mechanisms that drove the exchange systems (discussed earlier in this chapter), trade was an important aspect in the lives of the Plains nomads. Within the ethnographic record, there are some conflicting data and interpretations regarding which 
Plains groups traded at which specific pueblos, and when and at what time of year the trade occurred. It is clear, however, that various tribes and bands of Plains people acted as autonomous groups for purposes of trade, as did individual Pueblo villages regardless of any kinship, linguistic, or other social relationships they may have had with each other. It also is clear that, of several distinct Plains groups involved in this vast interregional trade, the Apaches show up more consistently and continuously in the archival records than do any other group. The Plains Apache tradition of trading at various pueblos was well established by A.D. 1601, if not earlier, and it continued throughout the seventeenth century (Hammond and Rey 1953:636, 639, 660; Kessell 1987:123, 134-138). Kessell (1987:123, 364) notes that the Plains Apaches regularly attended the fall trade fairs at Pecos Pueblo and maintained a strong trade alliance for well over a century.

The Plains Apache lifestyle suggests the following model for Garza complex lifeways. Garza peoples were nomads who spent most of the year roaming the plains, hunting buffalo, and living in tipis. They regularly traveled to various pueblos to trade, primarily during the fall corn harvest. During the coldest winter months, these peoples occupied residential sites located in well-watered and wooded river bottoms in the canyons along the Caprock Escarpment. They hunted and foraged locally but made no organized communal bison hunting excursions. They subsisted in part on stores of wild plant foods and dried (and salted?) meat. Processing of stored bison hides was a major winter activity. Tipis and/or brush huts provided shelter, and the valley bottoms provided forage for horses. If there were enough people (or horses) to deplete the resources in the immediate vicinity, individual bands might have moved short distances to new winter camps, probably in nearby parts of the valley. As soon as the cold weather gave way to spring, these nomads left their winter camps and moved out onto the Llano Estacado to hunt buffalo. Living in temporary camps, some people could hunt and forage locally while hunting parties searched for buffalo. Depending on the sizes of the kills, small task groups might have butchered animals on the spot and returned selected portions to their camps, or the entire band might have moved their camp to the kill location. As bison herds congregated for calving and rut during the spring, summer, and early fall, Garza peoples roamed the Llano Estacado and
Rolling Plains in search of buffalo. It is likely that each individual group or band made many kills over a vast area. Meat, hides, and plant foods were processed for long-term storage during this time. It is possible that groups periodically returned to residential sites during this time, perhaps to procure specific resources found only or primarily in the Caprock Canyonlands. Sometime in the fall, these peoples began traveling westward toward the pueblos, hunting along the way. Individual bands may have planned to arrive at specific pueblos to trade around corn harvest time, such as September to October at Pecos Pueblo according to Spielmann (1982:159-161). They probably arrived laden with buffalo hides, meat, and other goods, set up camp at the pueblo, and stayed for several weeks, perhaps even a month or more. While they traded, they continued to hunt and forage. When their trading was concluded, perhaps sometime in November or early December, the Plains peoples headed eastward toward the Caprock Canyonlands. Hunting buffalo along the way and across the Llano Estacado, they built up a store of meat and hides for the winter. Sometime in late December or early January, individual groups or bands of Garza people probably returned to one of their favored winter camps in the secluded canyons along the Caprock Escarpment. After settling into their new winter camps for two to three months, they began the entire journey again the following spring.

\section{INTERCULTURAL RELATIONSHIPS AND ETHNICITY}

This final section looks at Protohistoric huntergatherer groups in terms of ethnic identity and intercultural relationships. Rather than attempt to synthesize ethnographic evidence and resolve the issue of ethnicity, the following discussion summarizes (1) the most commonly accepted interpretation (i.e., model) of the ethnicity and interactions of the peoples defined in the archeological record as the Tierra Blanca and Garza complexes, and (2) the strength of the archeological evidence relevant to this question.

Any theory regarding the ethnicity of Protohistoric inhabitants of the Southern Plains must rely heavily on the chronicles of Coronado's 1541-1542 entrada into what is now the Texas PanhandlePlains, reconstructions of where the expedition went within the region, and identifications of the native 
peoples whom the Spaniards encountered. The Coronado narratives are extremely important because the expedition encountered peoples called Querecho just south of the Canadian River in the Texas Panhandle and peoples called Teya in the Caprock Canyonlands. Much has been written about the expedition, but the most important and informative account is George Parker Winship's translation of the original Spanish narrative by one of the expedition's Spanish soldiers, Pedro Castañeda (Castañeda 1904; Winship 1896). Other important interpretive studies of the Coronado expedition documents, its route through Texas, or possible expedition campsites are presented by Aiton (1939), Bolton (1949), Day (1940), Donoghue (1929), Hammond and Rey (1940), Holden (1944), Ivey et al. (1991), Kiser (1978), Rhodes (1992), and Wedel (1970b).

After Coronado's time, there is a tremendous gap in substantive ethnographic evidence relating to the native peoples of the Panhandle-Plains region. With a few exceptions, such as Oñate's 1598 expedition through the buffalo plains of Texas (Hammond and Rey 1953), few Europeans traversed the Panhandle-Plains during the late sixteenth and seventeenth centuries and saw native peoples firsthand. Consequently, most of what is known about the native inhabitants is based not on direct observations of the peoples in their homeland but on indirect evidence, primarily Spanish accounts of Plains Indians who came to trade at Spanish mission-pueblos. While the frequency of contact between Europeans and Native Americans and the number of ethnohistoric accounts increased early in the eighteenth century, indigenous Panhandle-Plains peoples changed dramatically during this time. The sudden appearence of the powerful Comanche tribe in the Southern Plains in the early 1700 s immediately disrupted and eventually displaced the previous bison hunting groups who lived there. The chronicles of the Coronado expedition provide the most reliable firsthand evidence relating to the lifestyles and identity of the region's native hunter-gatherer population between 1541 and the arrival of the Comanches soon after 1700 .

Most of the important Protohistoric ethnohistoric accounts are summarized and discussed from an archeological perspective in a variety of places (e.g., Baugh 1986, 1991, 1992; Habicht-Mauche 1987, 1988, 1992; Kelley 1986, 1990; Newcomb 1961; Spielmann 1982, ed. 1991; Wilcox 1981). Most of these researchers generally agree that the sixteenth- and seventeenth-century ethnohistoric accounts support the interpretation that the Llano Estacado and Caprock Escarpment were inhabited by two main groups of people, first recognized by Coronado as Querechos and Teyas. Other groups may have occupied or crossed the region on occasion, but only two were consistently and continuously recognized by Spaniards as separate and distinct, sizable populations of indigenous Plains people.

The Querechos are confidently identified as Athapascan speakers who later became known as Apaches. They inhabited and controlled much of the Panhandle-Plains region throughout the Protohistoric period and were identified by many different tribal/band names at different times by different observers (e.g., Vaqueros, Faraones, Escanjaques, Limitas, Trementinas, Quartelejo, Carlanas, and Lipan); some of these names definitely denote Apachean peoples, while there is less agreement on the identification of others. Uncertainty also remains as to the ethnic identification and linguistic affiliation of the Teyas.

Both groups were recognized by contemporary observers as being seminomadic, tipi-dwelling bison hunters with basically similar lifestyles. It is unlikely that either of these groups engaged in substantive agricultural activities, although some researchers (e.g., Baugh 1982:207) believe that at least one ethnographic account hints that the Teyas may have done some limited farming (for a contrary opinion, see Boyd et al. 1993:252). The Coronado expedition clearly documents that the Querechos were enemies of the Teyas, and subsequent ethnographic accounts suggest that the hostile relationship between the two continued throughout the Protohistoric period.

Disregarding the linguistic debate, which has little bearing on interpreting the archeological record, there is considerable agreement as to the ethnic distinctiveness and longevity of the Querecho and Teya peoples. The ethnographic evidence is less clear with respect to the cultural differences between the two groups, however, and this problem is critical when interpreting the archeological record.

Switching from ethnohistoric accounts to the archeological record, some researchers have suggested that the Querechos and Teyas may correlate with the archeological remains of the Tierra Blanca and Garza complexes, respectively. This model, hereafter referred to as the Querecho-Teya model, is most completely and succinctly stated by HabichtMauche (1992). It is based upon the premise that 
"both the Teyas and Querechos specialized in the processing of bison products which they brought annually to such eastern frontier pueblos as Pecos to trade for the agricultural resources and crafts of their more sedentary neighbors" (Habicht-Mauche 1992: 256). The strength of the model lies primarily in the fact that the Querecho-Tierra Blanca and TeyaGarza connections make sound geographic sense, and both complexes show strong economic ties to the eastern pueblos. The complexes seem to be in the right place at the right time to correspond with ethnographic evidence placing the Querechos in the upper reaches of the Red River on the Llano Estacado and the Teyas in the barrancas or canyons along the Caprock Escarpment. In addition, Tierra Blanca and Garza sites contain substantial amounts of exotic material culture (e.g., pottery, turquoise, and obsidian) indicating that the inhabitants were participants in an extensive exchange network with sedentary Puebloan peoples. This type of model is particularly important because the Protohistoric archeological record of the Panhandle-Plains cannot be adequately explained without some knowledge, via the ethnohistoric record, of the economic relationships between Plains and Puebloan peoples.

While the basic tenet of the model - that the Querecho and Teya were two distinct Plains peoples who were heavily involved in trading with Puebloan farmers - is intuitively sound and is likely to attract many supporters, including this author, some of the more specific interpretations are open to debate. The discussions below highlight only a few of the interpretive problems that warrant more attention in future studies.

Although few researchers would disagree that the Querechos were Athapaskan-speaking Apaches, there is little agreement as to the ethnic identity or language of the Teyas. Teyas are interpreted variously as a group of Plains Apaches (e.g., Forbes 1959; Gunnerson 1956:352, 1974:17; Kelley 1990; Thomas 1940:3; Wedel 1961:103) or an undefined group of Caddoan-speaking Plains peoples who may or may not have been the enigmatic peoples later called Jumanos (e.g., Bolton 1911; Hammond and Rey 1940:239; Hodge 1911; Kessell 1987:21; Newcomb 1961:99; Sauer 1971:143; Schroeder 1962:9). The Querecho-Teya model identifies the Garza complex as probably representing Plains Caddoan peoples who were later identified as Plains Jumanos (Habicht-Mauche 1992:256-257). The ethnicity problem is further compounded by the confusion and uncertainty regarding the cultural identity of Jumanos. Jumanos may have included, and were often confused with, some of the painted (probably tattooed) peoples generically called rayados or indios rayados (i.e., striped Indians) by the Spandiards. Jumanos may have been one group of rayados, but the term rayados seems likely to have been used for other painted peoples besides Jumanos. Linguistically, some researchers prefer the interpretation that the Plains buffalo-hunting Jumanos were Caddoan speakers (e.g., Hodge 1911), while others think that they spoke a Uto-Aztecan (Miller 1983:122; Sauer 1934:80), Athapaskan (Forbes 1959), or Tanoan (Scholes and Mera 1940:282) language. Most recently, Hickerson (1994) has suggested that Jumanos spoke a Piro dialect of the Tanoan language family and were related to Tompiro peoples who lived in pueblos along the lower Rio Grande in New Mexico. Like Habicht-Mauche (1992), Hickerson (1994:228-230) links the Garza complex with Plains Jumanos. In contrast, other researchers think that the Garza complex represents Apache peoples (e.g., J. Hughes 1991:34-36; Johnson et al. 1977:104-106).

The linguistic affiliation and precise ethnic identity of the Teyas and/or Jumanos is certainly debatable and probably never will be resolved to everyone's satisfaction. Because of this uncertainty, ascribing a Caddoan ethnic and linguistic affiliation to the Teyas is an unnecessary distraction within the Querecho-Teya model. If one views the QuerechoTeya model in its simplest form, then it matters little what language the Teyas spoke or to whom they were related. What is important for interpreting the archeological record is that the Teya were consistently recognized as a separate and distinct social group who were enemies of the Querechos peoples from at least the mid sixteenth century to the end of the seventeenth century.

Thorough testing of the Querecho-Teya model will require a rigorous and critical look at the relationship between the Tierra Blanca and Garza complexes. If these complexes do represent different peoples who were hostile toward each other for at least one and a half centuries, this should be manifest in the archeological record. A cultural boundary between the Tierra Blanca and Garza complexes may be indicated by the northern distribution of Garza points (see Figure 96), but there is not yet any definitive archeological evidence for violence or conflict between these groups. Given the limited 
sample of human burials attributed to these complexes, the absence of definitive evidence of conflict may be just an archeological sampling problem. In addition, Baugh's (1986:175-176) suggestion that the circular feature at the Bridwell site represents a fortification (i.e., palisade wall) trench indicative of intercultural warfare has yet to be proven. Rather than assume that these two groups of people were enemies, future archeological work should concentrate on defining the similarities and differences between the Tierra Blanca and Garza complexes, as well as testing the hypothesis of intercultural conflict.

Besides their relationships with each other, the Tierra Blanca and Garza peoples certainly interacted with many other peoples. Relationships with various groups may have been friendly or hostile at various times, but much remains to be learned about these social interactions. Evidence for violence is well represented in the surrounding Late Prehistoric and Protohistoric cultures, and intersocietal warfare may have played a significant role in the lives of Tierra Blanca and Garza peoples.

Evidence for interaction and exchange between the Plains bison hunters and Puebloan agriculturalists is extensive and has been the focus of much archeological attention. To date, most studies have been directed toward defining the nature of the exchange systems by concentrating on identifying sources of imported items. This line of research is important and should remain a primary goal. In particular, distinctive decorated Puebloan ceramics that may be identified to specific manufacturing sources may be the key to defining relationships between various Southern Plains peoples and individual pueblo villages. For example, ethnographic evidence suggests that the importance of individual pueblos or Puebloan areas and their autonomous economic relationships with specific Plains peoples changed through time, and such changes may be reflected in the archeological record. Occupations at the Tierra Blanca, Blackburn, and Bridwell sites, which have produced ceramic assemblages dominated by intermediate glazewares (i.e., Glazes C and D) manufactured in the Galisteo Basin, presumably date to the late fifteenth or early sixteenth centuries. In contrast, the well-dated mid-sixteenth- into seventeenthcentury occupations at the Longhorn and Headstream sites are dominated by late glazewares (i.e., Glazes $\mathrm{V}$ or VI or E and F) made at Pecos Pueblo and at unidentified Salinas-area pueblos, and no sherds of
Galisteo-made wares were recovered. These differences may reflect chronological changes in PlainsPueblo economic systems or denote relationships between specific Plains groups and individual pueblos or Puebloan areas. Further complicating archeological interpretations, it is likely that individual bands of Plains peoples also were autonomous in their trade alliances with various pueblos. If so, the frequency of occurrence and source areas for imported Puebloan items may vary on a micro-scale within the Tierra Blanca or Garza complexes. Recognizing such subtle differences will require better material culture data than are available for most Tierra Blanca and Garza complex sites.

The undefined Tierra Blanca-like sites in the northern Panhandle are of interest because of their bearing on the northern boundary of the Tierra Blanca complex. In addition, similar archeological remains defined as the Dismal River Aspect are found farther to the north. It has been proposed that Dismal River represents late-seventeenth- into earlyeighteenth-century Apachean occupations in the Central Plains (e.g., Gunnerson and Gunnerson 1971; Wedel 1935), but not all researchers agree (e.g., Opler 1971). Regardless, its relationship with the contemporary Tierra Blanca complex has yet to be studied. In addition, the relationships between the Tierra Blanca complex and reported Apachean occupations in northeastern New Mexico (e.g., Gunnerson 1969; Winter 1988) is uncertain.

As with the northern limits of the Tierra Blanca complex, the southern and eastern limits of the Garza complex are debatable because Garza or Garza-like points are found well beyond the core area. To the south, Garza complex occupations are found alongside Toyah phase occupations in westcentral Texas (e.g., Elm Creek, Davis Hackberry Spring, and Rush sites in Figures 97 and 99), and Perdiz points are found across much of the southern Llano Estacado (see Table 82) along with Garza points. Following Lee Johnson (1994:241-287), it appears that the southern Llano Estacado and the northern part of west-central Texas was a "shared area" that was simultaneously occupied by several cultures. The relationship between the contemporaneous Garza and Toyah peoples is far from clear, but archeological evidence, such as the finds of Garza and Perdiz points in a possible single-event bison processing activity area at the Rush site in Tom Green County, may eventually shed light on who was occupying the shared area. 
Garza components have been found as far south as the Blue Mountain and Red Bluff shelters (see Figure 99), and Garza points are commonly found in the Van Horn and La Junta areas of Trans-Pecos Texas (Hedrick 1989:Table 6, personal communication 1990; Mallouf 1992). The southern extent is further confused by Garza-like, basal-notched arrow points (i.e., Soto [Phelps 1987], Cienegas [Taylor 1966:84], and undefined points of the Bravo Valley Aspect [see Kelley 1986:Plate III, 88-89]) found throughout the Trans-Pecos region, in southern New Mexico and Arizona, and in northern Chihuahua and Coahuila, Mexico. Noting that Garza and Soto are contemporaneous styles, Phelps (1987:21) specifically suggested that they are related types, while Mallouf (1992:10-11) notes that both Garza and Soto styles are common in the La Junta area. Garza and Garzalike points are often found in Trans-Pecos sites yielding Perdiz, Toyah, and Livermore points, but the relationships between these various styles and the peoples that they may represent are unclear.

The relationship between the Garza complex and Protohistoric manifestations to the east is problematic. Following work by Baugh (1986), HabichtMauche (1992:256) links the Garza complex with the Wheeler phase (defined as including the Edwards and Wheeler complexes) of western Oklahoma within the Querecho-Teya model. The idea that the Garza complex is simply a western extension (or expansion?) of Plains Caddoans should be considered tentative and is only one of many different hypotheses. The similarities connecting these two manifestations are limited to (1) occasional Garza points found in Wheeler phase sites, (2) Wheeler phase ceramics (i.e., Edwards Plains and Little Deer Plain) found in Garza sites, and (3) gross similarities between the Bridwell site circular ridge and earthen features representing fortifications at the Edwards I and Duncan sites (Baugh 1986:175). Noting that Wheeler phase pottery is found only in a few of the easternmost Garza complex sites, Boyd et al. (1993:266-267) offer an alternative interpretation of the evidence. Wheeler phase ceramics are common only at the Montgomery and Floydada County Club sites, both of which are large residential sites that may have served as trade centers on the eastern periphery of the Garza territory. Wheeler ceramics occur only in low frequencies at a few other eastern Garza complex sites and are totally absent in the western part of the Garza culture area. Consequently, the distribution of these wares, which are confined primarily to the easternmost Garza sites, may be interpreted as evidence of interaction between two distinct cultural groups rather than as evidence of cultural relatedness between Wheeler and Garza.

In conclusion, the preceding discussions highlight the fact that the Querecho-Teya model is appealing and useful as a hypothesis to be tested using archeological data. This is especially true since one of the model's major tenets is the assumption that the Querechos and Teyas were long-time enemies, and such intercultural conflict should be evident in some form or fashion in the Protohistoric archeological record. In addition, the Querecho-Teya model is also important because it recognizes the pivotal roles of bison hunting and Plains-Pueblo trade within the Tierra Blanca and Garza societies.

The preceding discussions also highlight the fact that there are many interpretive problems for the Tierra Blanca and Garza complexes that the model fails to address, especially with respect to relationships with other archeological phases/complexes in surrounding areas. The Querecho-Teya model provides a useful framework for predicting subsistence and settlement patterns and the relationships between these bison hunting-trading societies, but we should be cautious not to attach too much ethnic or linguistic baggage to the Tierra Blanca and Garza complexes. For the Protohistoric period on the Southern Plains, Hofman (1989b:99) notes that "It is especially difficult to convincingly assign particular assemblages of this age to specific cultural groups. . .." The more productive avenue of research would be to test hypotheses of group identity and solidarity using archeological data, rather than interpreting archeological remains based on assumptions of ethnicity. For example, a researcher who believes that Garza peoples were Apaches is likely to view archeological evidence much differently than one who believes that the Garza complex represents Plains Caddoan peoples (e.g., the indiscriminate identification of plainware sherds as "Apache" pottery simply because they were found in Tierra Blanca or Garza sites is an example of an inappropriate use of ethnicity). Researchers who are not biased by assumptions of ethnicity are likely to be more objective when analyzing and interpreting archeological evidence.

In closing this discussion of the Protohistoric period, it is worth noting that there are some important research avenues that have received little archeo- 
logical attention. Hofman (1989b:99) notes at least four "big events . . . dramatically and irreversibly influenced the native cultures." One big event, which started prior to contact but continued throughout the Protohistoric period, was the development of "relationship[s] between hunters-traders and sedentary horticultural groups." The Plains-Pueblo trade is a research topic that has been the focus of most material culture and ethnographic studies by archeologists in recent years. A second big event was "the involvement of both hunting societies and horticulturalists in the Anglo-American economic sphere through trading." Noting that "trade fairs" developed in response to European involvement and increased intensity of the Plains-Pueblo trade, Hofman (1989b:99) states that the "locations of 'trade fairs' provide archeological opportunity and the potential for considerable 'confusion' in attempts to sort archeological assemblages by ethnic groups." The third and fourth big events were the "introduction of the horse with its subsequent impact on mobility, trade, economy, and overall lifeways" and the "introduction of European diseases and the demographic impacts brought about by rapid population reduction." With regard to the Tierra Blanca and Garza complexes, the latter two research topics have received almost no serious archeological attention. These events have been largely ignored because they are so difficult to detect in the archeological record, but the impacts of the introduction of horses and European diseases on Native Americans were tremendous and must be considered. Understanding the Protohistoric period is particularly challenging for Southwestern and Southern Plains archeologists because of the complexity and scope of the cultural changes-population movements, decline, acculturation, and assimilation - that occurred in the two centuries following European contact. 


\section{SUMMARY OF LATE HOLOCENE NATIVE AMERICAN ADAPTATION IN THE TEXAS PANHANDLE-PLAINS}

by Douglas K. Boyd

The long-range goal of archeological studies in the Texas Panhandle-Plains is to reveal the human past through careful recovery and thoughtful interpretation of all types of physical evidence. One approach to reaching this goal is to define the relationships between resource structure and human land-use patterns through time and space. This was the underlying theme in the intersite comparative analyses of late Holocene archeological data from the Lake Alan Henry project area (see Chapter 7) and throughout the Texas Panhandle-Plains (see Chapters 9-11). This chapter summarizes the interpretations of Native American culture history during the late Holocene using the concept that the distribution of key resources through time and across space was of critical importance to past peoples. Three concepts, summarized below, had a significant bearing on interpreting the archeological data.

The first important concept is the explicit recognition of the Caprock Canyonlands as a unique ecological and archeological subregion (see Chapter 2). This is based on the premise that the natural resources and archeology of the Caprock Canyonlands are intimately related to, yet distinct from, the natural resources and archeology of the High Plains and the Rolling Plains. The importance of the Canadian River valley as a unique environmental zone within the northern Texas Panhandle has long been recognized by archeologists, but the significance of the escarpment canyonlands has previously been ignored or underestimated. The Caprock Canyonlands provided past human populations with more abundant, higher quality, and more predictable resources than could be found over most of the
Southern Plains. Like the Canadian River valley, the resources of the Caprock Canyonlands included, but were not limited to, natural shelter, firewood, wood and raw lithic materials for making tools, plant and animal foods, and, most importantly, water. Freshwater springs emerging primarily from the Ogallala aquifer, and to a lesser extent from Triassic and Quaternary aquifers, are more abundant and predictable in the Caprock Canyonlands today than anywhere else in the region, and this also was true in the past. Historical documents indicate that prior to the depletion of ground water aquifers in the twentieth century, springs and spring-fed tributaries in the canyonlands provided abundant water that supported lush vegetation and attracted a variety of wildlife. Water has always been the most critical resource dictating the distributions of plants and animals in arid regions, and prehistoric humans probably perceived the Caprock Canyonlands as an oasis within the vast semiarid Southern Plains.

Current archeological research in the PanhandlePlains emphasizes the relationships between humans and their environments. The development of an ecological approach in the area has paralleled the evolution of archeological thought throughout the Southern Plains and the United States. Following this line of research, this synthesis examined differences between archeological remains in the Caprock Canyonlands and those on the Llano Estacado and Rolling Plains, finding significant differences in the archeology of the these subregions (see Chapter 3). Using survey-level data only, gross variations in the densities of Native American sites (i.e., the number of sites per acre) across vast areas are attributable, 
in large part, to differential human utilization of the landscape, which in turn reflects differential distribution of resources at the subregional level. Archeological sites that have been interpreted using testing or mitigation data reflect an even higher degree of spatial patterning corresponding to intraregional environmental variations. It is generally true that sites with evidence of intensive and/or long-duration occupations are, again not coincidentally, clustered primarily in the resource-rich Caprock Canyonlands but are rare and occur only in unique settings on the Llano Estacado and the Rolling Plains.

The second concept involves paleoenvironmental reconstruction as the foundation for interpreting and understanding significant changes in human behavior. It is widely recognized that the abundance and distribution of water, plants, animals, and other resources used by humans changed through time and that these changes were linked in complex but important ways to changing environmental conditions. A regional paleoenvironmental reconstruction for the Lake Alan Henry vicinity, based on various types of evidence from numerous localities within a 250-mile radius of the project area, is in general agreement with paleoenvironmental reconstructions for other parts of the Southern Plains (see Chapter 8). This reconstruction provides baseline data indicating that the late Holocene period was marked by significant climatic shifts that had a dramatic effect on the distribution of resources. In turn, these major climate-induced environmental changes are linked to major cultural events. Although the complex cause-and-effect relationships between climatic changes, environmental conditions, and human behavior remain ill defined, understanding these interactions is the key to interpreting the archeological record.

The third important concept was incorporated into the "model of late Holocene human adaptation" in the Texas Panhandle-Plains that was developed to guide the Lake Alan Henry data recovery work (see Chapter 4). Although the model was revised periodically, its final form proposes that the distribution and abundance of key subsistence resources and changes in these resources through time were primary factors controlling human subsistence strategies and settlement patterns. The model suggests that Native American peoples adapted their food procurement strategies and settlement patterns by shifting emphasis between collector and forager modes of resource acquisition according to the specific nature of the resources being exploited at any particular time and changes in the resource base through time. In the case of highly predictable bulk (i.e., abundant and spatially concentrated) foods, it was probably more efficient for people to use a collector-oriented strategy involving procurement by special task groups and subsequent processing, storage, and/or consumption of those resources at semipermanent residences or base camps. In contrast, it was probably more efficient for people to exploit lesspredictable, low-density (i.e., sparse and scattered) food resources using a forager strategy involving frequent moves of residential sites. In one sense, collectors are tethered to a home base and move resources to the people, resulting in an archeological record characterized by long-term occupations at residential sites (encompassing some form of domestic dwellings) or base camps and a variety of taskspecific, special activity sites. Foragers, on the other hand, are residentially mobile and move the people to the resources, thereby creating a larger number of limited-occupation campsites. The two strategies are not mutually exclusive, however, and the distribution and diversity of sites generated by a particular group in a particular area at a particular time should reflect the variety of resources utilized and the mix of procurement strategies used to exploit them. The model further predicts that past societies may have fluctuated between being collectors and foragers on a seasonal basis, depending upon what particular resources were available for exploitation at any given time. In addition, the model predicts that overall patterns of resource utilization changed significantly through time because of long-term, climatically induced shifts in resource availability, i.e., the abundance, density, and predictability of resources at the local and regional levels. Within this framework, site-specific archeological research attempts to determine precisely how each site fits into the collector-forager continuum. From a regional perspective, testing of the model will require archeological researchers to (1) investigate enough individual sites and a sufficient diversity of site types so that the full range of resource acquisition patterns may be defined for specific peoples at specific times, and (2) compile sufficient archeological data so that changes in resource acquisition patterns through time may be elucidated and the relationships between humans and past environments may be understood.

No model of human adaptation in the Southern Plains would be complete without some mention of the role of bison. Since Dillehay (1974) proposed 
extended periods of bison presence and absence in the Southern Plains, the pros and cons of this hypothesis have been considered by many researchers (e.g., Creel et al. 1990; Flynn 1982; Lynott 1979b). Most would probably agree that (1) there have been long-term fluctuations in Southern Plains bison populations during the Holocene, (2) bison population changes were tied to paleoclimatic changes and corresponding changes in grassland ecosystems, and (3) major changes in bison populations had significant impacts on human settlement and subsistence patterns. Most researchers also would agree that bison were probably never absent in the region and that it is more appropriate to think in terms of periods of bison scarcity and abundance. What remains controversial are the intensity and timing of bison population changes, how these changes related to environmental variables, how human populations adapted to these changes, and how these changes fit into the broader picture (i.e., what was happening in other regions in terms of paleoclimate, bison populations, and human adaptation).

Within the late Holocene adaptation model, bison are recognized as the most important, and most archeologically visible, bulk resource that could be efficiently exploited by humans using a collector strategy. Consequently, major shifts in the availability of bison had a tremendous impact on human populations. The model assumes that past peoples would have systematically exploited bison (i.e., they would have been bison collectors) as their primary subsistence resource whenever bison populations were large enough to support intensive exploitation. Only during times when bison were relatively scarce would people have altered their lifestyle to some other primary food resource. Besides bison, the model also allows for the probability that certain wild plant foods, either a single key species or a suite of important species, could have been sufficiently abundant and predictable to have been exploited by collectors. It also predicts that limited horticulture could have been incorporated into a wild plant food-based subsistence strategy with only minimal effects on overall hunter-gatherer procurement systems. ${ }^{10}$

When regional archeological data were reviewed

\footnotetext{
${ }^{10} \mathrm{~A}$ mix of bison hunting and intensive agriculture certainly allowed past peoples to adopt a collector-oriented lifestyle, but the model was developed for hunter-gatherer populations rather than for Plains Village adaptations such as seen among Antelope Creek phase peoples.
}

in the context of these three concepts, significant reinterpretations of late Holocene human behavior in the Panhandle-Plains emerged. The escarpment area seems to have been a critical zone, in terms of subsistence and settlement, for many different prehistoric populations over many thousands of years. In a simplistic fashion, the Caprock Canyonlands may be viewed as having been a home base for many Late Archaic, Late Prehistoric, and Protohistoric cultures whose seasonally oriented activities extended over a much larger territory that included the Llano Estacado and Rolling Plains and areas beyond. It is proposed that all past human populations who frequented the Panhandle-Plains (1) were cognizant of the geographic distributions of critical resources and the relative abundance and diversity of those resources in the Caprock Canyonlands environment, (2) adjusted their procurement strategies and settlement patterns to the seasonal availability and variability of different subsistence resources clustered within or scattered across the landscape, and (3) adapted to significant changes in climatic conditions and resource distributions by altering their subsistence resource procurement strategies and settlement patterns. In addition, archeological data support the interpretations that bison populations in the Panhandle-Plains fluctuated throughout the late Holocene as grasslands responded to long-term shifts in available moisture and that people incorporated bison hunting as a primary subsistence pursuit during all times when bison populations were sufficient to allow for intensive exploitation.

The remainder of this chapter summarizes the broad interpretations of the Late Archaic, Late Prehistoric I, Late Prehistoric II, and Protohistoric peoples who inhabited the Panhandle-Plains. In light of these ideas, Figure 105 illustrates key points relevant to the discussions.

\section{LATE ARCHAIC PERIOD (2000 B.C. to A.D. 500)}

Late Archaic (2000 B.C. to A.D. 500) human populations were nomadic hunters - small bands of people who ranged across a vast region in pursuit of bison, trapping small herds in arroyos, and dispatching animals with broad-bladed dart points. The consistency in sites and material culture signals the presence of a coherent bison hunting lifestyle across all of the Texas Panhandle-Plains and into western Oklahoma. More-detailed studies of the broadbladed dart points (variously typed as Castroville, 


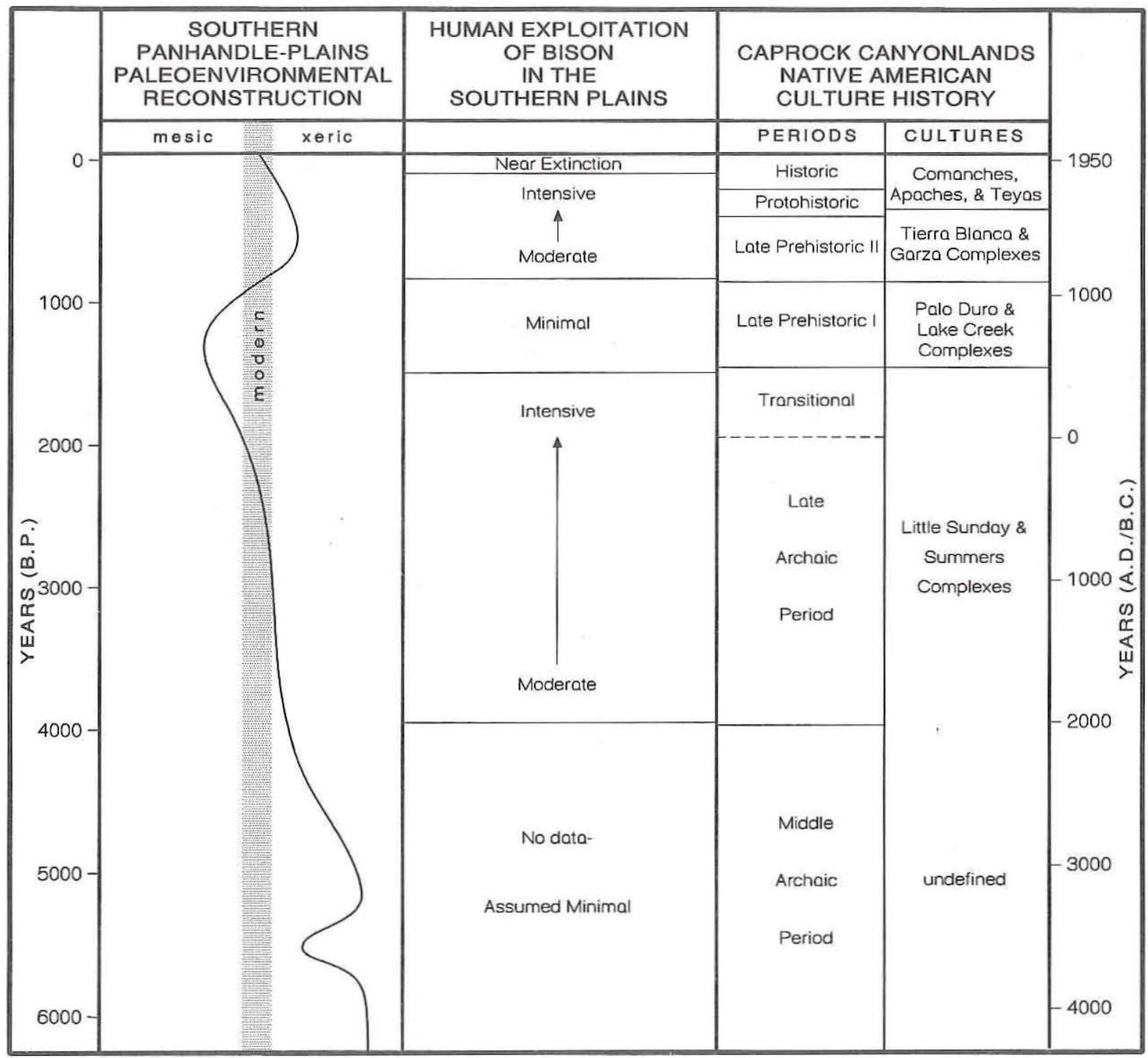

Figure 105. Comparison of interpretations of paleoenvironment, human exploitation of bison, and Native American culture history of the Caprock Canyonlands and the Texas Panhandle-Plains during the middle to late Holocene.

Edgewood, Elam, Ellis, Ensor, Kent, Lange, Marcos, Marshall, Palmillas, Trinity, and Williams) are needed to better define types, recognize subtle interregional stylistic variations, and delineate similarities and differences between Southern Plains specimens and their Central Texas counterparts. Although the larger forms appear to be somewhat earlier than the smaller styles, specimens from welldated contexts need to be studied to define the chronological sequence of dart point styles for the 2,500-year Late Archaic period.

Archeologically recognized as the Little Sunday complex (redefined in Chapter 9, it subsumes the
Summers complex of western Oklahoma), the remains left by these bison hunters are grossly divided into four site types: bison kills and processing sites, campsites, rockshelters, and burials. No evidence of habitation structures has been found, and residential village sites comparable to those of later times are not known. The campsites and rockshelters are clustered in the Caprock Canyonlands, while the bison kill and processing sites are found primarily in the Rolling Plains. Surface finds of broadbladed dart points indicate that these people probably hunted bison on the Llano Estacado as well, but no sites on the Llano Estacado have been adequately 
investigated (presumed Late Archaic site types there include bison kills, processing camps, and short-term hunting camps). Bison hunting in the Rolling Plains is fairly well documented at many kill/processing sites, and numerous campsites (but no bison kills) are known in the Caprock Canyonlands. Major archeological investigations of campsites have been limited or inadequately reported, and they provide little substantive data on the full range of resources (other than bison) utilized. More base camps need to be investigated to increase our understanding of Late Archaic hunter-gatherers, and researchers must recognize the potential for encountering specialized activity sites where no diagnostic points are present (e.g., localities where plant processing was the sole activity). One specialized type of campsite, which occurs on top of prominent mesas along the Caprock Escarpment, may have served as temporary observation stations where hunting parties camped and geared up for the hunt while watching for signs of bison herd movements along the edge of the Llano Estacado and on the Rolling Plains.

The geographic distribution of Late Archaic sites suggests that Little Sunday peoples made the Caprock Canyonlands their home base for part of the year and that they roamed the Rolling Plains of Texas and western Oklahoma and the Llano Estacado during bison hunting seasons. Seasonality data are poor, but it is speculated that communal bison hunting occurred during the spring, summer, and fall and that the hunters may have returned to the sheltered canyonlands to spend the winter. The density of sites, relative to subsequent periods, suggests that populations were generally low during Late Archaic times, perhaps peaking during the transitional Archaic (ca. A.D. 200-500). Burials provide evidence that these peoples obtained exotic ground stone (i.e., lunate stones made of nonlocal igneous rocks) and coastal shell ornaments, probably by trading bison products (e.g., meat and hides) to peoples elsewhere in Texas or Oklahoma. The bison hunters probably participated in a vast extraregional exchange system, perhaps something like the Late Archaic into Woodland "Eastern Import-Export Sphere" envisioned for Texas by Hall (1981:291309). Within this interaction sphere, Southern Plains people obtained exotic goods, probably including many perishable items (e.g., wild plant foods) in addition to the stone and shell ornaments, from their southerly neighbors in Central Texas.

Interpreting the transitional Archaic period is problematic, but a growing archeological data base hints at continued use of broad-bladed dart points concurrent with the appearance of early cornernotched and stemmed arrow points (and possibly Woodland pottery) between ca. A.D. 200 and 500 . During this time, bison hunting may have intensified, but it declined rapidly around A.D. $400-500$ as bison populations dwindled under climatic stress, presumably in response to increasingly wet conditions and concomitant changes in grassland communities. Natural decreases in bison herd size may have been exacerbated through overexploition by efficient communal hunting techniques (e.g., bison jumps and arroyo traps).

The Late Archaic bison hunting lifestyle disappeared from the Panhandle-Plains by ca. A.D. 500 . Whether the indigenous bison hunters adapted to changing conditions by adopting a Plains Woodland foraging lifestyle or were replaced by an influx of new peoples is not known, although an in situ transformation of the local populations is an appealing hyphothesis. In the waning years of their presence in the Southern Plains, the Late Archaic bison hunters were engaged in conflicts with neighboring peoples. Although burial data are limited, at least two sites in western Oklahoma contain mass graves of persons who apparently met violent deaths between ca. A.D. 300 and 600 (i.e., five individuals in one grave at Lake Altus and three persons in one grave at the Sullivan-Carpenter site). Outside the Panhandle-Plains, burial evidence indicates that intergroup hostilities also were commonplace in Central and South Texas during late Archaic times (Hall 1981:306-308). Hostilities in the Southern Plains and Central Texas may have been a response, at least in part, to a breakdown in the interaction sphere or exchange systems involving many cultures, perhaps resulting in part from climate-induced stress as more people competed for control of fewer resources and smaller territories.

\section{LATE PREHISTORIC I PERIOD (A.D. 500 to $1100 / 1200$ )}

During the brief mesic interval that spanned the Late Prehistoric I period (A.D. 500 to 1100), peoples living in the Caprock Canyonlands adapted to a paucity of bison by adopting a foraging lifestyle. Hunting of deer and smaller animals was important, but the primary economic pursuit involved gathering and processing of wild plant foods, perhaps supple- 
mented by limited horticulture. The Late Prehistoric I period is quite unlike other periods in the Southern Plains in that bison hunting was of little or no consequence. It appears that the northern Caprock Canyonlands was a home territory for peoples from an eastern Plains Woodland tradition, while the southern Caprock Canyonlands was occupied by peoples who maintained frequent contact with Southwestern horticultural villagers of the Jornada Mogollon tradition. Archeologically recognized as the Lake Creek and Palo Duro complexes, respectively, these cultural traditions converged somewhere in the upper headwaters of the Red River.

Substantive archeological data for the Lake Creek complex (reviewed in Chapter 10) are limited, but it appears to represent a western extension of the Plains Woodland lifestyle and material culture. Presumably derived from (and probably related to) Plains Woodland groups in western and central Oklahoma, diagnostic Lake Creek artifacts are Scallorn and Scallorn-like arrow points and Woodland cordmarked pottery. No residential villages are known, although Woodland pithouselike structures are suspected at two sites (i.e., the Greenbelt site and Duncan Ranch Site 1). Other sites attributed to the Lake Creek complex are campsites and burials, but few have been adequately investigated and reported. All Lake Creek sites are clustered in and north of the Canadian River valley and in the northern end of the Caprock Canyonlands in Texas and western Oklahoma. The distribution of sites, along with evidence for violence in probable Lake Creek/Plains Woodland burials, may indicate that these peoples were enemies of the Palo Duro peoples who mainly lived south of the Red River.

Archeological data for the Palo Duro complex (redefined in Chapter 10) are considerably better. Culturally diagnostic artifacts are corner-notched Scallorn and Scallorn-like arrow points, distinctive basal-notched Deadman's arrow points, and nonlocal brownwares manufactured in the Jornada Mogollon region of western Texas or southeastern New Mexico. Site types attributed to the Palo Duro complex include residential sites, campsites, rockshelters, and burials. Although some sites in the Canadian River valley have produced evidence of possible Palo Duro occupations, the majority of Palo Duro sites are clustered in the canyons along the southern Caprock Escarpment, and the complex's core area lies within the upper Red and Brazos River basins and perhaps extends southward into the upper Colorado River basin. There is little evidence that Palo Duro peoples utilized the Llano Estacado or Rolling Plains to any great extent, and the Caprock Canyonlands appears to have served as their principal territory. The consistent presence of imported brownware sherds indicates that Palo Duro peoples maintained contact with Jornada Mogollon peoples over many centuries, but the nature of the interactions is uncertain. Jornada Mogollon peoples, or their sphere of influence, may have expanded onto the southern Llano Estacado (i.e., the Querecho and early Maljamar phases of the eastern extension of the Jornada Mogollon) during Late Prehistoric I times, but little is known about the archeological sites there or the relationship between Palo Duro and Eastern Jornada peoples.

Based on investigations at two residential villages-Kent Creek and Sam Wahl-it appears that Palo Duro peoples lived for part of the year in rectangular and oval pithouses that are stylistically reminiscent of Jornada Mogollon pit structures. The occupants of these village sites processed large amounts of wild plant foods, including mesquite beans and shin oak acorns, using grinding tool kits that were impressive compared to those of other late Holocene peoples. Palo Duro peoples also stored some plant foods (probably many types that have yet to be identified) in subterranean storage pits and in small pithouselike structures. Hunting of deer and smaller animals is well represented at one residential site but is poorly represented at the other site where plant processing and storage were the primary activities. The limited evidence suggests that there is considerable variability in the types of activities, seasonality, size, and function of Palo Duro pithouse residences; this same degree of variability has been noted for pithouse sites in the Jornada Mogollon region.

Relatively intensive occupations also are represented at many campsites and at one rockshelter (i.e., Deadman's) that probably served as semipermanent base camps, while other rockshelters served only as temporary shelters for small groups. The base camps appear to be localities where a range of generalized domestic activities took place and have produced artifact assemblages and features similar to those found in the residential villages (noting that the absence of habitation structures at some campsites is probably due to limited subsurface sampling). In contrast, other campsites appear to be little more than specialized plant processing sites where exten- 
sive pit baking of plant foods occurred, but the full range of resources that were cooked in this manner is not known. Unlike the Edwards Plateau where repeated prehistoric pit baking activities resulted in large accumulations of heat-fractured limestone (i.e., middens), baking pits in the Caprock Canyonlands were lined and/or filled with more-durable Triassic sandstone slabs that are less susceptible to thermal breakdown. Consequently, specialized plant processing sites in the Caprock Canyonlands appear to represent the same types of generalized, communal earth-oven roasting activities as evident in Central Texas burned rock middens/mounds. It is possible that Southern Plains pit roasting sites were reused as intensively as their Central Texas conterparts, but much less burned rock debris was generated in the process. Alternatively, it is possible that the smaller Southern Plains plant processing sites were scattered more widely across the landscape where sandstone was available and that it was not necessary to reuse the same roasting pits as often.

In terms of subsistence, Palo Duro peoples were probably generalized hunter-gatherers who specialized in processing specific wild plant foods during part of the year. They may have utilized a forager strategy for part of the year, but Palo Duro peoples must have operated as logistical collectors during pithouse village occupations when large quantities of plant foods were processed and stored. Because pollen preservation is generally poor and few flotation samples have been processed for macrobotanical remains, only a few specific native plants used as food resources have been identified. In addition, the absence of domesticated plant remains may be due to inadequate sampling, and the question of whether Palo Duro peoples practiced limited horticulture is unresolved.

Although the nature and extent of the relationships and interactions between the Southwesterninfluenced Palo Duro peoples, Woodland-influenced Lake Creek peoples, and other nearby cultures are not well understood, intercultural conflicts may have been prevalent during this time. Definite or probable evidence of violence is represented in many burials in the Texas Panhandle-Plains, west-central Texas, and western Oklahoma. Such evidence is represented in the Palo Duro, Lake Creek, and Blow Out Mountain complexes, perhaps indicating that enemy peoples were present both north and south of the core Palo Duro culture area. Of particular interest are a Palo Duro woman who may have been killed and was buried in her pithouse at the Kent Creek site and two men who were killed and buried in a single grave nearby, called the Donley County Double Burial. These men were killed by arrows tipped with Deadman's-like arrow points, but it is unclear whether they were members of the Palo Duro society or perhaps Lake Creek people who were killed by Palo Duro warriors. Notably, the distribution of habitation sites seems to indicate a cultural boundary between the Lake Creek and Palo Duro societies somewhere along the Red River. The relatively high incidence of violence evident in human burials indicates that hostilities may have escalated to the point of full-scale intersocietal warfare throughout the Panhandle-Plains during the Late Prehistoric I period. By inference, human populations may have been larger during the Late Prehistoric I period than in the preceding Late Archaic period.

\section{LATE PREHISTORIC II (A.D. 1100/1200 to 1541) AND PROTOHISTORIC}

\section{(A.D. 1541 to 1750)} PERIODS

The Late Prehistoric II period (A.D. 1100 to 1541) was a transitional time when peoples in the Southern Plains shifted their economic focus to take advantage of significant increases in bison populations spurred by the onset of xeric conditions and widespread changes in grassland communities. While some groups in the Texas Panhandle and western Oklahoma turned to a mixed economy combining horticulture and bison hunting, peoples in the Caprock Canyonlands combined bison hunting with a foraging lifestyle. New peoples may have come into the picture just prior to European contact, but all of the peoples in the Panhandle-Plains underwent a gradual transition under increasing European influences during the Protohistoric period (A.D. 1541-1750). From an ethnoarcheological perspective, much remains to be learned about the identities and movements of various groups during these periods, and Late Prehistoric II and Protohistoric sites are often difficult to distinguish based on limited survey or testing data.

The period between A.D. 1100 and 1541 was a time of many cultural changes for peoples living in and around the Panhandle-Plains. These changes may have been initiated by the onset of xeric 
conditions at ca. A.D. 1100-1200, accompanied by an influx or increase in bison populations across the Southern Plains, which may have been due to development and/or expansion of shortgrass prairies on the Llano Estacado. New and more-efficient tools for bison killing, skinning, and processing were introduced, probably around A.D. $1100-1200$. This new technology, evidenced archeologically by the appearance of side-notched arrow points, beveled knives, and Plains-style end scrapers (also called snub-nosed, keeled, or turtle-back end scrapers), spread rapidly among the indigenous groups in the Southern Plains. These new weapons and tools may have been introduced by immigrants who came from the north, or these innovations may have spread southward in advance of the immigrants. In either case, one or more waves of Athapaskan-speaking peoples probably appeared in the Southern Plains and Southwest some time after A.D. 1000, and they were well established there by A.D. 1541 .

Incorporating this new technology and communal bison hunting into their existing economies, some peoples adopted a Plains Village lifestyle based on a mix of hunting, gathering, and agriculture. Other peoples apparently maintained a more mobile lifestyle, concentrating on bison hunting and generalized hunting-gathering subsistence pursuits, but excluded agriculture altogether or at least minimized horticultural input. The Plains Village lifestyle was adopted by peoples living in western Oklahoma and the Canadian River valley, while various groups of seminomadic bison hunters, possibly including some Puebloan peoples, occupied most of the southern Llano Estacado and Caprock Canyonlands.

The Plains Village cultures-the Antelope Creek phase and Buried City complex of the Texas Panhandle and the Zimms complex and Washita River phase of western Oklahoma-may have developed directly out of the local Plains Woodland manifestations. If Plains Woodland peoples were generalized hunter-gatherers who incorporated minimal horticulture, then the shift to a Plains Village economy only entailed intensifying their horticultural pursuits and gradually specializing in bison hunting as herd sizes increased. The relationships between all of these Plains Village peoples are uncertain, but it seems likely that the Washita River phase represents Caddoan-speaking peoples. The Antelope Creek, Buried City, and Zimms manifestations seem to be closely related in terms of archeological traits, and they also may represent groups of eastern Caddoan peoples. However closely related these peoples were, they apparently were not always friendly toward each other. Hostilities may have developed as they expanded and began to compete with each other and with other more-nomadic groups for territory and control of the bison hunting range. Intersocietal warfare may have been the inevitable result of the pressures of increasing human populations and competition over resources. In the Texas Panhandle, the Plains Village phenomenon developed quickly, thrived, and expanded for a century or two, and then declined rapidly and collapsed during the fifteenth century. A combination of factors may have been responsible for the disappearance of the Antelope Creek and Buried City peoples. Climatic change (e.g., short-term but severe droughts), increasing populations within their societies and among other indigenous neighboring groups, and the arrival of hostile immigrants may have led to increased competition for limited subsistence resources. Athapaskan-speaking peoples, or Apaches, are most often accused as the aggressors who may have played a significant role in the demise of Antelope Creek and eastern Puebloan peoples (e.g., in the Sierra Blanca and Middle Pecos areas).

The Late Prehistoric II period on the southern Llano Estacado is poorly known, and few sites have been adequately investigated or reported. The primary attraction was large numbers of bison, and habitation sites appear to be clustered primarily around spring-fed pluvial lakes, around some larger playas, and in the sand hills where the water table was shallow. The limited evidence indicates that the southern Llano Estacado was occupied most consistently by Puebloan or Puebloan-influenced peoples, manifested archeologically by the late Maljamar and Ochoa phases of the Eastern Jornada Mogollon and perhaps including refugees who abandoned the Middle Pecos region around A.D. 1350 (i.e., at the end of the McKenzie phase). The southern Llano Estacado also may have been occupied/utilized by other groups that have not yet been recognized archeologically, and perhaps by Toyah phase peoples as early as ca. A.D. 1300-1400. The southern Llano Estacado is a particularly problematic research area where limited archeological research severely hinders our understanding of the Late Prehistoric II period.

In the Caprock Canyonlands, there is a gap in the archeological data between the end of the Palo Duro complex, at ca. A.D. 1100-1200, and the appearance of the Tierra Blanca and Garza com- 
plexes at around A.D. 1400 (both complexes are redefined in Chapter 11). These cultures are thought to represent new peoples who appeared suddenly (or at least adopted new technology and styles very quickly), and both represent tipi-dwelling peoples whose primary subsistence pursuit involved hunting bison. They appeared near the end of the Late Prehistoric II period, and the Tierra Blanca and Garza complexes were present at the time of European contact and were the dominant groups in the Panhandle-Plains throughout the Protohistoric period. Ethnographic and archeological evidence indicates that their lifestyles were very similar, but subtle differences suggest that these two archeological manifestations probably represent different groups of people living primarily in the northern and southern (i.e., south of the Red River) Caprock Canyonlands. The prevailing theory on ethnicity links the Tierra Blanca and Garza complexes with the Querechos (probably Apachean peoples) and Teyas (possibly Caddoan-speaking peoples) who were seen by Coronado in 1541 (see Chapter 11).

Typical archeological sites of the Tierra Blanca and Garza complexes include bison kill/processing sites and short-term hunting camps, base camps and residential sites (the latter with evidence of ephemeral tipilike structures), rockshelters, and burials. Distinctive material culture includes Plains-style end scrapers (i.e., morphologically distinctive forms also called keeled or turtle-back end scrapers), beveled knives, and small triangular arrow points. Tierra Blanca sites generally produce unnotched Fresno and Fresno-like points (some long slender specimens have been inappropriately called Talco or Talco-like) and side-notched Washita arrow points. Garza complex arrow points also include these forms, but the most diagnostic specimens are the distinctive basal-notched Lott and Garza points. The Lott point, apparently the earlier of the two forms, probably appeared by around A.D. 1400 and may be the prototype for the Garza point. Garzas seem to have replaced Lotts completely by ca. A.D. 1600 or earlier.

Tierra Blanca and Garza material culture also is notable for its exotic artifacts. Turquoise and Olivella shell beads, pieces of obsidian, and large amounts of nonlocal pottery provide evidence that the Plains bison hunters regularly came in contact and traded with Puebloan agriculturalists. Tierra Blanca and Garza ceramic assemblages are dominated by Puebloan-made pottery, both decorated and plain. Some of the plainware pottery (which includes both striated and unfinished varieties) used by these people may have been locally made, and it has been suggested that local pottery was patterned after Puebloan prototypes or made by Puebloan women living among the Plains groups. Opinions differ regarding the extent of the ceramic industry among the Tierra Blanca and Garza cultures, however, and this author sees no convincing evidence for widespread or prolific local ceramic production.

For both complexes, pottery found at base camps and residential sites includes decorated and plain sherds, while only plainwares are typically found at ephemeral campsites and bison processing stations. The majority of decorated sherds are Rio Grande glazewares. Tierra Blanca sites generally have an abundance of intermediate glazes (e.g., Glazes C and D) manufactured in the Galisteo Basin ca. A.D. 1400-1515, while Garza complex sites have an abundance of late glazes (e.g., Glazes E and F or $\mathrm{V}$ and VI) made in the Salinas area or at Pecos Pueblo ca. A.D. 1515-1700. With regard to vessel form and function, globular plainware jars (i.e., bean pots) were used for cooking (and probably boiling of bone fragments to render bone grease), while glazedecorated ollas and bowls were used for storage and/or serving. Caching of ceramic vessels in isolated locations and at residential sites suggests that Tierra Blanca and Garza peoples were very mobile.

Ethnographic accounts of Plains-Pueblo interactions provide a basic framework for further interpreting the subsistence and settlement patterns of the Tierra Blanca and Garza cultures. These peoples organized their activities on a seasonal basis to exploit the principal Plains resource, bison, and to maximize the economic advantages of trading with sedentary farmers. Perhaps of minimal importance at first, the Plains-Pueblo trade became an increasingly important aspect of the Tierra Blanca and Garza economies. Precisely when and where these peoples moved and what they did during a typical year is impossible to determine because neither ethnographic nor archeological data are sufficiently refined. The following scenario, however, meshes well with ethnographic accounts (primarily those relating to Plains Apaches). This general model, or some version of it, may serve as a testable hypothesis regarding the annual movements and activities of Tierra Blanca and/or Garza peoples. Beginning in the spring, these Southern Plains groups conducted 
communal bison hunts and exploited a range of other animal and wild plant resources. These activities, alternating between collector-oriented communal hunting and generalized foraging, continued throughout the spring and summer and into the fall. Most communal hunts presumably occurred on the Llano Estacado or in the Rolling Plains and may have involved one or more bands of people. Some communal hunts may have occurred in the Caprock Canyonlands, but individual bands probably returned periodically to favorite localities along the escarpment or elsewhere in the Panhandle-Plains to exploit other abundant wild plant foods (e.g., mesquite, prickly pear) and animals (e.g., deer, antelope, and small mammals). After conducting numerous bison hunts and storing up a supply of hides, individual bands might have headed out across the Llano Estacado toward one of the eastern frontier pueblos (such as Pecos) for the annual trade fair. Collecting a supply of fresh hides and meat on the way, they arrived at the pueblo in mid to late fall, during or just after harvest time (probably September or October). They camped in close proximity to the pueblo for several weeks while trading. Many items may have changed hands, but the bulk of the goods were probably bison hides and meat that were traded for agricultural products, primarily corn. After trading was completed, the band probably left the pueblo in the late fall or early winter and headed home to spend the winter in the sheltered river valleys of the Caprock Canyonlands. They conducted hunts on the way to gather a supply of bison meat and hides for their own use. In the spring, bands probably broke their winter camps in the canyonlands and began their annual round again in search of bison herds.

The archeological remains of the Tierra Blanca and Garza complexes cannot be fully interpreted without taking the effects of European influence into account. While some sites are exclusively prehistoric (e.g., Garza and Lott), many others were occupied primarily or exclusively during the Protohistoric period as evidenced by radiocarbon dates, temporally diagnostic native artifacts, and occasional artifacts or items of European manufacture or origin (e.g., the Tierra Blanca and Longhorn sites). The introduction of European diseases and horses probably had the greatest impacts on these societies, but these are not readily visible in the archeological record. Conversely, material culture items of European origin that are typically found in Plains sites (e.g., metal tools and fragments, sherds of Spanish majolica, beads, and cow bones) or were, according to ethnographic records, commonly traded to Plains Indians (e.g., metal knives, beads, trinkets, and obsolete firearms) probably had little or no substantive impact on Tierra Blanca and Garza societies during the sixteenth and seventeenth centuries. Besides introducing diseases and horses, the European presence significantly impacted the economies of these cultures via European involvement in the Plains-Pueblo exchange (see Chapter 11). As the Spanish became increasingly active in the Pueblo trade, demand for Plains bison products rose. In response, Tierra Blanca and Garza peoples may have intensified their bison hunting pursuits. Competition for access to and control of the exchange markets was fierce, and direct hostilities between Spanish, Puebloan, and Southern Plains peoples became increasingly common. Not only did the Southern Plains groups fight among themselves (i.e., the longtime animosities between the Querechos and Teyas), they also were opportunistic in their relationships with various pueblos and the Spaniards. Depending upon which was most convenient and productive, the Plains hunters vacillated between raiding and trading causing further deterioration of strained relationships. The Spanish began conducting raids on the Plains Indians; some were official acts done as a form of retaliation, others were by profiteers who sought to acquire Indian slaves for trade. Perhaps increasing economic competition and intercultural conflicts were inevitable in this situation. Historic records document that conflicts between and among various Native American cultures and the Spanish intensified during the late sixteenth and seventeenth centuries. Although the participation of Tierra Blanca and Garza peoples in the Plains-Pueblo trade is well documented in the archeological record, hostilities between these groups or with Puebloan or Spanish peoples is not visible archeologically. 


\section{REFERENCES CITED}

Abbott, James T.

1990 Geomorphic and Geoarcheological Investigations. In Phase II Investigations at Prehistoric and Rock Art Sites, Justiceburg Reservoir, Garza and Kent Counties, Texas, by Douglas K. Boyd, James T. Abbott, William A. Bryan, Colin M. Garvey, Steve A. Tomka, and Ross C. Fields, pp. 23-62. Reports of Investigations No. 71, vol. I. Prewitt and Associates, Inc., Austin.

Abbott, James T., and Charles D. Frederick

1990 Magnetometer Surveys at 41GR323 and 41KT53. In Phase II Investigations at Prehistoric and Rock Art Sites, Justiceburg Reservoir, Garza and Kent Counties, Texas, by Douglas K. Boyd, James T. Abbott, William A. Bryan, Colin M. Garvey, Steve A. Tomka, and Ross C. Fields, pp. 345-362. Reports of Investigations No. 71, vol. II. Prewitt and Associates, Inc., Austin.

1993 Proton Magnetometer Investigations at 41KT53. In Data Recovery at Justiceburg Reservoir (Lake Alan Henry), Garza and Kent Counties, Texas: Phase III, Season 2, by Douglas K. Boyd, Jay Peck, Steve A. Tomka, and Karl W. Kibler, pp. 445-453. Reports of Investigations No. 88. Prewitt and Associates, Inc., Austin.

Adair, Mary $\mathbf{J}$.

1988 Prehistoric Agriculture in the Central Plains. Publications in Anthropology No. 15. University of Kansas, Lawrence.

Adams, Jenny L.

1988 Use-Wear Analysis on Manos and HideProcessing Stones. Journal of Field Archaeology 15:307-315.
Agogino, George A.

1989 Paleo-Indian Myths. In In Light of Past Experience: Papers in Honor of Jack T. Hughes, edited by Beryl Cain Roper, pp. 35-45. Publication No. 5. Panhandle Archeological Society, Amarillo.

Agogino, George, and Van Tries Button

1985 A Secondary Burial of Human Cranial Fragments from 34GR6, a Prehistoric Cemetery on the Shoreline of Lake Altus, Greer County, Oklahoma. U.S. Department of the Interior, Bureau of Reclamation, Southwest Region, Amarillo.

Aiton, Arthur S.

1939 The Muster Roll and Equipment of the Expedition of Francisco Vazquez de Coronado. The William L. Clements Library, Ann Arbor, Michigan.

Albert, Lois E.

1981 Ferndale Bog and Natural Lake: Five Thousand Years of Environmental Change in Southeastern Oklahoma. Studies in Oklahoma's Past No. 7. Oklahoma Archeological Survey, University of Oklahoma, Norman.

Albert, Lois E., and Don Wycoff

1984 Oklahoma Environments: Past and Present. In Prehistory of Oklahoma, edited by Robert E. Bell, pp. 1-43. Academic Press, Orlando, Florida.

Albrecht, Jaecques

1994 Osteological Analysis of Human Skeletal Remains from the Dillard Site (410C174). Bulletin of the Texas Archeological Society 62:201-217. 
Alex, Thomas C.

1990 The Search for the Elusive Kaolinite: Prehistoric Utilization of a Lithic Resource for Ornamental Artifacts. In Papers from the Third Symposium on Resources of the Chihuahuan Desert Region, pp. 163-168. Chihuahuan Desert Research Institute, Alpine, Texas.

Alexander, Robert K.

1982 Archaeological Site Reconnaissance in the Proposed Justiceburg Reservoir Area, Garza County, Texas. Grand River Consultants, Inc., Grand Junction, Colorado.

Alvey, Richard L.

1978 The Spring 1977 S.P.A.S. Field School. Bulletin of the South Plains Archeological Society 4:39-51.

Antevs, Ernst

1948 The Great Basin with Emphasis on Glacial and Postglacial Times. University of Utah Bulletin 38:168-191.

1955 Geologic-Climatic Dating in the West. American Antiquity 20(4):317-335.

Arbingast, Stanley A., Lorrin G. Kennamer, Robert H. Ryan, Alice Lo, David L. Karney, Charles P. Zlatkovich, Michael E. Bonine, and Roberta G. Steele

1973 Atlas of Texas. Bureau of Business Research, The University of Texas at Austin.

Archambeau, Ernest R.

1954 The Fort Smith-Santa Fe Trail Along the Canadian River in Texas. Panhandle-Plains Historical Review 27:1-26.

Archambeau, Ernest R. (editor)

1971 Lieutenant A. W. Whipple's Railroad Reconnaissance across the Panhandle of Texas in 1853. Panhandle-Plains Historical Review 44 (entire volume).

Bagot, Joe T., and Jack T. Hughes

1979 Archeological Inventory of a Portion of Caprock Canyons State Park in Briscoe County, Texas. Archeological Research Laboratory, Killgore Research Center, West Texas State University, Canyon.

Bailey, Carroll $\mathrm{H}$.

1951 The Texan Santa Fe Trail. Panhandle-Plains Historical Review 24 (entire volume).
Bailey, Gail L., James T. Abbott, Michael B. Collins, Martha Doty Freeman, Jeanine M. Seay, David L. Miller, and Dan K. Utley

1989 Cultural Resources Survey, Testing, and Assessments in the Dam Construction Zone at Stacy Reservoir, Coleman and Concho Counties, Texas. Reports of Investigations No. 65. Prewitt and Associates, Inc., Austin.

Baker, C. L.

1915 Geology and Ground-water Resources of Northern High Plains of Texas, Progress Report No. 1. Texas Board of Water Engineers Bulletin No. 6109.

Baker, Thomas R., Colleen M. Beck, Scott C. Schermer, and Phillip H. Shelley

1983 Cultural Resource Reconnaissance of the Conchas Reservoir. Llano Estacado Center for Advanced Professional Studies and Research, Eastern New Mexico University, Portales.

Baker, T. Lindsay

1985 The Survey of the Headwaters of the Red River, 1876. Panhandle-Plains Historical Review 58 (entire volume).

Baker, T. Lindsay, and Billy R. Harrison

1986 Adobe Walls: The History and Archeology of the 1875 Trading Post. Texas A\&M University, College Station.

Baker, William E., Tom N. Campbell, and Glen L. Evans 1957 The Nall Site: Evidence of Early Man in the Oklahoma Panhandle. Bulletin of the Oklahoma Anthropological Society 5:1-20.

Bandy, Philip A.

1977 A Review of Archaic Cultures of the Texas Panhandle. Transactions of the 12th Regional Archeological Symposium for Southeastern New Mexico and Western Texas, pp. 15-26.

1980 Archaeological Investigations at Sanderson Canyon Watershed, Terrell, Pecos, and Brewster Counties, Texas. Environment Consultants, Inc., Dallas.

Bandy, Philip, John Montgomery, William J. Mayer-Oakes, and Richard O. Keslin

1980 Archeological Mitigation at the Canyon Lakes Project, Texas. Cultural Resources Institute, Department of Anthropology, Texas Tech University, Lubbock. 
Banks, Larry D.

1990 From Mountain Peaks to Alligator Stomachs: A Review of Lithic Sources in the TransMississippi South, the Southern Plains, and Adjacent Southwest. Memoir No. 4. Oklahoma Anthropological Society, Norman.

Barnes, Virgil E.

1967 Geologic Atlas of Texas, Lubbock Sheet. Bureau of Economic Geology, The University of Texas at Austin.

Basehart, Harry W.

1960 Mescalero Apache Subsistence Patterns and Socio-Political Organization, Section I: Mescalero-Chiricahua Land Claims Project. The University of New Mexico, Albuquerque.

Bastian, Tyler

1964 Radiocarbon Date from an Archaic Site in Southwest Oklahoma. Oklahoma Anthropological Society Newletter 12(9):1-4.

Baugh, Timothy G.

1982 Edwards I (34BK2): Southern Plains Adaptations in the Protohistoric Period. Studies in Oklahoma's Past No. 8. Oklahoma Archeological Survey, Norman.

1983 Preliminary Studies at the Duncan (34WA2) Site. Oklahoma Anthropological Society Newsletter 31(2):4-6.

1984 Southern Plains Societies and Eastern Frontier Pueblo Exchange During the Protohistoric Period. Papers of the Archaeological Society of New Mexico 9:156-167.

1986 Culture History and Protohistoric Societies in the Southern Plains. In Current Trends in Southern Plains Archaeology, edited by Timothy G. Baugh, pp. 167-187. Plains Anthropologist 31(114, Pt. 2) Memoir 21.

1991 Ecology and Exchange: The Dynamics of Plains-Pueblo Interaction. In Farmers, Hunters, and Colonists: Interaction Between the Southwest and the Southern Plains, edited by Katherine A. Spielmann, pp. 107-127. University of Arizona Press, Tucson.

1992 Protohistoric Cultural Manifestations on the Southern Plains: A Reconsideration of the Wheeler Phase and Garza Complex. In Cultural Encounters and Episodic Droughts: The Protohistoric Period on the Southern Plains, edited by Eileen Johnson, pp. 21-39.
Lubbock Lake Landmark, Quaternary Research Center Series No. 3. Museum of Texas Tech University, Lubbock.

Baugh, Timothy G., and Frank W. Eddy

1987 Rethinking Apachean Ceramics: The 1985 Southern Athapaskan Ceramics Conference. American Antiquity 52(4):793-799.

Baumgardner, R. W., Jr.

1986 Stop 5: Terraces of the Upper Little Red River. In Geomorphology and Quaternary Stratigraphy of the Rolling Plains, Texas Panhandle, edited by Thomas C. Gustafson, pp. 20-28. Guidebook 22. Bureau of Economic Geology, The University of Texas at Austin.

Baumgardner, R. W., Jr., and S. C. Caran

1986a Stop 11: Fort Worth and Denver Railroad Cut. In Geomorphology and Quaternary Stratigraphy of the Rolling Plains, Texas Panhandle, edited by Thomas C. Gustafson, pp. 47-55. Guidebook 22. Bureau of Economic Geology, The University of Texas at Austin.

1986b Stop 15: Measured Sections, Henson Farm, near Quitaque, Texas. In Geomorphology and Quaternary Stratigraphy of the Rolling Plains, Texas Panhandle, edited by Thomas C. Gustavson, pp. 67-72. Guidebook 22. Bureau of Economic Geology, The University of Texas at Austin.

Baxevanis, Susan, Eileen Johnson, Briggs Buchanan, and William Shannon

1997 Test Excavations within the Plow Zone at the Hogue Site (41TY2), a Playa Site on the Southern High Plains of Texas. Bulletin of the Texas Archeological Society 68:337-386.

Baxter, Edward P., and Harry J. Shafer

1974 Northwest Laterals Watershed, Coleman County, Texas: An Archeological Survey of Structure No. 17-A1. Report No. 6. Anthropology Laboratory, Texas A\&M University, College Station.

Beardsley, Richard K.

1955 Seminars in Archeology: Functional and Evolutionary Implications of Community Patterning. American Antiquity, Memoir 11.

Beene, Debra L.

1995 Cultural Resources Survey of Areas XIII and XIV of the New Red River Chloride Control 
Project, Childress County, Southwestern [sic] Panhandle, Texas. Miscellaneous Report of Investigations No. 119 (draft). Geo-Marine, Inc., Plano, Texas.

Bell, Robert E.

1957 Clear Fork Gouges Found in Oklahoma. Bulletin of the Texas Archeological Society 28:285-288.

1984 The Plains Villagers: The Washita River. In Prehistory of Oklahoma, edited by Robert E. Bell, pp. 307-324. Academic Press, New York.

Bell, Robert E., Edward B. Jelks, and W. W. Newcomb 1967 A Pilot Study of Wichita Indian Archaeology and Ethnohistory. Final report submitted to the National Science Foundation.

Bell, Willis H., and Edward F. Castetter

1937 The Utilization of Mesquite and Screwbean by the Aborigines in the American Southwest. University of New Mexico Bulletin No. 314. Ethnobiological Studies in the American Southwest, Biology Series 5(2). University of New Mexico Press, Albuquerque.

Bement, Leland C., and Kent J. Buehler

1994 Preliminary Results from the Certain Site: A Late Archaic Bison Kill in Western Oklahoma. Plains Anthropologist 39(148):173183.

Bement, Leland C., and Solveig A. Turpin

1987 Technological Continuity and Functional Change: The Case of the Dorso End Scraper. Plains Anthropologist 32(116): 191-196.

Berlandier, Jean Louis

1969 The Indians of Texas in 1830. Smithsonian Institution Press, Washington, D.C.

Biesaart, Lynne A., Wayne R. Roberson, and Lisa C. Spotts

1985 Prehistoric Archeological Sites in Texas: A Statistical Overview. Special Report 28. Office of the State Archeologist, Texas Historical Commission, Austin.

Bilbo, Michael

1986 Return to Cowhead Mesa: The Proposed Cowhead Mesa National Register Archeological District. Transactions of the 21st Regional Archeological Symposium for South- eastern New Mexico and Western Texas, edited by Carrol Hedrick, pp. 1-23.

Binford, Lewis R.

1979 Organization and Formation Processes: Looking at Curated Technologies. Journal of Anthropological Research 35:255-273.

1980 Willow Smoke and Dog's Tails: HunterGatherer Settlement Systems and Site Formation. American Antiquity 45(1):4-20.

1983 Long-Term Land Use Patterns: Some Implications for Archaeology. In Working at Archaeology, edited by Lewis R. Binford, pp. 379-386. Academic Press, New York.

1990 Mobility, Housing and Environment: A Comparative Study. Journal of Anthropological Research 46(2):119-152.

Blair, W. Frank

1950 The Biotic Provinces of Texas. Texas Journal of Science 2(1):93-117.

Blakeslee, Donald J.

1994 Reconsideration of Coronado's Route Across Texas. Paper presented at the 52nd Annual Plains Anthropological Conference and 65th Texas Archeological Society Annual Meeting, Lubbock, Texas.

1996 Coronado's Campsite: A 1996 Field School Experience. Texas Archeology: The Newsletter of the Texas Archeological Society 40(2):5.

Bleed, Peter

1986 The Optimal Design of Hunting Weapons: Maintainability or Reliability. American Antiquity 51:737-747.

Bloom, France V.

1937 Troublous Times in New Mexico. New Mexico Historical Review 12(4):380-433.

Blum, Michael D.

1987 Late Quaternary Sedimentation in the Upper Pedernales River. Unpublished Masters thesis, Department of Geology, The University of Texas at Austin.

1989 Geoarcheological Investigations. In Phase I Cultural Resources Investigations at Justiceburg Reservoir on the Double Mountain Fork of the Brazos River, Garza and Kent Coun- 
ties, Texas, by Douglas K. Boyd, Martha Doty Freeman, Michael D. Blum, Elton R. Prewitt, and J. Michael Quigg, pp. 81-106. Reports of Investigations No. 66, vol. 1. Prewitt and Associates, Inc., Austin.

Blum, Michael D., James T. Abbott, and Salvatore Valastro Jr.

1992 Evolution of Landscapes on the Double Mountain Fork of the Brazos River, West Texas: Implications for Preservation and Visibility of the Archaeological Record. Geoarchaeology: An International Journal 7(4):339-370.

Blum, Michael D., and Christopher Lintz

1993 Late Quaternary Geology in the Reservoir Basin. In Cultural Resource Investigations in the O. H. Ivie Reservoir, Concho, Coleman, and Runnels Counties, Texas. Volume I: Project Introduction, Setting, and Methods, by Christopher Lintz, W. Nicholas Trierweiler, Amy C. Earls, Fred M. Oglesby, Michael Blum, Patrick L. O’Neill, John Kuhl, Richard Holloway, Linda Scott-Cummings, and Dan Scurlock, pp. 280-314. Technical Report 346-I. Mariah Associates, Inc., Austin.

Boldurian, Anthony T., and John L. Montgomery

1986 A Cultural Resource Survey for the Proposed Southwest Lubbock Regional (McAlister) Park for the City of Lubbock, Lubbock County, Texas. Report No. LB 86.4. Agency for Conservation Archeology, Llano Estacado Center for Advanced Professional Studies and Research, Eastern New Mexico University, Portales.

Bolton, Herbert E.

1911 The Jumano Indians of Texas, 1650-1771. The Quarterly of the Texas State Historical Association XV(1):66-84.

1949 Coronado: Knight of Pueblos and Plains. University of New Mexico Press, Albuquerque.

Bomar, George W.

1983 Texas Weather. University of Texas Press, Austin.

Booker, Rick, and Jeff Campbell

1978 An Excavation Report on Site 41LU6: Slaton Dump Site. Bulletin of the South Plains Archeological Society IV:19-38.
Bousman, C. Britt

1974a Archaeological Assessment of Alibates National Monument. Archaeological Research Program, Southern Methodist University, Dallas.

1974b Archaeological Assessment of Lake Meredith Recreation Area. Archaeological Research Program, Southern Methodist University, Dallas.

1991 Geoarcheological Investigatons. In Archeological Survey of Wildlife Mitigation Lands, Justiceburg Reservoir, Garza County, Texas, by Douglas K. Boyd, C. Britt Bousman, and Martha Doty Freeman, pp. 45-49. Reports of Investigations No. 79. Prewitt and Associates, Inc., Austin.

1992 Off-Site Geological Investigations. In Data Recovery at Justiceburg Reservoir (Lake Alan Henry), Garza and Kent Counties, Texas: Phase III, Season 1, by Douglas K. Boyd, Steve A. Tomka, C. Britt Bousman, Karen M. Gardner, and Martha Doty Freeman, pp. 135-142. Reports of Investigations No. 84. Prewitt and Associates, Inc., Austin.

Bovee, Dana L., and Douglas W. Owsley

1994 Evidence of Warfare at the Meerwald Site. In Skeletal Biology in the Great Plains: Migration, Warfare, Health, and Subsistence, edited by Douglas W. Owsley and Richard L. Jantz, pp. 355-362. Smithsonian Institution Press, Washington, D.C.

Bowden, Charles

1977 Killing the Hidden Waters: The Slow Destruction of Water Resources in the American Southwest. University of Texas Press, Austin.

Boyd, Douglas K.

1982 Human Skeletal Remains from 34GR6, Greer County, Oklahoma. Department of the Interior, Bureau of Reclamation, Southwest Region, Amarillo.

1990 Aboriginal Rock Art of Justiceburg Reservoir: A Regional Perspective for the Texas Panhandle-Plains. American Indian Rock Art 16:123-145.

1991 Plains Indian Rock Art in the Texas Panhandle-Plains. Heritage: A Publication of the Texas Historical Foundation 9(1):8-11. 
1992

Historic Native American Rock Art of Garza County, Texas. In Guidebook to the Ethnohistory and Selected Protohistoric Sites of the Southern Plains, edited by Eileen Johnson, pp. 69-89. Lubbock Lake Landmark Quaternary Research Center Series No. 3. Museum of Texas Tech University, Lubbock.

1994 The Justice Dugout, 41GR474. In Data Recovery at Lake Alan Henry (Justiceburg Reservoir), Garza and Kent Counties, Texas: Phase III, Season 3, by Douglas K. Boyd, Jay Peck, Steve A. Tomka, Karl W. Kibler, and Martha Doty Freeman, pp. 165-205. Reports of Investigations No. 93. Prewitt and Associates, Inc., Austin.

1995 The Palo Duro Complex: Redefining the Early Ceramic Period in the Caprock Canyonlands. Bulletin of the Texas Archeological Society 66:461-518.

Boyd, Douglas K., James T. Abbott, William A. Bryan, Colin M. Garvey, Steve A. Tomka, and Ross C. Fields

1990 Phase II Investigations at Prehistoric and Rock Art Sites, Justiceburg Reservoir, Garza and Kent Counties, Texas. Reports of Investigations No. 71. 2 vols. Prewitt and Associates, Inc., Austin.

Boyd, Douglas K., C. Britt Bousman, and Martha Doty Freeman

1991 Archeological Survey of Wildlife Mitigation Lands, Justiceburg Reservoir, Garza County, Texas. Reports of Investigations No. 79. Prewitt and Associates, Inc., Austin.

Boyd, Douglas K., Martha Doty Freeman, Michael D. Blum, Elton R. Prewitt, and J. Michael Quigg 1989 Phase I Cultural Resources Investigations at Justiceburg Reservoir on the Double Mountain Fork of the Brazos River, Garza and Kent Counties, Texas. Reports of Investigations No. 66. 2 vols. Prewitt and Associates, Inc., Austin.

Boyd, Douglas K., and Karl W. Kibler

1993 Rock Art Site Investigations, Monitoring and Survey, and Off-Site Geomorphological Investigations. In Data Recovery at Justiceburg Reservoir (Lake Alan Henry), Garza and Kent Counties, Texas: Phase III, Season 2, by Douglas K. Boyd, Jay Peck, Steve A. Tomka, and Karl W. Kibler, pp. 237-240. Reports of Investigations No. 88. Prewitt and Associates, Inc., Austin.

Boyd, Douglas K., and Jay Peck

1992 Protohistoric Site Investigations at Justiceburg Reservoir, Garza and Kent Counties, Texas. In Guidebook to the Ethnohistory and Selected Protohistoric Sites of the Southern Plains, edited by Eileen Johnson. pp 43-68. Lubbock Lake Landmark Quaternary Research Center Series No. 3. Museum of Texas Tech University, Lubbock.

Boyd, Douglas K., Jay Peck, Steve A. Tomka, and Karl W. Kibler

1993 Data Recovery at Justiceburg Reservoir (Lake Alan Henry), Garza and Kent Counties, Texas: Phase III, Season 2. Reports of Investigations No. 88. Prewitt and Associates, Inc., Austin.

Boyd, Douglas K., Jay Peck, Steve A. Tomka, Karl W. Kibler, and Martha Doty Freeman

1994 Data Recovery at Lake Alan Henry (Justiceburg Reservoir), Garza and Kent Counties, Texas: Phase III, Season 3. Reports of Investigations No. 93. Prewitt and Associates, Inc., Austin.

Boyd, Douglas K., and Kathryn Reese-Taylor

1993 Appendix D: Petrographic Analysis of Ceramic Sherds and Clay Samples. In Data Recovery at Justiceburg Reservoir (Lake Alan Henry), Garza and Kent Counties, Texas: Phase III, Season 2, by Douglas K. Boyd, Jay Peck, Steve A. Tomka, and Karl W. Kibler, pp. 339-378. Reports of Investigations No. 88. Prewitt and Associates, Inc., Austin.

Boyd, Douglas K., and Steve A. Tomka

1990 A Model of Late Holocene Human Adaptation for Justiceburg Reservoir. In Phase II Investigations at Prehistoric and Rock Art Sites, Justiceburg Reservoir, Garza and Kent Counties, Texas, by Douglas K. Boyd, James T. Abbott, William A. Bryan, Colin M. Garvey, Steve A. Tomka, and Ross C. Fields, pp. 261-273. Reports of Investigations No. 71. 2 vols. Prewitt and Associates, Inc., Austin.

Boyd, Douglas K., Steve A. Tomka, C. Britt Bousman, Karen M. Gardner, and Martha Doty Freeman

1992 Data Recovery at Justiceburg Reservoir (Lake Alan Henry), Garza and Kent Counties, Texas: Phase III, Season 1. Reports of 
Investigations No. 84. Prewitt and Associates, Inc., Austin.

Boydston, Roger A.

1989 A Cost-Benefit Study of Functionally Similar Tools. In Time, Energy and Stone Tools, edited by R. Torrence, pp. 67-77. Cambridge University Press, Cambridge.

Brand, John P.

1953 Cretaceous of the Llano Estacado of Texas. Report of Investigations No. 20. Bureau of Economic Geology, The University of Texas at Austin.

Breeding, A. W., Mrs.

1971 Gresham Lake Site: 41MT3. Transactions of the Sixth Regional Archeological Symposium for Southeastern New Mexico and Western Texas, pp. 1-8.

Brethauer, Douglas Paul

1979 The Possible Role of Mesquite as a Food Resource in the Jornada Mogollon Region. In Jornada Mogollon Archaeology: Proceedings of the First Jornada Conference, edited by Patrick $H$. Beckett and Regge N. Wiseman, pp. 67-80. Historic Preservation Bureau, State Planning Office, Santa Fe, and Cultural Resources Management Division, New Mexico State University, Las Cruces.

Briscoe, James

1987 Analysis of Cultural Materials from the Swift Horse Site, an Early Plains Woodland Site on the Black Kettle National Grasslands, Roger Mills County, Oklahoma. Briscoe Consulting Services, Butler, Oklahoma.

1989a Chronology and Distribution of Lake Creek Focus/Complex: Information from the Swift Horse Site. In In Light of Past Experience: Papers in Honor of Jack T. Hughes, edited by Beryl Cain Roper, pp. 105-115. Publication No. 5. Panhandle Archeological Society, Amarillo.

1989b Historical Archeological Investigations at Fort Supply, Woodward County, Oklahoma. Briscoe Consulting Services, Butler, Oklahoma.

1992 Artifact Analyses for an Area (34Wd-74, Area A) of Historic Fort Supply, Woodward County, Oklahoma. Studies in Oklahoma's Past, No. 18. Oklahoma Archeological Survey, University of Oklahoma, Norman.
Briscoe, James, and Timothy Perttula

1997 Cultural Resource Investigations of the Copper Breaks State Park, Hardeman County, Texas (final draft). Briscoe Consulting Services, Norman, Oklahoma.

Bronson, Bennet

1977 The Earliest Farmers: Demography as Cause and Consequence. In Origins of Agriculture, edited by Charles A. Reed, pp. 23-48. Mouton, The Hague.

Brooks, Robert L.

1989 Village Farming Societies. In From Clovis to Comanchero: Archeological Overview of the Southern Great Plains, by Jack L. Hofman, Robert L. Brooks, Joe S. Hays, Douglas W. Owsley, Richard L. Jantz, Murray K. Marks, and Mary H. Manhein, pp. 71-90. Research Series 35. Arkansas Archeological Survey, Fayetteville.

1993 Household Abandonment among Sedentary Plains Societies: Behavioral Sequences and Consequences in the Interpretation of the Archeological Record. In Abandonment of Settlements and Regions: Ethnoarchaeological and Archaeological Approaches, edited by Catherine M. Cameron and Steve A. Tomka, pp. 178-187. Cambridge University Press, Cambridge.

1994 Warfare on the Southern Plains. In Skeletal Biology in the Great Plains: Migration, Warfare, Health, and Subsistence, edited by Douglas W. Owsley and Richard L. Jantz, pp. 317-323. Smithsonian Institution Press, Washington, D.C.

Brown, Claude

1972 Preliminary Report of the SPAS 41LU6. Bulletin of the South Plains Archeological Society III:2-3.

1985 A Tale of Two Sites: A (41LU34) and B (41LU29). Transactions of the 20th Regional Archeological Symposium for Southeastern New Mexico and Western Texas, pp. 143-155.

1990a SPAS-LU-10: Report \#1-Middle Archaic. South Plains Archeological Society Newsletter 102.

1990b SPAS-LU-10: Report \#2-Late Archaic. South Plains Archeological Society Newsletter 103. 
1991a SPAS-LU-10: Report \#3-Arrow PointsManos-Core Knives-Perforators. South Plains Archeological Society Newsletter 104.

1991b SPAS-LU-10: Report \#4. South Plains Archeological Society Newsletter 105.

1993 S.P.A.S. LU-22. Transactions of the 29th Regional Archeological Symposium for Southeastern New Mexico and Western Texas, pp. 1-8.

n.d. A Lubbock County Site: 41LU75. Unpublished $\mathrm{ms}$.

Brown, David O.

1989 Prehistoric Subsistence Strategies in Northeastern Central Texas. Bulletin of the Texas Archeological Society 59:201-244.

Brown, David O. (editor)

1993 Archeological Investigations at the City of Lubbock Landfill, Lubbock County, Texas. Archeological Series 22. Hicks and Company, Inc., Austin.

Brown, David O., and Dana Anthony

1992 Archeological Survey of the Proposed Salt Creek II Substation and Electric Transmission Line, Kent County, Texas. Summary Report 10. Hicks and Company, Inc., Austin.

Brugge, David M.

1981 Comments on Athabaskans and Sumas. In The Protohistoric Period in the North American Southwest, A.D. 1450-1700, edited by David R. Wilcox and W. Bruce Masse, pp. 282-290. Anthropological Research Papers No. 24. Arizona State University, Tempe.

1982 Apache and Navajo Ceramics. In Southwestern Ceramics: A Comparative View, edited by A. H. Schroeder, pp. 279-295. The Arizona Archaeologist 15.

Brune, Gunnar

1975 Major and Historical Springs of Texas. Report No. 189. Texas Water Development Board, Austin.

1981 The Springs of Texas: Volume I. BranchSmith, Inc., Fort Worth.

Bryant, Frank

1953 The Coyote Lake Midden. Central Texas Archeologist 6:9-26.
Bryant, Vaughn M.

1993 Appendix I: Pollen Analysis of Archeological Sediments from 41KT53. In Data Recovery at Justiceburg Reservoir (Lake Alan Henry), Garza and Kent Counties, Texas: Phase III, Season 2, by Douglas K. Boyd, Jay Peck, Steve A. Tomka, and Karl W. Kibler, pp. 435-443. Reports of Investigations No. 88. Prewitt and Associates, Inc., Austin.

Bureau of Economic Geology

1992 Geologic Map of Texas. Virgil E. Barnes, Project Supervisor. Bureau of Economic Geology, The University of Texas at Austin.

Burgan, Scott

1992 A Proposal for the Identification of An Historic Indian Burial Found in Palo Duro Canyon. Transactions of the 28th Regional Archeological Symposium for Southeastern New Mexico and Western Texas, pp. 3-16.

Burton, Robert J., and Susan S. Burton

1969 An Archaeological Survey of the Lake Altus Shoreline, Greer and Kiowa Counties. General Report No. 12. Oklahoma River Basin Survey.

Button, Van Tries, and George Agogino

1986 A Report on Additional Human Skeletal Material Exposed by Reservoir-Induced Erosion at Lake Altus, Southwestern Oklahoma. U.S. Department of the Interior, Bureau of Reclamation, Southwest Region, Amarillo.

1987 Human Skeletal Material Exposed by Reservoir-Induced Erosion at Lake Altus, Southwestern Oklahoma. Bulletin of the Oklahoma Anthropological Society 36:15-37.

Calamia, Mark A.

1991 Ground Stone Variability among Jornada Mogollon Sites and Its Implications for Interpreting Residential Mobility. In Mogollon $V$, edited by Pat Beckett, pp. 119-132. COAS Publishing and Research, Las Cruces.

Cameron, Catherine M., and Steve A. Tomka (editors)

1993 Abandonment of Settlements and Regions: Ethnoarchaeological and Archaeological Approaches. Cambridge University Press, Cambridge.

Campbell, Robert G. 1975a Archaeological Reconnaissance of Portions of 
the South Plains Region. Texas Tech University, Lubbock.

1975b An Archaeological Survey of the South Plains Association of Governments Area. Transactions of the Tenth Regional Archeological Symposium for Southeastern New Mexico and Western Texas, pp. 49-50.

1976a The Panhandle Aspect of the Chaquaqua Plateau. University Graduate Studies 11. Texas Tech University, Lubbock.

1976b Archaeological Survey in the SPAG Area. Transactions of the Eleventh Regional Archeological Symposium for Southeastern New Mexico and Western Texas, pp. 93-97.

1977 Archaeological Reconnaissance of Portions of the South Plains Region. Report No. 2: Corrections and Additions. Texas Tech University, Lubbock.

Campbell, Robert G., and Sharon J. Judd

1977a Archaeological Reconnaissance of Portions of the South Plains Region. Report No. 3: Tabulation of Archaeological Sites and Materials. Department of Anthropology, Texas Tech University, Lubbock.

1977b Archaeological Reconnaissance of Portions of the South Plains Region. Report No. 4: Analysis of Archaeological Materials. Department of Anthropology, Texas Tech University, Lubbock.

Campbell, Thomas Jefferson

1983 The Greenbelt Site: An Example of Variation among Prehistoric Plains Village Sites in the Texas Panhandle. Unpublished Master's thesis, Department of Anthropology, Texas Tech University, Lubbock.

Caran, S. Christopher

1994 Quaternary Paleoenvironmental and Paleoclimatic Reconstruction in the South Plains: A Discussion and Critique. Paper presented at the 52nd Annual Plains Anthropological Conference and 65th Texas Archeological Society Annual Meeting, Lubbock, Texas.

Caran, S. Christopher, and Robert W. Baumgardner Jr. 1988 The Lingos Formation, Western Rolling Plains of Texas. In Decade of North American Geology: Geological Society of America, South-Central Section, Centennial Field
Guidebook 4:287-291. Edited by O. T. Hayward.

1990 Quaternary Stratigraphy and Paleoenvironments of the Texas Rolling Plains. Geological Society of America Bulletin 102:768-785.

Carlson, Gustav G., and V. H. Jones

1940 Some Notes on Uses of Plants by the Comanche Indians. Papers of the Michigan Academy of Science, Arts, and Letters 25: 517-542.

Carmichael, David L.

1985 Archeological Excavations at Two Prehistoric Campsites Near Keystone Dam, El Paso, Texas. Occasional Papers No. 14. New Mexico State University, Las Cruces.

1986 Archaeological Survey in the Southern Tularosa Basin of New Mexico. Historic and Natural Resources Report No. 3. Environmental Management Office, Directorate of Engineering and Housing, United States Army Air Defense Artillery Center, Fort Bliss, Texas.

Carroll, H. Bailey (editor)

1941 The Journal of Lieutenant J. W. Abert, from Bent's Fort to St. Louis in 1845. PanhandlePlains Historical Review 14:9-113.

Castañeda, Pedro

1904 The Journey of Coronado, 1540-1542. Translated and edited by George Parker Winship. Allerton Book Company, New York. Reprinted 1966, Readex Microprint Corporation.

Castetter, Edward F., and Morris E. Opler

1936 The Ethnobiology of the Chiricahua and Mescalero Apache. A. The Use of Plants for Foods, Beverages, and Narcotics. The University of New Mexico Bulletin, Biological Series 4(5). University of New Mexico Press, Albuquerque.

Chisolm, Brian, Jonathan Driver, Sylvain Dube, and Henry P. Schwarcz

1986 Assessment of Prehistoric Bison Foraging and Movement Patterns via Stable-Carbon Isotopic Analysis. Plains Anthropologist 31(113): 193-205.

Clark, John W., Jr. 1984 Archaeological Test Excavations at an Early 
Twentieth Century Dump in North San Antonio, Bexar County, Texas. Publications in Archaeology Report No. 26. State Department of Highways and Public Transportation, Highway Design Division, Austin.

Cliff, Maynard B., Richard Martynec, Sharlene N. Allday, and Duane E. Peter

1991 Cultural Resources Sample Survey of the Elm Creek Detention and Channelization Area, Abilene, Taylor County, Texas. Miscellaneous Report of Investigations No. 21. GeoMarine, Inc., Plano, Texas.

Cockrum, Dan

1963 A Multiple Burial from the Caprock Area. Bulletin of the South Plains Archeological Society 1:26-31.

Collins, Michael B.

1966 The Andrews Lake Sites: Evidence of SemiSedentary Prehistoric Occupation in Andrews County, Texas. Transactions of the Second Regional Archeological Symposium for Southeastern New Mexico and Western Texas, pp. 27-43.

1968 The Andrews Lake Locality: New Archeological Data from the Southern Llano Estacado, Texas. Unpublished Master's thesis, Department of Anthropology, The University of Texas at Austin.

1971 A Review of Llano Estacado Archaeology and Ethnohistory. Plains Anthropologist 16(52):85-104.

1995 Forty Years of Archeology in Central Texas. Bulletin of the Texas Archeological Society 66:361-400.

Collins, Michael B., and Peggy Caddell

1984 A Prehistoric Burial at Lake Spence: Preliminary. Findings. Transactions of the 19th Regional Archeological Symposium for Southeastern New Mexico and Western Texas, pp. 99-106.

Connor, Seymour V.

1954 Early Ranching Operations in the Panhandle: A Report on the Agricultural Schedules of the 1880 Census. Panhandle-Plains Historical Review 27:47-69.

Connor, Stuart W., and Betty Lu Connor

1971 Rock Art of the Montana High Plains. The
Art Galleries, University of California, Santa Barbara.

Corley, John A.

1965a Proposed Eastern Extension of the Jornada Branch of the Mogollon. Transactions of the First Regional Symposium for Southeastern New Mexico and Western Texas, pp. 31-36.

1965b Proposed Eastern Extension of the Jornada Branch of the Mogollon. Bulletin of the Lea County Archeological Society 1:30-36.

Corley, John A., and Robert H. Leslie

1960 The Boot Hill Site: L.C.A.S. B-5, a Preliminary Report. Reprinted 1965. Bulletin 2. Lea County Archeological Society, Hobbs, New Mexico.

Corliss, David W.

1972 Neck Width of Projectile Points: An Index of Culture Continuity and Change. Occasional Papers of the Idaho State University Museum No. 29. Pocatella.

Couzzourt, James E.

1982 Archaeological Testing at Cal Farley's Boys Ranch, Oldham County, Texas. Transactions of the 17th Regional Archeological Symposium for Southeastern New Mexico and Western Texas, pp. 57-134.

1985 Preliminary Report: Testing at the Tascosa Creek Site, Oldham County, Texas. Transactions of the 20th Regional Archeological Symposium for Southeastern New Mexico and Western Texas, pp. 65-142.

1988 The Tascosa Creek Site: New Developments and Dates. Transactions of the 23rd Regional Archeological Symposium for Southeastern New Mexico and Western Texas, pp. 44-79.

Covey, Cyclone (translator)

1961 Cabeza De Vaca's Adventures in the Unknown Interior of America. University of New Mexico Press, Albuquerque.

Creel, Darrell

1978 An Archeological Survey in the South Concho River Area, West Central Texas. Bulletin of the Texas Archeological Society 49:241-307.

1980 Results of a Non-Collection Archeological 
Survey at Buffalo Lake National Wildlife Refuge, Randall County, Texas. Texas Antiquities Committee Inundation Study. Texas Historical Commission, Austin.

1990 Excavations at 4ITG9I, Tom Green County, Texas. Publications in Archaeology Report No. 38. Texas State Department of Highways and Public Transportation, Highway Design Division, Austin.

1991 Bison Hides in Late Prehistoric Exchange in the Southern Plains. American Antiquity $56: 40-49$.

Creel, Darrell, Robert F. Scott IV, and Michael B. Collins 1990 A Faunal Record from West Central Texas and Its Bearing on Late Holocene Bison Population Changes in the Southern Plains. Plains Anthropologist 35(127):55-69.

Crook, Wilson W., Jr.

1955 Reconsideration and Geologic Revaluation [sic] of the Famous Abilene, Texas, Sites. Panhandle-Plains Historical Review 28:38-62.

Crouch, Daniel J.

1978 Archaeological Investigations of the Kiowa and Comanche Indian Agency Commissaries, 34CM232. Contributions of the Museum of the Great Plains No. 7. Lawton, Oklahoma.

Cruse, Jimmy Brett

1992 Archeological Investigations at the Kent Creek Site (41HL66): Evidence of Mogollon Influence on the Southern Plains. Publication No. 6. Panhandle Archeological Society, Amarillo.

Cummings, Linda Scott

1990 Appendix I: Phytolith and Pollen Analysis: A Feasibility Study. In Phase II Investigations at Prehistoric and Rock Art Sites, Justiceburg Reservoir, Garza and Kent Counties, Texas, by Douglas K. Boyd, James T. Abbott, William A. Bryan, Colin M. Garvey, Steve A. Tomka, and Ross C. Fields, pp. 533-550. Reports of Investigations No. 71, vol. II. Prewitt and Associates, Inc., Austin.

Curtis, N. M., Jr., and W. E. Ham

1972 Geology and Earth Resources of Oklahoma: An Atlas of Maps and Cross Sections. Education Publication No. 1. Oklahoma Geological Survey, Norman.
Davis, Dan R.

1991 Prehistoric Artifacts of the Texas Indians: An Identification and Reference Guide. Pecos Publishing Company, San Antonio.

Davis, W. A.

1985 Appraisal of the Archeological Resources of Sanford Reservoir, Hutchinson, Moore, and Potter Counties, Texas. Originally published in 1962. Publication No. 3. Panhandle Archeological Society, Amarillo.

Davis, William B.

1974 The Mammals of Texas. Bulletin No. 41. Texas Parks and Wildlife Department, Austin.

Day, A. Grove

1940 Coronado's Quest. Panhandle-Plains Historical Review 17:47-71.

DeBoer, Warren R.

1988 Subterranean Storage and the Organization of Surplus: The View from Eastern North America. Southeastern Archaeology 7(1): $1-20$.

Denton, Joe T.

1983 Test Excavations at Site 41KT32, Kent County, Texas. Texas State Department of Highways and Public Transportation, Austin.

Dering, J. Philip

1992 Appendix D: Macrobotanical Analysis of Three Flotation Samples from Justiceburg Reservoir. In Data Recovery at Justiceburg Reservoir (Lake Alan Henry), Garza and Kent Counties, Texas: Phase III, Season 1, by Douglas K. Boyd, Steve A. Tomka, C. Britt Bousman, Karen M. Gardner, and Martha Doty Freeman, pp. 207-209. Reports of Investigations No. 84. Prewitt and Associates, Inc., Austin.

1993a Appendix H: Plant Remains. In Data Recovery at Justiceburg Reservoir (Lake Alan Henry), Garza and Kent Counties, Texas: Phase III, Season 2, by Douglas K. Boyd, Jay Peck, Steve A. Tomka, and Karl W. Kibler, pp. 419-434. Reports of Investigations No. 88. Prewitt and Associates, Inc., Austin.

1993b Appendix M: Pollen Analysis of Sediments from Morgan Playa. In Data Recovery at Justiceburg Reservoir (Lake Alan Henry), 
Garza and Kent Counties, Texas: Phase III, Season 2, by Douglas K. Boyd, Jay Peck, Steve A. Tomka, and Karl W. Kibler, pp. 491-494. Reports of Investigations No. 88. Prewitt and Associates, Inc., Austin.

1994 Appendix E: Analysis of Plant Remains from 41GR291 and 41GR559. In Data Recovery at Lake Alan Henry (Justiceburg Reservoir), Garza and Kent Counties, Texas: Phase III, Season 3, by Douglas K. Boyd, Jay Peck, Steve H. Tomka, Karl W. Kibler, and Martha Doty Freeman, pp. 331-345. Reports of Investigations No. 93. Prewitt and Associates, Inc., Austin.

Dering, Phil, and Vaughn M. Bryant, Jr.

1992 Appendix E: Pollen Analysis of Archeological Sediments from Justiceburg Reservoir. In Data Recovery at Justiceburg Reservoir (Lake Alan Henry), Garza and Kent Counties, Texas: Phase III, Season 1, by Douglas K. Boyd, C. Britt Bousman, Steve A. Tomka, Karen M. Gardner, and Martha Doty Freeman, pp. 211-220. Reports of Investigations No. 84. Prewitt and Associates, Inc., Austin.

Diamond, David D., David H. Riskind, and Steve L. Orzell

1987 A Framework for Plant Community Classification and Conservation in Texas. The Texas Journal of Science 39(3):203-221.

Dibble, David S., and Dessamae Lorrain

1968 Bonfire Shelter: A Stratified Bison Kill Site, Val Verde County, Texas. Miscellaneous Papers of the Texas Memorial Museum, No. 1. The University of Texas at Austin.

Dick, Herb W.

1953 The Hodges Site, I: Two Rock Shelters near Tucumcari, New Mexico. Bureau of American Ethnology Bulletin 154, River Basin Surveys Papers 5, Pt. 1:267-284.

Didway, Charles (editor)

1973 Wagon Wheels: A History of Garza County. Pioneer Book Publishers, Inc., Seagraves, Texas.

Dillehay, Tom D.

1974 Late Quaternary Bison Population Changes on the Southern Plains. Plains Anthropologist 19(65): 180-196.
Doering, William, and Michael McFaul

1991 Geomorphological Assessment. In A Cultural Resource Survey at Mitchell County Reservoir, Mitchell County, Texas, by Christopher Lintz, W. Nicholas Trierweiler, Fred M. Oglesby, Patrick L. O'Neill, William Doering, and Michael McFaul, pp. 29-36. Technical Report 433. Mariah Associates, Inc., Austin.

Donoghue, David

1929 The Route of the Coronado Expedition in Texas. Southwestern Historical Quarterly 32(3):181-192.

Dorward, Donald A., and David J. Meltzer

1995 West Texas Traders: Archaeological Survey in Borden County. Ms. submitted to the Potts Sibley Foundation by Southern Methodist University, Dallas.

Douthit, Mary Lee

1978 An Archeological Survey of the North Concho River Valley, Sterling County, Texas. Unpublished Ph.D. dissertation, Department of Anthropology, The University of Texas at Austin.

Drass, Richard R.

1988 A Reanalysis of the Brewer Site: An Early Plains Village Settlement in Central Oklahoma. Oklahoma Anthropological Society Bulletin 37:1-110.

Drass, Richard R., and Peggy Flynn

1990 Temporal and Geographic Variations in Subsistence Practices for Plains Villagers in the Southern Plains. Plains Anthropologist 35(128): 175-190.

Drass, Richard R., and Michael C. Moore

1987 The Linville II Site (34RM492) and Plains Village Manifestations in Far Western Oklahoma. Plains Anthropologist 32(118):404418.

Duffield, Lathal Flay

1970 Some Panhandle Aspect Sites: Their Vertebrates and Paleoecology. Unpublished Ph.D. dissertation, University of Wisconsin. University Microfilms, Ann Arbor.

Dunbar, John

1918 Letters from John Dunbar. In Letters Concerning the Presbyterian Mission in the 
Pawnee Country, Near Bellevue, Nebraska, 1831-1849. Collections of the Kansas State Historical Society 14:570-689.

Dutton, S. P., Robert J. Finley, W. E. Galleway, Thomas C. Gustavson, C. Robertson Handford, and Mark W. Presley

1979 Geology and Geohydrology of the Palo Duro Basin, Texas Panhandle: A Report on the Progress of Nuclear Waste Isolation Feasibility Studies (1978). Geological Circular 79-1. Bureau of Economic Geology, The University of Texas at Austin.

Dyson-Hudson, R., and E. A. Smith

1978 Human Territoriality: An Ecological Reassessment. American Anthropologist 80:21-41.

Earls, Amy C.

1993a Results of Historic Site Investigations. In Historic and Prehistoric Data Recovery at Palo Duro Reservoir, Hansford County, Texas, by J. Michael Quigg, Christopher Lintz, Fred M. Oglesby, Amy C. Earls, Charles D. Frederick, W. Nicholas Trierweiler, Douglas Owsley, and Karl W. Kibler, pp. 357-424. Technical Report No. 485. Mariah Associates, Inc., Austin.

1993b Historic Issues. Part 2 of Research Design Issues. In Historic and Prehistoric Data Recovery at Palo Duro Reservoir, Hansford County, Texas, by J. Michael Quigg, Christopher Lintz, Fred M. Oglesby, Amy C. Earls, Charles D. Frederick, W. Nicholas Trierweiler, Douglas Owsley, and Karl W. Kibler, pp. 472-483. Technical Report No. 485. Mariah Associates, Inc., Austin.

Earls, Amy C., Patrick L. O'Neill, Dennis Williams, Christopher Lintz, W. Nicholas Trierweiler, J. Michael Quigg, Gus Hamblett, Abby C. Treece, and Dan Scurlock

1993 Cultural Resource Investigations in the O. H. Ivie Reservoir, Concho, Coleman, and Runnels Counties, Texas. Volume V: Historical Resources. Technical Report No. 346-V. Mariah Associates, Inc., Austin.

Early, Ann M.

1978 Turquoise Beads from the Standridge Site. The Arkansas Archeologist 19:25-31.

1988 Standridge: Caddoan Settlement in a Mountain Environment. Research Report No. 29. Arkansas Archeological Survey, Fayetteville.
Epp, Henry T.

1988 Way of the Migrant Herds: Dual Dispersion Strategy Among Bison. Plains Anthropologist 33(121):309-320.

Etchieson, Gerald Meeks

1979 Archeological Testing at the South Ridge Site, Lake Meredith Recreation Area, Hutchinson County, Texas. Archeological Research Laboratory, Killgore Research Center, West Texas State University, Canyon.

1981 Archeological Survey at Lake Meredith Recreation Area, Moore and Potter Counties, Texas. U.S. Department of the Interior, Water and Power Resources Service, Southwest Region, Amarillo.

1985 An Archeological Survey of Potential Borrow Areas at Twin Buttes Reservoir, Tom Green County, Texas. U.S. Department of the Interior, Bureau of Reclamation, Southwest Region, Amarillo.

Etchieson, Gerald Meeks, and James E. Couzzourt

1987 Shoreline Survey of Lake Meredith Recreation Area in the Texas Panhandle. U.S. Department of the Interior, Bureau of Reclamation, Southwest Region, Amarillo.

Etchieson, Gerald Meeks, Roberta D. Speer, and Jack T. Hughes

1977 An Archeological Survey of Certain Tracts in and near Caprock Canyons State Park in Eastern Briscoe County, Texas. Archeological Research Laboratory, Killgore Research Center, West Texas State University, Canyon.

1978 Archeological Investigations in the Truscott Reservoir Area, King and Knox Counties, Texas. Archeological Research Laboratory, Killgore Research Center, West Texas State University, Canyon.

1979 Archeological Investigations in the Crowell Reservoir Area, Cottle, Foard, King and Knox Counties, Texas. Archeological Research Laboratory, Killgore Research Center, West Texas State University, Canyon.

Evans, Glen L.

1951 Prehistoric Wells in Eastern New Mexico. American Antiquity 17:1-9.

Evans, Glen L., and Grayson E. Meade 1945 Quaternary of the Texas High Plains. In 
Contributions to Geology, 1944, pp. 485-507. Publication 4401. Bureau of Economic Geology, The University of Texas at Austin.

Everitt, B. S.

1977 The Analysis of Contingency Tables. Halstead Press, Chapman and Hall Ltd., London.

Eyerly, T. L.

1907a The Buried City of the Panhandle. Transactions of the Kansas Academy of Science 21(1):219-228.

1907b Archaeological Work in the Texas Panhandle. Bulletin of the Canadian Academy.

1910 The Indian Renoirs of the Canadian River Valley. The Archeological Bulletin 1(3): 77-80. Hico, Texas.

1912 The Buried City of the Panhandle. The Archeological Bulletin 3(1):1-5. Hico, Texas.

Ferring, C. Reid

1978 An Archaeological Reconnaissance of Fort Sill, Oklahoma. Contributions of the Museum of the Great Plains No. 6. Lawton, Oklahoma.

1986 Late Holocene Cultural Ecology in the Southern Plains: Perspectives from Delaware Canyon, Oklahoma. In Current Trends in Southern Plains Archaeology, edited by Timothy G. Baugh, pp. 55-82. Plains Anthropologist 31(114, Pt. 2) Memoir 21.

1992 Alluvial Pedology and Geoarcheological Research. In Soils in Archeology: Landscape Evolution and Human Occupation, edited by Vance T. Holliday, pp. 1-39. Smithsonian Institution Press, Washington, D.C.

Ferring, C. Reid (editor)

1982 The Late Holocene Prehistory of Delaware Canyon, Oklahoma. Contributions in Archeology 1. Institute of Applied Sciences, North Texas State University, Denton.

Fields, Ross C.

1993 Intersite Comparisons. In Excavations at the Tick, Spike, Johns Creek, and Peerless Bottoms Sites, Cooper Lake Project, Delta and Hopkins Counties, Texas, by Ross C. Fields, Eloise F. Gadus, L. Wayne Klement,
C. Britt Bousman, and Jerrilyn B. McLerran, pp. 227-243. Reports of Investigations No. 91. Prewitt and Associates, Inc., Austin.

Flint, Richard

1995 The Unique Pattern of Coronado Expedition Material Culture. Transactions of the 30th Regional Archeological Symposium for Southeastern New Mexico and Western Texas, pp. 73-81.

Flores, Dan

1990 Caprock Canyonlands: Journeys into the Heart of the Southern Plains. University of Texas Press, Austin.

Flynn, Peggy

1982 Distribution of Prehistoric Bison Populations on the Southern Plains: A Test of Dillehay's Model. Papers in Anthropology 23:7-35. Department of Anthropology, University of Oklahoma, Norman.

1986 Analysis of Test Excavations at the Zimms Site (34RM72), Western Oklahoma. In Current Trends in Southern Plains Archaeology, edited by Timothy G. Baugh, pp. 129-140. Plains Anthropologist 31(114, Pt. 2) Memoir 21.

Forbes, Jack D.

1959 Unknown Athapaskans: The Identification of the Jano, Jocome, Suma, Manco and Other Indian Tribes of the Southwest. Ethnohistory 6(2):97-159.

Ford, Richard I.

1985 Patterns of Prehistoric Food Production in North America. In Prehistoric Food Production in North America, edited by Richard I. Ford, pp. 341-364. Anthropological Papers No. 75. Museum of Anthropology, University of Michigan, Ann Arbor.

Foreman, Grant (editor)

1937 Adventures on the Red River: Report on the Exploration of the Headwaters of the Red River by Captain Randolph B. Marcy and Captain G. B. McClellan. University of Oklahoma Press, Norman.

1939 Marcy and the Gold Seekers: The Journal of Captain R. B. Marcy, with an Account of the Gold Rush over the Southern Route. University of Oklahoma Press, Norman. 
Forrester, Robert E.

1951 A Series of Eighteen Indian Skeletons Excavated in Shackelford County, Texas. Bulletin of the Texas Archeological and Paleontological Society 22:132-143.

1987 The Moran Point from North-Central Texas. Bulletin of the Oklahoma Anthropological Society 36:131-136.

1991 Pestles for Boat-Shaped Mortars in Texas. Bulletin of the Texas Archeological Society 60:191-207.

Fox, Anne A.

1976 Archaeological Investigations at Fort Griffin State Historical Park, Shackelford County, Texas. Archaeological Survey Report 23. Center for Archaeological Research, The University of Texas at San Antonio.

1986 Archaeological Investigations at Historic Sites in the Choke Canyon Reservoir, Southern Texas. Choke Canyon Series 12. Center for Archaeological Research, The University of Texas at San Antonio.

Fox, Daniel E.

1983 Traces of Texas History: Archeological Evidence of the Past 450 Years. Corona Publishing Company, San Antonio.

1985

Another Archeological Reconnaissance of Proposed Project Areas for Wastewater Treatment Improvements, City of Slaton, Lubbock County, Texas. Letter report to the Texas Historical Commission on EPH Construction Grant Project, C-48-1683. Construction Grants and Water Quality Management Division, Texas Department of Water Development, Austin.

Fox, Richard Allan, Jr.

1993 Archaeology, History, and Custer's Last Battle. University of Oklahoma Press, Norman.

Frederick, Charles

1993 Geomorphic Investigations. In Archeological and Geomorphological Investigations at Red Lake Dam Axis, Borrow Area, and Spillway, Martin County, Texas, by J. Michael Quigg, Charles Frederick, and Christopher Lintz, pp. 36-49. Technical Report 873. Mariah Associates, Inc., Austin. 1994a Late Quaternary Geology of the Sulphur Draw Reservoir. In Sulphur Springs Draw: Geoarchaeological and Archaeological Investigations at Sulphur Draw Reservoir, Martin County, Texas, by J. Michael Quigg, Charles D. Frederick, and Christopher Lintz, pp. 29-81. Technical Report No. 776. Mariah Associates, Inc., Austin.

1994b Late Holocene Aeolian Sedimentation and Climatic Change on the Llano Estacado, Texas. Paper presented at the 52nd Annual Plains Anthropological Conference and 65th Texas Archeological Society Annual Meeting, Lubbock, Texas.

Frederick, Charles D., and Chris Ringstaff

1994 Lithic Resources at Fort Hood: Further Investigations. In Archeological Investigations on 571 Prehistoric Sites at Fort Hood, Bell and Coryell Counties, Texas, edited by W. Nicholas Trierweiler, pp. 125-181. United States Army Fort Hood, Archeological Resource Management Series, Research Report No. 31. Mariah Associates, Inc., Austin.

Fredlund, Glen

1993 A Holocene Phytolith Record from Morgan Playa. In Data Recovery at Justiceburg Reservoir (Lake Alan Henry), Garza and Kent Counties, Texas: Phase III, Season 2, by Douglas K. Boyd, Jay Peck, Steve A. Tomka, and Karl W. Kibler, pp. 481-489. Reports of Investigations No. 88. Prewitt and Associates, Inc., Austin.

Freeman, Martha Doty

1989 Historic Resources in Justiceburg Reservoir. In Phase I Cultural Resources Investigations at Justiceburg Reservoir on the Double Mountain Fork of the Brazos River, Garza and Kent Counties, Texas, by Douglas K. Boyd, Martha Doty Freeman, Michael D. Blum, Elton R. Prewitt, and J. Michael Quigg, pp. 133-156. Reports of Investigations No. 66, vol. 1. Prewitt and Associates, Inc., Austin.

1990a Natural Resources Exploitation and Development: Buffalo Hunting on the Rolling Plains, 1874-1879. In Phase II Historical Investigations at Justiceburg Reservoir, Garza and Kent Counties, Texas, by Martha Doty Freeman and Douglas K. Boyd, pp. 7-48. 
Reports of Investigations No. 72. Prewitt and Associates, Inc., Austin.

1990b Agriculture in Texas: Ranching on the Western Rolling Plains, 1877-1945. In Phase II Historical Investigations at Justiceburg Reservoir, Garza and Kent Counties, Texas, by Martha Doty Freeman and Douglas K. Boyd, pp. 51-97. Reports of Investigations No. 72. Prewitt and Associates, Inc., Austin.

1990c Agriculture in the Context Area: Livestock and Crop Production, 1870-1945. In Historic Architectural Resources of the Palo Duro Reservoir, by Martha Doty Freeman, Robert A. Steinbomer, and Joe C. Freeman, pp. 7-64. RioGroup Architects and Planners, Austin.

Freeman, Martha Doty, and Douglas K. Boyd

1990 Phase II Historical Investigations at Justiceburg Reservoir, Garza and Kent Counties, Texas. Reports of Investigations No. 72. Prewitt and Associates, Inc., Austin.

Freeman, Martha Doty, Robert A. Steinbomer, and Joe C. Freeman

1990 Historic Architectural Resources of the Palo Duro Reservoir. RioGroup Architects and Planners, Austin.

Frye, John C., and A. Byron Leonard

1965 Quaternary of the Southern Great Plains. In Quaternary of the United States, edited by H. E. Wright Jr. and David G. Frye, pp. 203-216. Princeton University Press, Princeton, New Jersey.

Gallagher, James P.

1977 Contemporary Stone Tools in Ethiopia: Implications for Archaeology. Journal of Field Archaeology 4:407-414.

Galvin, John (editor)

1966 Western America in 1846-1847: The Original Travel Diary of Lieutenant J. W. Abert, who Mapped New Mexico for the United States Army. John Howell Books, San Francisco.

1970 Through the Country of the Comanche Indians in the Fall of the Year 1845: The Journal of a U.S. Army Expedition Led by Lieutenant James W. Abert of the Topographical Engineers. John Howell Books, San Francisco.
Gamble, C. S., and W. A. Boismier

1991 Ethnoarchaeological Approaches to Mobile Campsites: Hunter-Gatherer and Pastoralist Case Studies. Ethnoarchaeological Series 1. International Monographs in Prehistory, Ann Arbor, Michigan.

Gardner, Karen M., and Douglas K. Boyd

1992 Data Recovery at the Ed Scott Cabin, 41KT42. In Data Recovery at Justiceburg Reservoir (Lake Alan Henry), Garza and Kent Counties, Texas: Phase III, Season 1, by Douglas K. Boyd, Steve A. Tomka, C. Britt Bousman, Karen M. Gardner, and Martha Doty Freeman, pp. 31-49. Reports of Investigations No. 84. Prewitt and Associates, Inc., Austin.

Garrett, Elizabeth M.

1988a Appendix C: Petrographic Analysis of Twelve Sherds from Site 41EP2611, El Paso, Texas. In Class III Survey and Testing of Cultural Resources in Proposed Flood Control System Rights-of-way, Southeastern El Paso, El Paso County, Texas, by Amy C. Earls and Darryl C. Newton. Mariah Associates, Inc., Albuquerque.

1988b Appendix H: Petrographic Analysis of Prehistoric Ceramics from the Melrose Range Project, ACOE, 1987. In Class II Survey and Testing of Cultural Resources at the Melrose Air Force Range, Curry and Roosevelt Counties, New Mexico, by Christopher Lintz, Karen Kramer, Amy Earls, W. Nicholas Trierweiler, Terry Del Bene, John Acklen, Fred Nials, and Jack Bertram, pp. H1-H5. Mariah Associates, Inc., Albuquerque.

1988c Appendix G: Petrographic Analysis of Selected Conchas Reservoir Ceramics. In Report of the 1986 and 1987 Class II Surveys and Testing of Cultural Resources at Conchas Lake, New Mexico, by Karen Kramer, Christopher R. Lintz, W. Nicholas Trierweiler, Stephen Lent, John Frizell, Mary Stiner, John C. Acklen, and Stephen Kuhn, pp. G1-G7. Mariah Associates, Inc., Albuquerque.

1991 Preliminary Report on the Petrographic Analysis of 200 Sherds from Capitan North Areas. In Mogollon $V$, edited by Jane H. Kelley and Patrick H. Beckett, pp. 191-196. COAS Publishing and Research, Las Cruces, New Mexico. 
Garza County

Ad Valorem Tax Rolls

Map and Plat Records

Gates, Ted, and Alyce Hart

1977 The Garza Burial. Transactions of the 12th Regional Archeological Symposium for Southeastern New Mexico and Western Texas, pp. 145-154.

Gettys, Francie

1991 Salvage Excavation in Roger Mills County. Oklahoma Archeological Survey Newsletter 11(3).

Gile, Leland $\mathrm{H}$.

1979 Holocene Soils in Eolian Sediments of Bailey County, Texas. Soil Science Society of America Journal 43:994-1003.

1981 Soils and Stratigraphy of Dunes along a Segment of Farm Road 1731, Bailey County, Texas. Publication No. 81-2. International Center for Arid and Semi-Arid Land Studies, Texas Tech University, Lubbock.

1983 Holocene Soils Exposed in a Sandhills Blowout on the Southern High Plains. In Guidebook to the Central Llano Estacado, edited by Vance $\mathrm{T}$. Holliday, pp. 135-165. International Center for Arid and Semi-Arid Land Studies and The Museum, Texas Tech University, Lubbock.

Gilman, Patricia A.

1987 Architecture as Artifact: Pit Structures and Pueblos in the American Southwest. American Antiquity 52(3):538-564.

Gish, Jennifer W.

1982 Appendix D: Pollen Results from the Tierra Blanca Site, Northwestern Texas Panhandle. In Inter-Societal Food Acquisitions Among Egalitarian Societies: An Ecological Study of Plains/Pueblo Interaction in the American Southwest, by Katherine Ann Spielmann, pp. 384-402. Unpublished Ph.D. dissertation, Department of Anthropology, University of Michigan, Ann Arbor.

Goetzmann, William H.

1959 Army Exploration in the American West, 1803-1863. Yale University Press, New Haven.

Goland, Carol Ann

1983 The Ecological Context of Hunter-Gatherer
Storage Strategies. Unpublished Master's thesis, Department of Anthropology, University of North Carolina, Chapel Hill.

Gose, Wulf A.

1993 Appendix C: Archeomagnetic Dating of Burned Features. In Data Recovery at Justiceburg Reservoir (Lake Alan Henry), Garza and Kent Counties, Texas: Phase III, Season 2, by Douglas K. Boyd, Jay Peck, Steve A. Tomka, and Karl W. Kibler, pp. 327-337. Reports of Investigations No. 88. Prewitt and Associates, Inc., Austin.

Gould, F. W., and G. W. Thomas

1975 Texas Plants: A Checklist and Ecological Summary. The Texas Agricultural Experiment Station, Texas A\&M University, College Station.

Green, Donald

1973 Land of the Underground Rain: Irrigation on the Texas High Plains, 1910-1970. University of Texas Press, Austin.

Green, F. Earl

1961 Archaeological Salvage in the Twin Buttes Reservoir Area, San Angelo, Texas. Bulletin of the Texas Archeological Society 30:183197.

1962a Archeological Survey of the White River Reservoir Area, Crosby County, Texas. Ms. on file, Texas Tech University Museum, Lubbock.

1962b The Lubbock Lake Reservoir Site: 12,000 Years of Human Prehistory. The Museum Journal 6:83-123. West Texas Museum Association, Texas Tech University, Lubbock.

1962c Additional Notes on Prehistoric Wells at the Clovis Site. American Antiquity 28:230-234.

1986 Report on Archaeological Salvage in the Sanford Reservoir Area. Publication No. 4. Panhandle Archeological Society, Amarillo.

Gregg, Josiah

1954 Commerce of the Prairies: The Journal of a Santa Fe Trader. Edited by Max L. Moorhead. University of Oklahoma Press, Norman.

Guffee, Eddie J.

1976 The Merrell-Taylor Village Site: An Archeological Investigation of Pre-Anglo, Spanish- 
Mexican Occupation on Quitaque Creek in Floyd County, Texas. Llano Estacado Museum, Plainview, Texas.

1980 The Soda Lake Ruins: An Archeological Investigation of Anglo Occupation in the Sand Hills of Lamb County, Texas. Archeological Research Laboratory, Llano Estacado Museum, Plainview, Texas.

1989 Ballinger Reservoir: An Archeological Investigation on Valley Creek, Runnels County, Texas. Archeological Research Laboratory, Llano Estacado Museum, Plainview, Texas.

Guffee, Eddie, and Jack T. Hughes

1974 An Archeological Survey in the Running Water Draw Watershed. Archeological Research Laboratory, Killgore Research Center, West Texas State University, Canyon.

Guidry, Marion A., Derl L. Brooks, Larry Higgins, Jack T. Hughes, Flavius Killebrew, Gerald E. Schultz, and Robert Wright

1979 An Environmental Profile of the Palo Duro Creek Basin. Killgore Research Center, West Texas State University, Canyon.

Gunnerson, Dolores A.

1956 The Southern Athabascans: Their Arrival in the Southwest. El Palacio 63:346-365.

1974 The Jicarilla Apaches: A Study in Survival. Northern Illinois University, DeKalb.

Gunnerson, James H.

1960 An Introduction to Plains Apache Archeology-The Dismal River Aspect. Bureau of American Ethnology Bulletin 173, Anthropological Papers 58:131-260.

1968 Plains Apache Archaeology: A Review. Plains Anthropologist 13(41):167-189.

1969 Apache Archaeology in Northeastern New Mexico. American Antiquity 34(1):23-39.

1987 Archaeology of the High Plains. Cultural Resource Series 19. Bureau of Land Management, Denver.

Gunnerson, James H., and Dolores A. Gunnerson

1971 Apachean Culture: A Study in Unity and Diversity. In Apachean Culture History and Ethnology, edited by Keith H. Basso and Morris E. Opler, pp. 7-27. Anthropological
Papers of the University of Arizona No. 21. Tucson.

Gustafson, Alice A.

1994a The Duncan Ranch Site 1: Evidence for Late Woodland Transition to Antelope Creek Phase Development. Transactions of the 30th Regional Archeological Symposium for Southeastern New Mexico and Western Texas, pp. 51-71.

1994b The Duncan Ranch Site 1: Evidence for Late Woodland-Incipient Antelope Creek Phase Developments. Unpublished Master's thesis, Department of Anthropology, University of Colorado at Denver.

Gustavson, Thomas C. (editor)

1986 Geomorphology and Quaternary Stratigraphy of the Rolling Plains, Texas Panhandle. Guidebook 22. Bureau of Economic Geology, The University of Texas at Austin.

Gustavson, Thomas C., and Robert J. Finley

1985 Late Cenozoic Geomorphic Evolution of the Texas Panhandle and Northeastern New Mexico: Case Studies of Structural Control on Regional Drainage Development. Report of Investigations No. 148. Bureau of Economic Geology, The University of Texas at Austin.

Gustavson, Thomas C., Robert J. Finley, and Kathy A. McGillis

1980 Regional Dissolution of Permian Salt in the Anadarko, Dalhart, and Palo Duro Basins of the Texas Panhandle. Reports of Investigations No. 106. Bureau of Economic Geology, The University of Texas at Austin.

Gustavson, Thomas C., and Vance T. Holliday

1985 Depositional Architecture of the Quaternary Blackwater Draw and Tertiary Ogallala Formations, Texas Panhandle and Eastern New Mexico. Open File Report OF-WTWI1985-23, pp. 1-29. Bureau of Economic Geology, The University of Texas at Austin.

Gustavson, Thomas C., Vance T. Holliday, and Susan D. Hovorka

1995 Origin and Development of Playa Basins, Sources of Recharge to the Ogallala Aquifer, Southern High Plains, Texas and New Mexico. Reports of Investigations No. 229. Bureau of Economic Geology, The University of Texas at Austin. 
Gustavson, Thomas C., and William W. Simpkins 1989 Geomorphic Processes and Rates of Retreat Affecting the Caprock Escarpment, Texas Panhandle. Reports of Investigations No. 180. Bureau of Economic Geology, The University of Texas at Austin.

Habicht-Mauche, Judith

1987 Southwestern-style Culinary Ceramics on the Southern Plains: A Case Study of Technological Innovation and Cross-Cultural Interaction. Plains Anthropologist 32(116):175-189.

1988 An Analysis of Southwestern Style Ceramics from the Southern Plains in the Context of Plains-Pueblo Interaction. Unpublished $\mathrm{Ph} . \mathrm{D}$, dissertation, Department of Anthropology, Harvard University, Cambridge, Massachusetts.

1991 Evidence for the Manufacture of Southwestern-Style Culinary Ceramics on the Southern Plains. In Farmers, Hunters, and Colonists: Interaction between the Southwest and the Southern Plains, edited by Katherine A. Spielmann, pp. 51-70. University of Arizona Press, Tucson.

1992 Coronado's Querechos and Teyas in the Archaeological Record of the Texas Panhandle. Plains Anthropologist 37(140):247-259.

Habicht-Mauche, Judith A., Alytia A. Levendosky, and Margaret J. Schoeninger

1994 Antelope Creek Phase Subsistence: The Bone Chemistry Evidence. In Skeletal Biology in the Great Plains: Migration, Warfare, Health, and Subsistence, edited by Douglas W. Owsley and Richard L. Jantz, pp. 291-304. Smithsonian Institution Press, Washington, D.C.

Haley, J. Evetts

1929 Grass Fires of the Southern Plains. West Texas Historical Association Yearbook 5: 18-34.

1935 The Comanchero Trade. The Southwestern Historical Quarterly 38:157-176.

Hall, Grant D.

1977 Archeological Investigations at the Ernest Witte Site, Austin County, Texas. Ms. on file, Office of the State Archeologist, Texas Historical Commission, Austin.
1981 Allens Creek: A Study in the Cultural Prehistory of the Lower Brazos River Valley, Texas. Research Report No. 61. Texas Archeological Survey, The University of Texas at Austin.

Hall, Grant D., Stephen L. Black, and Carol Graves 1982 Archeological Investigations at Choke Canyon Reservoir, South Texas: The Phase I Findings. Choke Canyon Series 5. Center for Archaeological Research, The University of Texas at San Antonio.

Hall, Stephen A.

1977 Geology and Palynology of Archaeological Sites and Associated Sediments. In The Prehistory of the Little Caney River: 1976 Field Season, edited by Donald O. Henry, pp. 13-41. Contributions in Archaeology 1. Laboratory of Archaeology, University of Tulsa.

1982 Late Holocene Paleoecology of the Southern Plains. Quaternary Research 17:391-407.

1988 Environment and Archaeology of the Central Osage Plain. Plains Anthropologist 33(120): 203-218.

1990 Channel Trenching and Climatic Change in the Southern U.S. Great Plains. Geology 18: 342-345.

Hall, Stephen A., and Christopher Lintz

1984 Buried Trees, Water Table Fluctuations, and 3000 Years of Changing Climate in WestCentral Oklahoma. Quaternary Research 22:129-133.

Hammack, L. C.

1965 Archeology of the Ute Dam and Reservoir, Northeastern New Mexico. Museum of New Mexico Press, Santa Fe.

Hammatt, Hallett $\mathrm{H}$.

1976 The Gore Pit Site: An Archaic Occupation in Southwestern Oklahoma and a Review of the Archaic Stage in the Southern Plains. Plains Anthropologist 21(74):245-277.

Hammond, George P., and Agapito Rey

1966 The Rediscovery of New Mexico, 1590-1594: The Explorations of Chamuscado, Espejo, Castaño de Sosa, Morlete, and Leyva de Bonilla and Humaña. University of New Mexico Press, Albuquerque. 
Hammond, George P., and Agapito Rey (editors)

1953 Don Juan de Oñate, Colonizer of New Mexico, 1598-1628. Coronado Quarto Centennial Publication 5 and 6 . University of New Mexico Press, Albuquerque.

Hammond, George P., and Agapito Rey (editors and translators)

1940 Narratives of the Coronado Expedition, 1540-1542. University of New Mexico Press, Albuquerque.

Hannus, L. Adrien, and R. Peter Winham

1985a A Cultural Resources Reconnaissance Survey of the Proposed Central Basin $\mathrm{CO}_{2}$ Line from Denver City, Yoakim County, Texas, to McCamey, Upton County, Texas. Archeology Laboratory of the Center for Western Studies, Augustana College, Sioux Falls, South Dakota.

1985b Report of the Testing and Clearance at Sites 4IAD13, 41ADI5 and 4ICRI1 Along the Proposed Central Basin $\mathrm{CO}_{2}$ Mainline and a Survey of a Portion of the Cordona Lake Lateral Line with Subsequent Testing and Clearance of Site 4ICR13. Archeological Contract Series No. 19. Archeology Laboratory of the Center for Western Studies, Augustana College, Sioux Falls, South Dakota.

Hard, Robert J.

1990 Agricultural Dependence in the Mountain Mogollon. In Perspectives on Southwestern Prehistory, edited by P. E. Minnis and C. L. Redman, pp. 135-149. Westview Press, Boulder, Colorado.

Harper, Bob, and Emmett Shedd

1969 A Garza County Cave: SPAS-GR-269. South Plains Archeological Society Newsletter 22.

Harrison, Billy R., and Bob T. Griffin

1973 An Infant Burial in the Texas Panhandle. Bulletin of the Texas Archeological Society 44:61-68.

Harrison, Billy R., and Kay L. Killen

1978 Lake Theo: A Stratified Early Man Bison Butchering and Camp Site, Briscoe County, Texas: Archeological Investigations, Phase II. Panhandle-Plains Historical Museum, West Texas State University, Canyon.
Hart, Alyce

1976 An Open Report on Probes and Digs of LY42 by Individuals and the Archaeological Society of Dawson County. Transactions of the Eleventh Regional Archeological Symposium for Southeastern New Mexico and Western Texas, pp. 111-120.

1980 Experiments of Making Pottery from Local Clay of the Llano Estacado. Transactions of the 15th Regional Archeological Symposium for Southeastern New Mexico and Western Texas, pp. 1-13.

Haury, Cherie E.

1982 The Prehistory and Paleoenvironment of the Black Mesa Locality, Cimarron County, Oklahoma. Laboratory of Archaeology, Department of Anthropology, University of Tulsa.

Havins, T. R.

1960 Livestock and Texas Law. West Texas Historical Association Year Book 36:18-32.

Hayden, Brian

1986 Resource Models of Inter-Assemblage Variability. Lithic Technology 15(3):82-89.

1987 Reply to Conaty. Lithic Technology $16(2-3): 62$.

Hayes, Alden C., Jon Nathan Young, and A. H. Warren 1981 Excavations of Mound 7: Gran Quivira National Monument, New Mexico. Publications in Archeology No. 16. National Park Service, Washington, D.C.

Haynes, C. Vance, Jr.

1968 Geochronology of Late-Quaternary Alluvium. In Means of Correlation of Quaternary Successions, edited by R. B. Morrison and H. E. Wright Jr., pp. 591-631. Utah Press, Salt Lake City.

1975 Pleistocene and Recent Stratigraphy. In Late Pleistocene Environments of the Southern High Plains, edited by Fred Wendorf and James J. Hester, pp. 57-96. Fort Burgwin Research Center Publication No. 9. Ranchos de Taos, New Mexico. Southern Methodist University, Dallas.

Haynes, C. Vance, and George A. Agogino

1966 Prehistoric Springs and Geochronology of 
Blackwater No. 1 Locality, New Mexico. American Antiquity 31:812-821.

Hays, Joe Samuel

1986 An Archeological Survey of Portions of the Buffalo Lake National Wildlife Refuge, Randall County, Texas. U.S. Department of the Interior, Bureau of Reclamation, Southwest Region, Amarillo.

Hays, Joe S., Robert L. Brooks, and Jack L. Hofman 1989 Historical Archeology in the Southern Great Plains. In From Clovis to Comanchero: Archeological Overview of the Southern Great Plains, by Jack L. Hofman, Robert L. Brooks, Joe S. Hays, Douglas W. Owsley, Richard L. Jantz, Murray K. Marks, and Mary H. Manhein, pp. 101-110. Research Report No. 35. Arkansas Archeological Survey, Fayetteville.

Heartfield, Lorraine

1975 Archeological Investigations of Four Sites in Southwestern Coahuila, Mexico. Bulletin of the Texas Archeological Society 46:127-177.

Hedrick, John A.

1989 A Preliminary Report on Archeological Resources in Southern Culberson County in the Vicinity of Van Horn, Texas. Bulletin of the Texas Archeological Society 59:129-156.

Heffley, S.

1981 The Relationship Between Northern Athapaskan Settlement Patterns and Resource Distribution: An Application of Horn's Model. In Hunter-Gatherer Foraying Strategies: Ethnographic and Archaeological Analyses, edited by B. Winterholder and E. A. Smith, pp. 126-147. University of Chicago Press, Chicago.

Henderson, Mark

1976 An Archaeological Inventory of Brantley Reservoir, New Mexico: Models of Regional Culture History. Contributions in Anthropology No. 18. Institute for the Study of Earth and Man, Department of Anthropology, Southern Methodist University, Dallas.

Hester, James J.

1972 Blackwater Locality No. 1: A Stratified Early Man Site in Eastern New Mexico. Fort Burgwin Research Center Publication No. 8. Ranchos de Taos, New Mexico. Southern Methodist University, Dallas.
1975 The Sites. In Late Pleistocene Environments of the Southern High Plains, edited by Fred Wendorf and James J. Hester, pp. 13-32. Fort Burgwin Research Center Publication No. 8. Rancho de Taos, New Mexico. Southern Methodist University, Dallas.

Hester, Thomas R., Delbert Gilbow, and Alan D. Albee 1973 A Functional Analysis of "Clear Fork" Artifacts from the Rio Grande Plain, Texas. American Antiquity 38(1):90-96.

Hickerson, Nancy Parrott

1994 The Jumanos: Hunters and Traders of the South Plains. University of Texas Press, Austin.

Hiles, Harold

1993 Guide to Protein and Nutritional Values of Plants Used by Native Americans of the Southwest. Southwest Research Native, Fairacres, New Mexico.

Hill, A. T., and G. Metcalf

1942 A Site of the Dismal River Aspect in Chase Co., Nebraska. Nebraska History Magazine 22(2):158-226.

Hill, David V.

1988 Appendix D: Petrographic Analysis of El Paso Polychrome Pottery from Pickup Pueblo. In Pickup Pueblo: A Late Prehistoric House Ruin in Northeast El Paso. The Artifact 26(2):75-84. El Paso Archeological Society.

1990 Ceramic Production and Settlement Patterns in the Paso del Norte. In Historia Regional Comparada 1990. Actas del Segundo Congreso, pp. 29-40. Universidad Autonomia de Ciudad Juarez, Mexico.

Hines, Margaret Howard, Steve A. Tomka, and Karl W. Kibler

1994 Data Recovery at the Wind Canyon Site, 41HZ119, Hudspeth County, Texas. Reports of Investigations No. 99. Prewitt and Associates, Inc., Austin.

Hodge, Frederick W.

1911 The Jumano Indians. Proceedings of the American Antiquarian Society 20:249-268.

Hofman, Jack L.

1975 A Study of Custer-Washita River Foci Relationships. Plains Anthropologist 20(67): 41-51. 
1978a The Development and Northern Relationships of Two Archeological Phases in the Southern Plains Subarea. In The Central Plains Tradition: Internal Development and External Relationships, edited by Donald J. Blakeslee, pp. 6-35. Report No. 11. Office of the State Archeologist, Iowa City, Iowa.

1978b An Analysis of Surface Material from the Little Deer Site, 34CU10, of Western Oklahoma: A Further Investigation of the Wheeler Complex. Bulletin of the Oklahoma Anthropological Society 27:1-110.

1984a The Plains Villagers: The Custer Phase. In Prehistory of Oklahoma, edited by Robert E. Bell, pp. 287-305. Academic Press, New York.

1984b The Western Protohistoric: A Summary of the Edwards and Wheeler Complexes. In Prehistory of Oklahoma, edited by R. E. Bell, pp. 347-362. Academic Press, New York.

1989a Prehistoric Culture History-Hunters and Gatherers in the Southern Great Plains. In From Clovis to Comanchero: Archeological Overview of the Southern Great Plains, by Jack L. Hofman, Robert L. Brooks, Joe S. Hays, Douglas W. Owsley, Richard L. Jantz, Murray K. Marks, and Mary H. Manhein, pp. 25-60. Research Report No. 35. Arkansas Archeological Survey, Fayetteville.

1989b Protohistoric Culture History on the Southern Great Plains. In From Clovis to Comanchero: Archeological Overview of the Southern Great Plains, by Jack L. Hofman, Robert L. Brooks, Joe S. Hays, Douglas W. Owsley, Richard L. Jantz, Murray K. Marks, and Mary H. Manhein, pp. 91-100. Research Report No. 35. Arkansas Archeological Survey, Fayetteville.

Hofman, Jack L., and Robert L. Brooks

1989 Prehistoric Culture History: Woodland Complexes in the Southern Great Plains. In From Clovis to Comanchero: Archeological Overview of the Southern Great Plains, by Jack L. Hofman, Robert L. Brooks, Joe S. Hays, Douglas H. Owsley, Richard L. Jantz, Murray K. Marks, and Mary H. Manhein, pp. 61-70. Research Series No. 35. Arkansas Archeological Survey, Fayetteville.

Hofman, Jack L., Robert L. Brooks, Joe S. Hays, Douglas W. Owsley, Richard L. Jantz, Murray K. Marks, and Mary H. Manhein

1989 From Clovis to Comanchero: Archeological Overview of the Southern Great Plains.
Research Series No. 35. Arkansas Archeological Survey, Fayetteville.

Hofman, Jack L., and Joe S. Hays

1989 A History of Archeological Research on the Southern Great Plains. In From Clovis to Comanchero: Archeological Overview of the Southern Great Plains, by Jack L. Hofman, Robert L. Brooks, Joe S. Hays, Douglas W. Owsley, Richard L. Jantz, Murray K. Marks, and Mary H. Manhein, pp. 15-24. Research Series No. 35. Arkansas Archeological Survey, Fayetteville.

Holden, W. C.

1929 Some Recent Explorations and Excavations in Northwest Texas. Bulletin of the Texas Archeological and Paleontological Society $1: 23-35$

1931 Texas Tech Archeological Expedition Summer 1930. Bulletin of the Texas Archeological and Paleontological Society 3:43-52.

1938 Blue Mountain Rock Shelter. Bulletin of the Texas Archeological and Paleontological Society 10:208-221.

1944 Coronado's Route Across the Staked Plains. West Texas Historical Association Year Book 20:3-20.

1970 The Espuela Land and Cattle Company: A Study of a Foreign-Owned Ranch in Texas. Texas State Historical Association, Austin.

Holliday, Vance T.

1982 Morphological and Chemical Trends in Holocene Soils, Lubbock Lake Site, Texas. $\mathrm{Ph} . \mathrm{D}$. dissertation, Department of Geological Sciences, University of Colorado.

1983a Stratigraphy and Soils of the Lubbock Lake Landmark Area. In Guidebook to the Central Llano Estacado, edited by Vance T. Holliday, pp. 25-80. International Center for Arid and Semi-Arid Land Studies and The Museum, Texas Tech University, Lubbock

1983b Stratigraphy and Soils of the B.F.I. and Gentry Pits and Along Running Water Draw. In Guidebook to the Central Llano Estacado, edited by Vance T. Holliday, pp. 107-126. International Center for Arid and Semi-Arid Land Studies and The Museum, Texas Tech University, Lubbock.

1985a Archeological Geology of the Lubbock Lake 
Site, Southern High Plains of Texas. Geological Society of America Bulletin 96: 1483-1492.

1985b Holocene Soil-Geomorphological Relations in a Semi-Arid Environment: The Southern High Plains of Texas. In Soils and Quaternary Landscape Evolution, edited by J. Boardman, pp. 325-357. John Wiley and Sons, New York.

1985c New Data on the Stratigraphy and Pedology of the Clovis and Plainview Sites, Southern High Plains. Quaternary Research 23:388402.

1988 Late Pleistocene and Holocene Stratigraphy, Southern High Plains of Texas. In Geological Society of America Centennial Field Guide: South-Central Section 1988.

1989a Middle Holocene Drought on the Southern High Plains. Quaternary Research 31:74-82.

1989b The Blackwater Draw Formation (Quaternary): A 1.4-plus-m.y. Record of Eolian Sedimentation and Soil Formation on the Southern High Plains. Geological Society of America Bulletin 101:1598-1607.

1990 Investigations of the Plainview Site and Middle Running Water Draw. In Fifty Years of Discovery: The Lubbock Lake Landmark - Guidebook to the Quaternary History of the Llano Estacado, edited by Vance T. Holliday and Eileen Johnson, pp. 93-104. Lubbock Lake Landmark Quaternary Research Center Series No. 2. The Museum of Texas Tech University, Lubbock.

Holliday, Vance T. (editor)

1983 Guidebook to the Central Llano Estacado. International Center for Arid and Semi-Arid Land Studies and The Museum, Texas Tech University, Lubbock.

Holliday, Vance T., and B. L. Allen

1987 Geology and Soils. In Lubbock Lake: Quaternary Studies on the Southern High Plains, edited by Eileen Johnson, pp. 14-35. Texas A\&M University Press, College Station.

Holliday, Vance T., Eileen Johnson, Herbert Haas, and Robert Stuckenrath

1983 Radiocarbon Ages from the Lubbock Lake
Site, 1950-1980: Framework for Cultural and Ecological Change on the Southern High Plains. Plains Anthropologist 28(101):165182.

1985 Radiocarbon Ages from the Lubbock Lake Site: 1981-1984. Plains Anthropologist 30(110):277-291.

Holliday, Vance T., and Curtis M. Welty

1981 Lithic Tool Resources of the Eastern Llano Estacado. Bulletin of the Texas Archeological Society 52:201-214.

Honea, Kenneth

1980 Marks Beach, Stratified PaleoIndian Site, Lamb County, Texas: Preliminary Report. Bulletin of the Texas Archeological Society 51:243-269.

Hood, Charles H.

1978 Analysis of Seymour Gravels. In Archeological Investigations in the Truscott Reservoir Area, King and Knox Counties, Texas, by Gerald Meeks Etchieson, Roberta D. Speer, and Jack T. Hughes, pp. 379-385. Killgore Research Center, West Texas State University, Canyon.

Hood, Charles H., and Jack T. Hughes

1975 An Archeological Survey in the Lakeview Watershed. Report submitted to the Soil Conservation Service by the Archeological Research Laboratory, Killgore Research Center, West Texas State University, Canyon.

Hood, Charles H., and Carrie A. Wright

1979 Analysis of Seymour Gravels. In Archeological Investigations in the Crowell Reservoir Area, Cottle, Foard, King, and Knox Counties, Texas, by Gerald Meeks Etchieson, Roberta D. Speer, and Jack T. Hughes, pp. 381-388. Killgore Research Center, West Texas State University, Canyon.

Hood, Odie A.

1992 Interview with Mr. Odie A. Hood by Douglas K. Boyd, October 31, 1992, at site 41GR474, Garza County, Texas.

1993 Letter to Douglas K. Boyd, January 18, 1993. On file, Prewitt and Associates, Inc., Austin.

Hordes, Stanley M.

1992 Sixteenth-Century Spanish Campsite in the Tiguex Province: An Historical Perspective. 
In Current Research on the Late Prehistory and Early History of New Mexico, edited by Bradley J. Vierra, pp. 155-164. Special Publication No. 1. New Mexico Archaeological Council, Albuquerque.

Horn, H. S.

1968 The Adaptive Significance of Colonial Nesting in the Brewer's Blackbird (Euphagus cyanocephalus). Ecology 49:682-694.

Hornaday, William T,

1971 The Extermination of the American Bison, with a Sketch of its Discovery and Life History. Facsimile reproduction. The Shorey Book Store, Seattle, Washington. Originally published 1887, Report of National Museum.

Hoyt, Cathryn A.

1992 Material Culture of the Spanish Explorers. Bulletin of the Texas Archeological Society 63:7-26.

Hudson, LuAnn

1993 Protohistoric Pawnee Lithic Economy. Plains Anthropologist 38(146):265-277.

Hughes, David T.

1977 Analysis of Certain Prehistoric Bison Kills in the Texas Panhandle and Adjacent Areas. Unpublished Master's thesis, University of Arkansas, Fayetteville.

1984 The Foragers: Western Oklahoma. In Prehistory of Oklahoma, edited by Robert E. Bell, pp. 109-117. Academic Press, New York.

1989 Terminal Archaic Bison Kills in the Texas Panhandle. In In Light of Past Experience: Papers in Honor of Jack T. Hughes, edited by Beryl Cain Roper, pp. 183-204. Publication No. 5. Panhandle Archeological Society, Amarillo.

1991 Investigations of the Buried City, Ochiltree County, Texas: With an Emphasis on the Texas Archeological Society Field Schools of 1987 and 1988. Bulletin of the Texas Archeological Society 60:107-148.

Hughes, David T., and Alicia Hughes-Jones

1987 The Courson Archeological Projects: Final 1985 and Preliminary 1986. Innovative Publishing, Perryton, Texas.
Hughes, Jack T.

1942 An Archeological Report on the Harrell Site of North-Central Texas. Unpublished Master's thesis, The University of Texas at Austin.

1955 Little Sunday: An Archaic Site in the Texas Panhandle. Bulletin of the Texas Archeological Society 26:55-74.

1959 Archeological Survey of Greenbelt Reservoir, Donley County, Texas. Unpublished ms. on file, Panhandle-Plains Historical Museum, West Texas State University, Canyon.

1962 Lake Creek: A Woodland Site in the Texas Panhandle. Bulletin of the Texas Archeological Society 32:65-84.

Prehistory of the Caddoan-Speaking Tribes. Unpublished Ph.D. dissertation, Columbia University, New York.

1969 The Canyon City Club Cave in the Panhandle of Texas. Ms. on file, Office of the State Archeologist, Texas Historical Commission, Austin.

Archeological Reconnaissance in the Wichita River Drainage of North-Central Texas. Archeological Research Laboratory, Killgore Research Center, West Texas State University, Canyon. Reprint of report submitted to the U.S. Army Corps of Engineers, Tulsa District, for the Ark-Red Chloride Control Project, Part I, Areas VII, VIII, and X, Texas.

1973 Archeological Reconnaissance in the Upper Red River Drainage of Oklahoma and Texas. Archeological Research Laboratory, Killgore Research Center, West Texas State University, Canyon. Reprint of report submitted to the U.S. Army Corps of Engineers, Tulsa District, Environmental Inventory and Assessment: Areas VI, IX, XIII, XIV, and XV, Red River Chloride Control Project, Oklahoma and Texas.

1976 The Panhandle Archaic. The Texas Archaic: A Symposium, edited by Thomas R. Hester, pp. 28-38. Special Report No. 2. Center for Archaeological Research, The University of Texas at San Antonio.

1978 Archeology of Palo Duro Canyon. Panhandle-Plains Historical Review 51:35-57. 
1980 Some Early and Northerly Occurrences of the Clear Fork Gouge. In Papers on the Prehistory of Northeastern Mexico and Adjacent Texas, edited by Jeremiah F. Epstein, Thomas R. Hester, and Carol Graves, pp. 143-146. Special Report No. 9. Center for Archaeological Research, The University of Texas at San Antonio.

1982 Archeological Surveys of Certain Tracts in Castro, Deaf Smith, and Swisher Counties, Texas. Report submitted to Stone \& Webster Engineering Corporation, Boston, Massachusetts.

1991 Prehistoric Cultural Developments on the Texas High Plains. Bulletin of the Texas Archeological Society 60:1-55.

Hughes, Jack T., and Charles Hood

1976 Archeological Testing in the Lakeview Watershed, Hall County, Texas. Archeological Research Laboratory, Killgore Research Center, West Texas State University, Canyon.

Hughes, Jack T., H. Charles Hood, and Billy Pat Newman 1978 Archeological Testing in the Red Deer Creek Watershed in Gray, Roberts, and Hemphill Counties, Texas. Archeological Research Laboratory, Killgore Research Center, West Texas State University, Canyon.

Hughes, Jack T., H. Charles Hood, Billy Pat Newman, and Pollyanna B. Hughes

1977 Final Report on an Archeological Survey of the Red Deer Creek Watershed in Gray, Roberts, and Hemphill Counties, Texas. Submitted to the National Park Service by Archeological Research Laboratory, Killgore Research Center, West Texas State University, Canyon.

Hughes, Jack T., and Roberta D. Speer

1981 An Archeological Survey of the Pantex Plant, Carson County, Texas. Report submitted to Mason \& Hanger-Silas Mason Co., Inc.

Hughes, Jack T., and Patrick S. Willey

1978 Archeology at Mackenzie Reservoir. Office of the State Archeologist Survey Report 24. Texas Historical Commission, Austin.

Hurt, Richard D.

1980 Archeological Investigations of Portions of the Middle Concho Valley, Texas. Unpublished Master's thesis, Texas Tech University, Lubbock.
Ingold, Tim

1983 The Significance of Storage in Hunting Societies. Man 18:553-571.

Ippolito, John

1977 Archeological Investigations at Fort Richardson State Park. Anthropology Laboratory Report 21. Texas A\&M University, College Station.

Ivey, James E., Diane Lee Rhodes, and Joseph P. Sanchez 1991 The Coronado Expedition of 1540-1542: A Special History Report Prepared for the Coronado Trail Study. U.S. Department of the Interior, National Park Service, Santa Fe and Denver.

Jackson, A. T.

1938 Picture-Writing of Texas Indians. University of Texas Publication No. 3809. Austin.

Jackson, Marsha F., Gary L. Hume, and Roberta Speer

1973 Mayfield Dugout (41BI52). National Register of Historic Places Inventory - Nomination Form. On file, Texas Historical Commission, Austin.

Jaquier, J. A.

1986 A Petroglyph (41TG54) from Tom Green County, West-Central Texas. Bulletin of the Texas Archeological Society 55:145-151.

Jelinek, Arthur J.

1967 A Prehistoric Sequence in the Middle Pecos Valley, New Mexico. Anthropological Papers No. 31. Museum of Anthropology, University of Michigan, Ann Arbor.

Jelks, Edward B.

1952 Appraisal of the Archeological and Paleontological Resources of the Colorado City Reservoir, Borden and Scurry Counties, Texas. River Basin Surveys, Smithsonian Institution, Washington, D.C.

1962 The Kyle Site: A Stratified Central Texas Aspect Site in Hill County, Texas. Archaeology Series No. 5. Department of Anthropology, The University of Texas at Austin.

Jelks, Edward B., and Edward H. Moorman

1953 Survey and Appraisal of the Archeological Resources of Oak Creek Reservoir, Coke County, Texas. River Basin Surveys, Smithsonian Institution, Washington, D.C. 
Jochim, M. A.

1981 Strategies for Survival: Cultural Behavior in an Ecological Context. Academic Press, New York.

Johnson, Charles A., II, and Thomas W. Stafford Jr. 1975 Report of 1975 of the Archaeological Survey Investigation of the Canyon Lakes Project, Yellowhouse Canyon, Lubbock, Texas. Report submitted to the Bureau of Outdoor Recreation, City of Lubbock, Texas, by Texas Technological University, Lubbock.

Johnson, Eileen

1983 Lubbock Lake Landmark Master Plan. National Endowment for the Humanities, Washington, D.C., and the Texas Antiquities Committee, Austin.

1987 Lubbock Lake: Late Quaternary Studies on the Southern High Plains. Texas A\&M University Press, College Station.

Johnson, Eileen (editor)

1989 Lubbock Lake Landmark: 1987 Fenceline Corridor Survey and Testing Program. Lubbock Lake Landmark Quaternary Research Center Series No. 1. Museum of Texas Tech University, Lubbock.

1993 Late Holocene Investigations at the Lubbock Lake Landmark. Volume I: The 1988 Work. Lubbock Lake Landmark Quaternary Research Center Series No. 5. Museum of Texas Tech University, Lubbock.

1994 Archaeological Survey Along the Mobile ESTE $\mathrm{CO}_{2}$ Pipeline Corridor from Denver City to Clairemont, Texas. Lubbock Lake Landmark Quaternary Research Center Series No. 6. Museum of Texas Tech University, Lubbock.

1995 Playa Archaeology: Archaeological Investigations at Reese Air Force Base and Terry County Auxiliary Airfield, Lubbock and Terry Counties. Lubbock Lake Landmark Quaternary Research Center Series No. 7. Museum of Texas Tech University, Lubbock.

Johnson, Eileen, and Vance T. Holliday

1986 The Archaic Record at Lubbock Lake. In Current Trends in Southern Plains Archaeology, edited by Timothy G. Baugh, pp. 7-54. Plains Anthropologist 31(114, Pt. II) Memoir 21
1995 Archeology and Late Quaternary Environments of the Southern High Plains. Bulletin of the Texas Archeological Society 66:517540 .

Johnson, Eileen, Vance T. Holliday, Michael J. Kaczor, and Robert Stuckenrath

1977 The Garza Occupation at the Lubbock Lake Site. Bulletin of the Texas Archeological Society 48:83-109.

Johnson, Eileen, Leon Pope, and Kent Hicks

1993 Archaeological Survey of the City of Floydada Proposed Landfill Extension for Floyd County, Texas. Report submitted to the City of Floydada, Texas.

Johnson, Elmer H.

1931 The Natural Regions of Texas. University of Texas Bulletin No. 3113. Austin.

Johnson, LeRoy, Jr.

1987 A Plague of Phases. Bulletin of the Texas Archeological Society 57:1-26.

1994 The Life and Times of Toyah-Culture Folk: The Buckhollow Encampment, Site 41KM16, Kimble County, Texas. Office of the State Archeologist Report 38. Texas Department of Transportation and Texas Historical Commission, Austin.

Johnson, LeRoy, and Glenn T. Goode

1994 A New Try at Dating and Characterizing Holocene Climates, as Well as Archeological Periods, on the Eastern Edwards Plateau. Bulletin of the Texas Archeological Society 65:1-51.

Jones, J. Knox, David M. Armstrong, and Jerry R. Choate 1985 Guide to the Mammals of the Plains States. University of Nebraska Press, Lincoln.

Jones, John G.

1990 Appendix H: Assessment of Pollen Preservation and Macrobotanical Analysis. In Phase II Investigations at Prehistoric and Rock Art Sites, Justiceburg Reservoir, Garza and Kent Counties, Texas, by Douglas K. Boyd, James T. Abbott, William A. Bryan, Colin M. Garvey, Steve A. Tomka, and Ross C. Fields, pp. 521-532. Reports of Investigations No. 71, vol. II. Prewitt and Associates, Inc., Austin. 
Judd, Sharon J.

1977 Prehistoric Cultural Resources in the Central Llano Estacado and Western Rolling Plains of Texas. Unpublished Master's thesis, Department of Anthropology, Texas Tech University, Lubbock.

1978 Prehistoric Resources in the South Plains Association of Governments Area. Transactions of the 13th Regional Archeological Symposium for Southeastern New Mexico and Western Texas, pp. 23-26.

Jurgens, Christopher J.

1981 An Archeological Reconnaissance for the City of Slaton, Lubbock County, Texas. Letter report to the Texas Historical Commission on EPA Construction Grants Project, C-48-1683. Construction Grants and Water Quality Management Division, Texas Department of Water Resources, Austin.

1982 Archeological Reconnaissance of Facility Plan Revisions, Wastewater Treatment Facilities, City of Slaton, Lubbock County, Texas. Letter report to the Texas Historical Commission on EPA Construction Grants Project, C-48-1683. Construction Grants and Water Quality Management Division, Texas Department of Water Resources, Austin.

Justice, Mason

1988 Interview with Mason Justice, September 28, 1988, Justiceburg, Texas, by Martha Doty Freeman.

Kalokowski, H. Paul, Jr.

1986 Archeological Testing of the Fifth Green Site (A1363), Randall County, Texas. Ms. on file, Archeological Research Laboratory, Killgore Research Center, West Texas State University, Canyon.

Kane, A. E., and C. K. Robinson

1988 Dolores Archeological Program: Anasazi Communities at Dolores: McPhee Village. U.S. Department of the Interior, Bureau of Reclamation, Engineering and Research Center, Denver.

Katz, Susana R., and Paul Katz

1976 Archeological Investigations in Lower Tule Canyon, Briscoe County, Texas. Office of the State Archeologist Survey Report No. 16. Texas Historical Commission, Austin.
1985 The Prehistory of the Carlsbad Basin, Southeastern New Mexico: Technical Report of Prehistoric Archaeological Investigations in the Brantley Project Locality. Incarnate Word College, San Antonio, Texas.

Kehoe, Thomas R.

1966 The Small Side-Notched Point System of the Northern Plains. American Antiquity 31(6): 827-841.

Kelley, Jane Holden

1964 Comments on the Archeology of the Llano Estacado. Bulletin of the Texas Archeological Society 35:1-18.

1984 The Archaeology of the Sierra Blanca Region of Southeastern New Mexico. Anthropological Paper 74. University of Michigan, Museum of Anthropology, Ann Arbor.

Kelley, J. Charles

1947 The Lehmann Rock Shelter: A Stratified Site of the Toyah, Uvalde, and Round Rock Foci. Bulletin of the Texas Archeological and Paleontological Society 18:115-128.

1986 Jumano and Patarabueye: Relations at La Junta de los Rios. Anthropological Papers No. 77. Museum of Anthropology, University of Michigan, Ann Arbor.

1990 The Rio Concho Drainage: History, Archaeology, Significance. Journal of Big Bend Studies 2:29-42.

Kelly, Robert L.

1980 Hunter-Gatherer Settlement Systems. Master's thesis, Department of Anthropology, University of New Mexico, Albuquerque.

1983 Hunter-Gatherer Mobility Strategies. Journal of Anthropological Research 39(3):277-306.

Kenmotsu, Ray D.

1981 Appendix VII: An Assessment and Overview of the Flora of the Brazos Natural Salt Pollution Control Project Area. In Preliminary Assessment of the Cultural Resources in the Brazos Natural Salt Pollution Control Project, Kent, King, and Stonewall Counties, Texas, by J. Peter Thurmond, Martha Doty Freeman, and Susan L. Andrews, pp. 339351. Reports of Investigations No. 18. Prewitt and Associates, Inc., Austin. 
Kessell, John L.

1987 Kiva, Cross, and Crown: The Pecos Indians and New Mexico, 1540-1840. University of New Mexico Press, Albuquerque.

Keyser, James D.

1987 A Lexicon for Historic Plains Indian Rock Art: Increasing Interpretive Potential. Plains Anthropologist 32(115):43-71.

1992 A Thing to Tie on the Halter: An Addition to the Plains Rock Art Lexicon. Plains Anthropologist 36(136):261-267.

Kibler, Karl W.

1991 Surface Distributions of Sites and Survey Strategies for Draws on the Southern Llano Estacado. Unpublished Master's thesis, Anthropology Department, The University of Texas at Austin.

1992 Surface Distributions of Aboriginal Sites on the Southern Llano Estacado. Transactions of the 28th Regional Archeological Symposium for Southeastern New Mexico and Western Texas, pp. 26-48.

Kidder, Alfred V.

1932 The Artifacts of Pecos. Phillips Academy Papers of the Southwestern Expedition 6. Yale University Press, New Haven.

Kidder, Alfred V., and Anna O. Shepard

1936 The Pottery of Pecos, Volume 2. Phillips Academy Papers of the Southwestern Expedition 7. Yale University Press, New Haven.

Kingston, Mike (editor)

1991 1992-1993 Texas Almanac. Published for the Dallas Morning News by A. H. Belo Corporation, Dallas.

Kintigh, Keith W.

1984 Measuring Archaeological Diversity by Comparisons with Simulated Assemblages. American Antiquity 49:44-54.

1989 Sample Size, Significance, and Measures of Diversity. In Quantifying Diversity in Archaeology, edited by R. D. Leonard and G. T. Jones, pp. 25-36. Cambridge University Press, Cambridge.

1992 Tools for Quantitative Archaeology Programs for Quantitative Analysis in Archaeology. Privately published by the author, Tempe, Arizona.
Kirkland, Forrest

1941 Petroglyphs of the Abilene District. Bulletin of the Texas Archeological and Paleontological Society 13:63-75.

1942 Indian Pictographs and Petroglyphs in the Panhandle Region of Texas. Bulletin of the Texas Archeological and Paleontological Society 14:9-12.

Kirkland, Forrest, and W. W. Newcomb Jr.

1967 The Rock Art of Texas Indians. The University of Texas Press, Austin.

Kirkpatrick, Zoe Merriman

1978 A Preliminary Report on a Rare Form of Bedrock Mortar Holes in Garza County, Texas. Transactions of the 13th Regional Archeological Symposium for Southeastern New Mexico and Western Texas, pp. 31-38.

1992 Wildflowers of the Western Plains: A Field Guide. University of Texas Press, Austin.

Kiser, Edwin L.

1978 The Re-examination of Pedro de Castañeda's Bone Bed by Geological Investigations. Bulletin of the Texas Archeological Society 49:331-339.

Knight, George C., and James D. Keyser

1983 A Mathematical Technique for Dating Projectile Points Common to the Northwestern Plains. Plains Anthropologist 28(101):199207.

Knox, J. C

1983 Responses of River Systems to Holocene Climates. In Late Quaternary Environments of the United States, Volume 2: The Holocene, edited by H. E. Wright Jr., pp. 26-41. University of Minnesota Press, Minneapolis.

Kraenzel, Carl Frederick

1955 The Great Plains in Transition. University of Oklahoma Press, Norman.

Krieger, Alex D.

1946 Culture Complexes and Chronology in Northern Texas with Extension of Puebloan Dating to the Mississippi Valley. University of Texas Publication No. 4640. Austin.

1978 The Southern Limits of Central Plains Culture Complexes. Proceedings of the Fifth Plains Conference for Archeology, assembled by John L. Champe, pp. 98-99. Reprint of 
1949 Laboratory of Anthropology Note Book No. 1. University of Nebraska, Lincoln.

Krone, Milton F.

1976 The Ahumada Point: A Projectile Point from Northern Chihuahua, Mexico. The Artifact 14(2):41-43. El Paso Archeological Society.

1978 The Soto Ranch Site. The Artifact 16(4): 23-53. El Paso Archeological Society.

Largent, Floyd B., Jr.

1995 A Cultural Resources Survey of 2,400 Acres at the U.S. Department of Energy Pantex Plant, Carson County, Texas. Miscellaneous Reports of Investigations 87. Geo-Marine, Inc., Plano, Texas.

Largent, Floyd B., Jr., and Frank Winchell

1995a A Cultural Resources Survey of 500 Acres Surrounding the Sewage Playa at the Pantex Plant, Carson County, Texas. Miscellaneous Reports of Investigations 75. Geo-Marine, Inc., Plano, Texas.

1995b A Cultural Resources Survey of 4,200 Acres Leased by the U.S. Department of Energy, Pantex Plant, Carson County, Texas. Miscellaneous Reports of Investigations 80. GeoMarine, Inc., Plano, Texas.

Lea County Archeological Society

1971 The Laguna Plata Site, L.C.A.S. C-10-C, LA-5148: A Preliminary Report. Lea County Archeological Society, Hobbs, New Mexico.

Lee, J. Robert

1978 Site 41MT43: Analysis of Intensive Surface Survey. Bulletin of the South Plains Archeological Society 4:53-63.

Lees, William

1977 Investigations at Tx-33, Old Hardesty, Texas County, Oklahoma. Report 11. Archeological Research Associates, Tulsa.

Lehmer, Donald J.

1948 The Jornada Branch of the Mogollon. University of Arizona Social Science Bulletin 17. Tucson.

1963 The Plains Bison Hunt: Prehistoric and Historic. Plains Anthropologist 8(22):211217.
Leonhardy, Frank C.

1966 Test Excavations in the Mangum Reservoir Area of Southwestern Oklahoma. Contributions of the Museum of the Great Plains, No. 2. Lawton, Oklahoma.

Leslie, Robert H.

1965 The Merchant Site, L.C.A.S. E-4. Transactions of the First Regional Archeological Symposium for Southeastern New Mexico and Western Texas, pp. 23-29.

1968 The Monument Spring Site, LCAS No. D16, Lea County, New Mexico. Transactions of the Fourth Regional Archeological Symposium for Southeastern New Mexico and Western Texas, pp. 79-83.

1978 Projectile Point Types and Sequence of the Eastern Jornada-Mogollon, Extreme Southeastern New Mexico. Transactions of the 13th Regional Archeological Symposium for Southeastern New Mexico and Western Texas, pp. 81-157.

1979 The Eastern Jornada Mogollon, Extreme Southeastern New Mexico (A Summary). In Jornada Mogollon Archaeology: Proceedings of the First Jornada Conference, edited by Patrick H. Beckett and Regge N. Wiseman, pp. 179-199. Cultural Resources Management Division, New Mexico State University, Las Cruces.

LeVick, Gene, and Lawrence LeVick

1966 The Case of the Aching Ulna or Would you Believe a Projectile in an Elbow? Oklahoma Anthropological Society Newsletter 14(9):910 .

Levine, Frances

1983 A Brief Overview of the Comanchero Trade. Prepared for the Albuquerque Museum, Albuquerque.

Levine, Frances, and Martha Doty Freeman

1982 A Study of Documentary and Archeological Evidence for Comanchero Activity in the Texas Panhandle. Ms. on file, Texas Historical Commission, Austin.

Levine, Frances, and Joseph C. Winter (editors)

1987 Investigations at Sites 48 and 77, Santa Rosa Lake, Guadalupe County, New Mexico: An Inquiry into the Nature of Archeological 
Reality. Office of Contract Archeology, University of New Mexico, Albuquerque.

Lintz, Christopher

1976 Test Excavations at the Kenton Bison Kill Site (Ci-81), Cimarron County, Oklahoma. Oklahoma Anthropological Society Newsletter 24(7):2-7.

1978 The Johnson-Cline Site (Tx-40): An Upland Dune Site in the Oklahoma Panhandle. Bulletin of the Oklahoma Anthropological Society 27:111-140.

1982 An Overview of the Antelope Creek Focus. Transactions of the 17th Regional Archeological Symposium for Southeastern New Mexico and Western Texas, pp. 37-56.

1984 The Plains Villagers: Antelope Creek. In Prehistory of Oklahoma, edited by Robert E. Bell, pp. 325-346. Academic Press, New York.

1986 Architecture and Community Variability within the Antelope Creek Phase of the Texas Panhandle. Studies in Oklahoma's Past No. 14. Oklahoma Archeological Survey, Norman.

1990 The Landergin Mesa: The 1984 Phase II Field Results. Draft report prepared for the Texas Historical Commission, Austin.

1991 Texas Panhandle-Pueblo Interactions from the Thirteenth through the Sixteenth Century. In Farmers, Hunters, and Colonists: Interaction between the Southwest and the Southern Plains, edited by Katherine Spielmann, pp. 89-106. University of Arizona Press, Tucson.

1995 Radiocarbon Dates from the Chalk Hollow Site in Randall County, Texas. Paper presented at the 53rd Annual Plains Anthropological Conference, Laramie, Wyoming.

Lintz, Christopher, Michael Blum, Rick Holloway, and Linda Scott-Cummings

1993 Paleoenvironmental Reconstruction. In Cultural Resources Investigations in the O. H. Ivie Reservoir, Concho, Coleman, and Runnels Counties, Texas. Volume I: Project Introduction, Setting, and Methods, by Christopher Lintz, W. Nicholas Trierweiler, Amy C. Earls, Fred M. Oglesby, Michael Blum, Patrick L. O’Neill, John Kuhl, Richard
Holloway, Linda Scott-Cummings, and Dan Scurlock, pp. 261-279. Technical Report No. 346-I. Mariah Associates, Inc., Austin.

Lintz, Christopher, Karen Kramer, Amy Earls, W. N. Trierweiler, Terry Del Dene, John Acklen, Fred Nials, and Jack Bertram

1988 Class II Survey and Testing of Cultural Resources at the Melrose Air Force Range, Curry and Roosevelt Counties, New Mexico. Mariah Associates, Inc., Albuquerque.

Lintz, Christopher, John D. Speth, David T. Hughes, and Jeffrey A. Huebner

1991 Additional Radiocarbon Dates from the Twilla Bison Kill Site, Hall County, Texas. Bulletin of the Texas Archeological Society 60:257-266.

Lintz, Christopher, Abby Treece, Fred M. Oglesby, Karl Kibler, Patrick O'Neill, W. Nicholas Trierweiler, Charles Frederick, J. Michael Quigg, and A. J. Taylor

1993 Cultural Resource Investigations in the O. H. Ivie Reservoir, Concho, Coleman, and Runnels Counties, Texas: Volume II: Test Excavations at Prehistoric Sites and Assessment of Rock Cairn Features. Technical Report 346-II. Mariah Associates, Inc., Austin.

Lintz, Christopher, W. Nicholas Trierweiler, Fred Oglesby, Patrick O'Neill, William Doering, and Michael McFaul

1991 A Cultural Resource Survey at Mitchell Reservoir, Mitchell County, Texas. Technical Report 433. Mariah Associates, Inc., Austin.

Lintz, Christopher, and Leon George Zabawa

1984 The Kenton Caves of Western Oklahoma. In Prehistory of Oklahoma, edited by Robert E. Bell, pp. 161-174. Academic Press, New York.

Litwinionck, Luc, Eileen Johnson, and Michael Davis 1997 Survey at the Southeastern Edge of the Llano Estacado. Bulletin of the Texas Archeological Society 68:301-335.

Long, Austin, and Bruce Rippeteau

1974 Testing Contemporaneity and Averaging Radiocarbon Data. American Antiquity 39(2):205-215.

Lorrain, Dessamae

1968 Excavation at Red Bluff Shelter (Sotol Site) X41CX8, Crockett County, Texas. Transac- 
tions of the Fourth Regional Archeological Symposium for Southeastern New Mexico and Western Texas, pp. 18-39.

1969 Archeological Investigations in the Fish Creek Reservoir. Contributions in Archeology No. 4. Department of Anthropology, Southern Methodist University, Dallas.

Lorrain, Paul, and Mark Parsons

1968 A Subspecific Identification of a Petroglyph. The Record 24(3):15-18. Dallas Archeological Society.

Low, B. S.

1979 The Predictability of Rain, and the Foraging Patterns of the Red Kangaroo (Megaleia rufa) in Central Australia. Journal of Arid Environments 1:61-76.

Lowie, Robert H.

1954 Indians of the Plains. McGraw Hill Book Company, Inc., New York.

Lynott, Mark J.

1979a Survey and Testing in the Elm Creek Watershed, Upper Colorado River Drainage, Texas (Floodwater Retarding Structures 1-10). Research Report 106. Archeological Research Program, Southern Methodist University, Dallas.

1979b Prehistoric Bison Populations of Northcentral Texas. Bulletin of the Texas Archeological Society 50:89-101.

Mabry, W. S.

1938 Some Memoirs of W. S. Mabry. The Panhandle-Plains Historical Review 11:31-51.

MacDowell, April (compiler)

1986 Selected Articles from the South Plains Archeological Society Newsletters. South Plains Archeological Society, Lubbock, Texas.

Mack, Steven R.

1994 Archaeological Investigations at the Van York Site (41BD8): A Late Archaic Lithic Scatter in the Western Rolling Plains of Texas. Unpublished Master's thesis, Department of Anthropology, University of Tulsa.

MacNeish, Richard S.

1993 Preliminary Investigations of the Archaic in the Region of Las Cruces, New Mexico. Historic and Natural Resources Report No. 9. Cultural Resources Management Program,
Directorate of Environment, United States Army Air Defense Artillery Center, Fort Bliss, Texas.

Mallery, Garrick

1886 Pictographs of the North American Indians. Fourth Annual Report of the Bureau of American Ethnology, Washington, D.C.

1893 Picture-writing of the North American Indians. Tenth Annual Report of the Bureau of American Ethnology, Washington, D.C. Reprinted 1972, 2 vols. Dover Publications, Inc., New York.

Mallouf, Robert J.

1987 Las Haciendas: A Cairn-Burial Assemblage from Northeastern Chihuahua, Mexico. Office of the State Archeologist Report 35. Texas Historical Commission, Austin.

1989 Quarry Hunting with Jack - T. Hughes: Tecovas Jasper in the South Basin of the Canadian River, Oldham County, Texas. In In Light of Past Experience: Papers in Honor of Jack T. Hughes, edited by Beryl Cain Roper, pp. 307-326. Publication No. 5. Panhandle Archeological Society, Amarillo.

1992 A Commentary on the Prehistory of Far Northeastern Chihuahua, the La Junta District, and the Cielo Complex. English translation of "La Prehistoria del Noreste de Chihuahua: Complejo Cielo y Distrito La Junta,"- in Historia General de Chihuahua I: Geología, Geografia, y Arqueología, edited by Arturo Márquez-Alameda, pp. 137-152. Universidad Autónoma de Ciudad Juárez y Gobierno del Estado de Chihuahua.

Malone, James M.

1970 Archeological Reconnaissance in the Mackenzie Reservoir Area of Tule Canyon. Archeological Survey Report No. 8. Texas Historical Survey Committee and Texas Water Development Board, Austin.

Malone, James M., and Alton K. Briggs

1970 Archeological Reconnaissance in the Miller Creek Reservoir Area. Archeological Survey Report No. 6. Texas State Historical Survey Committee and Texas Water Development Board, Austin.

Marchbanks, Michael L., and J. Michael Quigg

1990 Appendix G: Organic Residue and Phytolith Analyses. In Phase II Investigations at 
Prehistoric and Rock Art Sites, Justiceburg Reservoir, Garza and Kent Counties, Texas, by Douglas K. Boyd, James T. Abbott, William A. Bryan, Colin M. Garvey, Steve A. Tomka, and Ross C. Fields, pp. 495-519. Reports of Investigations No. 71, vol. II. Prewitt and Associates, Inc., Austin.

Marcy, Randolph B.

1850 Report of Captain R. B. Marcy's Route from Fort Smith to Santa Fe. Reports of the Secretary of War, 31st Congress, 1st Session, Senate Executive Document 64, pp. 169-233.

1853 Exploration of the Red River of Louisiana, in the Year 1852: With Reports on the Natural History of the Country, and Numerous Illustrations. 32nd Congress, 2nd Session, Senate Executive Document 54. Robert Armstrong, Public Printer, Washington, D.C.

Marmaduke, William S., and Hayden Whitsett

1975 Reconnaissance and Archaeological Studies in the Canadian River Valley. Canadian Breaks: A Natural Area Survey: Part VII of VIII, pp. 68-126. Division of Natural Resources and Environment, The University of Texas at Austin.

Martin, Ernest R.

1994 The Dillard Site: A Late Prehistoric Plains Village Site in Cooke County, Texas. Bulletin of the Texas Archeological Society 62: 105-200.

Matthews, William H., III

1969 The Geologic Story of Palo Duro Canyon. Guidebook 8. Bureau of Economic Geology, The University of Texas at Austin.

Mauldin, Raymond

1991 Agricultural Intensification in the Mogollon Highlands. In Mogollon $\mathrm{V}$, edited by Jane $\mathrm{H}$. Kelley and Patrick H. Beckett, pp. 62-75. COAS Publishing and Research, Las Cruces, New Mexico.

1993 The Relationship between Ground Stone and Agricultural Intensification in Western New Mexico. Kiva 58(3):317-330.

Mauldin, Raymond P., and Steve A. Tomka

1988 Informe Preliminar sobre Experimentos en el Uso de Moledoras de Piedra (Khona) en la Communidad de Alota, Nor Lipz, Potosí, Bolivia. Ms. submitted to the Museo Nacional de Etnografia y Folklore, La Paz.
McHugh, Tom

1972 The Time of the Buffalo. University of Nebraska Press, Lincoln.

McKern, W. C.

1939 The Midwestern Taxonomic Method as an Aid to Archaeological Culture Study. American Antiquity 4:301-313.

McKown, Constance J.

1981 The Blue Canyon Petroglyphs: Armstrong County, Texas. Transactions of the 15th Regional Archeological Symposium for Southeastern New Mexico and Western Texas, pp. 7-12.

Meltzer, David J.

1991 Altithermal Archaeology and Paleoecology of Mustang Springs, on the Southern High Plains of Texas. American Antiquity 56(2): 236-267.

Meltzer, David J., and Michael B. Collins

1987 Prehistoric Water Wells on the Southern High Plains: Clues to Altithermal Climates. Journal of Field Archaeology 14:9-28.

Mercado-Allinger, Patricia

1982 Archeological Investigations at 41BI452, Caprock Canyons State Park, Briscoe County, Texas. Publication 4000-320. Texas Parks and Wildlife Department, Austin.

Metcalf, Duncan, and K. Renee Barlow

1992 A Model for Exploring the Optimal Trade-off between Field Processing and Transport. American Anthropologist 94(2):340-356.

Miller, Beth

1992 Appendix I: 41HG66 Skeletal Analysis. In Archeological Investigations at the Kent Creek Site (41HL66): Evidence of Mogollon Influence on the Southern Plains, by Jimmy Brett Cruse, pp. 161-165. Publication No. 6. Panhandle Archeological Society, Amarillo.

Miller, Wick R.

1983 Uto-Aztecan Languages. In Handbook of North American Indians, Vol. 10: Southwest, edited by Alfonso Ortiz, pp. 113-124. Smithsonian Institution, Washington, D.C.

Minnis, Paul E.

1985 Domesticating People and Plants in the Greater Southwest. In Prehistoric Food Production in North America, edited by Richard I. Ford, pp. 309-339. Anthropologi- 
cal Papers No. 75. Museum of Anthropology, University of Michigan, Ann Arbor.

Minnis, Paul E., and Charles L. Redman

1990 Perspectives on Southwestern Prehistory. Westview Press, Boulder, Colorado.

Mires, Peter B., and John A. Evaskovich

1992 Cultural Resources Survey for the Proposed Graham to Justiceburg Transmission Line, Garza County, Texas. Mariah Associates, Inc., Albuquerque, New Mexico.

Mitchell, Jimmy L.

1975 Notes on Some Archeological Materials from the Palo Duro Creek Area of Hansford County, Texas. Bulletin of the Texas Archeological Society 46:217-230.

Mobley, Charles M.

1976 Archaeological Investigations at Fort Concho, Texas. Research Report 98. Archeological Research Program, Southern Methodist University, Dallas.

Mobley, Charles M. (editor)

1978 Archeological Research and Management at Los Esteros Reservoir, New Mexico. Archeology Research Program, Southern Methodist University, Dallas.

Montgomery, John L.

1990 Cultural Resources Survey of the Proposed Southwest Public Service Tolk 345 Kilovolt Transmission Line, New Mexico and Texas. Agency for Conservation Archeology Report F89-145. Llano Estacado Center for Advanced Professional Studies and Research, Eastern New Mexico University, Portales.

Moore, Michael C.

1984 Reconnaissance Survey of Quartermaster Creek. In Archaeology of the Mixed Grass Prairie, Phase I: Quartermaster Watershed, edited by Timothy G. Baugh, pp. 51-214. Archeological Resource Survey Report 20. Oklahoma Archeological Survey, Norman.

1988 Archeology of the Mixed Grass Prairie, Phases II and III: May and Cyclone Creeks and Predictive Modeling in the Quartermaster Watershed. Archeological Resources Survey Report 33. Oklahoma Archeological Survey, Norman.

Moore, William, and Roger Moore

1986 Historical Archaeology in Texas: A Bibliog- raphy. Guidebooks in Archaeology No. 2. Center for Archaeological Research, The University of Texas at San Antonio.

Morris, Donald $\mathrm{H}$.

1990 Changes in Groundstone Following the Introduction of Maize into the American Southwest. Journal of Anthropological Research 46:177-194.

Nativ, Ronit

1988 Hydrogeology and Hydrochemistry of the Ogallala Aquifer, Southern High Plains, Texas Panhandle and Eastern New Mexico. Reports of Investigations No. 177. Bureau of Economic Geology, The University of Texas at Austin.

Natural Heritage Policy Research Project

1978 Preserving Texas' Natural Heritage. Policy Research Project Report No. 31. The Natural Heritage Policy Research Project, Lyndon B. Johnson School of Public Affairs, The University of Texas at Austin.

Newcomb, W. W., Jr.

1961 The Indians of Texas: From Prehistoric to Modern Times. University of Texas Press, Austin.

Nicholson, Anne, and Scott Cane

1991 Desert Camps: Analysis of Australian Aboriginal Proto-historic Campsites. In Ethnoarchaeological Approaches to Mobile Campsites: Hunter-Gatherer and Pastoralist Case Studies, edited by C. S. Gamble and W. A. Boismier, pp. 263-354. Ethnoarchaeological Series 1. International Monographs in Prehistory, Ann Arbor, Michigan.

Nordt, Lee C.

1992 Archeological Geology of the Fort Hood Military Reservation, Fort Hood, Texas. United States Army Fort Hood, Archeological Resource Management Series, Research Report No. 25. Mariah Associates, Inc., Austin.

1993 Additional Geoarcheological Investigations at the Fort Hood Military Reservation, Ft. Hood, Texas. United States Army Fort Hood, Archeological Resource Management Series, Research Report No. 28 (Addendum to Research Report No. 25). Mariah Associates, Inc., Austin.

Nordyke, Lewis

1949 Cattle Empire: The Fabulous Story of the 
3,000,000 Acre XIT. William Morrow, New York.

Northcutt, John

1979 An Archeological Survey in the Gypsum Breaks on the Elm Fork of the Red River. Contributions of the Museum of the Great Plains No. 8. Lawton, Oklahoma.

Northern, Martin James

1979 Archaeological Investigations of the Montgomery Site, Floyd County, Texas. Master's thesis, Texas Tech University, Lubbock.

Nunn, W. Curtis

1940 Eighty-six Hours Without Water on the Texas Plains. The Southwestern Historical Quarterly 43(January):356-364.

Oklahoma Archeological Survey

1993 Radiocarbon Dates for RM-668. Oklahoma Archeological Survey Newsletter 12(3).

O'Laughlin, Thomas C.

1980 The Keystone Dam Site and Other Archaic and Formative Sites in Northwest El Paso, Texas. Publications in Anthropology No. 8. El Paso Centennial Museum, The University of Texas at El Paso.

1993 The Long and Short of It: Jornada Pueblo Occupational History. Paper presented at the Jornada Mogollon Conference VIII, Tularosa, New Mexico.

O'Neill, Patrick L.

1993 Appendix J: Archival Documentation. In Historic and Prehistoric Data Recovery at Palo Duro Reservoir, Hansford County, Texas, by J. Michael Quigg, Christopher Lintz, Amy C. Earls, Charles D. Frederick, W. Nicholas Trierweiler, Douglas Owsley, and Karl W. Kibler, pp. J1-J11. Technical Report No. 485. Mariah Associates, Inc., Austin.

Opler, Morris E.

1971 Pots, Apache, and the Dismal River Culture Aspect. In Apachean Culture History and Ethnology, edited by Keith H. Basso and Morris E. Opler, pp. 29-33. Anthropological Papers of the University of Arizona 21. Tucson.

1983 The Apachean Culture Pattern and Its Origins. In Handbook of North American Indians, Vol. 10: Southwest, edited by Alfonso
Ortiz, pp. 368-392. Smithsonian Institution, Washington, D.C.

Ostercamp, W. R.

1987 Groundwater-An Agent of Geomorphic Change. In Geomorphic Systems of North America, edited by W. L. Graf, pp. 188-195. Centennial Special Volume 2. Geological Society of America, Boulder, Colorado.

Owsley, Douglas W., Robert W. Mann, and Timothy G. Baugh

1994 Culturally Modified Human Bones from the Edwards I Site. In Skeletal Biology in the Great Plains: Migration, Warfare, Health, and Subsistence, edited by Douglas W. Owsley and Richard L. Jantz, pp. 363-375. Smithsonian Institution Press, Washington, D.C.

Parker, Wayne

1979 Mackenzie's Supply Camp. Grain Producer's News 30(7):40-47. (Also published in Central States Archeological Journal, October 1979, pp. 178-183).

1982 Archaeology at the Bridwell Site. Crosby County Pioneer Memorial Museum, Crosbyton, Texas.

1990 The Bridwell Site (41CB27). Transactions of the 25th Regional Archeological Symposium for Southeastern New Mexico and Western Texas, pp. 99-114.

Parker, W. B.

1984 Notes Taken during the Expedition Commanded by Capt. R. B. Marcy, U.S.A., through Unexplored Texas, in the Summer of 1854. Texas State Historical Association, Austin.

Parry, William J., and John D. Speth

1984 The Garnsey Spring Campsite: Late Prehistoric Occupation in Southwestern New Mexico. Technical Reports No. 15. Museum of Anthropology, University of Michigan, Ann Arbor.

Parsons, Mark L.

1967 Archeological Investigations in Crosby and Dickens Counties, Texas, during the Winter, 1966-1967. Archeological Program Report 7. State Building Commission, Austin.

1987 Plains Indian Portable Art as a Key to Two Texas Historic Rock Art Sites. Plains Anthropologist 32(117):257-274. 
Parsons, M. L., Ronnie Hill, and Wayne Parker

1979 The Old Tom Burial. Bulletin of the Texas Archeological Society 50:69-87.

Pearce, William M.

1936 A Survey of the Sand-Hill Camp Sites of Lamb and Bailey Counties. Bulletin of the Texas Archeological and Paleontological Society 8:184-186.

Pearson, Emerson L.

1974 Soil Characteristics of an Archeological Deposit: Randall County, Texas. Bulletin of the Texas Archeological Society 45:151-189.

Peck, Jay, Steve A. Tomka, and Karl W. Kibler

1994a The Cat Hollow Site, 41GR303B. In Data Recovery at Lake Alan Henry (Justiceburg Reservoir), Garza and Kent Counties, Texas: Phase III, Season 3, by Douglas K. Boyd, Jay Peck, Steve A. Tomka, Karl W. Kibler, and Martha Doty Freeman, pp. 129-164. Reports of Investigations No. 93. Prewitt and Associates, Inc., Austin.

1994b Boren Shelter \#2, 41GR559. In Data Recovery at Lake Alan Henry (Justiceburg Reservoir), Garza and Kent Counties, Texas: Phase III, Season 3, by Douglas K. Boyd, Jay Peck, Steve A. Tomka, Karl W. Kibler, and Martha Doty Freeman, pp. 213-246. Reports of Investigations No. 93. Prewitt and Associates, Inc., Austin.

Pennington, Campbell W.

1963 The Tarahumar of Mexico. University of Utah Press, Salt Lake City.

Perino, Gregory

1968 Guide to the Identification of Certain American Indian Projectile Points. Special Bulletin No. 3. Oklahoma Anthropological Society, Norman.

Perry, Richard J.

1980 The Apachean Transition from the Subarctic to the Southwest. Plains Anthropologist 25(90):279-296.

1991 Western Apache Heritage: People of the Mountain Corridor. University of Texas Press, Austin.

Perttula, Timothy $\mathrm{K}$.

1992 The Caddo Nation: Archaeological and Ethnohistoric Perspectives. University of Texas Press, Austin.
Perttula, Timothy K., and James E. Bruseth

1983 Early Caddoan Subsistence Strategies, Sabine River Basin, East Texas. Plains Anthropologist 28(99):9-21.

Perttula, Timothy K., and Christopher Lintz

1995 Prehistoric and Protohistoric Ceramics from the Lower Plains, Caprock Canyonlands, and Texas Panhandle. In Prehistoric and Historic Aboriginal Ceramics in Texas, edited by Timothy K. Perttula, pp. 203-210. Bulletin of the Texas Archeological Society 66:176235.

Peterson, John Allen

1988 Prairie Hinterland: The Archaeology of Palo Duro Creek-A Cultural Resources Inventory. Archaeological Research, Inc., Austin.

Phelps, Alan L.

1964 Cultural Analyzation of Prehistoric Indian Sites of Northern Chihuahua, Mexico. Special Report No. 2. El Paso Archeological Society.

1968 An Incised Pendant and a Soto Projectile Point from Northwestern Chihuahua. The Artifact 6(3):16-22. El Paso Archeological Society.

1987 Soto: A Distinctive Projectile Point Type. The Artifact 25(4):7-22. El Paso Archeological Society.

Phillips, John Wesley

1985 Excavated Sites Near Lake Meredith. Publication No. 2. Panhandle Archeological Society, Amarillo.

Pope, Leon

1991 The Hogue Site (41TY2). Transactions of the 27th Regional Archeological Symposium for Southeastern New Mexico and Western Texas, pp. 4-8.

Pope, Leon, and Eileen Johnson

1993 Archaeological Survey of the City of Brownfield Proposed Landfill Location for Tarry County, Texas. Museum of Texas Tech University, Lubbock.

Portis, John, Fern Portis, Pat Bills, and Nelda Bills

1968 A Surface Site in Scurry County (41-S.C.). Transactions of the Fourth Regional Archeological Symposium for Southeastern New Mexico and Western Texas, pp. 60-64. 
Pough, Frederick $\mathrm{H}$.

1960 A Field Guide to Rocks and Minerals. The Peterson Field Guide Series. Houghton Mifflin Company, Boston.

Prewitt, Elton R.

1981 Cultural Chronology in Central Texas. Bulletin of the Texas Archeological Society 52: 65-89.

1983 Remote Sensing of Archeological Remains in the Stockton Plateau Region of Texas: An Experiment in Site Recognition and Prediction. Unpublished Master's thesis, Department of Geography, The University of Texas at Austin.

1985 From Circleville to Toyah: Comments on Central Texas Chronology. Bulletin of the Texas Archeological Society 54:201-238.

1995 Distributions of Typed Projectile Points in Texas. Bulletin of the Texas Archeological Society 66:83-173.

Prewitt, Elton R., and Roger Filson

1978 An Assessment of Archeological Resources to be Affected by Floodwater Retarding Structure 6A, Southwest Laterals of the Colorado River, McCulloch County, Texas. Technical Bulletin No. 21. Texas Archeological Survey, The University of Texas at Austin.

Prikryl, Daniel J.

1990 Lower Elm Fork Prehistory: A Redefinition of Concepts and Chronologies along the Trinity River, North-Central Texas. Office of the State Archeologist Report 37. Texas Historical Commission, Austin.

Quigg, J. Michael

1997a Bison Processing at the Rusk Site, 41TG346, and Evidence for Pemmican Production in the Southern Plains. Plains Anthropologist 42(159):145-161.

1997b The Sanders Site (41HF128): A Single Event Late Archaic Camp/Bison Processing Site, Hansford County, Texas. Technical Report No. 19751. TRC Mariah Associates, Inc., Austin.

Quigg, Michael J., and John H. Brumley

1984 Stone Circles: A Review Appraisal and Future Directions. Division of Archeology and Historic Preservation, State Historical Society of North Dakota, Bismark.

Quigg, Mike, Charles Frederick, and Christopher Lintz 1993 Archaeological and Geomorphic Investigations at Red Lake Dam Axis, Borrow Area, and Spillway, Martin County, Texas. Technical Report No. 873. Mariah Associates, Inc., Austin.

1994 Sulphur Springs Draw: Geoarchaeological and Archaeological Investigations at Sulphur Draw Reservoir, Martin County, Texas. Technical Report No. 776. Mariah Associates, Inc., Austin.

Quigg, J. Michael, Christopher Lintz, Fred M. Oglesby, Amy C. Earls, Charles D. Frederick, W. Nicholas Trierweiler, Douglas Owsley, and Karl W. Kibler

1993 Historic and Prehistoric Data Recovery at Palo Duro Reservoir, Hansford County, Texas. Technical Report No. 485. Mariah Associates, Inc., Austin.

Quigg, J. Michael, Christopher Lintz, Fred M. Oglesby, and Abby C. Treese

1993 The Testing Phase at Mitchell Reservoir, Mitchell County, Texas. Technical Report No. 820. Mariah Associates, Inc., Austin.

Quigg, J. Michael, and Jay Peck

1995 The Rush Site (4ITG346): A Stratified Late Prehistoric Locale in Tom Green County, Texas. Technical Report No. 816C. Mariah Associates, Inc., Austin.

Quinn, Jean, and Jane Holden

1949 Caves and Shelters in Dawson and Borden Counties. Bulletin of the Texas Archeological and Paleontological Society 20:115-131.

Raisz, Erwin

1957 Landforms of the United States. Map, 6th rev. ed., to accompany Atwood's "Physiographic Provinces of North America."

Randall, Mark E.

1970 The Archeology of the Lamb County, Texas, Area. Lower Plains Archeological Society Bulletin 1:43-53.

Rathjen, Frederick W.

1973 The Texas Panhandle Frontier. University of Texas Press, Austin. 
Ray, Cyrus N.

1929 A Differentiation of the Prehistoric Cultures of the Abilene Section. Bulletin of the Texas Archeological and Paleontological Society 7:70-88.

1932 Archeological Research in Central West Texas. Bulletin of the Texas Archeological and Paleontological Society 4:63-70.

1933 Multiple Burials in Stone Cist Mounds of the Abilene Region. Bulletin of the Texas Archeological and Paleontological Society 5:14-24, 32 (Plate 8).

1936 Some Unusual Cremated Burials Found near Colorado, Texas. Bulletin of the Texas Archeological and Paleontological Society 8:9-16.

1941 The Various Types of the Clear Fork Gouge. Bulletin of the Texas Archeological and Paleontological Society 13:152-162.

1946 Two Buried Multiple Stone Cist Structures. Bulletin of the Texas Archeological and Paleontological Society 17:104-107.

Raymer, Leslie E.

1988 The Form and Function of Subterranean Food Storage Structures: A Cross-Cultural Study of the Conditions Affecting Pit Storage in the Ethnographic Records. Paper presented at the symposium "The Economics of Storage: Developing an Interpretive Framework for Archaeology" at the 53rd Annual Meeting of the Society for American Archaeology, Phoenix, Arizona.

Redding, John, and Wayne Parker

1991 Crosby County Lunate Stone Burial. Bulletin of the Texas Archeological Society 60:217239.

Reese-Taylor, Kathryn

1993 Petrographic Analysis. In Historic and Prehistoric Data Recovery at Palo Duro Reservoir, Hansford County, Texas, by J. Michael Quigg, Christopher Lintz, Fred M. Oglesby, Amy C. Earls, Charles D. Frederick, W. Nicholas Trierweiler, Douglas Owsley, and Karl W. Kibler, pp. H1-H13. Technical Report No. 485. Mariah Associates, Inc., Austin.
Reeves, C. C., Jr.

1965 Pleistocene Climate of the Llano Estacado. Journal of Geology 73:181-189.

1976 Quaternary Stratigraphy and Geologic History of the Southern High Plains, Texas and New Mexico. In Quaternary Stratigraphy of North America, edited by W. C. Mahaney, pp. 213-234. Dowden, Hutchinson, and Ross, Stroudsburg, Pennsylvania.

1990 A Proposed Sequential Development of Lake Basins, Southern High Plains, Texas and New Mexico. In Geologic Framework and Regional Hydrology: Upper Cenozoic Blackwater Draw and Ogallala Formations, Great Plains, edited by Thomas C. Gustavson, pp. 209-232. Bureau of Economic Geology, The University of Texas at Austin.

Renfro, H. B.

1973 Geological Highway Map of Texas. United States Geological Highway Map Series, Map No. 7. American Association of Petroleum Geologists, Tulsa.

Rhodes, Diane Lee

1992 Coronado's American Legacy: An Overview of Possible Entrada Artifacts and Site Types, and a Discussion of Texas Sites. Bulletin of the Texas Archeological Society 63:27-51.

Richter, Bernd C., and Charles W. Kreitler

1986 Geochemistry of Salt-Spring and Shallow Subsurface Brines in the Rolling Plains of Texas and Southwestern Oklahoma. Reports of Investigations No. 155. Bureau of Economic Geology, The University of Texas at Austin.

Riemenschneider, Larry

1994a 1888 Gulf, Colorado, \& Santa Fe Railway Roundhouse (41TH311). The Cache: Collected Papers of Texas Archeology 2:11-16.

1994b A Fire Pit in Sterling County, Texas. The Cache: Collected Papers of Texas Archeology 2:27-32.

1994c An Historic Earthen Dwelling, Tom Green County, Texas. The Cache: Collected Papers of Texas Archeology 2:81-87.

1996 The Davis Hackberry Spring Site (41ST87), 
Sterling County, Texas. The Cache: Collected Papers of Texas Archeology 3:13-26.

Riggs, Aaron D., Jr.

1965a Petroglyphs of Garza County, Texas. Transactions of the First Regional Archeological Symposium for Southeastern New Mexico and Western Texas, pp. 9-14.

1965b LY-4: A Surface Site of the South Plains. Bulletin of the South Plains Archaeological Society 2:1-35.

1966 The Reed Shelter: A Petroglyph Site in Garza County, Texas. Transactions of the Second Archeological Symposium for Southeastern New Mexico and Western Texas, pp. 44-58.

1968 Comments on a Hearth. South Plains Archeological Society Newsbulletin 16:2-3.

1969 Yellowhouse Crossing Mesa Petroglyphs. Transactions of the Fifth Regional Archeological Symposium for Southeastern New Mexico and Western Texas, pp. 25-33.

1971 The Walker Site: A Food Preparation Area in Coke County, Texas (41CK137). Transactions of the Sixth Regional Archeological Symposium for Southeastern New Mexico and Western Texas, pp. 39-48.

1982 41SC3: A Historic Pictograph Site in Scurry Co., Texas. Transactions of the 17th Regional Archeological Symposium for Southeastern New Mexico and Western Texas, pp. 165-166.

Roberts, Frank H. H., Jr.

1942 Archeological and Geological Investigations in the San Jon District, Eastern New Mexico. Smithsonian Miscellaneous Collections 103(4):1-30.

Robinson, David G.

1992 Appendix F: Petrographic Analysis of Nonlocal Plainwares. In Data Recovery at Justiceburg Reservoir (Lake Alan Henry), Garza and Kent Counties, Texas: Phase III, Season 1, by Douglas K. Boyd, Steve A. Tomka, C. Britt Bousman, Karen M. Gardner, and Martha Doty Freeman, pp. 221-227. Reports of Investigations No. 84. Prewitt and Associates, Inc., Austin.

1994 Appendix G: Petrographic Analysis of Plain- wares from 41GR291. In Data Recovery at Lake Alan Henry (Justiceburg Reservoir), Garza and Kent Counties, Texas: Phase III, Season 3, by Douglas K. Boyd, Steve A. Tomka, Karl W. Kibler, and Martha Doty Freeman, pp. 355-361. Reports of Investigations No. 93. Prewitt and Associates, Inc., Austin.

Roe, Frank Gilbert

1972 The North American Buffalo: A Critical Study of the Species in its Wild State. 2nd ed. David \& Charles (Publishers) Limited, Newton Abbot, England.

Roney, John R.

1985 Projectile Points as Chronological Markers in the Guadalupe Mountains, Southeastern New Mexico. In Views of the Jornada Mogollon: Proceedings of the Second Jornada Mogollon Archaeology Conference, edited by Colleen M. Beck, pp. 5-29. Contributions in Anthropology 12. Llano Estacado Center for Advanced Professional Studies and Research, Eastern New Mexico University, Portales.

Roper, Donna C.

1991 John Dunbar's Journal of the 1834-5 Chawi Winter Hunt and Its Implications for Pawnee Archaeology. Plains Anthropologist 36(136): 193-214.

Rowell, Chester Morrison

1967 Vascular Plants of the Texas Panhandle and South Plains. Unpublished Ph.D. dissertation, Oklahoma State University, Stillwater.

Runkles, Frank A.

1964 The Garza Site: A Neo-American Campsite near Post, Texas. Bulletin of the Texas Archeological Society 35:101-125.

Runkles, Frank A. (editor)

1962 Perdiz Points Found on the South Plains of Texas. South Plains Archeological Society Newsletter 4.

Runkles, Frank A., and E. D. Dorchester

1987 The Lott Site (41GR56): A Late Prehistoric Site in Garza County, Texas. Bulletin of the Texas Archeological Society 57:83-115.

Runyan, John W.

1972 The Laguna Plata Site: LCAS-C10-C, LA 5148. Transactions of the Seventh Regional Archaeological Symposium for Southeastern New Mexico and Western Texas, pp. 101-114. 
Runyan, John W., and John A. Hedrick

1987 Pottery Types of the Southwest Federation of Archaeological Societies (SWFAS) Area. The Artifact 25(4):23-59. El Paso Archeological Society.

Russell, G. S.

1981 Preliminary Hydration Rates for the Polvadera Peak and Jemez Mountains Obsidian Sources. In Obsidian Dates III: A Compendium of the Obsidian Hydration Determinations Made at the UCLA Obsidian Hydration Laboratory, edited by C. V. Meigham and G. S. Russell. Monograph XVI. Institute of Archaeology, University of California at Los Angeles.

Salinas, Martín

1990 Indians of the Rio Grande Delta: Their Role in the History of Southern Texas and Northeastern Mexico. University of Texas Press, Austin.

Sappington, Robert Lee

1982 X-Ray Fluorescence Analysis of Obsidian Artifacts from Two Sites in the Texas Panhandle. Appendix B in Inter-Societal Food Acquisition Among Egalitarian Societies: An Ecological Study of Plains/Pueblo Interaction in the American Southwest, by Katherine Ann Spielmann, pp. 369-379. Unpublished Ph.D. dissertation, Department of Anthropology, University of Michigan, Ann Arbor.

Sauer, Carl Ortwin

1934 The Distribution of Aboriginal Tribes and Languages of Northwestern Mexico. IberoAmericana 5. University of California Press, Berkeley.

1971 Sixteenth Century North America: The Land and People as Seen by the Europeans. University of California Press, Berkeley.

Saunders, Joe W., C. S. Mueller-Wille, and David L. Carlson (editors)

1992 An Archeological Survey of the Proposed South Bend Reservoir Area: Young, Stephens, and Throckmorton Counties, Texas. Archeological Surveys No. 6. Archeological Research Laboratory, Texas A\&M University, College Station.

Saunders, Roger S.

1978 Archeological Resources of Black Mesa State Park, Cimarron County, Oklahoma. Archeological Resource Survey Report 7. Oklahoma Archeological Survey, Norman.
1983 The Carrizozo Bridge Site: A Plains Woodland Site on the Oklahoma/New Mexico Border. Papers in Highway Archaeology 7. Oklahoma Department of Transportation, Oklahoma City.

Sayles, E. B.

1930 A Rock Shelter in Coke County, Texas. Bulletin of the Texas Archeological and Paleontological Society 2:40.

1935 An Archaeological Survey of Texas. Medallion Papers 17. Gila Pueblo, Globe, Arizona.

Schaafsma, Curtis

1981 Early Apacheans in the Southwest: A Review. In Protohistoric Period in the American Southwest, A.D. 1450-1700, edited by David R. Wilcox and W. Bruce Masse, pp. 291-320. Anthropological Research Papers No. 24. Arizona State University, Tempe.

Schaafsma, Polly

1980 Indian Rock Art of the Southwest. School of American Research, University of New Mexico Press, Albuquerque.

1985 Form, Content, and Function: Theory and Method in North American Rock Art Studies. In Advances in Archaeological Method and Theory, vol. 8, edited by Michael B. Schiffer, pp. 237-277. Academic Press, Inc., New York.

1992 Rock Art in New Mexico. Museum of New Mexico Press, Santa Fe.

Schambach, Frank

1993 Spiroan Entrepots at and beyond the Western Border of the Trans-Mississippi South. Caddoan Archeology Newsletter 4(2):11-26.

Schiffer, M. B.

1975 The Effects of Occupation Span on Site Content. In The Cache River Project, edited by M. B. Schiffer and J. House, pp. 265269. Arkansas Archeological Survey, Fayetteville.

Schlanger, Sarah H.

1990 Artifact Assemblage Composition and Site Occupation Duration. In Perspectives on Southwestern Prehistory, edited by Paul E. Minnis and C. L. Redman, pp. 103-121. Westview Press, Boulder, Colorado.

1991 On Manos, Metates, and the History of Site 
Occupations. American Antiquity 56(3):460474.

Schlesier, Karl H.

1972 Rethinking the Dismal River Aspect and the Plains Athapaskans, A.D. 1692-1768. Plains Anthropologist 17(56):101-133.

Scholes, France V., and H. P. Mera

1940 Some Aspects of the Jumano Problem. In Contributions to American Anthropology and History 34, Carnegie Institution of Washington Publication 523, pp. 265-299. Washington, D.C.

Schroeder, Albert H.

1962 A Re-Analysis of the Routes of Coronado and Onate into the Plains in 1541 and 1601. Plains Anthropologist 7(15):2-23.

Schroeder, Eric A., and B. F. Rader

1995a Archeological Survey Report of the Texas Department of Criminal Justice Lubbock Facility, Lubbock County, Texas. Horizon Environmental Services, Inc., Austin.

1995b Archeological Survey Report of the Texas Department of Criminal Justice Amarillo Facility. Horizon Environmental Services, Inc., Austin.

1995c Archeological Survey Report of the Texas Department of Criminal Justice Plainview Facility. Horizon Environmental Services, Inc., Austin.

Schultz, Gerald E., and Viola M. Rawn

1978 Faunal Remains from the Deadman's Shelter Site. In Archeology at Mackenzie Reservoir by Jack T. Hughes and Patrick S. Willey, pp. 191-204. Archeological Survey Report No. 24. Office of the State Archeologist, Texas Historical Commission, Austin.

Scott, Douglas D., Richard A. Fox Jr., Melissa A. Connor, and Dick Harmon

1989 Archaeological Perspectives on the Battle of the Little Bighorn. University of Oklahoma Press, Norman.

Scudday, James F., and La Ferne Scudday

1975 A Preliminary Survey of the Vertebrate Fauna of the Upper Canadian Breaks Area. In Canadian River Breaks: A Natural Survey, Part VII of VIII, pp. 69-67. Division of Natural Resources and Environment, The University of Texas at Austin.
Seaman, Timothy J.

1984 Mackenzie Supply Camp (41CB1). National Register of Historic Places InventoryNomination Form. On file, Texas Historical Commission, Austin.

Secoy, Frank

1953 Changing Military Patterns on the Great Plains. Monographs of the American Ethnological Society, No. 21. University of Washington Press, Seattle.

Shaeffer, James B.

1965 Salvage Archaeology in Oklahoma, Volume I, Papers of the Oklahoma Archaeological Salvage Project, Numbers 8 to 15. Bulletin of the Oklahoma Anthropological Society 13:77-151.

Shafer, Harry J.

1967 An Archeological Survey of Robert Lee Reservoir, Coke County, Texas. Texas Archeological Salvage Project Survey Reports No. 4. The University of Texas at Austin.

1969 Archeological Investigations in the Robert Lee Reservoir Basin, West Central Texas. Papers of the Texas Archeological Salvage Project No. 17. The University of Texas at Austin.

1971 Investigations into South Plains Prehistory, West Central Texas: Salvage Archeology in the Robert Lee Reservoir District. Papers of the Texas Archeological Salvage Project No. 20. The University of Texas at Austin.

1977 Late Prehistory of Central Texas. Bulletin of the South Plains Archeological Society $3: 18-27$.

Shaffer, Brian S.

1993 Appendix G: Analysis of the Vertebrate Faunal Remains. In Data Recovery at Justiceburg Reservoir (Lake Alan Henry), Garza and Kent Counties, Texas: Phase III, Season 2, by Douglas K. Boyd, Jay Peck, Steve A. Tomka, and Karl W. Kibler, pp. 403-417. Reports of Investigations No. 88. Prewitt and Associates, Inc., Austin.

1994 Appendix C: Analysis of the Vertebrate Remains from 41GR291, 41GR303B, 41GR474, and 41GR559. In Data Recovery at Lake Alan Henry (Justiceburg Reservoir), Garza and Kent Counties, Texas: Phase III, Season 3, by Douglas K. Boyd, Jay Peck, 
Steve A. Tomka, Karl W. Kibler, and Martha Doty Freeman, pp. 307-322. Reports of Investigations No. 93. Prewitt and Associates, Inc., Austin.

Shafter, William R.

1933 Shafter's Explorations in Western Texas, 1875. West Texas Historical Association Yearbook 9:82-96.

Shawn, Ronnie

1975 The Bull Hill Site Excavation. Transactions of the Tenth Regional Archeological Symposium for Southeastern New Mexico and Western Texas, pp. 1-47.

Shedd, Emmett

1988 Telephone conversation with Emmett Shedd, September 29, 1988, Post, Texas, by Martha Doty Freeman.

Sheehan, Michael S.

1994 Cultural Responses to the Altithermal: The Role of Aquifer-Related Water Resources. Geoarchaeology: An International Journal 9(2):113-137.

Sheffy, L. F.

1938 Letters and Reminiscences of Gen. Theodore A. Baldwin: Socuting [sic] After Indians on the Plains of West Texas. Panhandle-Plains Historical Review 11:7-30.

Shiner, Joel L.

1975 The Clear Fork Gouge Revisited. Bulletin of the Texas Archeological Society 46:179-188.

Shott, Michael J.

1989 Diversity, Organization, and Behavior in the Material Record. Current Anthropology 30(3):283-315.

1990 Stone Tools and Economics: Great Lakes PaleoIndian Examples. In Early PaleoIndian Economies of Eastern North America, edited by K. B. Tankersley and B. L. Isaac, pp. 3-43. Research in Economic Anthropology, Supplement 4, B. L. Isaac, general editor. JAI Press, Inc., Greenwich.

Sikes, Samuel, and Jackie Smith

1975 A Vegetational Study of the Canadian River Breaks. In Canadian River Breaks: A Natural Survey, Part VII of VIII, pp. 46-58. Division of Natural Resources and Environment, The University of Texas at Austin.
Simpkins, William W., and Thomas C. Gustavson 1987 Erosion Rates and Processes in Subhumid and Semiarid Climates, Texas Panhandle: Statistical Evaluation of Field Data. Reports of Investigations No. 162. Bureau of Economic Geology, The University of Texas at Austin.

Skeels, Lydia Lowndes Maury

1972 An Ethnohistorical Survey of Texas Indians. Archeological Report No. 22. Texas Historical Survey Committee, Office of the State Archeologist, Texas Historical Commission, Austin.

Skinner, S. Alan

1975 Goals for the 1975 TAS Field School. Texas Archeology 19(2):3-5.

Smart, Tristine Lee

1982 Appendix E: Preliminary Report on the Plant Macro-Remains from the Tierra Blanca Site, Deaf Smith County, Texas. In Inter-Societal Food Acquisition Among Egalitarian Societies: An Ecological Study of Plains/Pueblo Interaction in the American Southwest, by Katherine Ann Spielmann, pp. 403-423. Unpublished Ph.D. dissertation, Department of Anthropology, University of Michigan, Ann Arbor.

Smith, Calvin, John Runyan, and George Agogino 1966 A Progress Report on a Pre-Ceramic Site at Rattlesnake Draw, Eastern New Mexico. Plains Anthropologist 11:302-313.

Snow, David H.

1982 The Rio Grande Glaze, Matte-Paint, and Plainware Tradition. In Southwestern Ceramics: A Comparative Review, edited by Albert H. Schroeder, pp. 235-278. The Arizona Archeologist 15.

Snyder, Texas Unit of the Ranch Headquarters Association (Ranching Heritage Association) (compiler)

1986 Early Ranching in West Texas. BraunBrumfield, Inc., Ann Arbor, Michigan.

Sollberger, J. B.

1971 A Technological Study of Beveled Knives. Plains Anthropologist 16(53):209-218.

Sommer, Arnold E.

1971 Big Spring Site. Transactions of the Sixth Regional Archeological Symposium for Southeastern New Mexico and Western Texas, pp. 111-122. 
Sonnichsen, C. L.

1958 The Mescalero Apaches. University of Oklahoma Press, Norman.

South, Stanley

1977 Method and Theory in Historical Archeology. Academic Press, New York.

Speth, John D.

1983 Bison Kills and Bone Counts: Decision Making by Ancient Hunters. Prehistoric Archeology and Ecology Series, edited by Karl W. Butzer and Leslie G. Freeman. University of Chicago Press, Chicago.

1991 Some Unexplored Aspects of Mutualistic Plains-Pueblo Food Exchange. In Farmers, Hunters, and Colonists: Interaction between the Southwest and the Southern Plains, edited by Katherine A. Spielmann, pp. 18-35. University of Arizona Press, Tucson.

Speth, John D., and William J. Parry

1978 Late Prehistoric Bison Procurement in Southeastern New Mexico: The 1977 Season at the Garnsey Site. Technical Reports 8 and Research Reports in Archaeology Contribution 4. Museum of Anthropology, University of Michigan, Ann Arbor.

1980 Late Prehistoric Bison Procurement in Southeastern New Mexico: The 1978 Season at the Garnsey Site (LA-18399). Technical Report 12. Museum of Anthropology, University of Michigan, Ann Arbor.

Speth, John D. and Katherine A. Spielmann

1983 Energy Source, Protein Metabolism, and Hunter-Gatherer Subsistence Strategies. Journal of Anthropological Archaeology 2:1-31.

Spielmann, Katherine A.

1982 Inter-Societal Food Acquisition among Egalitarian Societies: An Ecological Analysis of Plains/Pueblo Interaction in the American Southwest. Unpublished Ph.D. dissertation, Department of Anthropology, University of Michigan, Ann Arbor.

1983 Late Prehistoric Exchange Between the Southwest and Southern Plains. Plains Anthropologist 28(102, Pt. 1):257-272.

1991 Cooercion or Cooperation? Plains-Pueblo Interaction in the Protohistoric Period. In
Farmers, Hunters, and Colonists: Interaction Between the Southwest and the Southern Plains, edited by Katherine A. Spielmann, pp. 36-50. University of Arizona Press, Tucson.

Spielmann, Katherine A. (editor)

1991 Farmers, Hunters, and Colonists: Interaction Between the Southwest and the Southern Plains. University of Arizona Press, Tucson.

Spivey, Towana, C. Reid Ferring, Daniel J. Crouch, and Kathy Franklin

1977 Archaeological Investigations Along the Waurika Pipeline, Comanche, Cotton, Jefferson, and Stephens Counties, Oklahoma. Contributions of the Museum of the Great Plains No. 5. Lawton, Oklahoma.

Staley, David P., and John A. Evaskovich

1993 A Cultural Resource Survey for Cap Rock Electric Cooperative Proposed Transmission Lines, Borden, Howard, Martin, and Midland Counties, Texas. Project 695. Mariah and Associates, Inc., Albuquerque.

Steely, James Wright

1984 A Catalog of Texas Properties in the $\mathrm{Na}$ tional Register of Historic Places. Texas Historical Commission, Austin.

Steiert, Jim

1995 Playas: Jewels of the Plains. Texas Tech University Press, Lubbock.

Stephenson, Robert L.

1949 Archeological Survey of San Angelo Reservoir, Tom Green County, Texas. River Basin Surveys, Smithsonian Institution, Washington, D.C.

1950 Archeological Survey of Hords Creek Reservoir, Coleman County, Texas. River Basin Surveys, Smithsonian Institution, Washington, D.C.

Stickney, Francis, and Teddy Stickney

1984 Crane County: Sites 41CR1, 41CR2, 41CR3, 41CR4, 41CR5, 41CR6, 41CR7, 41CR8, 41CR9. Transactions of the 19th Regional Archeological Symposium for Southeastern New Mexico and Western Texas, pp. 37-73.

Stuart, David E., and Rory P. Gauthier

1988 Prehistoric New Mexico: Background for Survey. University of New Mexico Press, Albuquerque. 
Studer, Floyd V.

1931 Archeological Survey of the North Panhandle of Texas. Bulletin of the Texas Archeological and Paleontological Society 3:73-75.

1955 Archeology of the Texas Panhandle. Panhandle-Plains Historical Review 28:87-95.

Stuiver, Minze, and Henry A. Polach

1977 Discussion: Reporting of ${ }^{14} \mathrm{C}$ Data. Radiocarbon 19(3):355-363.

Stuiver, Minze, and Paula J. Reimer

1986 A Computer Program for Radiocarbon Age Calibration. Radiocarbon 28(2B):1022-1030.

1993 Extended ${ }^{14} \mathrm{C}$ Data Base and Revised CALIB $3.0{ }^{14} \mathrm{C}$ Age Calibration Program. Radiocarbon 35(1):215-230.

Suhm, Dee Ann

1962 The White Site: An Historic Indian Burial in Yoakum County, Texas. Bulletin of the Texas Archeological Society 32:85-119.

Suhm, Dee Ann, and Edward B. Jelks

1962 Handbook of Texas Archeology: Type Descriptions. Texas Memorial Museum Bulletin No. 4. Austin.

Suhm, Dee Ann, Alex D. Krieger, and Edward B. Jelks 1954 An Introductory Handbook of Texas Archeology. Bulletin of the Texas Archeological Society 25 .

Swartz, B. K., Jr.

1981 Recording Standards for Petroglyphs and Pictographs. Journal of Field Archeology 8(1):118-119.

Swenson, F. E.

1983a Goodwin-Baker (34RM14): An Early Edwards Complex Site in the Southern Plains. Oklahoma Anthropological Society Newsletter 31(5):5-9.

1983b Preliminary Analysis of the Goodwin-Baker (34RM14) Site in Western Oklahoma. Paper presented at the 41st Annual Plains Conference, Rapid City, South Dakota.

Taylor, A. J.

1980 A Survey of New Mexican Pastores in the Texas Panhandle-Plains, 1876-1886. Privately prepared $\mathrm{ms}$. for the Texas Historical Foundation, Austin. 1995a The Dark Canyon Shelter and Rock Art Site 41BI530, PPHM-A2230. Paper presented at the 66th Texas Archeological Society Annual Meeting, Nacogdoches, Texas.

1995b Historic Southern Plains Indian Burials Curated at the Panhandle-Plains Historical Museum Archeology Laboratory. Ms. on file, Panhandle-Plains Historical Museum, Canyon.

Taylor, A. J., Caleb Curren, and Kenneth Breisch

1983 New Mexican Pastor Sites in the Texas Panhandle. National Register of Historic Places Inventory - Nomination Form. On file, Texas Historical Commission, Austin.

Taylor, James W.

1987 Oklahoma's Oldest Arrowpoint? Salvage of an Ancient Hearth at the Canyon Road Site (34CN46), Canadian County. Oklahoma Anthropological Society Newsletter 35(7):7-9.

Taylor, Walter W.

1966 Archaic Cultures Adjacent to the Northeastern Frontiers of Meso America. In Handbook of Middle American Indians, vol. 4, Robert Wauchope, general editor, pp. 59-94. University of Texas Press, Austin.

Texas Department of Water Resources

1984 Water for Texas: A Comprehensive Plan for the Future. Vol. I. Report GP-4-1. Texas Department of Water Resources, Austin.

Texas. General Land Office

1936 Garza County. File 58825. Abstract 928. H\&GN Railway Company Certificate No. 12/2415. Patented to T. E. Payne, Assignee, November 14, 1936.

1939 Garza County. File 59132. Abstract 903. H\&GN Railway Company Certificate No. 12/2412. Patented to Jeff Justice, Assignee, August 16, 1939.

Texas Highway Department

1941 Aerial Photo Series Taken October 17, 1941. Texas Highway Department, Highway Planning Survey, Garza County 86, Austin.

Thomas, Alfred B.

1940 The Plains Indians and New Mexico, 17511778: A Collection of Documents Illustrative of the History of the Eastern Frontier of New Mexico. University of New Mexico Press, Albuquerque. 
Thompson, Jerome L.

1987 Modern, Historic, and Fossil Flora. In Lubbock Lake: Late Quaternary Studies on the Southern High Plains, edited by Eileen Johnson, pp. 26-35. Texas A\&M University Press, College Station.

Thoms, Alston

1976 Review of Northeastern New Mexico Archaeology. Awanyu 4(1):8-36.

1979 Archeological Excavation of a Petroglyph Boulder at O. C. Fisher Lake, Tom Green County, Texas. Benham-Blair and Affiliates, Inc., Oklahoma City.

Thurmond, J. Peter

1988a The 1988 Society Field School: The Beaver Dam Site, 34RM208, Roger Mills County. Oklahoma Anthropological Society Newsletter $36(4): 2-5$.

1988b An Update on Investigations at the Beaver Dam Site (34RM208), Roger Mills County. Oklahoma Anthropological Society Newsletter 36(6):3-9.

1988c Update on the 1988 Fall Dig at 34RM208. Oklahoma Anthropological Society Newsletter 36(8):3.

1989 An Accelerator Mass Spectrometry Date from a "Late Archaic" Component in Roger Mills County, Oklahoma. Oklahoma Anthropological Society Newsletter 37(8):3-4.

1991a Archeology of the Dempsey Divide: A Late Archaic/Woodland Hotspot on the Southern Plains. Bulletin of the Oklahoma Anthropological Society 39:103-157.

1991b A Late Archaic/Woodland Lunate Stone Burial in Far Western Oklahoma. Bulletin of the Texas Archeological Society 60:241-255.

Thurmond, J. Peter, Martha Doty Freeman, and Susan L. Andrews

1981 A Preliminary Assessment of the Cultural Resources in the Brazos Natural Salt Pollution Control Project, Kent, King, and Stonewall Counties, Texas. Reports of Investigations No. 18. Prewitt and Associates, Inc., Austin.

Thurmond, J. Peter, and Michael C. Moore

1985 A Preliminary Report of an Archeological
Inventory of the Thurmond Ranch, Roger Mills County, Oklahoma. Oklahoma Anthropological Society Newsletter 33(5):10-12.

Toom, Dennis L.

1979 The Middle Missouri Villagers and the Early Fur Trade: Implications for Archeological Interpretation. Unpublished Master's thesis, Department of Anthropology, University of Nebraska, Lincoln.

Toomey, R. S., III

1993 Late Pleistocene and Holocene Faunal Changes at Hall's Cave, Kerr County, Texas. Unpublished Ph.D. dissertation, The University of Texas at Austin.

Toomey, R. S., III, M. D. Blum, and S. Valastro Jr.

1993 Late Quaternary Climates and Environments of the Edwards Plateau, Texas. Global and Planetary Change 7:299-320.

Torrence, Robin

1989 Re-Tooling: Towards a Behavioral Theory of Stone Tools. In Time, Energy and Stone Tools, edited by R. Torrence, pp. 57-66. Cambridge University Press, Cambridge.

Treece, Abby C., Christopher Lintz, W. Nicholas Trierweiler, J. Michael Quigg, and Kevin A. Miller

1993a Cultural Resource Investigations in the O. H. Ivie Reservoir, Concho, Coleman, and Runnels Counties, Texas. Volume III: Data Recovery Results from Non-Ceramic Sites. Technical Report No. 346-III. Mariah Associates, Inc., Austin.

1993b Cultural Resource Investigations in the O. H. Ivie Reservoir, Concho, Coleman, and Runnels Counties, Texas. Volume IV: Data Recovery Results from Ceramic Sites. Technical Report No. 346-IV. Mariah Associates, Inc., Austin.

Treece, Abby C., Fred M. Oglesby, Christopher Lintz, and William Doering

1992 A Cultural Resources Survey of the O. H. Ivie Reservoir to Midland Pipeline: Concho, Tom Green, Sterling, Glasscock, and Midland Counties, Texas. Mariah Associates, Inc., Austin.

Treece, Abby C., J. Michael Quigg, Kevin Miller, and Christopher Lintz

1993 Elm Creek Site, 41CN95. In Cultural 
Resource Investigations in the O. H. Ivie Reservoir, Concho, Coleman, and Runnels Counties, Texas. Volume IV: Data Recovery Results from Ceramic Sites, by Abby C. Treece, Christopher Lintz, W. Nicholas Trierweiler, J. Michael Quigg, and Kevin A. Miller, pp. 307-386. Technical Report No. 346-IV. Mariah Associates, Inc., Austin.

Tucker, Gordon, Jr., and John L. Montgomery

1992 A Cultural Resources Inventory of the Proposed East End Manifold Expansion Project: Yoakum, Gaines, Andrews, Winkler, Ward, and Reeves Counties, Texas. Report No. EP 90.2. Agency for Conservation Archeology, Llano Estacado Center for Advanced Professional Studies and Research, Eastern New Mexico University, Portales.

Tunnell, Curtis D.

1960 Appraisal of the Archeological Resources of Champion Creek Reservoir, Mitchell County, Texas. Texas Archeological Salvage Project, The University of Texas at Austin.

1964 Two Burials from the Jim Arnold Site in Northwest Texas. Bulletin of the Texas Archeological Society 35:83-93.

1978 The Gibson Lithic Cache from West Texas. Office of the State Archeologist Report No. 30. Texas Historical Commission, Austin.

1989 Versatility of a Late Prehistoric Flint Knapper: The Weaver-Ramage Chert Cache of the Texas Rolling Plains. In In Light of Past Experience: Papers in Honor of Jack T. Hughes, edited by Beryl Cain Roper, pp. 367-397. Publication No. 5. Panhandle Archeological Society, Amarillo.

Tunnell, Curtis D., and Jack T. Hughes

1955 An Archaic Bison Kill in the Texas Panhandle. Panhandle-Plains Historical Review 28:63-70.

Turner, Ellen Sue, and Thomas R. Hester

1993 A Field Guide to Stone Artifacts of Texas Indians. 2nd ed. Texas Monthly Press, Austin.

Turpin, Solveig A.

1989a The End of the Trail: An 1870s Plains Combat Autobiography in Southwest Texas. Plains Anthropologist 34(124, Pt. 1):105-110. 1989b The Iconography of Contact: Spanish Influences in the Rock Art of the Middle Rio Grande. In Columbian Consequences: Archeological and Historical Perspectives on the Spanish Borderlands West, edited by David Hurst Thomas, pp. 277-299. Smithsonian Institution Press, Washington, D.C.

Upshaw, Emily

1972 Palo Duro Rock Art: Indian Petroglyphs and Pictographs. Master's thesis, West Texas State University, Canyon.

Vehik, Susan C.

1984 The Woodland Occupations. In Prehistory of Oklahoma, edited by Robert E. Bell, pp. 175-197. Academic Press, Orlando.

1990 Late Prehistoric Plains Trade and Economic Specialization. Plains Anthropologist 35(128):125-145.

Verbicky-Todd, Eleanor

1984 Communal Buffalo Hunting Among the Plains Indians. Occasional Papers No. 24. Archaeological Survey of Alberta, Edmonton.

Vestal, Paul A., and Richard Evans Schultes

1939 The Economic Botany of the Kiowa Indians as it Relates to the History of the Tribe. Botanical Museum, Harvard University, Cambridge, Massachusetts.

Vierra, Bradley J.

1989 A Sixteenth-Century Spanish Campsite in the Tiguex Province. Museum of New Mexico, Laboratory of Anthropology Note 475. Santa $\mathrm{Fe}$.

1992 A Sixteenth-Century Spanish Campsite in the Tiguex Province: An Archaeologist's Perspective. In Current Research on the Late Prehistory and Early History of New Mexico, edited by Bradley J. Vierra, pp. 165-174. Special Publication No. 1. New Mexico Archaeological Council, Albuquerque.

Walker, Danny N.

1980 The Garnsey Site Canid. In Late Prehistoric Bison. Procurement in Southeastern New Mexico: The 1978 Season at the Garnsey Site (LA 18399), edited by John D: Speth and William J. Parry, pp. 344-369. Technical Reports No. 7, Research Reports in Archaeology Contribution 7. Museum of Anthropology, University of Michigan, Ann Arbor. 
Wallace, Ernest

1965 Ranald S. Mackenzie's Official Correspondence Relating to Texas, 1871-1873. The Museum Journal 9:entire volume.

1966 Ranald S. Mackenzie's Official Correspondence Relating to Texas, 1873-1879. The Museum Journal 10:entire volume.

Wallace, Ernest, and E. Adamson Hoebel

1952 The Comanches: Lords of the South Plains. University of Oklahoma Press, Norman.

Wallerstein, Immanuel

1974 The Modern World System: Capitalist Agriculture and the Origins of the European World-Economy in the Sixteenth Century. Academic Press, New York.

1979 The Rise and Future Demise of the World Capitalist System: Concepts for Comparative Analysis. In The Capitalist World-Economy, pp. 1-36. Cambridge University Press, Cambridge.

Wallis, Charles S., Jr.

1984 Summary of Notes and Earlier Analysis of the Wickham \#3 Site, 34RM29, Roger Mills County, Oklahoma. Bulletin of the Oklahoma Anthropological Society 32:1-23.

Walter, Richard W.

1992 Caprock Mesa Sites near the Eastern Escarpment of the Llano Estacado: A Preliminary Report. Ms. on file, Crosby County Pioneer Memorial Museum, Crosbyton, Texas.

n.d. A Preliminary Report on the Z-Bar-L Mesa Site (41CB32) and Comparisons with Other Isolated Mesa Sites near the Eastern Escarpment of the Llano Estacado. Unpublished $\mathrm{ms}$. in possession of the author.

Ward, Albert E., John D. Schelberg, and Jerold G. Widdison (editors)

1987 Archeological Investigations at Los Esteros Reservoir, Northeastern New Mexico. Center for Anthropological Studies, Albuquerque.

Ward, H. Trawick

1985 Social Implications of Storage and Disposal Patterns. In Structure and Process in Southeastern Archaeology, edited by Roy S. Dickens and H. Trawick Ward, pp. 82-101. University of Alabama Press, University.

Warnica, J. M.

1965 Archaic Sites in Eastern New Mexico.
Transactions of the First Regional Archeological Symposium for Southeastern New Mexico and Western Texas, pp. 3-8.

1966 New Discoveries at the Clovis Site. American Antiquity 31(3):Part I, 345-357.

Watts, W. C.

1939 Lake Sites of the South Plains of Texas. Bulletin of the Texas Archeological and Paleontological Society 11:77-91.

1963 Distribution of Pottery in Surface Sites on the South Plains of Texas. Bulletin of the South Plains Archeological Society 1:1-25.

Webb, Walter Prescott

1931 The Great Plains. Grosset and Dunlap, New York.

Webb, Walter Prescott (editor)

1952 The Handbook of Texas. Vols. I and II. Texas State Historical Association, Austin.

Webley, Lita

1990 The Use of Stone "Scrapers" by Semisedentary Pastoralist Groups in Namagualand, South Africa. South African Archaeological Bulletin 45:28-32.

Weddle, Robert S.

1964 The San Sabá Mission: Spanish Pivot in Texas. University of Texas Press, Austin.

Wedel, Waldo R.

1935 Reports on Fieldwork by the Archeological Survey of the Nebraska State Historical Society, May 1 through July 23, 1934. Nebraska History Magazine 15(2):158-226.

1959 An Introduction to Kansas Archeology. Bureau of American Ethnology Bulletin 174.

1961 Prehistoric Man on the Great Plains. University of Oklahoma Press, Norman.

1970a Antler Tine Scraper Handles in the Central Plains. Plains Anthropologist 15(47):36-45.

1970b Coronado's Route to Quivira 1541. Plains Anthropologist 15(49):161-168.

1975 Chalk Hollow: Culture Sequence and Chronology in the Texas Panhandle. Actas del XLI Congreso Internacional de Americanistas 1:271-278. Mexico, D.F. 
1986 Central Plains Prehistory: Holocene Environments and Culture Change in the Republican River Basin. University of Nebraska Press, Lincoln.

Welch, John R.

1991 From Horticulture to Agriculture in the Late Prehistory of the Grasshopper Region, Arizona. In Mogollon V, pp. 75-92. COAS Publishing, Las Cruces, New Mexico.

Wendorf, Fred (assembler)

1961 Paleoecology of the Llano Estacado. Fort Burgwin Research Center Publication No. 1. Ranchos de Taos, New Mexico. Southern Methodist University, Dallas.

Wendorf, Fred, and James J. Hester (editors)

1975 Late Pleistocene Environments of the Southern High Plains. Fort Burgwin Research Center Publication No. 9. Ranchos de Taos, New Mexico. Southern Methodist University, Dallas.

Whalen, Michael E.

1977 Settlement Patterns of the Eastern Hueco Bolson. Publications in Anthropology No. 4. El Paso Centennial Museum, The University of Texas at El Paso.

1978 Settlement Patterns of the Western Hueco Bolson. Publications in Anthropology No. 6. El Paso Centennial Museum, The University of Texas at El Paso.

1980a The Pithouse Periods of South-Central New Mexico. In An Archeological Synthesis of South-Central and Southwestern New Mexico, edited by Steven A. LeBlanc and Michael E. Whalen, pp. 318-386. Office of Contract Archaeology, University of New Mexico, Albuquerque.

1980b The Pueblo Periods of South-Central New Mexico. In An Archaeological Synthesis of South-Central and Southwestern New Mexico, edited by Steven A. LeBlanc and Michael E. Whalen, pp. 388-448. Office of Contract Archaeology, University of New Mexico, Albuquerque.

1981a Origin and Evolution of Ceramics in Western Texas. Bulletin of the Texas Archeological Society 52:215-229.

1981b Cultural-Ecological Aspects of the Pithouse to Pueblo Transition in a Portion of the South- west. American Antiquity 46(1):75-92.

Whalen, Michael E., and Patricia A. Gilman

1990 Introduction: Transitions to Sedentism. In Perspectives on Southwestern Prehistory, edited by Paul E. Minnis and Charles L. Redman, pp. 71-75. Westview Press, Boulder, Colorado.

Wheat, Joe Ben

1955 Two Archaeological Sites near Lubbock, Texas. Panhandle-Plains Review 28:71-77.

Whipple, Lieutenant A. W., Thomas Eubank, and William W. Turner

1856 Report upon the Indian Tribes. In Reports of Explorations and Surveys to Ascertain the Most Practicable and Economical Route for a Railroad from the Mississippi River to the Pacific Ocean. 33rd Congress, 2nd session, Senate Executive Document 78. Government Printing Office, Washington, D.C.

White, Ralph

1987 The Muncy Site in the Oklahoma Panhandle: Indian Cultural Evidence Over a Long Time Span. Bulletin of the Oklahoma Anthropological Society 36:39-103.

Wilcox, David R

1981 The Entry of Athapaskans into the American Southwest: The Problem Today. In The Protohistoric Period in the North American Southwest, edited by David R. Wilcox and W. Bruce Masse, pp. 213-257. Anthropological Research Papers No. 24. Arizona State University, Tempe.

1991 Changing Contexts of Pueblo Adaptations: A.D. 1250-1600. In Farmers, Hunters, and Colonists: Interaction between the Southwest and the Southern Plains, edited by Katherine A. Spielmann, pp. 128-154. University of Arizona Press, Tucson.

Willey, Patrick S.

1978 Human Skeletal Remains from the Deadman's Shelter Site. In Archeology at Mackenzie Reservoir, by Jack T. Hughes and Patrick S. Willey, pp. 198-204. Office of the State Archeologist Survey Report 24. Texas Historical Commission, Austin.

Willey, Patrick S., Billy R. Harrison, and Jack T. Hughes 1978a The Rex Rodgers Site. In Archeology at Mackenzie Reservoir, by Jack T. Hughes and Patrick S. Willey, pp. 51-68. Office of the 
State Archeologist Survey Report No. 24. Texas Historical Commission, Austin.

1978b The Blue Clay Site. In Archeology at Mackenzie Reservoir, edited by Jack T. Hughes and Patrick S. Willey, pp. 138-140. Office of the State Archeologist Survey Report No. 24. Texas Historical Commission, Austin.

Willey, Patrick S., and Jack T. Hughes

1978a The County Line Site. In Archeology at Mackenzie Reservoir, by Jack T. Hughes and Patrick S. Willey, pp. 115-137. Office of the State Archeologist Survey Report 24. Texas Historical Commission, Austin.

1978b The Deadman's Shelter Site. In Archeology at Mackenzie Reservoir, edited by Jack T. Hughes and Patrick S. Willey, pp. 149-190. Office of the State Archeologist Survey Report No. 24. Texas Historical Commission, Austin.

Willey, Gordon R., and Philip Phillips

1958 Method and Theory in American Archaeology. University of Chicago Press, Chicago.

Williams, Jerry L, and Paul E. McAllister

1979 New Mexico in Maps. Technology Application Center, University of New Mexico, Albuquerque.

Williams, Joe, and John W. Clark

1976 Post West Dugout (41GR189). National Register of Historic Places InventoryNomination Form. On file, Texas Historical Commission, Austin.

Willis, Lewis E.

1958 Archeological Survey of Twin Buttes Reservoir, Tom Green County, Texas. Ms. on file, West Texas Museum, Texas Tech University, Lubbock.

Wilson, G. L.

1924 The Horse and Dog in Hidatsa Culture. Anthropological Papers of the American Museum of Natural History 15, Part $2: 125-311$.

Wilson, Michael

1980 Population Dynamics of the Garnsey Site Bison. In Late Prehistoric Bison Procurement in Southeastern New Mexico: The 1978 Season at the Garnsey Site (LA-18399), by John D. Speth and William J. Parry, pp.
88-129. Technical Report No. 12. Museum of Anthropology, University of Michigan, Ann Arbor.

Winship, George P.

1896 The Coronado Expedition. In The Fourteenth Annual Report of the Bureau of Ethnology, Smithsonian Institution, 1892-1893, Part 1, pp. 329-613. Smithsonian Institution, Washington, D.C.

Winter, Joe

1988 Stone Circles, Ancient Forts, and Other Antiquities of the Dry Cimarron Valley: $A$ Study of the Cimarron Seco Indians. New Mexico Historic Preservation Program, Santa Fe.

Wiseman, Regge N.

1981 Further Investigations at the King Ranch Site, Chaves County, New Mexico. The Artifact 19(3 and 4):169-198. El Paso Archeological Society.

1988 The Continuing Saga of the King Ranch Site (LA 26764): Update and Summaries of Findings. In Fourth Jornada Mogollon Conference (Oct. 1985) Collected Papers, edited by Meliha S. Duran and Karl W. Laumbach, pp. 223-254. Human Systems Research, Inc., Tularosa, New Mexico.

Wiseman, R. N., D. V. Hill, and D. McIntosh

1994 The Llano Estacado Pottery Project. Paper presented at the 52nd Annual Plains Anthropological Conference and 65th Texas Archeological Society Annual Meeting, Lubbock, Texas.

Witte, Adolph Henry

1947 Certain Archaeological Notes on the High Plains of Texas. Bulletin of the Texas Archeological and Paleontological Society 18:76-82.

1955 A Double Indian Burial from Donley County, Texas. Panhandle-Plains Historical Review 28:82-86.

Wolley, Anne M., and Alan J. Osborn

1991 An Isolated Storage Vessel at Site 42 SA20779 in Glen Canyon National Recreation Area: Adaptive Storage and Caching Behavior in the Prehistoric Southwest. Occasional Studies in Anthropology No. 25. Midwest Archeological Center, National Park Service, Lincoln, Nebraska. 
Wood, Warren W., and Blair F. Jones

1990 Origin of Solutes in Saline Lakes and Springs on the Southern High Plains of Texas and New Mexico. In Geologic Framework and Regional Hydrology: Upper Cenozoic Blackwater Draw and Ogallala Formations, Great Plains, edited by Thomas C. Gustavson, pp. 193-208. Bureau of Economic Geology, The University of Texas at Austin.

Woodbury, Richard A., and Ezra B. W. Zubrow

1979 Agricultural Beginnings, 2000 B.C.-A.D. 500. In Southwest, edited by Alfonso Ortiz, pp. 43-60. Handbook of North American Indians, vol. 9, William C. Sturtevant, general editor. Smithsonian Institution, Washington, D.C.

Woody, J. W.

1926 Interview with J. W. Woody by J. Evetts Haley, October 19, 1926, Snyder, Texas. Typescript in the collections of the Panhandle-Plains Historical Museum, Canyon, Texas.

1928 Interview with J. W. Woody by J. Evetts Haley, February 11, 1926, Snyder, Texas. Typescript in the collections of the Panhandle-Plains Historical Museum, Canyon, Texas.

Wooldridge, H. G.

1981 A Cultural Resource Inventory and Assessment of the Proposed Stacy Reservoir, Concho, Coleman, and Runnels Counties, Texas. Volume I: Prehistoric Cultural Resources. Document No. 81052. Espey, Huston and Associates, Inc., Austin.

Worcester, Donald E.

1944 The Spread of Spanish Horses in the Southeast. New Mexico Historical Review 19: 225-232.

Word, James H.

1963 Floydada Country Club Site (41FL1). Bulletin of the South Plains Archeological Society $1: 37-63$.

1965 The Montgomery Site in Floyd County, Texas. Bulletin of the South Plains Archeological Society II:55-102.

1991a The 1975 Field School of the Texas Archeo- logical Society. Bulletin of the Texas Archeological Society 60:57-106.

1991b Portales Spring Site. Transactions of the 27th Regional Archeological Symposium for Southeastern New Mexico and Western Texas, pp. 49-61.

1994 Coronado's Route in the Texas Panhandle. Paper presented at the 52nd Annual Plains Anthropological Conference and 65th Texas Archeological Society Annual Meeting, Lubbock.

Word, James H., and Anne Fox

1975 The Cogdell Burial in Floyd County, Texas. Bulletin of the Texas Archeological Society 46:1-63.

Wozniak, Frank E.

1983 An Archeological Reconnaissance of Blackwater Draw, Silver Lake, Yellow Lake, Yellow House Draw, and Sulphur Draw in the Western Texas Panhandle for the Bravo Pipeline Company. Office of Contract Archeology, University of New Mexico.

Wulfkuhle, Virginia A.

1986 Investigations into the Prehistory of the Upper Clear Fork of the Brazos River, Fisher and Jones Counties, Texas. Unpublished Master's thesis, The University of Texas at Austin.

Wyckoff, Don G.

1963 Mangum Reservoir Archeological Survey, Greer and Harmon Counties, Oklahoma. General Survey Report No. 2. Oklahoma River Basin Survey Project.

1989 An Introductory Study of Alibates Gravel Occurrences Along Western Oklahoma's Canadian River. In In Light of Past Experience: Papers in Honor of Jack T. Hughes, edited by Beryl Cain Roper, pp. 405-452. Publication No. 5. Panhandle Archeological Society, Amarillo.

Young, Wayne C.

1978 Archaeological Testing in the Camp Creek Locale, Payne and Pawnee Counties, Oklahoma. Project Report Series No. 1. Archaeological Research and Management Center, Norman, Oklahoma. 

APPENDIX A: INVENTORY AND SUMMARY OF LAKE ALAN HENRY ARCHEOLOGICAL SITES 

This appendix presents three tables summarizing the archeological resources at Lake Alan Henry. Within the project area, 425 sites are documented within $4 \mathrm{~km}$ of the Double Mountain Fork of the Brazos in Garza $(n=358)$ and Kent $(n=67)$ Counties. Of these sites, 111 (26.1 percent) sites are located on the USGS Justiceburg 7.5' quadrangle; 312 (73.4 percent) sites are located on the Justiceburg, SE $7.5^{\prime}$ quadrangle; and 2 (0.5 percent) are located on the Flat Top Mountain 7.5' quadrangle. Tables 133 and 134 summarize the sites by the types of components that are present. The three principal types of components are defined as:

1. Prehistoric components are characterized by evidence of Native American occupations. As used here, the term Prehistoric encompasses occupations by Native Americans during the Protohistoric period.

2. Historic components are characterized by evidence of Euro-American occupations.

3. Rock Art components are characterized by rock faces containing either Native American or EuroAmerican images.

Table 135 presents an inventory and summary of site data for the 425 Lake Alan Henry archeological sites. Some of the terms used in Table 135 are defined below.

Topographic Setting refers to the landform where a site is located.

Prehistoric Site Type refers to various types of sites that were occupied/utilized by Native Americans (excluding rock art). These site types were defined based on survey-level evidence and do not include specialized site types (such as plant processing sites, residential bases, etc.) that were defined during testing or data recovery. Prehistoric site types are:

1. Isolated Find $(n=45)$ : One or two isolated artifacts that are not associated with anything else. More formally, isolated finds were defined as single surface artifacts or features with no potential for associated materials or features in buried contexts or surface sites with a density of artifacts less than one item in $20 \mathrm{~m}^{2}$.
TABLE 133

SUMMARY OF ARCHEOLOGICAL SITES

DOCUMENTED AT LAKE ALAN HENRY

\begin{tabular}{|l|r|r|}
\hline Site Components & $\begin{array}{c}\text { \# of } \\
\text { Sites }\end{array}$ & $\begin{array}{r}\text { \% of } \\
\text { Total }\end{array}$ \\
\hline Prehistoric components only & 318 & 74.8 \\
Historic components only & 19 & 4.5 \\
Rock Art components only & 71 & 16.7 \\
Prehistoric \& Historic components & 13 & 3.1 \\
Prehistoric \& Rock Art components & 4 & 0.9 \\
\hline Total: & 425 & 100.0 \\
\hline
\end{tabular}

TABLE 134

SUMMARY OF COMPONENTS DEFINED AT LAKE ALAN HENRY ARCHEOLOGICAL SITES

\begin{tabular}{|l|c|c|}
\hline & \# of & \\
Component Type & Components & \% of Total \\
\hline Prehistoric & 335 & 75.8 \\
Historic & 32 & 7.2 \\
Rock Art & 75 & 17.0 \\
\hline Total: & 442 & 100.0 \\
\hline
\end{tabular}

2. Lithic Scatter $(n=10)$ : Open locations similar to campsites but lacking evidence of any types of activities other than lithic reduction. Lithic scatters do not occur on natural gravel outcrops.

3. Faunal Locality $(n=10)$ : Locations that contain mammal bones but no definite cultural materials. Faunal localities were considered to be possible isolated kills or processing areas.

4. Rockshelter $(n=5)$ : Protected areas or overhangs in or beneath ledges of erosion-resistant sandstone rocks where evidence of human occupation was encountered (excluding rockshelters that contain rock art but no evidence of cultural occupations).

5. Lithic Procurement Area $(n=64)$ : Natural outcrops of Quaternary-age Lingos Formation gravels which exhibit evidence (primarily early stages of lithic reduction) of having been utilized as a lithic source area. 
6. Campsite $(\mathrm{n}=127)$ : Open sites where a variety of domestic activities took place. Late stages of lithic tool manufacture/maintenance are represented, and burned or fire-cracked rocks and other features are inferred as evidence of hearths, food preparation, and other activities.

7. Lithic Procurement Area/Campsite $(n=74)$ : Natural gravel outcrops with evidence of earlystage lithic reduction, accompanyied by evidence of food processing, late-stage lithic tool manufacture and maintenance, and other activities.

Historic Site Type refers to various types of sites that were occupied/utilized by Euro-Americans (excluding rock art). Historic site types are:

1. Homestead $(n=7)$ : A location where people homesteaded to legally obtain land from the State of Texas. A homestead may be a single dwelling or a complex of structures and features such as dugouts, houses or remnants of foundations, wells or cisterns, corrals, barns, etc.

2. Housesite $(n=5)$ : A location of a permanent dwelling (regardless of whether the house exists or is now gone).

3. Line Camp $(n=3)$ : A dwelling or shelter used temporarily by ranch hands who rode lines or checked fences along the edges of ranches. Dugouts are the most common type of structure at line camps.

4. Isolated Find $(n=1)$ : One or two historic artifacts that are not associated with anything else.

5. Trash Dump $(\mathrm{n}=10)$ : A location where people dumped household trash. These may be isolated locations or they may be associated with a particular ranch or homestead.

6. Cemetery $(\mathrm{n}=1)$ : A designated burial ground.

7. Railroad Complex $(n=1)$ : A group of buildings and structures related to the operation of railroad steam engines.

8. Campsite/Grave $(\mathrm{n}=1)$ : A buffalo hunters' camp and a related grave.
9. Rock Wall $(n=1)$ : An isolated wall of stacked rocks of unknown function, possibly built as a water diversion.

10. Unknown Structure $(n=1)$ : Remnant of a building of unknown function.

11. Campsite/Homestead $(n=1)$ : An area where people camped and later built a permanent dwelling for homesteading.

Rock Art Site Type refers to the types of rock art found at a site. Rock art, which includes all types of images made on rock faces, is classified by the group that produced it. Rock art site types are:

1. Native American $(n=20)$

2. Euro-American $(n=41)$

3. Native/Euro-American $(n=14)$

Level of Effort refers to the level of archeological investigations that have been conducted at a site. Levels of effort are:

I. Survey: The site is known only through surface reconnaissance and limited shovel testing.

II. Survey/Testing: In addition to survey documentation, the site has been subjected to morerigorous subsurface investigation (including backhoe trenching and hand-excavated test units) or detailed recording (such as for rock art sites).

III. Survey/Testing/Data Recovery: In addition to survey documentation and testing, the site has been subjected to full-scale data recovery (i.e., intensive excavations and/or documentation).

Report No. refers to the Prewitt and Associates, Inc., Reports of Investigations ${ }^{11}$ that contain information about a particular site.

\footnotetext{
${ }^{11}$ See the inside of the front cover for a listing of all Reports of Investigations relating to Lake Alan Henry. These reports also are listed in the References Cited section of the main body of this report.
} 
TABLE 135

INVENTORY AND SUMMARY OF LAKE ALAN HENRY ARCHEOLOGICAL SITES

\begin{tabular}{|c|c|c|c|c|c|c|c|c|c|}
\hline Site & Component & \begin{tabular}{|l|} 
Top \\
Elevation
\end{tabular} & \begin{tabular}{|l|} 
Bottom \\
Elevation
\end{tabular} & Topographic Selting & Prehistoric Site Type & Historic Site Type & Rock Art Site Type & \begin{tabular}{|l|} 
Level of \\
Effort
\end{tabular} & Report No. \\
\hline 41GR13 & prehistoric/historic & 2260 & 2240 & upland margin & lithic procurement area/campsite & homestead & & 1 & 66 \\
\hline 41GR31 & prehistoric & 2260 & 2240 & bedrock terrace & campsite & & & 1 & 66 \\
\hline 41GR33 & prehistoric/historic & 2260 & 2240 & upland margin & lithic procurement area/campsite & trash dump & & 1 & 66 \\
\hline 41GR51 & rock art & 2220 & 2200 & bluff & & & Native/European & 11 & $66 / 71$ \\
\hline 41GR54 & prehistoric/rock art & 2240 & & bluff shelter & rockshelter & & Native/European & 1 & 66 \\
\hline 41GR203 & prehistoric/historic & 2280 & 2240 & upland margin & campsite & housesite & & 1 & 66 \\
\hline 41GR204 & prehistoric & 2230 & & alluvial terrace & lithic procurement area/campsite & & & 1 & 66 \\
\hline 41GR205 & prehistoric & 2250 & & upland margin & campsite & & & 1 & 66 \\
\hline 41GR206 & prehistoric & 2230 & & upper alluvial terrace & lithic procurement area/campsite & & & 1 & 66 \\
\hline 41GR207 & prehistoric & 2300 & 2260 & upland margin & campsite & & & II & $66 / 71$ \\
\hline 41GR238 & rock art & 2250 & & bluff overhang & & & Native & 1 & 66 \\
\hline 41GR239 & prehistoric & 2340 & 2290 & upland margin & lithic procurement area/campsite & & & II & $66 / 71$ \\
\hline $41 G R 240$ & prehistoric & 2255 & & erosional remnant & campsite & & & 1 & 66 \\
\hline 41GR242 & rock art & 2280 & 2260 & bluff & & & European & 1 & 66 \\
\hline $41 \mathrm{GR} 243$ & prehistoric & 2280 & 2220 & upland margin & lithic procurement area/campsite & & & 1 & 66 \\
\hline $41 G R 244$ & rock art & 2250 & & bluff shelter & & & European & 1 & 66 \\
\hline $41 G R 246$ & prehistoric & 2170 & & upper alluvial terrace & campsite & & & 1 & 66 \\
\hline $41 G R 248$ & prehistoric & 2240 & & alluvial terrace & isolated find & & & 1 & 66 \\
\hline $41 \mathrm{GR} 249$ & prehistoric & 2210 & & alluvial terrace & faunal locality & & & II & $66 / 71$ \\
\hline $41 G R 250$ & prehistoric/historic & 2260 & 2240 & upper alluvial terrace & lithic procurement area/campsite & homestead & & 11 & $66 / 72$ \\
\hline 41GR251 & prehistoric & 2270 & 2240 & upper alluvial terrace & lithic procurement area & & & 1 & 66 \\
\hline 41GR253 & prehistoric & 2250 & & alluvial terrace & campsite & & & 1 & 66 \\
\hline 41GR254 & prehistoric & 2230 & & alluvial terrace & campsite & & & 1 & 66 \\
\hline $41 G R 255$ & prehistoric & 2250 & & upland margin & lithic procurement area & & & 1 & 66 \\
\hline $41 \mathrm{GR} 256$ & prehistoric & 2250 & & erosional remnant & campsite & & & 1 & 66 \\
\hline $41 \mathrm{GR} 257$ & prehistoric & 2260 & & upland margin & isolated find & & & 1 & 66 \\
\hline 41GR258 & prehistoric & 2270 & 2240 & bedrock terrace & campsite & & & 1 & 66 \\
\hline 41GR259 & prehistoric & 2270 & 2260 & upland margin & lithic procurement area & & & 1 & 66 \\
\hline $41 G R 260$ & prehistoric & 2250 & 2240 & upland margin & lithic procurement area & & & 1 & 66 \\
\hline 41GR261 & prehistoric & 2250 & 2230 & upland margin & lithic procurement area & & & 1 & 66 \\
\hline 41GR262 & prehistoric & 2240 & 2170 & upland margin & lithic procurement area & & & 1 & 66 \\
\hline 41GR263 & prehistoric/historic & 2270 & 2250 & upland margin & lithic procurement area/campsite & homestead & & 1 & 66 \\
\hline
\end{tabular}




\begin{tabular}{|c|c|c|c|c|c|c|c|c|c|}
\hline \multicolumn{10}{|c|}{ Table 135, continued } \\
\hline Site & Component & $\begin{array}{l}\text { Top } \\
\text { Elevation }\end{array}$ & $\begin{array}{l}\text { Bottom } \\
\text { Elevation }\end{array}$ & Topographic Selting & Prehistoric Site Type & Historic Site Type & Rock Art Site Type & \begin{tabular}{|l|} 
Level of \\
Effort
\end{tabular} & Report No. \\
\hline 41GR265 & prehistoric & 2265 & & upland margin & lithic procurement area & & & 1 & 66 \\
\hline 41GR266 & prehistoric & 2260 & 2240 & upland margin & lithic procurement area & & & 1 & 66 \\
\hline 41GR267 & prehistoric & 2270 & 2240 & upland margin & lithic procurement area & & & 1 & 66 \\
\hline $41 G R 268$ & prehistoric & 2260 & 2240 & upland margin & lithic procurement area/campsite & & & 1 & 66 \\
\hline 41GR269 & prehistoric & 2260 & 2250 & upland margin & lithic procurement area/campsite & & & 1 & 66 \\
\hline $41 \mathrm{GR} 270$ & prehistoric & 2200 & & upper alluvial terrace & faunal locality & & & II & $66 / 71$ \\
\hline 41GR271 & prehistoric & 2270 & 2240 & upland margin & lithic procurement area/campsite & & & 1 & 66 \\
\hline 41GR272 & prehistoric & 2260 & 2180 & upland margin & lithic procurement area/campsite & & & 1 & 66 \\
\hline 41GR273 & prehistoric/historic & 2250 & 2230 & upland margin & lithic procurement area/campsite & trash dump & & 1 & 66 \\
\hline 41GR274 & prehistoric & 2300 & 2220 & erosional remnant & lithic procurement area/campsite & & & 1 & 66 \\
\hline 41GR275 & prehistoric & 2305 & 2260 & upland margin & lithic procurement area/campsite & & & 1 & 66 \\
\hline 41GR276 & prehistoric & 2305 & 2280 & upland margin & lithic procurement area/campsite & & & 1 & 66 \\
\hline 41GR277 & prehistoric & 2250 & 2230 & alluvial terrace & campsite & & & 1 & 66 \\
\hline 41GR278 & prehistoric & 2110 & & bedrock terrace & isolated find & & & 1 & 66 \\
\hline 41GR279 & prehistoric & 2245 & & upland margin & isolated find & & & 1 & 66 \\
\hline $41 G R 280$ & prehistoric & 2240 & 2220 & upland margin & lithic procurement area & & & 1 & 66 \\
\hline 41GR281 & prehistoric & 2190 & & upper alluvial terrace & lithic procurement area & & & 1 & 66 \\
\hline 41GR282 & rock art & 2220 & & bluff overhang & & & Native & II & $66 / 71$ \\
\hline 41GR283 & rock art & 2250 & & bluff & & & European & 1 & 66 \\
\hline 41GR284 & rock art & 2240 & & bluff & & & European & 1 & 66 \\
\hline 41GR285 & rock art & 2220 & & bluff & & & European & 1 & 66 \\
\hline 41GR286 & prehistoric & 2270 & 2240 & upland margin & lithic procurement area/campsite & & & II & $66 / 71$ \\
\hline $41 \mathrm{GR} 287$ & prehistoric/historic & 2290 & 2280 & upland margin & campsite & trash dump & & II & $66 / 71$ \\
\hline 41GR288 & historic & 2280 & & upland margin & & trash dump & & 1 & 66 \\
\hline 41GR289 & historic & 2260 & & upland margin & & trash dump & & 1 & 66 \\
\hline 41GR290 & historic & 2260 & & upland margin & & trash dump & & 1 & 66 \\
\hline 41GR291 & prehistoric & 2290 & 2250 & upland margin & campsite & & & III & $66 / 71 / 93$ \\
\hline 41GR292 & historic & 2230 & & upland margin & & isolated find & & 1 & 66 \\
\hline 41GR293 & prehistoric & 2240 & 2220 & upland margin & lithic procurement area & & & 1 & 66 \\
\hline 41GR294 & rock art & 2230 & & bluff & & & European & 1 & 66 \\
\hline 41GR295 & rock art & 2240 & & bluff & & & European & 1 & 66 \\
\hline 41GR296 & prehistoric & 2190 & & upper alluvial terrace & lithic procurement area & & & 1 & 66 \\
\hline 41GR297 & prehistoric & 2215 & & bedrock terrace & lithic procurement area & & & 1 & 66 \\
\hline 41GR298 & rock art & 2195 & & bluff & & & European & 1 & 66 \\
\hline 41GR299 & prehistoric & 2175 & & bedrock terrace & isolated find & & & 1 & 66 \\
\hline $41 G R 300$ & prehistoric & 2270 & 2260 & upland margin & lithic procurement area/campsite & & & 1 & 66 \\
\hline
\end{tabular}




\begin{tabular}{|c|c|c|c|c|c|c|c|c|c|}
\hline \multicolumn{10}{|c|}{ Table 135 , continued } \\
\hline Site & Component & $\begin{array}{l}\text { Top } \\
\text { Elevation }\end{array}$ & \begin{tabular}{|l|} 
Bottom \\
Elevation
\end{tabular} & Topographic Setting & Prehistoric Site Type & Historic Site Type & Rock Art Site Type & $\begin{array}{l}\text { Level of } \\
\text { Effort }\end{array}$ & Report No. \\
\hline 41GR301 & prehistoric & 2260 & & upland margin & isolated find & & & 1 & 66 \\
\hline 41GR302 & prehistoric & 2280 & 2270 & upland margin & campsite & & & II & $66 / 71$ \\
\hline 41GR303 & prehistoric & 2310 & 2240 & upland margin & campsite & & & III & $66 / 71 / 93$ \\
\hline 41GR304 & historic & 2300 & 2270 & upland margin & & trash dump & & 1 & 66 \\
\hline 41GR305 & rock art & 2230 & & bluff & & & European & 1 & 66 \\
\hline 41GR306 & prehistoric & 2250 & 2220 & upland margin & lithic procurement area/campsite & & & 1 & 66 \\
\hline 41GR307 & rock art & 2190 & & bluff & & & European & 1 & 66 \\
\hline 41GR308 & rock art & 2260 & & isolated mesa & & & European & 1 & 66 \\
\hline 41GR309 & prehistoric & 2260 & 2220 & upland margin & campsite & & & 1 & 66 \\
\hline 41GR310 & prehistoric & 2185 & & alluvial terrace & faunal locality & & & II & $66 / 71$ \\
\hline 41GR311 & prehistoric & 2240 & 2220 & erosional remnant & lithic procurement area/campsite & & & 1 & 66 \\
\hline 41GR312 & prehistoric & 2185 & 2175 & alluvial terrace & campsite & & & 1 & 66 \\
\hline 41GR313 & rock art & 2220 & & isolated mesa & & & European & 1 & 66 \\
\hline 41GR314 & prehistoric & 2260 & 2240 & bedrock terrace & lithic procurement area/campsite & & & 1 & 66 \\
\hline 41GR315 & rock art & 2220 & & bluff overhang & & & Native/European & 1 & 66 \\
\hline 41GR316 & prehistoric & 2260 & 2240 & erosional remnant & lithic procurement area/campsite & & & 1 & 66 \\
\hline 41GR317 & rock art & 2220 & & bluff & & & Native/European & 1 & 66 \\
\hline 41GR318 & prehistoric & 2230 & 2220 & talus slope & lithic procurement area & & & 1 & 66 \\
\hline 41GR320 & prehistoric & 2250 & 2230 & erosional remnant & lithic procurement area & & & 1 & 66 \\
\hline 41GR321 & rock art & 2260 & & bluff overhang & & & European & 1 & 66 \\
\hline $41 G R 322$ & rock art & 2230 & & bluff & & & European & 1 & 66 \\
\hline 41GR323 & prehistoric & 2140 & & upper alluvial terrace & campsite & & & II & $66 / 71$ \\
\hline 41GR324 & prehistoric & 2220 & 2200 & erosional remnant & campsite & & & 1 & 66 \\
\hline $41 G R 325$ & prehistoric & 2280 & 2260 & upland margin & campsite & & & 1 & 66 \\
\hline 41GR326 & prehistoric & 2250 & 2240 & bluff shelter & rockshelter & & & 1 & 66 \\
\hline 41GR327 & prehistoric & 2270 & 2220 & upland margin & lithic procurement area & & & 11 & $66 / 71$ \\
\hline 41GR328 & prehistoric & 2240 & 2180 & upland margin & lithic procurement area/campsite & & & 1 & 66 \\
\hline $41 \mathrm{GR} 329$ & prehistoric & 2240 & 2200 & upland margin & lithic procurement area & & & 1 & 66 \\
\hline $41 G R 330$ & prehistoric & 2260 & 2200 & upland margin & lithic procurement area/campsite & & & 1 & 66 \\
\hline 41GR331 & prehistoric/historic & 2250 & & upland margin & lithic procurement area & unknown structure & & 1 & 66 \\
\hline 41GR332 & prehistoric & 2280 & 2260 & upland margin & lithic procurement area/campsite & & & 1 & 66 \\
\hline 41GR333 & rock art & 2250 & & erosional remnant & & & Native/European & 1 & 66 \\
\hline 41GR334 & prehistoric & 2240 & 2230 & upland margin & lithic procurement area & & & 1 & 66 \\
\hline 41GR335 & prehistoric & 2240 & & upland margin & isolated find & - & & 1 & 66 \\
\hline 41GR336 & prehistoric & 2260 & 2240 & upland margin & campsite & & & 1 & 66 \\
\hline $41 \mathrm{GR} 337$ & prehistoric & 2300 & 2240 & upland margin & lithic procurement area/campsite & & & 1 & 66 \\
\hline
\end{tabular}




\begin{tabular}{|c|c|c|c|c|c|c|c|c|c|}
\hline \multicolumn{10}{|c|}{ Table 135, continued } \\
\hline Site & Component & $\begin{array}{l}\text { Top } \\
\text { Elevation }\end{array}$ & \begin{tabular}{|l|} 
Bottom \\
Elevation
\end{tabular} & Topographic Setting & Prehistoric Site Type & Historic Site Type & Rock Art Site Type & $\begin{array}{l}\text { Level of } \\
\text { Effort }\end{array}$ & Report No. \\
\hline 41GR338 & prehistoric & 2250 & 2200 & erosional remnant & campsite & & & 1 & 66 \\
\hline 41GR339 & prehistoric & 2270 & 2260 & upland margin & lithic procurement area/campsite & & & 1 & 66 \\
\hline 41GR340 & prehistoric & 2260 & 2240 & bedrock terrace & lithic procurement area/campsite & & & 1 & 66 \\
\hline 41GR342 & prehistoric & 2290 & & upland margin & campsite & & & 1 & 66 \\
\hline 41GR343 & prehistoric & 2240 & 2180 & erosional remnant & lithic procurement area & & & 1 & 66 \\
\hline 41GR344 & rock art & 2240 & & bluff shelter & & & Native & II & $66 / 71$ \\
\hline 41GR345 & prehistoric & 2260 & 2240 & upland margin & lithic procurement area & & & 1 & 66 \\
\hline 41GR346 & prehistoric & 2230 & & upland margin & isolated find & & & 1 & 66 \\
\hline 41GR347 & prehistoric & 2220 & & erosional remnant & lithic procurement area & & & 1 & 66 \\
\hline 41GR348 & prehistoric & 2220 & 2200 & upland margin & lithic procurement area & & & 1 & 66 \\
\hline 41GR349 & prehistoric & 2240 & 2200 & upland margin & lithic procurement area/campsite & & & 1 & 66 \\
\hline $41 \mathrm{GR} 350$ & prehistoric/historic & 2280 & 2200 & upland margin & lithic procurement area/campsite & trash dump & & 1 & 66 \\
\hline 41GR351 & prehistoric & 2240 & 2200 & upland margin & lithic procurement area/campsite & & & 1 & 66 \\
\hline 41GR352 & rock art & 2200 & & bluff shelter & & & Native & 1 & 66 \\
\hline 41GR353 & rock art & 2200 & 2190 & bluff overhang & & & Native & 1 & 66 \\
\hline 41GR354 & rock art & 2220 & & bluff overhang & & & Native & 1 & 66 \\
\hline 41GR355 & prehistoric & 2250 & 2230 & upland margin & isolated find & & & 1 & 66 \\
\hline 41GR356 & prehistoric & 2160 & & upper alluvial terrace & campsite & & & 1 & 66 \\
\hline 41GR357 & prehistoric & 2260 & & upland margin & isolated find & & & 1 & 66 \\
\hline 41GR358 & prehistoric & 2250 & & upland margin & isolated find & & & 1 & 66 \\
\hline 41GR359 & prehistoric & 2250 & 2210 & upland margin & lithic procurement area/campsite & & & $\|$ & $66 / 71$ \\
\hline 41GR360 & prehistoric & 2250 & 2220 & upland margin & lithic procurement area & & & 1 & 66 \\
\hline 41GR361 & prehistoric & 2260 & 2200 & upland margin & lithic procurement area & & & 1 & 66 \\
\hline 41GR362 & prehistoric & 2300 & 2260 & erosional remnant & lithic procurement area & & & 1 & 66 \\
\hline 41GR363 & prehistoric & 2270 & 2230 & upland margin & lithic procurement area/campsite & & & 1 & 66 \\
\hline 41GR364 & prehistoric & 2290 & 2260 & upland margin & lithic procurement area/campsite & & & 1 & 66 \\
\hline 41GR365 & prehistoric & 2290 & 2260 & upland margin & lithic procurement area & & & 1 & 66 \\
\hline 41GR366 & prehistoric & 2280 & 2260 & upland margin & lithic procurement area & & & 1 & 66 \\
\hline 41GR367 & prehistoric & 2280 & 2240 & upland margin & lithic procurement area & & & 1 & 66 \\
\hline 41GR368 & prehistoric & 2285 & & upland margin & campsite & & & 1 & 66 \\
\hline 41GR369 & prehistoric & 2260 & & upland margin & campsite & & & 1 & 66 \\
\hline 41GR370 & historic & 2285 & & upland margin & & trash dump & & 1 & 66 \\
\hline 41GR371 & prehistoric & 2265 & 2210 & erosional remnant & lithic procurement area & & & 1 & 66 \\
\hline 41GR372 & prehistoric & 2320 & & upland margin & campsite & & & 1 & 66 \\
\hline 41GR373 & prehistoric & 2290 & & upland margin & lithic scatter & & & $\|$ & $66 / 71$ \\
\hline 41GR374 & prehistoric & 2280 & & upland margin & campsite & & & II & $66 / 71$ \\
\hline
\end{tabular}




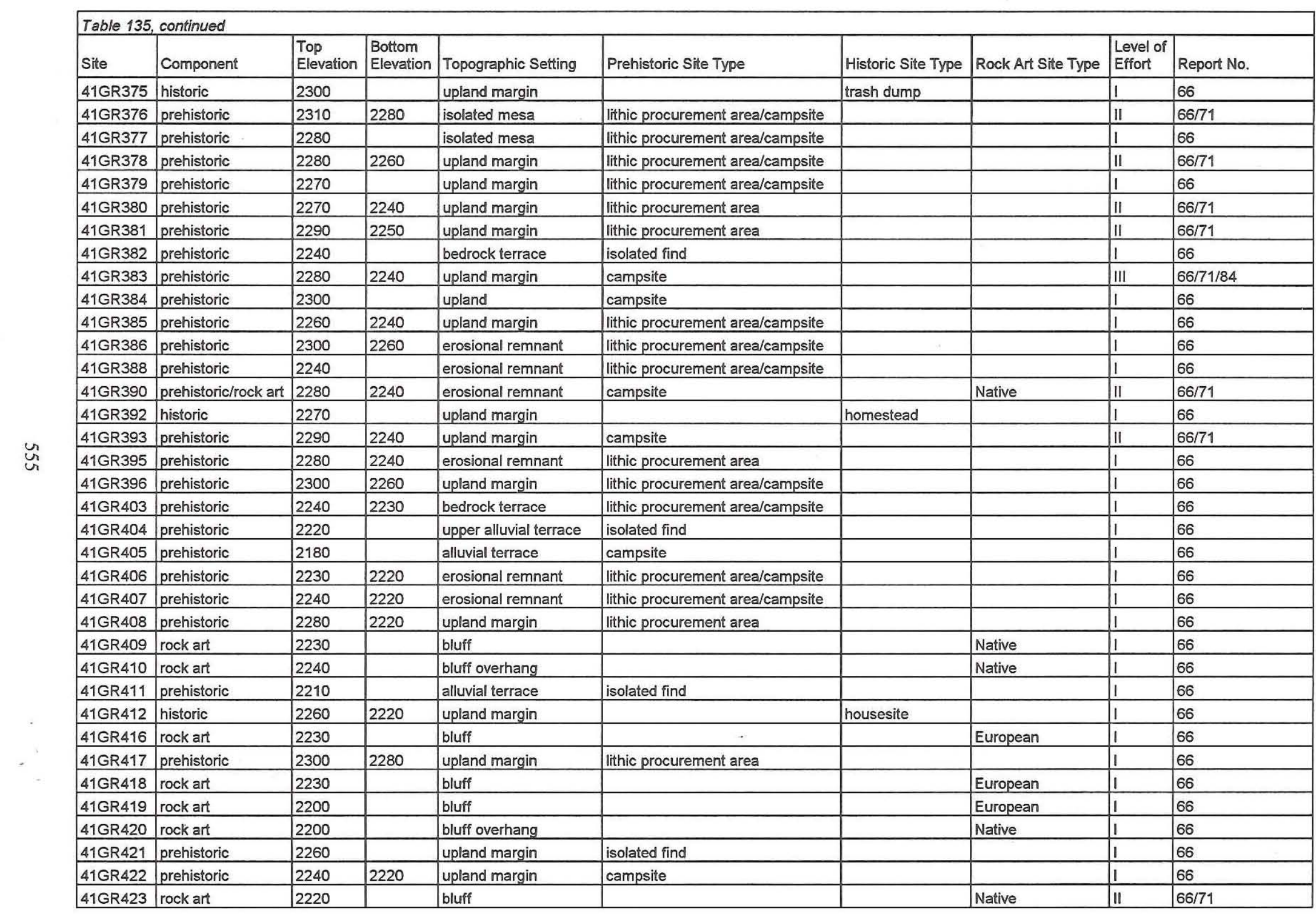




\begin{tabular}{|c|c|c|c|c|c|c|c|c|c|}
\hline \multicolumn{10}{|c|}{ Table 135 , continued } \\
\hline Site & Component & $\begin{array}{l}\text { Top } \\
\text { Elevation }\end{array}$ & \begin{tabular}{|l|} 
Bottom \\
Elevation
\end{tabular} & Topographic Setting & Prehistoric Site Type & Historic Site Type & Rock Art Site Type & \begin{tabular}{|l} 
Level of \\
Effort
\end{tabular} & Report No. \\
\hline 41GR424 & rock art & 2210 & & bluff & & & Native & 1 & 66 \\
\hline 41GR425 & prehistoric & 2190 & & bedrock terrace & campsite & & & 1 & 66 \\
\hline 41GR426 & rock art & 2210 & & erosional remnant & & & Native & III & $66 / 71$ \\
\hline $41 G R 427$ & prehistoric & 2245 & 2210 & erosional remnant & campsite & & & 1 & 66 \\
\hline 41GR428 & rock art & 2240 & & bluff & & & European & 1 & 66 \\
\hline $41 G R 429$ & prehistoric & 2250 & 2240 & erosional remnant & campsite & & & 1 & 66 \\
\hline 41GR430 & prehistoric & 2220 & & bedrock terrace & campsite & & & 1 & 66 \\
\hline 41GR431 & prehistoric & 2230 & 2220 & erosional remnant & campsite & & & 1 & 66 \\
\hline 41GR432 & prehistoric & 2240 & & upland margin & campsite & & & 1 & 66 \\
\hline 41GR433 & prehistoric & 2260 & & erosional remnant & campsite & & & 1 & 66 \\
\hline $41 \mathrm{GR} 434$ & prehistoric & 2240 & 2220 & alluvial terrace & lithic procurement area/campsite & & & 1 & 66 \\
\hline 41GR435 & prehistoric & 2230 & & alluvial terrace & campsite & & & 1 & 66 \\
\hline 41GR436 & prehistoric & 2280 & & talus slope & isolated find & & & 1 & 66 \\
\hline 41GR437 & rock art & 2230 & & bluff overhang & & & Native/European & II & $66 / 71$ \\
\hline 41GR438 & prehistoric & 2240 & & erosional remnant & campsite & & & 1 & 66 \\
\hline 41GR439 & prehistoric & 2280 & & upland margin & campsite & & & 1 & 66 \\
\hline $41 \mathrm{GR} 440$ & prehistoric & 2220 & & alluvial terrace & campsite & & & 1 & 66 \\
\hline 41GR441 & prehistoric & 2230 & 2220 & alluvial terrace & campsite & & & 1 & 66 \\
\hline $41 G R 442$ & prehistoric & 2240 & 2230 & erosional remnant & campsite & & & 1 & 66 \\
\hline $41 G R 443$ & historic & 2250 & & bedrock terrace & & camp/homestead & & 1 & 66 \\
\hline 41GR444 & prehistoric & 2260 & 2240 & erosional remnant & campsite & & & 1 & 66 \\
\hline $41 G R 445$ & rock art & 2240 & & bluff & & & Native/European & 1 & 66 \\
\hline 41GR446 & prehistoric & 2230 & 2220 & bedrock terrace & lithic procurement area/campsite & & & 1 & 66 \\
\hline $41 \mathrm{GR} 447$ & prehistoric & 2210 & & alluvial terrace & isolated find & & & 1 & 66 \\
\hline $41 G R 448$ & rock art & 2240 & & bluff shelter & & & European & 1 & 66 \\
\hline $41 \mathrm{GR} 449$ & historic & 2270 & 2250 & upland margin & & housesite & & 1 & 66 \\
\hline $41 \mathrm{GR} 450$ & prehistoric & 2240 & 2220 & erosional remnant & campsite & & & 1 & 66 \\
\hline 41GR451 & prehistoric & 2240 & 2220 & alluvial terrace & campsite & & & 1 & 66 \\
\hline 41GR452 & prehistoric & 2240 & & erosional remnant & isolated find & & & 1 & 66 \\
\hline 41GR453 & prehistoric & 2240 & 2220 & upper alluvial terrace & lithic scatter & & & 1 & 66 \\
\hline 41GR454 & prehistoric & 2260 & & isolated mesa & campsite & & & 1 & 66 \\
\hline 41GR455 & rock art & 2260 & & bluff & & & European & 1 & 66 \\
\hline 41GR456 & prehistoric & 2210 & 2180 & bedrock terrace & campsite & & & II & $66 / 71$ \\
\hline 41GR457 & rock art & 2230 & & bluff overhang & & & Native & 1 & 66 \\
\hline 41GR458 & prehistoric & 2270 & 2240 & erosional remnant & campsite & & & 1 & 66 \\
\hline 41GR459 & prehistoric & 2220 & & upland margin & campsite & & & 1 & 66 \\
\hline
\end{tabular}




\begin{tabular}{|c|c|c|c|c|c|c|c|c|c|}
\hline \multicolumn{10}{|c|}{ Table 135 , continued } \\
\hline Site & Component & $\begin{array}{l}\text { Top } \\
\text { Elevation }\end{array}$ & \begin{tabular}{|l|} 
Bottom \\
Elevation
\end{tabular} & Topographic Setting & Prehistoric Site Type & Historic Site Type & Rock Art Site Type & \begin{tabular}{|l} 
Level of \\
Effort
\end{tabular} & Report No. \\
\hline 41GR460 & historic & 2240 & & alluvial terrace & & rock wall & & I & 66 \\
\hline 41GR461 & prehistoric & 2240 & & alluvial terrace & isolated find & & & 1 & 66 \\
\hline 41GR462 & prehistoric & 2260 & & upland margin & campsite & & & 1 & 66 \\
\hline 41GR463 & prehistoric & 2260 & & alluvial terrace & isolated find & & & 1 & 66 \\
\hline $41 G R 464$ & rock art & 2260 & & bluff & & & European & 1 & 66 \\
\hline 41GR465 & rock art & 2260 & & bluff & & & European & I & 66 \\
\hline 41GR466 & prehistoric & 2260 & & upland margin & lithic procurement area & & & I & 66 \\
\hline $41 \mathrm{GR} 467$ & prehistoric & 2230 & & eolian dune(on terrace) & campsite & & & 11 & $66 / 71$ \\
\hline 41GR468 & prehistoric & 2230 & & alluvial terrace & isolated find & & & II & $66 / 71$ \\
\hline 41GR469 & prehistoric & 2235 & & alluvial terrace & isolated find & & & 1 & 66 \\
\hline 41GR470 & historic & 2260 & 2240 & alluvial terrace & & railroad complex & & 1 & 66 \\
\hline 41GR471 & prehistoric & 2245 & 2220 & eolian dune(on terrace) & campsite & & & 11 & $66 / 71$ \\
\hline 41GR472 & rock art & 2270 & & bluff overhang & & & Native & 11 & $66 / 71$ \\
\hline 41GR473 & rock art & 2250 & & bluff & & & European & 1 & 66 \\
\hline 41GR474 & prehistoric/historic & 2260 & 2220 & bedrock terrace & campsite & homestead & & III & 66/72/93 (Historic) \\
\hline 41GR475 & rock art & 2240 & & bluff & & & European & 1 & 66 \\
\hline $41 \mathrm{GR} 476$ & prehistoric & 2245 & & alluvial terrace & campsite & & & 1 & 66 \\
\hline $41 G R 477$ & prehistoric & 2240 & 2230 & alluvial terrace & campsite & & & 1 & 66 \\
\hline 41GR478 & prehistoric & 2240 & & alluvial terrace & campsite & & & 1 & 66 \\
\hline 41GR479 & prehistoric & 2240 & & alluvial terrace & campsite & & & 1 & 66 \\
\hline $41 G R 480$ & prehistoric & 2280 & & upland margin & lithic procurement area & & & 1 & 66 \\
\hline 41GR481 & prehistoric & 2320 & & upland & campsite & & & 11 & $66 / 79$ \\
\hline $41 G R 482$ & prehistoric & 2370 & & upland & isolated find & & & 1 & 66 \\
\hline 41GR483 & prehistoric & 2160 & & upper alluvial terrace & campsite & & & II & $66 / 71$ \\
\hline 41GR484 & prehistoric & 2150 & 2130 & alluvial terrace & campsite & & & III & $66 / 71 / 84$ \\
\hline $41 G R 485$ & prehistoric & 2170 & & eolian dune(on terrace) & campsite & & & 1 & 66 \\
\hline 41GR486 & prehistoric & 2280 & & upland margin & isolated find & & & 1 & 66 \\
\hline 41GR487 & prehistoric & 2260 & & erosional remnant & campsite & & & 1 & 66 \\
\hline 41GR488 & prehistoric & 2240 & & upper alluvial terrace & faunal locality & & & $\Perp$ & $66 / 71$ \\
\hline 41GR489 & prehistoric & 2260 & 2240 & erosional remnant & lithic procurement area & & & 1 & 66 \\
\hline $41 \mathrm{GR} 490$ & rock art & 2210 & & bluff & & & Native & 1 & 66 \\
\hline $41 \mathrm{GR} 491$ & rock art & 2220 & & bluff overhang & & & Native & 1 & 66 \\
\hline 41GR492 & prehistoric & 2265 & & upland margin & isolated find & & & 1 & 66 \\
\hline $41 \mathrm{GR} 493$ & prehistoric & 2280 & 2260 & upland margin & campsite & & & 1 & 66 \\
\hline 41GR494 & rock art & 2260 & & bluff overhang & & & Native/European & 11 & $66 / 71$ \\
\hline 41GR495 & prehistoric & 2270 & 2240 & upland margin & lithic procurement area & & & 1 & 66 \\
\hline
\end{tabular}




\begin{tabular}{|c|c|c|c|c|c|c|c|c|c|}
\hline \multicolumn{10}{|c|}{ Table 135, continued } \\
\hline Site & Component & $\begin{array}{l}\text { Top } \\
\text { Elevation }\end{array}$ & $\begin{array}{l}\text { Bottom } \\
\text { Elevation }\end{array}$ & Topographic Setting & Prehistoric Site Type & Historic Site Type & Rock Art Site Type & \begin{tabular}{|l} 
Level of \\
Effort
\end{tabular} & Report No. \\
\hline 41GR496 & prehistoric & 2260 & & upland margin & isolated find & & & 1 & 66 \\
\hline 41GR497 & prehistoric & 2260 & & upland margin & campsite & & & 1 & 66 \\
\hline 41GR498 & prehistoric & 2260 & & upland margin & isolated find & & & 1 & 66 \\
\hline 41GR499 & prehistoric & 2260 & & upland margin & isolated find & & & 1 & 66 \\
\hline $41 \mathrm{GR} 500$ & prehistoric & 2280 & & upland margin & isolated find & & & 1 & 66 \\
\hline $41 \mathrm{GR} 501$ & prehistoric & 2260 & & upland margin & isolated find & & & 1 & 66 \\
\hline $41 \mathrm{GR} 502$ & prehistoric & 2220 & & alluvial terrace & isolated find & & & 1 & 66 \\
\hline 41GR503 & prehistoric & 2260 & 2240 & erosional remnant & lithic procurement area & & & 1 & 66 \\
\hline 41GR504 & prehistoric & 2240 & 2220 & bedrock terrace & lithic procurement area/campsite & & & 1 & 66 \\
\hline 41GR505 & prehistoric & 2260 & 2240 & upland margin & Iithic procurement area & & & 1 & 66 \\
\hline 41GR506 & prehistoric & 2270 & 2260 & isolated mesa & lithic procurement area & & & 1 & 66 \\
\hline 41GR507 & prehistoric & 2240 & 2220 & bedrock terrace & lithic procurement area & & & 1 & 66 \\
\hline 41GR508 & prehistoric & 2240 & & bluff overhang & isolated find & & & 1 & 66 \\
\hline 41GR509 & prehistoric & 2240 & 2220 & upland margin & lithic procurement area/campsite & & & 1 & 66 \\
\hline 41GR510 & prehistoric & 2230 & & upland margin & isolated find & & & 1 & 66 \\
\hline 41GR511 & prehistoric & 2270 & 2240 & upland margin & lithic procurement area/campsite & & & 1 & 66 \\
\hline 41GR512 & prehistoric & 2220 & 2200 & alluvial terrace & faunal locality & & & II & $66 / 71$ \\
\hline 41GR513 & prehistoric & 2280 & & upland margin & lithic scatter & & & 1 & 66 \\
\hline 41GR514 & prehistoric & 2260 & & upland margin & campsite & & & 1 & 66 \\
\hline 41GR515 & prehistoric & 2230 & 2210 & erosional remnant & lithic procurement area/campsite & & & II & $66 / 71$ \\
\hline 41GR516 & rock art & 2240 & & bluff & & & European & 1 & 66 \\
\hline $41 \mathrm{GR} 517$ & rock art & 2270 & & bluff & & & Native/European & 1 & 66 \\
\hline 41GR518 & prehistoric & 2220 & 2200 & bedrock terrace & campsite & & & I & 66 \\
\hline 41GR519 & prehistoric & 2230 & & erosional remnant & isolated find & & & I & 66 \\
\hline 41GR520 & prehistoric & 2240 & & bedrock terrace & lithic procurement area & & & I & 66 \\
\hline 41GR521 & prehistoric & 2220 & & alluvial terrace & lithic scatter & & & 1 & 66 \\
\hline 41GR522 & historic & 2245 & & upper alluvial terrace & & cemetery & & 1 & 66 \\
\hline 41GR523 & prehistoric & 2280 & 2260 & erosional remnant & campsite & & & 1 & 66 \\
\hline 41GR524 & prehistoric & 2280 & 2260 & erosional remnant & campsite & & & 1 & 66 \\
\hline 41GR525 & rock art & 2220 & & bluff & & & European & 1 & 66 \\
\hline 41GR526 & rock art & 2240 & & bluff & & & European & 1 & 66 \\
\hline 41GR527 & prehistoric & 2240 & 2220 & bedrock terrace & lithic procurement area/campsite & & & 1 & 66 \\
\hline 41GR528 & prehistoric/historic & 2260 & 2240 & bedrock terrace & campsite & camp/grave & & II & $66 / 72$ \\
\hline 41GR529 & prehistoric & 2245 & 2230 & alluvial terrace & campsite & & & 1 & 66 \\
\hline 41GR530 & historic & 2240 & & upper alluvial terrace & & housesite & & 1 & 66 \\
\hline 41GR531 & prehistoric & 2230 & & bedrock terrace & campsite & & & 1 & 66 \\
\hline
\end{tabular}




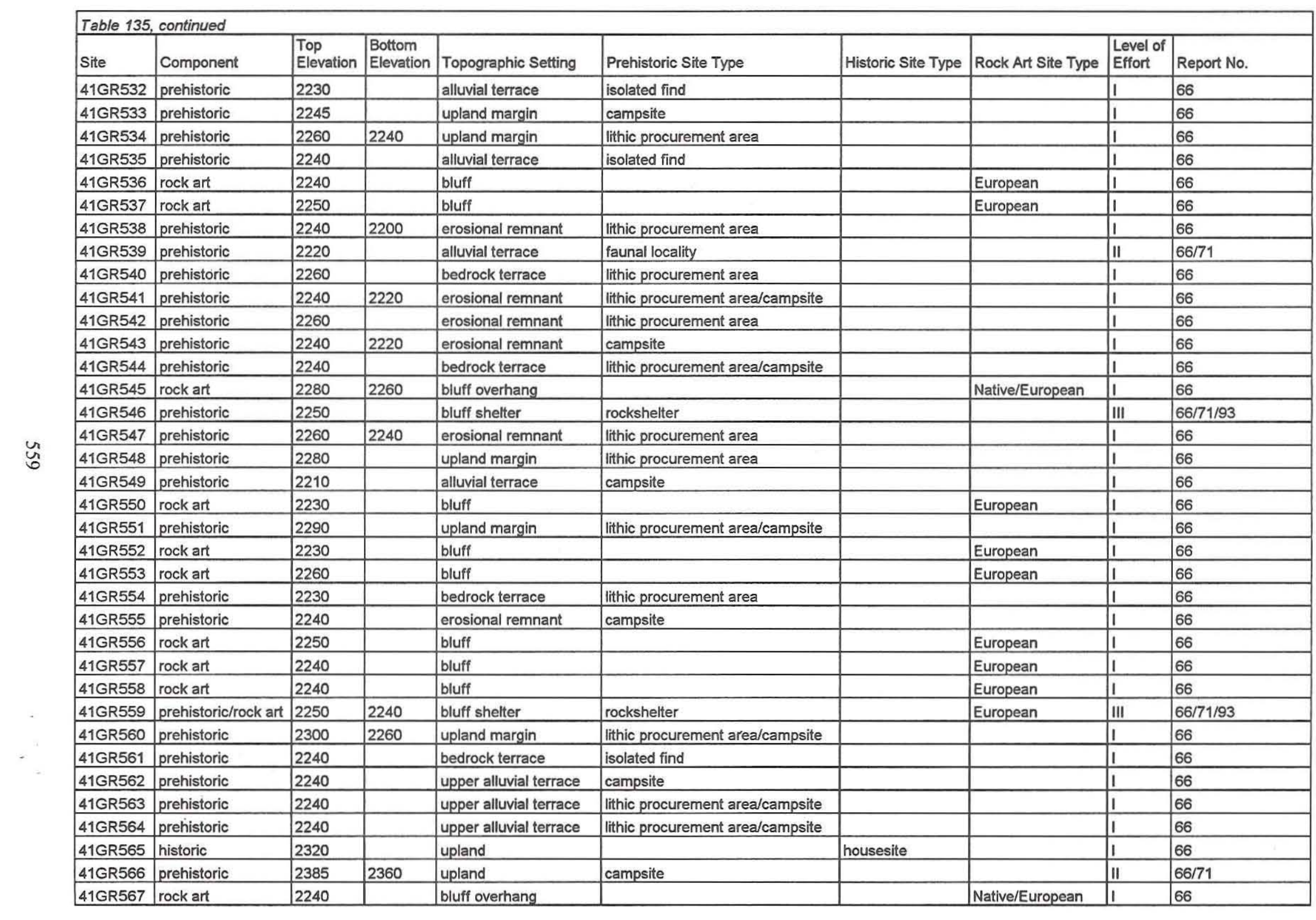




\begin{tabular}{|c|c|c|c|c|c|c|c|c|c|}
\hline \multicolumn{10}{|c|}{ Table 135, continued } \\
\hline Site & Component & \begin{tabular}{|l|} 
Top \\
Elevation
\end{tabular} & \begin{tabular}{|l|} 
Bottom \\
Elevation
\end{tabular} & Topographic Setting & Prehistoric Site Type & Historic Site Type & Rock Art Site Type & \begin{tabular}{|l|} 
Level of \\
Effort
\end{tabular} & Report No. \\
\hline $41 G R 568$ & prehistoric & 2150 & & alluvial terrace & faunal locality & & & 11 & 66 \\
\hline $41 G R 569$ & prehistoric & 2235 & & alluvial terrace & campsite & & & II & 71 \\
\hline $41 \mathrm{GR} 570$ & prehistoric & 2180 & & alluvial terrace & lithic scatter & & & 1 & 71 \\
\hline 41GR572 & prehistoric & 2290 & 2240 & upland margin & lithic procurement area & & & 1 & 79 \\
\hline $41 \mathrm{GR} 573$ & prehistoric & 2280 & 2260 & upland margin & lithic scatter & & & 1 & 79 \\
\hline 41GR574 & prehistoric & 2220 & & erosional remnant & campsite & & & I & 79 \\
\hline 41GR575 & prehistoric & 2190 & & alluvial terrace & faunal locality & & & 1 & 79 \\
\hline 41GR576 & prehistoric & 2280 & 2260 & bedrock terrace & lithic procurement area & & & 1 & 79 \\
\hline 41GR577 & prehistoric & 2290 & 2260 & upland margin & lithic procurement area & & & 1 & 79 \\
\hline 41GR578 & prehistoric & 2300 & 2240 & upland margin & lithic procurement area/campsite & & & 1 & 79 \\
\hline 41GR579 & prehistoric & 2300 & 2260 & upland margin & lithic procurement area/campsite & & & 1 & 79 \\
\hline 41GR580 & prehistoric & 2300 & 2260 & upland margin & lithic procurement area/campsite & & & 1 & 79 \\
\hline 41GR581 & prehistoric & 2310 & 2260 & upland margin & lithic procurement area & & & 1 & 79 \\
\hline $41 G R 582$ & prehistoric & 2320 & 2260 & upland margin & lithic procurement area/campsite & & & 1 & 79 \\
\hline 41GR583 & prehistoric & 2320 & 2260 & upland margin & lithic procurement area/campsite & & & 1 & 79 \\
\hline 41GR584 & prehistoric & 2310 & 2280 & upland margin & lithic procurement area/campsite & & & 1 & 79 \\
\hline 41GR585 & prehistoric & 2320 & 2290 & upland margin & campsite & & & 1 & 79 \\
\hline 41GR586 & historic & 2280 & 2260 & upland margin & & homestead & & 1 & 79 \\
\hline $41 G R 587$ & prehistoric & 2320 & 2260 & upland margin & lithic procurement area/campsite & & & 1 & 79 \\
\hline $41 G R 588$ & prehistoric & 2340 & & upland & campsite & & & 1 & 79 \\
\hline 41GR589 & prehistoric & 2280 & 2220 & bedrock terrace & lithic procurement area/campsite & & & 1 & 79 \\
\hline 41GR590 & prehistoric & 2300 & & upland margin & campsite & & & 1 & 79 \\
\hline 41GR591 & prehistoric & 2220 & & erosional remnant & lithic procurement area/campsite & & & 1 & 79 \\
\hline 41GR592 & prehistoric & 2300 & 2260 & upland margin & lithic procurement area/campsite & & & 1 & 79 \\
\hline $41 G R 593$ & prehistoric & 2340 & & upland & campsite & & & 1 & 79 \\
\hline 41GR594 & prehistoric & 2270 & 2240 & upland margin & lithic procurement area & & & 1 & 79 \\
\hline 41GR595 & prehistoric & 2270 & 2220 & upland margin & lithic procurement area & & & 1 & 79 \\
\hline 41GR596 & prehistoric & 2280 & 2240 & upland margin & lithic procurement area/campsite & & & 1 & 79 \\
\hline $41 G R 597$ & prehistoric & 2320 & & upland & campsite & & & 1 & 79 \\
\hline 41GR598 & prehistoric & 2315 & & upland & campsite & & & 1 & 79 \\
\hline 41GR599 & prehistoric & 2280 & 2240 & upland margin & campsite & & & 1 & 79 \\
\hline $41 \mathrm{GR} 600$ & prehistoric & 2280 & 2240 & upland margin & lithic procurement area/campsite & & & 1 & 79 \\
\hline 41GR601 & prehistoric & 2370 & & upland & campsite & & & 1 & 79 \\
\hline 41GR602 & prehistoric & 2370 & & upland & campsite & & & 1 & 79 \\
\hline $41 \mathrm{GR} 603$ & prehistoric & 2380 & & upland & campsite & & & 1 & 79 \\
\hline 41GR606 & prehistoric & 2140 & 2130 & alluvial terrace & campsite & & & II & 88 \\
\hline
\end{tabular}




\begin{tabular}{|c|c|c|c|c|c|c|c|c|c|}
\hline \multicolumn{10}{|c|}{ Table 135, continued } \\
\hline Site & Component & \begin{tabular}{|l|} 
Top \\
Elevation
\end{tabular} & \begin{tabular}{|l|} 
Bottom \\
Elevation
\end{tabular} & Topographic Setting & Prehistoric Site Type & Historic Site Type & Rock Art Site Type & \begin{tabular}{|l} 
Level of \\
Effort
\end{tabular} & Report No. \\
\hline $41 \mathrm{KT} 33$ & prehistoric & 2170 & 2150 & upper alluvial terrace & campsite & & & IIII & $66 / 71 / 84$ \\
\hline $41 \mathrm{KT} 34$ & prehistoric & 2155 & 2140 & erosional remnant & campsite & & & II & $66 / 71$ \\
\hline $41 \mathrm{KT} 35$ & prehistoric & 2180 & & erosional remnant & lithic procurement area & & & II & $66 / 71$ \\
\hline $41 \mathrm{KT} 36$ & prehistoric & 2255 & 2245 & upland margin & campsite & & & 1 & 66 \\
\hline $41 \mathrm{KT} 37$ & prehistoric & 2250 & & upland margin & campsite & & & 1 & 66 \\
\hline $41 \mathrm{KT} 38$ & prehistoric & 2270 & & upland margin & campsite & & & 1 & 66 \\
\hline $41 K T 39$ & prehistoric & 2250 & & upland margin & isolated find & & & 1 & 66 \\
\hline $41 \mathrm{KT} 40$ & prehistoric & 2240 & 2220 & erosional remnant & campsite & & & 1 & 66 \\
\hline $41 K T 41$ & prehistoric & 2270 & 2240 & upland margin & campsite & & & 1 & 66 \\
\hline $41 \mathrm{KT} 42$ & prehistoric/historic & 2170 & 2140 & upper alluvial terrace & campsite & line camp & & III & 66/72/84 (Historic) \\
\hline $41 \mathrm{KT} 43$ & prehistoric & 2260 & 2240 & upland margin & lithic procurement area & & & 1 & 66 \\
\hline $41 \mathrm{KT} 44$ & prehistoric & 2180 & & alluvial terrace & faunal locality & & & II & $66 / 71$ \\
\hline $41 \mathrm{KT} 45$ & prehistoric & 2250 & & upland margin & lithic procurement area & & & 1 & 66 \\
\hline $41 \mathrm{KT} 46$ & prehistoric & 2280 & & upland & isolated find & & & III & $66 / 71$ \\
\hline $41 \mathrm{~K} T 47$ & prehistoric & 2280 & 2270 & upland & campsite & & & II & $66 / 71$ \\
\hline $41 \mathrm{KT} 48$ & prehistoric & 2270 & 2265 & upland margin & isolated find & & & 1 & 66 \\
\hline $41 K T 49$ & prehistoric & 2280 & 2240 & upland margin & lithic procurement area/campsite & & & 11 & $66 / 71$ \\
\hline $41 \mathrm{KT} 50$ & rock art & 2260 & & bluff overhang & & & Native/European & 1 & 66 \\
\hline $41 \mathrm{KT} 51$ & prehistoric & 2170 & & alluvial terrace & campsite & & & III & $66 / 71 / 88$ \\
\hline $41 K T 52$ & prehistoric & 2170 & & upper alluvial terrace & campsite & & & 11 & $66 / 71$ \\
\hline $41 \mathrm{KT} 53$ & prehistoric & 2170 & & alluvial terrace & campsite & & & III & $66 / 71 / 88$ \\
\hline $41 \mathrm{KT} 54$ & rock art & 2260 & & bluff & & & European & 1 & 66 \\
\hline $41 \mathrm{KT} 55$ & rock art & 2245 & & bluff overhang & & & Native & 1 & 66 \\
\hline $41 \mathrm{KT} 56$ & prehistoric & 2170 & & alluvial terrace & campsite & & & 1 & 66 \\
\hline $41 \mathrm{KT} 57$ & prehistoric/rock art & 2250 & & bluff shelter & rockshelter & & Native & 1 & 66 \\
\hline $41 \mathrm{KT} 58$ & historic & 2310 & 2280 & upland margin & & homestead & & 1 & 66 \\
\hline $41 \mathrm{KT} 59$ & prehistoric & 2260 & & upland margin & isolated find & & & 1 & 66 \\
\hline $41 \mathrm{KT} 60$ & rock art & 2150 & & bluff & & & European & 1 & 66 \\
\hline 41KT61 & prehistoric & 2220 & 2180 & upper alluvial terrace & lithic procurement area/campsite & & & 1 & 66 \\
\hline $41 \mathrm{KT} 62$ & prehistoric & 2300 & 2280 & upland margin & lithic scatter & & & 1 & 66 \\
\hline $41 \mathrm{KT} 63$ & prehistoric & 2300 & 2290 & upland margin & lithic scatter & & & 1 & 66 \\
\hline $41 \mathrm{KT} 64$ & prehistoric & 2190 & & alluvial terrace & isolated find & & & 1 & 66 \\
\hline 41KT65 & rock art & 2270 & & bluff overhang & & & Native/European & 11 & $66 / 71$ \\
\hline $41 \mathrm{KT} 66$ & prehistoric & 2210 & & alluvial terrace & campsite & & & 1 & 66 \\
\hline $41 \mathrm{KT} 67$ & prehistoric & 2280 & & upland margin & lithic procurement area & & & 1 & 66 \\
\hline $41 \mathrm{KT} 68$ & rock art & 2245 & & bluff overhang & & & Native & II & $66 / 71$ \\
\hline
\end{tabular}




\begin{tabular}{|c|c|c|c|c|c|c|c|c|c|}
\hline \multicolumn{10}{|c|}{ Table 135 , continued } \\
\hline Site & Component & \begin{tabular}{|l|} 
Top \\
Elevation
\end{tabular} & \begin{tabular}{|l|} 
Bottom \\
Elevation
\end{tabular} & Topographic Sefting & Prehistoric Site Type & Historic Site Type & Rock Art Site Type & $\begin{array}{l}\text { Level of } \\
\text { Effort }\end{array}$ & Report No. \\
\hline $41 \mathrm{KT} 69$ & prehistoric & 2220 & & alluvial terrace & faunal locality & & & 11 & $66 / 71$ \\
\hline $41 \mathrm{KT} 70$ & prehistoric & 2300 & 2280 & upland margin & lithic procurement area/campsite & & & 1 & 66 \\
\hline $41 \mathrm{KT} 71$ & prehistoric & 2200 & & alluvial terrace & isolated find & & & 1 & 66 \\
\hline $41 \mathrm{KT72}$ & rock art & 2290 & 2280 & bluff & & & European & 1 & 66 \\
\hline $41 \mathrm{~K} T 73$ & rock art & 2250 & & bluff shelter & & & European & 1 & 66 \\
\hline $41 \mathrm{KT} 74$ & prehistoric & 2270 & & upland margin & isolated find & & & 1 & 66 \\
\hline $41 \mathrm{KT} 75$ & prehistoric & 2240 & 2220 & alluvial terrace & campsite & & & 1 & 66 \\
\hline $41 \mathrm{KT} 76$ & rock art & 2260 & 2240 & bluff & & & European & 1 & 66 \\
\hline $41 \mathrm{~K} T 77$ & prehistoric & 2230 & & alluvial terrace & campsite & & & 1 & 66 \\
\hline $41 \mathrm{~K} T 78$ & prehistoric & 2260 & 2240 & alluvial terrace & campsite & & & 1 & 66 \\
\hline $41 \mathrm{KT} 79$ & prehistoric & 2240 & & alluvial terrace & campsite & & & 1 & 66 \\
\hline $41 \mathrm{~K} T 80$ & prehistoric & 2240 & & bedrock terrace & campsite & & & 1 & 66 \\
\hline $41 \mathrm{KT} 81$ & prehistoric & 2265 & 2240 & alluvial terrace & campsite & & & 1 & 66 \\
\hline $41 \mathrm{KT} 82$ & prehistoric & 2250 & 2240 & alluvial terrace & campsite & & & 1 & 66 \\
\hline $41 \mathrm{~K} T 83$ & prehistoric & 2260 & & upper alluvial terrace & campsite & & & 1 & 66 \\
\hline $41 \mathrm{KT} 84$ & prehistoric/historic & 2280 & 2260 & alluvial terrace & campsite & line camp & & 1 & 66 \\
\hline $41 \mathrm{KT} 148$ & prehistoric & 2150 & & alluvial terrace & campsite & & & 1 & 71 \\
\hline $41 \mathrm{KT} 149$ & prehistoric & 2170 & & erosional remnant & lithic procurement area & & & 1 & 71 \\
\hline $41 \mathrm{KT} 150$ & historic & 2260 & & upland margin & & line camp & & 1 & 72 \\
\hline $41 K T 151$ & prehistoric & 2170 & & alluvial terrace & campsite & & & 11 & 71 \\
\hline $41 \mathrm{KT} 152$ & prehistoric & 2160 & 2140 & alluvial terrace & campsite & & & 1 & 84 \\
\hline $41 \mathrm{KT} 153$ & prehistoric & 2180 & 2120 & erosional remnant & lithic procurement area/campsite & & & 1 & 84 \\
\hline $41 \mathrm{KT} 154$ & prehistoric & 2130 & 2120 & alluvial terrace & campsite & & & 1 & 84 \\
\hline $41 \mathrm{KT} 155$ & prehistoric & 2120 & 2110 & alluvial terrace & campsite & & & 1 & 84 \\
\hline 41KT156 & prehistoric & 2170 & 2160 & upland margin & lithic procurement area & & & 1 & 84 \\
\hline $41 \mathrm{KT} 157$ & prehistoric & 2170 & 2160 & upland margin & lithic scatter & & & 1 & 84 \\
\hline $41 \mathrm{KT} 158$ & prehistoric & 2250 & 2220 & bedrock terrace & lithic scatter & & & 1 & 84 \\
\hline $41 \mathrm{KT} 159$ & prehistoric & 2190 & 2160 & alluvial terrace & campsite & & & 1 & 84 \\
\hline $41 \mathrm{KT} 160$ & prehistoric & 2180 & 2160 & alluvial terrace & campsite & & & 1 & 84 \\
\hline $41 \mathrm{KT} 161$ & prehistoric & 2200 & & bedrock terrace & campsite & & & 1 & 88 \\
\hline $41 \mathrm{KT} 164$ & rock art & 2260 & & bluff overhang & & & Native/European & II & 93 \\
\hline
\end{tabular}


APPENDIX B: Chronometric Dating at Lake Alan Henry

Douglas K. Boyd 



\section{INTRODUCTION}

Three dating techniques were employed in an attempt to establish absolute chronological control for the Lake Alan Henry project. The three techniques resulted in 137 dates or age estimates as follows: 106 radiocarbon, 20 thermoluminescence, and 11 archeomagnetic. These assays are summarized here.

The accuracy of the dates derived from these three techniques varies considerably. Radiocarbon dating was clearly the most productive technique and provided the most reliable data for supporting archeological and geomorphic interpretations for the Lake Alan Henry project. With very few exceptions, the radiocarbon dates generally met with the archeological expectations (i.e., age estimates based on other criteria), and they were chronologically consistent between different strata or cultural zones and within an individual stratum or a cultural zone. For various reasons, the results of the thermoluminescence and archeomagnetic dates appear to be much less reliable chronological indicators.

\section{RADIOCARBON DATING}

A total of 108 samples was submitted for radiocarbon assay; excluding two samples that were too small to date (i.e., samples GX-14452 from 41KT53 and GX-14596 from 41GR515), the other 106 samples produced radiocarbon ages that are summarized in Table 136. The majority of these dates $(n=79,75$ percent) were obtained on samples from archeological sites, but only 67 are from cultural contexts (i.e., obtained on samples from cultural zones or cultural features), while the other 12 are from noncultural samples (i.e., sediment dates from below cultural zones). The remaining 27 dates (25 percent) were derived from samples from nonsite geomorphic localities, including backhoe trenches and natural exposures.

The 106 radiocarbon ages were obtained from assays on sediments, charcoal, bones, and wood (Table 137). These assays were conducted by three different radiocarbon laboratories: 49 by Beta Analytic, Inc., of Miami, Florida (including two AMS dates run by the Lawrence Livermore National Laboratory in California); 30 by Geochron Laboratories Division of Krueger Enterprises, Inc., of Cambridge, Massachusetts (including one AMS date); and 27 by the Radiocarbon Laboratory at The
University of Texas at Austin. The pertinent data for all 106 radiocarbon dates are summarized in Table 138. During all previous phases of work, radiocarbon ages from Lake Alan Henry were calibrated using the 20-year record in the 1987 CALIB 2.0 (Stuiver and Reimer 1986). Discussions of Lake Alan Henry sites in Chapters 6 and 7 continue using the Rev. 2.0 calibrations since the resulting calendric dates were used to define all of the analysis units. However, this appendix presents radiocarbon age calibrations done using data set \#2 of the 1993 CALIB 3.0 (Stuiver and Reimer 1993), and these newer calibrated dates are presented for the Lake Alan Henry sites in Chapters 9-11 where comparisons with other radiocarbon dates in the region are made. Notably, the differences between the calibrated Lake Alan Henry dates done using CALIB Rev. 2.0 and Rev. 3.0 are negligible in most cases. The four radiocarbon ages older than 8100 B.P. were originally calibrated using the following formula from Stuiver et al. (1986:971): Calibrated age $=1.05$ (corrected age) +470 . For consistency, this calibration is used in the text, but this appendix recalibrates these dates using data set \#1 of CALIB 3.0.

\section{THERMOLUMINESCENCE DATING}

Twenty-eight samples ( 22 sandstone, 3 chert, 2 ceramic, and 1 limestone) were submitted for thermoluminescence dating to the TL Laboratory, Department of Archaeology, University of Durham. These samples were collected during the 1988 testing phase and were submitted for dating as a pilot study to determine if the thermoluminescence technique might be useful in the project area. The technical details and results of this study are discussed by Quigg (1990).

Eight of the samples could not be dated because the sample materials were not appropriate or they may not have been heated sufficiently, but thermoluminescence dates were obtained for the other 20 samples (Table 139). The results, unfortunately, are not particularly useful as chronological indicators because there are serious discrepancies between paired radiocarbon and thermoluminescence samples from the same archeological context that cast doubt on their accuracy. In general, the thermoluminescence dates on burned rocks were considerably older than expected, often by as much as 1,000 to 5,000 years. The two dates on ceramic 
TABLE 136

SUMMARY OF RADIOCARBON DATES BY PROVENIENCE AND SEASON OF INVESTIGATION ${ }^{1}$

\begin{tabular}{|c|c|c|c|c|c|c|}
\hline Site or Locality & $\begin{array}{c}1987 \\
\text { Survey }\end{array}$ & $\begin{array}{c}1988 \\
\text { Testing }\end{array}$ & $\begin{array}{l}1990 \text { Data } \\
\text { Recovery, } \\
\text { Season } 1\end{array}$ & $\begin{array}{l}1991 \text { Data } \\
\text { Recovery, } \\
\text { Season } 2\end{array}$ & $\begin{array}{l}1992 \text { Data } \\
\text { Recovery, } \\
\text { Season } 3\end{array}$ & Totals \\
\hline \multicolumn{7}{|c|}{ CAMPSITES $^{2}$} \\
\hline 41GR291 & - & - & - & - & 11 & 11 \\
\hline 41GR303A & - & 2 & - & - & - & 2 \\
\hline 41GR303B & - & 2 & - & - & 2 & 4 \\
\hline 41GR323 & (1) & 1 & - & - & - & 2 \\
\hline 41GR383 & - & - & 4 & - & - & 4 \\
\hline $41 \mathrm{GR} 484$ & $1(2)$ & - & - & - & - & 3 \\
\hline 41GR546 & - & 1 & - & - & - & 1 \\
\hline 41GR559 & - & 2 & - & - & 7 & 9 \\
\hline 41GR568 & 1 & - & - & - & - & 1 \\
\hline $41 \mathrm{KT} 33$ & - & - & 1 & - & - & 1 \\
\hline 41KT51 & - & - & - & $4(5)$ & - & 9 \\
\hline 41KT52 & - & 1 & - & - & - & 1 \\
\hline 41KT53 & - & $2(2)$ & - & $17(2)$ & - & 23 \\
\hline $41 \mathrm{KT} 151$ & - & 1 & - & - & - & 1 \\
\hline \multicolumn{7}{|c|}{ FAUNAL LOCALITIES $^{2}$} \\
\hline 41GR249 & - & 1 & - & - & $\therefore$ & 1 \\
\hline $41 \mathrm{GR} 270$ & _- & 1 & - & - & - & 1 \\
\hline 41GR488 & - & 1 & - & - & - & 1 \\
\hline $41 \mathrm{GR} 539$ & - & 1 & - & - & - & 1 \\
\hline $41 \mathrm{KT} 44$ & - & 1 & - & - & - & 1 \\
\hline 41KT69A & - & 1 & - & - & - & 1 \\
\hline $41 \mathrm{KT} 69 \mathrm{~B}$ & - & 1 & - & - & - & 1 \\
\hline \multicolumn{7}{|c|}{ OFF-SITE GEOMORPHIC DATES } \\
\hline Backhoe Trenches & 5 & 6 & 11 & 1 & - & 23 \\
\hline Natural Exposures & 2 & 2 & - & - & - & 4 \\
\hline Totals: & 12 & 29 & 16 & 29 & 20 & 106 \\
\hline \multicolumn{7}{|c|}{$\begin{array}{l}\text { '1987 Survey - Boyd et al. (1989:Table 6) } \\
1988 \text { Testing - Boyd et al. (1990:Table 74) } \\
1990 \text { Data Recovery } 1 \text { - Boyd et al. (1992:Table 84) } \\
1991 \text { Data Recovery } 2 \text { - Boyd et al. (1993:240, Tables } 4 \text { and 14) } \\
1992 \text { Data Recovery } 3 \text { - Boyd et al. (1994:54-55, 201, Tables 6, 28, and 54) }\end{array}$} \\
\hline \multicolumn{7}{|c|}{$\begin{array}{l}{ }^{2} \text { On-site dates. Most are from archeological contexts (i.e., cultural zones or features) but numbers in } \\
\text { parentheses denote dates from geomorphic contexts (i.e., noncultural). }\end{array}$} \\
\hline
\end{tabular}




\begin{tabular}{|l|c|c|c|c|}
\hline \multicolumn{5}{|c|}{$\begin{array}{c}\text { TABLE 137 } \\
\text { PUMMARY OF RADIOCARBON DATES BY } \\
\text { PROVENIENCE AND MATERIAL }\end{array}$} \\
\hline Provenience & Sediment & Charcoal & Bone & Wood \\
\hline On-Site & & & & \\
Campsites & 25 & 43 & 2 & 2 \\
Faunal Localities & - & - & 7 & - \\
\hline Off-Site & & & & \\
Backhoe Trenches & 20 & 2 & 1 & - \\
Natural Exposures & 4 & - & - & - \\
\hline Totals: & 49 & 45 & 10 & 2 \\
\hline
\end{tabular}

samples were of burned clay sediments associated with unlined basin hearths but some unburned sediments from nonfeature contexts were sampled for comparison. Each individual sample consists of 3 to 12 cubes (ca. $5 \times 5 \times 5 \mathrm{~cm}$ ) that were consolidated using a new method whereby sediments were hardened by applying sodium silicate with a brush. The field extraction methods, archeomagnetic analysis procedures, and the resulting data and interpretations are discussed in detail by Gose (1993).

sherds are considered to be more reliable and are only slightly younger than the expected ages based on typological identifications. Boyd et al. (1990: 246-248) provide a more thorough discussion of the relationship between radiocarbon and thermoluminescence dating results at Lake Alan Henry and the many potential problems with the thermoluminescence technique.

\section{ARCHEOMAGNETIC DATING}

Thirteen sets of sediment samples were extracted as consolidated cubes and submitted for archeomagnetic dating to Dr. Wulf Gose, Department of Geological Sciences, The University of Texas at Austin. All of the samples were obtained during the 1992 data recovery (Season 2) investigations at two protohistoric sites: $41 \mathrm{KT} 51$ and 41KT53. Most

Eleven of the samples produced age estimates (Table 140) that are in general agreement with the chronological assessments based on radiocarbon dating. Five sets of paired radiocarbon and archeomagnetic samples provide a basis for comparing and evaluating the archeomagnetic dates (discussed by Boyd et al. 1993:77-78, 203-204). Three of the five paired sets have archeomagnetic age ranges that overlap with the corresponding calibrated radiocarbon dates while the two sets that do not overlap are only off by 21 and 74 years. It is worth noting that the archeomagnetic dates were derived solely from the declination data because the inclination data were abnormally steep (as compared to other regional archeomagnetic data) and would have produced very different age estimates. No satisfactory explanation for unusual inclination data can be given (Gose 1993:333-335). 
TABLE 138

RESULTS OF ALL RADIOCARBON ASSAYS FOR LAKE ALAN HENRY

\begin{tabular}{|c|c|c|c|c|c|}
\hline \multicolumn{6}{|c|}{ ON-SITE DATES FROM CAMPSITES } \\
\hline Site & Provenience & $\begin{array}{l}\text { Lab No.' and } \\
\text { Material }\end{array}$ & $\begin{array}{l}\text { Uncorrected } \\
\text { Age B.P. }\end{array}$ & $\begin{array}{l}\text { Corrected Age } \\
\text { B.P., }{ }^{2}\left(\delta^{13} \mathrm{C} \% \mathrm{o}\right)\end{array}$ & $\begin{array}{l}\text { Calibrated Date Range } \\
\text { and Intercepts, A.D./B.C. }{ }^{3}\end{array}$ \\
\hline $41 \mathrm{GR} 291$ & Feature 12 & $\begin{array}{l}\text { Beta-61497 } \\
\text { Carbon }\end{array}$ & $720 \pm 110$ & $\begin{array}{l}730 \pm 110 \\
(-24.7)\end{array}$ & A.D. $1214(1280) 1390$ \\
\hline 41GR291 & Feature 12 & $\begin{array}{l}\text { Beta-59821 } \\
\text { Carbon }\end{array}$ & $810 \pm 60$ & $\begin{array}{l}820 \pm 60 \\
(-24.4)\end{array}$ & $\begin{array}{l}\text { A.D. } 1162(1220,1250,1260) \\
1280\end{array}$ \\
\hline $41 G R 291$ & Feature 17 & $\begin{array}{l}\text { Beta-61498 } \\
\text { Carbon }\end{array}$ & $1210 \pm 80$ & $\begin{array}{l}1250 \pm 80 \\
(-22.6)\end{array}$ & A.D. $686(780) 936$ \\
\hline 41GR291 & Feature 19 & $\begin{array}{l}\text { Beta-61499 } \\
\text { CAMS-5824 } \\
\text { Carbon }\end{array}$ & none given & $\begin{array}{l}1390 \pm 60 \\
\text { (none given) }\end{array}$ & A.D. $609(650) 688$ \\
\hline $41 \mathrm{GR} 291$ & Feature 21 & $\begin{array}{l}\text { Beta-59820 } \\
\text { Carbon }\end{array}$ & $690 \pm 60$ & $\begin{array}{l}710 \pm 60 \\
(-23.8)\end{array}$ & A.D. $1264(1290) 1382$ \\
\hline 41GR291 & Feature 23 & $\begin{array}{l}\text { Beta-61496 } \\
\text { Human Bone }\end{array}$ & $1530 \pm 60$ & $\begin{array}{l}1720 \pm 60 \\
(-13.6)\end{array}$ & $\begin{array}{l}\text { A.D. } 255(260,270,340,370 \text {, } \\
380) 415\end{array}$ \\
\hline 41GR291 & Feature 29 & $\begin{array}{l}\text { Beta-59822 } \\
\text { Carbon }\end{array}$ & $1370 \pm 90$ & $\begin{array}{l}1380 \pm 90 \\
(-24.7)\end{array}$ & A.D. $602(660) 766$ \\
\hline 41GR291 & Feature 37 & $\begin{array}{l}\text { Beta-61501 } \\
\text { Carbon }\end{array}$ & $980 \pm 80$ & $\begin{array}{l}970 \pm 80 \\
(-25.1)\end{array}$ & $\begin{array}{l}\text { A.D. } 996(1030,1140,1150) \\
1189\end{array}$ \\
\hline 41GR291 & Feature 37 & $\begin{array}{l}\text { Beta-59823 } \\
\text { Carbon }\end{array}$ & $1020 \pm 90$ & $\begin{array}{l}1030 \pm 90 \\
(-24.5)\end{array}$ & $\begin{array}{l}\text { A.D. } 900(1000,1010,1020) \\
1151\end{array}$ \\
\hline 41GR291 & Feature 41 & $\begin{array}{l}\text { Beta-61500 } \\
\text { Carbon }\end{array}$ & $1180 \pm 80$ & $\begin{array}{l}1200 \pm 80 \\
(-23.5)\end{array}$ & $\begin{array}{l}\text { A.D. } 693(780,790,810,820 \text {, } \\
830,840,870) 979\end{array}$ \\
\hline $41 \mathrm{GR} 291$ & $\begin{array}{l}\text { Excavation Unit } \\
95 \text {, Cultural } \\
\text { Zone }(22-33 \mathrm{~cm})\end{array}$ & $\begin{array}{l}\text { Beta-59824 } \\
\text { Sediment }\end{array}$ & $630 \pm 60$ & $\begin{array}{l}730 \pm 60 \\
(-18.8)\end{array}$ & A.D. $1260(1280) 1298$ \\
\hline 41GR303A & Feature 7 & $\begin{array}{l}\mathrm{Tx}-6294 \\
\text { Sediment }\end{array}$ & $1400 \pm 60$ & $\begin{array}{l}1510 \pm 60 \\
(-17.9)\end{array}$ & A.D. $433(560,570,580) 639$ \\
\hline 41GR303B & $\begin{array}{l}\text { Exploratory } \\
\text { Trench } 91 \text {, } \\
30-40 \mathrm{~cm}\end{array}$ & $\begin{array}{l}\text { Tx-6296 } \\
\text { Sediment }\end{array}$ & $560 \pm 70$ & $\begin{array}{l}700 \pm 70 \\
(-16.7)\end{array}$ & A.D. $1264(1290) 1388$ \\
\hline \multicolumn{6}{|c|}{$\begin{array}{l}{ }^{1} \text { Radiocarbon Laboratories: } \\
\text { BETA = Beta Analytic, Inc. Miami, Florida. } \\
\text { CAMS = Lawrence Livermore National Laboratory, Berkeley, California. } \\
\text { GX }=\text { Geochron Laboratories, Division of Krueger Enterprises, Inc., Cambridge, Massachusetts. } \\
\text { Tx = Radiocarbon Laboratory, The University of Texas at Austin. } \\
{ }^{2} \delta^{13} \mathrm{C} \text { corrections as stated by the radiocarbon laboratories. }\end{array}$} \\
\hline
\end{tabular}




\begin{tabular}{|c|c|c|c|c|c|}
\hline Site & Provenience & $\begin{array}{l}\text { Lab No. and } \\
\text { Material }\end{array}$ & $\begin{array}{l}\text { Uncorrected } \\
\text { Age B.P. }\end{array}$ & $\begin{array}{l}\text { Corrected Age } \\
\text { B.P., }\left(\delta^{13} \mathrm{C} \% \mathrm{o}\right)\end{array}$ & $\begin{array}{l}\text { Calibrated Date Range } \\
\text { and Intercepts, A.D./B.C. }\end{array}$ \\
\hline 41GR303B & Feature 5 & $\begin{array}{l}\text { GX-14597 } \\
\text { Carbon }\end{array}$ & $775 \pm 195$ & $\begin{array}{l}810 \pm 195 \\
(-22.9)\end{array}$ & $\begin{array}{l}\text { A.D. } 1021(1220,1230,1250 \text {, } \\
1260) 1390\end{array}$ \\
\hline 41GR303B & Feature 8 & $\begin{array}{l}\text { Tx-6295 } \\
\text { Sediment }\end{array}$ & $1150 \pm 50$ & $\begin{array}{l}1250 \pm 50 \\
(-18.6)\end{array}$ & A.D. $690(776) 871$ \\
\hline 41GR303B & $\begin{array}{l}\text { Excavation Unit } \\
27 \text {, Upper } \\
\text { Cultural Zone, } \\
25-35 \mathrm{~cm}\end{array}$ & $\begin{array}{l}\text { Beta-59825 } \\
\text { Sediment }\end{array}$ & $670 \pm 70$ & $\begin{array}{l}730 \pm 70 \\
(-21.5)\end{array}$ & A.D. $1258(1280) 1376$ \\
\hline 41GR303B & $\begin{array}{l}\text { Excavation Unit } \\
27, \text { Lower } \\
\text { Cultural Zone, } \\
93-103 \mathrm{~cm}\end{array}$ & $\begin{array}{l}\text { Beta-59827 } \\
\text { AMS-5168 } \\
\text { Carbon }\end{array}$ & None given & $\begin{array}{l}1880 \pm 50 \\
\text { (none given) }\end{array}$ & A.D. $73(130) 229$ \\
\hline $41 \mathrm{GR} 323$ & Feature 6 & $\begin{array}{l}\text { Tx-6222 } \\
\text { Sediment }\end{array}$ & $130 \pm 70$ & $\begin{array}{l}250 \pm 70 \\
(-17.5)\end{array}$ & A.D. $1531(1660) 1954$ \\
\hline $41 \mathrm{GR} 323$ & $\begin{array}{l}\text { Backline Trench } \\
1987-8,140 \mathrm{~cm}\end{array}$ & $\begin{array}{l}\text { Tx-5760 } \\
\text { Sediment }\end{array}$ & $810 \pm 50$ & not corrected & $\begin{array}{l}\text { A.D. } 1209(1224,1227,1245 \text {, } \\
\text { 1257) } 1280\end{array}$ \\
\hline 41GR383 & Feature 13 & $\begin{array}{l}\text { GX-16626 } \\
\text { Sediment }\end{array}$ & none given & $\begin{array}{l}1215 \pm 140 \\
(-15.0)\end{array}$ & $\begin{array}{l}\text { A.D. } 662(780,790,800,850 \text {, } \\
860) 989\end{array}$ \\
\hline 41GR383 & Feature 13 & $\begin{array}{l}\text { GX-16627-A } \\
\text { MS Carbon }\end{array}$ & none given & $\begin{array}{l}1390 \pm 65 \\
(-25.5)\end{array}$ & A.D. $607(650) 688$ \\
\hline 41GR383 & $\begin{array}{l}\text { Excavation Unit } \\
48,35-45 \mathrm{~cm}\end{array}$ & $\begin{array}{l}\text { GX-16515 } \\
\text { Sediment }\end{array}$ & none given & $\begin{array}{l}1865 \pm 140 \\
(-15.7)\end{array}$ & A.D. 3 (130) 341 \\
\hline $41 \mathrm{GR} 383$ & $\begin{array}{l}\text { Excavation Unit } \\
52,35-45 \mathrm{~cm}\end{array}$ & $\begin{array}{l}\text { GX-16512 } \\
\text { Sediment }^{4}\end{array}$ & none given & $\begin{array}{l}450 \pm 125 \\
(-17.1)\end{array}$ & A.D. $1334(1440) 1633$ \\
\hline 41GR484 & Feature 1 & $\begin{array}{l}\mathrm{Tx}-5758 \\
\text { Carbon }\end{array}$ & $260 \pm 70$ & not corrected & A.D. $1527(1650) 1954$ \\
\hline $41 \mathrm{GR} 484$ & $\begin{array}{l}\text { Backhoe Trench } \\
1987-14,100 \mathrm{~cm}\end{array}$ & $\begin{array}{l}\text { Tx-5765 } \\
\text { Sediment }\end{array}$ & $1160 \pm 60$ & not corrected & A.D. $779(890,930,940) 982$ \\
\hline 41GR484 & $\begin{array}{l}\text { Backhoe Trench } \\
1987-14,150 \mathrm{~cm}\end{array}$ & $\begin{array}{l}\text { Tx-5766 } \\
\text { Sediment }\end{array}$ & $1830 \pm 70$ & not corrected & A.D. $85(180,190,220) 322$ \\
\hline $41 \mathrm{GR} 546$ & Feature 2 & $\begin{array}{l}\text { GX-14447 } \\
\text { Carbon }\end{array}$ & $245 \pm 210$ & $\begin{array}{l}275 \pm 210 \\
(-23.4)\end{array}$ & A.D. $1433(1650) 1955$ \\
\hline $41 \mathrm{GR} 559$ & Feature 3 & $\begin{array}{l}\text { GX-14448 } \\
\text { Carbon }\end{array}$ & $815 \pm 190$ & $\begin{array}{l}855 \pm 190 \\
(-22.7)\end{array}$ & A.D. $998(1210) 1298$ \\
\hline $41 \mathrm{GR} 559$ & Feature 5 & $\begin{array}{l}\text { GX-14449 } \\
\text { Carbon }\end{array}$ & $1155 \pm 210$ & $\begin{array}{l}1180 \pm 210 \\
(-23.3)\end{array}$ & A.D. $652(880) 1146$. \\
\hline
\end{tabular}




\begin{tabular}{|c|c|c|c|c|c|}
\hline Site & Provenience & $\begin{array}{l}\text { Lab No. and } \\
\text { Material }\end{array}$ & $\begin{array}{l}\text { Uncorrected } \\
\text { Age B.P. }\end{array}$ & $\begin{array}{l}\text { Corrected Age } \\
\text { B.P., }\left(\delta^{13} \mathrm{C} \%\right)\end{array}$ & $\begin{array}{l}\text { Calibrated Date Range } \\
\text { and Intercepts, A.D. }\end{array}$ \\
\hline $41 \mathrm{GR} 559$ & Features $9 / 12$ & $\begin{array}{l}\text { Beta- } 61502 \\
\text { bison bone }\end{array}$ & $30 \pm 70$ & $\begin{array}{l}280 \pm 70 \\
(-9.7)\end{array}$ & A.D. $1519(1650) 1952$ \\
\hline $41 \mathrm{GR} 559$ & Features $13 / 26$ & $\begin{array}{l}\text { Beta- } 60262 \\
\text { Carbon }\end{array}$ & $1730 \pm 80$ & $\begin{array}{l}1720 \pm 80 \\
(-25.4)\end{array}$ & $\begin{array}{l}\text { A.D. } 240(260,270,340,370 \text {, } \\
380) 421\end{array}$ \\
\hline $41 \mathrm{GR} 559$ & Feature 16 & $\begin{array}{l}\text { Beta-60261 } \\
\text { Carbon }\end{array}$ & $1920 \pm 70$ & $\begin{array}{l}1930 \pm 70 \\
(-24.9)\end{array}$ & A.D. $3(80) 209$ \\
\hline 41 GR559 & Feature 18 & $\begin{array}{l}\text { Beta-59829 } \\
\text { Carbon }\end{array}$ & $790 \pm 80$ & $\begin{array}{l}790 \pm 80 \\
(-24.9)\end{array}$ & A.D. $1164(1260) 1289$ \\
\hline 41GR559 & Feature 22 & $\begin{array}{l}\text { Beta-59831 } \\
\text { Carbon }\end{array}$ & $1320 \pm 110$ & $\begin{array}{l}1300 \pm 110 \\
(-26.5)\end{array}$ & A.D. $645(690,750,760) 875$ \\
\hline $41 \mathrm{GR} 559$ & Feature 24 & $\begin{array}{l}\text { Beta-59832 } \\
\text { Carbon }\end{array}$ & $1520 \pm 90$ & $\begin{array}{l}1530 \pm 90 \\
(-24.5)\end{array}$ & A.D. $425(540) 641$ \\
\hline $41 \mathrm{GR} 559$ & Feature 27 & $\begin{array}{l}\text { Beta-59830 } \\
\text { Carbon }\end{array}$ & $950 \pm 60$ & $\begin{array}{l}930 \pm 60 \\
(-26.4)\end{array}$ & $\begin{array}{l}\text { A.D. } 1023(1070,1090,1120 \text {, } \\
1140,1150) 1209\end{array}$ \\
\hline 41 GR568 & $\begin{array}{l}\text { Backhoe Trench } \\
1987-13,180 \mathrm{~cm}\end{array}$ & $\begin{array}{l}\text { Tx-5764 } \\
\text { Sediment }\end{array}$ & $1910 \pm 40$ & not corrected & A.D. $33(83,102,125) 132$ \\
\hline $41 \mathrm{KT} 33$ & Feature 12 & $\begin{array}{l}\text { GX-16513/ } \\
16514 \\
\text { Carbon }\end{array}$ & none given & $\begin{array}{l}1005 \pm 110 \\
(-26.0)\end{array}$ & A.D. $901(1020) 1187$ \\
\hline $41 \mathrm{KT} 51$ & Feature 3 & $\begin{array}{l}\text { Beta-51502 } \\
\text { Carbon }\end{array}$ & $210 \pm 40$ & $\begin{array}{l}190 \pm 40 \\
(-26.6)\end{array}$ & $\begin{array}{l}\text { A.D. } 1663(1674,1779,1801 \text {, } \\
1943,1954) 1954\end{array}$ \\
\hline $41 \mathrm{KT} 51$ & Feature 3 & $\begin{array}{l}\text { Beta-51503 } \\
\text { Carbon }\end{array}$ & $280 \pm 40$ & $\begin{array}{l}260 \pm 40 \\
(-25.9)\end{array}$ & A.D. $1641(1653) 1667$ \\
\hline $41 \mathrm{KT} 51$ & Feature 9 & $\begin{array}{l}\text { Beta-52301 } \\
\text { Carbon }\end{array}$ & $290 \pm 60$ & $\begin{array}{l}270 \pm 60 \\
(-25.9)\end{array}$ & A.D. $1527(1650) 1952$ \\
\hline $41 \mathrm{KT} 51$ & $\begin{array}{l}\text { Excavation Unit } \\
50,34-44 \mathrm{~cm}\end{array}$ & $\begin{array}{l}\text { Beta-52302 } \\
\text { Carbon }\end{array}$ & $320 \pm 50$ & $\begin{array}{l}300 \pm 50 \\
(-25.9)\end{array}$ & A.D. 1519 (1642) 1656 \\
\hline 41KT51 & $\begin{array}{l}\text { Backhoe Trench } \\
\text { 1991-5, Locality } \\
\text { A, } 460 \mathrm{~cm}\end{array}$ & $\begin{array}{l}\text { Beta-45928 } \\
\text { Sediment }\end{array}$ & $2450 \pm 70$ & $\begin{array}{l}2460 \pm 70 \\
(-24.4)\end{array}$ & $\begin{array}{l}765(680,660,520,460,430) \\
405 \text { в.С. }\end{array}$ \\
\hline $41 \mathrm{KT} 51$ & $\begin{array}{l}\text { Backhoe Trench } \\
\text { 1991-5, Locality } \\
\text { C, 121-124 cm }\end{array}$ & $\begin{array}{l}\text { Beta-45929 } \\
\text { Sediment }\end{array}$ & $870 \pm 60$ & $\begin{array}{l}980 \pm 60 \\
(-18.3)\end{array}$ & A.D. $998(1030) 1155$ \\
\hline $41 \mathrm{KT} 51$ & $\begin{array}{l}\text { Backhoe Trench } \\
1991-9, \\
90-100 \mathrm{~cm}\end{array}$ & $\begin{array}{l}\text { Beta-53742 } \\
\text { Sediment }\end{array}$ & $110 \pm 70$ & $\begin{array}{l}190 \pm 70 \\
(-20.1)\end{array}$ & $\begin{array}{l}\text { A.D. } 1652(1670,1780,1800 \text {, } \\
1940,1950) 1954\end{array}$ \\
\hline
\end{tabular}




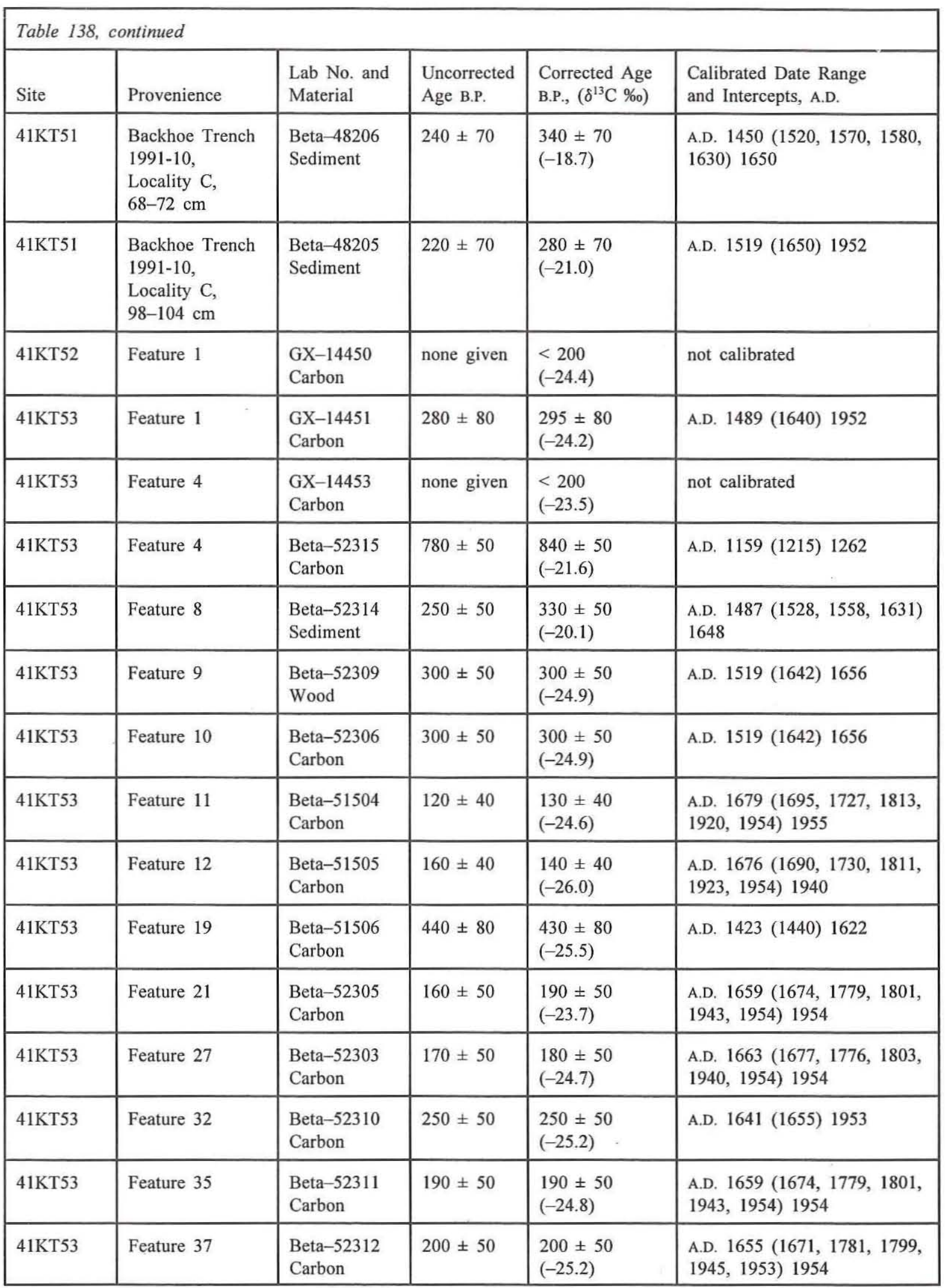




\begin{tabular}{|c|c|c|c|c|c|}
\hline Site & Provenience & $\begin{array}{l}\text { Lab No. and } \\
\text { Material }\end{array}$ & $\begin{array}{l}\text { Uncorrected } \\
\text { Age B.P. }\end{array}$ & $\begin{array}{l}\text { Corrected Age } \\
\text { B.P., }\left(\delta^{13} \mathrm{C} \% \mathrm{o}\right)\end{array}$ & $\begin{array}{l}\text { Calibrated Date Range } \\
\text { and Intercepts, A.D. }\end{array}$ \\
\hline $41 \mathrm{KT} 53$ & Feature 39 & $\begin{array}{l}\text { Beta-52307 } \\
\text { Carbon }\end{array}$ & $260 \pm 60$ & $\begin{array}{l}270 \pm 60 \\
(-24.4)\end{array}$ & A.D. $1527(1650) 1952$ \\
\hline $41 \mathrm{KT} 53$ & Feature 44 & $\begin{array}{l}\text { Beta-51507 } \\
\text { Wood }\end{array}$ & $540 \pm 60$ & $\begin{array}{l}530 \pm 60 \\
(-26.1)\end{array}$ & A.D. $1331(1410) 1438$ \\
\hline $41 \mathrm{KT} 53$ & Feature 48 & $\begin{array}{l}\text { Beta-52308 } \\
\text { Carbon }\end{array}$ & $280 \pm 50$ & $\begin{array}{l}250 \pm 50 \\
(-26.5)\end{array}$ & A.D. $1641(1655) 1953$ \\
\hline $41 \mathrm{KT} 53$ & $\begin{array}{l}\text { Feature } 54 \\
\text { (probably a } \\
\text { postoccupation, } \\
\text { noncultural } \\
\text { feature) }\end{array}$ & Beta-52313 & $20 \pm 50$ & $\begin{array}{l}20 \pm 50 \\
(-25.1)\end{array}$ & A.D. 1954 (1955) 1955 \\
\hline $41 \mathrm{KT} 53$ & Feature 55 & $\begin{array}{l}\text { Beta-52304 } \\
\text { Carbon }\end{array}$ & $210 \pm 30$ & $\begin{array}{l}220 \pm 30 \\
(-24.2)\end{array}$ & A.D. 1655 (1667) 1954 \\
\hline $41 \mathrm{KT} 53$ & $\begin{array}{l}\text { Backhoe Trench } \\
1988-25 \text {, } \\
63-75 \mathrm{~cm}\end{array}$ & $\begin{array}{l}\text { Tx-6226 } \\
\text { Sediment }\end{array}$ & $1100 \pm 50$ & $\begin{array}{l}1280 \pm 50 \\
(-15.0)\end{array}$ & $\begin{array}{l}\text { A.D. } 686(694,698,715,746 \text {, } \\
\text { 769) } 800\end{array}$ \\
\hline $41 \mathrm{KT} 53$ & $\begin{array}{l}\text { Backhoe Trench } \\
1988-25 \text {, } \\
160-175 \mathrm{~cm}\end{array}$ & $\begin{array}{l}\text { Tx-6227 } \\
\text { Sediment }\end{array}$ & $2490 \pm 70$ & $\begin{array}{l}2630 \pm 70 \\
(-16.6)\end{array}$ & 827 (800) 770 в.С. \\
\hline $41 \mathrm{KT} 53$ & $\begin{array}{l}\text { Backhoe Trench } \\
1991-11 \text {, } \\
50-55 \mathrm{~cm}\end{array}$ & $\begin{array}{l}\text { Beta-48213 } \\
\text { Sediment }\end{array}$ & $660 \pm 60$ & $\begin{array}{l}780 \pm 60 \\
(-17.2)\end{array}$ & $\begin{array}{l}\text { A.D. } 1213(1260,1270,1280) \\
1287\end{array}$ \\
\hline $41 \mathrm{KT} 53$ & $\begin{array}{l}\text { Backhoe Trench } \\
1991-17, \\
115-130 \mathrm{~cm}\end{array}$ & $\begin{array}{l}\text { Beta-48214 } \\
\text { Sediment }\end{array}$ & $520 \pm 70$ & $\begin{array}{l}550 \pm 70 \\
(-23.1)\end{array}$ & A.D. $1325(1410) 1436$ \\
\hline $41 \mathrm{KT} 51$ & $\begin{array}{l}\text { Backhoe Trench } \\
1988-30 \text {, } \\
250-270 \mathrm{~cm}\end{array}$ & $\begin{array}{l}\text { Tx-6228 } \\
\text { Sediment }\end{array}$ & $1990 \pm 70$ & $\begin{array}{l}2090 \pm 70 \\
(-18.3)\end{array}$ & $198(90,80,60$ B.C. $)$ A.D. 1 \\
\hline \multicolumn{6}{|c|}{ ON-SITE DATES FROM FAUNAL LOCALITIES } \\
\hline $41 \mathrm{GR} 249$ & $\begin{array}{l}\text { Test Unit 1, } \\
70 \mathrm{~cm}\end{array}$ & $\begin{array}{l}\mathrm{GX}-14418-\mathrm{G} \\
\text { bison bone }\end{array}$ & none given & $\begin{array}{l}90 \pm 115 \\
(-9.2)\end{array}$ & $\begin{array}{l}\text { A.D. } 1670(1890,1910,1950) \\
1955\end{array}$ \\
\hline $41 \mathrm{GR} 270$ & $\begin{array}{l}\text { Test Unit } 1 \text {, } \\
75-87 \mathrm{~cm}\end{array}$ & $\begin{array}{l}\mathrm{GX}-14417-\mathrm{G} \\
\text { bison bone }\end{array}$ & none given & $\begin{array}{l}70 \pm 110 \\
(-8.7)\end{array}$ & A.D. $1676(1950) 1955$ \\
\hline 41GR488 & $\begin{array}{l}\text { Test Unit } 1 \text {, } \\
114 \mathrm{~cm}\end{array}$ & $\begin{array}{l}\mathrm{GX}-14420-\mathrm{G} \\
\text { bison bone }\end{array}$ & none given & $\begin{array}{l}<200 \\
(-9.3)\end{array}$ & not calibrated \\
\hline 41GR539 & $\begin{array}{l}\text { Test Unit 1, } \\
141 \mathrm{~cm}\end{array}$ & $\begin{array}{l}\mathrm{GX}-14416-\mathrm{G} \\
\text { bison bone }\end{array}$ & none given & $\begin{array}{l}205 \pm 75 \\
(-9.7)\end{array}$ & $\begin{array}{l}\text { A.D. } 1674(1670,1780 ; 1800 \text {, } \\
\text { 1950) } 1954\end{array}$ \\
\hline $41 \mathrm{KT} 44$ & $\begin{array}{l}\text { Test Unit 1, } \\
78 \mathrm{~cm}\end{array}$ & $\begin{array}{l}\mathrm{GX}-14422-\mathrm{G} \\
\text { bison bone }\end{array}$ & $152 \pm 115$ & $\begin{array}{l}375 \pm 115 \\
(-10.9)\end{array}$ & A.D. 1432 (1491) 1653 \\
\hline
\end{tabular}




\begin{tabular}{|c|c|c|c|c|c|}
\hline Site & Provenience & $\begin{array}{l}\text { Lab No. and } \\
\text { Material }\end{array}$ & $\begin{array}{l}\text { Uncorrected } \\
\text { Age B.P. }\end{array}$ & $\begin{array}{l}\text { Corrected Age } \\
\text { B.P., }\left(\delta^{13} \mathrm{C} \%\right)\end{array}$ & $\begin{array}{l}\text { Calibrated Date Range } \\
\text { and Intercepts, A.D. }\end{array}$ \\
\hline $41 \mathrm{KT} 69 \mathrm{~A}$ & $\begin{array}{l}\text { Test Unit 1, } \\
33 \mathrm{~cm}\end{array}$ & $\begin{array}{l}\text { GX-14419-G } \\
\text { bison bone }\end{array}$ & none given & $<200(-9.8)$ & not calibrated \\
\hline $41 \mathrm{KT} 69 \mathrm{~B}$ & $\begin{array}{l}\text { Terrace Cutback, } \\
12 \mathrm{~cm}\end{array}$ & $\begin{array}{l}\mathrm{GX}-14421-\mathrm{G} \\
\text { bison bone }\end{array}$ & none given & $<200(-8.6)$ & not calibrated \\
\hline \multicolumn{6}{|c|}{ OFF-SITE GEOMORPHIC DATES FROM BACKHOE TRENCHES } \\
\hline$-^{5}$ & $\begin{array}{l}\text { Backhoe Trench } \\
1987-5,50 \mathrm{~cm}\end{array}$ & $\begin{array}{l}\text { Tx-5759 } \\
\text { Sediment }\end{array}$ & $1750 \pm 60$ & not corrected & $\begin{array}{l}\text { A.D. } 237(260,280,290,300 \text {, } \\
320) 389\end{array}$ \\
\hline- & $\begin{array}{l}\text { Backhoe Trench } \\
1987-9,140 \mathrm{~cm}\end{array}$ & $\begin{array}{l}\text { Tx-5761 } \\
\text { Sediment }\end{array}$ & $4780 \pm 60$ & not corrected & $\begin{array}{l}3643(3630,3560,3540) 3388 \\
\text { B.C. }\end{array}$ \\
\hline- & $\begin{array}{l}\text { Backhoe Trench } \\
1987-12,50 \mathrm{~cm}\end{array}$ & $\begin{array}{l}\text { Tx-5762 } \\
\text { Sediment }\end{array}$ & $520 \pm 50$ & not corrected & A.D. 1405 (1419) 1438 \\
\hline- & $\begin{array}{l}\text { Backhoe Trench } \\
1987-12,130 \mathrm{~cm}\end{array}$ & $\begin{array}{l}\text { Tx-5763 } \\
\text { Sediment }\end{array}$ & $860 \pm 70$ & not corrected & A.D. $1065(1210) 1262$ \\
\hline- & $\begin{array}{l}\text { Backhoe Trench } \\
1987-17,50 \mathrm{~cm}\end{array}$ & $\begin{array}{l}\text { Tx-5767 } \\
\text { Sediment }\end{array}$ & $740 \pm 50$ & not corrected & A.D. $1260(1282) 1293$ \\
\hline- & $\begin{array}{l}\text { Backhoe Trench } \\
1988-16, \\
147-153 \mathrm{~cm}\end{array}$ & $\begin{array}{l}\text { Tx-6223 } \\
\text { Sediment }\end{array}$ & $1580 \pm 80$ & $\begin{array}{l}1690 \pm 80 \\
(-17.9)\end{array}$ & A.D. $257(360,370,390) 428$ \\
\hline - & $\begin{array}{l}\text { Backhoe Trench } \\
1988-16 \text {, } \\
275-285 \mathrm{~cm}\end{array}$ & $\begin{array}{l}\text { Tx-6224 } \\
\text { Sediment }\end{array}$ & $2570 \pm 160$ & $\begin{array}{l}2650 \pm 160 \\
(-19.9)\end{array}$ & $969(800) 449$ в.C. \\
\hline - & $\begin{array}{l}\text { Backhoe Trench } \\
1988-22, \\
250-260 \mathrm{~cm}\end{array}$ & $\begin{array}{l}\text { Tx-6225 } \\
\text { Sediment }\end{array}$ & $690 \pm 110$ & $\begin{array}{l}770 \pm 110 \\
(-19.4)\end{array}$ & $\begin{array}{l}\text { A.D. } 1162(1260,1270,1280) \\
1300\end{array}$ \\
\hline - & $\begin{array}{l}\text { Backhoe Trench } \\
1988-40 \\
80-90 \mathrm{~cm}\end{array}$ & $\begin{array}{l}\text { Tx-6229 } \\
\text { Sediment }\end{array}$ & $2620 \pm 80$ & $\begin{array}{l}2770 \pm 80 \\
(-15.4)\end{array}$ & 1006 (900) 814 B.C. \\
\hline - & $\begin{array}{l}\text { Backhoe Trench } \\
1988-65 \text {, } \\
48-58 \mathrm{~cm}\end{array}$ & $\begin{array}{l}\text { Tx }-6230 \\
\text { Sediment }\end{array}$ & $410 \pm 60$ & $\begin{array}{l}510 \pm 60 \\
(-19.2)\end{array}$ & A.D. $1405(1430) 1442$ \\
\hline - & $\begin{array}{l}\text { Backhoe Trench } \\
1988-65, \\
205-215 \mathrm{~cm}\end{array}$ & $\begin{array}{l}\text { Tx-6231 } \\
\text { Sediment }\end{array}$ & $1430 \pm 50$ & $\begin{array}{l}1560 \pm 60 \\
(-16.6)\end{array}$ & A.D. $424(540) 598$ \\
\hline- & $\begin{array}{l}\text { Backhoe Trench } \\
1991-1, \\
32-65 \mathrm{~cm}\end{array}$ & $\begin{array}{l}\text { GX-16508 } \\
\text { Sediment }\end{array}$ & none given & $\begin{array}{l}3370 \pm 205 \\
(-17.9)\end{array}$ & $\begin{array}{l}1916(1680,1670,1660 \\
1650,1630) 1412 \text { в.C. }\end{array}$ \\
\hline
\end{tabular}




\begin{tabular}{|c|c|c|c|c|c|}
\hline Site & Provenience & $\begin{array}{l}\text { Lab No. and } \\
\text { Material }\end{array}$ & $\begin{array}{l}\text { Uncorrected } \\
\text { Age B.P. }\end{array}$ & $\begin{array}{l}\text { Corrected Age } \\
\text { B.P., }\left(\delta^{13} \mathrm{C} \% \mathrm{o}\right)\end{array}$ & $\begin{array}{l}\text { Calibrated Date Range } \\
\text { and Intercepts, A.D. }\end{array}$ \\
\hline 一 & $\begin{array}{l}\text { Backhoe Trench } \\
1991-2, \\
90-120 \mathrm{~cm}\end{array}$ & $\begin{array}{l}\text { GX-16509 } \\
\text { Sediment }\end{array}$ & none given & $\begin{array}{l}8690 \pm 305 \\
(-18.1)\end{array}$ & $9899-9289$ в.С. ${ }^{6}$ \\
\hline - & $\begin{array}{l}\text { Backhoe Trench } \\
1991-26 \text {, } \\
35-50 \mathrm{~cm}\end{array}$ & $\begin{array}{l}\text { GX-16625 } \\
\text { Sediment }\end{array}$ & none given & $\begin{array}{l}3320 \pm 165 \\
(-15.8)\end{array}$ & $\begin{array}{l}1768(1600,1590,1580, \\
1560,1540,1530) 1410 \text { в.с. }\end{array}$ \\
\hline - & $\begin{array}{l}\text { Backhoe Trench } \\
1991-3 \text {, } \\
\text { Profile 1, } \\
60-80 \mathrm{~cm}\end{array}$ & $\begin{array}{l}\text { GX-16510 } \\
\text { Sediment }\end{array}$ & none given & $\begin{array}{l}65 \pm 135 \\
(-19.9)\end{array}$ & A.D. $1671(1950) 1955$ \\
\hline - & $\begin{array}{l}\text { Backhoe Trench } \\
\text { 1991-3, } \\
\text { Profile 2, } \\
148-158 \mathrm{~cm}\end{array}$ & $\begin{array}{l}\text { GX-16511 } \\
\text { Sediment }\end{array}$ & none given & $\begin{array}{l}1160 \pm 145 \\
(-17.3)\end{array}$ & A.D. $690(890,930,940) 1020$ \\
\hline - & $\begin{array}{l}\text { Pipeline Trench, } \\
\text { Profile 1, } \\
82-86 \mathrm{~cm}\end{array}$ & $\begin{array}{l}\text { GX-16619 } \\
\text { Sediment }\end{array}$ & none given & $\begin{array}{l}1020 \pm 140 \\
(-17.5)\end{array}$ & $\begin{array}{l}\text { A.D. } 890(1000,1010,1020) \\
1206\end{array}$ \\
\hline - & $\begin{array}{l}\text { Pipeline Trench, } \\
\text { Profile } 1, \\
155-170 \mathrm{~cm}\end{array}$ & $\begin{array}{l}\text { GX-16620 } \\
\text { Sediment }\end{array}$ & none given & $\begin{array}{l}1765 \pm 145 \\
(-20.9)\end{array}$ & $\begin{array}{l}\text { A.D. } 82(260,280,290,300 \text {, } \\
320) 426\end{array}$ \\
\hline - & $\begin{array}{l}\text { Pipeline Trench, } \\
\text { Profile 2, } \\
54-61 \mathrm{~cm}\end{array}$ & $\begin{array}{l}\text { GX-16621 } \\
\text { Sediment }\end{array}$ & none given & $\begin{array}{l}620 \pm 115 \\
(23.1)\end{array}$ & $\begin{array}{l}\text { A.D. } 1282(1330,1350,1360 \text {, } \\
1370,1390) 1428\end{array}$ \\
\hline - & $\begin{array}{l}\text { Pipeline Trench, } \\
\text { Profile 2, } \\
74-80 \mathrm{~cm}\end{array}$ & $\begin{array}{l}\text { GX-16622 } \\
\text { Sediment }\end{array}$ & none given & $\begin{array}{l}825 \pm 75 \\
(-23.1)\end{array}$ & A.D. $1157(1220) 1281$ \\
\hline - & $\begin{array}{l}\text { Pipeline Trench, } \\
\text { Profile } 3, \\
164-185 \mathrm{~cm}\end{array}$ & $\begin{array}{l}\text { GX-16623 } \\
\text { Sediment }\end{array}$ & none given & $\begin{array}{l}1330 \pm 130 \\
(-17.2)\end{array}$ & A.D. $606(690) 869$ \\
\hline - & $\begin{array}{l}\text { Pipeline Trench, } \\
\text { Fill from new } \\
\text { Profile } 2, \\
\text { ca. } 79-178 \mathrm{~cm}\end{array}$ & $\begin{array}{l}\text { GX-16624-G } \\
\text { Bison Bone }\end{array}$ & none given & $\begin{array}{l}810 \pm 75 \\
(-9.5)\end{array}$ & $\begin{array}{l}\text { A.D. } 1161(1220,1230,1250 \text {, } \\
1260) 1284\end{array}$ \\
\hline - & $\begin{array}{l}\text { Backhoe Trench } \\
\text { 1991-15, } \\
\text { Morgan Playa, } \\
170-180 \mathrm{~cm}\end{array}$ & $\begin{array}{l}\text { Beta-48207 } \\
\text { Sediment }\end{array}$ & $6740 \pm 140$ & $\begin{array}{l}6840 \pm 140 \\
(-18.7)\end{array}$ & B.C. $5925(5680) 5581$ \\
\hline
\end{tabular}


Appendix B: Chronometric Dating at Lake Alan Henry

\begin{tabular}{|l|l|l|l|l|l|}
\hline \multicolumn{2}{|c|}{ Table 138, continued } \\
\hline Site & Provenience & $\begin{array}{l}\text { Lab No. and } \\
\text { Material }\end{array}$ & $\begin{array}{l}\text { Uncorrected } \\
\text { Age B.P. }\end{array}$ & $\begin{array}{l}\text { Corrected Age } \\
\text { B.P., }\left({ }^{13} \mathrm{C} \%\right)\end{array}$ & $\begin{array}{l}\text { Calibrated Date Range } \\
\text { and Intercepts, A.D. }\end{array}$ \\
\hline \multicolumn{6}{|c|}{ OFF-SITE GEOMORPHIC DATES FROM NATURAL EXPOSURES } \\
\hline- & $\begin{array}{l}\text { Geomorphic } \\
\text { Locality 1, } \\
90 \mathrm{~cm}\end{array}$ & $\begin{array}{l}\text { Tx-5798 } \\
\text { Sediment }\end{array}$ & $4730 \pm 70$ & not corrected & $\begin{array}{l}3635(3620,3610,3510, \\
3400,3390) 3373 \text { B.C. }\end{array}$ \\
\hline- & $\begin{array}{l}\text { Geomorphic } \\
\text { Locality 2, } \\
530-540 \mathrm{~cm}\end{array}$ & $\begin{array}{l}\text { Tx-6233 } \\
\text { Sediment }\end{array}$ & $\begin{array}{l}10,820 \pm \\
180\end{array}$ & $\begin{array}{l}10,960 \pm 180 \\
(-17.0)\end{array}$ & $10,975(10,798) 10,612$ B.C. $^{6}$ \\
\hline- & $\begin{array}{l}\text { Geomorphic } \\
\text { Locality 2, } \\
550-560 \mathrm{~cm}\end{array}$ & $\begin{array}{l}\text { Tx-6232 } \\
\text { Sediment }\end{array}$ & $\begin{array}{l}12,550 \pm \\
940\end{array}$ & $\begin{array}{l}12,670 \pm 960 \\
(-16.6)\end{array}$ & $14,204(12,772) 11,585$ B.C. $^{6}$ \\
\hline- & $\begin{array}{l}\text { Geomorphic } \\
\text { Locality 2, } \\
560-580 \mathrm{~cm}\end{array}$ & $\begin{array}{l}\text { Tx-5796 } \\
\text { Sediment }\end{array}$ & $\begin{array}{l}13,500 \pm \\
280\end{array}$ & not corrected & $14,585(14,213) 13,811$ B.C. $^{6}$ \\
\hline
\end{tabular}


TABLE 139

RESULTS OF LAKE ALAN HENRY THERMOLUMINESCENCE DATING ${ }^{1}$

\begin{tabular}{|c|c|c|c|c|}
\hline Lab No. & Provenience & Material & Survey Date & Age B.P. \\
\hline Dur89TL 134-1 & 41GR287, Feature 1 & sandstone & $\begin{array}{l}\text { suspected insufficient } \\
\text { heating }\end{array}$ & - \\
\hline Dur89TLqi $134-2 B S$ & 41GR287, Feature 2 & chert & $1650 \pm 730$ в.C. & 3600 \\
\hline Dur89TLqi $134-3$ AS & 41GR291, Feature 2 & sandstone & $3220 \pm 1040$ B.C. & 5170 \\
\hline Dur89TLpfg 134-4AS & 41GR303, Feature 3 & sandstone & $4875 \pm 1375$ в.С. & 6825 \\
\hline Dur89TLpfg 134-5AS & 41GR303, Feature 4 & sandstone & $4460 \pm 1290$ в.C. & 6410 \\
\hline Dur89TL 134-6 & 41GR303, Feature 7 & sandstone & $\begin{array}{l}\text { suspected insufficient } \\
\text { heating }\end{array}$ & - \\
\hline Dur89TL 134-7AS & 41GR303, Feature 8 & sandstone & $2200 \pm 850$ B.C. & 4150 \\
\hline Dur89TLpfg 134-8AS & 41GR359, Feature 2 & chert & $2790 \pm 960$ B.C. & 4740 \\
\hline Dur89TLqi 134-9BS & 41GR471, Feature 1 & sandstone & $1360 \pm 670$ в.С. & 3310 \\
\hline Dur89TL $134-10$ & 41GR484, Feature 2 & sandstone & $\begin{array}{l}\text { insufficient TL sample } \\
\text { within material }\end{array}$ & - \\
\hline Dur89TLqi $134-11 B S$ & 41KT33, Feature 1 & sandstone & 2475895 в.C. & 4425 \\
\hline Dur89TLqi $\quad$ 134-12 & $41 \mathrm{KT} 33$, Feature 2 & limestone & cannot date limestone & - \\
\hline Dur89TLpfg 134-13BS & 41GR53, Feature 5 & ceramic $^{2}$ & A.D. $1805 \pm 40$ & 145 \\
\hline Dur89TLpfg 134-141BS & 41KT53, Feature 6 & ceramic $^{3}$ & A.D. $1770 \pm 45$ & 180 \\
\hline Dur89TLqi $135-1$ & 41GR303, Feature 5 & sandstone & $\begin{array}{l}\text { suspected insufficient } \\
\text { heating }\end{array}$ & - \\
\hline Dur89TLqi $135-2 B S$ & 41GR303, ET $91,40 \mathrm{~cm}$ & chert & $4100 \pm 1200$ B.C. & 6050 \\
\hline Dur89TLpfg 135-3BS & 41GR323 Feature 6 & sandstone & A.D. $110 \pm 375$ & 1840 \\
\hline Dur89TLqi $135-4 B S$ & 41GR323, Feature 7 & sandstone & A.D. $470 \pm 305$ & 1480 \\
\hline Dur89TLqi $135-5 B S$ & 41GR383, Feature 2 & sandstone & $2645 \pm 925$ в.C. & 4595 \\
\hline Dur89TLqi $135-6 \mathrm{BS}$ & 41GR456, Feature 3 & sandstone & $2545 \pm 900$ B.C. & 4495 \\
\hline Dur89TLqi $135-7 B S$ & 41GR515, Feature 2 & sandstone & $1465 \pm 690$ в.C. & 3415 \\
\hline Dur89TLpfg 135-8 & 41GR546, Feature 2 & sandstone & $\begin{array}{l}\text { suspected insufficient } \\
\text { heating }\end{array}$ & - \\
\hline Dur89TLpfg 135-9S & 41GR559, Feature 5 & sandstone & $\begin{array}{l}\text { suspected insufficient } \\
\text { heating }\end{array}$ & - \\
\hline Dur89TLpfg 135-10AS & 41GR559, Feature 3 & sandstone & A.D. $1470 \pm 105$ & 480 \\
\hline Dur89TLqi $135-11 \mathrm{AS}$ & $41 \mathrm{KT} 34$, Feature 1 & sandstone & $600 \pm 520$ B.C. & 2550 \\
\hline
\end{tabular}




\begin{tabular}{|c|c|c|c|c|}
\hline Lab No. & Provenience & Material & Survey Date & Age в.P. \\
\hline Dur89TLqi $135-12 B S$ & $41 \mathrm{KT} 49$, Feature 4 & sandstone & A.D. $1125 \pm 175$ & 825 \\
\hline Dur89TL 135-13 & 41KT52, Feature 1 & sandstone & $\begin{array}{l}\text { poor } \mathrm{TL} \\
\text { characteristics }\end{array}$ & - \\
\hline Dur89TLqi $135-14 A S$ & $41 \mathrm{KT} 53$, Feature 3 & sandstone & $850 \pm 570$ в.С. & 2800 \\
\hline \multicolumn{5}{|c|}{$\begin{array}{l}{ }^{1} \text { These thermoluminescence (TL) dates were originally published in Ouigg (1990:Table 75). } \\
{ }^{2} \text { Identified as a Pecos Glaze V polychrome sherd from Glazeware Vessel } 1 \text { (Boyd et al. 1993:177-179). } \\
\text { 3Identified as a striated utility ware sherd from Plain Utility Vessel } 1 \text { (Boyd et al. 1993:163-164). }\end{array}$} \\
\hline
\end{tabular}

\begin{tabular}{|c|c|c|c|c|c|c|c|c|c|}
\hline \multicolumn{10}{|c|}{$\begin{array}{l}\text { TABLE } 140 \\
\text { RESUITS OFE }\end{array}$} \\
\hline Site/Provenience & 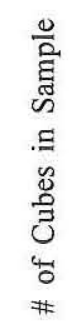 & 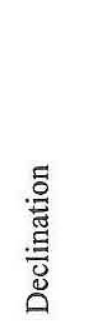 & 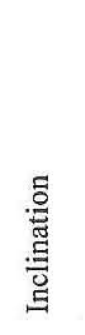 & $\alpha_{95}$ & $\alpha_{63}$ & 芯 & 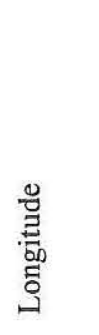 & $\begin{array}{l}\text { Age } \\
\text { (A.D.) }\end{array}$ & $\begin{array}{l}\text { Age Range } \\
\text { (A.D.) }\end{array}$ \\
\hline 41KT51, Feature 3 & 12 & 0.1 & 60.6 & 4.3 & 2.5 & 81.4 & 259.4 & 1392 & $1384-1562$ \\
\hline 41KT51, Feature 7 & 4 & -5.2 & 51.9 & 14.6 & 8.4 & 85.6 & 164.1 & 1346 & \\
\hline 41KT51, Feature 8 & 9 & 4.4 & 63.7 & 5.5 & 3.2 & 77.2 & 273.2 & 1632 & $1518-1686$ \\
\hline 41KT51, Feature 9 & & & & & & & & & \\
\hline Sample 2 & 3 & -2.9 & 65.4 & - & - & 75.3 & 251.2 & - & - \\
\hline Sample 3 & 3 & 45.1 & 67.4 & - & - & 52.9 & 307.6 & - & - \\
\hline Sample 4 & 3 & 6.6 & 67.6 & 2.8 & 1.6 & 71.8 & 272.6 & 1672 & $1648-1695$ \\
\hline 41KT53, Feature 4 & 10 & 0.0 & 61.8 & 3.0 & 1.7 & 80.1 & 259.0 & 1518 & $1372-1562$ \\
\hline 41KT53, Feature 8 & 10 & 1.6 & 58.9 & 4.8 & 2.8 & 83.2 & 269.4 & 1528 & $1378-1632$ \\
\hline 41 KT53, Feature 30 & 10 & 6.1 & 67.0 & 3.6 & 2.1 & 72.8 & 272.5 & 1668 & $1623-1743$ \\
\hline 41KT53, Feature 39 & 7 & 10.8 & 58.1 & 6.0 & 3.5 & 79.5 & 312.3 & 1752 & $1684-1789$ \\
\hline 41KT53, EU 233 & & & & & & & & & \\
\hline Sample 1 & $3^{*}$ & 20.8 & 64.8 & 14.9 & 8.6 & 69.1 & 302.0 & 1842 & - \\
\hline Sample 2 & $3 *$ & 12.6 & 61.5 & 14.0 & 8.1 & 76.1 & 301.1 & 1772 & - \\
\hline 41KT53, BHT & $3^{*}$ & 10.4 & 59.4 & 12.0 & 6.9 & 78.9 & 305.0 & 1742 & - \\
\hline Sample Mean & 80 & 5.0 & 62.1 & 2.2 & 1.3 & 78.9 & 278.3 & - & - \\
\hline
\end{tabular}




\section{REFERENCES CITED}

Boyd, Douglas K., Jay Peck, Steve A. Tomka, and Karl W. Kibler

1993 Data Recovery at Justiceburg Reservoir (Lake Alan Henry), Garza and Kent Counties, Texas: Phase III, Season 2. Reports of Investigations No. 88. Prewitt and Associates, Inc., Austin.

Boyd, Douglas K., Jay Peck, Steve A. Tomka, Karl W. Kibler, and Martha Doty Freeman

1994 Data Recovery at Lake Alan Henry (Justiceburg Reservoir), Garza and Kent Counties, Texas: Phase III, Season 3. Reports of Investigations 93. Prewitt and Associates, Inc., Austin.

Boyd, Douglas K., Steve A. Tomka, C. Britt Bousman, Karen M. Gardner, and Martha Doty Freeman

1992 Data Recovery at Justiceburg Reservoir (Lake Alan Henry), Garza and Kent Counties, Texas: Phase III, Season 1. Reports of Investigations 84. Prewitt and Associates, Inc., Austin.

Boyd, Douglas K., James T. Abbott, William A. Bryan, Colin M. Garvey, Steve A. Tomka, and Ross C. Fields

1990 Phase II Investigations at Prehistoric and Rock Art Sites, Justiceburg Reservoir, Garza and Kent Counties, Texas. Reports of Investigations 71. Prewitt and Associates, Inc., Austin.

Boyd, Douglas K., Martha Doty Freeman, Michael D. Blum, Elton R. Prewitt, and J. Michael Quigg

1989 Phase I Cultural Resources Investigations at Justiceburg Reservoir on the Double Mountain Fork of the Brazos River, Garza and Kent Counties, Texas. Reports of Investigations 66. Prewitt and Associates, Inc., Austin.

DuBois, R. L.

1989 Archeomagnetic Results from Southwest United States and Mesoamerica, with Comparisons with Other Areas. Physics of the Earth Planetary Interiors 56:18-33.

Gose, Wulf A.

1993 Appendix C: Archeomagnetic Dating of Burned Features. In Data Recovery at Justice- burg Reservoir (Lake Alan Henry), Garza and Kent Counties, Texas: Phase III, Season 2, by Douglas K. Boyd, Jay Peck, Steve A Tomka, and Karl W. Kibler, pp. 327-337. Reports of Investigations 88. Prewitt and Associates, Inc., Austin.

Kromer, B., and B. Becker

1993 German Oak and Pine ${ }^{14} \mathrm{C}$ Calibration, 7200 B.C -9400 B.C. Radiocarbon 35:125-135.

Pearson, G. W., and M. Stuiver

1993 High-Precision Bidecadal Calibration of the Radiocarbon Time Scale 500-2500 B.C. Radiocarbon 35:25-33.

Quigg, J. Michael

1990 Appendix C: Chronometric Dating. In Phase II Investigations at Prehistoric and Rock Art Sites, Justiceburg Reservoir, Garza and Kent Counties, Texas, by Douglas K. Boyd, James T. Abbott, William A. Bryan, Colin M. Garvey, Steve A. Tomka, and Ross C. Fields. pp. 363-376. Reports 'of Investigations 88, vol. I. Prewitt and Associates, Inc., Austin.

Stuiver, Minze, and Bernd Becker

1993 High-Precision Decadal Calibration of the Radiocarbon Time Scale, A.D. 1950-6000 B.C. Radiocarbon 35(1):35-65.

Stuiver, M., and G. W. Pearson

1993 High-Precision Bedecadal Calibration of the Radiocarbon Time Scale, A.D. 1950-500 B.C. and 2500-6000 B.C. Radiocarbon 35:1-23.

Stuiver, Minze, and Paula J. Reimer

1986 A Computer Program for Radiocarbon Age Calibration. Radiocarbon 28(2B):1022-1030.

1993 Extended ${ }^{14} \mathrm{C}$ Database and Revised CALIB Radiocarbon Calibration Program. Radiocarbon 35:215-230.

Stuiver, Minze, Bernd Kromer, Bernd Becker, and C. W. Ferguson

1986 Radiocarbon Age Calibration Back to 13,300 Years B.P. Radiocarbon 28(2B):969-979. 
APPENDIX C: CONCLUDING STUDIES

Douglas K. Boyd 
This appendix presents previously unreported results of three separate special studies that were initiated during the course of the Lake Alan Henry archeological investigations. These unrelated studies were not completed until after the third season of data recovery, and the results are described herein for the first time. The studies reported here are (1) a dendrochronological assessment of live oak trees from the project area, (2) an attempt at radiocarbon dating of pictograph pigments, and (3) the construction and installation of a protective enclosure at a unique and pristine rock art site.

\section{LIVE OAK TREE RING STUDY}

During the initial reservoir survey in 1987, archeological survey crews noted the presence of several groves of live oak trees in the Grape Creek valley. Local residents were aware of their existence and informed the crews that these trees were some of the northernmost live oaks in Texas. A few live oak trees also were later observed along South Sage Creek during the 1990-1991 survey, and locals report that there may be other remnant groves located outside the reservoir area farther to the east. These sporadic occurrences of live oaks represent remnant populations of a species generally thought to be absent from the area.

Some of the live oaks within the lake area were extremely large and appeared to be several hundred years old. Many smaller trees are located above the reservoir's conservation flood pool, but the greatest concentration and largest trees are down in the floodplain of Grape Creek, well below the 2,200-ft conservation pool. Because many of the trees were threatened by the reservoir, Prewitt and Associates, Inc., obtained permission from the U.S. Army Corps of Engineers to cut down a few of the largest trees to conduct a pilot study on their suitability for dendrochronology. Sections of trunks were removed for study, but the fallen trees were left in place to provide fish habitat.

Six of the largest live oak trees in the Grape Creek floodplain were cut down on November 13 and 14, 1991. Two trees (samples 1 and 6) were located about $1.6 \mathrm{~km}$ upstream from the dam and four trees (samples 2-5) were in a grove about $2.3 \mathrm{~km}$ upstream from the dam. Using chain saws, 50 -cm-thick sections were removed from the trunk of each tree, with the center of the section being about 1-m above the ground surface. The trunk diameters of the various samples are as follows:

$\begin{array}{cc}\text { Sample } & \text { Maximum } \\ \text { Number } & \text { Diameter }(\mathrm{cm}) \\ 1 & 83 \\ 2 & 64 \\ 3 & 80 \\ 4 & 67 \\ 5 & 82 \\ 6 & 70\end{array}$

After the samples were brought to Austin, each trunk section was cut into several 10 -cm-thick slabs by Texas Kiln Products in Smithville, Texas. The best slab from each tree was selected and sanded down with 400-grit sandpaper. In December 1991, these six slabs were sent to Dr. Malcolm K. Cleaveland at the Department of Geography, University of Arkansas for analysis. Since a tree ring study had not been budgeted, a limited analysis was requested with the goals being to address the following simple research questions: (1) Do the live oaks put on annual growth rings like related species of oak in Texas? (2) Are the growth rings climatically sensitive? (3) Are the growth rings consistent enough to allow crossdating of specimens?

Soon after receiving the slabs, Dr. Cleaveland requested that we locate a live oak of known age from the same general area to provide a comparative sample. Our search for a comparative specimen was aided by local botanist and author of Wildflowers of the Western Plains (University of Texas Press), Zoe Kirkpatrick. When we told her of our problem, she contacted numerous people in the area, and several arborists expressed an interest in the live oaks at Lake Alan Henry. She arranged two trips and brought arborists to visit the project area. During one trip, Benny J. Simpson (author of $A$ Field Guide to Texas Trees, Texas Monthly Press), of Texas A\&M University's Agriculture Experiment Station in Dallas, positively identified the trees in question as escarpment live oaks, Quercus fusiformis Small. ${ }^{12}$ $\mathrm{He}$ also stated that the Lake Alan Henry finds constitute the northwesternmost occurrence of this species in Texas. During a second trip on October 12, 1992, arborist James Tuttle of Tuttle Landscape Company in Wolfforth, Texas, became interested in

\footnotetext{
${ }^{12}$ Or, according to Dr. Cleaveland, Quercus virginiana var. fusiformis (Small) Sarg.
} 
the Lake Alan Henry live oaks. He began searching for a control specimen of known age. Within two months he had located a live oak tree that had been transplanted from Erath County to Lubbock County in 1972 or 1973 but subsequently died of oak wilt in 1992. Tuttle obtained a cross section that appeared to have about 20 annual growth rings in addition to a serious trauma that was caused by transplanting. The section was then sanded with 400-grit paper and sent to the University of Arkansas in January 1993.

The preliminary analysis of the Lake Alan Henry live oaks and the control specimen was completed in December 1993, when Dr. Cleaveland sent a letter report detailing his findings. $\mathrm{He}$ suggested that the control specimen did confirm that live oaks put on only one ring per year. By comparing two of the Lake Alan Henry cross sections, he was able to determine the following: (1) sample 5 appears to be older than 200 years, and the variability in its rings suggests that it is sensitive to climatic variability; and (2) sample 6 appears to be ca. 65 years old, and its rings appear to correlate or crossdate with those of sample 5 .

In conclusion, the results of this preliminary study were quite positive, and there is no reason to think that escarpment live oaks (Quercus fusiformis Small) could not be used for chronological and climatic studies in the Texas Panhandle-Plains. Climatic studies on post oaks in Texas (Stahle and Cleaveland 1988) and across the south-central United States (Stahle and Hehr 1984) have been very successful. Live oaks may be useful as a single species, but there also appears to be considerable potential for crossdating live oaks and post oaks. Similar conclusions were reached during a dendrochronological study of a 146-year-old live oak from the Lyndon Baines Johnson Cemetery in Gillespie County, Texas. Based on this study, Jurney (1994:10-12) concluded that cross sections of the Johnson Cemetery live oak could be crossdated against the well-established post oak chronology for Central Texas.

Complete sets of dendrochronological samples from the Lake Alan Henry live oaks (i.e., slabs from all six trees) are curated at the University of Arkansas's Department of Geography and at The Museum of Texas Tech University in Lubbock.

\section{ATTEMPTED RADIOCARBON DATING OF PICTOGRAPH PIGMENTS}

During the Phase II testing phase, detailed recording of Native American rock art was done at 11 sites. As part of this work, pigment samples were salvaged from pictographs at two endangered sites (i.e., sites below the reservoir's conservation pool). A sample of red pigment was taken from a negative handprint at 41GR426, and black pigment was taken from severly eroded and unidentifiable images at 41GR437 (Boyd and Garvey 1990:222224). These samples were subsequently submitted for mineralogical analysis, and Tweedy (1990:493) concluded that the red pigment appeared to be ruststained quartz (probably derived from a crushed Triassic or Permian sandstone or mudstone), and the black pigment was probably a dark green mineral of the tourmaline group called chromian dravite. The red sample was too small for any additional chemical analyses, but analysis of the total organic content indicted that the black pigment sample was comprised of 1 percent organic carbon. The carbon is thought to represent an organic binder (Boyd and Garvey 1990:224).

Because an organic binder was recognized in a pictograph pigment sample from the project area, it highlighted the possibility of radiocarbon dating organic components. This potential was further explored during data recovery work. Three additional pigment samples were taken from two sites in 1991. Another sample of red pigment was taken from the handprint at 41GR426, and a sample of red pigment was taken from each of the two human figures at 41GR423 (see Boyd and Garvey 1990: Figure 52). A reexamination of site 41 GR 437 found that the black-painted images had spalled away, and no additional samples could be taken.

All three red pigment samples were subsequently submitted for analysis to Dr. Marvin Rowe, Department of Chemistry at Texas A\&M University (Boyd and Kibler 1993). Rowe and others had recently developed a technique for extracting organic carbon from small pictograph samples. They then used the accelerator mass spectrometry technique to radiocarbon date the organic components isolated from pigments. The results that they obtained were encouraging and indicated that the technique was 
providing valid results (Russ et al. 1990, 1992). After the initial processing of the samples, Rowe requested samples of unaltered (i.e., unpainted) sandstone to determine if there was any organic carbon within the natural rock. Two samples of sandstone cut from an unaltered portion of the rock face at 41GR423 were sent. In July 1994, after processing the natural sandstone and pigment samples, Rowe determined that no organic carbon was present in the red pigment above the background level in the unpainted sandstone. Consequently, no attempt was made to AMS date the pigment sample carbon.

In conclusion, although this preliminary attempt to radiocarbon date pigment from a Native American pictograph in the Texas Panhandle-Plains failed, the results should not discourage future attempts. These results do not indicate that all sandstone rocks will have a natural organic component or that no organic binders were used in all pictographs throughout the region. Rather, these results simply indicate that some pictograph pigments probably were made without the use of organic binders. The evidence does not indicate that other colors of pigments, or even all red pigments, do not have an organic component that may be extracted and radiocarbon dated.

\section{PROTECTION OF ROCK ART AT HUDDLESTON SHELTER}

During the 1987 reservoir survey, a panel of well-preserved Native American rock art was found inside a small rockshelter overlooking the Double Mountain Fork of the Brazos River. This rock art site (41GR344), named Huddleston Shelter for the former landowner, was recorded in more detail during the 1988 testing phase (Boyd and Garvey 1990:Figure 50). The Native images consisted of petroglyphs and painted petroglyphs, with the latter being most unusual for the region. Among the various images were several recognizable historic motifs (e.g., a longhorn cow and a Spanish priest), and the rock art was identified as belonging to the early Plains Biographic Style (see Chapter 5).

Because the rock art was pristine (i.e., without damage from historic or modern graffiti and fairly well protected from the elements) and the site was located above the shoreline of the proposed lake, plans were made to investigate conservation measures that might be implemented to protect it. As was quite evident from the condition of other moreobvious rock art sites in Garza County, unintentional vandalism (i.e., carving names and dates into rock faces) posed the greatest threat to Huddleston Shelter. During the data recovery phase, Prewitt and Associates contacted Associated Rock Art Consultants of Los Osos, California, and a visit to the project area was scheduled. Rock art specialist Antoinette Padgett visited Huddleston Shelter and four other Lake Alan Henry rock art sites in July of 1991.

Based on her findings, Padgett and Lee (1993) prepared a report that described each site, defined the problems relating to deterioration of the rock art by natural or human activities, and outlined potential options for conservation. The various options for each site were carefully considered in terms of cost vs. benefit, and the recommendation to construct a protective wire-mesh cage around Huddleston Shelter was considered to be the most viable. After consultation with representatives of the City of Lubbock, the Texas State Historic Preservation Officer, the Fort Worth District of the U.S. Army Corps of Engineers, and Freese and Nichols, Inc., the decision was made to proceed with constructing and installing a protective cage at the site.

Along with City of Lubbock engineer, Mike Gilliland, and welder, Ignacio Faz, the author made a trip to the site on August 17, 1993, for the purpose of designing a protective cage. Based on the preliminary design, Gilliland supervised the construction of the cage. He also supervised the installation of the cage at Huddleston Shelter on April 26, 1994.

The cage that was installed is constructed of seven separate sections, or panels, each composed of a welded frame of 1-inch-square steel tubing with 10-gauge, 4-x-4-inch wire mesh welded on. The metal panels completely cover the open front and sides of the shelter, while the ceiling and floor are utilized to complete the enclosure. The metal panels are located entirely underneath the large rock slab that forms the shelter's ceiling. The entire cage is painted brown to blend in with the rock and not draw unwarranted attention to the site.

Each panel was specifically measured so that that it would fit a particular spot, and each is approximately 42 inches wide and 52 inches high and weighs about 30 pounds. The only exception is that the front center panel weighs approximately 50 pounds because this section includes a smaller square frame and a hinged door. 
The panels were carried up to the site and assembled together in place such that the top of the panels were placed against the ceiling of the shelter, while the bottoms were placed inside a footing trench dug about $1 \mathrm{ft}$ into the loose sterile sediments on the shelter floor. The panel bottoms are securely planted about 3-4 inches deep into the weathered bedrock substrate. Panels are bolted together with $3 / 8$-inch hex bolts along the top and bottom, and the hinged door on the front-central panel opens outward. The door is secured with a keyed master lock but is large enough to allow a person full access to the rock art panel. The 4-x-4-inch openings in the wire mesh allow people to clearly view or photograph the images but do not allow anyone to get close enough to reach the rock art panel. An interpretive/warning sign was placed inside the enclosure. Caging and signing have been found to be effective conservation measures at other rock art sites (Padgett and Lee 1993:565-568, Figure 128), but each site and its setting are unique. Only time will tell whether the wire-mesh cage and interpretive/warning sign are effective in protecting the Huddleston Shelter rock art. The sign at Huddleston Shelton reads as follows:

\section{NATIVE AMERICAN ROCK ART}

Preserved on the back wall of this small shelter are numerous Native American images that were scratched into and painted on the rock surface. The style of the rock art, along with depictions of a longhorn (on the left) and the brimmed "cowboy" hats worn by some of the human figures, indicate that these images were made by Historic Plains Indians after the time of European contact.

This site was discovered by archeologists in 1987. The metal cage has been placed here to protect it for future generations to enjoy, photograph, and study. Defacing or damaging Native American rock art or any other archeological remains in the lake area is prohibited by the Texas Antiquities Code (Texas Natural Resources Code of 1977, Title 9, Chapter 191).

$$
\text { [City of Lubbock logo] [Brazos River Authority logo] }
$$

PLEASE HELP PROTECT AND PRESERVE THE FRAGILE AND IRREPLACEABLE EVIDENCE OF AMERICA'S PAST. For more information, or to report vandalism of archeological sites, please contact a lake official. 


\section{REFERENCES CITED}

Boyd, Douglas K., and Colin M. Garvey

1990 Investigations at Rock Art Sites. In Phase II Investigations at Prehistoric and Rock Art Sites, Justiceburg Reservoir, Garza and Kent Counties, Texas, by Douglas K. Boyd, James T. Abbott, William A. Bryan, Colin M. Garvey, Steve A. Tomka, and Ross C. Fields, pp. 209-234. Reports of Investigations No. 71, vol. I. Prewitt and Associates, Inc., Austin.

Boyd, Douglas K., and Karl W. Kibler

1993 Rock Art Site Investigations, Monitoring and Survey, and Off-Site Geomorphological Investigations. In Data Recovery at Justiceburg Reservoir (Lake Alan Henry), Garza and Kent Counties, Texas: Phase III, Season 2, by Douglas K. Boyd, Jay Peck, Steve A. Tomka, and Karl W. Kibler, pp. 237-240. Reports of Investigations No. 88. Prewitt and Associates, Inc., Austin.

Jurney, David H.

1994 Dendrochronological Studies of a Live Oak Tree from the Lyndon Baines Johnson Family Cemetery, Gillespie County, Texas. Unpublished ms. submitted to the Lyndon Baines Johnson Library, Austin, Texas.

Padgett, Antoinette, and Georgia Lee

1993 Appendix K: Recommendations for Rock Art Conservation at Justiceburg Reservoir. In Data Recovery at Justiceburg Reservoir (Lake Alan Henry), Garza and Kent Counties, Texas: Phase III, Season 2, by Douglas K. Boyd, Jay Peck, Steve A. Tomka, and Karl
W. Kibler, pp. 455-473. Reports of Investigations No. 88. Prewitt and Associates, Inc., Austin.

Russ, J., Marian Hyman, and Marvin W. Rowe

1992 Direct Radiocarbon Dating of Rock Art. Radiocarbon 34(3):867-872.

Russ, J., Marian Hyman, Harry J. Shafer, and Marvin W. Rowe

1990 Radiocarbon Dating of Prehistoric Rock Paintings by Selective Oxidation of Organic Carbon. Nature 348(6303):710-711.

Stahle, David W., and Malcolm K. Cleaveland

1988 Texas Drought History Reconstructed and Analyzed from 1698 to 1980 . Journal of Climate 1:59-74.

Stahle, David W., and J. G. Hehr

1984 Dendroclimatic Relationships of Post Oak Across a Precipitation Gradient in the Southcentral United States., Annals, Association of American Geographers 74:561-574.

Tweedy, Steve W.

1990 Appendix F: Mineralogical Analyses of Kaolinite and Pictograph Pigments. In Phase II Investigations at Prehistoric and Rock Art Sites, Justiceburg Reservoir, Garza and Kent Counties, Texas, by Douglas K. Boyd, James T. Abbott, William A. Bryan, Colin M. Garvey, Steve A. Tomka, and Ross C. Fields, pp. 489-493. Reports of Investigations No. 71, vol. II. Prewitt and Associates, Inc., Austin. 

